UNIVERSIDADE DE SÃO PAULO

INSTITUTO DE GEOCIÊNCIAS

\title{
PROVENIÊNCIA E AMBIENTE DE SEDIMENTAÇÃO DO GRUPO SÃO ROQUE COM BASE NA QUÍMICA DE ROCHA TOTAL E DATAÇÃO U-Pb DE ZIRCÕES DETRÍTICOS
}

Renato Henrique Pinto

Orientador: Prof. Dr. Valdecir de Assis Janasi

TESE DE DOUTORAMENTO

Programa de Pós-Graduação em Mineralogia e Petrologia

SÃO PAULO

2012 


\section{Provenance and sedimentation environment of the São Roque Group using whole- rock chemistry and detrital zircons dating}

The São Roque Group (SRG) is characterized by volcano-sedimentary sequences deposited probably after the late Paleoproterozoic. U-Pb zircon dating by LA-MC-ICPMS of predominantly equigranular monzogranite clasts from the Morro Doce and Morro do

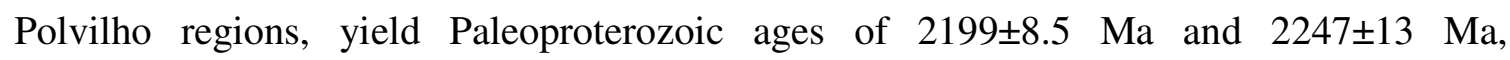
respectively. These data represent the ages of the main granite source for the metaconglomerates of the Boturuna Formation (basal unit of SRG). The polycyclic history of this unit is reinforced by the presence of inherited Archean zircons (2694 $\pm 29 \mathrm{Ma}$ ) found within the clasts. Moreover, these clasts have also been overprinted by the Neoproterozoic metamorphic event $(527 \pm 72 \mathrm{Ma})$ as indicated by their lower intercept Concordia ages. Sm$\mathrm{Nd}$ isotope data obtained on the main clast varieties of the Morro Doce metaconglomerates, yield TDM ages of 2.6-2.7 Ga, demonstrating that these granites are the recycling products of an Archean crustal component. The arkosean framework of the metaconglomerate yields slightly lower $\varepsilon_{\mathrm{Nd}(\mathrm{t})}$ values than those for the clasts, indicating that a younger and/or more primitive source also contributed to the Boturuna Formation.

The SRG is derived from the Archean and Paleoproterozoic source desagregation in a medium-grade chemical weathering (CIA value between 73 to 87 ) and was deposited in a marine environment. This sedimentary sequence comprises proximal deposits, characterized predominantly by metasandstones and meta-felspathic wacke (Boturuna Formation), and more distal successions, which include mainly metawackes and metamudstones (Pirajibu Formation). The whole sequence seems to derive from granitic (with moderate fractionated REE patterns, enriched in LREE, and subtle negative Eu anomalies), intermediate (with increased $\mathrm{Eu} / \mathrm{Eu}^{*}=0.72-1.03$ ), basic (with high values of $\mathrm{Fe}_{2} \mathrm{O}_{3}, \mathrm{MgO}, \mathrm{V}, \mathrm{Rb}$ and $\mathrm{Cr}$ ) and recycled mature polycyclic quartzose sources, as evidenced by the clasts in the metaconglomerate of the Boturuna Formation. 
The strong negative linear correlation of $\mathrm{SiO} 2$ with the main major $\left(\mathrm{Al}_{2} \mathrm{O}_{3}, \mathrm{Fe}_{2} \mathrm{O}_{3}\right.$, $\left.\mathrm{K}_{2} \mathrm{O}, \mathrm{TiO}_{2}\right)$ and trace elements $(\mathrm{Cr}, \mathrm{Rb}, \mathrm{Ba}, \mathrm{V}, \mathrm{Ga})$ highligths the sedimentary sorting, responsible for the concentration of quartz depleted and more aluminous materials in the fine clay fraction (metasiltstones/metamudstones), when compared to the metasandstones. The rising in $\mathrm{Fe}_{2} \mathrm{O}_{3}, \mathrm{MnO}, \mathrm{MgO}, \mathrm{Zn}$ and $\mathrm{Cr}$ concentrations in the metamudstones can also reflect the contribution of basic to intermediate sources, with higher concentrations in clay mineral phases.

Sm-Nd isotopical data from the Piragibu Formation enable to calculate the ages in intervals varying from 1.9 to $3.0 \mathrm{Ga}$, with the main peaks in $2.1,2.4,1.9$ and $3.0 \mathrm{Ga}$. The positive $\varepsilon_{\mathrm{Nd}(1.75)}$ correspond to younger $\mathrm{Sm}-\mathrm{Nd} \mathrm{T}_{\mathrm{DM}}$ ages $(1.88-1.93 \mathrm{Ga})$, which characterize the upper limit of sedimentation as younger than $1.9 \mathrm{Ga}$. The samples with these $\mathrm{T}_{\mathrm{DM}}$ values represent the contribution of the younger sources, possibly with juvenile signature. The main group of metamudstones with $\mathrm{T}_{\mathrm{DM}}(\mathrm{Sm}-\mathrm{Nd})$ ages between 2.2-2.6 Ga, probably represents the mixture of similar sources from the basement of the Açungui Domain and younger sources with less negative $\varepsilon_{\mathrm{Nd}}$ in $1.75 \mathrm{Ga}$ (the best estimative for the depositional age), or even additional sources like gneisses found in tectonic slices within the Andrelândia nappe system.

The main $\mathrm{T}_{\mathrm{DM}}$ peaks concur with the peaks found by $\mathrm{U}-\mathrm{Pb}$ dating in detritical zircons. They can be explained as an apparent feature without a straight geological link or by the presence of juvenile sources (recorded as a mixture component) deposited together with higher crustal residence granites, highlighted by the metaconglomerate pebbles with $\varepsilon_{\mathrm{Nd}(0)}=-23.9$ to -36.2 . Additionally, some detrital zircons with geochemical signatures similar to MORB, were identified in the assemblage of dated zircons and are compatible with the age of mafic juvenile sources of 2.2 and $2.4 \mathrm{Ga}$.

The post-depositional metamorphic overgrowths recognized in the detrital zircons were dated in $584 \pm 47 \mathrm{Ma}$. This data is similar to the age found in the lower intercept on $\mathrm{U}-\mathrm{Pb}$ Concordia from granitic pebbles of the metaconglomerates, as well as the ages of the regional granites. This event is related to the thermal overprint associated to the Brazilian/Panafrican deformation, responsible to modify the chemistry of the zircon rims with the coupled xenotime substitution. When compared to the pristine crystals, the overgrowth are enriched in $\mathrm{Ca}, \mathrm{Fe}, \mathrm{Al}, \mathrm{U}, \mathrm{Na}, \mathrm{Mg}, \mathrm{Ba}, \mathrm{Pb}, \mathrm{Sr}$, Th, $\mathrm{U}$, and $\mathrm{P}$, including the

\section{Renato Henrique Pinto}


LREE. These changes may not reflect relevant intracrystalline diffusion proccesses, suggesting interaction with other mineral phases.

The metamorphic recrystallization-free detrital zircons contain a common interval of $\mathrm{SiO}_{2}, \mathrm{ZrO}_{2}$ and $\mathrm{HfO}_{2}(0.9-1.8 \mathrm{wt} \%)$, and are enriched in $\mathrm{Y}$ and HREE. Most of the crystals from all studied sites seem to be derived from felsic rocks, predominantly the plagioclase-rich ones (e.g., tonalites and granodiorites). Some singularities restrict to gabbros were also identified, for example: strong Ce positive anomaly, high $\mathrm{Lu}_{N} / \mathrm{Sm}_{\mathrm{N}}$ ratios, low $\mathrm{U} / \mathrm{Yb}$, and the concave down shape of the intermediate REE, product of the coeval crystallization of zircon and pyroxene.

The main peak of the detrital zircon in $2.2 \mathrm{Ga}$ is similar to all metasandstones in the São Roque Domain, including usual peaks between 2.5-2.4 Ga and 2.9-2.7 Ga. The K-S statistic test does not exclude the possibility that all samples had been deposited by terrigenous influx coming from the denudation of similar source areas.

The similar geochemical behavior consistent with sediments deposited in a passive margin basin after the erosion of ancient Proterozoic sources, as shown by the detrital zircons of proximal deposits of the Boturuna Formation $(2.2 \mathrm{Ga})$, the younger zircons dated in $1.7 \mathrm{Ga}$ and the $\mathrm{T}_{\mathrm{DM}}$ ages between 1.9 e $3.0 \mathrm{Ga}$ obtained in the Piragibu Formation, suggest a period of sedimentation younger than $1.9 \mathrm{Ga}$. Furthermore, they indicate that the deposition of both formations (Boturuna and Piragibu) were coeval, with possible lateral correlation among them. However, the mudstones (Piragibu Formation) yield Ce-depleted REE patterns compatible with open sea clays, suggesting a more complex paleoenvironment, probably with interaction between passive margin basin and additional volcanogenic source related to oceanic island arc. 


\section{Proveniência e Ambiente de Sedimentação do Grupo São Roque com Base na Química de Rocha Total e Datação U-Pb de Zircões Detríticos}

O grupo São Roque (GSR) é caracterizado por uma sequiência vulcano-sedimentar com deposição provavelmente iniciada no Paleoproterozóico tardio. Datações U-Pb via LA-MC-ICPMS de zircões extraídos da variedade predominante de clasto de monzogranito equigranular das regiões do Morro Doce e Morro do Polvilho forneceram idades

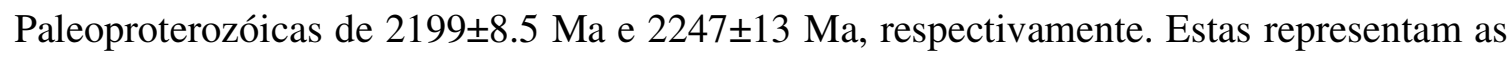
idades do principal granito-fonte dos metaconglomerados da Formação Boturuna (unidade basal do GSR). A história policíclica é reforçada pela presença de zircões Arqueanos herdados (2694 $\pm 29 \mathrm{Ma})$ encontrados nos clastos. No entanto, estes também foram afetados por um evento metamórfico $(527 \pm 72 \mathrm{Ma})$ como indicado pelo intercepto inferior das idades concórdia. Isótopos de $\mathrm{Sm}-\mathrm{Nd}$ das principais variedades de clastos dos metaconglomerados da região do Morro Doce fornecem idades TDM de 2.6-2.7 Ga, o que demonstra que estes granitos são produtos da reciclagem de componente de crosta Arqueana. O arcabouço dos metaconglomerados fornecem valores $\varepsilon_{\mathrm{Nd}(\mathrm{t})}$ ligeiramente baixos quando comparados aos clastos, indicando que uma fontes mais jovens e / ou mais primitiva também contribuíram para a Formação Boturuna.

Através da desagregação de fontes Arqueanas e Paleoproterozóicas sob processo de intemperismo de médio grau (CIA entre 73 e 87) e depositados em ambiente marinho, o GSR é formado predominantemente por depósitos proximais (Formação Boturuna) com metarenitos e meta-feldspato wackes, e depósitos mais distais (Formação Pirajibu) com predomínio de metawackes e metargilitos. Toda a seqüência parece derivar de rochas graníticas (com moderado fracionamento de ETR, enriquecimento em ETR leves e sutil negativa anomalia de Eu), rochas intermediárias (com aumento da $\mathrm{Eu} / \mathrm{Eu}^{*}=0.72-1.03$ ), rochas básicas (com altos teores de $\mathrm{Fe}_{2} \mathrm{O}_{3}, \mathrm{MgO}, \mathrm{V}, \mathrm{Rb}$ e $\mathrm{Cr}$ ) e fontes policíclicas maturas. Conforme evidenciam os clastos dos metaconglomerados da Formção Boturuna.

Forte correlação linear negativa de $\mathrm{SiO}_{2}$ com os principais elementos maiores $\left(\mathrm{Al}_{2} \mathrm{O}_{3}, \mathrm{Fe}_{2} \mathrm{O}_{3}, \mathrm{~K}_{2} \mathrm{O}, \mathrm{TiO}_{2}\right)$ e traços $(\mathrm{Cr}, \mathrm{Rb}, \mathrm{Ba}, \mathrm{V}, \mathrm{Ga})$ é devido a triagem sedimentar responsável pela concentração destes elementos em frações argilosas (metasiltitos/metargilitos) mais aluminosas, empobrecidas em quartzo, quando comparados 
aos metarenitos. $\mathrm{O}$ aumento de $\mathrm{Fe}_{2} \mathrm{O}_{3}, \mathrm{MnO}, \mathrm{MgO}, \mathrm{Zn}$ e $\mathrm{Cr}$ nos metargilitos podem refletir contribuições de fontes básicas e intermediárias, com maiores concentrações em fases minerais mais argilosas.

Dados isotópicos de Sm-Nd da Formação Piragibu permitiram calcular idades com intervalos que variam de 1.9 a $3.0 \mathrm{Ga}$, com picos principais nos intervalos de $2.1 \mathrm{Ga}, 2.4$ $\mathrm{Ga}, 1.9 \mathrm{Ga}$ e $3.0 \mathrm{Ga}$. Os $\varepsilon_{\mathrm{Nd}(1.75)}$ positivos correspondem as mais jovens idades $\mathrm{Sm}-\mathrm{Nd} \mathrm{T}_{\mathrm{DM}}$ (1.88-1.93 Ga), que caracteriza um limite superior de sedimentação mais jovem que $~ 1.9$ Ga. As amostras com estes $T_{D M}$ podem refletir grande contribuição de fontes mais jovens, possivelmente incluindo rochas com assinatura juvenil. $\mathrm{O}$ principal grupo de metargilitos com idades $\mathrm{T}_{\mathrm{DM}}(\mathrm{Sm}-\mathrm{Nd})$ em um intervalo de 2.2-2.6 Ga, provavelmente representa uma mistura de fontes semelhantes a dos núcleos do embasamento do Domínio Açungui e fontes mais jovens com $\varepsilon_{\mathrm{Nd}}$ menos negativo em $1.75 \mathrm{Ga}$ (a melhor estimativa para a idade de deposição), ou ainda, fontes adicionais como por exemplo, gnaisses encontrados como lascas tectônicas no sistema de nappes Andrelândia.

Os principais picos de idade $\mathrm{T}_{\mathrm{DM}}$ são coincidentes com os principais picos de idade U-Pb em zircões detríticos. Podendo ser explicado como uma feição aparente, sem vínculo geológico direto, ou deve-se a presença de fontes juvenis (registrada como componente de mistura), que forneceram sedimentos concomitantemente com os granitos de mais alta residência crustal, por exemplo, os clastos dos metaconglomerados com $\varepsilon_{\mathrm{Nd}(0)}=-23.9$ to 36.2. Adicionalmente alguns zircões detríticos com comportamento geoquímico similar a MORB, foram identificados e são compatíveis com a idéia de fontes máficas juvenis em 2.2 Ga e $2.4 \mathrm{Ga}$.

Os sobrecrescimentos metamórficos pós deposicionais identificados em cristais de zircão detríticos, foram datados em $584 \pm 47 \mathrm{Ma}$. Esta idade é similar a identificada através do intercepto inferior das idades concórdias nos clastos graníticos dos metaconglomerados, bem como as encontradas em datações de granitos regionais. Este evento está relacionado à sobreposição térmica associada deformação Brasiliana/Panafricana, responsável por alterar significativamente a química das bordas dos zircões, através de substituição acoplada de xenotima. Quando comparados aos cristais não alterados, os sobrecrescimentos são enriquecidos em $\mathrm{Ca}, \mathrm{Fe}, \mathrm{Al}, \mathrm{U}, \mathrm{Na}, \mathrm{Mg}, \mathrm{Ba}, \mathrm{Pb}, \mathrm{Sr}, \mathrm{Th}, \mathrm{U}$, e $\mathrm{P}$, além de fortes

\section{Renato Henrique Pinto}


enriquecimentos ETR leves. Estas mudanças não devem refletir grandes processos de difusão intracristalina, sugerindo interações com outras fases minerais.

Cristais de zircões detríticos não afetados por recristalização metamórfica tem um intervalo similar de $\mathrm{SiO}_{2}, \mathrm{ZrO}_{2}$ e $\mathrm{HfO}_{2}$ (0.9-1.8 wt\%), e são enriquecidos em Y e ETR pesados. A maioria dos cristais de todas as localidades estudadas parece provir de rochas félsicas com predomínio de fontes ricas em plagioclásio (ex., tonalitos e granodioritos). Algumas singularidades restritas a gabros também foram identificadas, como: forte anomalia positiva de Ce, altas razões $\mathrm{Lu}_{\mathrm{N}} / \mathrm{Sm}_{\mathrm{N}}$, baixas razões $\mathrm{U} / \mathrm{Yb}$, além da particular concavidade desenhada pelos elementos de terras raras intermediários, fruto da cristalização do zircão paralelamente a piroxênios.

O pico principal de zircões detríticos em torno de $2.2 \mathrm{Ga}$ é similar para todas as unidades de metarenitos amostrados dentro do Domínio São Roque, além de picos em comum em 2.5-2.4 Ga e 2.9-2.7 Ga. Teste estatístico K-S não exclui a possibilidade de todas as amostras terem sido depositadas por influxos terrígenos provindos da denudação de semelhantes áreas-fonte.

Com comportamento geoquímico similar a sedimentos de margem passiva depositados após a erosão de antigas fontes proterozóicas, como mostram o pico de zircões detríticos dos depósitos proximais da Formação Boturuna $(2.2 \mathrm{Ga})$ e os mais jovens cristais detríticos datados em $1.7 \mathrm{Ga}$, além das idades $\mathrm{T}_{\mathrm{DM}}$ entre 1.9 e $3.0 \mathrm{Ga}$ obtidas em sedimentos distais da Formação Piragibu, sugere um período de sedimentação mais jovem que $1.9 \mathrm{Ga}$. Provavelmente a deposição das duas Formações (Boturuna e Piragibu) aconteceu em tempo relativamente similar, com possível correlação lateral entre estas unidades. Entretanto, o comportamento de ETR dos metargilitos da Formação Piragibu somado a forte diminuição de Ce, é compatível com ambientes de abertura oceânica com restrita contribuição vulcanogênica, sugerindo então, um paleo-ambiente mais complexo, com interação entre margem passiva e restritos arcos de ilhas oceânicos. 
Agradeço ao Conselho Nacional de Pesquisa CNPq (Processo 143521/2008-0) e FAPESP (Processo 2012/04148-0), pelo financiamento desta Tese.

Agradeço ao Professor Valdecir de Assis Janasi por toda a dedicação dispensada ao longo de muitos anos de ensinamentos e trabalho. Sempre pronto para receber minhas idéias, apontando meus erros de uma forma tão particular sem nunca me chatear. Tenho muito respeito e admiração por você professor!

Poucas palavras não seriam suficientes para expressar toda minha gratidão por Bruna Borges Carvalho, pelo apoio diário para com a vida e para construção desta Tese.

Agradeço aos meus pais, irmãos e família, pelo apoio vital.

Agradeço de coração a muitos amigos, com participação efetiva na construção de idéias e corpo da Tese, são eles: Vinícius Tieppo Meira, Thaís Nogueira Hyppolito, Caue Rodrigues Cioffi, Brenda Chung da Rocha, Sarah Dare, Carlos E. Ganade de Araújo, Frederico Castro Jobim Vilalva, Alice Westin Teixeira, Bruno Boito Turra, Giovanni Belchior Basei.

Agradeço a todo o corpo técnico laboratorial do IGc-USP e da Universidade do Quebec em Chicoutimi, Canadá, em especial: Walter M. Sproesser, Dany Savard, Henrique, José Paulo Sertek, Ricardo, José Carlos, Vasco Antonio P. Loios, Marinês Lopes de Silva, Samuel (Samuca), Sadia , Ricardo Silva Cardenete, Paulo Ernesto Mori, Sandra Andrade.

Agradeço também a muitos professores pela ajuda indispensável a esta tese: Edward W. Sawyer, Lucelene Martins, André Oliveira Sawakuchi, Carlos Henrique Grohmann de Carvalho, Rogério Guitarrari Azzone, Adriana Alves, Miguel Angelo Stipp Basei, Renato Paes de Almeida, Silvio Roberto Farias Vlach, Renato Moraes, Colombo Celso Gaeta Tassinari, Sarah-Jane Barnes. 
Sumário

I.1. Introdução

I.2. Estrutura da Tese

3

I.3. Materiais e Métodos

1.3.1. Análises químicas em rocha total. 4

1.3.2. Análises isotópicas $\mathrm{Sm}-\mathrm{Nd}$ em rocha total ........................................................ 5

1.3.3. Separação e seleção de cristais de zircão ...................................................... 6

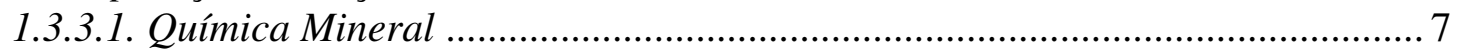

1.3.3.2. Datação U-Pb por LA-MC-ICPMS ............................................................... 8

I.3.4. Compilação, Digitalização e Integração de Mapas Geológicos ......................... 9

I.4. Principais Estudos sobre a Geologia do Grupo São Roque ........................................ 9

I.4.1. Posicionamento Tectônico Regional ................................................................... 9

I.4.2. Estratigrafia e Ambientes de Sedimentação ..................................................... 13

I.4.3. Geocronologia das Seqüências Supracrustais do Grupo São Roque ................ 25

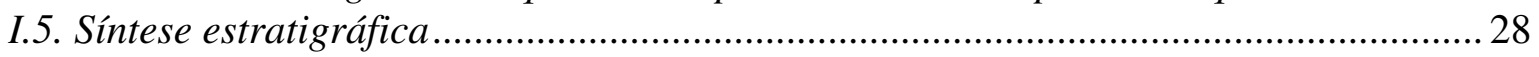

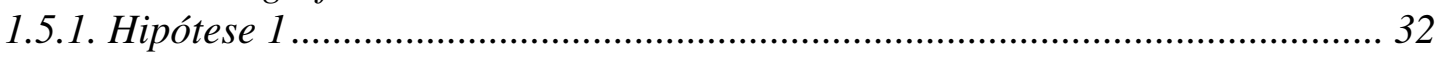

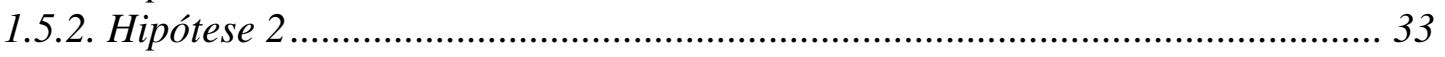

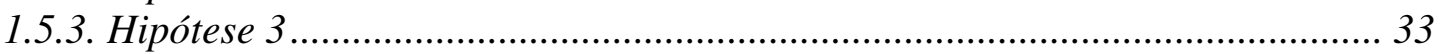

1.5.4. Hipótese Adotada ...................................................................................... 34

II. Análises de proveniência através do estudo de zircões detríticos ..................................... 35

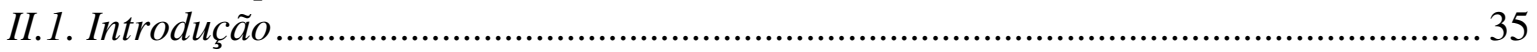

II.2. Composição química de zircões detríticos (LA-Q-ICP-MS) ..................................... 37

II.2.1. Aspectos texturais e químicos de sobrecrescimentos metamórficos pós-

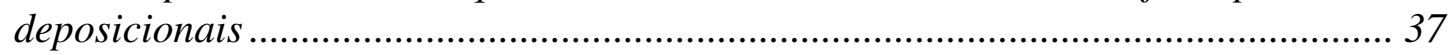

II.2.2. Química de zircões detríticos e inferências sobre as áreas-fontes................... 43

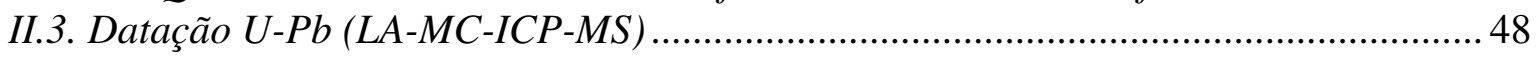

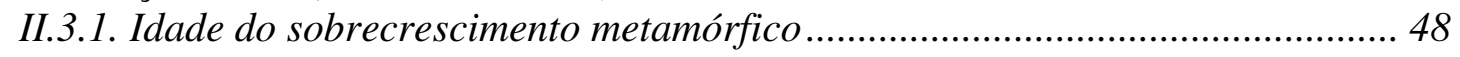

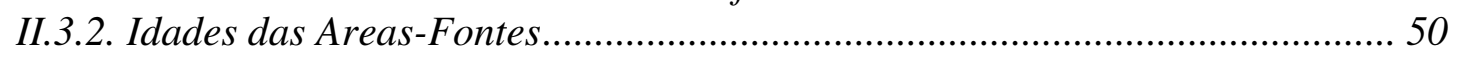

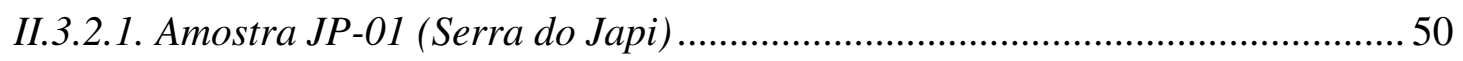

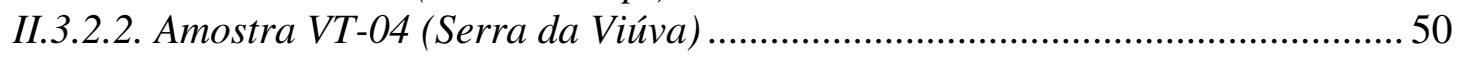

II.3.2.3. Amostra VT-03 (Serra do Voturuna) ........................................................... 51

II.3.2.4. Amostra JP-19 (Serra do Pirucaia) ............................................................. 51

II.3.2.5. Amostra PJ-1M (Pico do Jaraguá) ............................................................... 51

II.4. Síntese do Padrão de Proveniência do Domínio São Roque ........................................ 52

II.5. Comparação com padrões de proveniência em metassedimentos de faixas de dobramento vizinhas e avaliação sobre potenciais áreas-fonte ......................................... 56

II.5.1. Província Mantiqueira: Grupo Açungui e Faixa Ribeira............................... 56

II.5.2. Província Tocantins: Grupos Andrelândia, Araxá, Canastra e Supergrupo São

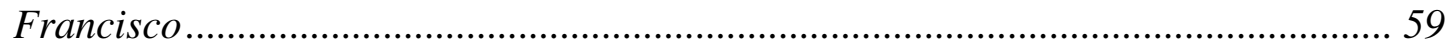

II.5.3. Cráton São Francisco x Paranapanema como potenciais áreas-fonte ............ 60

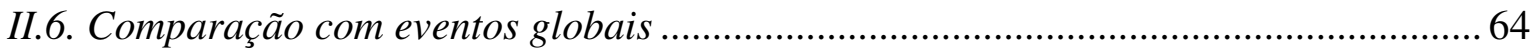

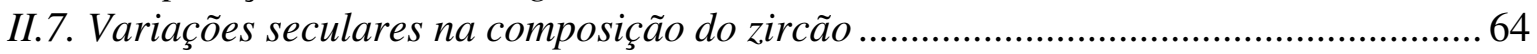

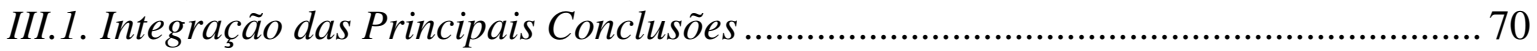

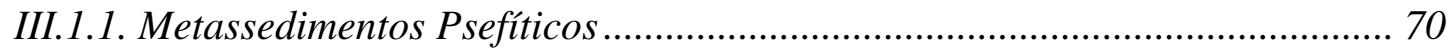

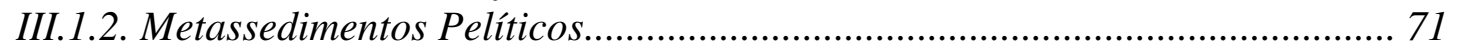

III.1.3. Metassedimentos Psamíticos ....................................................................... 72

III.1.4. Áreas-Fonte e Inferências sobre Ambientes Tectônicos................................. 74

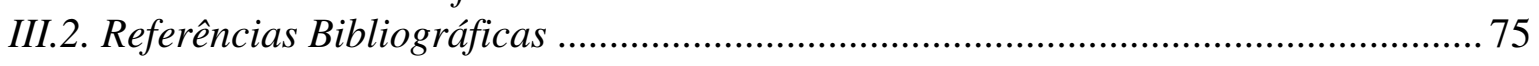




\section{I.1. Introdução}

Historicamente o primeiro agrupamento litoestratigráfico proposto para as seqüências metassedimentares no Estado de São Paulo encontra-se nos trabalhos de Oliveira (1887) e Gonzaga de Campos (1888), designadas “camadas de São Roque”. No Estado do Paraná estas sequiências foram identificadas por Derby (1878), e posteriormente denominadas Serie de Açungui (Oliveira, 1927), enquanto que no Estado de São Paulo, consagrou-se o nome Serie de São Roque a partir dos trabalhos de Moraes Rego (1930). Paoliello (1964), em nota explicativa do Mapa Geológico editado pelo Instituto Geográfico e Geológico em 1963, substitui o termo Serie São Roque por Grupo São Roque. No Estado do Paraná, o termo Serie Açungui também foi modificado para Grupo Açungui (Marini et al., 1967).

A idade de deposição e as correlações estratigráficas das sequiências supracrustais que compõem as faixas dobradas do sudeste do Brasil são temas ainda bastante controversos, em especial pelas dificuldades de datação absoluta. As determinações de idade feitas até o momento nessas seqüências baseiam-se normalmente na datação de rochas metavulcânicas, e não estão isentas de ambigüidades. Assim, por exemplo, a idade U-Pb em zircão de $1790 \pm 14$ Ma obtida para rochas metavulcânicas ácidas (Van Schmus et al., 1986) para o Grupo São Roque, foi questionada com base em trabalhos de petrografia nos quais supostos "metariodacitos" datados foram reinterpretados como metarcóseos por Juliani et al. (1997). Assim, por essa ótica, os zircões datados seriam detríticos, o que representaria a idade de uma das fontes, e não da sedimentação, como proposto para a base do Grupo São Roque a partir de zircões magmáticos. No entanto, estudos recentes confirmam a origem magmática destas rochas que foram reclassificadas como metatraquidacitos e metariolitos porfiríticos (HenriquePinto, 2008).

Já a idade admitida por Hackspacher et al. (1999) para a deposição do Grupo São Roque (608 \pm 7 Ma e $628 \pm 9$ Ma) baseia-se na datação U-Pb de zircão e monazita de rochas metavulcânicas básicas da região de Pirapora do Bom Jesus. Essas idades são contemporâneas à do magmatismo granítico cálcio-alcalino intrusivo no próprio Domínio São Roque e em terrenos adjacentes, o que levou os autores a admitirem a formação do Grupo São Roque em uma bacia de retro-arco continental. Tal sugestão motivou pesquisas que investigaram a possibilidade de que as fontes dos seixos graníticos nos metaconglomerados da porção inferior 
do Grupo São Roque correspondessem a granitos neoproterozóicos, o que não foi confirmado (Henrique-Pinto \& Janasi, 2007).

Mineralizações de $\mathrm{Pb}$ na Formação Perau no Vale do Ribeira, apresentaram idades $\mathrm{Pb}$ $\mathrm{Pb}$ em galena entre 1,7 e 1,5 Ga (Tassinari et al., 1990), e posteriormente idades $\mathrm{U}-\mathrm{Pb}$ em zircão mais precisas foram obtidas em anfibolitos das Formações Perau (1484 \pm 16 Ma) e Votuverava (1479 \pm 12 Ma) (Basei et al., 2003; Siga Jr. et al., 2011), que se mostram cronocorrelatas à Formação Água Clara (Weber et al., 2004). Este intervalo levou Siga Jr. et al. (2011) a correlacionarem com a Formação Morro da Pedra Preta, tida como unidade basal do Grupo Serra do Itaberaba (Domínio São Roque), com datação U-Pb em zircão de metandesito em $1395 \pm 10$ Ma (Juliani et al., 2000).

Considerando as ambigüidades ainda presentes na literatura, esta tese toma proveito de novas técnicas aplicadas à análise de proveniência, bem como estudos clássicos na caracterização da associação de minerais pesados (e.g., Pettijohn 1941; Hubert, 1962), procurando aplicar técnicas tradicionais, como por exemplo, geoquímica de rocha total (FRX e ICPMS), análises de zircões detríticos utilizando a química de elementos maiores, determinados via microssonda eletrônica, além de dados mais refinados, combinando datações U-Pb em zircões detríticos obtidas através de LA-MC-ICPMS e química dos mesmos cristais, determinada com LA-Q-ICPMS.

Os três pilares desta tese se baseiam no estudo de proveniência com investigação dos metassedimentos de caráter psefítico, psamítico e pelítico, através do estudo geoquímico e isotópico dos clastos graníticos dos metaconglomerados da Formação Boturuna, que permite o acesso direto a algumas das principais rochas-fonte; o estudo geoquímico de metarenitos e metawakes, com ênfase na datação e química de zircões detríticos, que permitiram a caracterização de fontes diversas amarradas às idades; além do estudo geoquímico vinculado à sistemática isotópica $\mathrm{Sm}-\mathrm{Nd}$ de metasiltitos/metargilitos, que juntamente com o espectro de zircões detríticos solidificam as idéias sobre a idade máxima de sedimentação, permitindo um amplo acesso às composições das áreas fontes através de componentes de misturas, gravados no registro sedimentar. 


\section{I.2. Estrutura da Tese}

As primeiras atividades desenvolvidas consistiram na transformação de parte do volume de informações obtidas durante o trabalho de Mestrado (Henrique-Pinto, 2008), no qual se abordava tema semelhante com o estudo de parte do Grupo São Roque, em um artigo publicado na Revista Brasileira de Geociências (Metaconglomerados e Rochas Associadas do Grupo São Roque a Norte da Cidade de São Paulo, Brasil ; Henrique-Pinto \& Janasi, 2010 Apêndice I) e outro publicado na Revista Geologia USP (Paleoproterozoic source contributions to the São Roque Group sedimentation: LA-MC-ICPMS U-Pb dating and Sm-Nd systematics of clasts from metaconglomerates of the Boturuna Formation; Henrique-Pinto et al., 2012 - Apêndice II). Parte do texto que serviu como preparação para estes artigos foi apresentado oralmente no X Congresso de Geoquímica dos Países de Língua Portuguesa nos dias 28 de março a 1 de abril de 2010 na Faculdade de Ciências da Universidade do Porto Portugal.

A redação da tese segue as formalidades propostas pela Associação Brasileira de Normas Técnicas (ABNT), conforme sugerem as diretrizes para apresentação de dissertações e teses da Universidade de São Paulo (Funaro et al., 2009).

O Capítulo I consiste em uma apresentação ao tema, caracterização dos métodos e equipamentos utilizados, uma breve revisão bibliográfica que discute as propostas de estratigrafia e ambientes de sedimentação, além dos principais dados isotópicos disponíveis na literatura.

O Capítulo II aborda questões de proveniência com foco na química e datação de zircões detríticos de rochas metapsamíticas, já organizadas sob a forma de artigo científico a ser submetido em versão para o inglês (Henrique-Pinto et al., em preparação - Chemistry and $U$-Pb dating of detrital zircons from São Roque Domain: provenance and implications for the evolution of part of Precambrian crust).

O Capítulo III faz a integração dos textos submetidos a periódicos científicos, em preparação para submissão e publicados em periódicos científicos (com tradução para a língua portuguesa quando necessário) e inclui também, o item de referências bibliográficas, que compreende todas as citações da tese, com exceção as referências mais antigas que constam no Anexo I. 
Apêndice III (Provenance and sedimentation environments of the São Roque Group, Brazil: contributions from petrography, geochemistry and Sm-Nd isotopic systematics of metasediments): manuscrito que aborda questões de proveniência e ambiência tectônica usando elementos da química de rocha, submetido para publicação.

Anexo I (Histórico do Conhecimento Geológico sobre o Pré-Cambriano Paulista até o ano de 1955): manuscrito de revisão histórica, que relata importantes e pioneiras descobertas vinculadas ao Grupo São Roque. Texto submetido para publicação na revista Terrae Didatica da Universidade de Campinas, São Paulo. (Henrique-Pinto \& Janasi, 2012 - submetido).

Anexo II (Fotos de Campo): inclui fotos representativas de locais de coleta de amostras e estudos geológicos pormenorizados.

Anexo III (Fotomicrografias): inclui fotomicrografias de secções delgadas, principalmente de amostras utilizadas nos manuscritos da tese.

Anexo IV (Zircões): inclui quadro detalhado de todos os zircões analisados por diversos métodos, sobrepostos a imagens de elétrons retro-espalhados e catodoluminescência.

Anexo V (Tabelas): inclui tabelas com principais feições de campo, resultados de análises químicas de rocha total obtidas via FRX e ICPMS, além de resultados de análises químicas obtidas em zircões detríticos via LA-Q-ICPMS e análises U-Pb (zircões detríticos) obtidas via LA-MC-ICPMS.

Anexo VI (Mapa Geológico Integrado): inclui mapa litológico fruto da extensa integração de mapas compilados de IPT (1983), Dantas (1990), Bergmann (1988), Juliani (1993), Andrade (1993), Neves (2005) e Serviço Geológico do Brasil - CPRM (2006).

\section{I.3. Materiais e Métodos}

\subsubsection{Análises químicas em rocha total}

O tratamento das amostras se deu no Laboratório de Tratamento de Amostras (LTA) do $I G c-U S P$, envolvendo as etapas de fragmentação de amostras representativas em britador de mandíbulas de aço até a fração grânulo, seguida do quarteamento em quarteador do tipo Jones. A moagem na fração granulométrica de argila foi feita utilizando moinho de disco de ágata, na intenção de evitar sensíveis contaminações. As chances de um possível "efeito de matriz" provocado pela compressão mecânica durante o pastilhamento, como a orientação de 
filossilicatos em estratos horizontais, foram reduzidas com a utilização de micronizadores de ágata.

As amostras selecionadas para as análises químicas foram tratadas no laboratório de geoquímica analítica Instituto de Geociências, Universidade de São Paulo (Geoanalitica Core Research Center). A concentração de elementos traços foi determinada através do material previamente pulverizado compactado em forma de pastilhas prensadas, já a concentração de elementos maiores através da fusão do material previamente pulverizado seguido de vitrificação em forma de pastilha fundida. Elementos maiores e traços foram quantificados através de espectrometria de fluorescência de raios-X (FRX) seguindo o protocolo analítico descrito por Mori et al. (1999).

Elementos de terras raras e outros elementos traços com baixos teores (tipicamente < $100 \mathrm{ppm}$ ) foram quantificados usando espectrometria de massa com plasma acoplado (ICPMS - Perkin Elmer Plasma Quadrupole MS ELAN 6100DRC), seguindo o protocolo analítico descrito por Navarro et al. (2002). As amostras foram dissolvidas em bombas do tipo Parr, sob altas temperaturas $\left(\sim 200^{\circ} \mathrm{C}\right)$ em forno microondas, por aproximadamente cinco dias, com a intenção de garantir a dissolução completa de minerais ultra-estáveis (ex., zircão). A partir de $100 \mathrm{mg}$ de amostra, adicionou-se $5 \mathrm{~mL}$ de $\mathrm{HNO}_{3}$ destilado e $15 \mathrm{ml}$ de $\mathrm{HF}$ destilado. Após três etapas de secagem em chapa elétrica (eliminação de HF) as amostras foram avolumadas para 100ml. Os padrões usados para o controle de qualidade analítico do método ICPMS provêm do Centre de Recherches Pétrographiques et Géochimiques (BR - basalto, Govindaraju (1995)) e Geological Survey do Japan (JGb-1 - gabro, Imai et al., 1995). Os resultados obtidos tanto por FRX como ICPMS são reportados no Anexo V.

\subsubsection{Análises isotópicas $\mathrm{Sm}$-Nd em rocha total}

As análises isotópicas $\mathrm{Sm}-\mathrm{Nd}$ foram realizadas no Centro de Pesquisas Geocronológicas (CPGeo), Instituto de Geociências, Universidade de São Paulo, seguindo os procedimentos descritos por Sato et al. (1995). As amostras foram dissolvidas em bombas sob temperaturas de $\sim 160^{\circ} \mathrm{C}$ durante um período de dez dias. Para as etapas de separação isotópica foram empregadas convencionais colunas de troca catiônica, preenchidas com resina tipo AG 50 (200-400 mesh), utilizando água e HCL em concentrações variáveis. 
A razões isotópicas de $\mathrm{Nd}$ foram quantificadas através de espectrometria de massa (multi-coletor Finnigan MAT-262), enquanto as de Sm foram obtidas usado espectrômetro de massa com coletor simples (VG-354). Os valores médios obtidos para os padrões La Jolla e $B C R-1$ no período de 1 ano, foram $0.511849 \pm 0.000025$ e $0.512662 \pm 0.000027$, respectivamente. Os erros médios foram de $0.09 \%$ para a razão ${ }^{147} \mathrm{Sm} /{ }^{144} \mathrm{Nd}$ e \pm 0.00002 para a razão ${ }^{143} \mathrm{Nd} /{ }^{144} \mathrm{Nd}$ (com nível de precisão de $2 \sigma$ ). Os cálculos foram assumidos para o $\varepsilon N d$ presente no reservatório condrítico uniforme (CHUR) para as razões de ${ }^{143} \mathrm{Nd} /{ }^{144} \mathrm{Nd}=0.512638 \mathrm{e}{ }^{147} \mathrm{Sm} /{ }^{144} \mathrm{Nd}=0.1967$. A constante de decaimento usada foi de $6.54 \mathrm{x}$ $10^{-12} \operatorname{anos}^{-1}$. Os cálculos das idades modelo $\left(\mathrm{T}_{\mathrm{DM}}\right)$ foram obtidos utilizando o método de DePaolo (1988).

\subsubsection{Separação e seleção de cristais de zircão}

O tratamento das amostras se deu no Laboratório de Tratamento de Amostras do IGc$U S P$, envolvendo as etapas de fragmentação de amostras representativas em britador de mandíbulas de aço até a fração grânulo, seguida de moagem em moinho de disco de tungstênio. Os concentrados foram obtidos no Laboratório de Separação Mineral do IGcUSP, segundo procedimento padrão de:

- peneiramento na fração areia muito fina $(0,0625-0,125 \mathrm{~mm})$ e areia fina $(0,125$ $0,25 \mathrm{~mm})$

- separação mineral por diferença de densidade, através do uso de mesa vibratória (Wiffle) e líquidos densos (bromofórmio e iodeto de metileno).

Após a montagem de lâminas de grãos pesados usando bálsamo do Canadá, para o estudo petrográfico de minerais detríticos a partir de luz transmitida em microscópios Zeiss Axioplan, os concentrados foram submetidos a processo de separação usando propriedades magnéticas em separador do tipo Frantz, com coleta de zircões das frações não magnéticas a 1,0 A. A escolha dos cristais foi feita de maneira aleatória para garantir o maior número de populações possíveis. Posteriormente esses cristais foram colocados em montagens feitas em resina (araldite), que foram então polidas manualmente até expor os grãos.

Imagens dos cristais de zircão foram obtidas no Laboratório do CPGeo - USP através de microscópio eletrônico de varredura (SEM- FEI model) operado a $15 \mathrm{Kv}$ com $5 \mu \mathrm{m}$ de feixe, 
além de imagens geradas por catodoluminescência a partir de detector CENTAURUS. Este estudo permitiu a identificação de zoneamentos internos e o realce de feições como inclusões e fraturas dos grãos, possibilitando que elas fossem evitadas quando da escolha das posições de incidência do feixe de laser, durante as análises por LA-ICPMS.

\subsubsection{Química Mineral}

A química de cristais de zircão foi obtida através de ablação a laser em espectrômetro de massa quadrupolo com fonte de plasma induzido (LA-Q-ICPMS, Agilent Technologies 7700 series Resolution M-50) no laboratório LabMaTer (Laboratoire des matériaux terrestres) do Departamento de Ciências Aplicadas da Université du Québec à Chicoutimi (UQAC), Canadá. A calibração externa foi feita utilizando o padrão NIST-610 (Norman et al., 1998); já para a calibração interna optou-se pela utilização do Hf (padrão interno), pois este elemento provou ser mais favorável para a reprodução dos dados, quando comparados aos teores quantificados previamente através de microssonda eletrônica e micro fluorescência de raios-X (micro-XRF). As aquisições e reduções dos dados foram trabalhadas utilizando software Iolite 2.2 (Paton et al., 2011) e os resultados são reportados no Anexo V.

Imagens composicionais foram produzidas por ablação a laser de uma série de transectos paralelos, cujos dados são então combinados digitalmente. Na produção de imagens elementares por LA-ICP-MS, uma das considerações mais importantes para a obtenção de apropriada resolução, é a combinação do tamanho do ponto e a taxa de translação (Woodhead et al., 2007). A área analisada para a maioria dos cristais de zircão é de cerca de $0,20 \times 0,15$ milímetros e as imagens foram produzidas a partir de um intervalo de 9 a 13 linhas paralelas (sem haver espaçamento entre elas), dependendo da variação da dimensão dos cristais. $\mathrm{O}$ comprimento total de faixas é cerca de $0,1 \mathrm{~mm}$ (ex., 11 linhas paralelas), com uma taxa de translação de fase de $3 \mu \mathrm{m} / \mathrm{s}$, o que representa cerca de 10 minutos de tempo de aquisição. $\mathrm{O}$ diâmetro do feixe de laser utilizado foi de $11 \mu \mathrm{m}$ com frequiência de $15 \mathrm{~Hz}$, a $5 \mathrm{~mJ}$ de energia/pulso, com velocidade de $5 \mu \mathrm{m} / \mathrm{s}$ de deslocamento.

Análises por micro fluorescência de raios- $\mathrm{X}$ foram obtidas através do equipamento Edax EAGLE III da Université du Québec à Chicoutimi (UQAC) utilisando tubo Rh e poli 
capilaridade com janela de área de 1.7 por $1.3 \mathrm{~mm}$ (64 por 50 pixels), com feixe operado a 20 $\mathrm{kV}$ e $200 \mu \mathrm{A}$. O aparelho combina rápidas e não-destrutivas análises elementares usando energia dispersiva de fluorescência de raios-X (EDXRF) com a capacidade de amostragem de pontos com diâmetros menores que $50 \mu \mathrm{m}$. Elementos com massas que variam de $\mathrm{Na}$ até $\mathrm{U}$ podem ser analisados semi-quantitativamente, com limites de quantificação variando de porcentagens para níveis em ppm; os elementos de número atômico menor que 11 são mais difíceis de analisar.

Os elementos maiores foram obtidos na Universidade de Laval na cidade de Quebec, Canadá, utilizando microssonda eletrônica CAMECA SX-1000. Algumas anomalias previamente identificadas via micro-XRF serviram como guia para a locação dos pontos durante as análises de microssonda. A configuração da aceleração de voltagem utilizada foi de $15 \mathrm{kV}$ com corrente de $20 \mathrm{nA}$ e feixe de $5 \mu \mathrm{m}$ de diâmetro.

\subsubsection{Datação U-Pb por LA-MC-ICPMS}

As determinações isotópicas U-Pb foram realizadas no Centro de Pesquisas Geocronológicas (CPGeo) do Instituto de Geociências da Universidade de São Paulo. As análises foram obtidas por de ablação a laser em espectrômetro de massa multicoletor Neptune com fonte de plasma induzido (LA-MC-ICPMS). O espectrômetro tem analisador de energia (ESA - electrostatic analyser) e analisador de massa via setor magnético. O sistema de detecção do equipamento contém 9 detectores Faraday (L4, L3, L2, L1, C, H1, H2, H3 e H4, sendo que 8 são móveis e o central C é fixo), 6 multicontadores iônicos (MIC) e 1 multicontador de elétrons secundários.

Foi analisado um total de 361 pontos em zircões detríticos, sendo que 61 analises foram excluídas da regressão por apresentarem idades com mais que 5\% de discordância. As idades são reportadas em termos da razão ${ }^{207} \mathrm{~Pb} /{ }^{206} \mathrm{~Pb}$ para cristais mais velhos que $1.4 \mathrm{Ga}$ (Anexo V).

A exatidão e a precisão das análises foram validadas com determinações em zircão padrão GJ-1. O feixe de $19 \mu \mathrm{m}$ permitiu análises em núcleos e bordas na maioria dos zircões, o que resultou em sinais com intensidades adequadas de $\mathrm{U}$ e $\mathrm{Pb}$, permitindo a locação do laser 
em regiões cristalográficas livres de fraturas e inclusões. Todos os dados foram tratados utilizando os softwares Microsoft Excel e Isoplot 3 (Ludwig, 2003).

\section{I.3.4. Compilação, Digitalização e Integração de Mapas Geológicos}

As bases referentes à cartografia geológica a norte da cidade de São Paulo foram compiladas do mapa geológico publicado pelo Instituto de Pesquisas Tecnológicas do Estado de São Paulo (IPT, 1983) produzido na escala 1: 50.000 com base topográfica vinculada à Folha Santana do Parnaíba de mesma escala, e do trabalho de Dantas (1990), vinculado à base topográfica da Folha Guarulhos, também na escala 1: 50.000. A compilação de folhas vizinhas foi feita utilizando o trabalho de Neves (2005) responsável por uma integração prévia das folhas 1: 50.000- Atibaia, Jundiaí, Indaiatuba e parte das folhas Cabreúva, Itu e Salto. Trabalhos em escala ampliada (1: 25. 000) foram compilados de Bergmann (1988), referente à região de Santana do Parnaíba, e Juliani (1993) referente à região da Serra do Itaberaba.

Todos estes mapas foram digitalizados usando software ArcGis 9.2, e sobre eles foram inseridos os pontos com as informações obtidas no campo (perfis localizados). A integração geológica foi feita preferencialmente a partir dos dados de campo obtidos nesta tese. Em áreas não visitadas foi, a princípio, dada preferência aos mapas em maior escala (e.g., mapas compilados de Bergmann, 1988 e Juliani, 1993). Para os casos em que não havia correspondência de unidades mapeadas em mapas de mesma escala, usou-se o critério de extrapolação, para ambos os mapas, de unidades que ocupam espaços geometricamente maiores, em concordância com as estruturas geomorfológicas obtidas via imagem SRTM e com as unidades geológicas extraídas da base cartográfica digital do Serviço Geológico do Brasil - CPRM (2006) (Anexo VI).

\section{I.4. Principais Estudos sobre a Geologia do Grupo São Roque}

\section{I.4.1. Posicionamento Tectônico Regional}


Moraes Rego (1931) chamou de Pré-Brasilides as estruturas que se anexaram a escudos arqueanos para dar origem à "grande molhe continental chamada Brasilia". No Brasil, a fragmentação dessa grande massa continental em grande evento tafrogênico do período Estateriano resultou na geração de algumas bacias oceânicas, com sedimentação provavelmente iniciada ao final do Paleoproterozóico (Brito Neves et al., 1995).

Na Província Estrutural Mantiqueira (Almeida et al., 1981), o Domínio São Roque é um bloco tectônico localizado entre rochas de alto grau metamórfico a norte (SocorroGuaxupé Nappe, atualmente interpretado como parte do ramo sul - meridional da Faixa de Dobramentos Brasília), e o Domínio Embu a sul, que está relacionado com a Faixa de Dobramentos Ribeira. No modelo tectônico de Campos Neto (2000), o Grupo São Roque faz parte de um grande bloco dominado por seqüências meta-vulcano sedimentares que apresentam de baixo a médio grau de metamorfismo (Domínio Apiaí-São Roque), que juntamente com as rochas relacionadas ao Domínio Socorro-Guaxupé, correspondem a um arco magmático desenvolvido as margens de um antigo núcleo cratônico, que em grande parte encontra-se por baixo de sedimentos fanerozóicos da Bacia do Paraná (Craton do Paranapanema - Mantovani \& Brito Neves, 2005; De Wit et al., 2008 - Figura I-1).

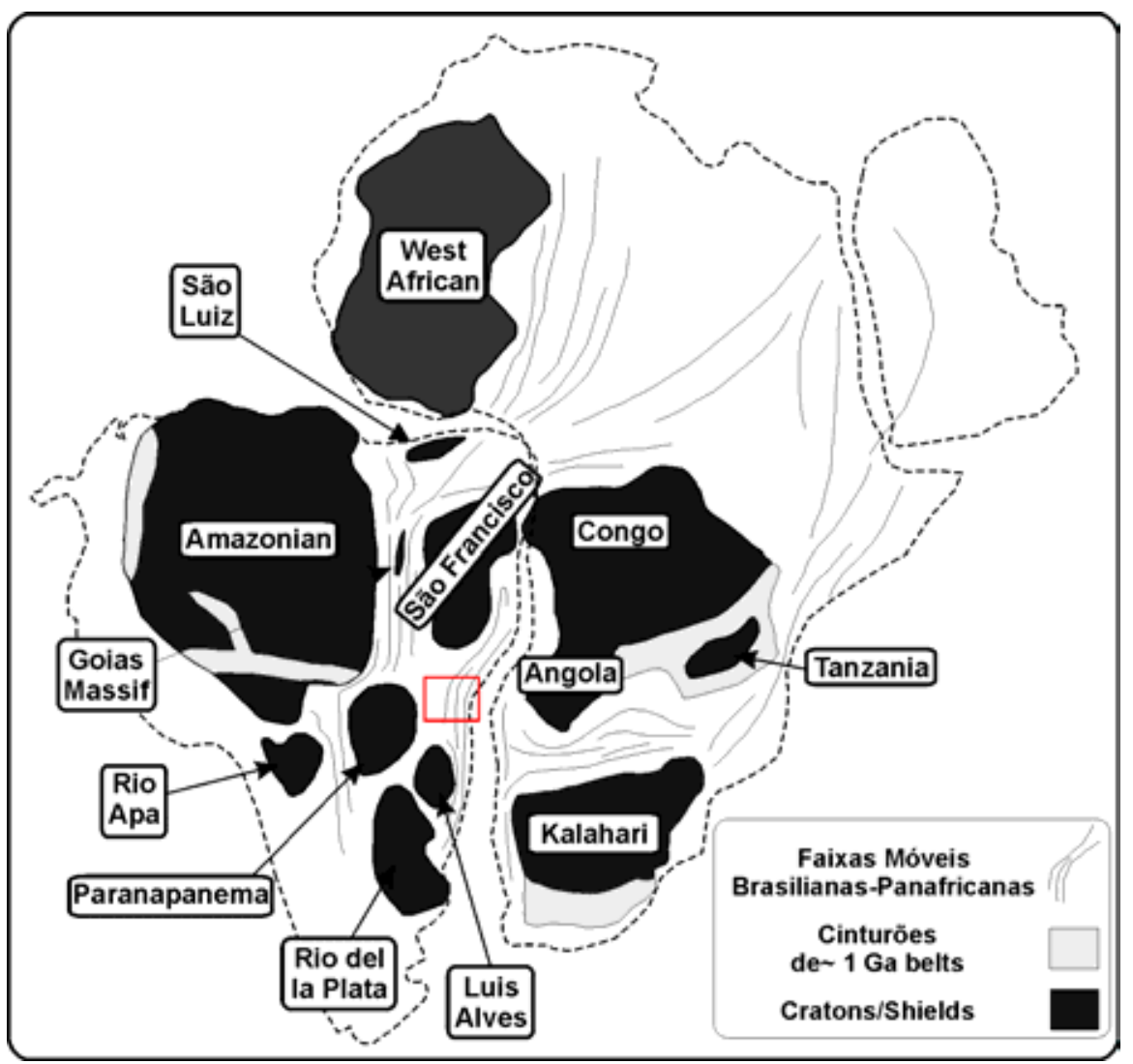


Figura I-1: Visão moderna do Gondwana ocidental durante o Paleozóico intermediário com fragmentos de escudos cratônicos representando massas continentais pré-existentes, além de assembléias de cinturões orogênicos formados durante no ciclo Pan-Africano/Brasiliano (modificado de De Wit et al., 2008).

Hennies et al. (1967) propuseram que o Falhamento de Taxaquara corresponde a um importante limite com um rejeito transcorrente destral "superior a 100 km", que confrontaria dois blocos de constituição litológica e estrutural distintas designados "Bloco Cotia" a sul, e a norte o Bloco São Roque. O Bloco Cotia inclui "rochas ectiníticas e migmatíticas", posteriormente separadas por Hasui (1975) em Complexos Pilar e Embu, respectivamente. Trabalhos recentes (e.g., Campos Neto, 2000) têm demonstrado que a Falha de Caucaia (Figura I-2) subdivide o Bloco Cotia em duas porções, e pode corresponder a um limite tectônico de ordem maior, separando a Faixa de Dobramentos Ribeira sensu strictu a sul (localmente representada pelo Domínio Embu) e a borda retrabalhada do Cráton Paranapanema a norte (região de afloramento do "Complexo Ectinítico Pilar" e do Batólito Granítico Agudos Grandes).

A zona de falhamento transcorrente de Jundiuvira (Figura I-2) foi também caracterizada por uma descontinuidade limítrofe entre blocos, definindo o limite norte do Bloco São Roque, e separando-o do Bloco Jundiaí, onde predominam rochas de mais alto grau metamórfico (Hasui et al., 1969). As rochas metassedimentares da região da Serra do Japi que ocorrem a norte da Falha de Jundiuvira foram incluídas por Wernick (1976) no Grupo Amparo, e divididas em membros pelíticos (Formações Ermida) e psamo-pelíticos (Formação Japi). Nesse sentido, como também proposto por Hasui et al. (1978), elas não teriam continuidade com as rochas do Grupo São Roque. Observa-se, contudo, que nos estudos iniciais dedicados aos quartzitos da Serra do Japi, eles foram comparados aos do morro do Voturuna e Jaraguá (Grupo São Roque) (Moraes, 1944). 
O extenso magmatismo granítico do Domínio Apiaí-São Roque, é caracterizado por Campos Neto (2000) como um arco magmático desenvolvido na margem do cráton Paranapanema. Predominam granitos cálcio-alcalinos potássicos neoproterozóicos, que constituem a massa principal de três extensos batólitos alongados na direção NE-SW (Cunhaporanga, Três Córregos e Agudos Grandes). Inúmeros plútons isolados, incluindo as principais intrusões no Domínio São Roque, devem constituir satélites dessas grandes massas graníticas, tendo em vista as semelhanças composicionais e de idade (Janasi \& Ulbrich, 1991).

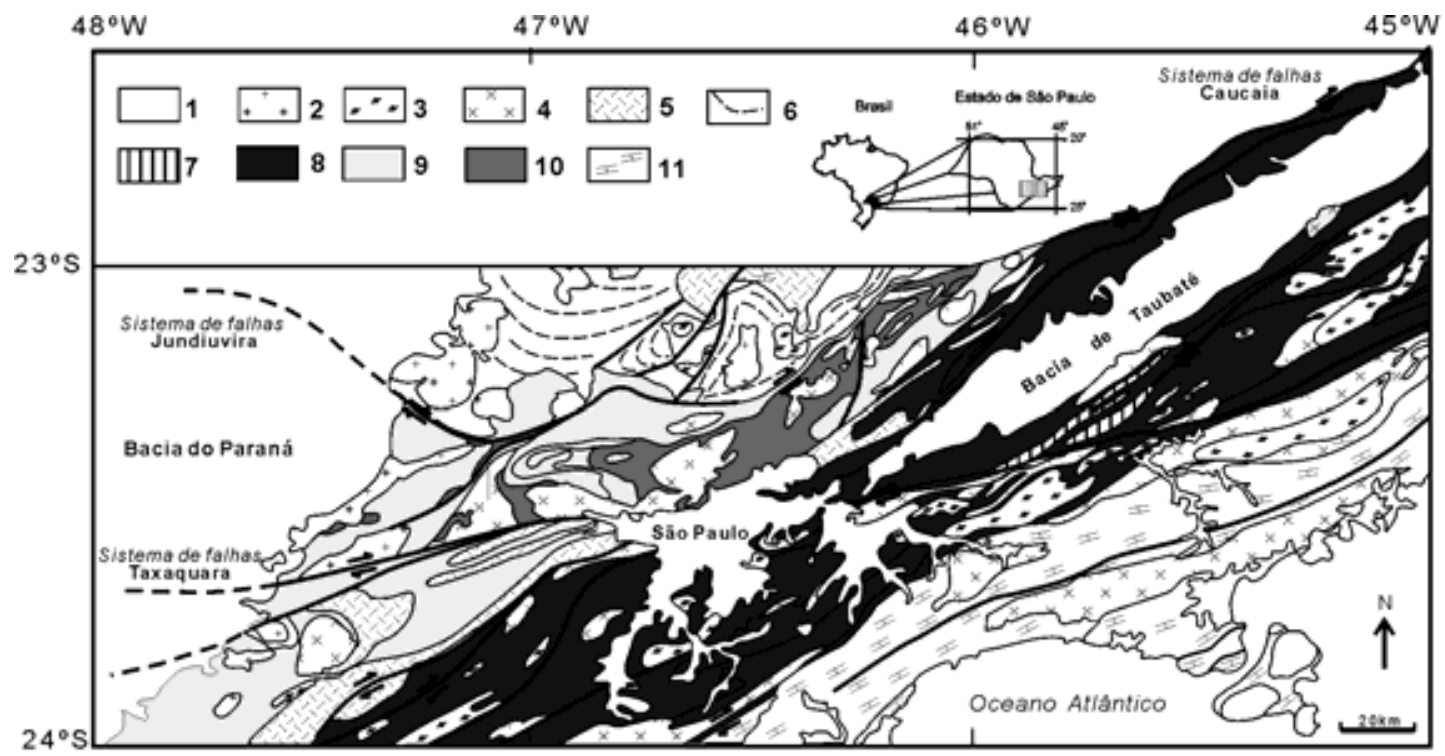

Figura I-2: Mapa regional modificado de Campos Neto (2000). 1- Rochas Fanerozóicas sedimentares e rochas intrusivas Mesozóicas (Bacia do Paraná); 2- Granitos do Neoproterozóico tardio e granitos pós-orogênicos; 3- (Granada)-(Muscovita)-Biotita granitos; 4- Biotita granitos porfiríticos; 5(Hornblenda) Biotita granitos porfiríticos; 6- Domínio Socorro-Guaxupé (com predomínio de granada migmatitos); 7 e 8- Domínio Embu: gnaisses do embasamento Paleoproterozóico (7); rochas metasupracrustais (8); 9- Domínio Apiaí-São Roque: Grupos São Roque e Açungui; 10- Grupo Serra do Itaberaba; 11- Complexo Costeiro. 


\section{I.4.2. Estratigrafia e Ambientes de Sedimentação}

"Consideramos agora as formações, distinctas do complexo archeano, que se encontram abaixo da formação glacial e do devoniano" (Moraes Rego, 1930).

A primeira proposta estratigráfica para o sudeste brasileiro encontra-se nos estudos de Derby (1878), e cabem bem as palavras de Moraes Rego. O termo "serie de São Roque" é, segundo Moraes Rego (1930), pioneiramente introduzido na geologia paulista por Gonzaga de Campos, que já em 1888 escrevia sobre as "camadas de São Roque”, formadas pela série de "schistos metamorphicos", definidos por Oliveira (1887) (Anexo I).

O conceito de Série, segundo o Código Brasileiro de Nomenclatura Estratigráfica (Petri et al., 1986a), não representa um conjunto de unidades litoestratigráficas, e sim de unidades cronoestratigráficas (que geocronologicamente representa uma Época). Recomenda-se então (NACSN, 2005; Petri et al., 1986b) a substituição do termo Série, para Grupo ou Supergrupo.

Muitos autores que correlacionam às rochas metamórficas do Estado do Paraná com as do Estado de São Paulo priorizam o termo "serie de Assunguy" (Oliveira, 1925; Coutinho, 1968a; Coutinho, 1968b), atribuindo a Derby (1878) a introdução deste termo na literatura, o que de fato não ocorreu, pois Derby (1878) apenas referia-se à "região de Assunguy".

Gonzaga de Campos (1888) ao referenciar as "camadas de São Roque" (camada: unidade formal de menor hierarquia na classificação litoestratigráfica (Petri et al., 1986a)), compostas pela Série de "schistos metamorphicos", calcários magnesianos, granitos com anfibólio, xistos e gnaisses, pioneiramente introduz um termo litoestratigráfico para estas rochas, que, por geograficamente ocorrerem na região da Serra de São Roque, receberam tal denominação. Estas são separadas em dois grupos: o mais metamorfisado, chamado de "schistos micaceos", e o que menos o é, dos "schistos argillosos" (ver Anexo I).

Uma das primeiras propostas para o paleo-ambiente sedimentar, admitindo uma origem marinha para as series metamórficas de São Roque, foi sugerida por Moraes Rego (1933). Tais considerações foram seguidas por Almeida (1944) que encontrou em Itapeva, no Estado de São Paulo, quartzitos com estratificações que exibem marcas com "característica do refluxo das ondas em praias de areias finas", recobertos por filitos que se intercalam com espessos 
pacotes dolomíticos, contendo em seus horizontes mais altos as estruturas organógenas, caracterizadas como do gênero Collenia itapevensis sp. $n$..

Para Almeida (1957) os gnaisses, xistos e quartzitos da Serra do Mar se encontram sobrepostos, após um período de erosão, pelos sedimentos da Série de São Roque, fato atestado, segundo Coutinho (1955), pela presença de seixos de quartzitos, encontrados nos metaconglomerados basais, cuja sedimentação se deu "em profundidade" sob condições marinhas (Odman, 1955).

Semelhantes à estratigrafia de Coutinho (1955) são as propostas de Cordani et al. (1961) para a geologia da região do Jaraguá, que contempla uma unidade inferior de metarcóseos com metaconglomerados seguidos pela deposição de "grauvacas", descritos como depósitos marinhos de grande profundidade gerados por correntes de turbidez.

Paoliello (1964), em nota explicativa do Mapa Geológico editado pelo Instituto Geográfico e Geológico em 1963, substitui o termo Série São Roque para Grupo São Roque, posicionado no Pré-cambriano superior. Já no Estado do Paraná, o termo Série Açungui, também foi modificado para Grupo Açungui (Marini et al., 1967).

O Grupo Açungui, segundo Marini et al. (1967), representa uma seqüência do PréCambriano superior, com "mais de $10.000 \mathrm{~m}$ de metassedimentos", que estariam representados na base pela Formação Setuva, separada por discordância litológica e angular das Formações Capiru, Votuverava (Bigarella et al., 1958) e Água Clara (Marini et al., 1967).

A Formação Capiru (Bigarella et al., 1958) é comparada à Formação Itaiacoca, que contém as estruturas "organógenas" descritas por Almeida (1944; 1945 e 1957). Ambas são compostas predominantemente por dolomitos, quartzitos e secundariamente por filitos. Já a Formação Votuverava é considerada a unidade litoestratigráfica mais espessa (Marini et al., 1967), com aproximadamente 3.500 metros, sendo composta predominantemente por filitos, quartzitos, metaconglomerados e calcários. Assenta-se em "aparente discordância" sobre a Formação Votuverava a Formação Água Clara, definida por Marini et al. (1967) como um pacote de rochas calcárias impuras que ocupam o topo do Grupo Açungui.

Petri \& Suguio (1969) atribuem uma possível correlação lateral entre as formações Votuverava, Capiru (Bigarella, 1958) e Itaiacoca (Almeida, 1957). Porém quanto às formações Capiru e Itaiacoca (que contêm os horizontes fossilíferos), Petri \& Suguio (1969) preferem não juntá-las em uma mesma formação, devido às diferenças litoestratigráficas, e ao 
afastamento geográfico entre elas. Diferenças quanto ao conteúdo fossilífero são apontadas por Fairchild (1977) ao identificar formas distintas de estromatólitos, formados sob condições calmas (sub-litorais) na Formação Itaiacoca (ex: Conophyton cf. C. garganicum), e formados em ambiente mais energético (planície de maré) na Formação Capiru.

Coutinho $(1968,1971)$ retoma a proposta de continuidade geográfica entre os Grupos São Roque e Açungui, nos Estados de São Paulo e Paraná, respectivamente. Segundo Coutinho (1971), a unidade mais extensa que aflora continuamente "desde o Paraná até o nordeste da Capital de São Paulo", corresponderia à Formação Votuverava (Bigarella et al., 1958), onde predominam filitos secundados por calcários, quartzitos e conglomerados, depositados em ambiente marinho de águas relativamente rasas e movimentadas.

Hasui (1973) mantém a proposta de correlação entre as unidades de São Paulo e Paraná, distinguindo-as apenas no padrão deformacional. A seqüência terrígena inferior, composta por metapelitos com intercalações lenticulares metapsamíticas, sotoposta a um pacote de metapelitos com intercalações de metacalcários, e uma sequiência superior de metapelitos e meta-psamitos com estruturas rítmicas, cuja deposição se daria em um ambiente de sedimentação tido sob condições marinhas, permitiram a subdivisão do Grupo São Roque em duas unidades: a Formação Boturuna (seqüência inferior), e a Formação Piragibu (seqüência superior) (Hasui, 1973 e Hasui et al., 1976, ver coluna estratigráfica 1 e 2 na Figura I-3). Mesmo admitindo semelhanças metamórficas e de idades, Hasui (1975), Hasui et al. (1976) e Hasui \& Sadowski (1976), preferiram manter os Grupos São Roque e Açungui como dois "tectonogrupos" estratigraficamente distintos. 


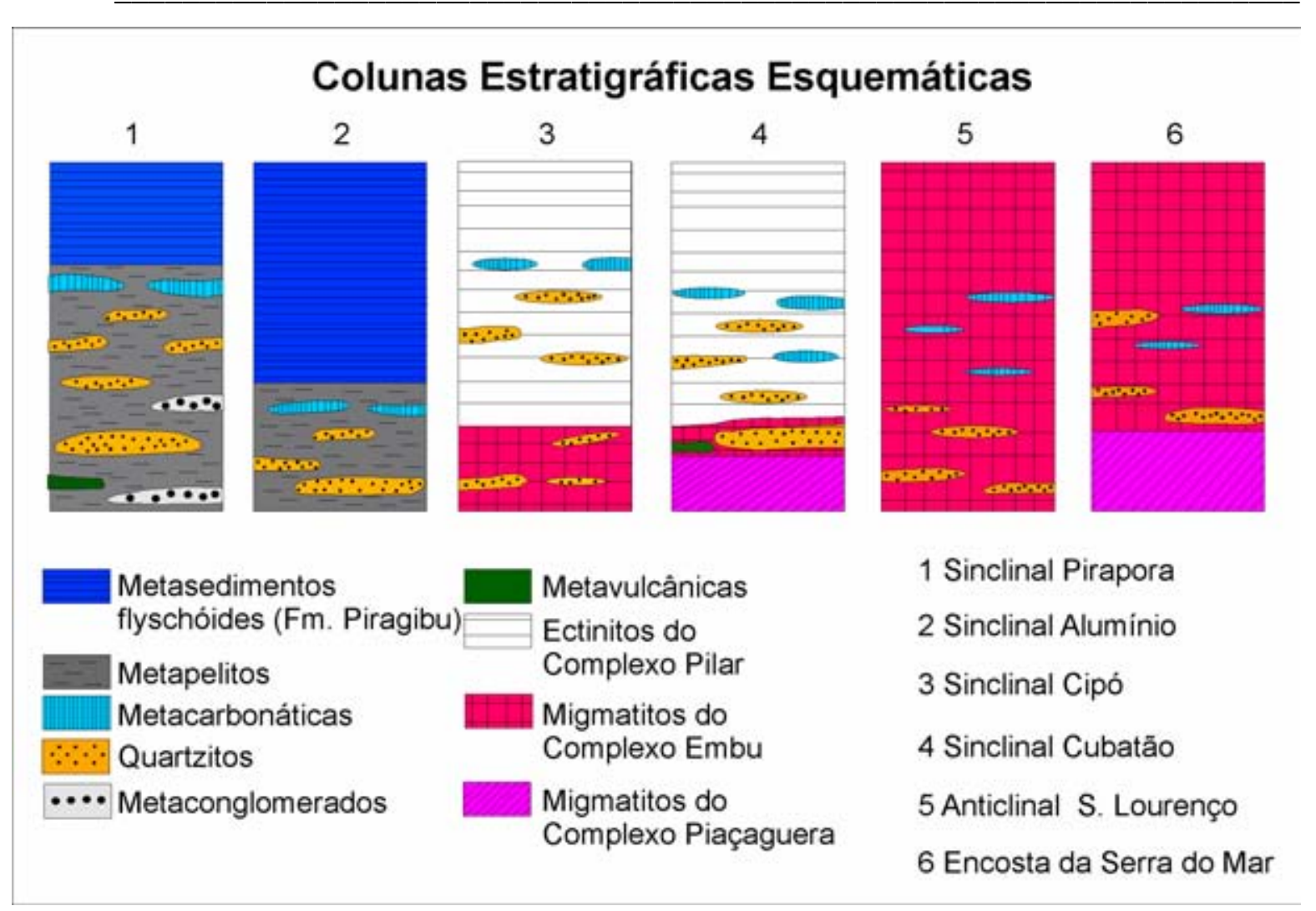

Figura I-3: Secções estratigráficas esquemáticas para algumas seqüências do Pré-cambriano no estado de São Paulo. Primeira subdivisão estratigráfica proposta para o Grupo São Roque ilustrada nas colunas 1 e 2 . Desenho digitalizado seguindo os formatos originais com a mais próxima fidelidade possível (Hasui et al., 1976).

Foi caracterizada por Coutinho et al. (1982) uma seqüência vulcano-sedimentar na região da Serra do Itaberaba, provavelmente iniciada por erupções submarinas, representadas por rochas vulcânicas ou sub-vulcânicas básicas e seus tufos, bem como por camadas argilosas, margas e intercalações de sedimentos químicos silicosos. Esta seqüência foi descrita por Campos Neto et al. (1983) como a base do Grupo São Roque, caracterizada por anfibolitos finos e bandados, sobrepostos por meta-ritmitos compostos por "quartzitos hematíticos" e rochas calciossilicáticas. Já o pacote superior, de mais baixo grau de metamorfismo, é segundo Campos Neto et al. (1983), representado na base por metarcóseos rítmicos que passam para filitos de intercalações quartzíticas, no topo (Figura I-4). 


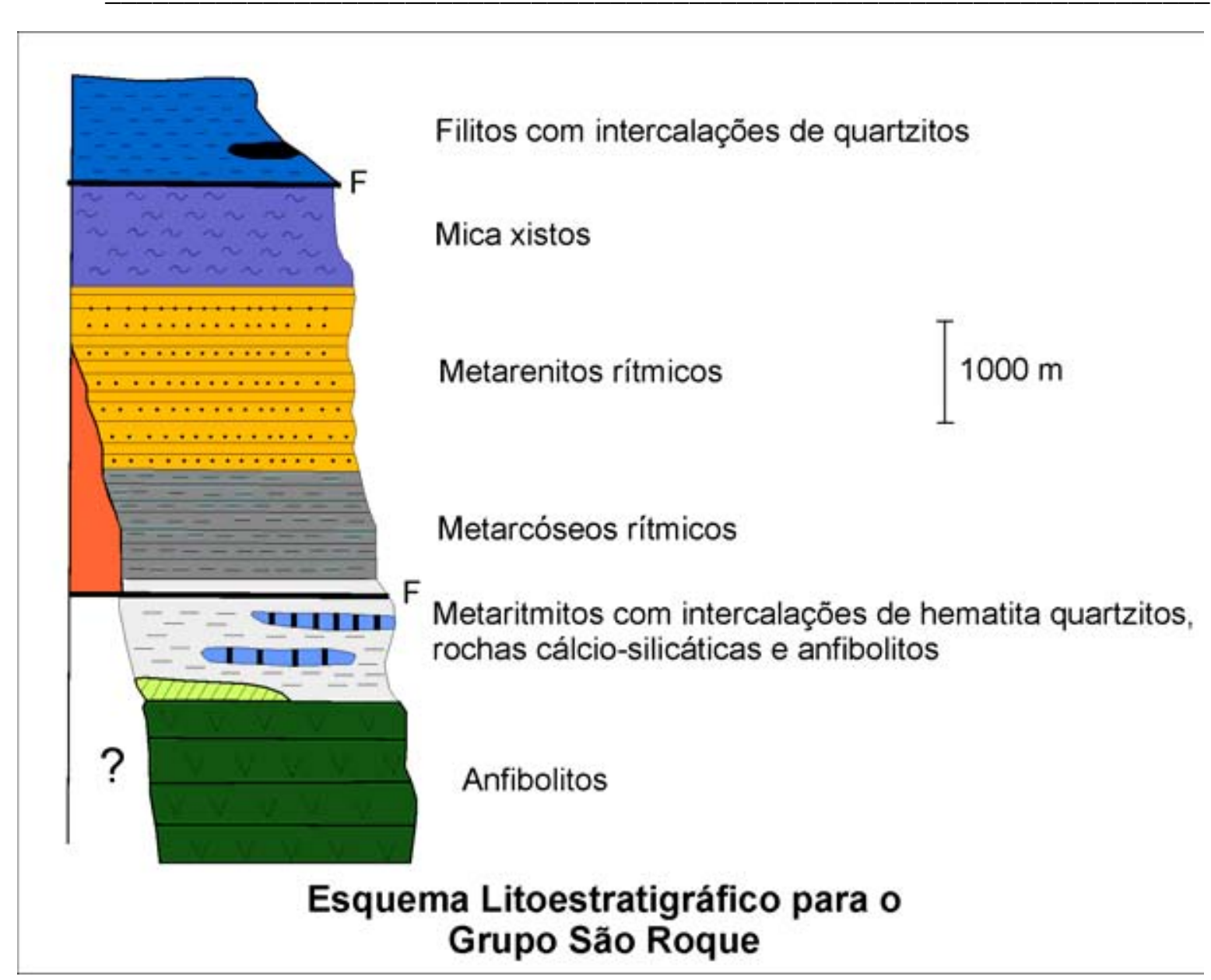

Figura I-4: Secção estratigráfica esquemática para o Grupo São Roque na região da Serra do Itaberaba. Desenho digitalizado seguindo os formatos originais com a mais próxima fidelidade possível (Campos Neto et al., 1983).

Recebeu a denominação Grupo Serra do Itaberaba (Juliani et al., 1986) a seqüência descrita por Coutinho et al. (1982). Este Grupo foi caracterizado pela Formação Morro da Pedra Preta (basal), composta por rochas metavulcânicas, metatufos, calciossilicáticas, e formações ferríferas, depositados em ambiente marinho de águas profundas. Sobrepõe-se "concordantemente" a esta a Formação Nhanguçu, composta por sedimentos clasto-químicos depositados em ambiente de águas mais rasas. Compondo "as fácies marginais" da bacia, encontra-se a Formação Pirucaia, possivelmente cronocorrelata às formações Nhanguçu e Morro da Pedra Preta, formada por rochas essencialmente quartzíticas, provavelmente depositadas em ambiente litorâneo (Juliani, 1993; Juliani \& Beljaviskis, 1995 - Figura I-5) 


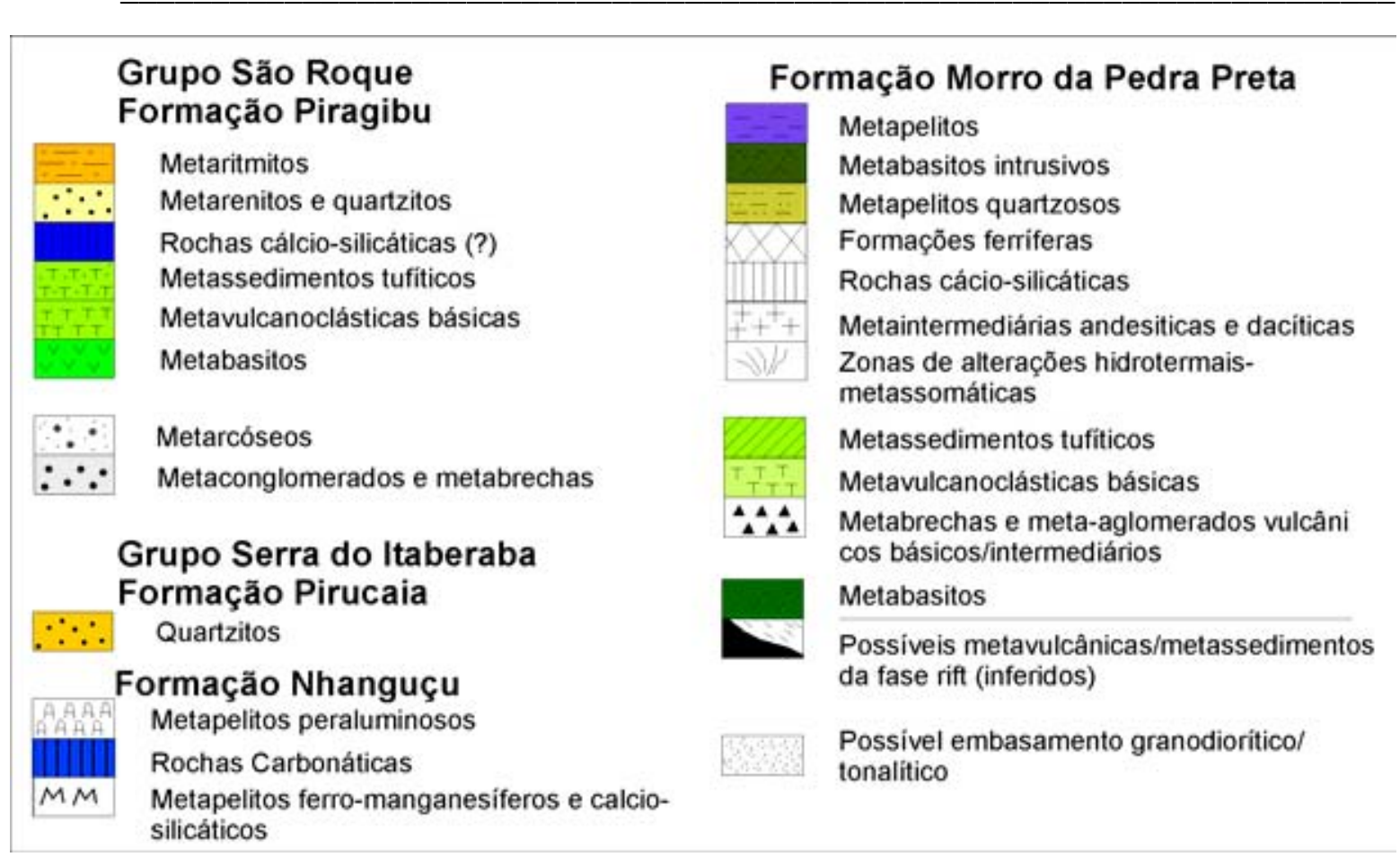

Figura I-5: Secção estratigráfica esquemática para o Grupo São Roque e Grupo Serra do Itaberaba na região da Serra do Itaberaba. Desenho digitalizado seguindo os formatos originais com a mais próxima fidelidade possível (Juliani \& Beljavskis, 1995).

As colocações de granitos pós-tectônicos ocupando núcleos de anticlinórios seriam responsáveis pela exposição destas camadas basais, e pelo metamorfismo de contato representado pela paragênese granada-cummingtonita-cordierita hornfels em metassedimentos sílico-magnesianos. Transformações termometamórficas também são descritas por Moraes Rego (1938), Coutinho (1955), Franco (1958), Bigarella et al. (1958), Cordani et al. (1961) e Gomes (1962).

Com dimensões de aproximadamente 1,5 por 2,5 km, o corpo anfibolítico do Jaraguá, encontra-se, segundo Gomes (1962), adjacente a uma extensa massa granítica tipo Pirituba (granito Cantareira), e em aparente discordância em relação aos xistos e quartzitos. Cordani et al. (1961) atribuíram para estes anfibolitos idade anterior à atividade magmática granítica da região, o que resultou em metamorfismo de contato em alguns locais desta unidade.

O Grupo São Roque é caracterizado por Carneiro (1983) como metapsamitos impuros, compostos, na base, por metarcóseos, metarenitos com intercalações de metaconglomerados 
polimíticos, rochas metavulcânicas e quartzitos. Esse pacote é sobreposto por meta-psamitos rítmicos e bandados de menor espessura, gerados por prováveis seqüências turbidíticas em ambiente marinho raso (Carneiro, 1983 e Carneiro et al., 1984 - Figura I-6). As rochas metavulcânicas intercaladas na unidade basal são caracterizadas por dois tipos petrográficos: anfibolitos metabasíticos (ex: corpo anfibolítico do Jaraguá), e rochas metavulcânicas e metasubvulcânicas (ex: pequenos corpos dentro da unidade de metarcóseos e "metariodacitos" da região do Morro do Polvilho) (Carneiro et al., 1984). Estas rochas metavulcânicas ácidas são correlacionadas às ocorrências do morro do Boturuna por Bergmann \& McReath (1992).

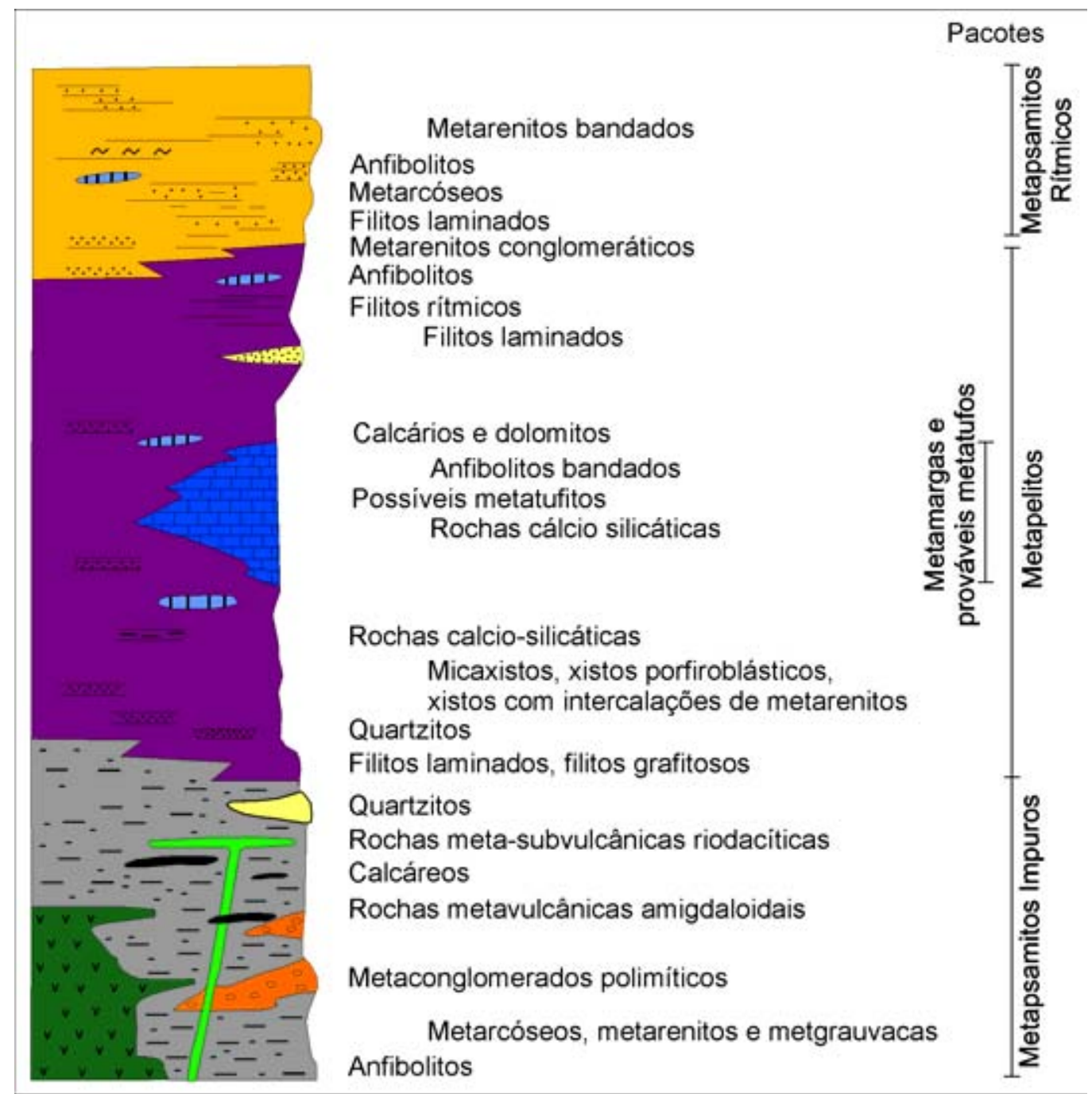


Figura I-6: Secção estratigráfica esquemática para o Grupo São Roque para a faixa entre o Pico do Jaraguá e Serra dos Cristais. Desenho digitalizado seguindo os formatos originais com a mais próxima fidelidade possível (Carneiro, 1983).

A seqüência meta-vulcano sedimentar descrita por Bistrichi (1982) na região de Pirapora do Bom Jesus (Figura I-7) foi caracterizada por Bergmann (1988) como Formação Pirapora do Bom Jesus. Trata-se de rochas metavulcânicas básicas com pillow-lavas estiradas (Figueiredo et al., 1982) de caráter toleítico (Lazzari, 1987), associadas a rochas piroclásticas, com um membro carbonático, que localmente apresenta estruturas estromatolíticas (Bergmann \& Fairchild, 1985; 1986). Sugere-se também (Bergmann, 1988) a ocorrência de centros eruptivos do tipo vulcão, através da disposição de recifes carbonáticos, alguns com estromatólitos que circundam corpos metabasíticos estratificados de geometria oval, em um ambiente marinho de águas rasas de uma provável margem continental passiva.

Segundo Bergmann (1988), encontra-se em contato transicional com a Formação Pirapora a Formação Estrada dos Romeiros, que comporta um membro arenoso com metarenitos ritimitos por vezes micro-conglomeráticos, e subordinadas intercalações metapelíticas e hematíticas. A ciclicidade observada na sedimentação levou à interpretação de uma zona de transição, com ao menos um evento transgressivo (Figura I-8).

O pacote com predomínio de metarenitos arcoseanos e ortoquartzitos originalmente posicionado como formação basal do Grupo São Roque (Formação Boturuna - Hasui et al., 1976) foi considerado como o topo da seqüência. Bergmann (1988) atribui como parte desta formação dois conjuntos distintos de rochas metavulcânicas chamadas de membro vulcânico 1, que compreende anfibolitos com estruturas tipo pillow-lavas e metatufos, e membro vulcânico 2, que compreende anfibolitos amigdaloidais e rochas metavulcânicas ácidas (Figura I-9).

Machado \& Fragoso César (1992) mantêm a proposta de um paleoambiente com sedimentação em margem continental passiva, que se aprofunda e espessa para sudeste. São caracterizados sistemas deltáicos com plataforma carbonática e siliciclástica, localmente afetados por magmatismo básico contemporâneo. 


\section{Estratotipo da Formação Pirapora do Bom Jesus no corpo de Pirapora de Bom Jesus}

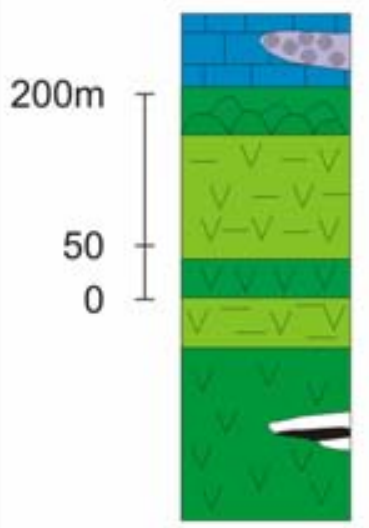

\section{Estratotipo da Formação Pirapora do Bom Jesus a leste de Santana do Paranaíba}

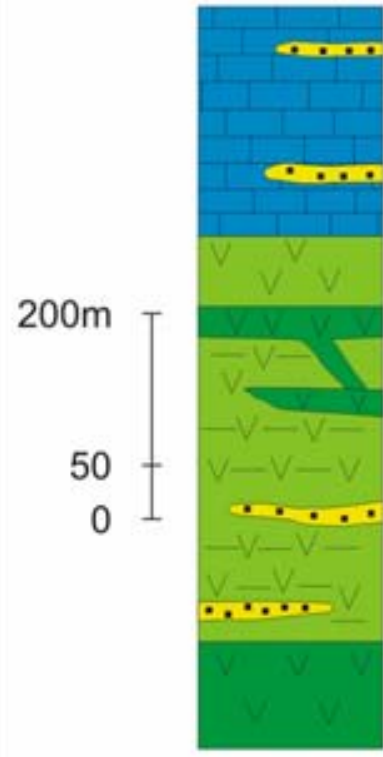

Calciofilitos com lentes de extensão decimétrica a métrica de metadolomito quartzoso e com intercalaçōes arenosas e peliticas no topo.

Metatufos bandados a laminados com diques e niveis métricos de ortoanfibolitos grossos a finos, localmente amigdalóides.

Intercalações de bancos sub-métricos a métricos de metagrauvacas, metarcóseos micáceos, metapelitos e lentes restritas de "chert".

Ortoanfibolitos médios a finos, granolepidoblásticos, localmente amigdalóides.

Figura I-7: Secção estratigráfica esquemática para a Formação Pirapora do Bom Jesus nas regiões de Santana do Parnaíba e Pirapora do Bom Jesus. Desenho digitalizado seguindo os formatos originais com a mais próxima fidelidade possível (Bergmann, 1988). 


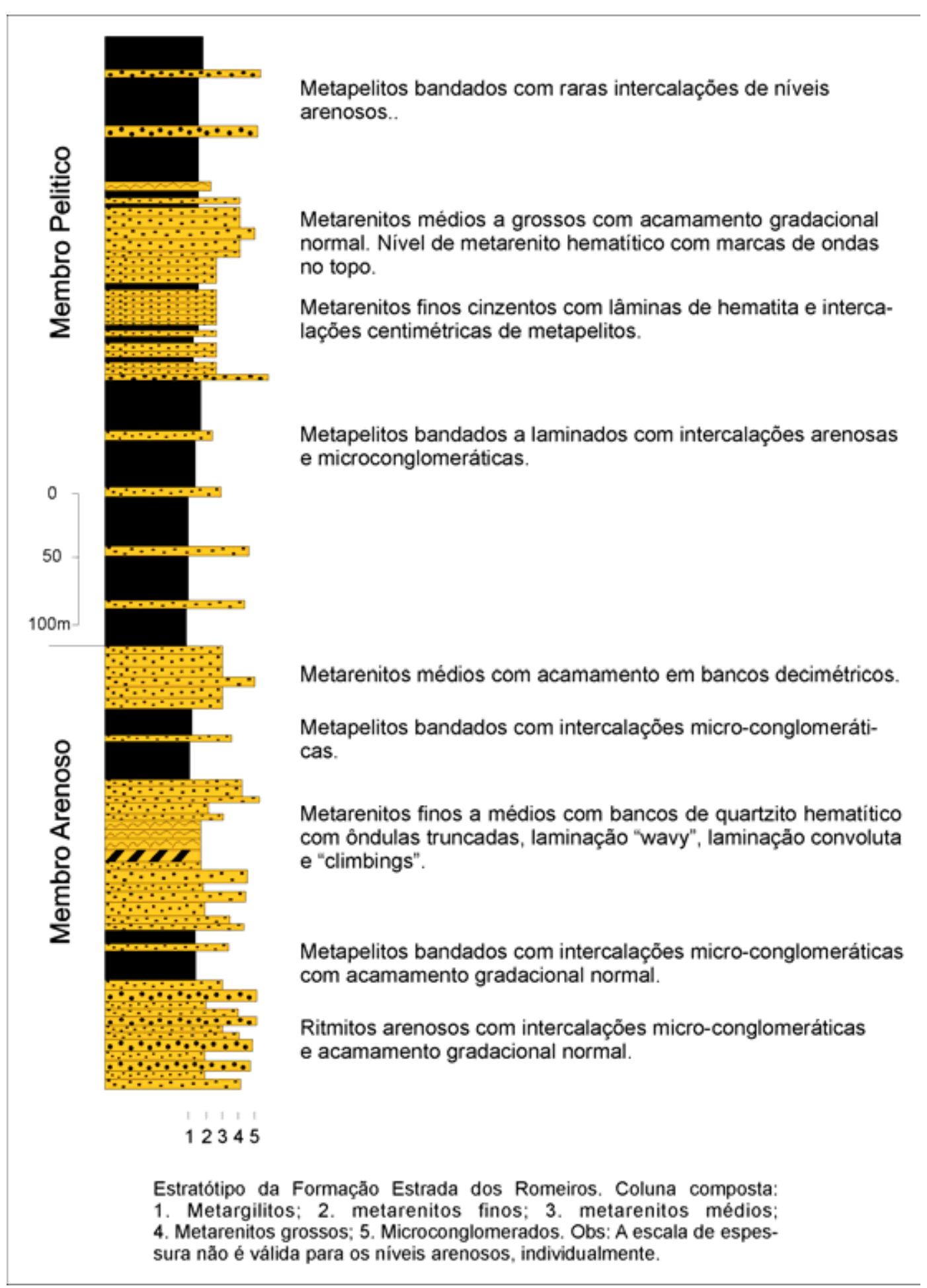

Figura I-8: Secção estratigráfica esquemática para a Formação Estrada dos Romeiros nas regiões de Santana do Parnaíba e Pirapora do Bom Jesus. Desenho digitalizado seguindo os formatos originais com a mais próxima fidelidade possível (Bergmann, 1988). 


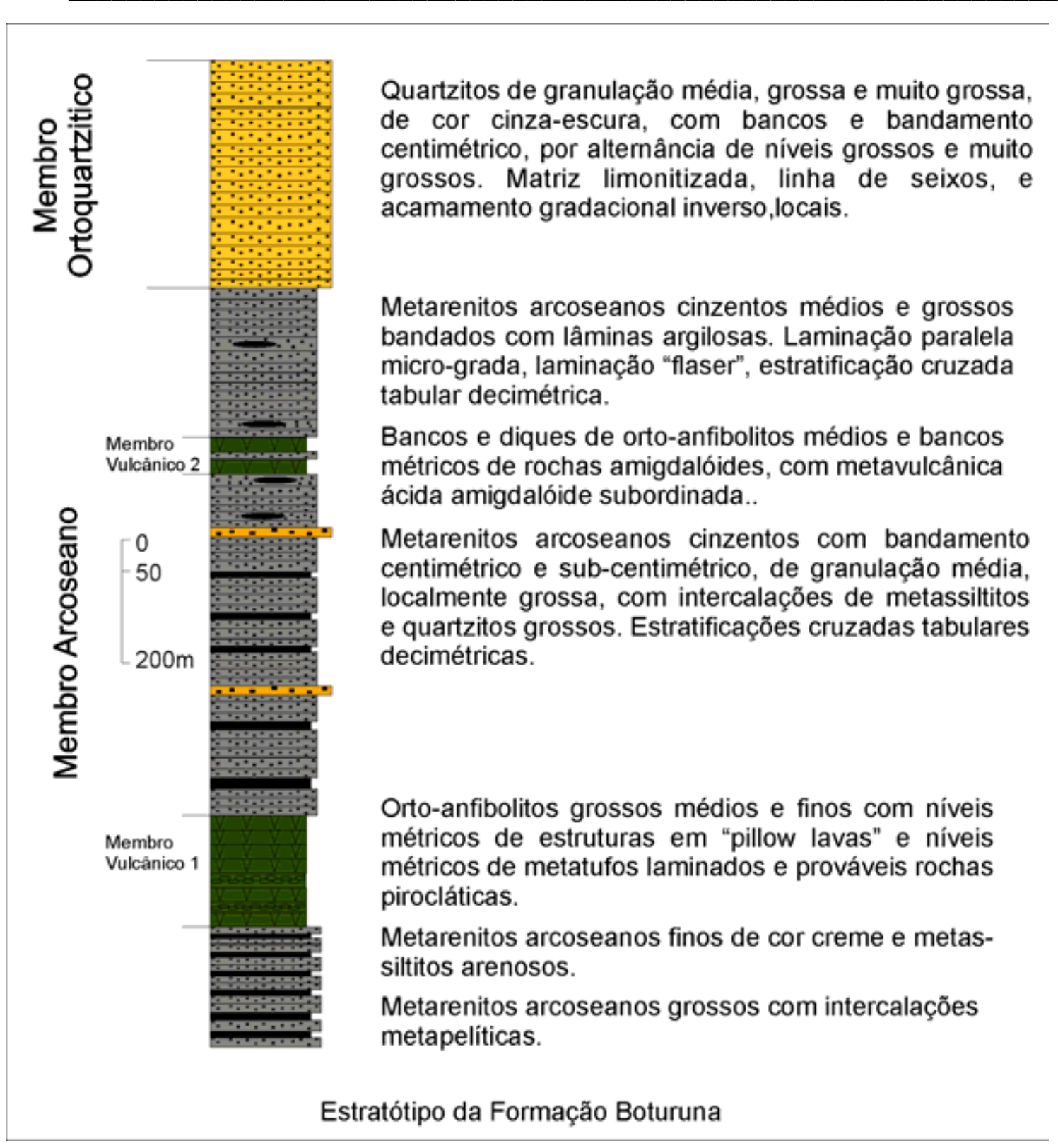

Figura I-9: Secção estratigráfica esquemática para a Formação Boturuna nas regiões de Santana do Parnaíba e Pirapora do Bom Jesus. Desenho digitalizado seguindo os formatos originais com a mais próxima fidelidade possível (Bergmann, 1988).

Dantas et al. (1986), propõem uma estratigrafia com três formações: do topo para base os autores mantêm a proposta inicial de Hasui et al., (1976), Formação Piragibu seguida da Formação Boturuna, e na base Formação Jaraguá, que compreende rochas incluídas como 
Grupo Serra do Itaberaba por Juliani et al., (1986) e os terrenos basais de Igaratá de Campos Neto et al., (1983) (Figura I-10).

Dantas (1990) restringe a nomenclatura estratigráfica para duas unidades (inferior e superior). A unidade inferior seria composta por metapelitos (micaxistos, filitos laminados), rochas metabásicas intrusivas e extrusivas com níveis metatufíticos, rochas calciossilicáticas, metapsamitos impuros (níveis subordinados de metarcóseos, bancos de quartzitos e raros conglomerados). Esta unidade, somada aos níveis metavulcânicos, é comparada à Formação Boturuna de Hasui et al. (1976), e à Formação Pirapora de Bom Jesus (basal) de Bergmann (1988).

Já a unidade superior, confinada na borda N-NW da faixa estudada por Dantas (1990), é caracterizada como uma seqüência metarrítimica que compreende filitos bandados com alternância de sericita xistos e filitos, além de metapsamitos puros a subarcoseanos, depositados em um possível sistema deltáico marinho progradante sobre a plataforma adjacente, chegando a atravessar os presumidos limites NNW da bacia. Esta unidade é comparada à Formação Piragibu de Hasui et al. (1976).

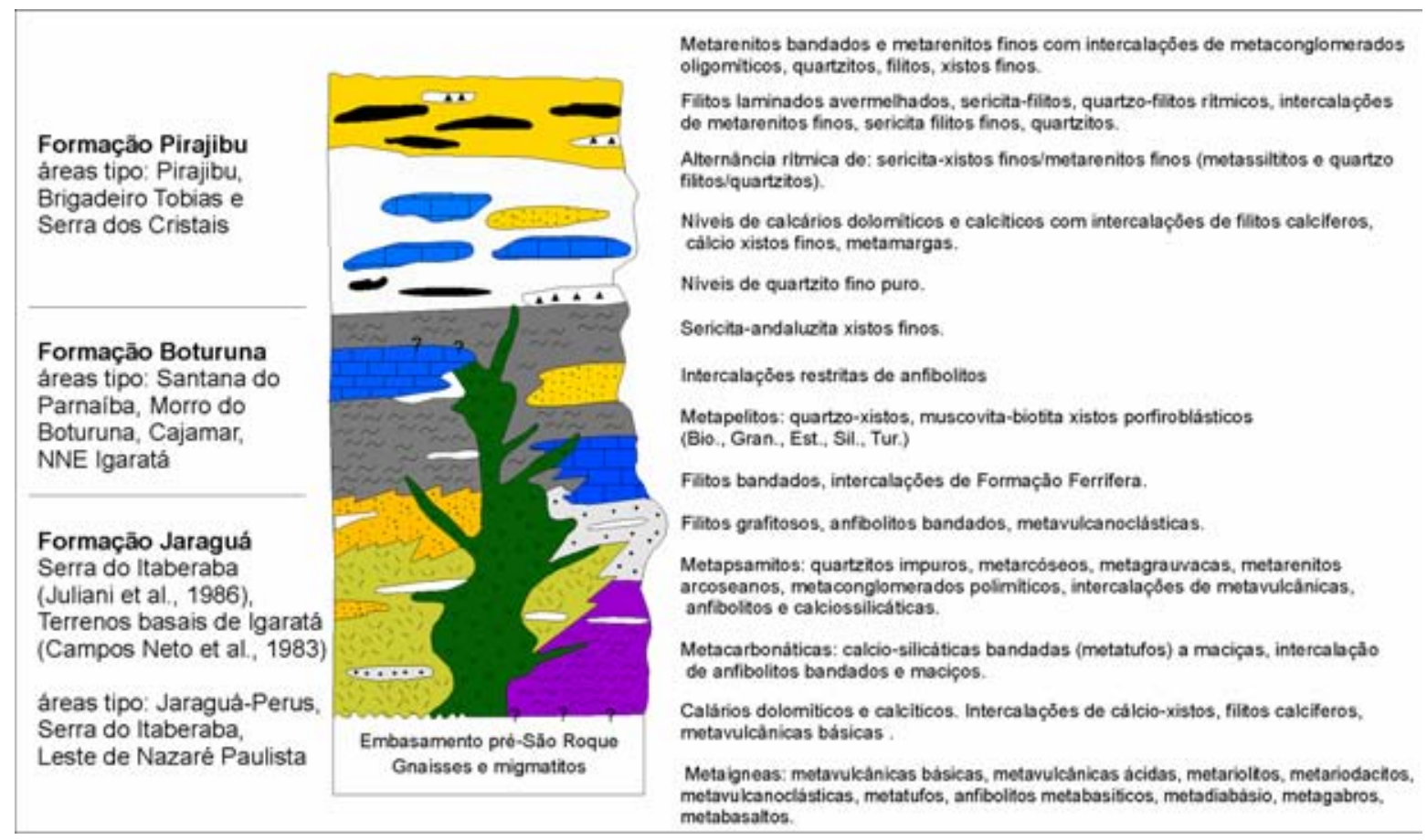


Figura I-10: Secção estratigráfica esquemática do Grupo São Roque na região da folha Guarulhos. Desenho digitalizado seguindo os formatos originais com a mais próxima fidelidade possível (Dantas et al., 1986).

Dantas (1990) propõe a partir de um "rift assimétrico" um paleoambiente de sedimentação limitado por falhamentos profundos, com disposição preferencial de influxos terrígenos provindos da borda S-SE da paleobacia. Ortognaisses miloníticos são tidos como parte do embasamento, que possivelmente foram alçados tectonicamente a níveis superiores.

Para a base do Grupo São Roque, Martin (2000) propõe correlação lateral com as Formações Morro Doce (Juliani et al., 1999) e Pirapora (Bergmann, 1988). Em contato transicional com metarcóseos e metaconglomerados da Formação Morro Doce, estariam representados os sedimentos da Formação Boturuna (Hasui et al., 1976). A unidade de topo, composta predominantemente por sedimentos rítmicos, foi comparada por Martin (2000) à Formação Piragibu (Hasui et al., 1976) e ao membro arenoso da Formação Estrada dos Romeiros (Bergmann, 1988).

Na região de Votorantim e Salto de Pirapora, Silva (2004) caracteriza quatro litofácies, que da base para o topo estão representadas pela associação siliciclástica basal, que corresponde a uma sucessão turbidítica gerada em águas profundas; associação siliciclástica intermediária, que corresponde a uma plataforma rasa progradante; associação clasto-química transicional, que marca a mudança de ambientes deposicionais de plataforma rasa para planície de maré mista; e associação carbonática impura superior, que representa porções mais proximais e superiores de uma planície de maré.

\section{I.4.3. Geocronologia das Seqüências Supracrustais do Grupo São Roque}

A primeira proposta de idade para os metassedimentos do Estado de São Paulo e Paraná as situa em um período pré-Devoniano, devido às ocorrências fósseis da Formação Furnas (Devoniano) encontradas por Derby (1878). Somente com descoberta de estruturas "organógenas" da Formação Itaiacoca, referíveis ao gênero Collenia Itapevensis (Almeida, 1944 e 1945), estes metassedimentos foram posicionados no Pré-cambriano. O intervalo entre 850 e 1700 Ma é sugerido pela presença de estromatólitos Conophyton cf. C. garganicum para a Formação Itaiacoca (Fairchild, 1977). 
Tassinari et al. (1985) obtiveram isócronas Rb-Sr, com idade de $1200 \pm 75$ Ma para os seixos "granito-gnáissicos" dos metaconglomerados posicionados na base do Grupo São Roque por Coutinho (1955). As idades K-Ar em biotitas obtidas para a "matriz" foram de 800$750 \mathrm{Ma}$, o que foi interpretado como o último evento metamórfico que atuou sobre essas rochas. Diagrama de evolução isotópica do Sr foi usado para sugerir que a fonte dos seixos teria se formado em idade anterior a 2,4 Ga, sendo assim, segundo Tassinari (1988) não estaria mais "aflorando hoje em dia".

A possibilidade de que a parte inferior do Grupo São Roque seja mais antiga que os pacotes superiores foi levantada por van Schmus et al. (1986), a partir da idade U-Pb em zircão de $1790 \pm 14$ Ma obtida para rochas metavulcânicas ácidas da região do Morro do Polvilho. Os autores posicionam estas rochas estratigraficamente abaixo dos metaconglomerados descritos por Coutinho (1955), apontando similaridades petrográficas e de idade com as rochas metavulcânicas ácidas do Supergrupo Espinhaço, da região de Conceição do Mato Dentro - MG, datadas em 1770 Ma (Brito Neves et al., 1979). McReath et al. (1981) propuseram possíveis correlações entre as rochas metavulcânicas ácidas do Espinhaço Meridional com ocorrências similares da região de Paramirim, Chapada Diamantina - BA, datadas em $1752 \pm 4$ (Schobbenhaus et al. 1994).

A idade obtida por van Schmus et al. (1986) foi questionada por Juliani et al. (1997) que, com base na petrografia, reinterpretaram os "metariodacitos" como metarcóseos. Portanto, por essa ótica, os zircões datados seriam detríticos, o que representaria a idade de uma das fontes, e não da sedimentação, como proposto para a base do Grupo São Roque a partir de zircões magmáticos. No entanto estudos recentes confirmam a origem magmática destas rochas que foram reclassificadas como metatraquidacitos e metariolitos porfiríticos (Henrique-Pinto, 2008).

Os anfibolitos da Serra do Itaberaba forneceram idade pelo método K-Ar em anfibólio de $598 \pm 23 \mathrm{Ma}$, que corresponderia à época do resfriamento regional (Tassinari, 1988). A base do Grupo Serra do Itaberaba, representada pela formação Morro de Pedra Preta (Juliani et al., 2000), tem idade U-Pb em zircão em metandesito de $1395 \pm 10$ Ma. Já riolitos interpretados como intrusivos na mesma seqüência foram datados em $619 \pm 3$ Ma.

Mineralizações singenéticas de $\mathrm{Pb}$ na Formação Perau no Vale do Ribeira, apresentaram idades $\mathrm{Pb}-\mathrm{Pb}$ em galena entre 1,7 e 1,5 Ga (Tassinari et al., 1990). Idades U-Pb 
em zircão mais precisas foram obtidas em anfibolitos das Formações Perau (1484 \pm 16 Ma) e Votuverava (1479 $\pm 12 \mathrm{Ma}$ ) (Basei et al., 2003; Siga Jr. et al., 2011), que se mostram cronocorrelatas à Formação Água Clara, com sedimentação estimada com base em idades em um intervalo de 1590 - 1470 Ma obtidas em rochas metavulcânicas básicas (Weber et al., 2004). Este intervalo que caracteriza a idade de sedimentação para estas unidades no Domínio Açungui levou Siga Jr. et al. (2011), a correlacionarem estas sequiências com a Formação Morro da Pedra Preta, tida como a base do Grupo Serra do Itaberaba (Juliani, 1993).

Anfibolitos da região de Pirapora de Bom Jesus foram datados pelo método K-Ar em concentrados de plagioclásio, e forneceram idades de $1053 \pm 96$ Ma (Tassinari, 1988), o que destoa das idades U-Pb em zircão $(608 \pm 7 \mathrm{Ma})$ e monazita $(628 \pm 9 \mathrm{Ma})$ de rochas equivalentes obtidas por Hackspacher et al. (1999) e Hackspacher et al. (2000), respectivamente. Estas últimas idades foram interpretadas como indicativas de que a sedimentação do Grupo São Roque teria se dado em uma bacia de backarc neoproterozóica, devido à presença de granitos sin-orogênicos de mesma idade (615-605 Ma) (ex., batólito Agudos Grandes; Leite et al., 2007).

Oliveira et al. (2008) obtiveram idade U-Pb de $1750 \pm 40 \mathrm{Ma}$ em rochas metavulcânicas básicas da região de Cajamar (actinolita-albita-epidoto-clorita xisto; Oliveira et al., 2011), indicando contemporaneidade com as metavulcânicas ácidas da região do Morro do Polvilho (van Schmus et al. 1986), e reafirmando a idade Paleoproterozóica do Grupo São Roque. 


\section{I.5. Síntese estratigráfica}

"Na margem do Sorocaba, junto á ponte do Taboão, apparecem camadas d'um calcareo magnesiano esverdeado muito siliciso, com direcção $\mathrm{N} 80^{\circ}$ L. A associação desta rocha com granitos amphibolicos e sua posição fazem-nos antes suppol-a a continuação das camadas de S. Roque. Com effeito nas circumvisinhanças desse ponto o granito amphibolico espalha-se entre os schistos micaceos por uma área de cerca de 4 kilometros de largura, tomando freqüentemente a estructura de gneiss." [Gonzaga de Campos, (1888), p.27, $1^{\circ}$ parágrafo].

Devido ao fato de haverem muitas proposições estratigráficas e ambíguas correlações entre diferentes localidades geográficas, além de muitos trabalhos publicados com formatos restritos, principalmente em resumos de congressos e simpósios regionais, com carência de trabalhos completos publicados em periódicos científicos; propõe-se aqui uma síntese que procura abordar a forma original como estes assuntos foram tratados, porém dentro de um quadro mais atual de datações radiométricas disponíveis na literatura, com as respectivas prioridades de nomenclatura conforme sugerem as diretrizes do código estratigráfico brasileiro e norte americano.

Deveríamos prioritariamente adotar o nome São Roque para quaisquer que fossem as grandes correlações regionais agrupadas em mega-sequiências, devido ao fato da precedência na data de publicação da conotação litoestratigráfica que consta em manuscritos (NACSN, 2005 - article 19 (a); Petri et al., 1986a - artigo B. 16), mesmo sendo eles de caráter embrionário. Tal é o caso da designação "camadas de São Roque”, referentes à associação calcários magnesianos, anfibólio-granitos, xistos e gnaisses (Gonzaga de Campos, 1888). O nome São Roque, além de mais antiga citação, também representa um definição consagrada (NACSN-article 7 (c); Petri et al., 1986a - artigo B. $16 \S 1^{\circ}$ ), sendo amplamente utilizada por muitos autores em um espectro de mais de 130 anos (Figura I-11) .

As camadas de São Roque passaram a se chamar Serie de São Roque, sendo modificado para categoria de Grupo somente em 1963. O primeiro empilhamento estratigráfico que introduz nomes de formações e membros consta nos perfis esquemáticos de Hasui et al., 1976. Como constituintes da Formação Boturuna foram designados 
metassedimentos como metaconglomerados, quartzitos, metacalcários e xistos com mais alto grau metamórfico, enquanto para a Formação Piragibu ficaram restritos os metapelitos (filitos) e metarenitos com feições rítmicas.

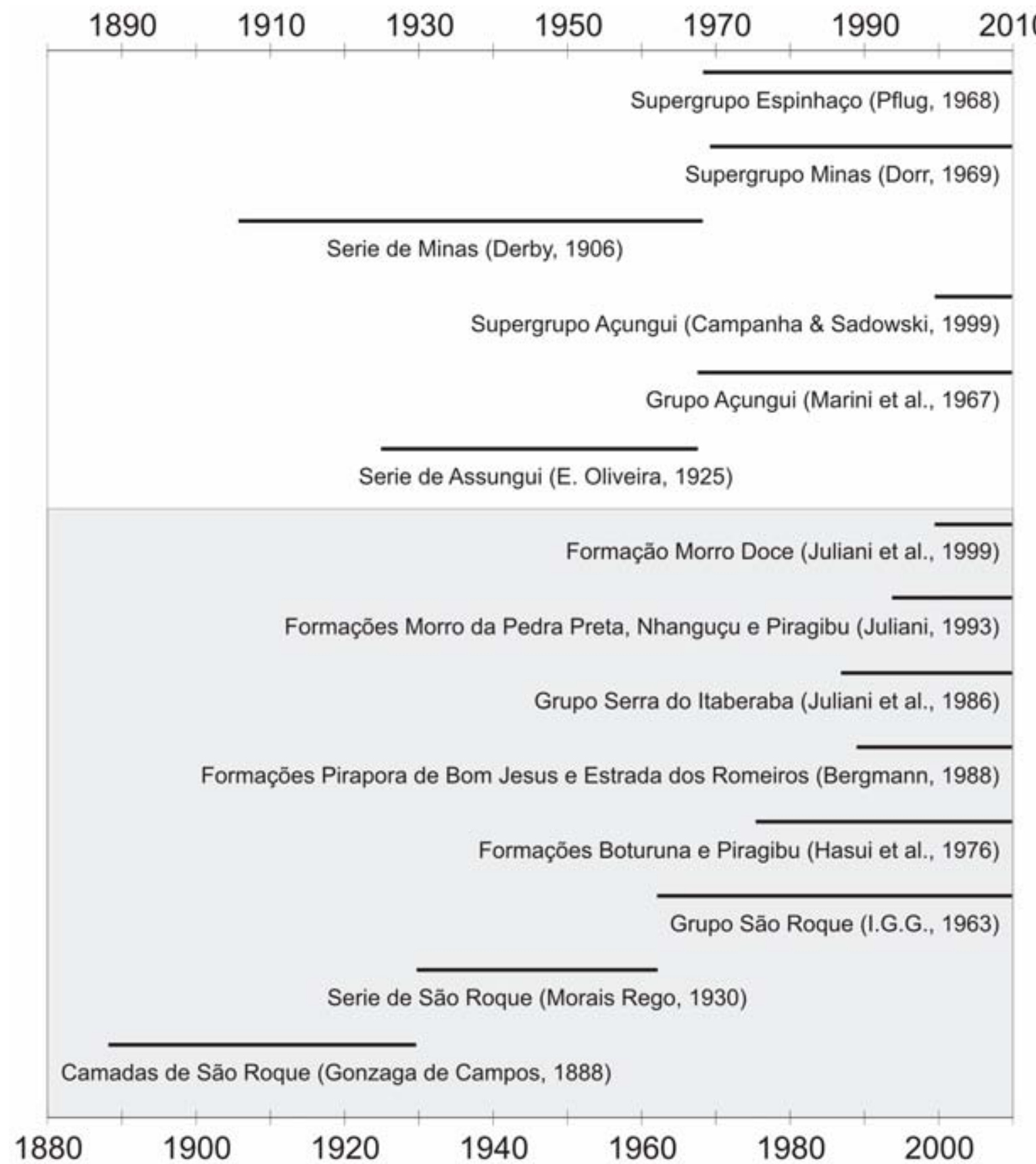

Figura I-11: Quadro resumido com as principais propostas estratigráficas de 1888 até os tempos atuais, para metassedimentos do Domínio São Roque (campo em cinza) e outros domínios. 
A proposta de empilhamento com divisão em três pacotes principais, porém muitas vezes sem a atribuição da categoria Formação, tornou-se uma constante ao longo dos anos, sendo atribuída de forma semelhante por diversos autores (faz-se à ressalva das diferenças relacionadas às localidades geográficas), como por exemplo:

\section{(Campos Neto et al., 1983).}

-Unidade basal com predomínio de anfibolitos, formações ferríferas e rochas cálciosilicáticas;

-Unidade intermediária com predomínio metarcóseos, metarenitos e cianita-estaurolita xistos;

-Unidade de topo com predomínio de metapelitos e restritas intercalações de quartzitos.

\section{(Carneiro, 1983).}

-Meta-psamitos impuros basais que incluem predominantemente metarcóseos, metaconglomerados, quartzitos, rochas metavulcânicas e anfibolitos (intrusivos);

-Metapelitos intermediários que incluem predominantemente rochas cálcio-silicáticas, metacalcários dolomíticos, metatufos e xistos de mais alto grau metamórfico;

-Meta-psamitos rítmicos no topo com predomínio de filitos laminados, metarenitos bandados, anfibolitos e metarcóseos.

\section{(Dantas et al., 1986).}

-Formação Jaraguá (basal) que incluem as sequiências basais de Campos Neto et al., (1986) e Grupo Serra do Itaberaba (Juliani et al., 1986), além do pacote de metarcóseos e metaconglomerados polimíticos;

-Formação Boturuna (intermediária) essencialmente inclui semelhante seqüência descrita por Hasui et al., (1976), no entanto a seqüência de anfibolitos e metavulcânicas são separadas e colocadas na base (Formação Jaraguá);

-Formação Piragibu (topo) essencialmente as mesmas litologias descritas por Hasui et al., (1976) com metapelitos e metarenitos rítmicos, no entanto com a presença de metacalcários. 


\section{(Bergmann, 1988).}

-Formação Pirapora do Bom Jesus (basal) que incluem predominantemente anfibolitos com estruturas tipo pillow-lavas, metatufos, formações ferríferas e metacalcários dolomíticos com estruturas estromatolíticas;

-Formação Estrada dos Romeiros (intermediária) que incluem predominantemente rochas metapelíticas (filitos), com níveis restritos de metarenitos com estruturas rítimicas, por vezes micro-conglomeráticos;

-Formação Boturuna (topo) composta por metarenitos arcoseanos que passam para meta-quartzo arenitos no topo desta formação. É incluído dentro desta seqüência também, nível vulcânico com estruturas tipo pillow-lavas na base desta formação.

\section{(Martin, 2000).}

-Formação Pirapora do Bom Jesus (basal) com agrupamento similar ao de Bergmann, (1988), no entanto com correlação lateral a metaconglomerados polimíticos e metarcóseos chamados de Formação Morro Doce por Juliani et al., (1999);

-Formação Boturuna (intermediária) com agrupamento similar ao de Hasui et al., (1976), no entanto é incluído nesta formação o membro arenoso da Formação Estrada dos Romeiros de Bergmann, (1988);

-Formação Piragibu (topo) composta essencialmente por metarenitos e metapelitos com estruturas rítmicas como proposto por Hasui et al., (1976).

Foram desvinculadas do Grupo São Roque rochas de caráter essencialmente metavulcânico, incluindo metabasaltos com assinatura tipo MORB, metandesitos, metatufos, formações ferríferas bandadas, rochas cálcio-silicáticas, cianita-estaurolita xistos e alguns quartzitos. Juliani et al., (1986), atribuíram uma nova nomenclatura que agrupa estas rochas em um diferente grupo (Grupo Serra do Itaberaba), que significaria seqüências com hiato deposicional dado através de discordância angular e erosiva com rochas essencialmente de mais baixo grau metamórfico, ficando restrita ao Grupo São Roque apenas a Formação Piragibu (Juliani \& Beljaviskis, 1995). Somente em Juliani et al., (1999), foi atribuída mais uma formação ao Grupo São Roque, basicamente constituída de metarcóseos e metaconglomerados polimíticos chamados de Formação Morro Doce. 


\section{(Juliani, 1993).}

-Formação Morro da Pedra Preta (basal), composta por rochas metavulcânicas, metatufos, cálcio-silicáticas, e formações ferríferas;

-Formação Nhanguçu (intermediária) caracterizada pelo predomínio de metapelitos metaluminosos e metacalcários;

-Formação Pirucaia (topo) formada por rochas essencialmente quartzíticas.

1.5.1. Hipótese 1 - Considera que a grande maioria dos empilhamentos estratigráficos estão corretos, assim como as datações dos níveis vulcânicos e sub-vulcânicos.

Trabalhando com esta hipótese, deveríamos considerar dentro do Domínio São Roque dois grupos e pelo menos uma formação com histórias deposicionais e de metamorfismo distintas. Neste caso, seria natural que estas seqüências fossem enfeixadas na categoria de Supergrupo. Dentro deste agrupamento ficariam dispostos como basais o Grupo São Roque devido às datações U-Pb em zircão $(1790 \pm 14$ Ma) de metavulcânicas ácidas intercaladas aos metaconglomerados e metarenitos arcoseanos (Van Schmus et al., 1986) e devido ao fato de haverem inúmeras ambigüidades entre as propostas estratigráficas, seria mais prudente, $a$ priori, manter uma separação em apenas duas unidades, com as Formações Boturuna e Piragibu originalmente formuladas por Hasui et al. (1976), já que não existem secções tipos com camadas e membros devidamente documentadas na literatura. Tentativas de empilhamento neste sentido foram propostas por Bergmann (1988), mas não se sustentam com os dados geocronológicos.

O Grupo Serra do Itaberaba permaneceria com a disposição estratigráfica sugerida por Juliani (1993) (Formações Morro da Pedra Preta, Nhanguçu, Pirucaia), no entanto ocuparia uma posição intermediaria dentro desta mega-seqüência, ao considerar a idade mesoproterozóica obtida em metavulcânicas da Formação Morro da Pedra Preta (1395 \pm 10 Ma).

Ocuparia o topo como uma seqüência mais jovem, a Formação Pirapora do Bom Jesus de Bergmann, (1988), que deveria também ser desvinculada do Grupo São Roque, a se julgar corretas as idades U-Pb em zircão (608 \pm 7 Ma) e monazita (628 \pm 9 Ma) (Hackspacher et al., 1999 e Hackspacher et al., 2000) de anfibolitos, tidos como parte da seqüência supracrustal 
com estruturas tipo pillow-lavas associadas a paleorecifes estromatolíticos (Figueiredo et al., 1982; Bergmann, 1988; Tassinari et al., 2001).

1.5.2. Hipótese 2 - Considera que a grande maioria dos empilhamentos estratigráficos estão corretos, porém as datações dos níveis vulcânicos e sub-vulcânicos precisam de revisões.

Ao considerar esta hipótese, deveríamos abandonar a terminologia original Formação Boturuna de Hasui et al., (1976) que propõe a associação com predomínio de metaconglomerados e metarenitos feldspáticos, somados a níveis metavulcânicos na base, e considerá-la como topo do Grupo São Roque, devido ao fato de serem apresentados por Bergmann, (1988) de maneira formal, em uma secção tipo, no entanto considerada como superior. Semelhante mudança deveria acontecer com o nome Formação Piragibu, passando a ser chamada de Formação Estrada dos Romeiros, que segundo Bergmann, (1988), faz contato lateral de fácies com a Formação Pirapora do Bom Jesus, na base da seqüência.

Dentro desta hipótese deveria permanecer como distinto grupo as rochas de mais alto grau metamórfico denominadas Grupo Serra do Itaberaba, com suas respectivas formações originalmente propostas por Juliani et al., (1986).

1.5.3. Hipótese 3 - Considera que a grande maioria dos empilhamentos estratigráficos estão corretos, porém sem a presença de grandes discordâncias dentro do Domínio São Roque.

Considerando esta hipótese deveríamos supor que toda a seqüência faz parte de um grande ciclo de deposição e assim sendo, seria correto adotar a nomenclatura proposta de maneira formal por Bergman (1988), conforme é sugerido pelo código estratigráfico brasileiro e norte-americano, através de atribuições pormenorizadas de camadas membros em estratotipos de acordo com os padrões de discordâncias e inconformidades. Neste caso, seria correto abandonar a nomenclatura Formação Piragibu (Hasui et al., 1976), assim como o nome Grupo Serra do Itaberaba (Juliani et al., 1986).

Caso venha a se confirmar similaridade entre as Formações Pirapora do Bom Jesus (Bergman, 1988) e Morro da Pedra Preta (Juliani, 1993), deveríamos priorizar o nome Pirapora do Bom Jesus, pois esta representa a primeira nomenclatura proposta para a 
sequiência vulcano-sedimentar do Grupo São Roque. Dentro desta hipótese, deveria ser reavaliado se os nomes Formação Nhanguçu e Formação Pirucaia, se sustentariam como distintas formações ou se enquadrariam no contexto da Formação Estrada dos Romeiros e Formação Boturuna (membro ortoquartzítico), respectivamente.

\subsubsection{Hipótese Adotada}

Esta tese trabalha com a hipótese 1, no entanto considera também a possibilidade de revisão nas datações radiométricas dos níveis vulcânicos previamente datados na Formação Pirapora do Bom Jesus, pois esta representa a melhor exposição subaquática, que nos dá boa precisão de sua posição, com contemporaneidade a sedimentação, no caso carbonática que incluem também marcadores fossilíferos.

Quanto à possibilidade da sequiência caracterizada como Formação Boturuna representar o topo do Grupo São Roque (Bergmann, 1988), não foi confirmado nesta pesquisa. Coluna similar foi observada na região entre o Morro Doce e Morro do Polvilho, no entanto esta marca a base da seqüência e não inclui o membro vulcânico 1 (Bergmann, 1988 - Figura I-9), que é caracterizado por corpos intrusivos na seqüência de metarenitos arcoseanos e metaconglomerados (ex., corpo anfibolítico do Jaraguá).

Esta tese considera também importante a revisão das datações de metavulcânicas básicas presentes na Formação Morro da Pedra Preta do Grupo Serra do Itaberaba e na Formação Pirapora do Bom Jesus do Grupo São Roque. As semelhanças litológicas entre elas, ambas caracterizadas pela associação de anfibolitos com afinidades MORB, formações ferríferas bandadas, metatufos e metacalcários dolomíticos, permitem considerar a possibilidade de representarem a mesma seqüência, conforme sugere também a compilação dos mapas geológicos apresentada no Anexo IV. 


\section{Análises de proveniência através do estudo de zircões detríticos}

\section{II.1. Introdução}

A revolução das ciências geológicas e planetárias que foi promovida após a descoberta da possibilidade de datação de processos geológicos através de isótopos de $\mathrm{U}$ e $\mathrm{Pb}$ em zircões elevou a importância deste mineral, que se tornou um dos mais estudados na atualidade. Sua importância não se deve somente à capacidade de datação de processos magmáticos, mas também à sua estrutura cristalina robusta, capaz de suportar altas temperaturas e moderadas pressões sem alterar o registro isotópico. O zircão mantém-se relativamente estável a alterações intempéricas e a condições de baixo a médio grau de metamorfismo, com a exceção de casos que envolvem processos hidrotermais e em zonas de falhas (ex., condições de alta pressão) (Sinha \& Glover, 1978; Hoskin \& Black, 2000; Martin et al., 2008; Rubatto et al., 2008; Hay \& Dempster, 2009).

O metal de transição $\mathrm{Zr}$ foi descoberto por Martin Klaproth em 1789 no mineral zircão, um silicato onde ocorre solução sólida entre ${ }^{[\mathrm{VIII}]} \mathrm{Zr}^{+4}(0.84 \AA) \mathrm{e}^{\left[{ }^{[\mathrm{VIII}}\right]} \mathrm{Hf}^{+4}(0.83 \AA)$, com predominância do primeiro. Devido aos similares raios iônicos e atômicos, e proximidade nas dimensões das células unitárias, a descoberta do Hf foi retardada, sendo descrito na estrutura de zircões somente em 1923 por D. Coster e G.C. von Hevesey (Finch e Hanchar, 2003). O zircão representa um nesossilicato de estrutura relativamente simples (fórmula $A T O_{4}$ ), onde os tetraedros isolados do sítio $\mathrm{T}$ são ocupados por elementos com alto poder de ionização e os dodecaedros do sítio A são ocupados por grandes sítios estruturais de coordenação oito; tornando-se compatível com a maioria das variedades de magmas. Como resultados destas feições, este mineral pode ser encontrado desde as mais primitivas rochas (e.g., meteoritos: Ireland \& Wlotzka, 1992; Hirata, 2001), até as extremamente diferenciadas.

Os estudos clássicos na caracterização de associações de minerais pesados (e.g., Pettijohn 1941; Hubert, 1962) utilizaram o zircão além de outros minerais ultra-estáveis como indicadores de proveniência e maturidade sedimentar. Feições cristalográficas típicas dos zircões permitem reconhecer a identidade composicional e de temperatura de seus magmas geradores. A forma do zircão é constituída pelas faces prismáticas $\{100\}$ e $\{110\}$ e pelas faces bipiramidais $\{211\}$ e $\{101\}$. São determinados 64 tipos e subtipos teóricos, porém apenas 48 
ocorrem na natureza. A temperatura (índice de temperatura IT) influi no crescimento das faces prismáticas, enquanto as faces bipiramidais são favorecidas pelo índice de alcalinidade IA $\left(\mathrm{Al}_{2} \mathrm{O}_{3} / \mathrm{K}_{2} \mathrm{O}+\mathrm{Na}_{2} \mathrm{O}\right)$. $\mathrm{O}$ teor e a natureza dos voláteis presentes controlam principalmente o intervalo de cristalização do zircão e assim o número de tipologias formadas na rocha geradora. Em magmas anidros ficam restritas as tipologias; já em magmas hidratados a cristalização do zircão permanece até as ultimas frações residuais mais diferenciadas, permitindo a coexistência de diversas formas cristalográficas, resultando em cristais zonados (Pupin, 1980; Belousova et al., 2006).

$\mathrm{O}$ advento da datação U-Pb pontual em minerais, principalmente através de LAICPMS e SHRIMP, trouxe a possibilidade de investigação das idades dos zoneamentos e sobrecrescimentos em zircões, permitindo o reconhecimento dos amplos e variados eventos comumente encontrados em assembléias de zircões detríticos, anteriormente identificados somente como componentes de mistura em análises por TIMS.

Tradicionais análises de proveniência em zircões detríticos têm usado a química de elementos maiores determinados por microssonda eletrônica e podem também ser refinados através de determinações de elementos traços por LA-ICP-MS (Heaman et al., 1990; Belousova et al., 1998; Hoskin \& Ireland, 2000; Belousova et al., 2002; Hoskin \& Schaltegger, 2003; Belousova et al., 2006; Bomparola et al., 2007; Grimes et al., 2009; Hoskin \& Ireland, 2012; Grimes et al., 2007).

Este capítulo apresenta o estudo de proveniência de diferentes seqüências de rochas meta-psamíticas do Domínio São Roque, combinando datações U-Pb em zircões detríticos obtidas através de LA-MC-ICPMS e química dos mesmos cristais, determinada com LA-QICP-MS. A combinação destas duas técnicas permitiu um reconhecimento das áreas-fonte, além da caracterização dos efeitos do metamorfismo pós-deposicional, registrados nos cristais de zircão, tornando-se uma ferramenta poderosa no estudo de proveniência, bem como na identificação de eventos episódicos de geração de crosta (e.g., Condie et al., 2009; Condie \& Aster (2010)). 


\section{II.2. Composição química de zircões detríticos (LA-Q-ICP-MS)}

Anomalias químicas de núcleos e bordas de zircões foram previamente identificadas através de análises e imagens composicionais semi-quantitativas, obtidas via micro-XRF e através de teores mais elevados de alguns elementos determinados via microssonda eletrônica (ex., teores de fósforo). Este procedimento possibilitou a escolha de grãos potencialmente ricos em informações adicionais, considerando que cada secção com as montagens dos grãos contém por volta de 300 cristais.

A composição dos zircões obtida através de LA-ICPMS, associada à obtenção de imagens composicionais de elementos traço, ferramenta inédita que se mostrou poderosa na compreensão da zonalidade desses minerais, trouxe uma nova perspectiva no estudo de proveniência dentro do Domínio São Roque, particularmente no que diz respeito ao estudo dos sobrecrescimentos metamórficos, que registram grandes diferenças composicionais, quando comparados aos zircões não metamórficos. Devido a isto, este capítulo inicia-se com essa abordagem.

\section{II.2.1. Aspectos texturais e químicos de sobrecrescimentos metamórficos pós-deposicionais}

Cristais de zircão provindos de rochas com alto grau metamórfico normalmente apresentam geometrias arredondadas que registram frentes de recristalização e zonas convolutas, enquanto os cristais provenientes de rochas ígneas são comumente euédricos com zoneamentos oscilatórios (Bomparola et al., 2007; Rubatto, 2009). Os zircões detríticos estudados do Domínio São Roque freqüentemente apresentam sobrecrescimentos metamórficos que são normalmente identificados como porções escuras observadas em imagens por catodoluminescência (CL com zircões ricos em elementos traços), além de mostrarem significativas diferenças químicas quando comparados aos zircões não afetados por metamorfismo pós-deposicional.

Durante os processos metamórficos, o deslocamento de elementos traços para as bordas dos cristais de zircão pode resultar na formação de minerais como xenotima $\left(\mathrm{YPO}_{4}\right)$, xenotima- $(\mathrm{Yb})\left(\mathrm{YbPO}_{4}\right)$, thorita $\left(\mathrm{ThSiO}_{4}\right)$, thortveitita $\left(\mathrm{Sc}_{2} \mathrm{Si}_{2} \mathrm{O}_{7}\right)$ e yttrialita $\left(\mathrm{Y}_{2} \mathrm{Si}_{2} \mathrm{O}_{7}\right)(\mathrm{Bea}$ et al., 1996; Hoskin \& Black, 2000; Finch \& Hanchar, 2003; Spandler et al., 2004). O 
mecanismo mais comum de acomodação de elementos traços em zircões é o de substituição acoplada de xenotima $\left[(\mathrm{REE}+\mathrm{Y})^{3+}+\mathrm{P}^{5+} \leftrightarrow \mathrm{Zr}^{4+}+\mathrm{Si}^{4+}\right]$, e isto é o que parece acontecer com os sobrecrescimentos que apresentam coloração escura em imagens de CL.

Adicionalmente, cátions quadrivalentes como $\mathrm{Hf}^{4+}, \mathrm{U}^{4+}$ e $\mathrm{Th}^{4+}$ podem substituir diretamente o $\mathrm{Zr}^{4+}$ sem a necessidade de uma compensação de carga, em contraste com a incorporação de cátions trivalentes, que requerem mecanismos de troca mais complexos para que se mantenha o balanço de carga (Spandler et al., 2004; Rubatto et al., 2008). Alternativamente, mecanismos de substituição podem incluir outros elementos como $\mathrm{Mg}, \mathrm{Fe}$, Al (Hoskin et al., 2000), conforme também é sugerido através do comportamento dos zircões analisados (Fig. II-2).

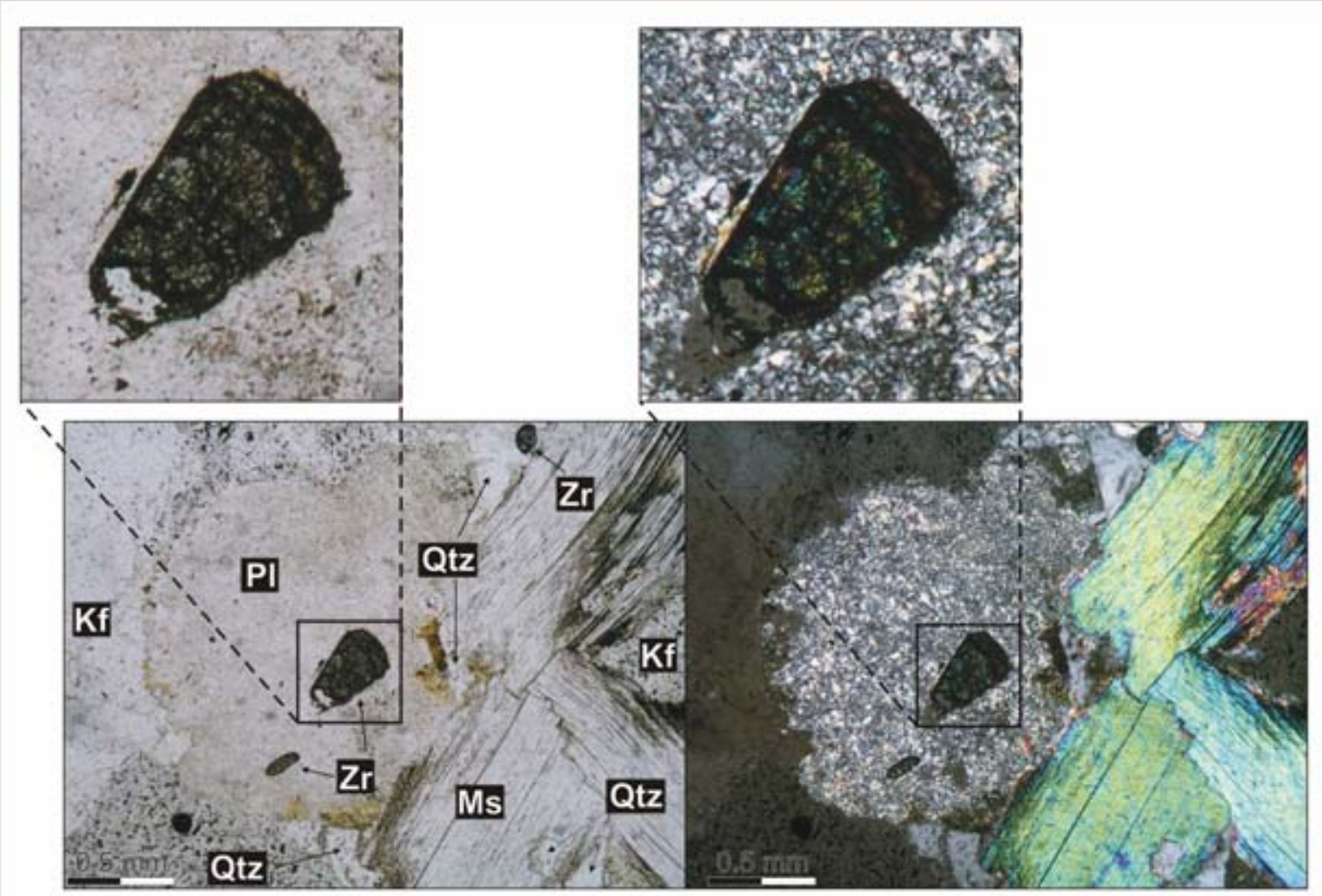

Figura II-1: Fotomicrografia que exemplifica a interação entre zircões e outras fases minerais, como muscovita $(\mathrm{Ms})$, plagioclásio $(\mathrm{Pl})$ e feldspato alcalino $(\mathrm{Kf})$ (polarizadores paralelos à esquerda; polarizadores cruzados a direita). 
O enriquecimento em elementos como $\mathrm{Ca}, \mathrm{Fe}, \mathrm{Al}, \mathrm{U}, \mathrm{Na}, \mathrm{Mg}, \mathrm{Ba}, \mathrm{Pb}, \mathrm{Sr}, \mathrm{Th}, \mathrm{U}, \mathrm{Ta}, \mathrm{W}$ e P identificados nos sobrecrescimentos (Fig. II-3) deve refletir processos locais de difusão intra-cristalina, a julgar pela quantidade de elementos com grande raio iônico que normalmente não aparecem em proporções significativas em zircões não metamórficos. Isto sugere interações com outras fases minerais, como por exemplo, plagioclásio, feldspato alcalino e muscovita, conforme ilustra a Figura II-1. A possibilidade de elementos como Ca, $\mathrm{Al}, \mathrm{Na}, \mathrm{Mg}$, provirem de outras fases minerais intercrescidas como micro-cristais nos zircões, deve ser considerada, no entanto estudos mais aprofundados neste sentido (ex., análises via MEV), ainda não foram executados.

O padrão de ETR dos sobrecrescimentos metamórficos pós-deposicionais é enriquecido em relação aos núcleos não metamórficos e tem como característica principal o enriquecimento em elementos de terras raras leves, podendo alcançar diferenças de mais de uma ordem de magnitude (com média da $\sum$ LREE $=747 \mathrm{ppm}$ nos sobrecrescimentos e $\sum$ LREE = 68 ppm nos núcleos) (Fig. II-4). Adicionalmente, outras feições típicas são as menores anomalias positivas de $\mathrm{Ce}=[\mathrm{Ce} / \sqrt{ }(\mathrm{La}) *(\mathrm{Pr})]$ (média $\left.\mathrm{Ce}^{*}=1.8\right)$, menores anomalias negativas de $\mathrm{Eu}=[\mathrm{Eu} / \sqrt{ }(\mathrm{Sm}) *(\mathrm{Gd})]\left(\right.$ média $\left.\mathrm{Eu}^{*}=0.88\right)$, baixa razão $\mathrm{Sm}_{\mathrm{N}} / \mathrm{La}_{\mathrm{N}}($ média $=2.8)$ e $\mathrm{Lu}_{\mathrm{N}} / \mathrm{Sm}_{\mathrm{N}}$ (média $=7.1$ ), quando comparados aos núcleos não afetados pelo processo metamórfico (média dos núcleos $\mathrm{Ce}^{*}=3.0, \mathrm{Eu}^{*}=0.51, \mathrm{Sm}_{N} / \mathrm{La}_{\mathrm{N}}=4.9$ e $\mathrm{Lu}_{\mathrm{N}} / \mathrm{Sm}_{\mathrm{N}}=29.3$ ). 


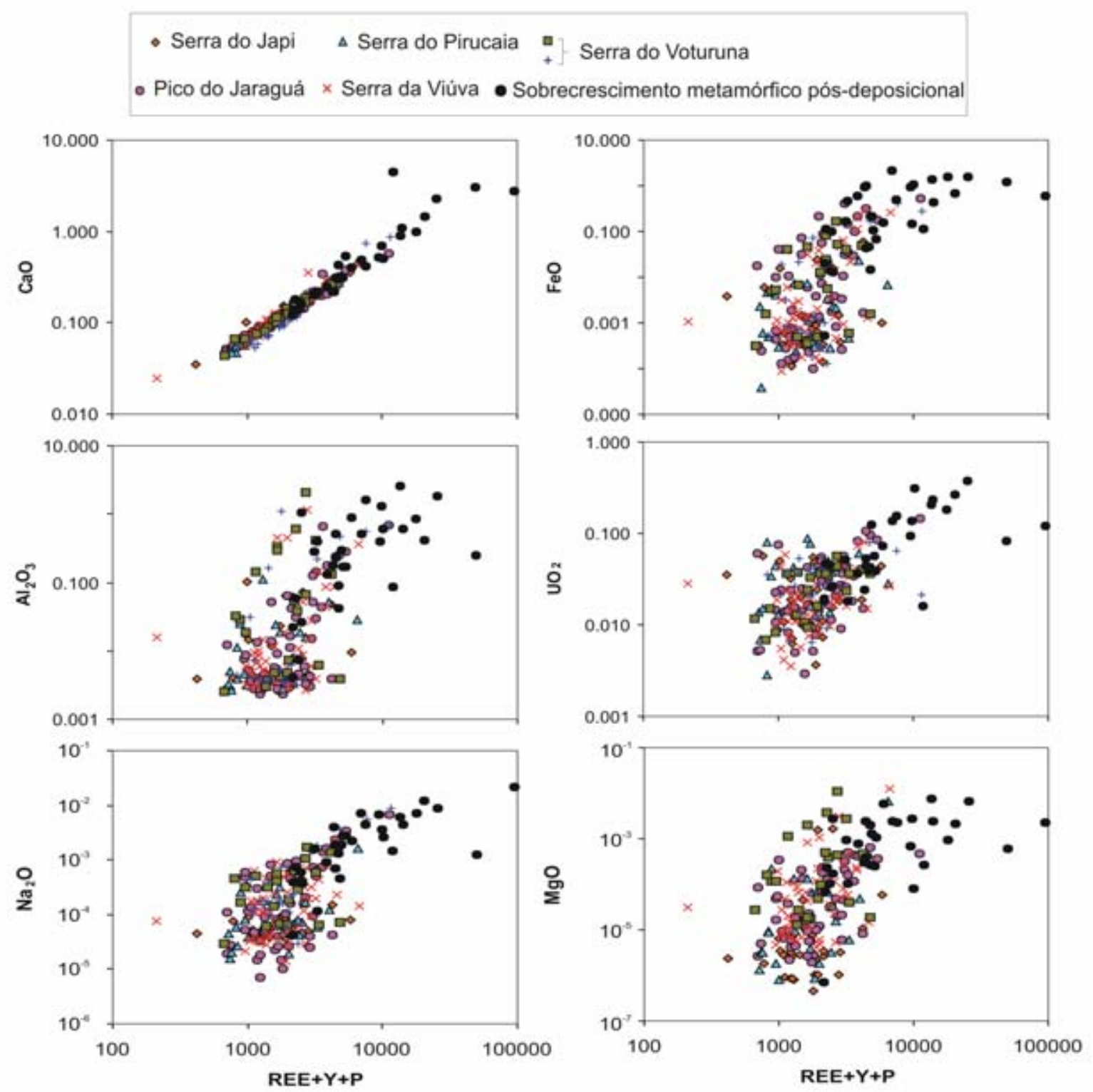

Figura II-2: Diagramas binários usando o componente xenotima $(\mathrm{REE}+\mathrm{Y}+\mathrm{P})$ para a diferenciação dos sobrecrescimentos metamórficos pós-deposicionais em zircões do Domínio São Roque. 


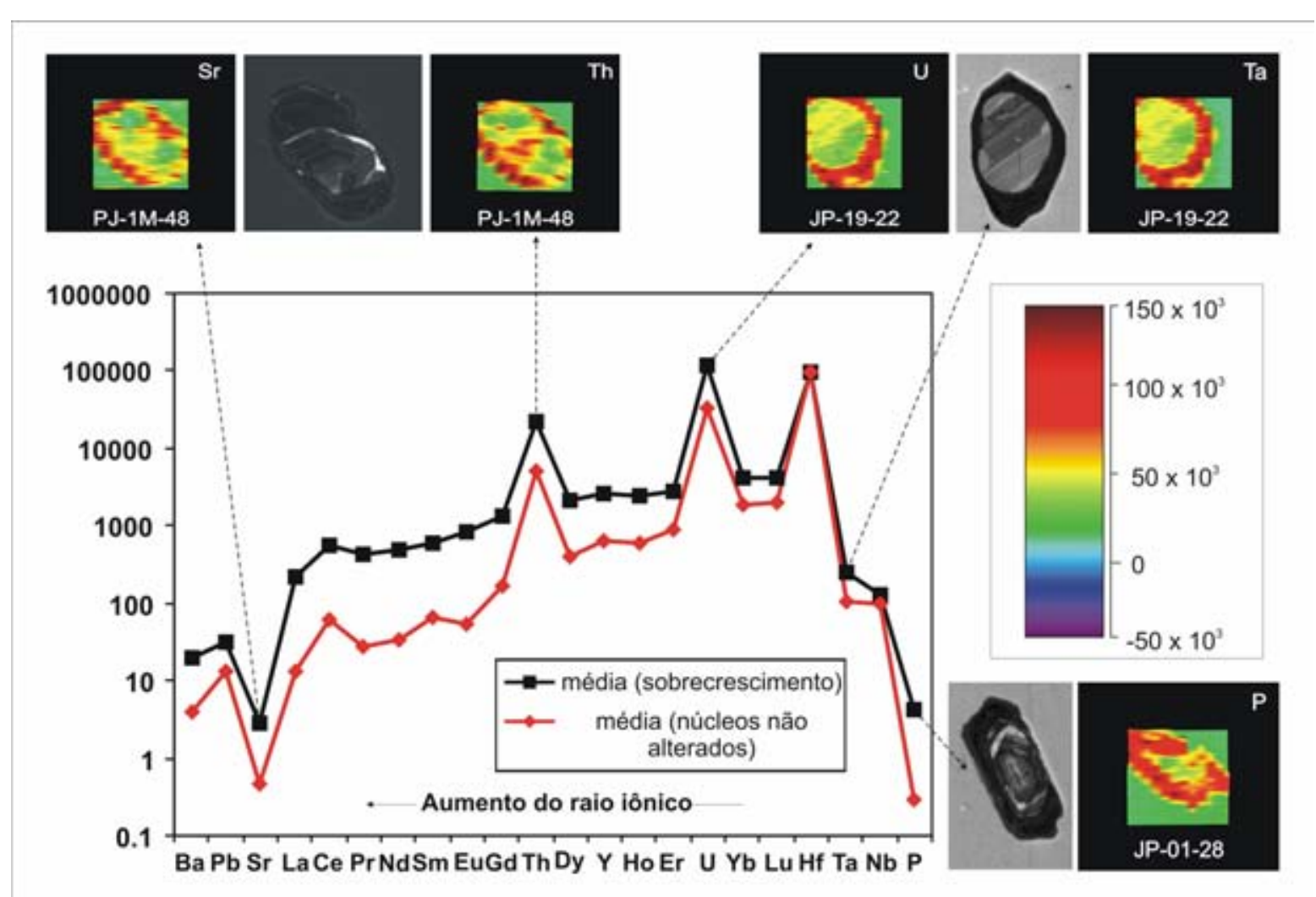

Figura II-3: Elementos incompatíveis de zircões detríticos de meta-psamitos do Domínio São Roque normalizados pelos teores condríticos (McDonough \& Sun, 1995). Imagens de CL e imagens composicionais (produzidas por ablação a laser em secções paralelas transversais a partir de um espaçamento de linhas ordenado - LA-ICPMS) de cristais de zircão, ilustrando diferenças entre os sobrecrescimentos metamórficos pós-deposicionais e núcleos não afetados pelo metamorfismo. 


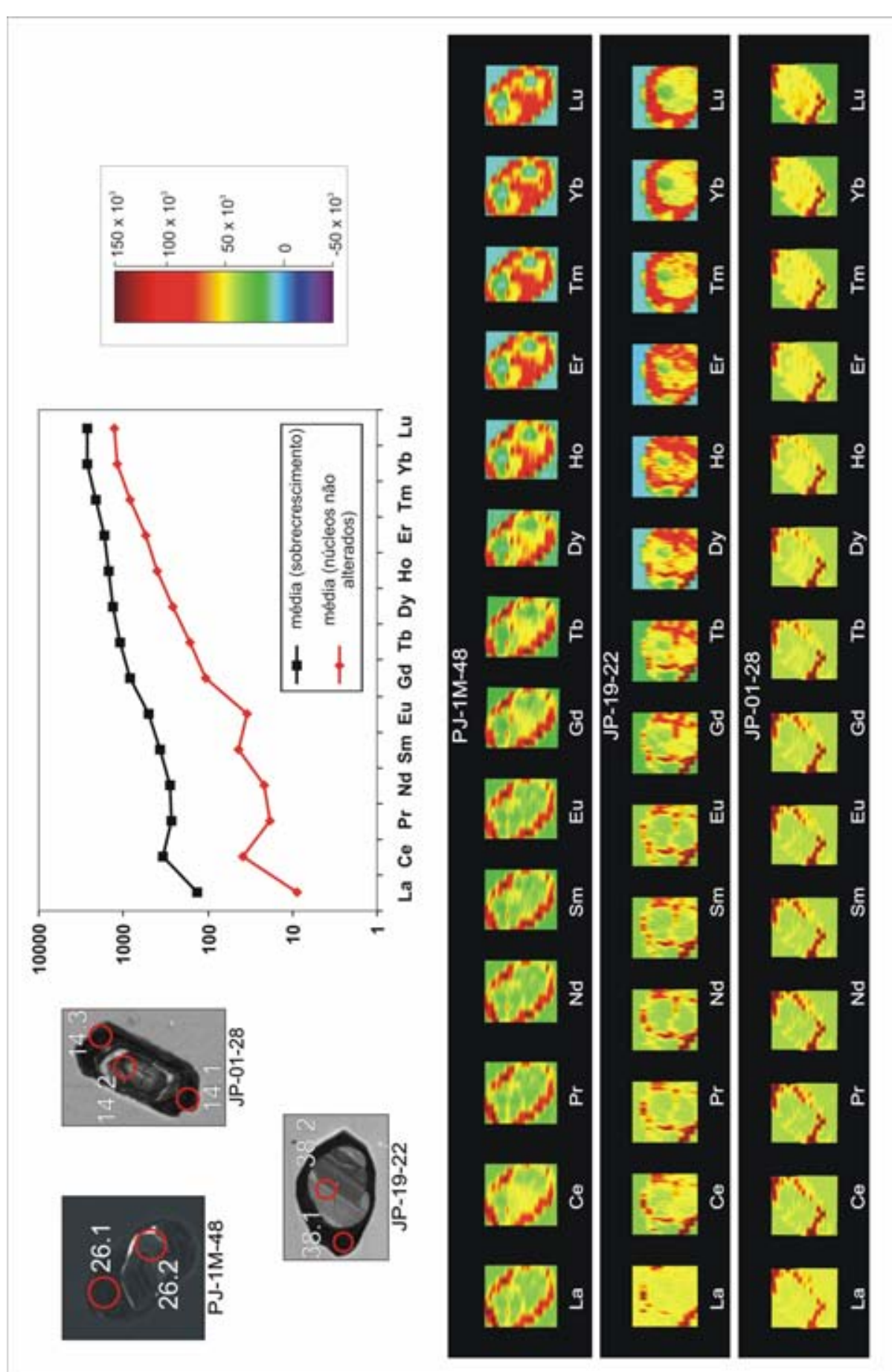

Figura II-4: Concentração de elementos terras raras de zircões detríticos de meta-psamitos do Domínio São Roque normalizados pelos teores de condritos (McDonough \& Sun, 1995). Imagens de CL e imagens composicionais (produzidas por ablação a laser em secções transversais paralelas a partir de um espaçamento de linhas ordenado - LA-ICPMS) de cristais de zircão, ilustrando diferenças entre os sobrecrescimentos metamórficos pós-deposicionais e núcleos não afetados pelo metamorfismo. 


\section{II.2.2. Química de zircões detríticos e inferências sobre as áreas-fontes}

Todos os cristais não metamórficos têm intervalos similares de $\mathrm{SiO}_{2}$ (31-34\%), $\mathrm{ZrO}_{2}$ (63-65\%) e $\mathrm{HfO}_{2}$ (0.9-1.8\%), além de altos teores de $\mathrm{Y}$ (acima de 2\%). Diferenças significativas na composição são identificadas somente nos elementos de terras raras, em especial nos pesados. Devido a este comportamento, propõe-se o uso da razão $\mathrm{Lu}_{N} / \mathrm{Sm}_{\mathrm{N}}$, inicialmente sugerida por Heaman et al. (1990), como índice de diferenciação, que se mostrou eficiente na identificação de algumas fontes de zircões.

Com feições típicas identificadas em zircões provenientes da crosta continental (ex., granitos, álcali-granitos, tonalitos e granodioritos), conforme mostram os dados compilados de Heaman et al. (1990), Belosouva et al. (2002) e Bomparola et al. (2007), a maioria dos zircões parece derivar de rochas félsicas, que contêm cristais normalmente mais enriquecidos em elementos traços de grande raio iônico (Fig. II-5). Todo o conjunto mostra comportamentos similares com características de fontes graníticas predominantemente ricas em plagioclásio, quando consideradas as razões $\sum \mathrm{HFSE} / \sum \mathrm{LILE}$, os teores de ETR $+\mathrm{Y}$ e anomalias de $\mathrm{Eu}^{*}$ menores que 0.5. (Fig. II-6).

Diferentemente de zircões provenientes de crosta continental, são características de gabros gerados em dorsais meso-oceânicas modernas (Puga et al., 2005 e Grimes et al., 2007; Grimes et al., 2012), zircões enriquecidos no componente xenotima (ETR+Y+P) com baixos conteúdos de ETRL, fortes anomalias positivas de Ce* (predominantemente maiores que 80), baixa razão U/Yb (< 0.1- Fig.II-7), além da curvatura desenhada como uma concavidade negativa no padrão dos elementos de terras raras intermediários, causada pela cristalização de zircões paralelamente a piroxênios, quantificada pela relação $[2 \mathrm{Ho} /(\mathrm{Gd}+\mathrm{Yb})] \leq 1.19$ (Lizuka et al., 2006) (ver tabela II-1) 


\begin{tabular}{|c|c|c|c|c|c|c|}
\hline & \multicolumn{3}{|c|}{ Zircões de crosta continental } & \multicolumn{3}{|c|}{ Zircões de crosta oceânica } \\
\hline & $\operatorname{Max}$ & Min & Averege & $\operatorname{Max}$ & Min & Averege \\
\hline \multirow{5}{*}{$\begin{array}{c}\sum \mathrm{ETRL} \\
\mathrm{Ce}^{*} \\
\mathrm{Sm}_{\mathrm{N}} / \mathrm{La}_{\mathrm{N}} \\
\mathrm{Eu}^{*} \\
((2 \mathrm{Ho} / \mathrm{Gd}+\mathrm{Yb}))\end{array}$} & 1248.33 & 1.87 & 90.74 & 269.98 & 2.61 & 40.23 \\
\hline & 79.39 & 0.39 & 12.01 & 326.25 & 1.50 & 82.06 \\
\hline & 310.33 & 0.98 & 59.70 & 1207.45 & 3.88 & 376.32 \\
\hline & 0.51 & 0.04 & 0.25 & 0.89 & 0.11 & 0.37 \\
\hline & 3.26 & 0.29 & 0.68 & 1.19 & 0.26 & 0.66 \\
\hline \multirow{3}{*}{$\begin{array}{c}\mathbf{L u}_{\mathrm{N}} / \mathrm{Sm}_{\mathrm{N}} \\
\sum \mathrm{ETR} / \sum \mathrm{ETRL} \\
\mathbf{U} / \mathrm{Yb}\end{array}$} & 768.73 & 20.85 & 107.94 & 1288.39 & 110.00 & 367.18 \\
\hline & 249.71 & 2.53 & 58.68 & 322.98 & 18.55 & 156.49 \\
\hline & 8.99 & 0.18 & 1.04 & 0.99 & 0.02 & 0.27 \\
\hline
\end{tabular}

Tabela II-1: Principais relações usadas para diferenciar zircões provenientes de crosta continental de crosta oceânica. Campos em cinza foram utilizados para estabelecer critérios de valores máximos e mínimos com a maior chance de certeza quando da discriminação de zircões provenientes de crosta oceânica.

Em todas as unidades de meta-psamitos estudadas podem existir contribuições de zircões com características de zircões provenientes de gabros tipo MORB, que são aqui identificados como aqueles que apresentam razão $\mathrm{Lu}_{N} / \mathrm{Sm}_{\mathrm{N}}$ maiores que 105 , anomalias de Ce* maiores que 1.50, anomalias de $\mathrm{Eu}^{*}$ maiores que 0.11, razões $\mathrm{Sm}_{\mathrm{N}} / \mathrm{La}_{\mathrm{N}}$ maiores que 26.6 (valores mínimos, porém maiores que os mínimos encontrados em zircões de crosta continental), além da somatória dos ETR leves menores que 270 ppm e razões U/Yb menores que 0.1 (valores máximos, porem menores que os máximos identificados em zircões de crosta continental). Trata-se de um grupo restrito de 13 cristais, geralmente não zonados, o que pode indicar fontes de magmas anidros (Pupin, 1980), com exceção dos zircões de $\mathrm{n}^{\circ} 9$ e 10 com zoneamentos contínuos e intensos (Figura II-9).

Similaridades com zircões derivados de rochas ultramáficas, como lamprófiros, kimberlitos e carbonatitos (dados compilados de Heaman et al., 1990; Belosouva et al., 2002), não foram identificadas nos zircões estudados nesta tese (Fig. II-8). 

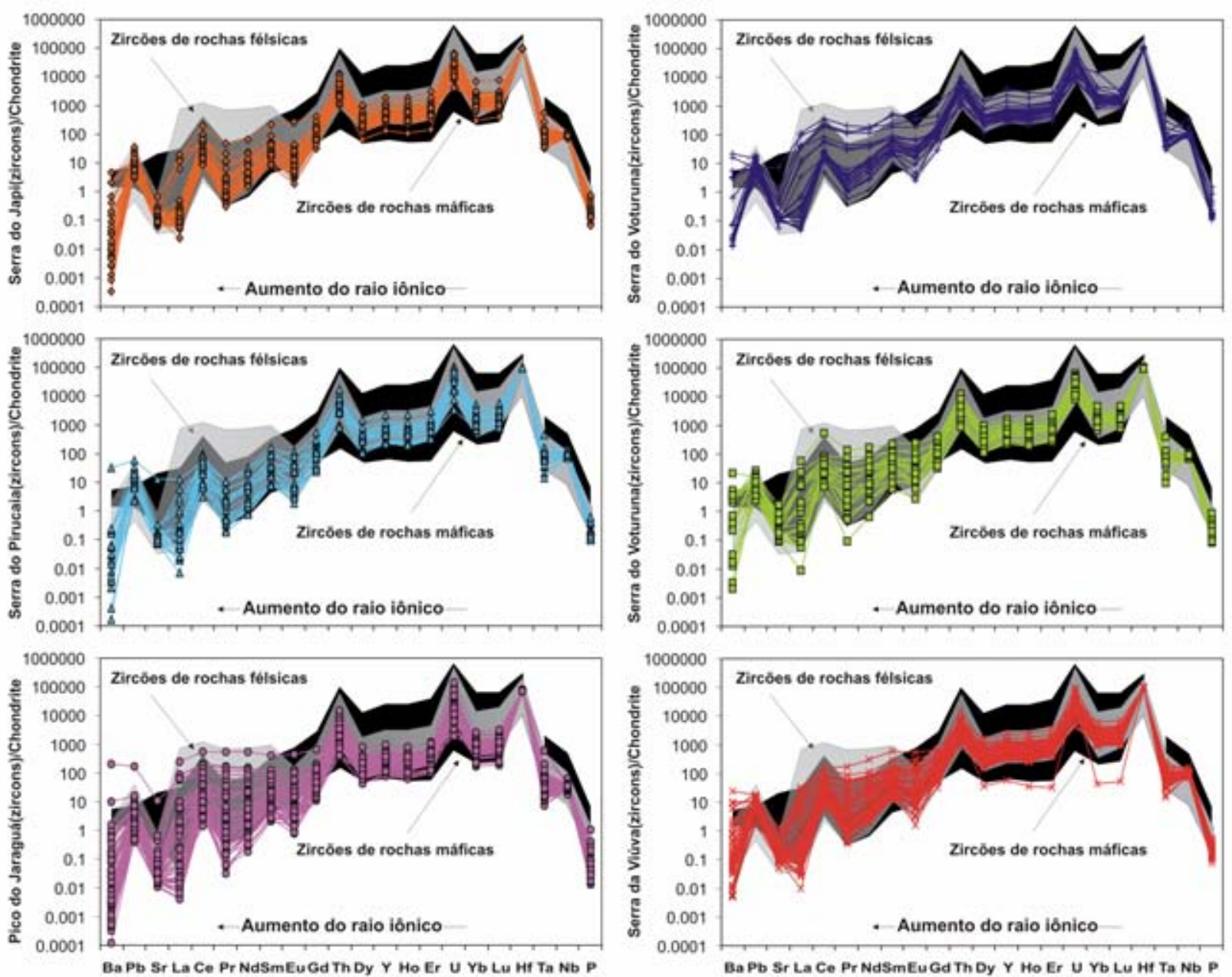

Figura II-5: Elementos incompatíveis de zircões detríticos de meta-psamitos do Domínio São Roque normalizados pelos teores de condritos (McDonough \& Sun, 1995). Campos de rochas félsicas e máficas desenhados a partir da compilação de Heaman et al. (1990); Belosouva et al. (2002); Bomparola et al. (2007); Puga et al. (2005) e Grimes et al. (2007). 

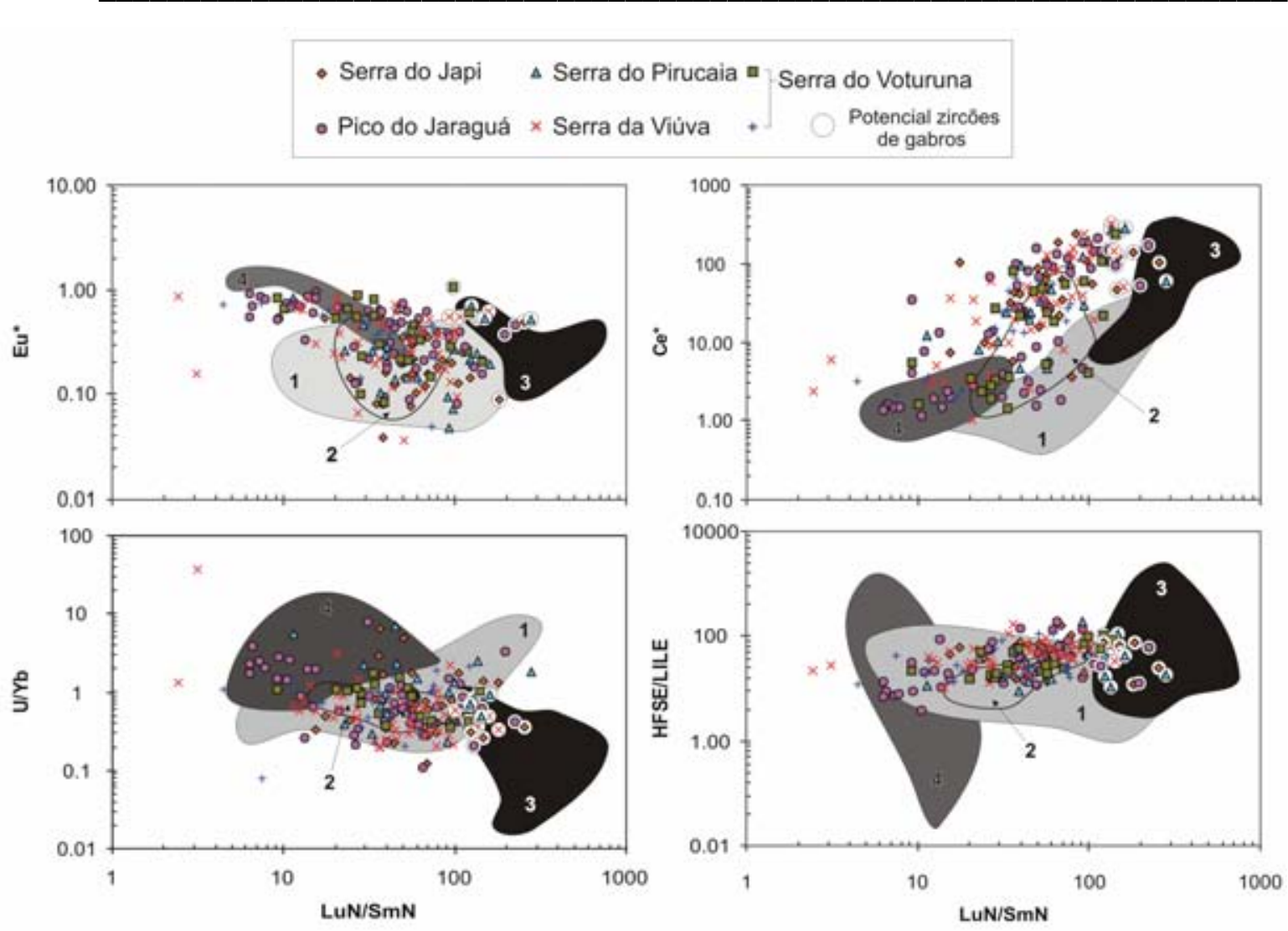

Figura II-6: Diagrama binário usando a razão $(\mathrm{Lu} / \mathrm{Sm})_{\mathrm{N}}$ para diferenciar potenciais diferenças entre as fontes de magmas geradores de zircões. Campo 1= biotita - piroxênio monzogranitos, 2 = granitóides ricos em plagioclásio, $3=$ basaltos e gabros, 4= kimberlitos, carbonatitos e lamprófiros. Dados compilados de Heaman et al., (1990); Belosouva et al., (2002); Bomparola et al., (2007); Puga et al., 2005 e Grimes et al., 2007.

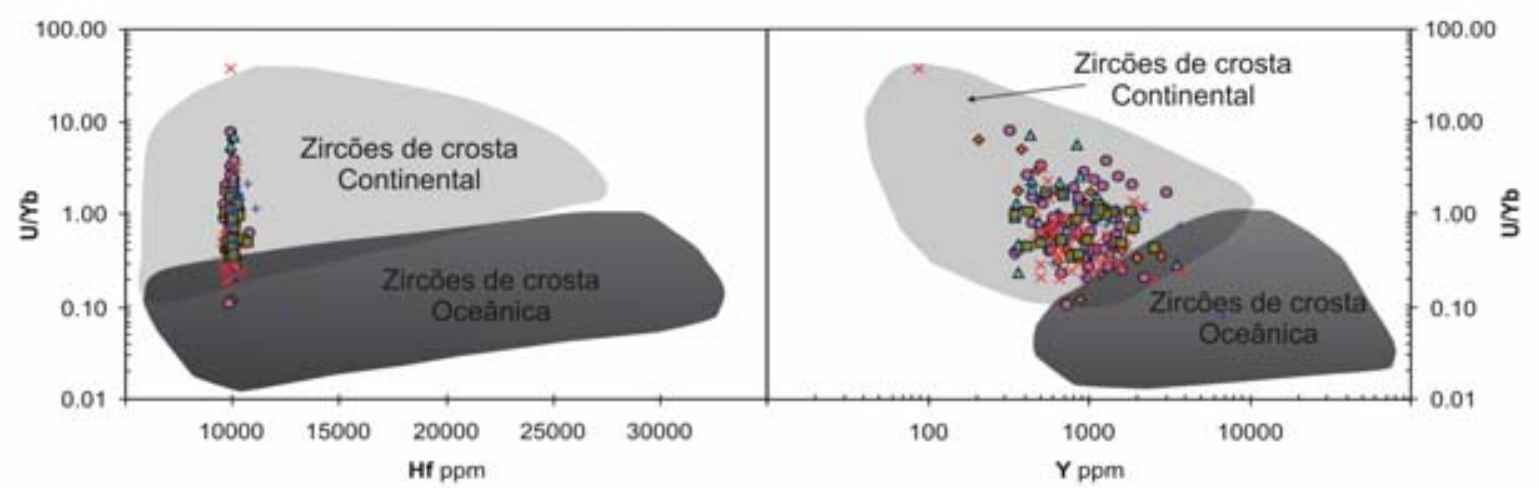

Figura II-7: Diagrama de discriminação de zircões provenientes de crosta oceânica e continental de Grimes et al. (2007), mostrando proveniência predominantemente de zircões de crosta continental dentro da assembléia de minerais detríticos do Domínio São Roque. 

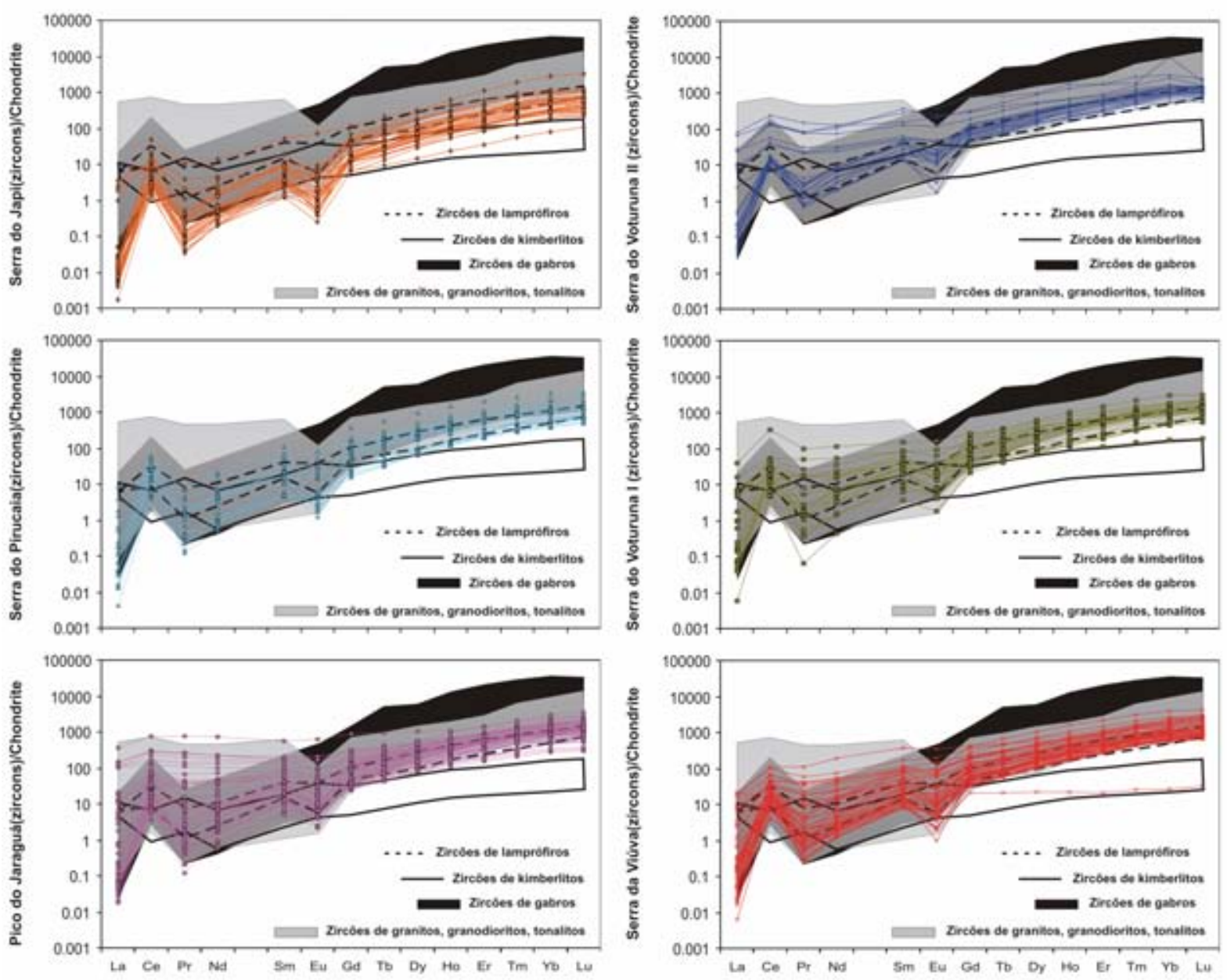

Figura II-8: Elementos terras raras de zircões detríticos de meta-psamitos do Domínio São Roque normalizados pelos teores condríticos (McDonough \& Sun, 1995). 


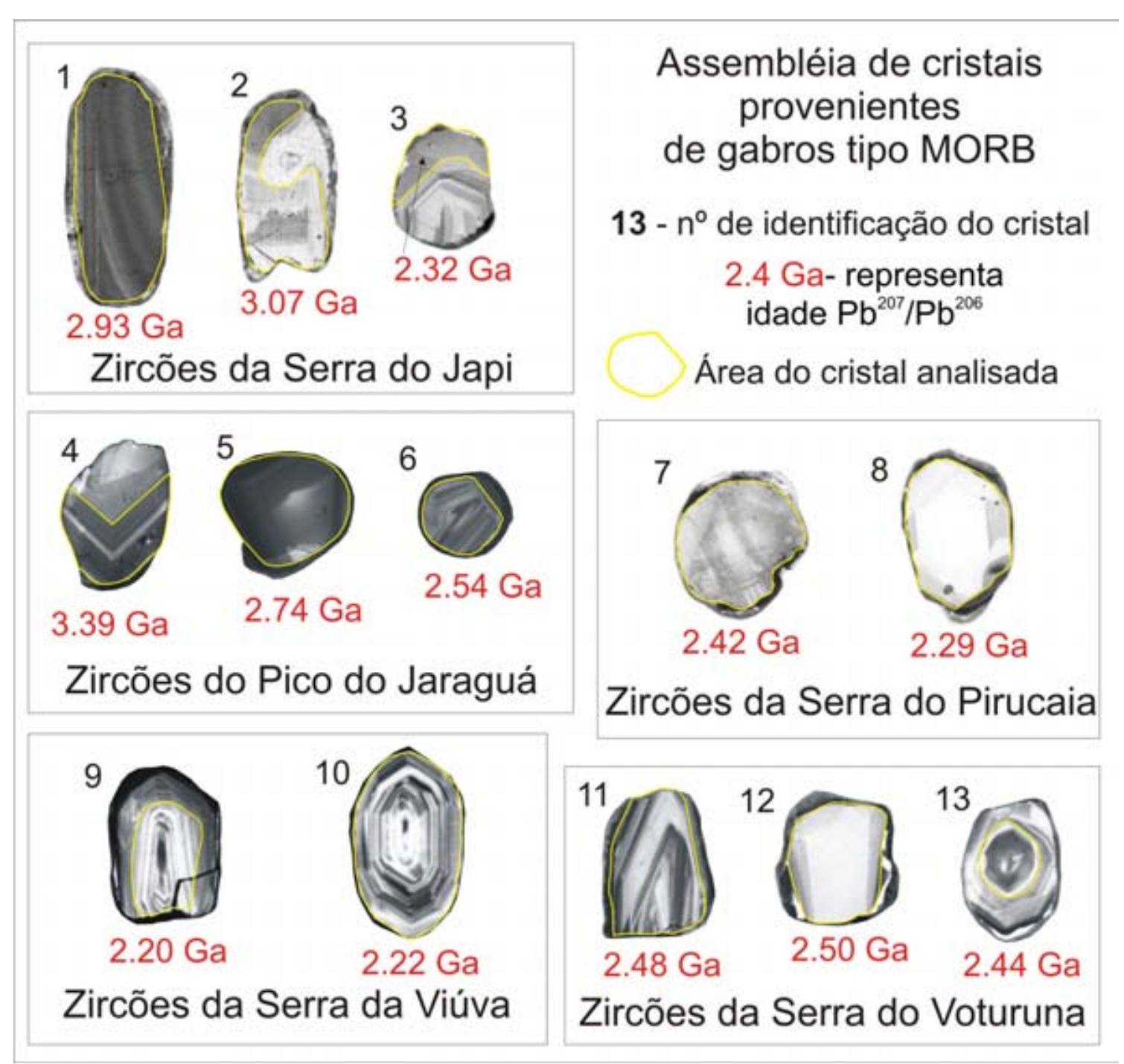

Figura II-9: Cristais de zircões com assinaturas químicas compatíveis com zircões provenientes de garbros tipo MORB. Resultados das análises químicas destacados em campos cor de cinza no Anexo V.

II.3. Datação U-Pb (LA-MC-ICP-MS)

\section{II.3.1. Idade do sobrecrescimento metamórfico}

A obtenção de idades precisas em sobrecrescimentos metamórficos nas assembléias de zircões detríticos enriquecidos no componente xenotima do Domínio São Roque não é uma tarefa trivial, considerando os baixos teores de ${ }^{208} \mathrm{~Pb}$ e os altos teores de ${ }^{206} \mathrm{~Pb}$ e U, que 
tipicamente responde pelas cores escuras observadas nas imagens de catodoluminescência, sem contar as possibilidades de perda de $\mathrm{Pb}$ radiogênico que aumentam as chances de não obter idades concordantes. As imagens da Figura II-9 mostram que o núcleo apresenta variações nos teores de $\mathrm{U}$ e dos isótopos de $\mathrm{Pb}$; por exemplo, a área mais escura da imagem CL, além de altos teores de U (ver mesmo cristal Fig. II-3), tem altos teores de ${ }^{207} \mathrm{~Pb}$ e ${ }^{206} \mathrm{~Pb}, \mathrm{o}$ que responde pelas idades mais antigas com alta razão ${ }^{207} \mathrm{~Pb} /{ }^{206} \mathrm{~Pb}$. Já os sobrecrescimentos ricos em $\mathrm{U}$ apresentam altos teores de ${ }^{206} \mathrm{~Pb}$, mas têm baixa razão ${ }^{207} \mathrm{~Pb} /{ }^{206} \mathrm{~Pb}$, reflexo das idades mais jovens. Somente três idades concordantes puderam ser utilizadas para estimar a idade do evento de sobreposição metamórfica; as demais foram excluídas da regressão, embora constem da Figura II-10 com caráter ilustrativo. A média das três idades, $584 \pm 47$ Ma, é uma aproximação da época do evento térmico regional Neoproterozóico.

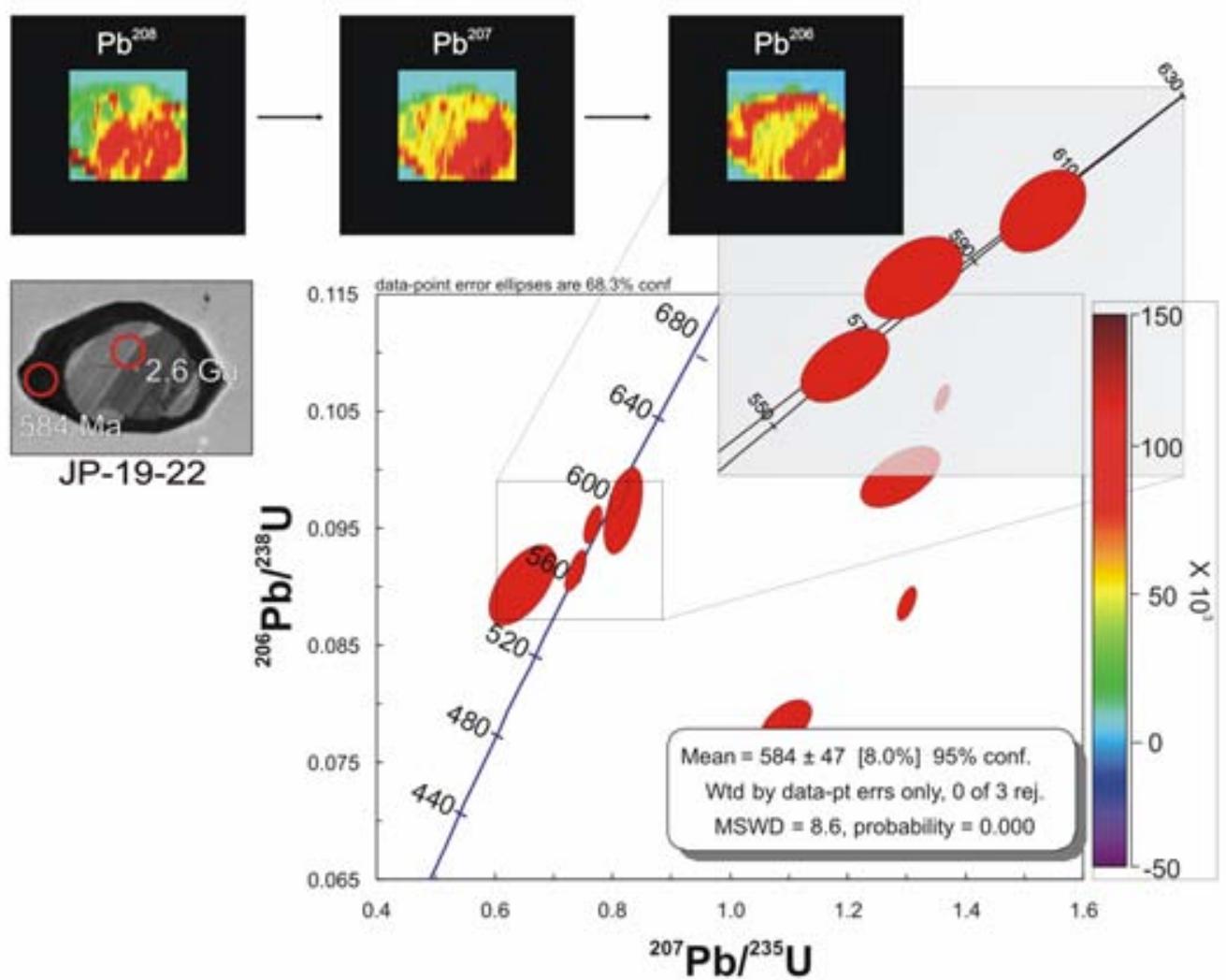

Figura II-10: Diagrama concórdia com idades U-Pb em zircão obtidas por LA-MC-ICPMS em sobrecrescimentos metamórficos pós-deposicionais. Imagens de CL e imagens composicionais (produzidas por ablação a laser em secções transversais paralelas a partir de um espaçamento de linhas ordenado - LA-ICPMS) de cristais de zircão. 


\section{II.3.2. Idades das Areas-Fontes}

\section{II.3.2.1. Amostra JP-01 (Serra do Japi)}

A população de zircões detríticos do meta-subarcóseo da Serra do Japi, maior área exposta de rochas meta-psamiticas dentro do Domínio São Roque (Anexo VI), localizado a norte do sistema de falhas de Jundiuvira (ver discussão no subitem I.3.1 Posicionamento Tectônico Regional), tem um espectro de idades com dois principais picos de idade em um intervalo de 2.3-2.1 Ga, mostrando que as principais fontes têm idades relacionadas ao período Riaciano. No entanto, esta unidade recebeu também grande aporte de zircões com idades relacionadas ao Orosiriano (10\%). Outro pico bem definido em 2.6 Ga está presente, além de um contínuo de zircões de idades arqueanas até $~ 3.1 \mathrm{Ga}$, sendo que o mais antigo cristal foi datado em $3.4 \mathrm{Ga}$; um aspecto notável é que $44 \%$ de os zircões detríticos totais são arqueanos, mais velhos que $2.5 \mathrm{Ga}$. A única idade mais jovem concordante é de $1762 \pm 10$ Ma, marcando o limite superior para a deposição para esta unidade.

\section{II.3.2.2. Amostra VT-04 (Serra da Viúva)}

Metarenitos a norte do Domínio São Roque, localizados a sul do sistema de falhas de Jundiuvira, formam serranias alongadas concordantemente ao falhamento (Serra da Viúva). A amostra de meta-subarcóseo VT-04 tem uma população de zircões detríticos com pico unimodal em $\sim 2.2 \mathrm{Ga}$, e a maior contribuição de zircões do período Riaciano comparados às outras amostras estudadas (53\%). No entanto, importante contribuição arqueana também está presente (37\%), com um cristal mais antigo também datado em $\sim 3.4 \mathrm{Ga}$. O limite superior para a deposição, identificado com a datação do zircão mais jovem em $1765 \pm 17$ Ma, também é marcado no período Estateriano, que forneceu $7 \%$ da população de zircões detríticos. 


\section{II.3.2.3. Amostra VT-03 (Serra do Voturuna)}

Localizado na porção central do Domínio São Roque, próximo às ocorrências de anfibolitos da região de Pirapora de Bom Jesus, o metarcóseo amostrado na Serra do Voturuna tem um espectro de zircões detríticos em sua grande maioria com idades do período Riaciano (40\%); dois picos de idades são bem definidos no intervalo de 2.1-2.5 Ga. A maior contribuição do período Sideriano $(27 \%)$ e discreta contribuição de zircões com idades mais antigas que $2.5 \mathrm{Ga}(18 \%)$, são características desta amostra, cujo cristal mais antigo foi datado em $\sim 3.3 \mathrm{Ga}$. Um único cristal com idade mesoproterozóica (1410 $\pm 58 \mathrm{Ma})$ marca o limite superior para a deposição.

\section{II.3.2.4. Amostra JP-19 (Serra do Pirucaia)}

Da porção centro-leste do Domínio São Roque (Anexo VI), provavelmente inserido no contexto da Formação Serra do Itaberaba (Formação Pirucaia - Juliani, 1993), o metarenito amostrado na região da Serra do Pirucaia apresenta um pico de zircões detríticos bem definido em $2.2 \mathrm{Ga}$, com metade de sua população datada no período Riaciano. Esta amostra apresenta um espectro de idades um pouco mais restrito quando comparado ao das outras unidades (com um intervalo de 1.9-3.0 Ga), sendo que $21 \%$ das idades são mais antigas que $2.5 \mathrm{Ga}$. O zircão mais novo foi datado em $1939 \pm 42$ Ma, marcando um limite superior de deposição mais antigo quando comparado às outras ocorrências. Esta unidade tem a maior proporção de zircões detríticos relacionados ao período Orosiriano, chegando a $16 \%$ do total, além da ausência de fontes Paleoarqueanas.

\section{II.3.2.5. Amostra PJ-1M (Pico do Jaraguá)}

A porção amostrada no centro-sul da área de estudo, com exposição mais próxima à cidade de São Paulo, está representada pela amostra de meta-quartzo arenito do Pico do Jaraguá, diretamente associada ao pacote de metarcóseos e metaconglomerados da região do Morro Doce. A população de zircões detríticos também se caracteriza pela grande contribuição de fontes Riacianas $(42 \%)$, com pico em $2.2 \mathrm{Ga}$, além da maior concentração de 
zircões Paleoarqueanos (7\%) e Neoarqueanos (27\%), com o zircão de idade mais antiga datado em 3.4 Ga. Já o limite deposicional superior é marcado pela idade do zircão mais novo datado em $1771 \pm 32$ Ma. Estas características somadas a uma distribuição de idades praticamente contínua de zircões com idades superiores a $2.5 \mathrm{Ga}$, são fortes argumentos a favor de similaridades entre as áreas-fontes da amostra da região da Serra do Japi e Pico do Jaraguá.

\section{II.4. Síntese do Padrão de Proveniência do Domínio São Roque}

O espectro de análises de todo o conjunto de zircões detríticos analisados dentro do Domínio São Roque mostra um intervalo de idades entre 1410 Ma (idade mínima obtida em um cristal de zircão da Serra do Voturuna) e 3437 Ma (idade máxima obtida em zircões da Serra do Japi). O pico principal de zircões detríticos em torno de $2.2 \mathrm{Ga}$ é similar para todas as unidades (Fig. II-11). Outros picos de idade também são comuns a todas as unidades, como os de 2.5-2.4 Ga e 2.9-2.7 Ga; por outro lado, intervalos com ausência de idades, como 1.9-1.8 $\mathrm{Ga}$, também parecem ser uma feição comum. Restritos intervalos com ausência de idades são encontrados em amostras da Serra do Pirucaia e Serra da Viúva (de 2.5 a 2.4 Ma), bem como em amostras da Serra do Japi e Serra da Viúva (3.3 a 3.2 Ga).

O único cristal de zircão mais novo proveniente do metarcóseo da Serra do Voturuna é uma exceção, visto que o limite superior de sedimentação identificado em outras amostras mostra-se consistente em $\sim 1.7 \mathrm{Ga}$, idade aproximada da deposição determinada pela datação de rochas metavulcânicas intercaladas no Grupo São Roque (van Schmus et al., 1986) . A idade de $\sim 1.4$ Ga é compatível com a idade mínima de sedimentação proposta para o Grupo Serra do Itaberaba e correlatos no Grupo Açungui (Juliani et al., 2000; Siga Jr. et al., 2011). A amostra da Serra da Pirucaia, associada na literatura ao Grupo Serra do Itaberaba, não mostra contribuições mais jovens que $1.9 \mathrm{Ga}$, e não apresenta zircões paleoarqueanos (amostra da Serra do Pirucaia). Por outro lado, a relativa abundância de zircões mais velhos que $3.0 \mathrm{Ga}$, são características comuns aos metarenitos da Serra do Japi e Pico do Jaraguá. 
Idades em bilhões de anos

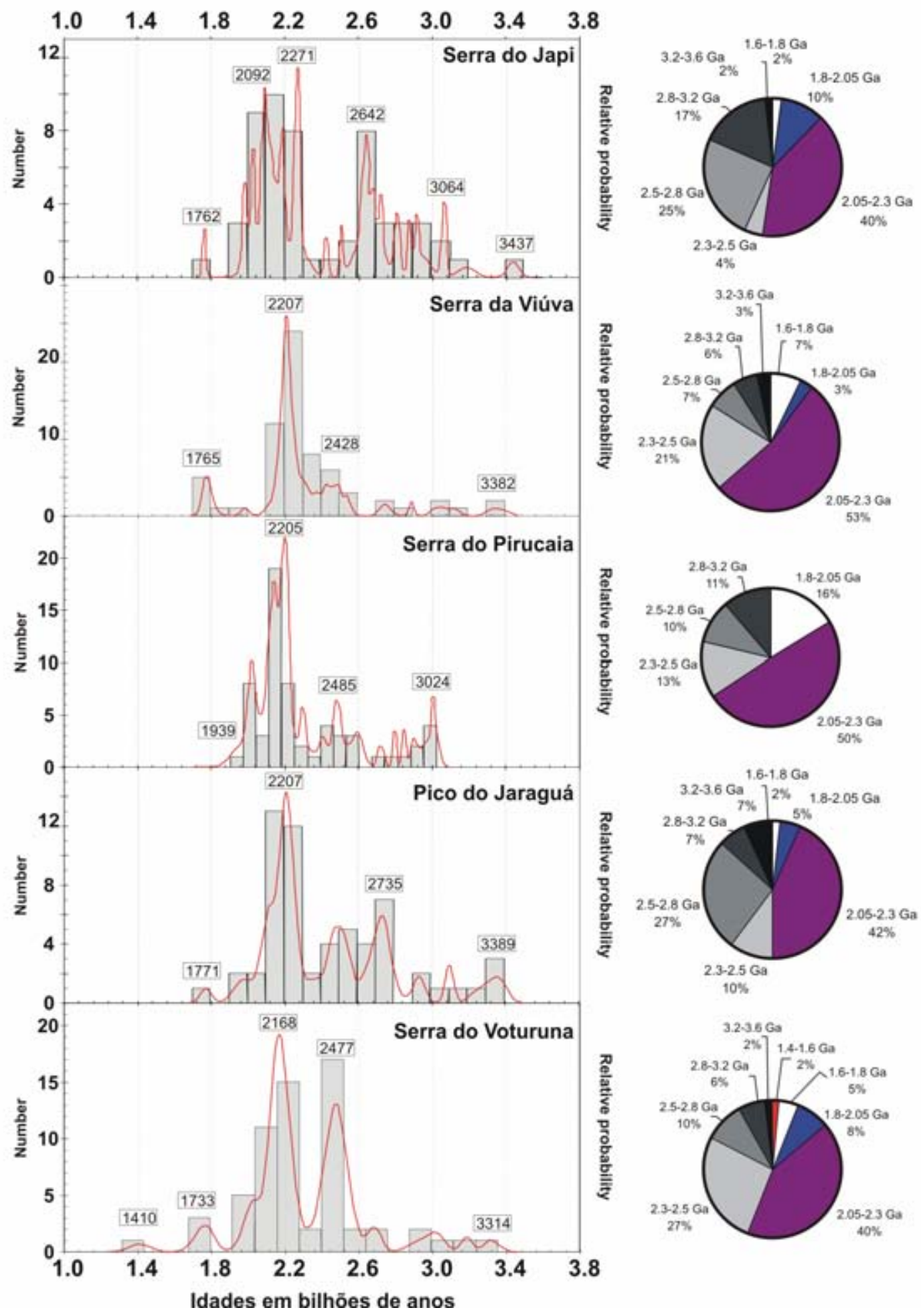

Figura II-11: Espectro de idades e diagramas tipo pizza mostrando relativa proporção de idades de zircões detríticos de meta-psamitos do Domínio São Roque. 
Teste estatístico Kolmogorov-Smirnov (K-S) foi usado para comparar potenciais similaridades de proveniência entre as amostras. Este teste leva em consideração a distribuição cumulativa da probabilidade de idades calculadas, com base na distância máxima entre os patamares das curvas de distribuição (Birnbaum, 1952; Drew et al., 2000; Sircombe \& Hazelton, 2004).

O método é independente de quaisquer hipóteses sobre a distribuição de probabilidade de uma amostra e permite a comparação entre os dois valores de pico de idade e suas distribuições, utilizando o parâmetro $(\mathrm{P})$. Quanto maior o valor de $\mathrm{P}$, mais provável é que as duas distribuições de idades foram geradas a partir da mesma população. Dentro do limite de confiança de $95 \%$, duas populações não são consideradas diferentes quando o valor de P é superior a 0,05 .

A maioria das amostras apresenta similaridades estatísticas, com valores de $\mathrm{P}$ maiores que 0,05 , o que significa que não pode ser descartada a hipótese de que as amostras estudadas tenham compartilhado de similares influxos terrígenos a partir da denudação das mesmas áreas-fontes. A exceção é observada quando da comparação entre as distribuições de idades da Serra do Japi com as idades obtidas nos zircões da Serra da Viúva e Voturuna, para os quais os valores de $\mathrm{P}$ são inferiores a 0,05 . Neste caso, não há probabilidade estatística de que a população de zircões detríticos destas unidades provenha da denudação de áreas fontes similares. Em contrapartida, fortes correlações entre as idades da população de zircões detríticos de pares de amostras, como Serra do Japi e Serra do Jaraguá $(\mathrm{P}=0.89)$, bem como Serra do Pirucaia e Serra da Viúva $(\mathrm{P}=0.78)$, são indicativas de notável similaridade do aporte sedimentar (Fig. II-12). 


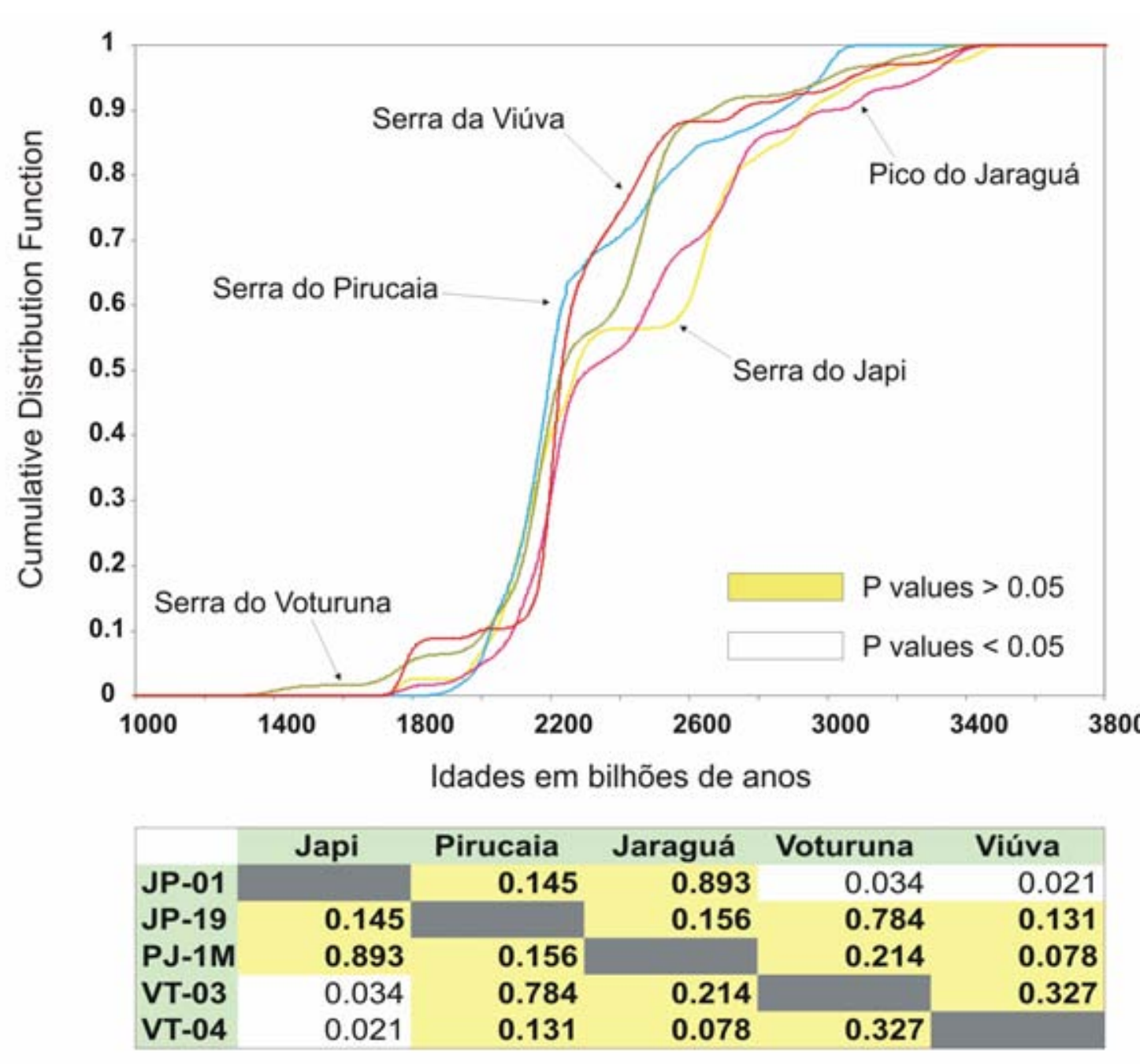

Figure II-12: Teste Kolmogorov-Smirnov (K-S) (Birnbaum, 1952; Drew et al., 2000) usado para comparar potenciais similaridades de proveniência entre metassedimentos do Domínio São Roque, através da função cumulativa da distribuição de idades.

II.5. Implicações para a idade de deposição das sequências sedimentares do Domínio São Roque

O limite superior de deposição identificado na maioria dos espectros de idades de zircões detríticos $(\sim 1.75 \mathrm{Ga})$, com exceção das amostras da Serra do Pirucaia e Serra do Voturuna, também coincide com a idade proposta para a sedimentação do Grupo São Roque (Van Schmus et al., 1986; Oliveira et al., 2008), assim como as idades de intrusões tardias de sienogranitos, que representam atividade magmática vinculada a eventos extensionais 
identificados nos mesmos núcleos do embasamento do Grupo Açungui (Cury et al., 2002; Siga Jr. et al., 2011). Este evento extensional é atribuído a um evento global de tafrogênese no Estateriano (Brito Neves et al., 1995; Rogers \& Santosh, 2001; Condie, 2002), que também tem manifestações equivalentes dentro do Domínio São Roque, como por exemplo, a atividade magmática geradora do vulcanismo bimodal com assinatura geoquímica típica de ambientes intraplaca (Henrique-Pinto \& Janasi, 2010 - Apêndice I), que marca o início da deposição do Grupo São Roque.

Formações de topo do Grupo Votuverava, caracterizadas como rochas siliciclásticas e carbonáticas plataformais (Subgrupo Lajeado; Campanha \& Sadowski., 1999), têm limite superior de sedimentação mais jovem que as unidades inferiores (Subgrupo Ribeira), com zircões detríticos mais novos datados em $~ 1.4$ Ga (Campanha et al., 2009).

A idade de deposição da Formação Betari (Siga Jr. et al., 2009) foi estimada como mesoproterozóica (Calimiana), e é similar às idades U-Pb em zircão entre 1.4 e $1.5 \mathrm{Ga}$ de rochas metavulcânicas básicas, que definem o limite inferior de sedimentação das sequiências Votuverava, Perau e Água Clara (Basei et al., 2003; Siga Jr. et al., 2011). Idade mínima de sedimentação similar é indicada pela datação de rochas metavulcânicas do Grupo Serra do Itaberaba (Formação Morro da Pedra Preta; Juliani, 2000). Esses valores correspondem ao limite superior identificado na amostra da Serra do Voturuna estudada neste trabalho, mas cumpre observar que até o momento apenas esta ocorrência mostra indícios de contribuição de rochas de idade mesoproterozóica como fonte de zircões detríticos dentro do Domínio São Roque.

\section{II.5. Comparação com padrões de proveniência em metassedimentos de faixas de dobramento vizinhas e avaliação sobre potenciais áreas-fonte}

\section{II.5.1. Província Mantiqueira: Grupo Açungui e Faixa Ribeira}

A maioria dos zircões detríticos analisados neste trabalho tem comportamento químico compatível com rochas granitóides, sugerindo que o principal pico de idades observado em todas as unidades $(\sim 2.2 \mathrm{Ga})$ representa em grande parte a erosão de uma crosta granítica de idade Riaciana. Tal observação é consistente com a datação dos clastos graníticos dos 


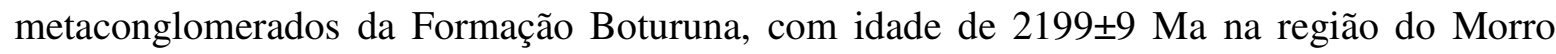
Doce e idade de 2247士13 Ma na região do Morro do Polvilho (Henrique-Pinto et al., 2012Apêndice II).

Conforme reportado por Henrique-Pinto et al. (submetido), fontes com idades equivalentes estão presentes em núcleos do embasamento do Grupo Açungui no sudeste brasileiro (Tigre, Setuva e Betara - Siga Jr. et al., 2007). Estes núcleos expõem ortognaisses que têm a mesma idade que os clastos graníticos dos metaconglomerados, além de peculiares similaridades geoquímicas (Apêndice III). A possibilidade de que se trate das áreas-fonte do Grupo São Roque também é favorecida pelo fato destas exposições serem geograficamente mais próximas do Domínio São Roque.

A idade de 2.2 Ga provavelmente não corresponde a fontes nas quais estão presentes apenas granitos similares aos clastos dos metaconglomerados da Formação Boturuna, que são resultado de retrabalhamento crustal, com idades-modelo $\mathrm{Sm}-\mathrm{Nd}$ da ordem de $2.7 \mathrm{Ga}$ (Henrique-Pinto et al., 2012) mas também, provavelmente representa a idade de fontes de caráter juvenil, conforme sugere pico de idade $\mathrm{T}_{\mathrm{DM}} \mathrm{Sm}-\mathrm{Nd}$ de metasiltitos da Formação Piragibu, componente de mistura coincidente com pico de zircões detríticos (Henrique-Pinto et al., submetido), além da presença restrita de zircões com assinatura geoquímica similar a zircões de gabros do tipo MORB.

Apesar de ainda escasso, o banco de dados sobre zircões detríticos de domínios regionais adjacentes à área de estudo permite extrapolar algumas cronocorrelações com os picos de idades de zircões detríticos datados dentro do Domínio São Roque, como as sucessões correlacionadas ao Grupo Votuverava (Campanha \& Sadowski, 1999) no estado do Paraná, onde são identificadas grandes concentrações de zircões detríticos com idade entre 2.1 a $2.5 \mathrm{Ga}$ (Campanha et al., 2009) e restritas idades arqueanas de $2.8 \mathrm{Ga}$ e $3.2 \mathrm{Ga}$ (Basei et al., 2008). A predominância de pico de zircões detríticos em 2.2 Ga parece ser uma constante dentro do espectro de idades no Domínio Apiaí, assim como mostram as análises das Formações Capiru e Antinha (Basei et al., 2008). O limite superior para a idade de deposição em 1.8 Ga é marcado pelo zircão mais novo identificado em metaconglomerados oligomíticos associados a metapelitos com subordinadas ocorrências de metabasitos, metacalcários, metarenitos e formações ferríferas de pequeno porte, caracterizando as ocorrências típicas do Subgrupo Ribeira (Grupo Votuverava - Campanha \& Sadowski, 1999; Campanha et al., 2009). 
Desde os trabalhos de Derby (1878) são atribuídas similaridades entre as unidades metassedimentares presentes no estado do Paraná e São Paulo. Estas considerações foram seguidas por muitos autores como Morais Rego (1930), Almeida (1944) e Coutinho, (1968a) entre outros. No entanto, a partir dos trabalhos de Hasui et al., (1975) e Hasui \& Sadowski, 1976, foi introduzida a idéia de que estas sequiências compreendiam grupos geotectônicos distintos, separados pelo sistema de falhas Taxaquara, que segundo Hennies et al. (1967), corresponderia a um limite com um rejeito transcorrente destral "superior a $100 \mathrm{~km}$ ", que confrontaria dois blocos de constituição litológica e estrutural distintas, designados Bloco Cotia a sul, e a norte o Bloco São Roque.

O Bloco Cotia inclui "rochas ectiníticas e migmatíticas", separadas por Hasui et al., (1975) em Complexos Pilar e Embu, respectivamente. Campos Neto (2000) propôs que a Falha de Caucaia subdivide o Bloco Cotia em duas porções, e pode corresponder a um limite tectônico de ordem maior, separando a Faixa de Dobramentos Ribeira a sul (localmente representada pelo Domínio Embu) e a borda retrabalhada do Cráton Paranapanema a norte (região de afloramento do "Complexo Ectinítico Pilar" e do Batólito Granítico Agudos Grandes).

Dados recentes e ainda inéditos de datação de zircões detríticos mostram que amostra de quartzito localizado no Domínio Embu (região do vale do Paraíba) também mostra pico de idade em $2.2 \mathrm{Ga}$, e não se distinguiria de quartzitos situados no Terreno Apiaí-Guaxupé (Trouw et al., 2012).

O sistema de falhas de Cubatão deve representar importante estrutura dentro da Faixa Ribeira, separando o Complexo Embu de um bloco alóctone (Complexo Costeiro/Terreno Oriental) interpretado como um arco magmático neoproterozóico (Heilbron et al., 2008). Os padrões de zircões detríticos obtidos por Valadares et al. (2008) de quartzitos desse terreno são nitidamente distintos, com predomínio de idades mais jovens (mesoproterozóicas e neoproterozóicas); trata-se, contudo, de idades ${ }^{207} \mathrm{~Pb} /{ }^{206} \mathrm{~Pb}$, não sendo possível, portanto avaliar o grau de discordância e o significado das idades individuais. 


\section{II.5.2. Província Tocantins: Grupos Andrelândia, Araxá, Canastra e Supergrupo São} Francisco

A proveniência de seqüências supracrustais da Faixa de Dobramentos Brasília (Província Tocantins de Almeida et al., 1981), que têm idade de sedimentação significantemente mais jovem que as seqüências do Domínio São Roque, foi estudada por diversos autores (Valeriano et al., 2004, Pimentel et al., 2001, Campos Neto et al., 2011).

Idades modelo $\mathrm{T}_{\mathrm{DM}} \mathrm{Sm}-\mathrm{Nd}$ no intervalo entre 1.2-0.9 $\mathrm{Ga}$ foram identificadas em ritmitos do Grupo Paranoá e 1.7-2.1 Ga, identificadas em sedimentos "detrítico/carbonáticos" do Grupo Vazante, e também registram a presença de fontes Paleoproterozóicas, atribuída segundo Pimentel et al. (2001), à erosão do cráton do São Francisco. Fontes com idades arqueanas e paleoproterozóicas também são identificadas em sucessões sedimentares neoproterozóicas de margem ativa da borda do craton do São Francisco (Campos Neto et al., 2011), como os Grupos Araxá, Canastra e Andrelândia. Os padrões de zircões detríticos dessas unidades, no entanto, diferenciam-se do Domínio São Roque por apresentarem importante contribuição de fontes mesoproterozóicas (Valeriano et al., 2004). Localmente, a contribuição neoproterozóica pode ter caráter unimodal típica de ambientes colisionais, como bacias de foreland e forearc (Cawood et al., 2012a), como em xistos do Grupo Andrelândia estudados por Teixeira et al. (2012), com pico de zircão detrítico em 610 Ma.

Provavelmente o bloco cratônico do Paranapanema constituía-se como uma região em elevação, se considerarmos que foi a principal área fonte para as bacias Andrelândia, Araxá e Canastra, conforme apontam as assinaturas de proveniência descritas por Campos Neto et al. (2011). Por outro lado o cráton do São Francisco neste momento, entre 700-630 Ma, encontrava-se em subsidência como registram os espessos depósitos plataformais do Grupo Bambuí - Supergrupo São Francisco (Dardenne, 1978; Uhlein et al. 1995) (ver Figura II13D).

O Supergrupo São Francisco é caracterizado por uma fase rift com a deposição de sedimentos pré-glaciogênicos do Grupo Macaúbas, que apresentam zircões detríticos com pico em $2.2 \mathrm{Ga}$ com limite superior de sedimentação marcado por zircões mais novos com 1.16 Ga (Martins et al., 2008), recoberta por sedimentos plataformais do Grupo Bambuí com zircões detríticos mais novos datados em 610 Ma (Rodrigues, 2008). 


\section{II.5.3. Cráton São Francisco x Paranapanema como potenciais áreas-fonte}

Atualmente a história geológica dos blocos cratônicos São Francisco e Paranapanema tem sua evolução tida como distinta (Campos Neto, 2000; Mantovani \& Brito Neves, 2005; De Wit et al., 2008), o que inviabiliza para o Grupo São Roque a possibilidade de fontes provindas do cráton do São Francisco, já que estes blocos só haveriam de se juntar no neoproterozóico.

Muitos trabalhos (Machado et al., 1996; Valladares et al., 2004; Chemale Jr. et al., 2011; Campos Neto et al., 2012a), mostram uma proveniência vinculada ao cráton do São Francisco para as bacias Espinhaço e Minas, com pico de zircões detríticos em $2.2 \mathrm{Ga}$, provavelmente relacionadas ao ciclo orogênico Riaciano identificado em rochas do embasamento, no Cinturão Mineiro (Ávila et al., 2010; Ávila et al., 2012b; Teixeira et al., 2008; Teixeira et al., 2012a). Estas idades são raras quando analisado o espectro mundial de zircões detríticos (Condie et al., 2009; Cawood et al., 2012b), o que torna esta característica uma particularidade das bacias vinculadas ao cráton do São Francisco.

O embasamento do Supergrupo Espinhaço no sul de Minas Gerais possivelmente está representado por plútons graníticos paleoproterozóicos, com idades que variam de 2121 a 2255 Ma, como discutido por Teixeira et al. (2008) e Teixeira et al. (2012a). O inicio da sedimentação do rift Espinhaço tem sido determinado pela idade de rochas metavulcânicas ácidas (1.75 Ga; Brito Neves et al., 1979; Schobbenhaus et al., 1994), que são cronocorrelatos com os metatraquidacitos com assinaturas geoquímicas típicas de ambiente intraplaca presentes na base do Grupo São Roque (Van Schmus et al., 1986; Henrique-Pinto \& Janasi, 2010). Dados recentes apontam para idades mais jovens (1416 $\pm 28 \mathrm{Ma}$ ), obtidas em cristais de zircão de metatufos, para formações intermediárias do Supergrupo Espinhaço (Formação Tombador - Grupo Chapada Diamantina) (Guadagnin et al., 2012).

Além das rochas graníticas Riacianas, os núcleos do embasamento no Domínio Açungui também registram magmatismo intraplaca de características extensionais de mesma idade (Kaulfuss, 2001; Cury et al., 2002; Ribeiro, 2006; Siga Jr. et al., 2007; Siga Jr. et al., 2011), o que mostra evolução similar à do craton do São Francisco. A principal diferença é a presença marcante de sequências vulcano-sedimentares geradas no mesoproterozóico (1.4-1.6 Ga) nas margens retrabalhadas do cráton Paranapanema (e.g., Grupo Serra do Itaberaba; Juliani et al., 2000, e Formações Perau, Água Clara, Votuverava e Betara. Basei et al., 2003; 
Weber et al., 2004; Siga Jr. et al., 2011). Não há registro de rochas desta idade no Supergrupo Minas, e o registro no Supergrupo Espinhaço parece subordinado (Chemale Jr. et al., 2011; Guadagnin et al., 2012).

O espectro de zircões detríticos das seqüências relacionadas ao Supergrupo Espinhaço, como por exemplo, as identificadas em São João Del Rei (Valladares et al., 2004) e Formação São João da Chapada (Espinhaço inferior - Chemale Jr. et al., 2011) tem um comportamento de idade similar aos identificados no Domínio São Roque, com pico principal em $2.2 \mathrm{Ga}$, grande contribuição de fontes em $\sim 2.4 \mathrm{Ga}$ e com zircão mais novo datado em $\sim 1.8 \mathrm{Ga}$. Particular feição das seqüências de São João Del Rei é a ausência de fontes paleoarqueanas, similar ao espectro da amostra da Serra do Pirucaia (Grupo Serra do Itaberaba).

Rochas neste intervalo de idade (2.1-2.2 Ga) são descritas ao sul do cráton do São Francisco como ortognaisses migmatíticos com fontes de assinatura juvenil (Campos Neto et. al., 2004; Campos Neto et al., 2009; Campos Neto et al., 2011; Campos Neto et al., 2012a), assim como anfibolitos também com $\varepsilon_{\mathrm{Nd}}$ positivo no Cinturão Mineiro (Ávila et al., 2012a), sugerindo segundo os autores, um ambiente de geração do tipo arco de ilhas no Riaciano, associado a um "arco magmático intra-oceânico" caracterizado como a suíte félsica Tiradentes, também com idade de cristalização em 2.2 Ga e assinatura juvenil (Ávila et al., 2010; Ávila et al., 2012b).

$\mathrm{O}$ pico de zircão detrítico de $\sim 2.4 \mathrm{Ga}$ caracteriza a segunda área-fonte com maior contribuição dentro do Domínio São Roque, e assim como o pico em 2.2 Ga, também coincide com o pico de idades $\mathrm{T}_{\mathrm{DM}} \mathrm{Sm}-\mathrm{Nd}$ obtidas em metassiltitos (Apêndice III), o que sugere uma contribuição de área-fonte com assinatura juvenil identificada como componente de mistura, assim como também a presença de zircões detríticos com assinatura de gabros tipo-MORB de mesma idade. Rochas com esta idade $(\sim 2.4 \mathrm{Ga})$, são reportadas somente a sul do cráton São Francisco, no Cinturão Mineiro, com a exposição de ortognaisses (Teixeira et al., 2012b).

A predominância de zircões detríticos dentro do Domínio São Roque com idades relacionadas ao arqueano tardio, além de grande contribuição de zircões Paleoarqueanos, assemelha-se às principais fontes identificadas em unidades distintas, como Supergrupo Minas no Quadrilátero Ferrífero (Machado et al., 1996; Campos Neto et al., 2012b) e na sequiência da Serra do Ouro Grosso a sul do cráton do São Francisco (Valladares et al., 2004). Dados 
recentes sugerem que o início de deposição do Supergrupo Minas tenha sido em um período posterior a $2.0 \mathrm{Ga}$, conforme mostra a presença do cristal mais novo datado no Grupo Itabira (Campos Neto et al., 2012b).

Nesse contexto, uma eventual correlação entre os grupos Espinhaço e São Roque somente poderia ser possível caso a evolução dos crátons do São Francisco e Paranapanema tivesse se dado em conjunto, pelo menos no período anterior à deposição das seqüências mesoproterozóicas. O modelo idealizado da evolução destes dois blocos continentais apresentado na Figura II-13 trabalha com a hipótese de um mega-bloco aglutinado após a orogênese Riaciana, que hipoteticamente incluiria os proto-crátons São Francisco, Congo, Angola e Paranapanema (Figura II-13A), que teria sido seguido por um primeiro processo de rifteamento durante a Tafrogênese do Estateriano (1.8-1.7 Ga), dando início à deposição das bacias São Roque e Espinhaço (Figura II-13B). O período prolongado de separação destas massas continentais teria evoluído com a geração de assoalho oceânico (Formação Pirapora do Bom Jesus ?), concomitantemente com a deposição das bacias Açungui e Serra do Itaberaba (1.5-1.4 Ga - Figura II-13C). A separação dos crátons do Paranapanema e São Francisco teria se dado concomitantemente à deposição das bacias Araxá, Canastra e Andrelândia, seguida de colisão. Neste momento o cráton do Paranapanema deveria constituir um alto, fornecendo sedimentos para estas bacias em um ambiente colisional, enquanto o cráton do São Francisco encontrava-se em período de subsidência com a deposição da bacia intra-cratônica do Supergrupo São Francisco (Figura II-13D e E). Após nova aglutinação destes blocos continentais, para dar origem à parte da configuração do Gondwana ocidental, o bloco que passou a sofrer processo de subsidência foi o do Paranapanema, dando início a deposição da bacia intra-cratônica do Paraná (Figura II-13F). 
A

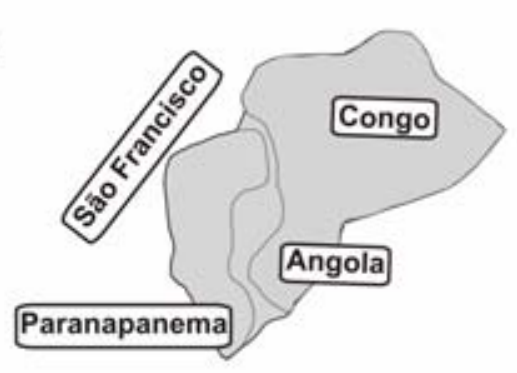

Configuração pós orogênese Riaciana (2.2-2.1)

C

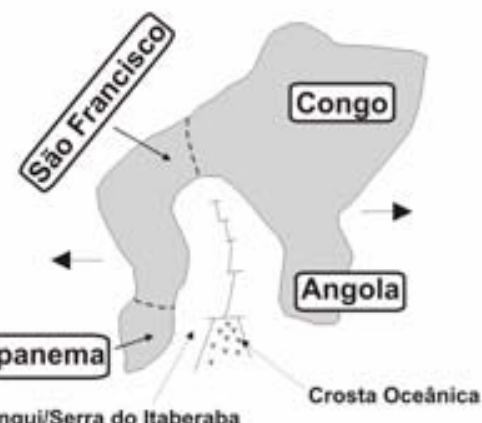

Bacia Açungui/Serra do Itaberaba

Configuraçăo a 1.5-1.4 Ga

E

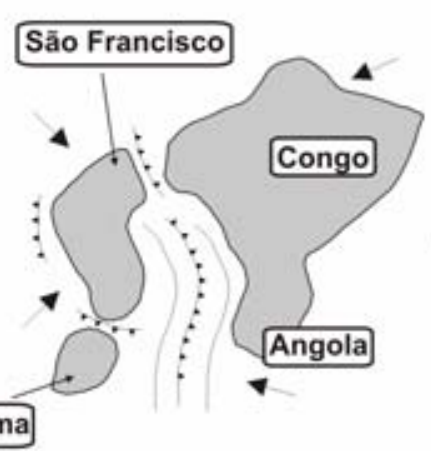

Configuração a 630-600 Ma
B

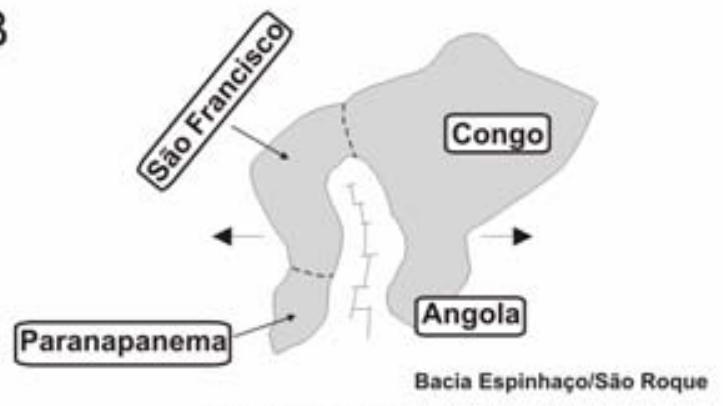

Configuraçăo a $1.8-1.7 \mathrm{Ga}$

D

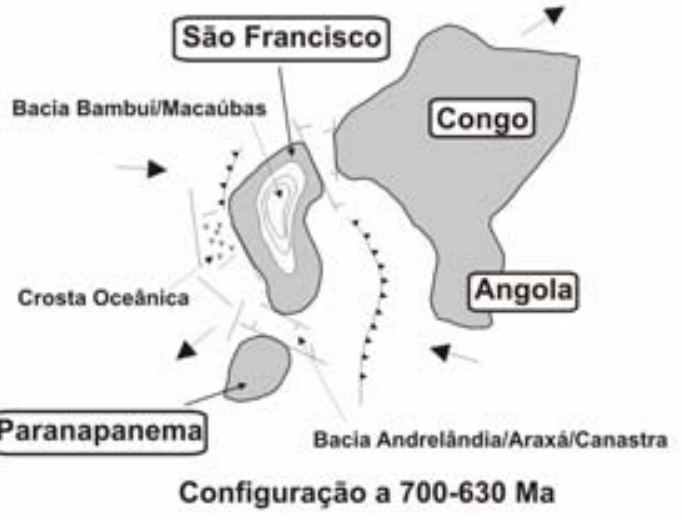

$\mathrm{F}$

São Francisco

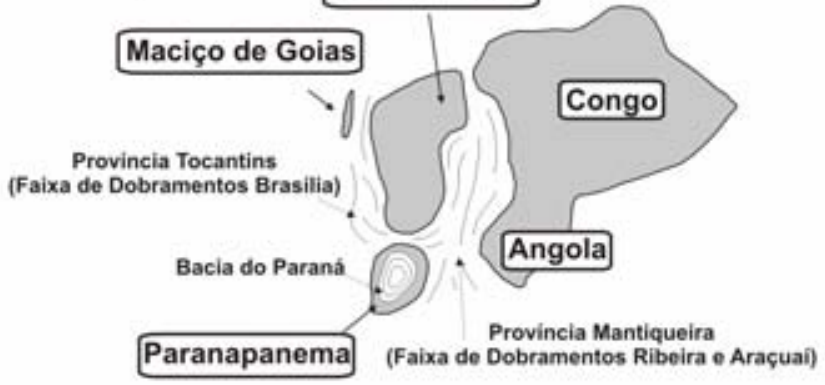

Configuração no Gondwana

Figure II-13: Evolução idealizada simplificada para uma hipótese alternativa que atribui evolução em comum dos crátons do Paranapanema e São Francisco, pelo menos para um período anterior a 1.4 Ga. 


\section{II.6. Comparação com eventos globais}

O principal pico de idades de zircões detríticos dentro do Domínio São Roque (2.2 Ga) não é comumente identificado entre as fontes predominantes em outras regiões cratônicas do mundo. Este pico é reportado no terreno Cassiar em Yúkon e Columbia Britânica no Canadá (Evenchick et al., 1984; Erdmer \& Baadsgaard, 1987). Já o limite superior de sedimentação ( $1.7 \mathrm{Ga})$ é reportado como um importante evento de geração de crosta continental de caráter juvenil (Condie et al., 2009).

Os espectros de idades de zircões detríticos podem ser relacionados com eventos formadores de rochas graníticas bem como seu papel na evolução da crosta continental. Como por exemplo, é o pico global de zircões detríticos em 2700 Ma identificado em alguns crátons como: Superior-Karelia, São Francisco-Nain, Kaapvaal-Siberia, Wyoming-Kaapvaal-Slave, Superior-Nain, e oeste África-Amazônia (Condie et al., 2009), que também é atribuído ao pico de idade de granitos orogênicos em muitas partes do mundo (Condie \& Aster, 2010). Idades de proveniência da ordem de $2.7 \mathrm{Ga}$ foram encontradas em todas as amostras do Grupo São Roque, mas não definem picos de acumulação importantes.

\section{II.7. Variações seculares na composição do zircão}

Zircões provenientes de núcleos cratônicos hadeanos representam os mais antigos segmentos de crosta continental terrestre ainda intactos, como por exemplo, as seqüências supracrustais e gnaisses tonalíticos do oeste da Groenlândia (Kinny, 1986; Whitehouse, 1999), os granulitos do oeste Australiano (Kinny et al., 1988; Myers, 1988; Myers \& Williams, 1985), além dos famosos Acasta gnaisses do noroeste do Canadá, que são interpretados como um amplo segmento da crosta continental pré- 4 Ga (Bowring et al., 1990; Stern \& Bleeker, 1998; Lizuka, 2006). Outros segmentos que representam possivelmente os primeiros ciclos de sedimentação do planeta têm seu melhor exemplo com os metaconglomerados Jack Hills, bem como as seqüências do Monte Narryer da Austrália ocidental (Compston \& Pidgeon, 1986; Pidgeon et al., 1990; Mass et al., 1991; Maas et al., 1992; Wilde et al., 2001; Peck et al., 2001). 
Normalizados pelo mais antigo cristal de zircão do sistema solar datado com idade ${ }^{207} \mathrm{~Pb} /{ }^{206} \mathrm{~Pb}$ de $4563 \pm 15 \mathrm{Ma}$ (Vaca Muerta II- Meso-siderito zircão - Ireland \& Wlotzka 1992; Hirata, 2001), todos os zircões analisados neste trabalho apresentam padrão de elementos terras raras similar, comparado aos mais antigos zircões terrestres (com idades predominantemente mais antigas que $3.3 \mathrm{Ga}$.) (Fig. II-14).
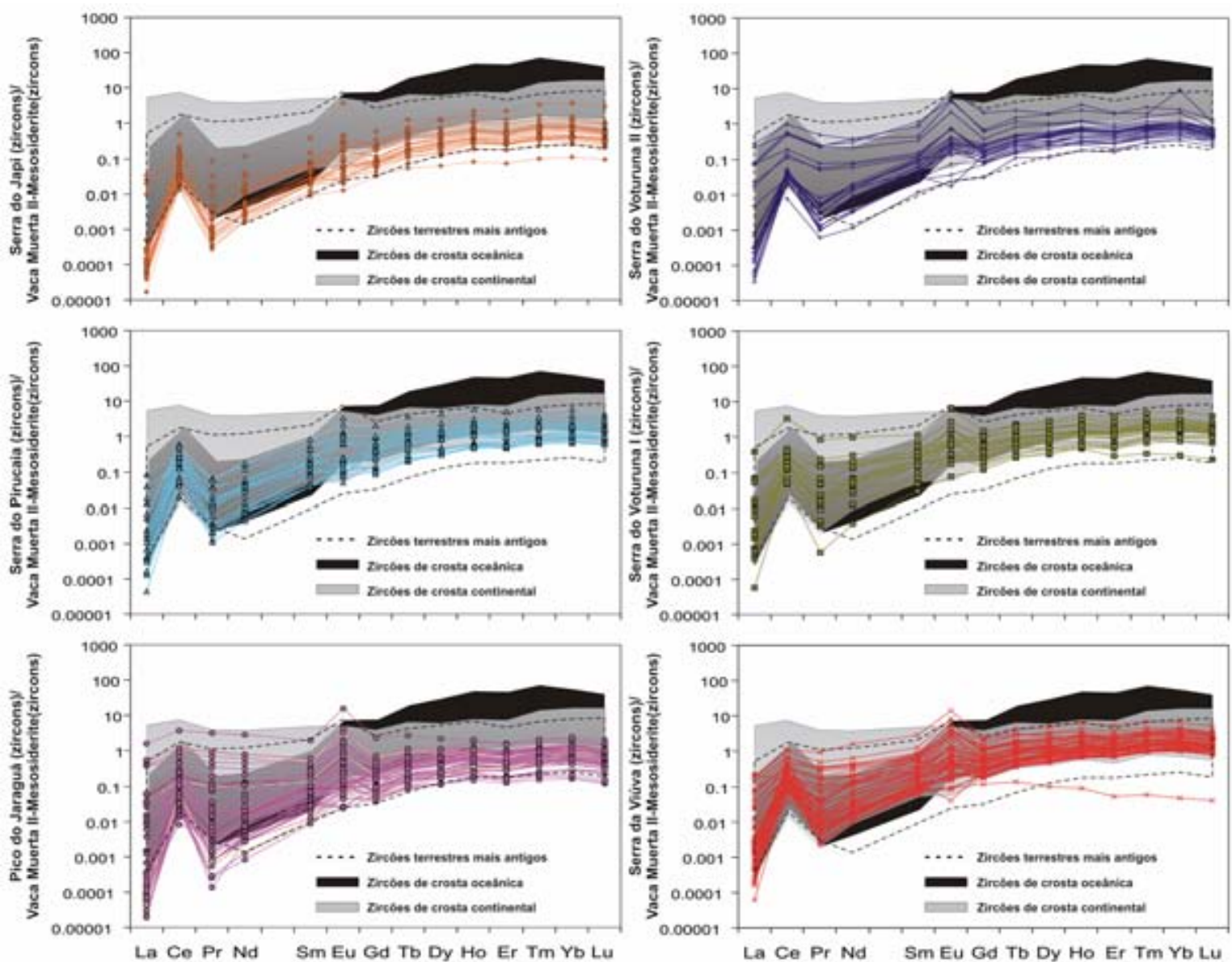

Figura II-14: Elementos de terras raras de zircões detríticos de meta-psamitos do Domínio São Roque normalizados pelos teores do mais antigo zircão do sistema solar (Vaca Muerta II- Mesosiderito Hirata, 2001). 
Apesar da geração contínua de rochas básicas relacionadas à evolução de crosta oceânica se dar provavelmente desde os primórdios do planeta Terra, são poucas as evidências destes eventos, devido ao baixo potencial de preservação deste ambiente no registro geológico, ficando restritas às exposições de crosta oceânica (ofiolitos), que foram alçadas para porções continentais em prismas acrescionários. Mais difícil ainda, tornam-se estas evidências baseadas em zircões, pois este representa um mineral pouco abundante em basaltos e gabros.

Eventos de break up de crosta com geração de assoalho oceânico podem ser identificados com a presença de alguns cristais de zircão detrítico com comportamento químico similar a zircões de gabros tipo MORB, amostrados em dorsais oceânicas modernas (Puga et al., 2005 e Grimes et al., 2007). Estes intervalos dentro do Domínio São Roque estão definidos entre 2.20-2.32 Ga, 2.42-2.54 Ga, 2.74 Ga, 2.93-3.06 Ga e 3.39 Ga, a partir de 13 cristais de zircões (Fig. II.9) com assinaturas químicas particulares definidas no item III.2.2. Provavelmente a geração de crosta oceânica ao longo do período datado em zircões detríticos, represente eventos prolongados, no entanto normalmente tornam-se lacunas no espectro sedimentar, devido à porcentagem reduzida de zircões gerados neste tipo de ambiente e sua preservação ao longo do tempo.

Zircões com características similares a zircões de gabros tipo MORB também podem estar presentes, segundo os critérios utilizados neste trabalho, em cristais que representam os mais jovens datados na Sequiência Narryer (3.3 Ga - Maas et al., 1991), idade similar à dos cristais detríticos mais antigos datados dentro do Domínio São Roque, além de zircões com idades de $3.30 \mathrm{Ga}, 3.75 \mathrm{Ga}, 3.93 \mathrm{Ga}, 4.15 \mathrm{Ga}$ e $4.20 \mathrm{Ga}$ (Fig. II-14 e II-15).

Apesar do comportamento químico com feições normalmente identificadas em zircões provenientes de MORB, como o forte enriquecimento em ETR pesados, altos teores de $\mathrm{Lu}_{\mathrm{N}} / \mathrm{Sm}_{\mathrm{N}}$, forte anomalia positiva de $\mathrm{Ce}^{*}$, além da típica feição de curvatura dos ETR intermediários, os zircões detríticos do Domínio São Roque, são na sua maioria, menos enriquecidos em ETR pesados (média da $\sum$ ETR pesados $=700 \mathrm{ppm}$ ) quando comparados a zircões com as mesmas características do Fanerozóico (média de $\sum$ ETR pesados $=4787$ ppm). Ao menos para o período Arqueano, a literatura registra indicações de um manto empobrecido (Durrheim \& Mooney, 1991; McCulloch \& Bennett, 1994; Vervoort \& Blichert-Toft, 1999; Albarède et al., 2000). 

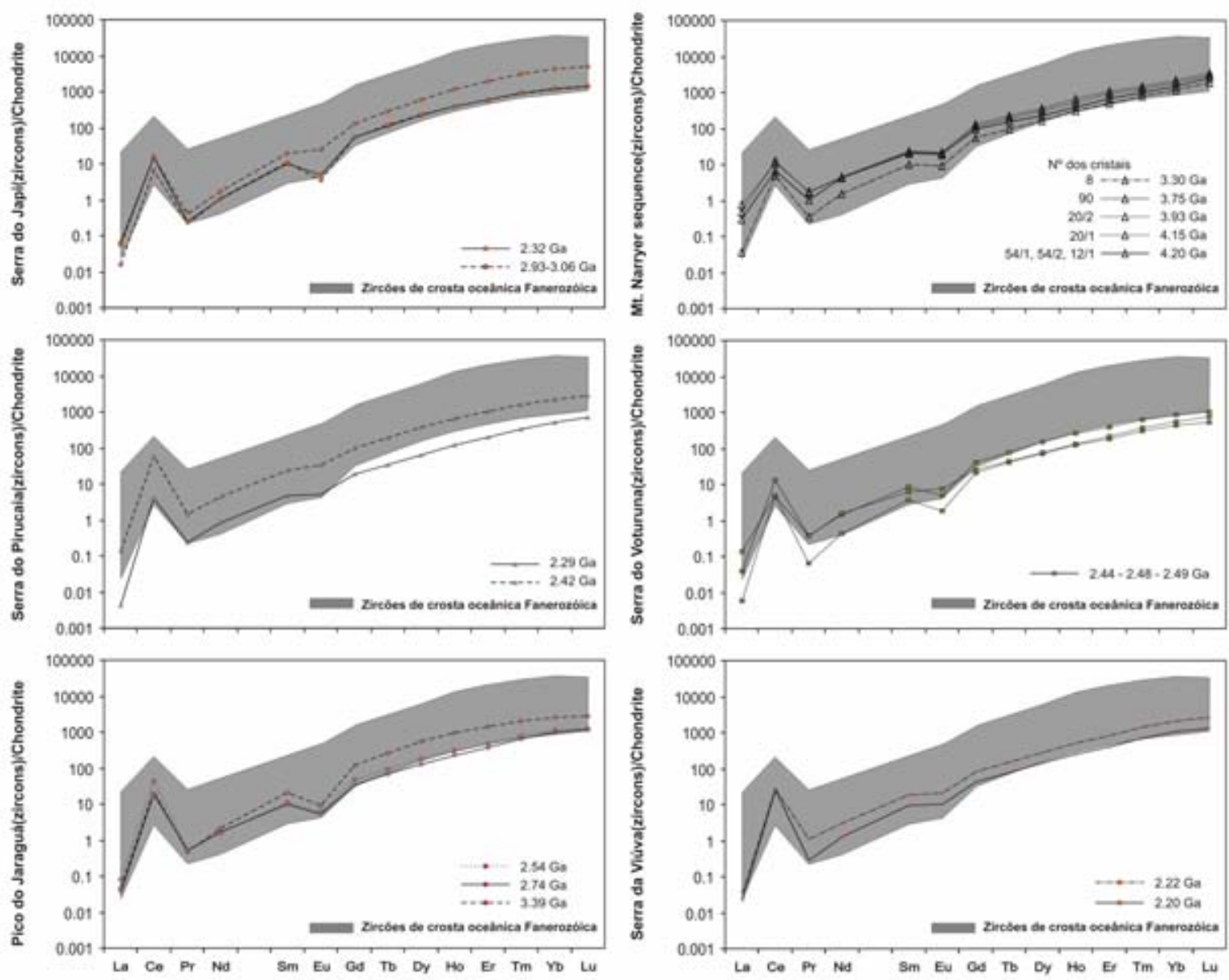

Figura II-15: Elementos de terras raras de zircões detríticos (tipo MORB) de meta-psamitos do Domínio São Roque normalizados pelos teores condríticos (McDonough \& Sun, 1995). 


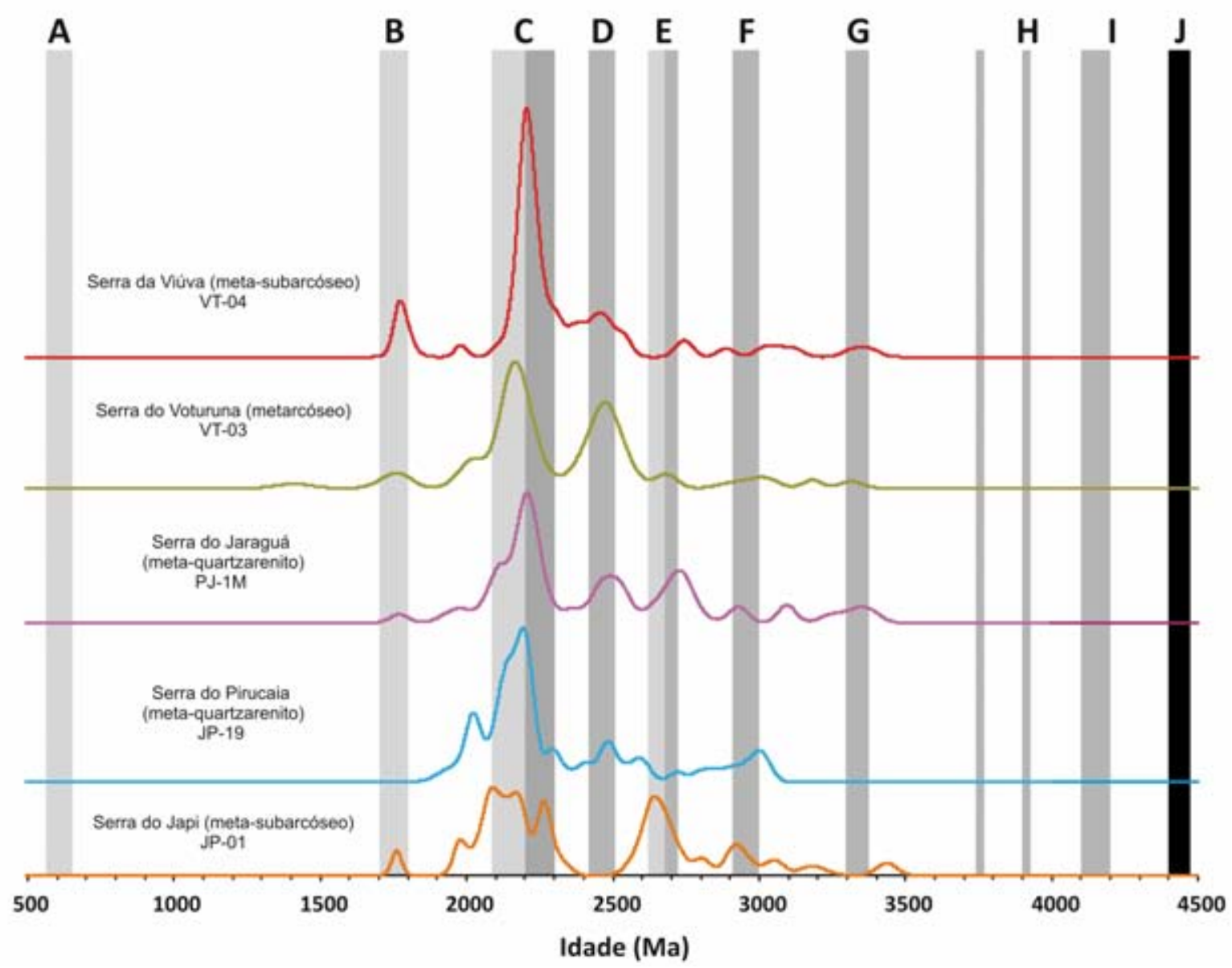

Figura II-16: Diagrama de probabilidade relativa de idades de zircões detríticos provenientes de metapsamitos do Domínio São Roque. Adicionalmente estão sinalizados em cinza claro os picos de idades de zircões interpretados como de origem granítica (eventos de crescimento crustal), e em cinza escuro as idades de zircões detríticos com comportamento químico similar ao de modernos gabros tipo MORB (intervalos que possivelmente representam tanto eventos de crescimento de crosta, como de restritos break-up). A- Metamorfismo regional (geração dos sobrecrescimentos em zircões detríticos, ca. 620$540 \mathrm{Ma}$ ) e colocação de grandes volumes de magmas graníticos sin-orogênicos (ex., Batólito Agudos Grandes; Leite et al., 2007, ca. 625-605 Ma), relacionados ao ciclo brasiliano/panafricano; B- Evento extensional do Estateriano ca. 1800-1700 Ma (ex., Rogers \& Santosh, 2001); C - Orogênese Riaciana (Ávila et al., 2010; Campos Neto et al., 2011 - ca. 2200-2100 Ma), cristalização de zircões magmáticos dos clastos dos metaconglomerados da Formação Boturuna (Henrique-Pinto et al., 2012), e intervalo de idade das potencias áreas-fontes do Grupo São Roque, além da presença restrita de zircões provenientes de MORB, o que poderia indicar fontes juvenis, conforme sugere pico de idade $\mathrm{T}_{\mathrm{DM}}$ em 2.2 Ga de metassiltitos da Formação Piragibu, coincidente com pico de zircões detríticos; D - Evento 
Sideriano ( $c$. 2500-2400 Ma) com picos de idades de zircões detríticos de química compatível à de zircões graníticos; E - Pico Global de zircões detríticos (Condie et al., 2009), também identificados no Domínio São Roque; (F, G, H, I) representam episódios discretos de crescimento crustal e geração de crosta oceânica, $(\mathbf{G})$ representa o cristal mais antigo datado em zircões detríticos no Domínio São Roque e o mais novo zircão identificado nos terrenos gnáissicos do Monte Narryer (Mass et al., 1991) e metaconglomerados Jack Hills (Wilde et al., 2001; Peck et al., 2001), (I) mais antigo zircão do Planeta Terra; J - Mais antigo cristal de zircão do Sistema Solar (Vaca Muerta meso-siderito - Ireland \& Wlotzka 1992; Hirata, 2001). 


\section{III.1. Integração das Principais Conclusões}

\section{III.1.1. Metassedimentos Psefíticos}

O estudo petrográfico dos clastos graníticos dos metaconglomerados do Grupo São Roque na região do Morro Doce, permitiu a identificação de quatro variedades petrográficas: biotita monzogranito porfirítico, monzogranito inequigranular, monzogranito equigranular e leucogranito inequigranular. $\mathrm{O}$ caráter comagmático entre os clastos é sugerido pelo alinhamento em uma mesma tendência, com diminuição nos teores de $\mathrm{Na}_{2} \mathrm{O}, \mathrm{MgO}, \mathrm{CaO}, \mathrm{Fe}_{2} \mathrm{O}_{3}, \mathrm{TiO}_{2}$ e $\mathrm{P}_{2} \mathrm{O}_{5}$ com o aumento da sílica, refletindo a tendência normal de diferenciação em magmas graníticos. Existe uma correlação negativa entre mg\# e $\mathrm{SiO}_{2}$, de forma que quanto mais félsico é o seixo (leucogranito inequigranular), menor é o mg\#. Portanto, a variedade biotita monzogranito porfirítico com maior IC representaria um membro mais primitivo com relação à evolução magmática dos magmas parentais.

Datação U-Pb via LA-MC-ICPMS de zircões extraídos das variedades predominantes de clastos graníticos (monzogranitos equigranulares), das regiões do Morro

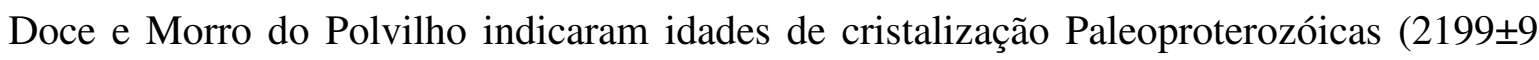
Ma e 2247 $\pm 13 \mathrm{Ma}$, respectivamente). Levando em conta as incertezas de $\sim 10 \mathrm{Ma}$ associadas as idades, os clastos diferem cerca de $50 \mathrm{Ma}$, o que permite afirmar, apesar das semelhanças petrográficas e químicas, que a variedade de clasto granítico do Morro do Polvilho não deriva exatamente da mesma fonte quando comparado a variedade analisada no Morro Doce.

A história policíclica dos zircões é reforçada pela presença de cristais herdados encontrados nos clastos (ex., 2694 $29 \mathrm{Ma}$ ), além de indicações da presença do evento termal no Neoproterozóico que afetou os metaconglomerados, conforme mostram os interceptos inferiores com um intervalo de 530-640 Ma. Isótopos de Sm-Nd das variedades “comagamáticas" do Morro Doce permitem calcular idades $\mathrm{T}_{\mathrm{DM}}$ de 2.6-2.7 Ga, indicando que estes granitos são produtos de reciclagem de crosta Arqueana, o que corrobora com a presença de cristais de zircão herdados datados em $~ 2.7$ Ga. Já o arcabouço feldspático dos metaconglomerados tem valores de $\varepsilon_{\mathrm{Nd}(0)}=-28.84$ ligeiramente mais baixos quando comparado aos clastos $\left(\mathcal{E}_{\mathrm{Nd}(0)}=\mathrm{de}-30.62\right.$ a -36.26$)$, sugerindo contribuição de fontes mais jovens. 


\section{III.1.2. Metassedimentos Pelíticos}

A composição modal usando os critérios de Dott (1964) e McBride (1963) permite classificar as rochas com baixa maturidade textural, porém com alta maturidade composicional (relativamente ricas em quartzo), como meta-quartzo wakes e metasiltitos/metargilitos (chamadas no campo genericamente de filitos).

Correlação linear fortemente negativa de $\mathrm{SiO}_{2}$ com os principais elementos maiores $\left(\mathrm{Al}_{2} \mathrm{O}_{3}, \mathrm{Fe}_{2} \mathrm{O}_{3}, \mathrm{~K}_{2} \mathrm{O}, \mathrm{TiO}_{2}\right)$ e traços $(\mathrm{Cr}, \mathrm{Rb}, \mathrm{Ba}, \mathrm{V}, \mathrm{Ga})$ é devido a triagem sedimentar responsável pela concentração destes elementos em frações argilosas (metasiltitos/metargilitos) mais aluminosas, empobrecidas em quartzo, quando comparados aos metarenitos. $\mathrm{O}$ aumento de $\mathrm{Fe}_{2} \mathrm{O}_{3}, \mathrm{MnO}, \mathrm{MgO}, \mathrm{Zn}$ e $\mathrm{Cr}$ nos metargilitos podem refletir contribuições de fontes básicas e intermediárias, com maiores concentrações em fases minerais mais argilosas.

Dados isotópicos de Sm-Nd em metargilitos/metasiltitos da Formação Piragibu permitiram calcular idades com intervalos que variam de 1.9 a $3.0 \mathrm{Ga}$, com picos principais nos intervalos de $2.1 \mathrm{Ga}, 2.4 \mathrm{Ga}, 1.9 \mathrm{Ga}$ e 3.0 Ga. A assinatura dos isótopos de $\mathrm{Nd}$ dos clastos dos metaconglomerados da Formação Boturuna quando calculados para a idade de sedimentação (1.75 Ga, rochas metavulcânicas - van Schmus et al., 1986 e Oliveira et al., 2008) tem $\varepsilon_{\mathrm{Nd}(1.75)}=-8$ to -11 , valores mais negativos quando comparados aos metargilitos. Com exceção a amostra com idade $\mathrm{T}_{\mathrm{DM}}$ mais antiga $(3.0 \mathrm{Ga})$ que se sobrepõe aos clastos. Devido ao caráter proximal os meta-wake feldspáticos (Formação Boturuna) tem um comportamento intermediário $\left(\varepsilon_{\mathrm{Nd}(1.75)}=-7\right)$ entre os clastos e os demais metargilitos.

Os $\varepsilon_{\mathrm{Nd}(1.75)}$ positivos correspondem as mais jovens idades $\mathrm{Sm}-\mathrm{Nd} \mathrm{T}_{\mathrm{DM}}(1.88-1.93$ $\mathrm{Ga}$ ), que caracteriza um limite superior de sedimentação mais jovem que $1.9 \mathrm{Ga}$. As amostras com estes $\mathrm{T}_{\mathrm{DM}}$ podem refletir grande contribuição de fontes mais jovens, possivelmente incluindo rochas com assinatura juvenil. O principal grupo de metargilitos com idades $\mathrm{T}_{\mathrm{DM}} \mathrm{Sm}-\mathrm{Nd}$ em um intervalo de 2.2-2.6 Ga, provavelmente representam uma mistura de fontes semelhantes a dos núcleos do embasamento do Domínio Açungui e fontes mais jovens com $\varepsilon_{\mathrm{Nd}}$ menos negativo em 1,75 Ga (a melhor estimativa para a idade de deposição), ou ainda, fontes adicionais como por exemplo, gnaisses encontrados como lascas tectônicas no sistema de nappes Andrelândia (Campos Neto et al., 2011), com idades de cristalização em torno de $2.2 \mathrm{Ga}$, no entanto com assinaturas de $\varepsilon_{\mathrm{Nd}}$ positivas (idades $\mathrm{T}_{\mathrm{DM}}$ entre 2.2-2.4). 
Os principais picos de idade $\mathrm{T}_{\mathrm{DM}}$ são coincidentes com os principais picos de idade $\mathrm{U}-\mathrm{Pb}$ em zircões detríticos. Podendo ser explicado como uma feição aparente, sem vinculo geológico direto, ou deve-se a presença de fontes juvenis (registrada como componente de mistura), que forneceram sedimentos concomitantemente com os granitos de mais alta residência crustal, por exemplo, os clastos dos metaconglomerados com $\varepsilon_{\mathrm{Nd}(0)}=-23.9$ to 36.2. Adicionalmente alguns zircões detríticos com comportamento geoquímico similar a MORB, foram identificados na assembléia de zircões datados e são compatíveis com a idéia de fontes máficas juvenis em $2.2 \mathrm{Ga}$ e $2.4 \mathrm{Ga}$.

\section{III.1.3. Metassedimentos Psamíticos}

As rochas metapsamíticas analisadas têm alta maturidade textural, o que concorda com a presença de minerais pesados ultra-estáveis quantificados através do índice ZTR (sempre maior que 70). Foram identificas algumas diferenças na assembléia de minerais pesados transparentes não micáceos como a predominância de zircão, rutilo e turmalina nos concentrados separados de meta-subarcóseos e meta-quartzo arenitos da região da Serra do Japi e Pico do Jaraguá, respectivamente, comparado ao concentrado com grande variedade de minerais pesados encontrados nos meta-quartzo arenitos da Serra do Pirucaia (ex., monazita, apatita, sillimanita), além da ausência de turmalina nos concentrados da Serra do Voturuna.

Cristais de zircões detríticos não afetados por recristalização metamórfica tem um similar intervalo de $\mathrm{SiO}_{2}, \mathrm{ZrO}_{2}$ e $\mathrm{HfO}_{2}(0.9-1.8$ wt\%), e são enriquecidos em Y e HREE. A maioria dos cristais de todas as localidades estudadas parece provir de rochas félsicas com predomínio de fontes ricas em plagioclásio (ex., tonalitos e granodioritos). Algumas singularidades restritas a gabros também foram identificadas, como: forte anomalia positiva de Ce, altas razões $\mathrm{Lu}_{N} / \mathrm{Sm}_{N}$, baixas razões $\mathrm{U} / \mathrm{Yb}$, além da particular concavidade desenhada pelos elementos de terras raras intermediários, fruto da cristalização do zircão paralelamente a piroxênios.

O espectro de análises de todo o conjunto de zircões detríticos analisados dentro do Domínio São Roque mostra um intervalo de idades entre 1410 Ma (idade mínima obtida em um cristal de zircão da Serra do Voturuna) e 3437 Ma (idade máxima obtida em zircões da Serra do Japi). O pico principal de zircões detríticos em torno de 2.2 Ga é similar para todas as unidades. Outros picos de idade também são comuns a todas as unidades, como os 
de 2.5-2.4 Ga e 2.9-2.7 Ga; por outro lado, intervalos com ausência de idades, como 1.9$1.8 \mathrm{Ga}$, também parecem ser uma feição comum.

O único cristal de zircão mais novo proveniente do metarcóseo da Serra do Voturuna é uma exceção, visto que o limite superior de sedimentação identificado em outras amostras mostra-se consistente em $\sim 1.7 \mathrm{Ga}$, idade aproximada da deposição determinada pela datação de rochas metavulcânicas intercaladas no Grupo São Roque (van Schmus et al., 1986) . A idade de $\sim 1.4$ Ga é compatível com a idade mínima de sedimentação proposta para o Grupo Serra do Itaberaba e correlatos no Grupo Açungui (Juliani et al., 2000; Siga Jr. et al., 2011). A amostra da Serra da Pirucaia, associada na literatura ao Grupo Serra do Itaberaba, não mostra contribuições mais jovens que $1.9 \mathrm{Ga}$, e não apresenta zircões paleoarqueanos (amostra da Serra do Pirucaia). Por outro lado, a relativa abundância de zircões mais velhos que $3.0 \mathrm{Ga}$, são características comuns aos metarenitos da Serra do Japi e Pico do Jaraguá.

Os sobrecrescimentos metamórficos pós deposicionais identificados tipicamente como escuras imagens de catodoluminescência, enriquecidos em $\mathrm{Pb}^{206}$, foram datados em $584 \pm 47$ Ma. Esta idade é similar a identificada através do intercepto inferior das idades concórdias nos clastos graníticos dos metaconglomerados, bem como as encontradas em datações de granitos regionais (e.g., Leite et al., 2001; Hackspacher et al., 2003). Este evento está relacionado à sobreposição térmica associada deformação Brasiliana/Panafricana, responsável por alterar significativamente a química das bordas dos zircões detríticos, através de substituição acoplada de xenotima. Quando comparados aos cristais não alterados, os sobrecrescimentos são enriquecidos em $\mathrm{Ca}, \mathrm{Fe}, \mathrm{Al}, \mathrm{U}, \mathrm{Na}, \mathrm{Mg}$, $\mathrm{Ba}, \mathrm{Pb}, \mathrm{Sr}, \mathrm{Th}, \mathrm{U}$, e $\mathrm{P}$, além de fortes enriquecimentos em lantanídeos leves. Estas mudanças não devem refletir grandes processos de difusão intracristalina, sugerindo interações com outras fases minerais.

Similaridades estatísticas (K-S teste) entre o espectro de zircões detríticos separados de rochas metapsamíticas sugerem influxos terrígenos provindos da denudação de semelhantes áreas-fonte. A exceção é observada quando da comparação entre as distribuições de idades da Serra do Japi, com as da Serra da Viúva e Voturuna, aonde não há probabilidade estatística de que a população de zircões detríticos destas unidades provenha da denudação de áreas fontes similares. Em contrapartida, fortes correlações entre as idades da população de zircões detríticos de pares de amostras, como Serra do Japi e Serra do Jaraguá $(\mathrm{P}=0.89)$, bem como Serra do Pirucaia e Serra da Viúva $(\mathrm{P}=0.78)$, são indicativas de notável similaridade do aporte sedimentar. Estas feições sugerem que não há 
diferenças entre os metarenitos da Serra do Japi e os demais localizados a sul do sistema de falhas de Jundiuvira, portanto este sistema de falhas não separaria blocos tectônicos distintos, conforme já apontavam os trabalhos de Moraes (1944) e Campos Neto (2000).

\section{III.1.4. Áreas-Fonte e Inferências sobre Ambientes Tectônicos}

As inferências sobre as composições das áreas-fonte podem ser apontadas pela presença em similar proporção de plagioclásio e feldspato alcalino nos metarcóseos e meta-wakes feldspáticos da Formação Boturuna, o que indica uma fonte predominantemente granítica. Adicional presença de restritos fragmentos líticos (Anexo III), como intraclastos de meta-quartzo arenitos e rochas metabásicas revelam a presença de fontes adicionais. No entanto os clastos dos metaconglomerados polimíticos da Formação Boturuna, dão acesso direto a algumas das fontes como granitos, rochas metabásicas e quartzitos.

As potenciais áreas-fonte de mesma idade dos clastos graníticos dos metaconglomerados ( 2.2 Ga), e com maior proximidade geográfica com o Grupo São Roque, são mapeadas em núcleos de embasamento do Grupo Açungui (Kaulfuss, 2001; Siga Jr. et al., 2007; Siga Jr. et al., 2011). A composição química destas rochas é similar a dos clastos graníticos quando comparadas em um mesmo intervalo de conteúdo de sílica (65-78 wt.\%), no entanto estes núcleos expõem rochas plutônicas de caráter intermediário, que não são encontradas em forma de seixos, mais parecem contribuir para o entulhamento da paleo-bacia São Roque.

O grau de intemperismo da área-fonte pode ser mensurado pelo índice de variação química (ICV), que sugere moderado processo intempérico para as fontes dos metassedimentos do Grupo São Roque, capaz de transformar os feldspatos da rocha fonte em argilo-minerais como a ilita, porém não suficientemente forte para transformá-los em caulinita. Assim também como mostram os índices de alteração intempérica (CIA) com valores entre 73 e 87.

Com comportamento geoquímico similar a sedimentos de margem passiva depositados após a erosão de antigas fontes Proterozóicas, como mostram o pico de zircões detríticos dos depósitos proximais da Formação Boturuna (2.2 Ga) e os mais jovens detríticos cristais datados em $1.7 \mathrm{Ga}$, além das idades $\mathrm{T}_{\mathrm{DM}}$ entre 1.9 e $3.0 \mathrm{Ga}$ obtidas em sedimentos distais da Formação Piragibu, sugerem um período de 
sedimentação mais jovem que 1.9 Ga. Além disso, indicam que a deposição das duas Formações (Boturuna e Piragibu) aconteceu em tempo relativamente similar, com possível correlação lateral entre estas unidades. Entretanto, o comportamento de ETR dos metargilitos da Formação Piragibu somado a forte diminuição de Ce, é compatível com ambientes de abertura oceânica com restrita contribuição vulcanogênica, sugerindo então, um paleo-ambiente mais complexo, com interação entre margem passiva e restritos arcos de ilhas oceânicos.

\section{III.2. Referências Bibliográficas}

Ahrens, L. H. \& Erlank, A. J. 1969. Hafnium. In: Wedepohl, K.H. (ed.). Handbook of Geochemistry. New York, Springer-Verlag. v. II/5, sections B-O.

Albarède, F; Blichert-Toft, J; Vervoort, J. D; Gleason, J. D; Rosing, M. 2000. Hf-Nd isotope evidence for a transient dynamic regime in the early terrestrial mantle. Nature, v. 404: 488-490.

Almeida, F. F. M. de. 1944. Collenia Itapevensis sp. n. - um fóssil pré-cambriano do Estado de São Paulo. Faculdade de Filosofia, Ciências e Letras, Universidade de São Paulo, Boletim 1, no 45, p. 89-106.

Almeida, F. F. M. de. 1945. A Vida Pré-Cambriana. Geologia e Metalurgia. Boletim 1: 81-90.

Almeida, F. F. M. de. 1957. Novas Ocorrências de Fósseis no Pré-Cambriano Brasileiro. Anais da Academia Brasileira de Ciências, 29(1): 63-72.

Almeida, F. F. M. De; Hasui, Y; Brito Neves, B. B; Fuck, R. A. 1981. Brazilian Structural Provinces: An Introduction. Earth-Science Reviews, 17(1/2): 1-29.

Andersen, T. 2005. Detrital Zircons as tracers of sedimentary provenance: limiting conditions from statistics and numerical simulation. Chemical Geology, 216, 249-270.

Andrade, F.R.D. de. 1993. Complexo Granitóide São Roque: petrografia, litoquímica e tipologia de zircão. Dissertação de Mestrado, UNESP, Rio Claro.

Ávila, C. A; Teixeira, W; Cordani, U.G; Moura, C.A.V; Pereira, R.M. 2010. Rhyacian (2.23-2.20 Ga) juvenile accretion in the southern São Francisco craton, Brazil: Geochemical and isotopic evidence from the Serrinha magmatic suíte, Mineiro belt. Journal of South American Earth Sciences, 29: 464-482.

Ávila, C. A; Teixeira, W; Vasques, F. de S.G.; Dussin, I.A; Mendes, J.C. 2012a. Geoquímica e Idade U-Pb (LA-ICPMS) da Crosta Oceânica Riaciana do Cinturão Mineiro, Borda Meridional do Cráton São Francisco. $46^{\circ}$ Congresso Brasileiro de Geologia, Anais, Santos, SP. CD arquivo digital (PAP011435). 
Ávila, C. A; Teixeira, W; Bongiolo, E.M; Dussin, I.A; Vieira, T.A.T; Guerrero, J.C. 2012b. Suíte félsica Tiradentes: gênese associada a um arco magmático intra-oceânico Ryaciano do Cinturão Mineiro. $46^{\circ}$ Congresso Brasileiro de Geologia, Anais, Santos, SP. CD arquivo digital (PAP010187).

Basei, M. A. S; Siga Jr, O; Kaulfuss, G. A; Cordeiro, H; Nutman, A; Sato, K; Cury, L. F; Prazeres Filho, H. J; Passarelli, C. R; Harara, O. M; Reis Neto, J. M; Weber, W. 2003. Geochronology and isotope geochemistry of Votuverava and Perau Mesoproterozoic basins, southern Ribeira Belt, Brazil, IV South American Symposium on Isotope Geology, Salvador, Brazil. Short Papers: 501-504.

Basei, M. A. S; Frimmel, H. E; Nutman, A. P; Preciozzi, F. 2008. West Gondwana amalgamation based on detrital zircon ages from Neoproterozoic Ribeira e Dom Feliciano belts of South American of comparison with coeval sequences form SW Africa. 2008. Geological Society, London, special publications, v. 294: 239-256.

Bathia. M. R. 1983. Plate tectonics and geochemical composition of sandstones. Journal of Geology, 91: 611-627.

Bathia. M. R. \& Taylor. S. R. 1981. Trace element geochemistry and sedimentary provinces: a study from the Tasman geosynclines. Australia. Chemical Geology, 33:115-125.

Bathia. M. R. \& Crook. K. A. W. 1986. Trace element characteristics of graywackes and tectonic setting discrimination of sedimentary basins. Contributions to Mineralogy and Petrology. 92:181-193.

Bauluz, B; Mayayo, M. J; Fernandez-Nieto, C; Lopez, J. M. G. 2000. Geochemistry of Precambrian and Paleozoic siliciclastic rocks from the Iberian Range (NE Spain): implications for source-area weathering, sorting, provenance, and tectonic setting. Chemical Geology, 168: 135-150.

Bahlburg, H. \& Dobrzinski, N. 2009. A review of the Chemical Index of Alteration (CIA) and its application to the study of Neoproterozoic glacial deposits and climate transitions. The Geological Record of Neoproterozoic Glaciations. Geological Society of London: 1-31.

Bea, F. 1996. Residence of REE, Y, Th and U in Granites and Crustal Protoliths; Implications for the Chemistry of Crustal Melts. Journal of Petrology, 37, 521-552.

Belousova, E.A., Griffin, W.L., Pearson, N.J. 1998. Trace element composition and cathodoluminescence properties of southern African kimberlitic zircons, Mineralogical Magazine, 62, 355-366.

Belousova, E. A., Griffin, W.L., O’Reilly, S.Y., Fisher, N.I. 2002. Igneous Zircon: Trace Element Composition as an Indicator of Source Rock Type. Contributions to Mineralogy and Petrology, (143):602-622.

Belousova, E.A., Griffin, W.L., O’Reilly, S.Y. 2006. Zircon Crystal Morphology, trace element signatures and $\mathrm{Hf}$ isotope composition as a tool for petrogenetic modeling: examples from 
Eastern Australian Granitoids. Journal of Petrology, 47, 329-353. doi: 10.1093/petrology/egi077.

Bergmann. M. e Fairchild. T. R. 1985. Estromatólitos do Grupo São Roque. Proterozóico Superior. Região de Pirapora de Bom Jesus. Estado de São Paulo. Anais da Academia Brasileira de Ciências. 57(1): 116-117.

Bergmann, M. \& Fairchild, T. R. 1986. Estromatólitos do Grupo São Roque: Uma Hipótese Paleogeográfica. In: XXXIV Congresso Brasileiro de Geologia, Goiânia (GO), Resumos e Breves Comunicações, 1: p.79

Bergmann. M. 1988. Caracterização Estratigráfica e Estrutural da Sequiência Vulcano-Sedimentar do Grupo São Roque na Região de Pirapora do Bom Jesus - Estado de São Paulo. Dissertação de Mestrado - Instituto de Geociências USP: 167 p.

Bergmann, M. \& Mcreath, I. 1992. Rochas Vulcânicas do Grupo São Roque, na Região do Morro do Boturuna em São Paulo. Boletim IG - USP, Publicação Especial 12: 19-21.

Bigarella, J. J. \& Salamundi, R. 1958. Contribuição à Geologia da Região Sul da Série Açunguí (Estado do Paraná). Boletim Paulista de Geografia, 29: 3-19.

Birnbaum, Z.W. 1952. Numerical tabulation of the distribution of Kolmogorov's statistic for finite sample size, J. Amer. Statist. Assoc. 47, 425-441.

Bistrichi. C. A. 1982. Geologia do Sinclinório de Pirapora. SP. Dissertação de Mestrado. Instituto de Geociências - USP: 92 p.

Black, L.P., William, I.S., Compston, W. 1986. Four zircons ages from one rock: the history of a 3930 Ma-old granulite from Mount Sones, Endeby Land, Antartica. Contributions to Mineralogy and Petrology, 94: 427-437. doi: 10.1007/BF00376336.

Bomparola, R.M., Ghezzo, C., Belousova, E., Griffin, W.L. O'Reilly, S.Y. 2007. Resetting of the U$\mathrm{Pb}$ zircon system in Cambro-Ordovivian Intrusives of the Deep Freeze range, Northern Victoria Landm Antarctica. Journal of Petrology, 48, 327-364. doi: 10.1093/petrology/eg1064.

Bowring, S.A. Housh, T.B., Isachsen, C.E. 1990. The Acasta gneisses: Remnant of Earth's early crust. In: Newson, H.E. and Jones, J.H., eds, Origin of the Earth: New York, Oxford University Press, p. 319-343.

Brito Neves, B. B. de; Kawashita, K; Cordani, U. G; Delhal, J. 1979. A Evolução Geocronológica da Cordilheira do Espinhaço; Dados Novos e Integração. Revista Brasileira de Geociências, 9: 71-85.

Brito Neves, B. B. de; Sá, de J. M; Nilson, F. B. 1995. A Tafrogênese Estateriana nos Blocos Paleoproterozóicos da América do Sul e Processos Subseqüentes. Geonomos, 3 (2): 1-21.

Campanha, G. A. da C. \& Sadowski, G. R. 1999. Tectonics of the southern portion of the Ribeira Bellt (Apiaí Domain). Precambrian Research, 98: 31-51. 
Campanha, G. A. da C; Basei, M. A. S; Faleiros, F. M; Tassinari, C. C. G; Nutman, A. P; Vasconcelos, P. M; Dantas, E. L. 2009. Geocronologia do Terreno Apiaí no Sul do Estado de São Paulo. Simpósio 45 Anos de Geocronologia no Brasil. CPGeo - IGc - USP. Boletim de Resumos Expandidos: 220-222.

Campos Neto, M. Da C; Basei, M. A. S; Artur, A. C; Silva, M. E. Da; Machado, R; Dias Neto, C. De M; Fragoso Cesar, A. R; SouzA, A. P. 1983. Geologia das Folhas Piracaia e Igaratá. IPT - Pró-Minério, $1^{o}$ Jornada Sobre a Carta Geológica do Estado de São Paulo em 1: 50.000: 55-76.

Campos Neto, M. Da C e Figueiredo, M. C. H. 1995. The Rio Doce Orogeny, Southeastern Brazil. Journal of South American Earth Sciences, 8(2): 143-162.

Campos Neto. M da C. 2000. Orogenic Systems From Southwestern Gondwana: an Approach to Brasiliano-Pan African Cycle and Orogênic Collage in Southeastern Brazil. In: U.G. Cordani. E.J. Milani. A. Thomaz Filho \& D.A. Campos. (Eds.): Tectonic Evolution of South American. In: XXXI International Geological Congress. Rio de Janeiro. Brazil: 335365.

Campos Neto, M.C.; Basei, M.A.S.; Vlach, S.R.F.; Caby, R.; Szabo, G.A.J.; Vasconcelos, P. 2004. Migração de Orógenos e Superposição de Orogêneses; Um Esboço da Colagem Brasiliana no Sul do Cráton do São Francisco, SE-Brasil. Geologia USP: Série Científica. São Paulo, v. 4, p. 13-40.

Campos Neto, M da C; Basei, M. A. S; Janasi, V. A; Moraes, R; Garcia, M. G. M; Siga Jr., O. 2009. Aglutination of a Neoproterozoic Proto-Continent During the Western Gondwana Collage: Tectonic Setting of the Southern Brasilia Orogen. Simpósio 45 Anos de Geocronologia no Brasil. CPGeo - IGc - USP. Boletim de Resumos Expandidos: 223.

Campos Neto, M da C; Basei, M. A. S; Janasi, V. A; Moraes, R. 2011. Orogen migration and tectonic setting of the Andrelândia Nappe system: An Ediacaran western Gondwana collage, south of São Francisco craton. Journal of South American Earth Sciences, 32(4): 393-406.

Campos Neto, M da C; Lima, R.B; Frugis, G.L; Moraes, R; Basei, M.A.S. 2012a. Idade da Sedimentação, Proveniência e Subducção-Colisão na Nappe Andrelândia. $46^{\circ}$ Congresso Brasileiro de Geologia, Anais, Santos, SP. CD arquivo digital (PAP010971).

Campos Neto, M da C; Caby, R; Basei, M.A.S; Vlach, S.R.F. 2012b. Idade Pós-Riaciana para a Deposição do Supergrupo Minas. $46^{\circ}$ Congresso Brasileiro de Geologia, Anais, Santos, SP. CD arquivo digital (PAP010985).

Carneiro. C. D. R. 1983. Análise Estrutural do Grupo São Roque na Faixa entre o Pico do Jaraguá e a Serra dos Cristais. SP. Tese de Doutoramento. Instituto de Geociências - USP: 155p. 
Carneiro, C. D. R; Hasui, Y; Dantas, A.S.L. 1984. Contribuição ao Estudo da Litoestratigrafia do Grupo São Roque na Faixa Jaraguá-Cristais - SP. In: XXXIII Congresso Brasileiro de Geologia, Rio de Janeiro (RJ), Anais: 3212-3226.

Cawood, P.A; Hawkesworth, C.J. \& Dhuime, B. 2012a. Detrital zircon record and tectonic setting. Geology, 40(10): 875-878.

Cawood, P.A; Hawkesworth, C.J. \& Dhuime, B. 2012b. The Evolution of the Continental Crust: The Zircon Archive and Implications for Proterozoic Supercontinents. $46^{\circ}$ Congresso Brasileiro de Geologia, Anais, Santos, SP. CD arquivo digital (cp3).

Compston, W. \& Pidgeon, R.T. 1986. Jack Hills, evidence of more very old detrital zircons in Western Australia. Nature 321, 766-769.

Condie, K.C., Belousova, E., Griffin, W.L., Sircombe, K.N. 2009. Granitoid events in space and time: constraints from igneous and detrital zircons age spectra. Gondwana Research, 15: 228-242. doi: 10.1016/j.gr.2008.06.001.

Condie, K.C. \& Aster, R.C. 2010. Episodic zircon age spectra of orogenic granitoids: The supercontinent connection and continental growth. Precambriam Research, 180: 227-236. doi:10.1016/j.precamres.2010.03.008.

Condie, C. K. 2002. Breakup of a Paleoproterozoic Supercontinent. Gondwana Research, 5(1): 4143.

Cordani, U. G; Campos, A. C. R; Davino, A; Björnber, A. J. S. 1961. Geologia da Região do Jaraguá. Boletim da Sociedade Brasileira de Geologia, 10(20): 73-91.

Cordani, U.G; Gomes, C. De B; Girardi, V.A.V. 1963. Rochas Cálcio-Silicatadas da Região de Perus, SP. Anais da Academia Brasileira de Ciências, 35(3): 361-372.

Cordani, U. G; Coutinho, J. M. V; Nutman, A. P. 2002. Geochronological Constraints on the Evolution of the Embu Complex, São Paulo, Brazil - Journal of South American Earth Sciences, 14: 903-910.

Corfu, J.F; Hanchar, M.J; Hoskin, P.W. O; Kinny P. 2003. Atlas of Zircon Textures. Editors: Hanchar, J. M. \& Hoskin, O. W. Reviews in Mineralogy \& Geochemistry, (53): 469 -495.

Coutinho, J.M.V. 1968a. O Grupo Açungui nas vizinhanças da capital de São Paulo. In: Congresso Brasileiro de Geologia, Belo Horizonte, Res. das Com., p. 2.

Coutinho, J.M.V. 1968b. Petrologia do Pré-Cambriano em São Paulo e Arredores. (Tese - Professor Catedrático) - Faculdade de Filosofia Ciências e Letras - USP: 174 p.

Coutinho, J.M.V. 1955. Metaconglomerado e rochas associadas no Município de São Paulo. Boletim Faculdade de Filosofia Ciências e Letras - Universidade de São Paulo, São Paulo, 186, Mineralogia 13, p. 5-56.

Coutinho, J.M.V. 1971. Estado Atual de Conhecimentos do Pré-Cambriano Superior Sul Brasileiro; Uma Síntese. In: XXV Congresso Brasileiro de Geologia, Anais, 25(1): 83-92. 
Coutinho. J.M.V; Rodrigues. E de P; Suemitsu. A; Juliani. C; BeljavskiS. P; Paulo de T. Y. P. 1982. Geologia e Petrologia da Sequiência Vulcano-Sedimentar do Grupo São Roque na Serra de Itaberaba - SP. In: XXXII Congresso Brasileiro de Geologia. Salvador - Bahia. Anais. 2: 624-640.

Cox, R; Lowe, D.R. \& Cullers. R.L. 1995. The influence of sediment recycling and basement composition on evolution of mudrock chemistry in the southwestern United States. Geochimica et Cosmochimica Acta, 59(14): 2919-2940.

Cullers, R.L; Barret, T; Carlson, R; Robinson, B. 1987. Rare earth element and mineralogic changes in Holocene soil and stream sediment: a case study in the Wet Mountains, Colorado, USA. Chemical Geology, 63: 275-297.

Cullers, R.L. \& Berendsen, P. 1988. The provenance and chemical variation of sandstones associated with the Mid-continental rift system, USA. European Journal of Mineralogy, 10: $987-1002$.

Cullers, R.L. 2000. The geochemistry of shales, siltstones and sandstones of Pennsylvanian-Permian age, Colorado, USA: implications for provenance and metamorphic studies. Lithos, 51: 181-203.

Cullers, R. \& Podkovyrov, N.V. 2002. The source and origin of terrigenous sedimentary rocks in the Mesoproterozoic Ui group, southeastern Russia. Precambrian Research, 117: 157-183.

Cury, L.F.; Kaulfuss, G.A.; Siga Jr., O.; Basei, M.A.S.; Harara, O.M.; Sato, K. 2002. Idades U-Pb (Zircões) de 1.75 Ga em Granitóides Alcalinos Deformados dos Núcleos Betara e Tigre: Evidências de Regimes Extensionais do Estateriano na Faixa Apiaí. Geologia USP, Série Científica, v. 2, p. 95-108.

Dantas, A.S.L; Almeida, M.A. de; Teixeira, A.L; Nagata, N; Bistrichi, C. A. 1986. Integração geológica das folhas de Guarulhos e Santana do Parnaíba na escala 1: 50.000. In: Jornada sobre a carta geológica do Estado de São Paulo em 1: 50.000, 2, São Paulo.

Dantas, A.S.L. 1990. Geologia da Faixa São Roque e Intrusivas Associadas na Região entre São Paulo e Mairiporã. Norte de São Paulo. Dissertação de Mestrado. Instituto de Geociências - USP: 199 p.

Dantas E.L., Hackspacher P., Godoy A.M., Sato K., Pimentel M.M., Oliveira M.A.F., Fetter A. 1999. Characterization of the generating sources of continental crust of the Ribeira Belt through isotope of $\mathrm{Nd}$ in the State of São Paulo, SE of Brazil In: South- American Symposium on Isotope Geology, 2, Villa Carlos Paz, Argentina, Anais, p. 192-195.

Dardenne, M.A. 1978. Síntese sobre a estratigrafia do Grupo Bambuí no Brasil Central. In: SBG, Congresso Brasileiro de Geologia, 30, Recife, Anais, v. 2, p. 597-610.

Davis, D.W; Williams, I.S; Krogh, T.E. 2003. Historical Development of Zircon Geochronology. Editors: Hanchar, J.M. \& Hoskin, O.W. Reviews in Mineralogy \& Geochemistry, (53): 145 $-173$. 
Depaolo, D. J. 1988. Neodymium Isotope Geochemistry. An Introduction. Springer, Berlin. 187p.

Derby, O. A. 1878. A Geologia da Região Diamantifera da Provincia do Paraná no Brasil. Archivos do Museu Nacional, vol. III: 89-98.

Derby, O.A. Relatório acerca dos estudos geológicos praticados nos Valles do rio da Velhas e alto S. Francisco. Apresentado ao Conselheiro Manoel de Araújo, 29 de março, 1882. Typographia Nacional, Rio de Janeiro.

Derby, O.A. 1895. A denominação "Serra da Mantiqueira". Revista do Instituto Historico e Geografico de São Paulo, 1: 5-15.

De Wit, M.J., Brito Neves, B.B., Trouw, R.A.J., Pankhurst, R.J., 2008. Pre-Cenozoic cor- relations across the South Atlantic region: the ties that bind. In: Pankhurst, R.J., Trouw, R.A.J., Brito Neves, B.B., De Wit, M.J. (Eds.), West Gondwana: Pre-Cenozoic Correlations Across the Atlanti Region. Geological Society, London, Special Pub- lications 294, 1-8.

Dickinson, W.R. 1970. Interpreting detrital modes of greywacke and arkose. Journal of Sedimentary Petrology, 40:695 - 707.

Dickinson, W.R. 1985. Interpreting provenance relations from detrital modes of sandstones. In: G.G. Zuffa (ed.). Provenance of Arenites. by D. Reidel Publishing Company: 333-361.

Dickinson, W.R. \& Suczek. C.A. 1979. Plate tectonics and sandstones compositions. AAPG Bulletin, 63: 2164-2182.

Dorr, J.V.N. 1969. Physiographic, Stratigraphic and Structural development of the Quadrilatero Ferrífero, Minas Gerais, Brazil. Washington,USGS/DNPM. Prof. Paper 641-A, 110p.

Dott Jr., R.H. 1964. Wacke, Graywacke and Matrix - What Approach to Immature Sandstone Classification?. Journal of Sedimentary Petrology, 33(3): 625 - 632.

Drew, J.H., Glen, A.G. \& Leemis, L.M. 2000. Computing the cumulative distribution function of the Kolmogorov-Smirnov statistic, Computational Statistics and Data Analysis, 34, 1-15.

Durrheim, R.J. \& Mooney, W.D. 1991. Archean and Proterozoic crustal evolution: Evidence from crustal seismology. Geology, v. 19: 606-609.

Elderfield, H. \& Greaves. M.J. 1982. The rare earth elements in seawater. Nature, 296: 214-219.

Eschwege, W.L. von. 1824. Brasil, novo mundo. Tradução Domício de Figueiredo Murta. Centro de Estudos Históricos e Culturais. Fundação João Pinheiro. Belo Horizonte, 1996: 197 p.

Fairchild, T. R. 1977. Conophyton and other Columnar Stromatolites from the Upper Precambrian Açungui Group near Itapeva, SP, Brazil. In: I Simpósio Regional de Geologia, Anais: 179198.

Fedo, M.C; Sircombe, N.K; Rainbird, R.H. 2003. Detrital Zircon Analysis of the Sedimentary Record. Editors: Hanchar, J.M. \& Hoskin, O.W. Reviews in Mineralogy \& Geochemistry, (53): 277 - 298. 
Fedo, C. M; Nesbitt, H. W; Young, G. M. 1995. Unraveling the effects of potassium metassomatism in sedimentary rocks and paleosols, with implications for paleoweathering conditions and provenance. Geology, Geological Society of America, 23: 921-924.

Figueiredo. M.C.H; Bergmann. M; Penalva. F; Tassinari. C.C.G. 1982. Ocorrência de pillow-lavas no Grupo São Roque. Estado de São Paulo. Revista Ciências da Terra, 2: 6-8.

Finch, R. J. \& Hanchar, J. M. 2003. Structure and Chemistry of Zircon and Zircon-Group Minerals. Editors: Hanchar, J. M. \& Hoskin, O. W. Reviews in Mineralogy \& Geochemistry, (53): 121.

Floyd, P. A. \& Leveridge, B. E. 1987. Tectonic environment of the Devonian Gramscatho basin, south Cornwall: framework mode and geochemical evidence from turbiditic sandstones. Journal of the Geological Society of London, 144:531-542.

Folk, R. L. 1974. Petrology of sedimentary rocks. Hemphill Publishing, Austin, Texas 182 p.

Franco, R. R. 1958. Contribuição ao Conhecimento das Rochas Termometamórficas da Serie São Roque. Faculdade de Filosofia Ciências e Letras, USP. Boletim 189, Mineralogia 14: 181.

Funaro, V. M. B. de O; Pestana, M. C; Garcia, E. M; Rebello, M. A. de F. R; Ayello, M. A. B; Carvalho, M. J. de J; Nascimento, M; Paschoalino, R. A; Cardoso, S. C; Lombardi, V. de V. 2009. Diretrizes para apresentação de dissertações e teses da USP: documento eletrônico e impresso Parte I (ABNT) / Sistema Integrado de Bibliotecas da USP. Caderno de Estudos 9, 102p.

Gerdes, A. \& Zeh, A. 2006. Combined U-Pb and Hf isotope LA-(MC-)ICP-MS analyses of detrital zircons: Comparison with SHRIMP and new constraints for the provenance and age of an Armorican metasediment in Central Germany. Earth and Planetary Science Letters, 249: 47-61.

Gomes, C de B., 1962. Contribuição ao Conhecimento dos Anfibolitos da Região do Jaraguá, SP. Boletim Sociedade Brasileira de Geologia. São Paulo, 11(1), p. 57-73.

Gonzaga de Campos, L. F. 1888. Secção Geológica. Relatório apresentado ao Dr. Orville A. Derby. Commisão Geographica e Geológica da Província de São Paulo. 15 de Dezembro: 21-34.

Govindaraju. K. 1995. Working values with confidence limits for twentysix CRPG. ANRT and IWT-GIT geostandards. Geostandards Newsletter. 19: 1-32.

Grimes, C.B., John, B.E., Kelemen, P.B., Mazdab, F.K., Wooden, J.L., Cheadle, M.J, Hanghøj, K., Schwartz, J.J. 2007. Trace element chemistry of zircons from oceanic crust: a method for distinguishing detrital zircon provenance. Geology, 35, 643-646.

Grimes, C.B., John, B.E., Cheadle, M.J., Mazdab, F.K., Wooden J.L., Swapp, S., Schwartz, J.J. 2009. On the occurrence, trace element geochemistry, and crystallization history of zircon from in situ ocean lithosphere. Contributions to Mineralogy and Petrology, 158: 757-783. 
Guadagnin, F; Chemale Jr. F; Magalhães, A.J; Santana, A; Dussin, I; Takehara, L. 2012. Geocronologia de Tufos a Cristal do Supergrupo Espinhaço - Implicações para os Ciclos Deposicionais Intracratônicos Paleoproterozóicos a Mesoproterozóicos do Cráton São Francisco. $46^{\circ}$ Congresso Brasileiro de Geologia, Anais, Santos, SP. CD arquivo digital (PAP011172).

Hasui. Y. 1976. Considerações Sobre a Estratigrafia do Pré-Cambriano na Região de São Paulo. Boletim Instituto de Geociências - USP, 7: 107-112.

Hay, D.C. \& Dempster, T.J. 2009. Zircon behaviour during low-temperature metamorphism. Journal of Petrology, 50, 571-589.

Hackspacher, P.C.; Dantas, E.L.; Godoy, A.M.; Oliveira, M.A.F.; Fetter, A.; Van Schmus, W.R., 1999. Considerations About the Evolution of the Ribeira Belt in the São Paulo State Brazil, From U/Pb Geochronology in Metavolcanic Rocks of the São Roque Group. In: II SOUTH AMERICAN SYMPOSIUM ON ISOTOPE GEOLOGY, Actas, p. 310-313.

Hackspacher, P.C., Dantas, E.L., Spoladore, A., Fetter, A.H., Oliveira, M.A.F. 2000. Evidence for Neoproterozoic back-arc basin development in the Central Ribeira Belt, southeastern Brazil: new geochronological and geochemical constraints from the São Roque-Açungui Groups. Revista Brasileira de Geociências, 30, p. 110-114.

Hackspacher, P. C.; Janasi, V. A.; Fetter, A. H.; Dantas, E. L.; Braga, I. F.; Negri, F. A.; Oliveira, M. A. F. de; Ebert, H. D. 2003. Magmatismo há ca. 660 - 640 Ma no Domínio Socorro: Registros de Convergência Pré-Colisional na Aglutinação do Gondwana Ocidental. Geologia USP, São Paulo, v. 3: 85-96

Hackspacher, P.C., Dantas, E.L., Godoy, A.M., Oliveira, M.A.F., Fetter, A., Van Schmus, W.R. Considerations About the Evolution of the Ribeira Belt in the São Paulo State - Brazil, From U/Pb Geochronology in Metavolcanic Rocks of the São Roque Group. In: II SOUTH AMERICAN SYMPOSIUM ON ISOTOPE GEOLOGY, Actas, 1999. p. 310-313.

Harnois, L. 1988. The CIW index: a new chemical index of weathering. Sedimentary Geology, 55: 319-322.

Hasui, Y; Penalva, F; Hennies, W. T. 1969. Geologia do Grupo São Roque. In: XXIII Congresso Brasileiro de Geologia, Salvador (BA), Anais: 101-134.

Hasui, Y. 1973. Tectônica da área das folhas de São Roque e Pilar do Sul. São Paulo. Tese LivreDocência - Instituto de Geociências - USP: 134 p.

Hasui, Y. 1975. Geologia da Folha de São Roque. Boletim do Instituto de Geociências -USP, 6: 157-183.

Hasui, Y; Carneiro, C. D. R; Coimbra, A. M. 1975. The Ribeira Folded Belt. Revista Brasileira de Geociências, 5: 257-266.

Hasui, Y. \& Sadowski, G. R. 1976. Evolução geológica do Pré-cambriano na região sudeste do Estado de São Paulo. Revista Brasileira de Geociências, 6(3): 182-200. 
Hasui, Y; Tognon, A. A; Soares, L; Csordas, S. M. 1978. Geologia e Tectônica da Serra do Japi. Boletim Instituto de Geociências - USP, 9: 17-24.

Hasui. Y; Sadowski, G. R; Carneiro, C.D.R. 1976. Considerações Sobre a Estratigrafia do PréCambriano na Região de São Paulo. Boletim Instituto de Geociências - USP. 7: 107-112.

Heaman, L.M.; Bowins, R. \& Crocket, J. 1990. The chemical composition of igneous zircon suites: Implications for geochemical tracer studies. Geochimica et Cosmochimica Acta, (54):1597-1607.

Heilbron, M; Pedrosa-Soares, A. C; Campos Neto, M. C; Silva, L. C; Trouw, R. A. J; Janasi, V. A. 2004. Província Mantiqueira. In: V. Mantesso-Neto,. Bartorelli, A., Carneiro, C. D. R. \& Brito Neves, B. B. (Organizadores): Geologia do Continente Sul-Americano: Evolução da obra de Fernando Flávio Marques de Almeida. São Paulo, Beca Prod. Culturais: 647p.

Hennies. W.T; Hasui Y; Penalva. F. 1967. O Falhamento Transcorrente de Taxaquara. In: XXI Congresso Brasileiro de Geologia. SBG. Curitiba. Anais. 21: 159-168.

Henrique-Pinto, R. 2008. Metaconglomerados e Rochas Associadas do Grupo São Roque a Noroeste da Cidade de São Paulo: Proveniência e Implicações para a Idade da Sedimentação. Dissertação de Mestrado, Instituto de Geociências, Universidade de São Paulo. 82 p.

Henrique-Pinto, R. \& Janasi, V.A. 2007. Proveniência dos Metaconglomerados do Grupo São Roque (SP): contribuições a partir da geoquímica dos seixos graníticos. In: XI Congresso Brasileiro de Geoquímica, Atibaia (SP), Resumos Expandidos: 1-4

Henrique-Pinto, R. \& Janasi. V.A. 2010. Metaconglomerados e Rochas Associadas do Grupo São Roque a Norte da Cidade de São Paulo. Brasil. Revista Brasileira de Geociências. 40(3): 409-425.

Henrique-Pinto, R; Janasi. V.A; Simonetti. A; Tassinari. C. C. G; Heaman. L. M. 2012. Paleoproterozoic source contributions to the São Roque Group sedimentation: LA-MCICPMS U-Pb dating and $\mathrm{Sm}-\mathrm{Nd}$ systematics of clasts from metaconglomerates of the Boturuna Formation. Geologia USP. (article accepted for publication) v. 12, n. 3.

Henrique-Pinto, R; Janasi. V.A; Tassinari, C. C. G; Carvalho, B. B; Stríkis, N. M. Provenance and sedimentation environments of the São Roque Group, Brazil: contributions from petrography, geochemistry and $\mathrm{Sm}-\mathrm{Nd}$ isotopic systematics of metassediments. (para submissão).

Herron, M. M. 1988. Geochemical classification of terrigenous sands and shales from core or log data. Journal of Sedimentary Research, 58(5): 820-829.

Hirata, T. 2001. Determinations of $\mathrm{Zr}$ isotopic composition and $\mathrm{U}-\mathrm{Pb}$ ages for terrestrial and extraterrestrial Zr-bearing minerals using laser ablation-inductively coupled plasma mass spectrometry: implications for $\mathrm{Nb}-\mathrm{Zr}$ isotopic systematics. Chemical Geology, 176, 323342. 
Hoskin, P.W.O. \& Black, L.P. 2000. Metamorphic zircon formation by solid-state recrystallization of protolith igneous zircon. Journal of Metamorphic Geology, 18:423-439.

Hoskin, P.W.O. \& Ireland, T.R. 2000. Rare earth element chemistry of zircon and its use as a provenance indicator. Geology, 28(7):627-630.

Hoskin, P.W.O. \& Ireland, T.R. 2012. Rare earth element chemistry of zircon and its use as a provenance indicator. Geology, 28: 627-630.

Hoskin, P.W.O. \& Schaltegger, U. 2003. The composition of zircon and igneous and metamorphic petrogenesis. In: Hanchar, J.M. and Hoskin, P.W.O., Ed., Zircon, vol.53, p. 27-62. Reviews in Mineralogy and Geochemistry, Mineralogical Society of America, Washington, D.C.

Hubert, J.F. 1962. A zircon-tourmaline-rutile maturity index and the interdependence of the composition of heavy mineral assemblages with the gross composition and texture of sandstones. Journal of Sedimentary Petrology, 32, 440-450.

Imai. N; Terashima. S; Itoh. S and Ando. A. 1995. Compilation of Analytical Data for Minor and Trace Elements in Seventeen GSJ Geochemical Reference Samples. "Igneous Rock Series". Geostandards Newsletter. 19: 135-213.

IPT - Instituto de Pesquisas Tecnológicas 1983. Carta Geológica do Estado de São Paulo em Escala 1:50.000. Secretaria da Industria Comércio Ciência e Tecnologia - Pró-Minério.

Ireland, T.R. \& Wlotzka, F. 1992. The oldest zircons in the solar system. Earth and Planetary Science Letters, 109, 1-10.

Irvine, T. N. \& Baragar, W. R. A. 1971. A Guide to the Chemical Classification of the Common Volcanic Rocks. Canadian Journal of Earth Sciences, 8: 523-548.

Janasi, V. A. \& Ulbrich, H. H. G. J. 1991. Late Proterozoic granitoid magmatism in the state of São Paulo, southeastern Brazil. Precambrian Research, 51: 351-374.

Juliani. C. 1993. Geologia. Petrogênese e Aspectos Metalogenéticos dos Grupos Serra do Itaberaba e São Roque na Região das Serras do Itaberaba e Pedra Branca. NE da Cidade de São Paulo. SP. São Paulo. Tese de Doutorado. Instituto de Geociências - USP: 803p.

Juliani, C; Beljavskis, P; Schorscher, H. D. 1986. Petrogênese do Vulcanismo e Aspectos Metalogenéticos Associados: Grupo Serra do Itaberaba na Região do São Roque - SP. In: XXXIV Congresso Brasileiro de Geologia, Goiânia, Anais 2: 730-745.

Juliani, C. \& Beljavskis, P. 1995. Revisão Litoestratigráfica da Faixa São Roque/Serra do Itaberaba (SP). Revista do Instituto Geológico de São Paulo, 16(1/2): 33-58.

Juliani, C; Martin, M. A. B; Clarimundo S. de J. 1997. Os metarcoseos do Morro do Polvilho: implicações para geocronologia e para evolução crustal dos grupos Serra do Itaberaba e São Roque (SP). Anais da Academia Brasileira de Ciencias, 69: 441.

Juliani, C; Martin, M. A. B; Clarimundo, S. De J; Mcreath, I; Pertersen Jr., K. J. 1999. Geologia dos Grupos Serra do Itaberaba e São Roque entre o Pico do Jaraguá e Araçarigüama, São 
Paulo. In: Simpósio de Geologia do Sudeste, SBG/NSP-NRJ/ES Águas de São Pedro, Boletim de Resumos, 6: 26.

Juliani, C., Hackspaker, P., Dantas, E.L., Fetter, A.H. 2000. The Mesoproterozoic volcanosedimentary Serra do Itaberaba Group of the central Ribeira Belt, São Paulo, Brazil: implications for the age of the overlying São Roque Group. Revista Brasileira de Geociências, 30, p. 82-86.

Kaulfuss. G. A. 2001. Geocronologia dos Núcleos de Embasamento Setuva. Betara e Tigre. Norte de Curitiba-Paraná. Dissertação de Mestrado. Instituto de Geociências - USP: 115p.

Krynine. P.D. 1948. The tourmaline group in sediments. The Journal of Geology. 54 (2) :65-87.

Kinny, P.D. 1986. 3820 Ma zircons from a tonalitic Amitsoq gneiss in the Godthab district of southern West Greenland. Earth and Planetary Science Letters, 79, 337-347.

Kinny, P.D., Williams, I.S., Froud, D.O., Ireland, T.R. and Compston, W. 1988. Early Archean zircon ages from orthogneisses and anorthosites at Mount Narryer, Western Australia. Precambrian Research, 38, 325-341.

Kosler. J. \& Sylvester. J. P. 2003. Present Trends and the Future of Zircon in Geochronology: Laser Ablation ICPMS. Editors: Hanchar, J. M. \& Hoskin, O. W. Reviews in Mineralogy \& Geochemistry, (53): 243 - 271.

Lazzari, M. L. 1987. O Metabasito de Pirapora do Bom Jesus. Tese Instituto de Geociências, Universidade de São Paulo: 84p.

Le Bas, M. J; Le Maitre, R. W; Streckeisen, A; Zanettin. 1986. A Chemical Classification of Volcanic Rocks Based on Total Alkali-Silica Diagram. Journal of Petrology, 27(3): 745750.

Leite, R.J., Heaman, L.M., Janasi, V.A., Martins, L., and Creaser, R.A., 2007. The late- to postorogenic transition in the Neoproterozoic Agudos Grandes Granite Batholith (Apiai Domain, SE Brazil): Constraints from geology, mineralogy, and U-Pb geochronology. Journal of South American Earth Sciences, 23(2-3): 193-212.

Lizuka, T., Horie, K., Komiya, T., Maruyama, S., Hirata, T., Hidaka, H., Windley, B.F. 2006. 4.2 Ga zircon xenocryst in an Acasta gneiss from northwestern Canada: evidence for early continental crust. Geology, 34, 245-248.

Ludwig, K. R. 2003. User's Manual for Isoplot 3.0 a Geochronological Toolkit for Microsoft Excel. Berkeley Geochronology Center, Special Publication n. 4. 70p.

Maas, R., Kinny, P. D., Williams, I. S., Froude, D. O., and Compston, W. 1992. The Earth's oldest known crust: A geochronological and geochemical study of 3900-4200 Ma detrital zircons from Mt Narryer and Jack Hills, Western Australia. Geochemica et Cosmochimica Acta, v.56: $1281-1300$. 
Machado, R. \& Fragoso Cesar, A. R. S. 1992. Nota Preliminar sobre a Estruturação do Grupo Açungui no Vale do Ribeira e a Norte da Cidade de São Paulo. In: XXXVII Congresso Brasileiro de Geologia, Boletim de Resumos Expandidos: 167.

Machado, N; Schrank, A; Noce, C. M; Gauthier, G. 1996. Ages of detrital zircon from ArcheanPaleoproterozoic sequences: Implications for Greenstone Belt setting and evolution of a Transamazonian foreland basin in Quadrilátero Ferrífero, southeast Brazil. Earth and Planetary Science Letters, 141: 259-276.

Mantovani, M. S. M. \& Brito Neves, B. B. 2005. The Paranapanema Lithospheric Block: Its Importance for Proterozoic (Rodinia, Gondwana) Supercontinent Theories. Gondwana Research, 8, 303-315.

Marini, O. J; Trein, E; Fuck, R. A. 1967. O Grupo Açungui no Estado do Paraná. Boletim Paranaense de Geociências, (23/25): 43-102.

Martin. M. A. B. 2000. Geologia e Petrografia e Metamorfismo dos Grupos Serra do Itaberaba e São Roque a Noroeste da Cidade de São Paulo (SP). Dissertação de Mestrado - Instituto de Geociências -USP: 256p.

Martin, L.A.J., Duchêne, S., Deloule, E., Vanderhaeghe, O. 2008. Mobility of trace elements and oxygen in zricons during metamorphism: consequences for geochemical tracing. Earth and Planetary Science Letters, 267, 161-174.

Martins, M; Karfunkel, J; Noce, C.M; Babinski, M; Pedrosa-Soares, A.C; Sial, A.N \& Liu, D. 2008. A sequência pré-glacial do Grupo Macaúbas na área-tipo e o registro da abertura do rifte Araçuaí. Revista Brasileira de Geociências, 38(4): 761-772.

McBride, E. F. 1963. A Classification of Common Sandstones. Journal of Sedimentary Petrology, 33(3): 664-669.

McCulloch, M. T. \& Bennett, C. V. 1994. Progressive growth of the Earth's continental crust and depleted mantle: Geochemical constraints. Geochimica et Cosmochimica Acta, 58(21): 4717-4738.

McDonough, W.F. \& Sun, S.-S., 1995. The composition of the Earth, Chemical Geology, 120, pp228.

McLennan, S. M. \& Hemming, S. R. 1991. Samarium/neodymium elemental and isotopic systematics in sedimentary rocks. Geochimica et Cosmochimica Acta, v. 56: 887-898.

McLennan, S. M; Taylor, S. R; McCulloch, M. T; Maynard, J. B. 1990. Geochemical and Nd-Sr isotopic composition of deep-sea turbidites: Crustal evolution and plate tectonic associations. Geochimica et Cosmochimica Acta, 54: 2015-2050.

McLennan, S. M; Hemming, S. McDaniel D. K. and Hanson, G. N. 1993. Geochemical approaches to sedimentation, provenance, and tectonics. Geological Society of America, Special Paper, 248: 21-40. 
McLennan, S. M; Hemming, S. R; Taylor, S. R; Eriksson, K. A. 1995. Early Proterozoic crustal evolution: Geochemical and $\mathrm{N}-\mathrm{Pb}$ isotopic evidence from metasedimentary rocks, southwestern North America. Geochimica et Cosmochimica Acta, 59(6): 1153-1177.

McReath, I; Jardim de Sá. E. F; Fryer, B. J. 1981. As Vulcânicas Ácidas Proterozóicas da Região da Bacia do Rio Paramirim - Bahia. Geologia e Recursos Minerais do Estado da Bahia. Secretaria de Minas e Energia, 4: 121-134.

Moecher, D.P. \& Samson, S.D. 2006. Differential zircon fertility of source terrenes and natural bias in the detrital zircon record: implications for sedimentary provenance analysis. Earth and Planetary Science Letters 247, 252-266.

Myers, J.S. 1988. Early Archean Narryer Gneiss Complex, Yilgarn Craton, Western Australia. Precambrian Research, 38, 297-307.

Myers, J.S. \& Williams, I.R. 1985. Early Precambrian crustal evolution at Mount Narryer, Western Australia. Precambrian Research, 27, 153-163.

Molinaroli, E; Blom. M. and Basu. A. 1991. Methods of provenance determination tested with discriminant function analysis. Journal of Sedimentary Petrology, 61(6): 900-908.

Moraes, L. J. de. 1944. A Serra do Japí, Estado de São Paulo. Faculdade de Filosofia, Ciências e Letras. Universidade de São Paulo. Boletim 1(45): 34-40.

Moraes Rego, L.F. de. 1930. A Geologia do Petróleo no Estado de S. Paulo. Serviço Geológico e Mineralógico do Brasil. Rio de Janeiro, Boletim 46: 1-70.

Moraes Rego, L. F. de. 1931. As estructuras antigas do Brasil. Annaes da Escola de Minas: 27-85.

Moraes Rego, L. F. de. 1933. Contribuição ao estudo das formações pré-devonianas de São Paulo. Boletim do Instituto Astronômico e Geographico. São Paulo - SP: 55p.

Mori, P. E; Reeves, S; Correia, C.T; Haukka, M. 1999. Development of a fused glass disc XRF facility and comparison with the pressed powder pellet technique at Instituto de Geociências, Universidade de São Paulo. Revista Brasileira de Geociências, 29: 441-446.

NACSN (North American Commission on Stratigraphic Nomenclature). 2005. North American Stratigraphic Code ${ }^{1}$, AAPG Bulletin, 89(11): 1547-1591.

Navarro, M.S; Ulbrich, H. H. G. J; Andrade, S; Janasi, V.A. 2002. An adaptation of ICP-OES routine determination techniques for the analysis of rare-earth elements by chromatographic separation in geologic materials: tests with reference materials and granitic rock. Journal of Alloys and Compounds, Amsterdam, 344: 40-45.

Nesbitt, H. W. \& Young, G. M. 1982. Early Proterozoic climates and plate motions inferred from major element chemistry of lutites. Nature, 299: 715-717.

Nesbitt, H. W. \& Young, G. M. 1989. Formation and Diagenesis of Weathering Profiles. The Journal of Geology, 97(2): 129-147. 
Nesbitt, H. W. \& Young, G. M. 1996. Petrogenesis of sediments in the absence of chemical weathering: effects of abrasion and sorting on bulk composition and mineralogy. Sedimentology, 43: 341-358.

Nesbitt, H. W; Young, G. M; McLennan, S. M. and Keays, R. R. 1996. Effects of Chemical Weathering and Sorting on the Petrogenesis of Siliciclastic Sediments, with Implications for Provenance Studies. The Journal of Geology, 104(5): 525-542.

Nesbitt, H. W. \& Markovics, G. 1997. Weathering of granodioritic crust, long-term storage of elements in weathering profiles, and petrogenesis of siliciclastic sediments. Geochimica et Cosmochimica Acta, 6(8): 1653-1670.

Neves. M. A. 2005. Análise Integrada Aplicada à Exploração de Água Subterrânea na Bacia do Rio Jundiaí (SP). Tese de Doutoramento. Instituto de Geociências e Ciências Exatas. Universidade Estadual Paulista. Rio Claro: 200 p.

Norman, M.D., Griffin, W.L., Pearson, N.J., Garcia, M.O., O’Reilly, S.Y. 1998. Quantitative analysis of trace element abundances in glasses and minerals: a comparison of laser ablation ICPMS, solution ICPMS, proton microprobe, and electron microprobe data. Journal of Analytical Atomic Spectroscopy 13: 477-482.

Odman, O.H. A Pre-Cambrian Conglomerate With Pebbles of Deep-Seated Rocks Near São Paulo, Brazil. 1955. Engenharia, Mineração e Metalurgia, XXI. (121), p. 32.

Oliveira, E.P. de. 1925. Analyses de Calcareos. Serviço Geológico e Mineralógico do Brasil. Ministério da Agricultura Indústria e Commercio. Boletim 10: 1-45.

Oliveira, E. P. de. 1927. Geologia e Recursos Mineraes do Estado do Paraná. Serviço geológico e Mineralógico do Brasil. Monographia. VI: 53p.

Oliveira, F de P. 1887. Esboço Geológico da Região Comprehendida entre os Rios Sorocaba e Tieté. Relatório da Província de São Paulo, Comissão Geographica e Geológica. 19 de novembro: $26-28$.

Oliveira, M. A. F., Souza, S. C. A., Teixeira, W. and Vasconcelos, P. M. 2003. ${ }^{40} \mathrm{Ar} /{ }^{39} \mathrm{Ar}$ ages of the Aluminio (Serra do Itaberaba group) and Hermida (Itapira group) Amphibolite, central portion of the Ribeira Belt, Brazil: preliminary inferences. In: , Proceedings of: Crustal Evolution Of South America. Short Papers - IV South American Symposium on Isotope Geology. IV South American Symposium on Isotope Geology, Salvador-Bahia, Brazil: 233-236).

Oliveira, M.A.F. de., Melo, R.P., Nardy, A.J.R., Arab, P.B., Trindade, I. 2008. New U/Pb Palaeoproterozoic Zircon Age For The Cajamar Metabasite, São Roque Group, Central Ribeira Belt, Southeastern Brazil. In: VI SOUTH AMERICAM SYMPOSIUM ON ISOTOPE GEOLOGY. San Carlos de Bariloche, Argentina, p. 1-4. 
Oliveira, M.A.F. de., Melo, R.P., Nardy, A.J.R., Arab, P.B. 2011. Caracterização geotermobarométrica dos metabasitos de Cajamar (SP), Grupo São Roque, Cinturão Ribeira. Revista Brasileira de Geociências, 41(3): 375-389.

Paoliello, P. C. 1964. Geologia do Estado de São Paulo - Explanação do Mapa Geológico. Boletim I.G.G., 41: 37-44.

Paton, C., Hellstrom, J., Paul, B.,Woodhead, J. and Hergt, J. 2011. Iolite: Freeware for the visualisation and processing of mass spectrometric data. Journal of Analytical Atomic Spectrometry. doi:10.1039/c1ja10172b.

Pearce, J. A \& Cann, J. R. 1973. Tectonic Setting of Basic Volcanic Rocks Determined Using Trace Element Analyses. Earth and Planetary Science Letters, 19(2): 290-300.

Pearce, J. A \& Norry, M. J. 1979. Petrogenetic Implications of Ti, Zr, Y, and Nb Variations in Volcanic Rocks. Contributions to Mineralogy and Petrology, 69: 33-47.

Pflug, R., 1968. Observações sobre a estratigrafia da Série Minas na região de Diamantina, Minas Gerais. Departamento Nacional de Produção Mineral, Div. Geol. Min., Rio de Janeiro, Not. Prelim. Est., 142, 20p.

Petri, S. \& Suguio, K. 1969. Sôbre os Metassedimentos do Grupo Açunguí do Extrêmo Sul do Estado de São Paulo. Convenio USP - DAEE (Serviço do Vale do Ribeira), 2: 11-98.

Petri, S; Coimbra, A. M; Amaral, G; Ojeda, H. O. Y; Fúlfaro, V. J; Ponçano, W. L. 1986a. Código Brasileiro de Nomenclatura Estratigráfica. Revista Brasileira de Geociências, 16(4): 372376.

Petri, S; Coimbra, A. M; Amaral, G; Ponçano, W. L. 1986b. Guia de Nomenclatura Estratigráfica. Revista Brasileira de Geociências, 16(4): 376-415.

Pettijohn, F.J. 1941. Persistence of heavy minerals and geologic age. Journal of Geology. 49: 610 625.

Pidgeon, R.T., Wilde, S.A., Compston, W., 1990. Zircon U-Pb dating of Archean granite activity associated with Jack Hills Metasedimentary Belt, Yilgarn Craton, Western Australia. Australian Journal Earth Sciences, 37, 279-292.

Pimentel, M.M; Dardenne, M.A; Fuck, R.A; Viana, M.G; Junges, S.L; Fischel, D.P; Seer, H.J; Dantas, E.L. 2001. Nd isotopes and the provenance of detrital sediments of the Neoproterozoic Brasília Belt, central Brazil. Journal of South American Earth Sciences, 14: 571-585.

Puga, E., Fanning, C.M., Nieto, J.M., Diaz de Frederico, A. 2005. Recrystallization textures in zircon generated by ocean-floor and eclogite-facies metamorphism: a cathodoluminescence and U-Pb SHRIMP study, with constraints from REE elements. The Canadian Mineralogist, 43, 183-202.

Pupin, J. P. 1980. Zircon and Granite Petrology. Contributions to Mineralogy and Petrology, (73): 207-220. 
Ribeiro, L.M de A.L. 2006. Estudo Geocronológico dos Terrenos Granito-Gnáissicos e Seqüências

Metavulcanossedimentares da Região do Betara (PR). Dissertação de Mestrado. Instituto de Geociências - USP: 121p.

Rogers, J. W. \& Santosh, M. 2001. Configuration of Columbia, a Mesoproterozoic Supercontinent. Gondwana Research, 5(1): 5-22.

Roser. B. P. \& Korsch. R. J. 1988. Provenance Signatures of Snadstone-Mudstone Suites Determined Using Discriminant Function Analysis of Major-Element Data. Chemical Geology, 67: 119-139.

Ross, G.M., Patchett, P.J., Hamilton, M., Heaman, L., DeCelles, P.G., Rosenberg, E., and Giovanni, M.K., 2005, Evolution of the Cordilleran orogen (southwestern Alberta, Canada) inferred from detrital mineral geochronology, geochemistry, and $\mathrm{Nd}$ isotopes in the foreland basin. Geological Society of America Bulletin, 117: 747-763.

Rubatto, D., Müntener, O., Barnhoorn, A., Gregory, C. 2008. Dissolution-reprecipitation of zircon at low-temperature, high-pressure conditions (Lanzo Massif, Italy). American Mineralogist, 93: 1519-1529. doi: 10.2138/am.2008.2874.

Sadowski, G.R. \& Tassinari, C.C.G. 1988. The São Roque volcano-sedimentary sequence of proterozoic age. In: International Gondwana Symposiun, 7, São Paulo, Brazil. Excursions. p. 27.

Santos, M; Bica, M; Guadagnin, F. Chemale Jr, F; Jelinek, A; Dussin, I; Borba, M. 2009. Idades $\mathrm{U} / \mathrm{Pb}$ de Zircões Detríticos Aplicadas à Análise de Proveniência Sedimentar: estudos de caso de Bacias Pré-Cambrianas. Simpósio 45 Anos de Geocronologia no Brasil. CPGeo IGc - USP. Boletim de Resumos Expandidos: 310-313.

Sato, K.; Tassinari, C.C.G.; Kawashita, K.; Petronilho, L. 1995. Método geocronológico Sm- Nd no IG-USP e suas aplicações. Anais da Academia Brasileira de Ciências, 67(3): 315-336.

Sawyer, E. W. 1986. The influence of source rock type, chemical weathering and sorting on the geochemistry of clastic sediments from the Quetico mesedimentary belt, Superior Province, Canada. Chemical Geology, 55: 77-95.

Schobbenhaus, C; Hoppe, A; Baumann, A; Lork, A. 1994. Idade U/Pb do Vulcanismo Rio dos Remédios, Chapada Diamantina, Bahia. In: XXXVIII Congresso Brasileiro de Geologia, Balneário Camboriú (SC), Anais: 397-398.

Serviço Geológico Do Brasil - CPRM. 2006. Geologia e Recursos Minerais do Estado de São Paulo. Mapas Geológicos Estaduais na Escala 1:750.000. Ministério de Minas e Energia.

Shimizu, H. \& Masuda, A. 1977. Cerium in chert as an indication of marine environment of its formation. Nature, 266: 346-348.

Siga Jr. O; Basei. M. A. S; Passarelli. C. R; Harara. O. M; Sato. K; Cury. L. F. e Prazeres Filho. H. J. dos. 2007. Geocronologia das Rochas Gnáissico-Migmatíticas e Sienograníticas do 
Núcleo Setuva (PR): implicações tectônicas. Revista Brasileira de Geociências 37(1): 114-128.

Siga Jr, O; Sato, K; Basei, M. A. S; McReath, I; Passarelli, C. R. 2009. Geologia e Geocronologia da Região do Betara (PR): Evidências de Regimes Extensionais do Paleoproterozóico Superior (1.80 - $1.75 \mathrm{Ga})$ e do Mesoproterozóico (1.50 - $1.45 \mathrm{Ga})$ no Sul-Sudeste Brasileiro. Simpósio 45 Anos de Geocronologia no Brasil. CPGeo - IGc - USP. Boletim de Resumos Expandidos: 316-318.

Siga Jr, O., Basei, M.A.S., Sato, K., Passarelli, C.R., Nutman, A., McReath, I. e Prazeres Filho, H.J.d., 2011. Calymmian (1.50-1.45 Ga) magmatic records in Votuverava and Perau sequences, south-southeastern Brazil: Zircon ages and $\mathrm{Nd}-\mathrm{Sr}$ isotopic geochemistry. Journal of South American Earth Sciences, 32(4): 301-308.

Silva, P. C. F. da. 2004. Litofácies e Prováveis Ambientes de Sedimentação do Grupo São Roque na Região de Votorantim e Salto de Pirapora, SP. Revista do Instituto Geológico. São Paulo, $25,29-48$.

Simonetti, A.; Heaman, L.M.; Hartlaub, R.P.; Creaser, R.A.; Machattie, T.G., 2005U-Pb Zircon Dating by Laser Ablation-MC-ICP-MS Using a New Multiple Ion Counting Faraday Collector Array. Journal of Analytical Atomic Spectrometry, 20, p. 677-686.

Singh, P \& Rajamani, V. 2001. REE geochemistry of recent clastic sediments from the Kaveri floodplains, southern India: Implication to source area weathering and sedimentary processes. Geochimica et osmochimica Acta, Vol. 65, nº. 18, pp. 3093-3108.

Sinha, A.K. \& Glover, L. 1978. U/Pb Systematics of zircons during dynamic metamorphism. Contributions to Mineralogy and Petrology, 66, 305-310.

Sircombe, K.N. \& Hazelton, M.L. 2004. Comparison of detrital zircon age distributions by kernel functional estimation. Sedimentary Geology, 171, 91-11.

Sircombe, K.N. \& Stern, R.A. 2002. An investigation of artificial biasing in detrital zircon U-Pb geochronology due to magnetic separation in sample preparation. Geochimica et Cosmochimica Acta, 66: 2379-2397.

Spandler, C., Hermann, J., Rubatto, D. 2004. Exsolution of thortveitite, yttrialite and xenotime during low-temperature reccrystallization of zircon from New Caledonia, and their significance for trace element incorporation in zircon. American Mineralogist, 89: 17951806.

Stern, R.A. \& Bleeker, W. 1998. Age of the World's oldest rocks refined using Canada's SHRIMP: The Acasta Gneiss Complex, Northwest Territories, Canada. Geoscience Canada, 25, $27-$ 31.

Tassinari, C.C.G. 1988. As Idades das Rochas e dos Eventos Metamórficos da Porção Sudeste do Estado de São Paulo e sua Evolução Crustal. Tese (Doutorado) - Instituto de Geociências, Universidade de São Paulo, São Paulo. 
Tassinari, C. C. G; Kawashita, K; Kikuchi, R. K. P. 1985. Estudo Geocronológico nos Metaconglomerados do Grupo São Roque, Estado de São Paulo. In: X Simpósio Regional de Geologia, São Paulo. Boletim de Resumos, SBG, 1: 201-208.

Tassinari, C. C. G; Barbour, A. P; Daitx, E. C; Sato, K. 1990. Aplicação dos Isótopos de Pb e Sr na Determinação da Natureza das Fontes das Mineralizações de Chumbo do Vale do Ribeira - SP e PR. In: XXXIV Congresso Brasileiro de Geologia, Natal (RN), Anais (3): 12541266.

Tassinari, C. C. G; Munhá, J. M. U; Correia, C. T. 2001. Neoproterozoic Oceans in the Ribeira Belt (southeastern Brazil): The Pirapora do Bom Jesus Ophiolitic Complex. Episodes, 24(4): 245-251.

Taylor. S. R; McLennan. S. M; Armstrong. R. L. and Tarney, J. 1981. The Composition and Evolution of the Continental Crust: Rare Earth Element Evidence from Sedimentary Rocks (and Discussion). Phil. Trans. R. Soc. Lond. 301(1461): 381-399.

Taylor. S. R. \& McLennan. S. M. 1985. The Continental Crust: Its Composition and Evolution. Blackwell.pg 298.

Teixeira, A.W \& Campos Neto, M.C. 2012. O Grupo Carrancas e a Frente da Nappe Andrelândia na Borda Sul do Cráton do São Francisco: Proveniência Sedimentar e Implicações Tectônicas. $46^{\circ}$ Congresso Brasileiro de Geologia, Anais, Santos, SP. CD arquivo digital (PAP009393).

Teixeira, W; Carneiro, M.A; Noce, C.M; Machado, N; Sato, K; Taylor, P.N. 1996. Pb, Sr and Nd isotope constraints on the Archaean evolution of gneissic-granitoid complexes in the southern São Francisco Craton, Brazil. Precambrian Research, 78:151-164.

Teixeira, W; Ávila, A.C; Nunes, L.C. 2008. Nd-Sr Isotopic Geochemistry and U-Pb Geocronology of the Fé Granitic Gneiss and Lajedo Granodiorite: Implications for Paleoproterozoic Evolution of the Mineiro Belt, Southern São Francisco Craton, Brazil. Geologia USP : Série Científica. São Paulo, 8(1), p. 53-74.

Teixeira, W; Ávila, C.A; Dussin, I.A; Vasques, F. de S.G.; Hollanda, M.H.M de. 2012a. Geocronologia U-Pb (LA-ICPMS) em Zircão Detrítico de Sequiências Metassedimentares do Cinturão Mineiro: Idade, Proveniência e Implicações Tectônicas. $46^{\circ}$ Congresso Brasileiro de Geologia, Anais, Santos, SP. CD arquivo digital (PAP011451).

Teixeira, W; Ávila, C.A; Souza, V.H.P; Dussin, I.A; Bongiolo, E.M; Rigueti, A.L; Pinho, R.E de. 2012b. Caracterização de Arco Magmático Sideriano no Cinturão Mineiro: Evidências Isotópicas a partir do Ortognaisse Resende Costa e Rochas Coevas. $46^{\circ}$ Congresso Brasileiro de Geologia, Anais, Santos, SP. CD arquivo digital (PAP010212).

Trow, R.A.J; Nunes, M.R.P; Costa, R.V.C da; Duffles, P; Fontainha, M.V.F; Paula, R.R de. 2012. Novos Dados da Transição entre as Faixas Brasília Meridional e Ribeira Central. $46^{\circ}$ Congresso Brasileiro de Geologia, Anais, Santos, SP. CD arquivo digital (PAP009694). 
Turra, B. B; Campanha, G. A. C; Henrique-Pinto, R. 2007. Análise de Deformação nos Metaconglomerados do Morro Doce, Grupo São Roque, Faixa Ribeira ao Norte da Cidade de São Paulo. In: XIV Simpósio de Geologia de Minas Gerais - X Simpósio de Geologia do Sudeste, Diamantina (MG), Livro de Resumos: p.19.

Uhlein, A; Trompette, R; Egydio-Silva, M.E. 1995. Proterozoic rifting and closure, SE border of the São Francisco Craton, Brazil. Journal of South America Earth Science, 11:191-203.

Valeriano, C. M; Machado, N; Simonetti, A; Valladares, C.S; Seer, H.J; Simões, L.S.A. 2004. U-Pb geochronology of the southern Brasília belt (SE-Brazil): sedimentary provenance, Neoproterozoic orogeny and assembly of West Gondwana. Precambrian Research, 130: 27-55.

Valladares, C. S; Machado, N; Heilbron, M; Gauthier, G. 2004. Ages of Detrital Zircon from Siliciclastic Successions South of the São Francisco Craton, Brazil: Implications for Evolution of Proterozoic Basins. Gondwana Research, 7(4): 913-921.

Valladares, C.S; Machado, N; Heilbron, M; Duarte, B.P; Gauthier, G. 2008. Sedimentary provenance in the central Ribeira belt based on laser-ablation ICPMS ${ }^{207} \mathrm{~Pb} /{ }^{206} \mathrm{~Pb}$ zircon ages. Gondwana Research, 13(4): 516-526.

Van Schmus. W.R; Tassinari. C.C.G; Cordani. U.G. 1986. Estudo Geocronológico da Parte Inferior do Grupo São Roque. In: XXXIV Congresso Brasileiro de Geologia. Goiânia (GO). Anais. 3: $1399-1406$.

Vermeesh, P. 2006. Tectonic Discrimination Diagrams Revisited. Geochemistry Geophysics Geosystems, 7(6): 1-55.

Vervoort, J. D. \& Blichert-Tof, J. 1999. Evolution of the depleted mantle: Hf isotope evidence from juvenile rocks through time. Geochimica et Cosmochimica Acta, 62(3/4): 533-556.

Vlach S.R.F. 2001. Microprobe monazite constraints for an early (ca. 790 Ma) Brasiliano orogeny: the Embu Terrane, Southeastern Brazil. In: SOUTH-AMERICAN SYMPOSIUM ON ISOTOPE GEOLOGY III, Pucon, Chile, Extended Abstracts, p. 265-268.

Weber, W; Siga Jr, O; Sato, K; Reis Neto, J. M dos; Basei, M. A. S; Nutman, A. P. 2004. A Formação Água Clara na Região de Araçaíba - SP: Registro U-Pb de Uma Bacia Mesoproterozóica. Geologia USP - Série Científica, 4(1): 101-110.

WedepohL, K. H. 1995. The composition of the continental crust. Geochimica et Cosmochimica Acta, 59(7): 1217-1232.

Wernick, E; Oliveira, M. A. F. de; Kawashita, K; Cordani, U. G; Delhal, J. 1976. Estudo Geocronológico pelo Método Rb/Sr em Rochas do Bloco Jundiaí e Regiões Adjacentes. Revista Brasileira de Geociências, 6(2): 125-135. 
Whitehouse, M. J., Kamber, B. S., Moorbath, S. 1999. Age significance of U-Th-Pb zircon data from early Archean rocks of west Greenland-a reassessment based on combined ionmicroprobe and imaging studies. Chemical Geology, 160: 201-224.

Woodhead, J., Hellstrom, J., Hergt, J., Greig, A. \& Maas, R (2007) Isotopic and elemental imaging of geological materials by laser ablation Inductively Coupled Plasma mass spectrometry. Journal of Geostandards and Geoanalytical Research, 31, p. 331-343. 


\section{Apêndice - I}

(Metaconglomerados e Rochas Associadas do Grupo São Roque a Norte da Cidade de São Paulo, Brasil) 


\title{
Metaconglomerados e rochas associadas do Grupo São Roque a norte da cidade de São Paulo, Brasil
}

\author{
Renato Henrique-Pinto $^{1}$ \& Valdecir de Assis Janasi $^{1}$
}

\begin{abstract}
Resumo O Grupo São Roque caracteriza-se por rochas depositadas em ambiente marinho com atividade vulcânica submarina, as ocorrências da Formação Morro Doce são dominadas por metarcóseos e metarenitos feldspáticos com expressivas lentes de metaconglomerados, que formam uma seqüência considerada como unidade basal do Grupo São Roque. Rochas metavulcânicas ácidas e básicas intercaladas nesta seqüência constituem importante marcador tectônico e geocronológico, e foram usadas para determinar sua idade de deposição (1.75-1.79 Ga). O estudo petrográfico dos clastos graníticos dos metaconglomerados permitiu a identificação de quatro variedades petrográficas: biotita monzogranito porfirítico, monzogranito inequigranular, monzogranito equigranular e leucogranito inequigranular. O caráter comagmático entre os clastos é confirmado pelos dados geoquímicos e geocronológicos. Rochas metavulcânicas ácidas que ocorrem intercaladas a metarcóseos e metaconglomerados, na região do Morro do Polvilho, caracterizam-se por meta-traquidacitos e meta-riolitos porfiríticos. Com características geoquímicas típicas de magmatismo intraplaca, em especial baixo mg\# ( 20), altos teores de $\mathrm{Zr}$ (560-730 ppm), Y e Nb, além de baixo Sr (70-120 ppm), as rochas metavulcânicas ácidas do Grupo São Roque apresentam similaridades com as metavulcânicas ácidas da base do Supergrupo Espinhaço. Por outro lado, o corpo anfibolítico do Jaraguá, de idade ainda desconhecida, parece ser intrusivo na Formação Morro Doce tem características geoquímicas mais próximas de magmatismo de fundo oceânico, com baixas concentrações de elementos incompatíveis como $\mathrm{Rb}, \mathrm{Nb}$ e $\mathrm{Th}$, o que as aproximam das rochas metabásicas supracrustais da região de Pirapora do Bom Jesus.
\end{abstract}

Palavras-chave: Grupo São Roque, metaconglomerados, ambientes tectônicos.

\begin{abstract}
Metacoglomerates and associated rocks of the São Roque Group, northern São Paulo city, Brazil. The São Roque Group is composed of rocks deposited in marine environment with coeval volcanic activity, the Morro Doce Formation is dominated by meta-arkose and feldspatic meta-sandstone with expressive metaconglomeratic lenses, which form a sequence regarded as the basal unit of São Roque Group. Metavolcanic acidic and basic rocks interspersed in this sequence are an important tectonic and geochronologic marker (1.75-1.79 $\mathrm{Ga}$ ). The petrographic study of the granite pebbles from the Morro Doce Formation metaconglomerates allowed the identification of four petrographic varieties: porphyritic biotite monzogranite, inequigranular monzogranite, equigranular monzogranite and inequigranular leucogranite. The comagmatic character of these pebbles is confirmed by petrographic and geochemical data. Acid metavolcanic rocks interlayered with meta-arkose and metaconglomerates in the Morro do Polvilho region correspond to trachydacite and porphyritic meta-rhyolite. The meta-arkose shows geochemical affinities with metaconglomerate granitic pebbles, and differs from the acid metavolcanic rocks both in their geochemical signature and in its sedimentary fabrics. Their geochemical characteristics are typical of within-plate magmatism, especially the low $\mathrm{mg} \#(\sim 20)$, high $\mathrm{Zr}$ (560-730 ppm), Y, Nb, and low $\mathrm{Sr}$ (70-120 ppm), and is similar to the acid metavolcanics from the on Espinhaço Supergroup. The Jaraguá amphibolite body, still of unknown age, seems to be intrusive into the Morro Doce Formation, and has geochemical characteristics akin to ocean-floor magmatism, with low concentrations of incompatible elements such as Rb, $\mathrm{Nb}$ and $\mathrm{Th}$, and are similar to supracrustal metabasics from the Pirapora do Bom Jesus region.
\end{abstract}

Keywords: São Roque Group, metacoglomerates, tectonics environment.

INTRODUÇÃO A cadeia de montanhas que compõe as faixas dobradas da porção leste do Brasil, chamada por Eschwege (1824) de "serra do Espinhaço", abriga antigas bacias sedimentares cujas idades e correlações ainda são temas controversos. Parte desta cadeia de montanhas, localizada nos Estados de Minas Gerais e São Paulo, recebe o nome Serra da Mantiqueira, e especificamente a norte de São Paulo, Serra da Cantareira (Derby, 1895).
A "serie de xistos metamorphycos" (Oliveira, 1887) que compõe parte do substrato rochoso que sustenta as regiões elevadas no Estado de São Paulo foi chamada por Gonzaga de Campos (1888) de "camadas de São Roque", e posteriormente de "Série de São Roque" (Oliveira 1925). Esta seqüência que se expõe principalmente a norte da cidade de São Paulo foi elevada à categoria de Grupo São Roque em 1963 (Paoliello, 1964). 
O Grupo São Roque caracteriza-se por rochas depositadas em ambiente marinho (Moraes Rego, 1933), com atividade vulcânica submarina (Carneiro et al. 1984). As ocorrências da Formação Morro Doce (Juliani et al. 1999) são dominadas por metarcóseos e metarenitos feldspáticos com expressivas lentes metaconglomeráticas, que formam uma seqüência considerada como unidade basal do Grupo São Roque. Os metaconglomerados que afloram a norte da cidade de São Paulo têm chamado a atenção dos geólogos desde os trabalhos de Coutinho (1955), e o amplo predomínio de clastos graníticos tem excelente potencial para identificação de suas fontes e idades.

Datação U-Pb em monazita de rocha metabásica apresentada por Hackspacher et al. (2000) (628 \pm $9 \mathrm{Ma}$ ) foi interpretada como indicativa de que o Grupo São Roque se depositou no Ediacarano, tratando-se de unidade mais jovem que o Grupo Serra do Itaberaba, do Mesoproterozóico (Juliani et al. 2000). Datações K-Ar em biotita do arcabouço do metaconglomerado sugerem, no entanto, idades de metamorfismo da ordem de $800 \mathrm{Ma}$ (Tassinari et al. 1985).

A deposição do Grupo São Roque tem sido determinada com maior segurança através de datações U-Pb de rochas metavulcânicas ácidas e básicas que ocorrem intercaladas na Formação Morro Doce (Carneiro et al. 1984), e indicam idades na passagem Estateriano-Caliminiano (1790 + 14 Ma, van Schmus et al. 1986; 1750 $\pm 40 \mathrm{Ma}$; Oliveira et al. 2008). Esta idade sugere que a sedimentação do Grupo São Roque teve início a partir da "Tafrogênese Estateriana" (Brito Neves et al. 1995), o que abre a possibilidade de cronocorrelação com a base do Supergrupo Espinhaço (Schobbenhaus et al., 1994; Brito Neves et al., 1979) e a base do Supergrupo Açungui (Basei et al. 2003; Weber et al. 2004).

A idade obtida por Van Schmus et al. (1986) foi questionada por Juliani et al. (1997) com base na petrografia, uma vez que os meta-riodacitos por eles datados foram reinterpretados como metarcóseos. Portanto, por essa ótica, os zircões datados seriam detríticos, o que representaria a idade de uma das fontes, e não da deposição do pacote sedimentar intercalado com essas rochas.

Em uma fase inicial, a presente pesquisa explorou a possibilidade de proveniência dos metaconglomerados do Grupo São Roque a partir de um arco magmático continental neoproterozóico, sugerido pela datação e interpretação paleogeográfica (bacia de "back-arc") de Hackspacher et al. (2000). Foi feita uma comparação geoquímica detalhada entre os clastos dos metaconglomerados e os granitos neoproterozóicos, a partir das variedades petrograficamente similares às identificadas nos clastos. Embora tenham sido reveladas similaridades com alguns dos granitos neoproterozóicos do batólito Agudos Grandes (Henrique-Pinto \& Janasi 2007), discrepâncias para importantes elementos traços como $\mathrm{Rb}$, Nb e Ga mostraram que os clastos não têm equivalência com nenhum dos granitos neoproterozóicos regionais conhecidos.

Os clastos graníticos do metaconglomerado foram estudados em detalhe por Henrique-Pinto (2008) e datados em $2.2 \mathrm{Ga}$ (U-Pb por LA-MC-ICPMS), que é, portanto a idade da área-fonte predominante da Fm. Morro Doce, consistente com a idade de deposição dos metaconglomerados de 1.75-1.79 Ga, indicada pelas datações U-Pb em rochas metavulcânicas intercaladas.

SITUAÇÃO TECTÔNICA Moraes Rego (1931) chamou de Pré-Brasilides as estruturas que se anexaram a escudos arqueanos para dar origem à "grande molhe continental chamada Brasilia". No Brasil, a fragmentação dessa grande massa continental resultou na geração de bacias oceânicas, com sedimentação provavelmente iniciada ao final do Paleoproterozóico (Brito Neves et al. 1995). Registros da geração de um "supercontinente" durante o período Orosiriano, com fragmentação iniciada no Estateriano, são encontrados em outras partes do mundo (Condie 2002; Rogers \& Santosh 2002).

O Grupo São Roque caracteriza-se por rochas depositadas em ambiente marinho (Moraes Rego 1933) com atividade vulcânica submarina (Carneiro et al. 1984). Está localizado na Província Estrutural Mantiqueira (Almeida et al. 1981), e seria parte, segundo diferentes autores, da Faixa de Dobramentos Ribeira (Hasui et al. 1975a), Faixa Apiaí (Campos Neto \& Figueiredo 1995) ou Domínio Apiaí (Campanha \& Sadowski 1999). No modelo tectônico de Campos Neto 2000, ele faz parte do Domínio Apiaí-São Roque, que é limitado a sul pelo Domínio Embu (Complexos Pilar e Embu) e a norte pelo Domínio Socorro Guaxupé (Fig. 1).

Uma seqüência vulcano-sedimentar presente na região da Serra do Itaberaba foi caracterizada como a base do Grupo São Roque (Coutinho et al. 1982), sendo composta por vulcânicas e sub-vulcânicas básicas e seus tufos, bem como camadas argilosas, margas e intercalações de sedimentos químicos silicosos. Acima desta seqüência foi descrito um pacote com menor metamorfismo, representado na base por "metarcóseos rítmicos" sucedido por filitos com intercalações quartzíticas (Campos Neto et al. 1983).

A seqüência basal foi posteriormente distinguida como Grupo Serra do Itaberaba por Juliani et al. (1986), que a subvidiram em três formações. A Formação Morro da Pedra Preta (basal) composta por rochas metavulcanoclásticas, calciossilicáticas, e formações ferríferas, sobreposta pela Formação Nhanguçu, composta por sedimentos clasto-químicos; a Formação Pirucaia formada por rochas essencialmente quartzíticas, corresponderia às fácies marginais da bacia, e seria cronocorrelata às outras duas.

Esta seqüência foi separada do Grupo São Roque principalmente por tratar-se de rochas que registram "durante o desenvolvimento da foliação $\mathrm{S}_{1}$ ", grau metamórfico predominantemente da fácies anfibolito médio, em contraposição ao Grupo São Roque (fácies xistos verdes). O contato erosivo entre os dois grupos seria atestado pela presença de clastos de fragmentos vulcânicos relacionados ao Grupo Serra do Itaberaba nos metaconglomerados da base do Grupo São Roque (Juliani 1993; Martin 2000). Juliani et al. (2000) apresentaram idade U-Pb em zircão de $1395 \pm 10$ Ma para 


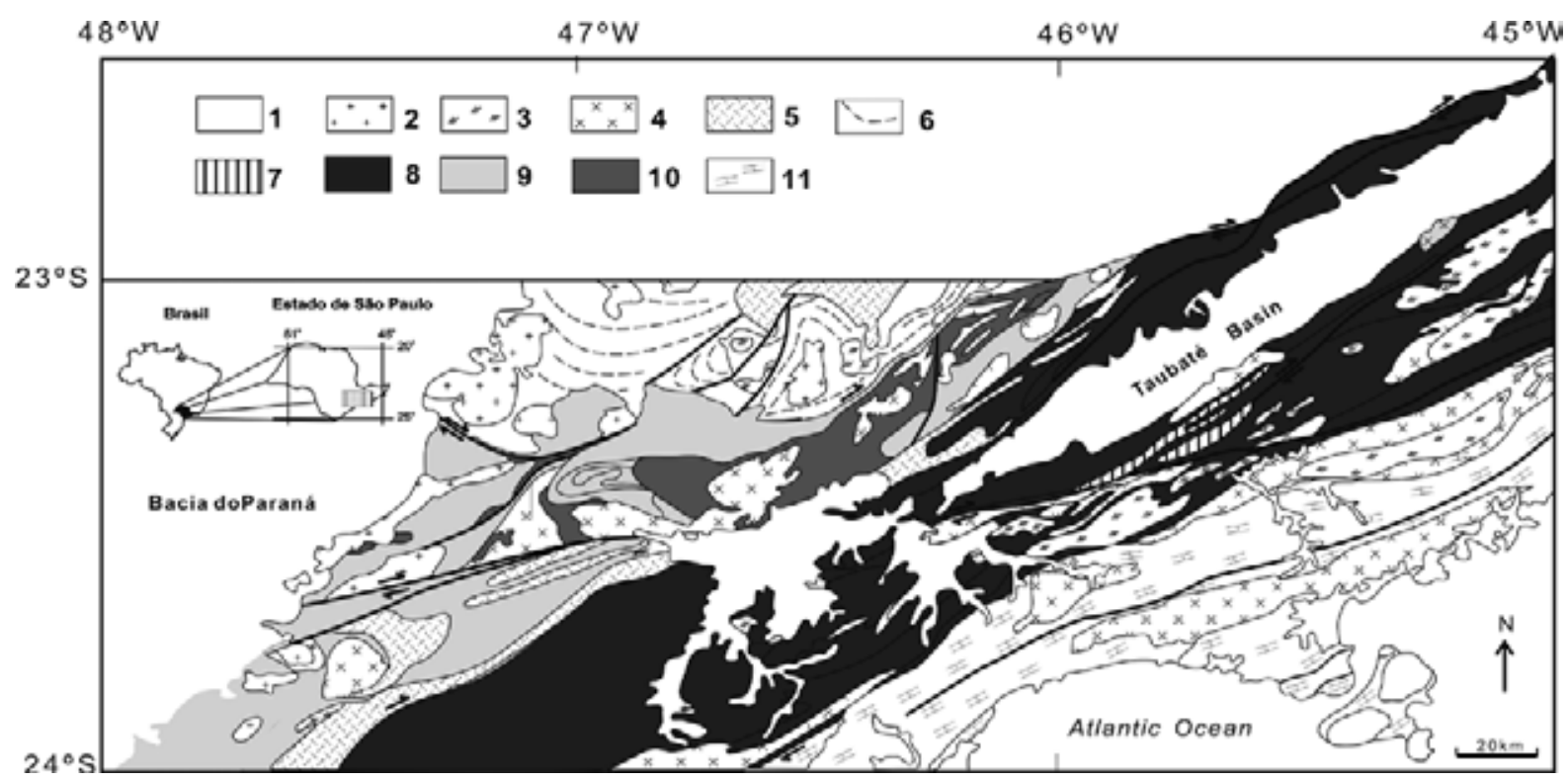

Figura 1 - Mapa Geotectônico modificado de Campos Neto (2000). 1- Coberturas fanerozóicas e rochas intrusivas; 2- Granitos tardi e pós-tectônicos; 3- (Granada)-(muscovita)-miotita granitos; 4Biotita granitos porfiriticos; 5- Hornblenda-biotita granitos porfiriticos; 6- Domínio Socorro- Guaxupé (predomínio de granada migmatitos); 7- Gnaisses paleoproterozóicos; 8-Domínio Embu (Complexos Pilar e Embu); 9- Grupo São Roque; 10- Grupo Serra do Itaberaba; 11- Complexo Costeiro.

meta-andesito da Formação Morro da Pedra Preta, posicionando a deposição do Grupo Serra do Itaberaba no Mesoproterozóico.

A zona de falhamento transcorrente de Jundiuvira foi caracterizada como uma descontinuidade limítrofe entre blocos, separando o "Bloco São Roque" do "Bloco Jundiaí", situado a norte (Hasui et al. 1969). As rochas da região da Serra do Japi foram incluídas por Wernick (1976) no Grupo Amparo, e divididas em membros pelíticos ("Formações Ermida") e psamo-pelíticos ("Formação Japi"), sem continuidade com as rochas do Grupo São Roque, o que também foi observado por Hasui et al. (1978). No entanto, Moraes (1944) e Campos Neto (2000), admitem que os metassedimentos da Serra do Japi constituam continuidade do Grupo São Roque a norte deste limite (Fig. 1).

O magmatismo granítico é intenso no Domínio Apiaí-São Roque, caracterizado por Campos Neto (2000) como um arco magmático desenvolvido na margem do cráton Paranapanema. É dominado por granitos cálcio-alcalinos potássicos neoproterozóicos, que constituem a massa principal de três extensos batólitos alongados na direção NE-SW (Cunhaporanga, Três Córregos e Agudos Grandes). Inúmeros plútons isolados, incluindo as principais intrusões no Domínio São Roque, devem constituir satélites dessas grandes massas graníticas, tendo em vista as semelhanças composicionais e de idade (Janasi \& Ulbrich 1991) (Fig. 1).

GEOLOGIA LOCAL A área de estudo concentrase nas ocorrências da Formação Morro Doce (Juliani 1999), considerada unidade basal do Grupo São Roque (Coutinho 1955); parte das rochas em estudo foi tam- bém posicionada como seqüência inferior (Cordani et al. 1961; Dantas 1990), e chamada de Formação Boturuna (Hasui 1973). Outras designações como "pacote superior" (Campos Neto et al. 1983), unidade "metapsamítica impura" (Carneiro 1983) ou "associação siliciclástica basal" (Fernandes da Silva 2004), também foram usadas para definir ocorrências similares, embora definidas em diferentes localidades.

Para a base do Grupo São Roque, Martin (2000) propõe correlação lateral entre as Formações Morro Doce (Juliani et al. 1999) e Pirapora (Bergmann 1988). Em contato transicional com metarcóseos e metaconglomerados da Formação Morro Doce, estariam representados os sedimentos da Formação Boturuna (Hasui 1973). A unidade de topo, composta predominantemente por sedimentos rítmicos, foi comparada por Martin (2000) à Formação Piragibu (Hasui 1973), e ao membro arenoso da Formação Estrada dos Romeiros (Bergmann 1988).

A maior área de ocorrência da Formação Morro Doce encontra-se a noroeste da cidade de São Paulo, na porção sudeste da Folha Santana do Parnaíba (IPT 1983). Esta Formação caracteriza-se por predomínio de metarcóseos que se interdigitam com espessas lentes de metaconglomerados polimíticos de seixos e calhaus estirados, sustentados por um arcabouço bem recristalizado. Nas regiões topograficamente mais elevadas, como o Pico do Jaraguá, ocorrem metarenitos e metarenitos feldspáticos. Pequenos corpos de rochas metavulcânicas encontram-se intercalados no pacote, como rochas metavulcânicas básicas (ex: pequenos corpos dentro da unidade de metarcóseos) e "metariodacitos" (da região do Morro do Polvilho).

O corpo anfibolítico do Jaraguá, com dimen- 
sões de aproximadamente 1,5 x 2,5 km (Gomes 1962), ocorre a oeste do Granito Cantareira, em aparente discordância em relação aos xistos e quartzitos. Pequenas manchas de metacalcários impuros circundam localmente a ocorrência.

Ocorrências de estaurolita xistos, que devem estar associadas ao Grupo Serra do Itaberaba encontram-se embutidas no pacote de metarcóseos, mas as relações de contato não puderam ser definidas em decorrência do intemperismo. No centro-norte da área de estudo (Fig. 2) aparecem expressivas ocorrências de rochas cálcio-silicatadas (Cordani 1963).

Entre os plútons graníticos neoproterozóicos que aparecem na área do mapa (Fig. 2) destacam-se os batólitos Itaqui e Cantareira que, segundo IPT (1983), são separados entre si por zonas miloníticas, e um pequeno plúton presente na região da Fazenda Ithayê, intrudindo a unidade de metarcóseos. Todas estas ocorrências apresentam características petrográficas similares (biotita granitos porfiríticos, em parte com hornblenda). Diferem destas ocorrências o Granito Tico-Tico, constituído por leucogranitos a duas micas, que é intrusivo no Grupo Serra do Itaberaba, e veios pegmatíticos que ocorrem ocasionalmente invadindo o pacote de metarcóseos.

Metaconglomerados Uma expressiva exposição de metaconglomerados da Formação Morro Doce encontra-se nas pistas sul e norte do Rodoanel Viário Metropolitano de São Paulo (km 9,5), na região do Morro Doce (Ponto MD-01) (Henrique-Pinto 2008). Outras ocorrências estudadas encontram-se na região da Fazenda Itahyê (Ponto MD-25) e Morro do Polvi-
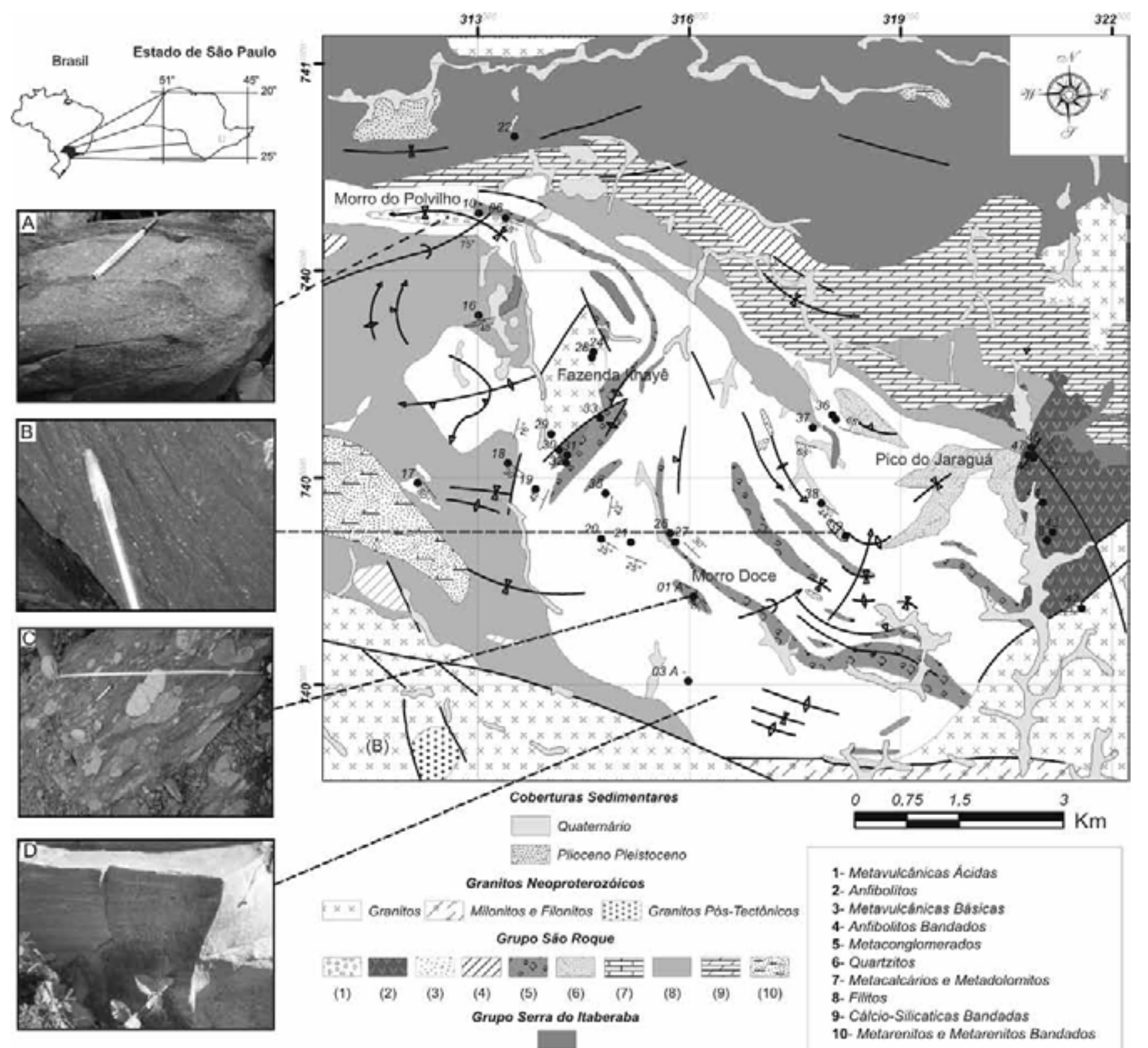

1- Metanulcánicas Acidas

2. Anfibolitos

3.- Metavulcanicas Bäsicas

4. Anfibolitos Bandados

5. Motaconglamerados

6. Quartzitos

7- Metacalcánios e Metadonomitos

8. Fintos

9. Cálcio-Sificatices Bandedes

10- Motarenifos a Metarenitos Bandados

Figura 2 - Mapa Geológico da Folha Santana de Parnaíba (SF-23-Y-C-III-3): Noroeste da cidade de São Paulo - modificado de IPT (1981): A-Metavulcânicas Ácidas; B-Metavulcânicas Básicas; C-Metaconglomerados; D-Metarcóseos. 
lho (Ponto MD-10) (Fig. 2).

Em todas essas exposições, os metaconglomerados caracterizam-se como polimíticos, com calhaus e seixos de dimensões variadas, a maioria com 10 a 20 $\mathrm{cm}$; os maiores podem alcançar até $50 \mathrm{~cm}$ para o eixo de elongação maior. Muitos dos clastos se tocam, porém entre eles sempre aparecem vestígios de arcabouço. São amoldados pela deformação, de modo que os contatos entre os seixos podem ser sinuosos. As características estruturais observadas assemelham-se às descritas por Coutinho $(1955,1968)$ em outras ocorrências desta unidade, nas quais a deformação não apaga por completo o acentuado arredondamento original dos clastos graníticos. Muitos, entretanto, também exibem forte deformação, manifestada por feições como interpenetração, elongamento assimétrico e fragmentação de material dentro do arcabouço (Fig. 2C). A exposição do Morro Doce mostra uma aparente orientação da petrotrama pretérita à deformação, indicativa de um possível imbricamento provocado por transporte em ambiente fluvial, porém não se descarta a possibilidade de se tratar de depósitos gerados por fluxo de massa (Turra et al. 2007).

Os metaconglomerados da região do Morro Doce registram efeitos hidrotermais de carbonatização e sulfetação ao longo de veios e microvenulações. Os veios de quartzo e calcita mais expressivos aparecem posicionados ortogonalmente à foliação principal, porém as ramificações são disseminadas por toda a exposição. A introdução de pirita secundária pode ser responsável pela redução nos valores de susceptibilidade magnética (SM) nos clastos graníticos $(\mathrm{K}=0,07-0,47 \mathrm{x}$ $10^{-3} \mathrm{SI}$ ), uma vez que os metaconglomerados da região da Fazenda Itahyê e do Morro do Polvilho, apesar da intensa deformação e da presença de pirita, mostramse menos afetados pelo hidrotermalismo, e seus clastos graníticos registram valores de SM significativamente mais altos $\left(\mathrm{K}=2,1-12,2 \times 10^{-3} \mathrm{SI}\right)$.

PETROGRAFIA DOS CLASTOS Embora os metaconglomerados da Formação Morro Doce sejam polimíticos, existe um amplo predomínio de clastos graníticos, que formam cerca de 80 a $90 \%$ do volume total, e apresentam características petrográficas similares em todas as exposições estudadas. Os demais litotipos encontrados correspondem a quartzitos e rochas metabásicas (Figs. 3E e F, respectivamente), que não foram estudados em maior detalhe neste trabalho.

Por apresentarem maior resistência à deformação, os clastos graníticos, principalmente aqueles de maior dimensão (acima de $20 \mathrm{~cm}$ ), ainda preservam estruturas reliquiares. Predominam amplamente biotita monzogranitos leucocráticos equigranulares e inequigranulares, de granulação média a grossa com baixo índice de cor $(\mathbf{I C}=3-5)$; embora muito restritas, foram também encontradas variedades porfiríticas com $\mathbf{I C}=6-7$. As diferenças texturais e petrográficas dos clastos graníticos permitiram a caracterização de quatro variedades:

-Biotita Monzogranito Porfiritico $\quad(I C=6-7)$ (Fig. 3A) apresenta textura porfiroclástica, com megacristais de microclínio rotacionados, com peque- nas inclusões de plagioclásio (andesina-oligoclásio), circundados por uma matriz fina composta por quartzo e feldspatos granoblásticos, muscovita e biotita associada a clorita nas bordas. O quartzo apresenta-se bem recristalizado, com contatos serrilhados, e entre os minerais acessórios mais comuns aparecem zircão, apatita, allanita, epidoto, titanita, minerais opacos e calcita.

-Monzogranito Inequigranular (IC= 3-5) (Fig. 3B) apresenta textura granular hipidiomórfica média a grossa (4-6 mm). O plagioclásio (andesina-oligoclásio) encontra-se intensamente sericitizado, com hábito parcialmente preservado e geminações deformadas. O quartzo é xenomórfico de contatos interlobados a serrilhados. Entre os minerais acessórios mais comuns aparecem titanita, allanita euédrica, apatita e zircão, este último definindo expressivos halos pleocróicos em cristais de biotita. Entre os minerais opacos predomina a pirita; calcita ocorre em microvenulações.

-Monzogranito Equigranular $(\mathbf{I C}=3-5)$ (Fig. 3C) apresenta textura granular hipidiomórfica média (3-4 mm). O plagioclásio (oligoclásio-andesina) está fortemente sericitizado, porém com geminações ainda visíveis. O quartzo é xenomórfico de contatos interlobados a serrilhados. É comum a associação entre mineral opaco e biotita com bordas substituídas por clorita. Os minerais acessórios mais comuns são minerais opacos euédricos, titanita e carbonatos subidiomórficos.

-Leucogranito Inequigranular $(\mathbf{I C}=2-3)$ (Fig. 3D) apresenta textura granular hipidiomórfica grossa (5-7 mm); apesar da intensa deformação, alguns aspectos da textura ígnea original ainda podem ser observados. Os cristais de plagioclásio (oligoclásio) muitas vezes estão inclusos em feldspato alcalino pertítico; já o quartzo encontra-se xenomórfico de contatos interlobados a serrilhados. É comum a associação mineral opaco-biotitaclorita-titanita; epidoto e calcita são euédricos e ocorrem em relações texturais que sugerem crescimento tardio.

Metarcóseos Os metarcóseos, rochas de maior expressão da Formação Morro Doce, abrigam as maiores ocorrências de metaconglomerados, com os quais ocorrem intercalados. Quando inalterados, os metarcóseos apresentam brilho "sedoso" e bandamento composicional (Fig. 2D); os valores de susceptibilidade magnética são baixos $\left(\mathrm{K} \leq 0,2 \times 10^{-3} \mathrm{SI}\right)$.

Os metarcóseos e metarenitos arcoseanos apresentam petrotrama sedimentar composta predominantemente por feldspatos detríticos sub-angulosos dispersos em uma matriz fina constituída essencialmente por muscovita, biotita, clorita e pequenas acumulações de quartzo. Entre os minerais acessórios mais comuns aparecem titanita, zircão, minerais opacos e calcita.

Rochas Metavulcânicas A maior manifestação do magmatismo básico da região estudada corresponde ao corpo anfibolítico do Jaraguá (Gomes 1962); estas ocorrências foram designadas anfibolitos metabasíticos por Carneiro (1983). Aparentemente discordante com relação ao pacote metapsmítico, com feições de mapa sugerindo um contato intrusivo de geometria oval (Fig. 2), o 

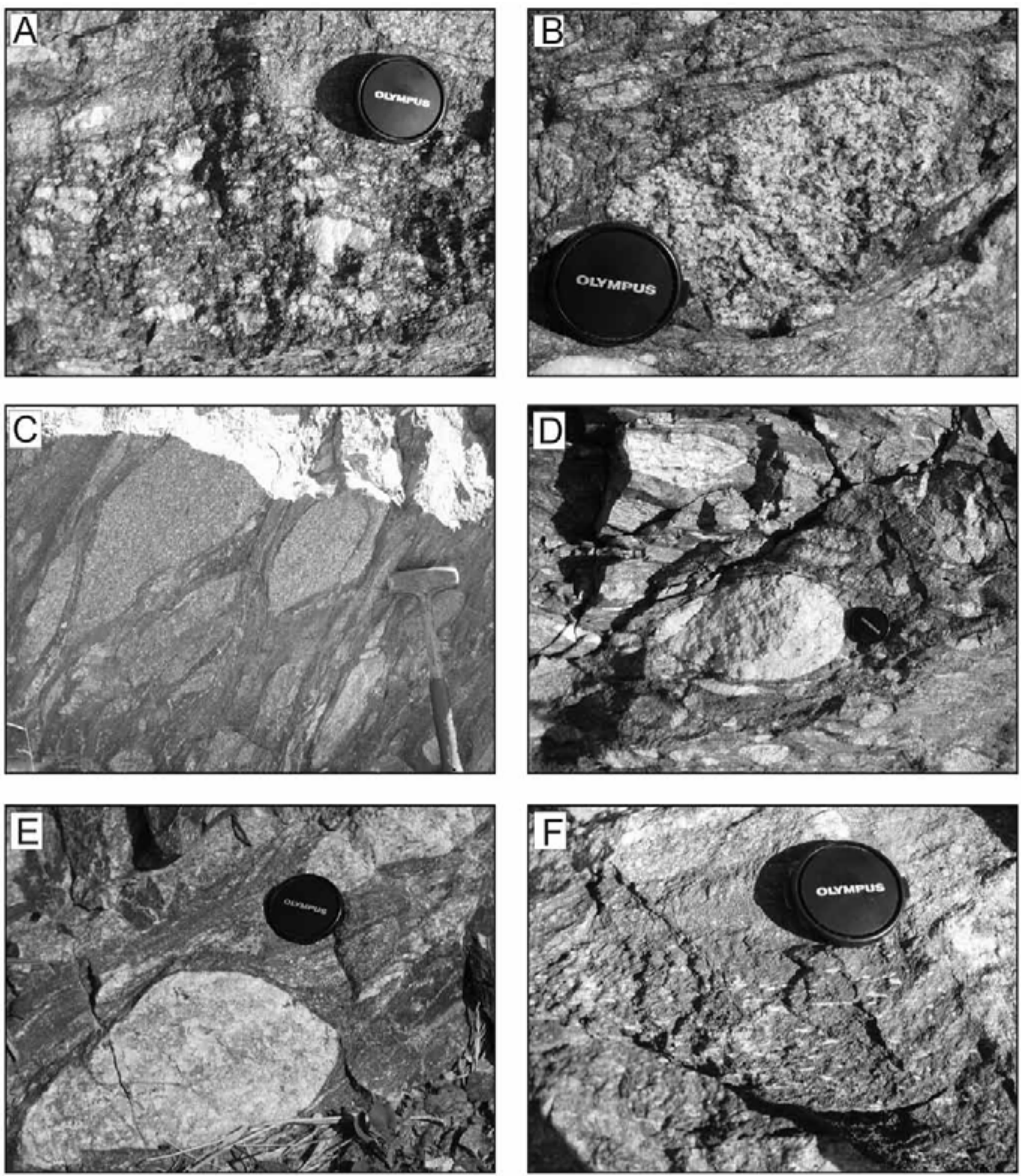

Figura 3 - Aspectos de campo dos diferentes litotipos de clastos dos metaconglomerados da Formação Morro Doce: A-Biotita Monzogranito Porfirítico; B- Monzogranito Inequigranular; C- Monzogranito Equigranular; D- Leucogranito Inequigranular; E- Quartzito; F- Rocha Metabásica.

corpo anfibolítico do Jaraguá (Ponto MD-43) tem foliação metamórfica incipiente, e apresenta mineralogia à base de hornblenda, plagioclásio, epidoto e titanita.

Na região do Morro do Polvilho ocorrem rochas metavulcânicas ácidas (Ponto MD-06 - Fig. 2A) que se intercalam com metarcóseos e metaconglome- rados, e foram designadas por Carneiro et al. (1984) como "meta-riodacitos". Com base na sua composição química (Le Bas et al. 1986), elas são reclassificadas neste trabalho como meta-traquidacitos e meta-riolitos porfiríticos (Fig. 4). Essas rochas têm fenocristais $(0,5$ - 1,0 cm) de plagioclásio sódico (oligoclásio) que ape- 
sar da deformação, responsável pela geração de sombras de pressão, ainda preservam as características de cristais magmáticos (e.g., caráter subidiomórfico).

A susceptibilidade magnética das rochas metavulcânicas ácidas alcança valores muito elevados $\left(\mathrm{K}=100 \times 10^{-3} \mathrm{SI}\right)$, refletindo a grande quantidade de magnetita; esses valores tendem a diminuir próximo ao contato com os metaconglomerados, mas mantém-se tipicamente muito elevados e contrastados com os dos metarcóseos (e.g., $\mathrm{K}=45 \times 10^{-3}$ SI - Ponto MD-10).

Rochas metavulcânicas básicas amigdaloidais ocorrem preferencialmente como pequenos corpos dentro da unidade de metarcóseos (Ponto MD-39). Estas podem ocorrer na forma de dique cortando a unidade metaconglomerática na região do Morro Doce (Fig. 2B - Ponto MD-01), onde a deformação e recristalização metamórfica apagaram por completo a textura original do protólito ígneo. Em outra ocorrência estudada (Ponto MD-39), são comuns amígdalas estiradas que variam de 0,5 a $3 \mathrm{~cm}$ em uma matriz fina composta por epidoto, biotita, quartzo e plagioclásio granoblásticos, e minerais opacos.

\section{GEOQUÍMICA DOS CLASTOS GRANÍTICOS, METARCÓSEOS E ROCHAS METAVULCÂNI-}

CAS Os seixos graníticos predominantes têm características metaluminosas a fracamente peraluminosas, são ricos em $\mathrm{SiO}_{2}(65-78 \%)$, e têm $\mathrm{mg} \#=25-35$. As razões $\mathrm{A} / \mathrm{CNK}$ originais devem ter sido em geral menores que 1 , como indicado pela presença característica de minerais acessórios cálcicos como titanita e allanita. Entretanto, o caráter metaluminoso de alguns seixos mais afetados por alteração hidrotermal foi exagerado pela introdução de calcita secundária.

Diagramas de variação usando sílica como índice de diferenciação mostram tendências lineares de correlação negativa com $\mathrm{Na}_{2} \mathrm{O}, \mathrm{MgO}, \mathrm{CaO}, \mathrm{Fe}_{2} \mathrm{O}_{3}$, $\mathrm{TiO}_{2}$ e $\mathrm{P}_{2} \mathrm{O}_{5}$, compatíveis com a evolução de uma suite comagmática. Observa-se uma correlação negativa entre mg\# e $\mathrm{SiO}_{2}$, de forma que os seixos de biotita monzogranito porfirítico com maior IC, representaria um membro mais primitivo da suíte (Fig. 5 - dados na tabela 1).

A maioria dos elementos traço, como $\mathrm{Ba}, \mathrm{Sr}, \mathrm{V}$, Zr e Ga, mostra tendência de diminuição a partir de seixos graníticos menos diferenciados. Outros, como $\mathrm{Ce}, \mathrm{Y}$ e Th, mostram variação distinta, onde os teores são mais baixos no granito porfirítico, atingem valores máximos nos seixos graníticos inequigranulares e equigranulares, e diminuem nos leucogranitos inequigranulares. (Fig. 6 - dados na tabela 1).

Os padrões de elementos de terras raras mostram pequeno aumento em ETR leves, como indicado pelo maior fracionamento $\left(\mathrm{La}_{\mathrm{N}} / \mathrm{Yb}_{\mathrm{N}}=23-43\right)$ nas variedades equi e inequigranulares em relação à variedade mais primitiva porfirítica $\left(\mathrm{La}_{\mathrm{N}} / \mathrm{Yb}_{\mathrm{N}}=17\right)$. Em contrapartida, o seixo de leucogranito apresenta padrão pouco fracionado, com forte enriquecimento em ETR pesados $\left(\mathrm{La}_{\mathrm{N}} / \mathrm{Yb}_{\mathrm{N}}=5\right)$, característico de rochas graníticas mui-

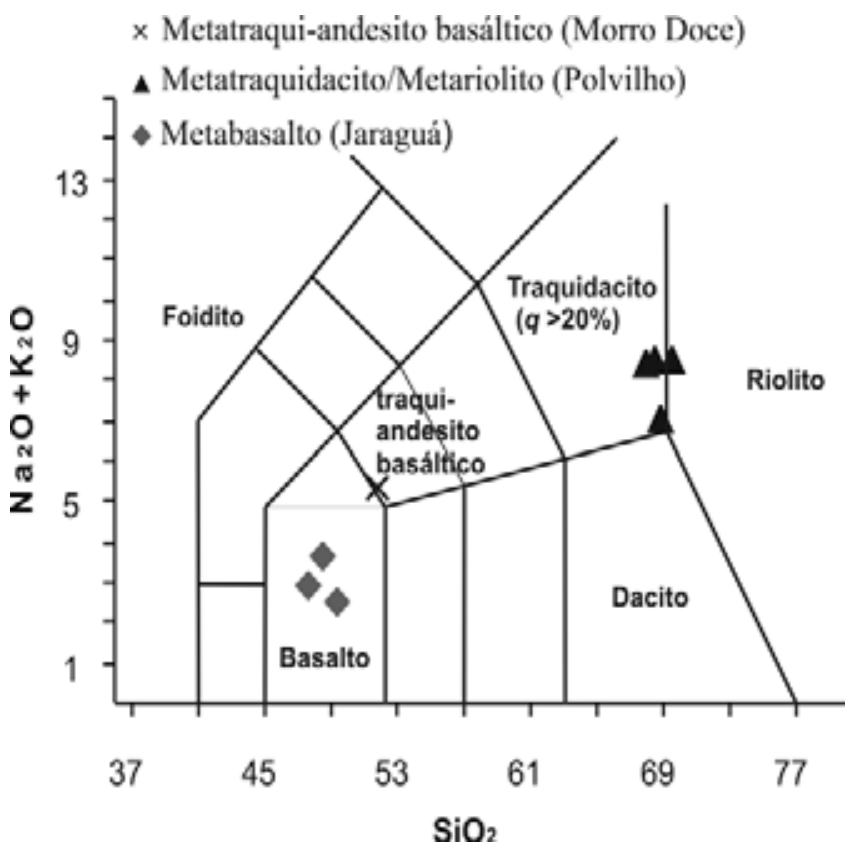

Figura 4 - Classificação química (Le Bas et al. 1986) das rochas metavulcânicas da Formação Morro Doce.

to diferenciadas. Todas as variedades apresentam leve anomalia negativa de $\mathrm{Eu}\left(\mathrm{Eu} / \mathrm{Eu}^{*}=0,46\right.$ e 0,64$)$, com exceção das amostras de monzogranito inequigranular $(\mathrm{MD}-25 \mathrm{~A})$ e leucogranito inequigranular coletadas na região da Fazenda Ithayê (Fig. 7A - dados na tabela 3).

O padrão de elementos terras-raras do metarcóseo é, em linhas gerais, semelhante à média dos clastos, com razão $\mathrm{La}_{\mathrm{N}} / \mathrm{Yb}_{\mathrm{N}}=12$, mas apresenta anomalia negativa de Eu pouco expressiva $\left(\mathrm{Eu} / \mathrm{Eu}^{*}=0,82\right)$, o que sugere a contribuição de fontes adicionais. Fontes ígneas de caráter máfico parecem ter tido um papel importante durante a sedimentação dos metarcóseos, como mostram as razões $\mathrm{Cr} / \mathrm{Th}, \mathrm{Ti} / \mathrm{Zr}$ e Co/Th (Fig. 7B), mas a assinatura de ETR do clasto de rocha metabásica analisado não poderia responder pelo comportamento do $\mathrm{Eu}$, pois tem anomalia fortemente negativa $\left(\mathrm{Eu} / \mathrm{Eu}^{*}=0,48\right)$.

Os meta-traquidacitos e metariolitos, quando comparados aos metarcóseos, formam um grupo quimicamente coeso (e.g., intervalo de $\mathrm{SiO}_{2}$ entre 67 e $68 \%$, enquanto nos metarcóseos este intervalo é de 69 e $76 \%$ ). Altos teores de $\mathrm{Fe}_{2} \mathrm{O}_{3}(7-5 \%)$, baixo $\mathrm{P}_{2} \mathrm{O}_{5}(0,08-$ $0,13 \%)$ e $\mathrm{mg} \#=(19-23)$ também diferenciam as rochas metavulcânicas ácidas dos metarcóseos, que acompanham o espalhamento dos clastos de granito dos metaconglomerados. São menores também os valores de perda ao fogo nas rochas metavulcânicas ácidas (Fig. 5 - dados na tabela 2).

As rochas metavulcânicas básicas amigdaloidais (meta-traquiandesitos basálticos) que ocorrem intercaladas no pacote metarcoseano diferem petrograficamente dos anfibolitos regionais (ex: corpo anfibolítico do Jaraguá). Estas diferenças são confirmadas pela geoquímica, que mostra teores mais ele- 

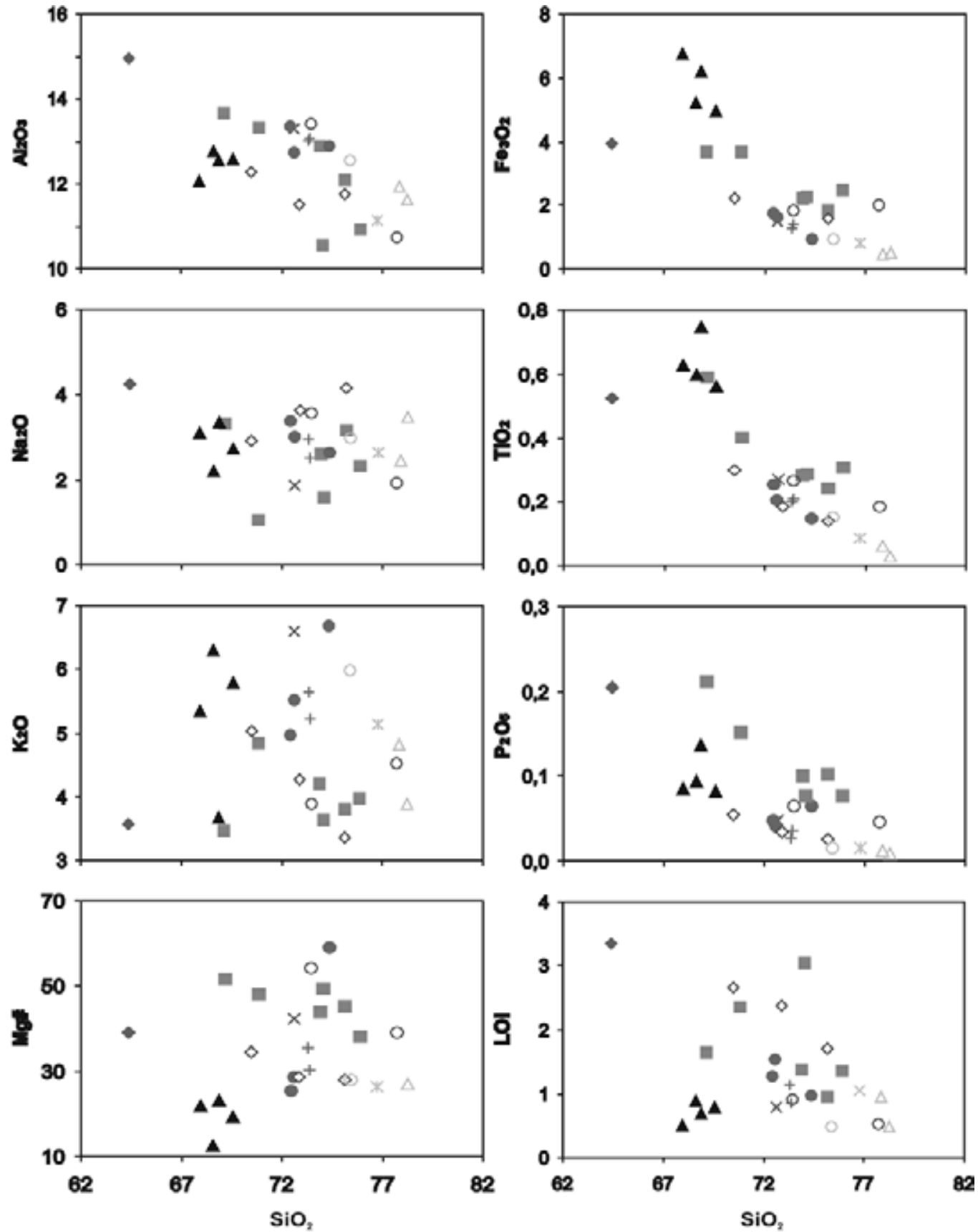

o Seixe de Monzogranito Inequigranular (Morro Doce) $\times$ Seixe de Monzogranito Inequigranular (Morro do Polvilho) - Seixo de Monzogranito Equigranular (Morro Doce) + Seixo de Monzogranito Equigranular (Morro do Polvilho)

K Seixo de Leucogranito Inequigranular (Morro Doce) $\Delta$ Seixo de Leucogranito Inequigranular (Morro do Polvilho)

- Seixo de Monzogranito Porfiritico (Morro Doce) o Seiso de Monzogranito Inequigranular (Fazenda Ithayê)

n Metarcoseo A Metatraquidacito/Metariolito o Seixo de Leucogranito Inequigranular (Fazenda Ithayê)

Figura 5 - Diagramas de variação (elementos maiores) para rochas da Formação Morro Doce utilizando $\mathrm{SiO}_{2}$ como índice de diferenciação.

vados de $\mathrm{P}_{2} \mathrm{O}_{5}, \mathrm{TiO}_{2}, \mathrm{~K}_{2} \mathrm{O}, \mathrm{Ba}, \mathrm{Sr}, \mathrm{Zn}, \mathrm{Ce}$ e $\mathrm{Y}$ com relação aos anfibolitos, que por sua vez apresentam mais alto $\mathrm{CaO}$. (Fig. 8 - dados na tabela 2).

A assinatura das rochas metavulcânicas ácidas é típica de magmatismo intraplaca (Fig. 10), com destaque para o baixo mg\#, altos teores de HFSE (em especial $\mathrm{Zr}$ e Hf), e altos teores de LILE (Rb, Ba, Th e U), contrastados com baixo $\mathrm{Sr}$ (70-120 ppm), além de baixas razões $\mathrm{Cr} / \mathrm{Th}$ e Al/Ti (Figs. 9A, B, C, D). Tais características as aproximam das metavulcânicas ácidas Rio dos Remédios que ocorrem na base do Supergrupo Espinhaço, Chapada Diamantina (McReath et al. 1981).

A amostra de meta-traquiandesito basáltico (Ponto MD-39, Fig. 4) com elevados teores de $\mathrm{K}_{2} \mathrm{O}$ e outros elementos litófilos, tem teores relativamente altos de LILE (Rb, Ba e U), HFSE ( $\mathrm{Zr}$ e $\mathrm{Nb}$ ), e altas razões $\mathrm{La} / \mathrm{Sc}, \mathrm{Zr} / \mathrm{Y}$. Estas características, somadas ao padrão mais fracionado, com enriqueci- 

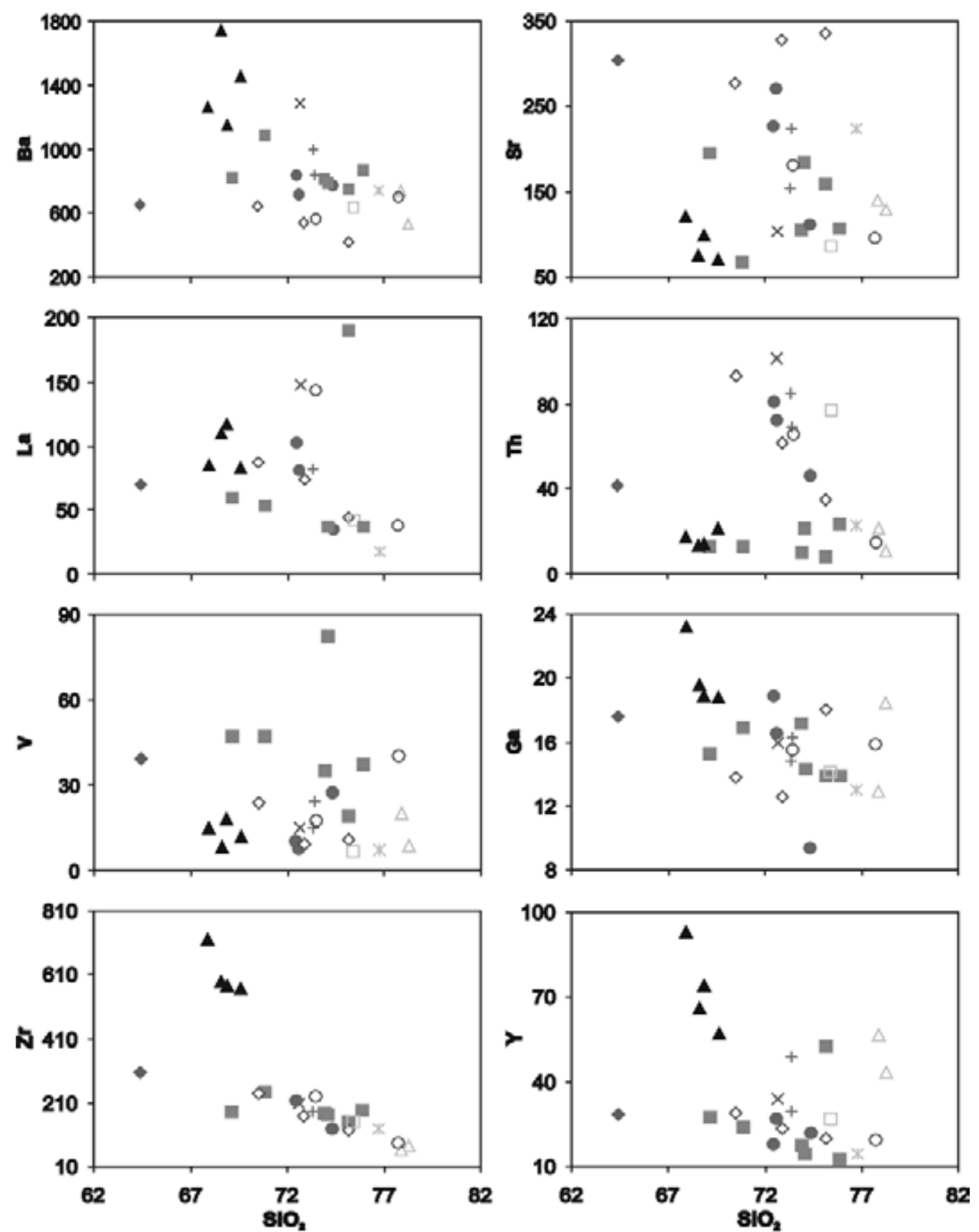

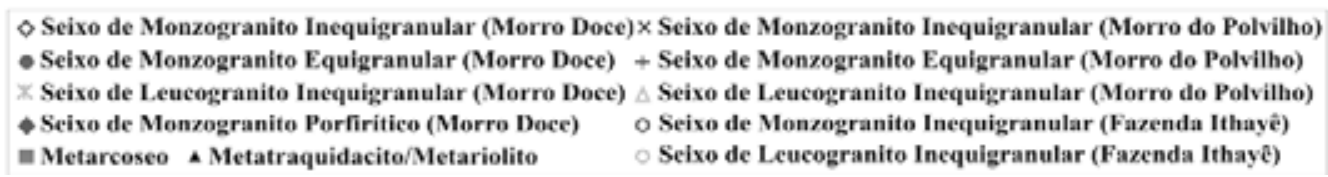

Figura 6 - Diagramas de variação (elementos traços) para rochas da Formação Morro Doce utilizando $\mathrm{SiO}_{2}$ como índice de diferenciação.

mento equivalente em ETR leves $\left(\mathrm{La}_{\mathrm{N}} / \mathrm{Yb}_{\mathrm{N}}=13\right)$, e anomalia negativa de $\mathrm{Eu}\left(\mathrm{Eu} / \mathrm{Eu}^{*}=0,74\right.$ nas metavulcânicas básicas e 0,59 nas ácidas), sugerem um magmatismo intraplaca de caráter bimodal para o vulcanismo associado à Formação Morro Doce.

Os anfibolitos do Jaraguá apresentam padrão de ETR pouco fracionado, com razão $\mathrm{La}_{\mathrm{N}} / \mathrm{Yb}_{\mathrm{N}}=1,6$ e $\mathrm{Eu} / \mathrm{Eu}^{*}=1,0$ (Fig. $9 \mathrm{C}$ - dados na tabela 3 ) e características geoquímicas de basaltos toleíticos, quando comparados aos dados de Irvine \& Baragar (1971) (Fig. 11C), mais próximas de magmatismo de fundo oceânico tipo MORB quando comparados aos dados de Pearce \& Cann (1973); Pearce \& Norry (1979); Vermeesh (2006) (Figs.11 A, B, D), com baixas concentrações de elementos incompatíveis como $\mathrm{Rb}, \mathrm{Nb}$ e Th. Nesse sentido, embora de idade ainda desconhecida, mostram semelhanças com as rochas metabásicas supracrustais (com estruturas tipo "pillow lava") 


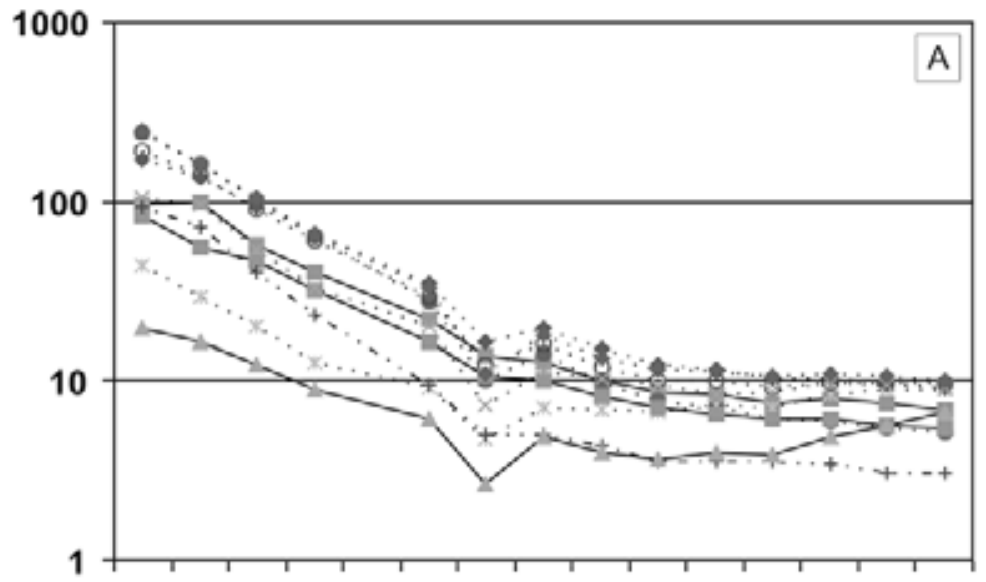

La Ce Pr Nd Sm Eu Gd Tb Dy Ho Er Tm Yb Lu

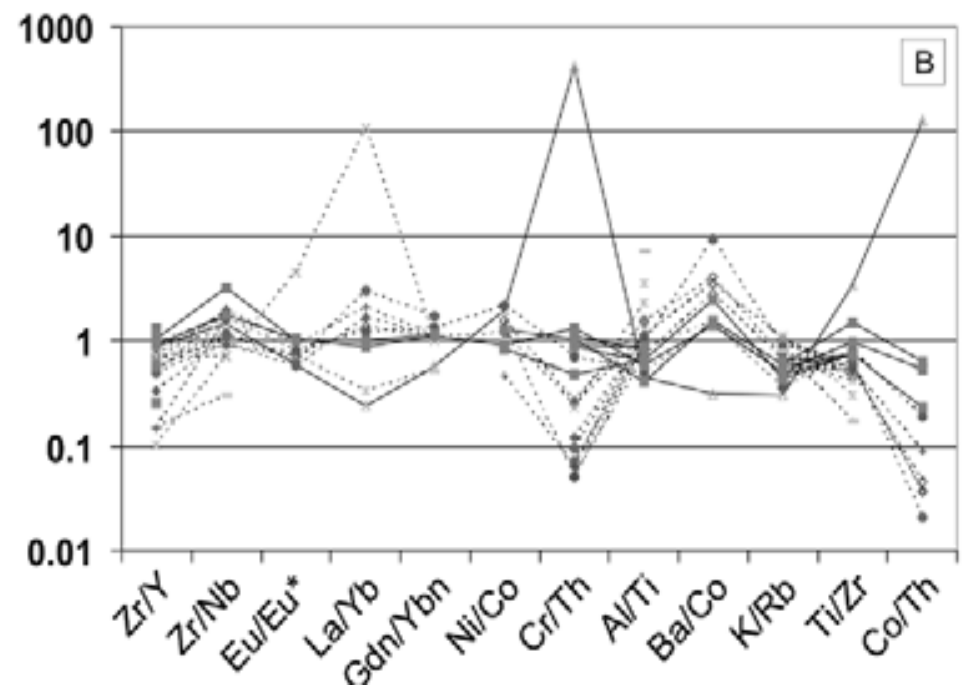

..... Clasto de monzogranito equigranular - Região do Morro do Polvilho Clasto de leucogranito inequigranular - Região do Morro do Polvilho

-.. Clasto de monzogranito inequigranular - Região do Morro do Polvilho

..+*. Clasto de monzogranito inequigranular - Região da Fazenda Ithayê

Clasto de leucogranito inequigranular - Região da Fazenda Ithayê

—_ Clasto de rocha metabásica - Região do Morro Doce

..... Clasto de monzogranito inequigranular - Região do Morro Doce

-.. Clasto de monzogranito equigranular - Região do Morro Doce

Clasto de leucogranito inequigranular - Região do Morro Doce

- Clasto de biotita monzogranito porfírítico - Região do Morro Doce

- - Metarcóseos da Formação Morro Doce

Figura 7 - (A) Padrões de elementos terras raras de clastos dos metaconglomerados e metarcóseos da Formação Morro Doce normalizados para o condrito (Taylor \& MacLennan 1985); (B) razões de clastos dos metaconglomerados e metarcóseos da Formação Morro Doce normalizadas pela média da crosta (Wedepohl 1995). 

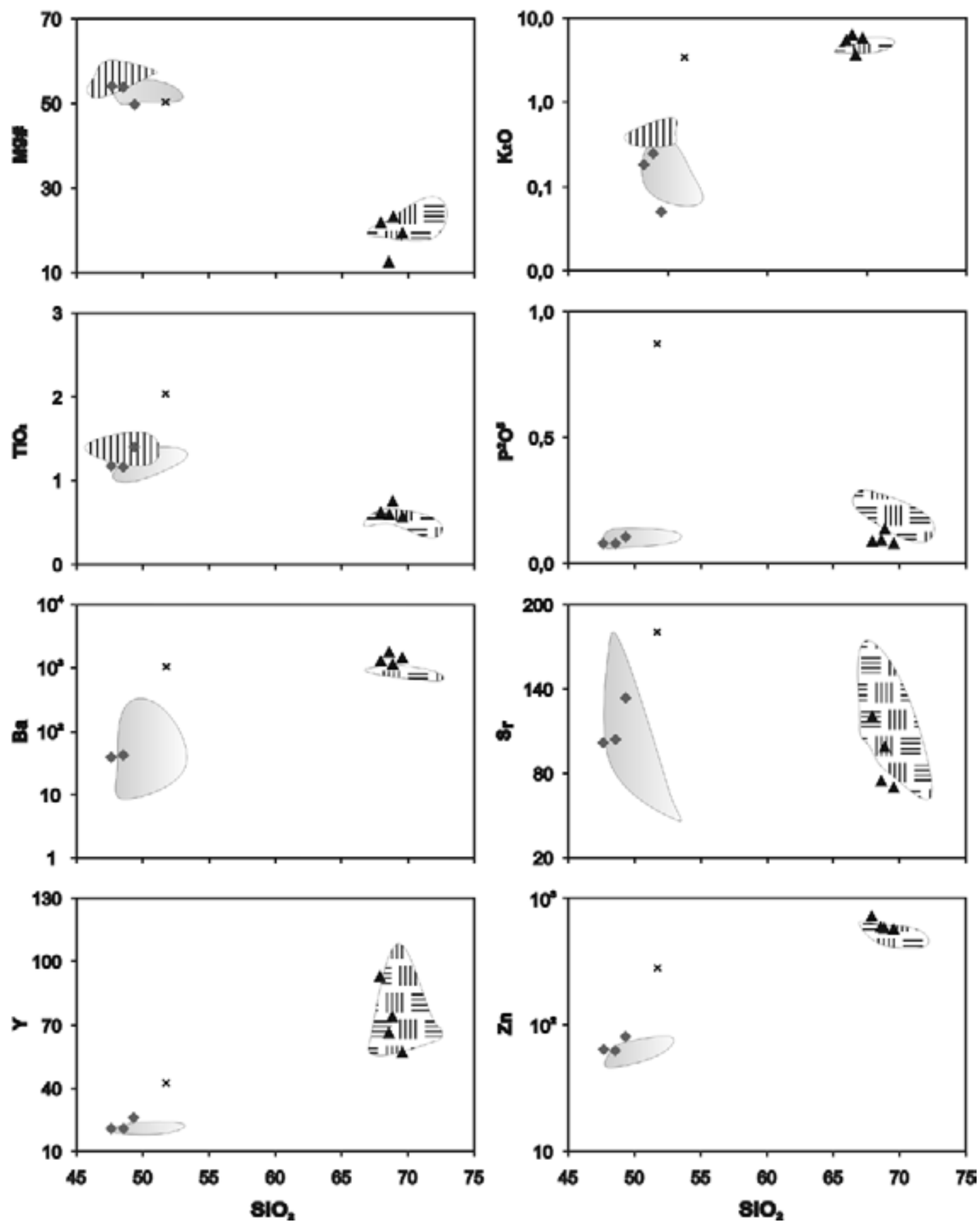

\footnotetext{
-11 Metavulcånicas Ácidas - Chapada Diamantina, Bahia (McReath, 1981) \ Metabasalto (Jaraguá)

Metabásicas - Pirapora, SP (Tassinari, 2001)

ム Metatraquidacito/Metariolito (Polvilho)

III Metabásicas - Pirapora, SP (Lazzari, 1987)

$\times$ Metatraqui-andesito basáltico (Morro Doce)
}

Figura 8 - Diagramas de variação utilizando $\mathrm{SiO}_{2}$ como índice de diferenciação comparando as rochas metavulcânicas com ocorrências estudadas por Lazzari (1987) e Tassinari et al. (2001).

da região de Pirapora do Bom Jesus (Lazzari 1987; Tassinari et al. 2001).

CONCLUSÕES $\mathrm{O}$ estudo petrográfico dos clastos graníticos do metaconglomerado do Grupo São Roque permitiu a identificação de quatro variedades petrográ- ficas: biotita monzogranito porfiritico, monzogranito inequigranular, monzogranito equigranular e leucogranito inequigranular. O caráter comagmático entre os clastos é sugerido pelo alinhamento em uma mesma tendência, com diminuição nos teores de $\mathrm{Na}_{2} \mathrm{O}, \mathrm{MgO}$, $\mathrm{CaO}, \mathrm{Fe}_{2} \mathrm{O}_{3}, \mathrm{TiO}_{2}$ e $\mathrm{P}_{2} \mathrm{O}_{5}$ com o aumento da sílica, refle- 

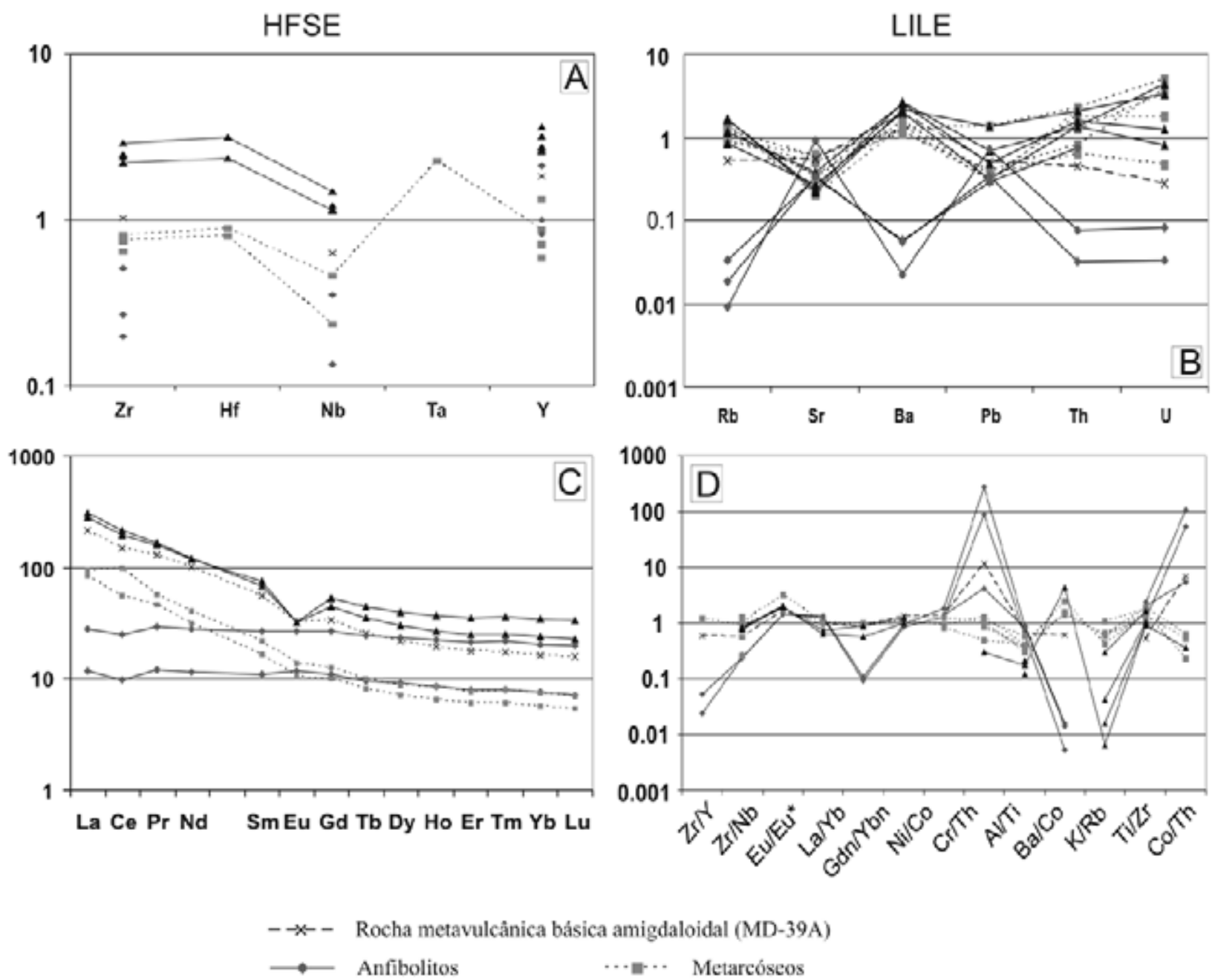

$\longrightarrow$ Metavulcânicas ácidas

Figura 9 - Comparação geoquímica entre rochas metavulcânicas e metarcóseos da Formação Morro Doce. (A)- HFSE normalizados pela média da crosta (Wedepohl 1995); (B) LILE normalizados pela média da crosta (Wedepohl 1995); (C) ETR normalizados por valores condríticos (Taylor \& MacLennan 1985); (D) razões normalizadas pela média da crosta (Wedepohl 1995).

tindo a tendência normal de diferenciação em magmas graníticos. Existe uma correlação negativa entre mg\# e $\mathrm{SiO}_{2}$, de forma que quanto mais félsico é o seixo (leucogranito inequigranular), menor é o mg\#. Portanto, a variedade biotita monzogranito porfirítico com maior IC representaria um membro mais primitivo com relação à evolução magmática dos magmas parentais.

De características metaluminosas a fracamente peraluminosas, os seixos graníticos predominantes são ricos em $\mathrm{SiO}_{2}(65-78 \%)$, e têm $\mathrm{mg} \#=25-35$. As razões $\mathrm{A} / \mathrm{CNK}$ originais devem ter sido em geral menores que 1, como indicado pela presença característica de minerais acessórios cálcicos como titanita e allanita. Entretanto, o caráter metaluminoso de alguns seixos mais afetados por alteração hidrotermal foi exagerado pela introdução de calcita secundária.

Os metarcóseos diferenciam-se das rochas metavulcânicas ácidas por apresentarem petrotrama sedimentar composta predominantemente por feldspatos detríticos sub-angulosos e geoquímica que acompanha o espalhamento dos clastos dos metaconglomerados aos quais estão associados. São diferentes também os valores de susceptibilidade magnética, notavelmente mais elevados nas metavulcânicas ácidas $\left(\mathrm{K}=40-100 \times 10^{-3}\right.$ SI), quando comparados aos metarcóseos $\left(0,2 \times 10^{-3}\right.$ SI). Portanto, conclui-se que a idade U-Pb em zircão de $1790 \pm 14$ Ma obtida por van Schumus et al. (1986) representa a idade de cristalização das rochas metavulcânicas ácidas, e não a idade da área fonte do Grupo São Roque, como proposto por Juliani et al. (1997).

Os meta-traquidacitos e meta-riolitos apresentam geoquímica típica de magmatismo intraplaca (Pearce et al. 1979), em especial baixo mg\#, altos teores de HFSE, em especial Zr, Hf, e altos teores de LILE (Rb, $\mathrm{Ba}$, Th e U), além do baixo $\mathrm{Sr}$ (70-120 ppm), e de baixas razões $\mathrm{Cr} / \mathrm{Th}$ e $\mathrm{Al} / \mathrm{Ti}$. É interessante notar que essas feições são similares às das rochas metavulcânicas ácidas Rio dos Remédios, que ocorrem na base do Supergrupo 

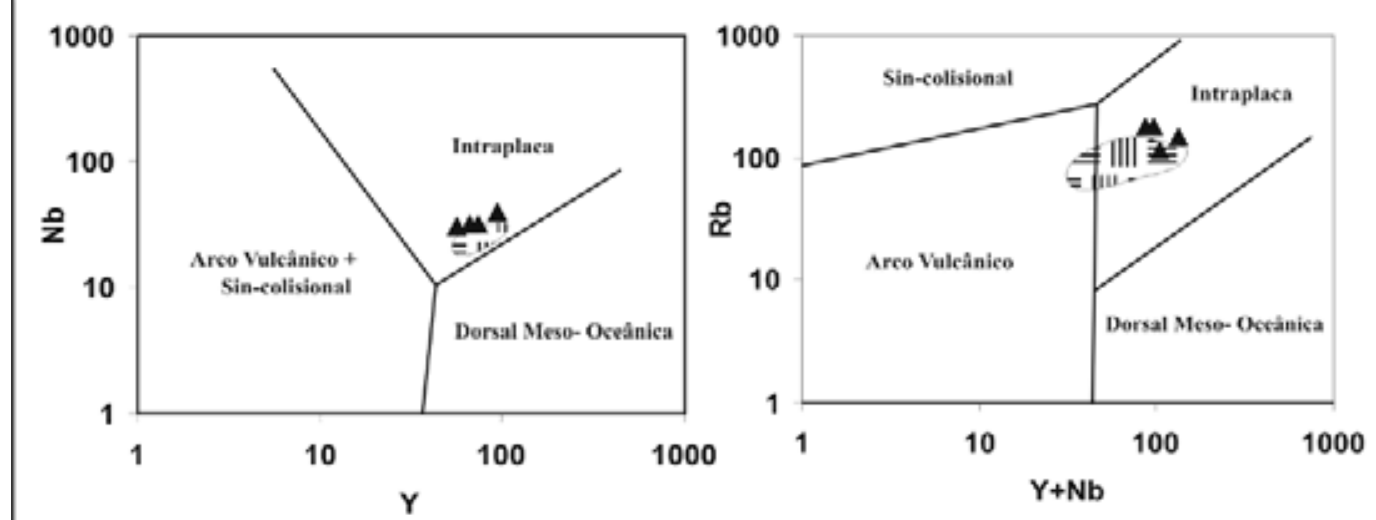

=11 Metavulcanicas Ácidas - Chapada Diamantina, Bahia (McReath et al., 1981)

A Meta-traquidacito/Metariolito (Morro do Polvilho)

Figura 10 - Diagrama $(N b \times Y)$ e (Rb $\times Y+N b)$ (Pearce et al. 1984) para rochas metavulcânicas ácidas da região do Morro do Polvilho.
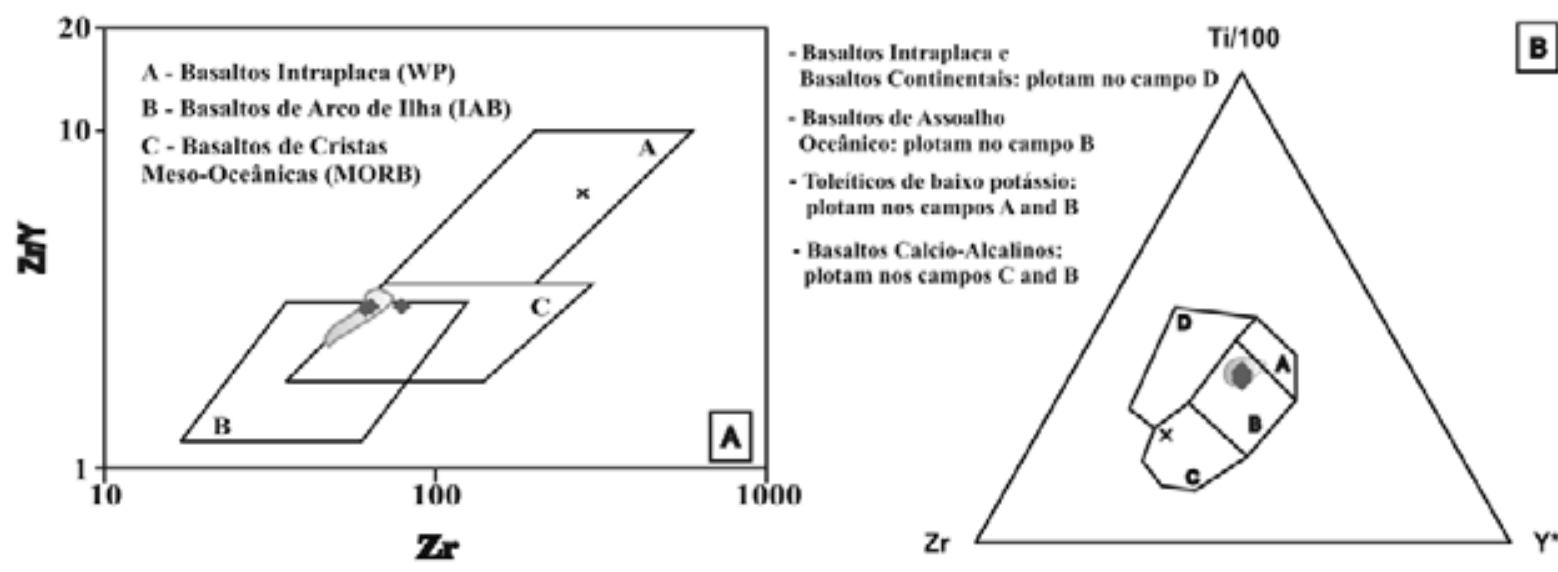

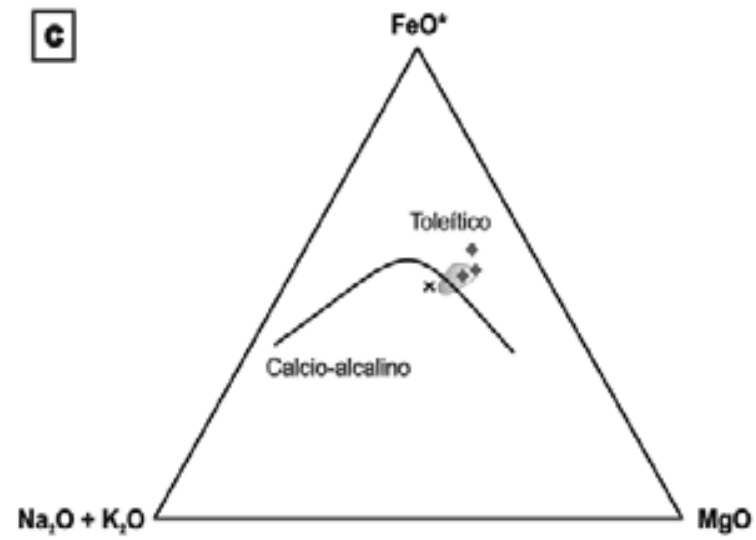

Metabasicas - Piarapora, SP (Tassinari, 2001)

$\times$ Metatraqui-andesito basáltico (Morro Doce)

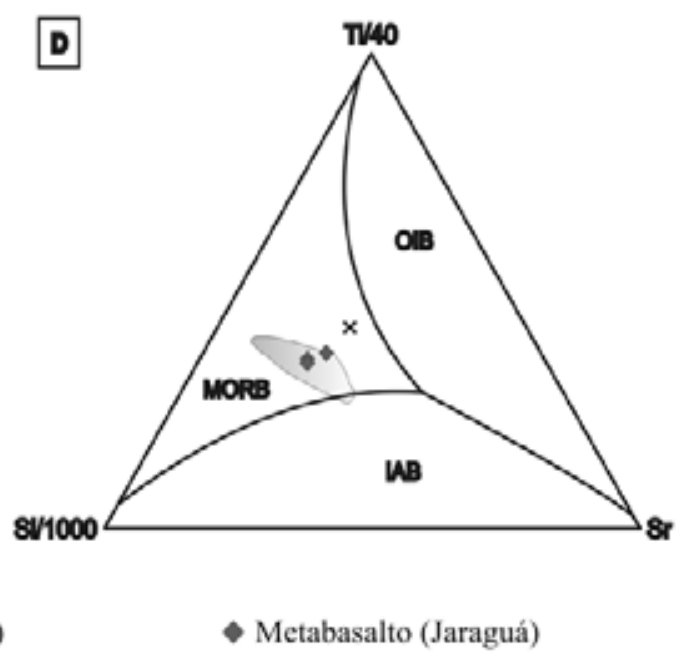

ム Metatraquidacito/Metariolito (Polvilho)

Figura 11 - Diagramas de discriminação tectônica para rochas metavulcânicas da região do Pico do Jaraguá e Morro Doce. A - Diagrama (Zr/Y x Zr) (Pearce \& Norry 1979); B - Diagrama (Ti/100 $\left.x \operatorname{Zr} \times Y^{*} 3\right)$ (Pearce \& Cann 1973); C - Diagrama AFM (Irvine \& Baragar 1971); D Diagrama (Ti/40 x Sr x Si/1000) (Vermeesh 2006). 
Tabela 1 - Análises químicas de seixos graníticos da Formação Morro Doce obtidas por FRX. smp = biotita monzogranito porfirítico; smi = monzogranito inequigranular; sme = monzogranito equigranular; sli = leucogranito inequigranular.

\begin{tabular}{|c|c|c|c|c|c|c|c|c|c|c|c|c|c|c|c|c|}
\hline & $\begin{array}{c}\text { MD } \\
01 \mathrm{~N} \\
\end{array}$ & $\begin{array}{l}\text { MD } \\
01 \mathrm{E}\end{array}$ & $\begin{array}{l}\mathrm{MD} \\
01 \mathrm{~F}\end{array}$ & $\begin{array}{l}\text { MD } \\
01 \text { I }\end{array}$ & $\begin{array}{c}\text { MD- } \\
25 \mathrm{a} \\
\end{array}$ & $\begin{array}{c}\text { MD- } \\
34 a \\
\end{array}$ & $\begin{array}{l}\text { MD- } \\
07 \mathrm{~A} \\
\end{array}$ & $\begin{array}{c}\text { MD } \\
01 \mathrm{C}\end{array}$ & $\begin{array}{c}\text { MD } \\
01 \mathrm{H}\end{array}$ & $\begin{array}{l}\text { MD } \\
03 B \\
\end{array}$ & $\begin{array}{l}\text { MD- } \\
11 \mathrm{~B}\end{array}$ & $\begin{array}{l}\text { MD- } \\
10 \mathrm{~B}\end{array}$ & $\begin{array}{c}\text { MD- } \\
26 \mathrm{a}\end{array}$ & $\begin{array}{l}\text { MD } \\
01 \mathrm{D} \\
\end{array}$ & $\begin{array}{l}\text { MD- } \\
10 \mathrm{~A} \\
\end{array}$ & $\begin{array}{l}\text { MD- } \\
11 \mathrm{~A}\end{array}$ \\
\hline & $s m p$ & smi & smi & smi & smi & smi & smi & sme & sme & sme & sme & sme & sli & sli & sli & sli \\
\hline $\mathrm{SiO}_{2}$ & 64.40 & 72.87 & 75.16 & 70.49 & 77.71 & 73.46 & 72.58 & 72.45 & 72.60 & 74.35 & 73.20 & 73.33 & 75.40 & 76.76 & 78.26 & 77.87 \\
\hline $\mathrm{Al}_{2} \mathrm{O}_{3}$ & $\begin{array}{l}14.95 \\
\end{array}$ & 1.50 & 11.74 & 12.28 & 10.73 & 13.41 & 13.29 & 13.36 & 12.73 & 12.89 & 13.00 & 13.01 & 12.56 & 11.13 & 11.63 & 11.93 \\
\hline $\mathrm{MnO}$ & $\begin{array}{l}0.067 \\
\end{array}$ & 0.044 & 0.036 & 0.048 & 0.019 & 0.024 & 0.027 & 0.025 & 0.028 & 0.018 & 0.022 & 0.023 & 0.010 & 0.024 & 0.014 & 0.012 \\
\hline $\mathrm{MgO}$ & 1.28 & .29 & 0.31 & 0.60 & 0.65 & 1.09 & 0.55 & 0.30 & 0.33 & 0.68 & 0.29 & 0.36 & 0.18 & 0.15 & 0.10 & 0.59 \\
\hline $\mathrm{CaO}$ & 3.58 & 77 & 73 & 2.83 & 0.80 & 0.48 & 1.72 & 1.03 & 1.12 & $\begin{array}{l}0.59 \\
\end{array}$ & 2.03 & 1.34 & 0.38 & 0.84 & 0.87 & 1.59 \\
\hline $\mathrm{Na}_{2} \mathrm{O}$ & 4.25 & 3.64 & 4.16 & 2.93 & 1.93 & 3.56 & 1.88 & 3.38 & 3.02 & 2.63 & 2.48 & 2.95 & 3.00 & 2.64 & 3.47 & 2.45 \\
\hline $\mathrm{K}_{2} \mathrm{O}$ & 3.57 & 4.27 & 3.35 & 5.03 & 4.52 & 3.88 & 6.59 & 4.97 & 5.52 & 6.68 & 5.23 & 5.65 & 5.99 & 5.14 & 3.89 & 4.81 \\
\hline $\mathrm{TiO}_{2}$ & 0.525 & 0.185 & 0.140 & 0.299 & 0.184 & 0.268 & 0.270 & 0.256 & 0.207 & 0.147 & 0.217 & 0.200 & 0.150 & 0.087 & 0.029 & 0.060 \\
\hline $\mathrm{P}_{2} \mathrm{O}_{5}$ & 0.204 & 0.034 & 0.025 & 0.054 & 0.046 & 0.064 & 0.048 & 0.048 & 0.041 & 0.064 & 0.032 & 0.027 & 0.016 & 0.015 & 0.005 & 0.012 \\
\hline $\mathrm{Fe}_{2} \mathrm{O}_{3}$ & 3.95 & 1.42 & 1.57 & 2.24 & 2.01 & 1.82 & 1.48 & 1.75 & 1.62 & 0.94 & 1.41 & 1.29 & 0.92 & 0.83 & 0.53 & 0.46 \\
\hline P.F. & 3.35 & 2.38 & 1.70 & 2.66 & 0.53 & 0.92 & 0.79 & 1.27 & 1.55 & 0.98 & 0.86 & 1.14 & 0.48 & 1.06 & 0.48 & 0.96 \\
\hline Total & 100.13 & 99.40 & 99.92 & 99.46 & 99.13 & 98.98 & 99.23 & 98.84 & 98.77 & 99.97 & 98.77 & 99.32 & 99.09 & 98.68 & 99.28 & 100.74 \\
\hline $\mathrm{Ba}$ & 647 & 539 & 416 & 645 & 701 & 565 & 1286 & 833 & 711 & 769 & 827 & 993 & 636 & 738 & 528 & 735 \\
\hline $\mathrm{Ce}$ & 123 & 118 & 66 & 157 & 61 & 62 & 139 & 172 & 144 & $<35$ & 87 & 102 & 76 & 32 & $<35$ & $<35$ \\
\hline $\mathrm{Cr}$ & 83 & 51 & 32 & 16 & $<13$ & 15 & 18 & 17 & 23 & $<13$ & 30 & 20 & $<13$ & 24 & $<13$ & $<13$ \\
\hline $\mathrm{Cu}$ & 29 & 41 & 32 & 20 & 7 & 19 & 35 & 45 & 38 & 40 & 17 & 104 & 7 & 44 & 34 & 5 \\
\hline $\mathrm{Ga}$ & 18 & 13 & 18 & 14 & 16 & 16 & 16 & 19 & 17 & 9 & 17 & 15 & 14 & 13 & 19 & 13 \\
\hline $\mathrm{La}$ & 69 & 74 & 45 & 87 & 38 & 144 & 148 & 102 & 81 & 35 & 71 & 82 & 43 & 18 & $<28$ & $<28$ \\
\hline $\mathrm{Nb}$ & 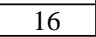 & 15 & 13 & 14 & $<9$ & 16 & $<9$ & 20 & 19 & 8 & 18 & 17 & 24 & 14 & 27 & 10 \\
\hline $\mathrm{Nd}$ & 48 & 43 & 34 & 34 & $<14$ & 59 & 60 & 63 & 41 & $<14$ & 36 & 42 & 21 & 25 & $<14$ & 26 \\
\hline $\mathrm{Ni}$ & 26 & 5 & 5 & 9 & $<5$ & 5 & $<5$ & $<5$ & $<5$ & 5 & $<5$ & $<5$ & $<5$ & $<5$ & $<5$ & $<5$ \\
\hline $\mathrm{Pb}$ & 31 & 40 & 14 & 21 & 33 & 20 & 19 & 26 & 20 & 40 & 30 & 29 & 22 & 24 & 21 & 26 \\
\hline $\mathrm{Rb}$ & 156 & 73 & 77 & 123 & 151 & 129 & 194 & 101 & 113 & 113 & 143 & 112 & 99 & 79 & 78 & 119 \\
\hline $\mathrm{Sr}$ & 305 & 328 & 336 & 277 & 96 & 181 & 104 & 227 & 271 & 112 & 222 & 155 & 86 & 224 & 128 & 141 \\
\hline Th & 41 & 62 & 35 & 93 & 15 & 66 & 101 & 81 & 72 & 46 & 72 & 85 & 77 & 23 & 11 & 22 \\
\hline $\mathrm{U}$ & 8 & 7 & 7 & 9 & 12 & 15 & 10 & 9 & 8 & 9 & 14 & 16 & 19 & 7 & 7 & 7 \\
\hline $\mathrm{V}$ & 39 & 9 & 11 & 24 & 41 & 17 & 15 & 10 & 8 & 27 & 11 & 15 & 7 & 7 & 9 & 20 \\
\hline $\mathrm{Y}$ & 28 & 23 & 20 & 29 & 20 & 140 & 34 & 18 & 27 & 22 & 47 & 30 & 27 & 14 & 44 & 56 \\
\hline $\mathrm{Zn}$ & 62 & 22 & 17 & 50 & 28 & 17 & 17 & 19 & 17 & 16 & 12 & 17 & 8 & 7 & 7 & 5 \\
\hline $\mathrm{Zr}$ & 307 & 170 & 127 & 239 & 84 & 231 & 208 & 218 & 198 & 128 & 185 & 184 & 152 & 131 & 76 & 65 \\
\hline
\end{tabular}

Tabela 2 - Análises químicas de rochas metassedimentares (metarcóseos) e metavulcânicas da Formação Morro Doce obtidas por FRX. ma = metarcóseo; mva = rocha metavulcânica ácida; mvb = rocha metavulcânica básica; anfibolito.

\begin{tabular}{|c|c|c|c|c|c|c|c|c|c|c|c|c|c|c|}
\hline & MD-03a & MD-04a & MD-26b & MD-36 & MD-38 & MD $01 \mathrm{~B}$ & Т 327 & MD-06 & MD-08 & MD-09 & MD-39a & MD-43 & MD-46 & MD-47 \\
\hline & $m a$ & $m a$ & $m a$ & $m a$ & $m a$ & $m a$ & $m v a$ & $m v a$ & $m v a$ & $m v a$ & $m v b$ & anfibolito & anfibolito & anfibolito \\
\hline $\mathrm{SiO}_{2}$ & 74.07 & 73.91 & 75.89 & 75.16 & 69.14 & 70.85 & 69.59 & 67.92 & 68.59 & 68.87 & 51.74 & 49.35 & 47.65 & 48.55 \\
\hline $\mathrm{Al}_{2} \mathrm{O}_{3}$ & 10.55 & 12.90 & 10.92 & 12.09 & 13.65 & 13.31 & 12.57 & 12.07 & 12.77 & 12.56 & 13.85 & 13.80 & 13.86 & 14.04 \\
\hline $\mathrm{MnO}^{2}$ & 0.034 & 0.023 & 0.025 & 0.030 & 0.055 & 0.039 & 0.050 & 0.046 & 0.066 & 0.080 & 0.206 & 0.189 & 0.190 & 0.164 \\
\hline $\mathrm{MgO}$ & 1.11 & 0.88 & 0.78 & 0.76 & 1.98 & 1.70 & 0.60 & 0.95 & 0.38 & 0.95 & 6.43 & 6.97 & 8.13 & 7.54 \\
\hline $\mathrm{CaO}$ & 2.75 & 0.65 & 0.75 & 1.07 & 1.58 & 1.16 & 1.18 & 1.30 & 1.55 & 1.43 & 3.99 & 10.05 & 10.45 & 9.90 \\
\hline $\mathrm{Na}_{2} \mathrm{O}$ & 1.57 & 2.60 & 2.32 & 3.18 & 3.33 & 1.07 & 2.75 & 3.10 & 2.21 & 3.36 & 1.89 & 2.43 & 2.76 & 3.36 \\
\hline $\mathrm{K}_{2} \mathrm{O}$ & 3.63 & 4.20 & 3.98 & 3.80 & 3.47 & 4.85 & 5.79 & 5.35 & 6.31 & 3.68 & 3.43 & 0.05 & 0.18 & 0.25 \\
\hline $\mathrm{TiO}_{2}$ & 0.287 & 0.282 & 0.306 & 0.244 & 0.591 & 0.403 & 0.563 & 0.627 & 0.599 & 0.748 & 2.039 & 1.406 & 1.182 & 1.167 \\
\hline $\mathrm{P}_{2} \mathrm{O}_{5}$ & 0.077 & 0.100 & 0.077 & 0.103 & 0.212 & 0.152 & 0.081 & 0.086 & 0.093 & 0.136 & 0.873 & 0.106 & 0.081 & 0.079 \\
\hline $\mathrm{Fe}_{2} \mathrm{O}_{3}$ & 2.27 & 2.23 & 2.50 & 1.82 & 3.68 & 3.66 & 4.98 & 6.74 & 5.23 & 6.21 & 12.52 & 13.92 & 13.64 & 12.87 \\
\hline P.F. & 3.05 & 1.38 & 1.37 & 0.95 & 1.64 & 2.36 & 0.80 & 0.51 & 0.90 & 0.70 & 1.40 & 0.58 & 1.03 & 1.19 \\
\hline Total & 99.40 & 99.16 & 98.92 & 99.21 & 99.33 & 99.55 & 98.95 & 98.70 & 98.70 & 98.72 & 98.37 & 98.85 & 99.15 & 99.11 \\
\hline $\mathrm{Ba}$ & 787 & 814 & 864 & 749 & 821 & 1088 & 1454 & 1263 & 1744 & 1146 & 1036 & $<37$ & 39 & 42 \\
\hline $\mathrm{Ce}$ & 42 & 43 & 48 & $<35$ & 87 & 87 & 78 & 121 & 146 & 156 & 130 & 71 & 73 & 80 \\
\hline Co & 6 & $<6$ & $<6$ & $<6$ & 9 & 11 & $<6$ & 7 & & & 36 & 48 & 48 & 41 \\
\hline $\mathrm{Cr}$ & 36 & 25 & 69 & 26 & 45 & 82 & $<13$ & 17 & $<13$ & $<13$ & 181 & 240 & 111 & 315 \\
\hline $\mathrm{Cu}$ & 20 & $<5$ & 13 & 9 & $<5$ & $<5$ & 7 & $<5$ & 17 & 25 & 172 & 220 & 81 & 94 \\
\hline $\mathrm{Ga}$ & 14 & 17 & 14 & 14 & 15 & 17 & 19 & 23 & 20 & 19 & 19 & 18 & 17 & 20 \\
\hline $\mathrm{La}$ & 37 & $<28$ & 37 & 189 & 59 & 53 & 83 & 85 & 109 & 117 & 64 & $<28$ & $<28$ & $<28$ \\
\hline $\mathrm{Nb}$ & $<9$ & $<9$ & $<9$ & $<9$ & $<9$ & 12 & 30 & 39 & 32 & 32 & 15 & $<9$ & $<9$ & $<9$ \\
\hline $\mathrm{Nd}$ & 18 & 26 & 21 & 116 & 53 & 37 & 37 & 81 & 85 & 78 & 72 & 16 & 21 & 18 \\
\hline $\mathrm{Ni}$ & 7 & 10 & 12 & 11 & 19 & 16 & $<5$ & $<5$ & $<5$ & $<5$ & 78 & 102 & 108 & 120 \\
\hline $\mathrm{Pb}$ & 5 & $<4$ & 22 & $\frac{11}{7}$ & -1 & $<4$ & 22 & 7 & 12 & $<4$ & 12 & $\frac{102}{11}$ & 5 & $\frac{120}{9}$ \\
\hline $\mathrm{Rb}$ & 131 & 124 & 130 & 94 & 95 & 172 & 182 & 150 & 182 & 114 & 68 & 3 & 4 & 4 \\
\hline Sr & 184 & 106 & 108 & 159 & 196 & 68 & 70 & 121 & 75 & 99 & 180 & 134 & 102 & 104 \\
\hline Th & 22 & 10 & 23 & 8 & 13 & 13 & 22 & 17 & 14 & 14 & 10 & 8 & 8 & 7 \\
\hline $\mathrm{U}$ & $<3$ & 13 & 13 & 10 & 8 & 9 & 8 & 12 & 11 & 8 & 3 & $<3$ & $<3$ & $<3$ \\
\hline V & 82 & 35 & 37 & 19 & 47 & 47 & 12 & 15 & 8 & 18 & 215 & 369 & 309 & 344 \\
\hline $\mathrm{Y}$ & 15 & 17 & 12 & 53 & 28 & 24 & 57 & 93 & 66 & 74 & 43 & 26 & 21 & 21 \\
\hline $\mathrm{Zn}$ & 30 & 9 & 34 & 8 & 66 & 70 & 51 & 54 & 49 & 76 & 160 & 106 & 101 & 138 \\
\hline $\mathrm{Zr}$ & 175 & 177 & 187 & 153 & 182 & 242 & 568 & 723 & 589 & 577 & 281 & 80 & 64 & 63 \\
\hline
\end{tabular}


Tabela 3 - Análises químicas de elementos traço em rochas da Formação Morro Doce obtidas por ICP-MS. smp = biotita monzogranito porfirítico; $s m i=$ monzogranito inequigranular; sme = monzogranito equigranular; sli = leucogranito inequigranular; $s m v b=$ seixo de rocha metavulcânica básica; $m a=$ metarcóseo; $m v a=$ rocha metavulcânica ácida; $m v b$ = rocha metavulcânica básica; anfibolito.

\begin{tabular}{|c|c|c|c|c|c|c|c|c|c|c|c|c|c|c|c|}
\hline & MD-01N & MD-01E & MD-25A & MD-01C & MD-10B & MD-01D & MD-26A & MD-01M & MD-01B & MD-04A & MD-06 & MD-09 & MD-39A & MD-43 & MD-47 \\
\hline & smp & smi & smi & sme & sme & sli & sli & smvb & ma & ma & mva & mva & mvb. & anfiboli & nfibol \\
\hline $\mathrm{Rb}$ & 159.40 & 66.14 & 142.55 & 90.98 & 97.41 & 72.86 & 92.13 & 326 & 154.50 & 117.79 & 125.57 & 93.88 & 57.54 & 0.99 & 2.05 \\
\hline $\mathrm{Sr}$ & 307.27 & 347.06 & 94.05 & 261.94 & 167.18 & 238.46 & 86.39 & 16 & .49 & 109.46 & 18.48 & 3.31 & 173.15 & 81.56 & 108.24 \\
\hline $\mathrm{Y}$ & 04 & 80 & 11.74 & 24 & 7.10 & 6.30 & 19.54 & 03 & .10 & 4.88 & 5.09 & 4.27 & 37.72 & & 16.92 \\
\hline $\mathrm{Zr}$ & 298.25 & 149.81 & 84.82 & 182.28 & 189.67 & 131.31 & 149.89 & 90.0 & 191.29 & 180.06 & 689.81 & 520.04 & 244.13 & 121.37 & 47.02 \\
\hline $\mathrm{Nb}$ & 19.53 & 14.65 & 4.78 & 17.49 & 19.71 & 16.54 & 23.42 & 6.86 & 11.88 & 12 & 38.43 & 29.73 & 16.42 & .24 & 3.53 \\
\hline Cs & & 11 & 34 & & 66 & 61 & 28 & 31 & 2.37 & & .06 & 1.05 & 2.74 & 06 & 07 \\
\hline $\mathrm{Ba}$ & 622.48 & 518.06 & 874.32 & 913.96 & 902.34 & 751.89 & 807.23 & 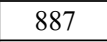 & 888.09 & 1025.20 & 1666.75 & 1335.59 & \begin{tabular}{|l|}
1296.31 \\
\end{tabular} & 4.79 & 37.55 \\
\hline $\mathrm{La}$ & & 69.75 & 34.15 & .66 & 92.30 & 15.97 & 38.71 & 7.24 & 35.07 & 30.78 & 104.83 & 114.89 & 79.34 & 30 & 4.34 \\
\hline $\mathrm{Ce}$ & 7 & 135.50 & 68.83 & 2 & 156.75 & 28.26 & 92.00 & 10.1 & 94.45 & 16 & 189.94 & 205.28 & 143.57 & 93 & 52 \\
\hline $\operatorname{Pr}$ & 12.92 & 59 & 5.48 & 2 & 14.30 & 2.73 & 7.44 & 17 & 7.78 & 34 & 21.80 & 22.89 & 17.76 & 4.03 & 1.67 \\
\hline $\mathrm{Nd}$ & & 60 & 16.66 & 25 & 7.65 & & 23.45 & 6.46 & 28.78 & 2.56 & 85.48 & 87.27 & 72.45 & 19.90 & .21 \\
\hline $\mathrm{Sm}$ & & & & & 55 & & 4.62 & 1 & & 87 & 17.39 & 15.76 & 13.02 & 7 & 54 \\
\hline $\mathrm{Eu}$ & & 7 & 0.44 & & 7 & 11 & 0.64 & 23 & 1.19 & 2 & 2.84 & 2.82 & 2.81 & 36 & .03 \\
\hline Gd & & & & & & & 47 & & & 08 & 16.34 & 13.58 & 10.45 & 0 & 3.37 \\
\hline $\mathrm{Tb}$ & & 0 & 0.25 & 7 & 8 & 0 & 0.60 & 24 & 8 & 8 & 2.56 & 2.06 & 1.50 & 41 & 56 \\
\hline Dy & & & 1. & 9 & 39 & & 3.59 & 39 & & & 15.10 & 11.57 & 28 & 3.85 & 3.47 \\
\hline Но & & & & & 6 & 63 & 0.73 & 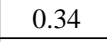 & & 55 & 3.12 & 2.29 & 1.65 & 1.91 & 0.74 \\
\hline $\mathrm{Er}$ & 2.62 & 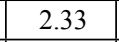 & 0.89 & & 66 & 1.78 & 2.16 & 0.97 & 0 & 52 & .85 & 6.24 & 4.44 & 5.34 & 2.01 \\
\hline $\mathrm{Tm}$ & & & 0 & & 0 & 30 & 0.35 & o & & 2 & 1.30 & 0.89 & 0.62 & 0.77 & 0.29 \\
\hline $\mathrm{Yb}$ & 2.41 & & 0.76 & & 62 & 2.22 & 2.38 & 1.39 & & 42 & 8.67 & 5.90 & 4.08 & 5.09 & 1.89 \\
\hline $\mathrm{Lu}$ & & & 0.12 & & 0.39 & 0.34 & 0.35 & 0.25 & 0.27 & 21 & 1.29 & 0.87 & 0.61 & 0.76 & 0.27 \\
\hline $\mathrm{Hf}$ & & & 2.43 & & 5.94 & 5.82 & 4.84 & 2 & 5.18 & 4.66 & 18.18 & 13.61 & 6.78 & 4.31 & 1.67 \\
\hline $\mathrm{Ta}$ & 2.36 & 2.02 & & & 3.76 & 3.58 & & 3.05 & 3.38 & & & & & & \\
\hline $\mathrm{Pb}$ & 36.45 & 44.46 & 30.72 & 22.43 & 40.03 & 27.37 & 23.75 & 19.9 & 5.20 & $v_{1}$ & 0.10 & 5.35 & 8.66 & 12.16 & 5.85 \\
\hline $\mathrm{Th}$ & 35.20 & 61.37 & 16.73 & 71.73 & 90.15 & 30.09 & 83.78 & 0.34 & 18.27 & 58 & 16.27 & 14.07 & 4.65 & .79 & 0.33 \\
\hline $\mathrm{U}$ & 6.73 & 13.37 & 1.16 & 14.70 & 20.01 & 6.74 & 13.87 & 1.73 & 4.35 & 1.18 & 3.06 & 2.01 & 0.70 & 0.20 & 0.08 \\
\hline
\end{tabular}

Espinhaço, Chapada Diamantina (McReath, et al. 1981), que também ocorrem intercaladas a metaconglomerados e foram datadas em $1752 \pm 4 \mathrm{Ma}$ (Schobbenhaus et al. 1994). Uma amostra de meta-traquiandesito basáltico com elevados teores possivelmente primários de $\mathrm{K}_{2} \mathrm{O}$ e outros elementos litófilos mostra teores relativamente altos de $\mathrm{Zr}, \mathrm{Y}$ e Th, também típicos de magmatismo intraplaca, e sugere caráter bimodal para a seqüência.

O corpo anfibolítico do Jaraguá, com mineralogia à base de hornblenda, plagioclásio, epidoto e titanita, apresenta características geoquímicas mais pró- ximas de magmatismo de fundo oceânico, com baixas concentrações de elementos incompatíveis como $\mathrm{Rb}$, $\mathrm{Nb}$ e Th. Nesse sentido, embora de idade ainda desconhecida, mostra semelhanças com as rochas metabásicas da região de Pirapora do Bom Jesus (Lazzari 1987; Tassinari et al. 2001).

Agradecimentos Os autores agradecem ao Conselho Nacional de Pesquisa (CNPq), pelo apoio fornecido a esta pesquisa.

\section{Referências}

Almeida F.F.M. de, Hasui Y., Brito Neves B.B., Fuck R.A. 1981. Brazilian Structural Provinces: An Introduction. Earth-Science Reviews, 17(1/2):1-29.

Basei M.A.S., Siga Jr. O., Kaulfuss G.A., Cordeiro H., Nutman A., Sato K., Cury L.F., Prazeres Filho H. J., Passarelli C.R., Harara O.M., Reis Neto J.M., Weber W. 2003. Geochronology and isotope geochemistry of Votuverava and Perau Mesoproterozoic basins, southern Ribeira Belt, Brazil, South American Symposium on Isotope Geology, 4, Salvador, Brazil, Short Papers, p.501-504.
Bergmann M. 1988. Caracterização Estratigráfica e Estrutural da Seqüência Vulcano-Sedimentar do Grupo São Roque na Região de Pirapora do Bom Jesus - Estado de São Paulo. Dissertação de Mestrado, Instituto de Geociências USP, 167 p.

Brito Neves B.B. de, Kawashita K., Cordani U.G., Delhal J. 1979. A Evolução Geocronológica da Cordilheira do Espinhaço; Dados Novos e Integração. Revista Brasileira de Geociências, 9: 71-85.

Brito Neves B.B. de, Sá de J.M., Nilson F.B. 1995. A Ta- 
frogênese Estateriana nos Blocos Paleoproterozóicos da América do Sul e Processos Subseqüentes. Geonomos, 3(2):1-21.

Campanha G.A. da C. \& Sadowski G.R. 1999. Tectonics of the southern portion of the Ribeira Bellt (Apiaí Domain). Precambrian Research, 98:31-51.

Campos Neto M. da C., Basei M.A.S., Artur A.C., Silva M.E. da, Machado R., Dias Neto C. de M., Fragoso Cesar A.R., Souza A.P. 1983. Geologia das Folhas Piracaia e Igaratá. In: IPT - Pró-Minério, Jornada Sobre a Carta Geológica do Estado de São Paulo em 1: 50.000, 1, São Paulo, Atas, p. 55-76.

Campos Neto M. da C. \& Figueiredo M.C.H. 1995. The Rio Doce Orogeny, Southeastern Brazil. Journal of South American Earth Sciences, 8(2):143-162.

Campos Neto M. da C. 2000. Orogenic Systems From Southwestern Gondwana: an Approach to Brasiliano-Pan African Cycle and Orogênic Collage in Southeastern Brazil. In: Cordani U.G., Milani E.J., Thomaz Filho A., Campos D.A. (eds.) Tectonic Evolution of South American. In: International Geological Congress, 31, Rio de Janeiro, Brazil, p. 335-365.

Carneiro C.D.R. 1983. Análise Estrutural do Grupo São Roque na Faixa entre o Pico do Jaraguá e a Serra dos Cristais, SP. Tese de Doutoramento, Instituto de Geociências, USP, 155 p.

Carneiro C.D.R., Hasui Y., Dantas A.S.L. 1984. Contribuição ao Estudo da Litoestratigrafia do Grupo São Roque na Faixa Jaraguá-Cristais-SP. In: Congresso Brasileiro de Geologia, 33, Rio de Janeiro (RJ), Anais, p.3212-3226.

Condie C.K. 2002. Breakup of a Paleoproterozoic Supercontinent. Gondwana Research, 5(1):41-43.

Cordani U.G., Campos A.C.R., Davino A., Björnber A.J.S. 1961. Geologia da Região do Jaraguá. Boletim da Sociedade Brasileira de Geologia, 10(20):73-91.

Cordani U.G., Gomes C. de B., Girardi V.A.V. 1963. Rochas Cálcio-Silicatadas da Região de Perus, SP. Anais da Academia Brasileira de Ciências, 35(3):361-372.

Coutinho J.M.V. 1955. Metaconglomerado e rochas associadas no Município de São Paulo. Boletim da Faculdade de Filosofia, Ciências e Letras - Universidade de São Paulo, São Paulo, 186(13):5-56.

Coutinho J.M.V. 1968. Petrologia do Pré-Cambriano em São Paulo e Arredores. Tese de Professor Catedrático, Faculdade de Filosofia Ciências e Letras, USP, 174 p.

Coutinho J.M.V., Rodrigues E de P., Suemitsu A., Juliani C., Beljavskis P., Paulo de T.Y.P. 1982. Geologia e Petrologia da Seqüência Vulcano-Sedimentar do Grupo São Roque na Serra de Itaberaba - SP. In: Congresso Brasileiro de Geologia, 32, Salvador, Bahia, Anais, 2:624-640.

Dantas A.S.L. 1990. Geologia da Faixa São Roque e Intrusivas Associadas na Região entre São Paulo e Mairiporã, Norte de São Paulo. Dissertação de Mestrado, Instituto de Geociências, USP, 199 p.

Derby O.A. 1895. A denominação "Serra da Mantiqueira". Revista do Instituto Historico e Geografico de São Paulo, 1:5-15.

Eschwege W.L. Von. 1824. Brasil, novo mundo. Tradução Domício de Figueiredo Murta. Centro de Estudos Históricos e Culturais. Belo Horizonte, Fundação João Pi- nheiro, 1996, 197 p.

Fernandes da Silva P.C. 2004. Litofácies e Prováveis Ambientes de Sedimentação do Grupo São Roque na Região de Votorantim e Salto de Pirapora, SP. Revista do Instituto Geológico, São Paulo, 25 (1/2):29-48.

Gomes C de Barros. 1962. Contribuição ao Conhecimento dos Anfibolitos da Região do Jaraguá, SP. Boletim Sociedade Brasileira de Geologia, 11(1):57-73.

Gonzaga de Campos L.F. 1888. Secção Geológica. Relatório apresentado ao Dr. Orville A. Derby. Relatório da Commisão Geographica e Geológica da Província de São Paulo. São Paulo, Typographia a Vapor de Jorge Seckler \& Comp., 15 de Dezembro, p.21-34.

Hackspacher P.C., Dantas E.L., Spoladore A., Fetter A.H., Oliveira M.A.F. 2000. Evidence for Neoproterozoic back-arc basin development in the Central Ribeira Belt, southeastern Brazil: new geochronological and geochemical constraints from the São Roque-Açungui Groups. Revista Brasileira de Geociências, 30:110-114.

Hasui Y., Penalva F., Hennies W.T. 1969. Geologia do Grupo São Roque. In: Congresso Brasileiro de Geologia, 23, Salvador (BA), Anais, 101-134.

Hasui Y. 1973. Tectônica da área das folhas de São Roque e Pilar do Sul. São Paulo. Tese Livre-Docência, Instituto de Geociências, USP, 134 p.

Hasui Y. 1975b. Geologia da Folha de São Roque. Boletim do Instituto de Geociências USP, 6:157-183.

Hasui Y., Carneiro C.D.R., Coimbra A.M. 1975a. The Ribeira Folded Belt. Revista Brasileira de Geociências, 5:257-266.

Hasui Y. \& Sadowski G. R. 1976. Evolução geológica do Pré-cambriano na região sudeste do Estado de São Paulo. Revista Brasileira de Geociências, 6(3):182-200.

Hasui Y., Tognon A.A., Soares L., Csordas S.M. 1978. Geologia e Tectônica da Serra do Japí. Boletim Instituto de Geociências USP, 9:17-24.

Henrique-Pinto R. \& Janasi V.A. 2007. Proveniência dos Metaconglomerados do Grupo São Roque (SP): contribuições a partir da geoquímica dos seixos graníticos. In: Congresso Brasileiro de Geoquímica, 11, Atibaia (SP), Resumos Expandidos, p. 1-4.

Henrique-Pinto R. 2008. Metaconglomerados e Rochas Associadas do Grupo São Roque a Noroeste da Cidade de São Paulo: Proveniência e Implicações para a Idade da Sedimentação. Dissertação de Mestrado, Programa de Pós-Graduação em Mineralogia e Petrologia, Universidade de São Paulo, 82 p.

INSTITUTO DE PESQUISAS TECNOLÓGICAS (IPT). 1983. Carta Geológica do Estado de São Paulo em Escala 1:50.000. Secretaria da Industria, Comércio, Ciência e Tecnologia - Pró-Minério.

Irvine T.N. \& Baragar W.R.A. 1971. A Guide to the Chemical Classification of the Common Volcanic Rocks. Canadian Journal of Earth Sciences, 8:523-548.

Janasi V.A. \& Ulbrich H.H.G.J. 1991. Late Proterozoic granitoid magmatism in the state of São Paulo, southeastern Brazil. Precambrian Research, 51:351-374.

Juliani C. 1993. Geologia, Petrogênese e Aspectos Metalogenéticos dos Grupos Serra do Itaberaba e São Roque na Região das Serras do Itaberaba e Pedra Branca, NE 
da Cidade de São Paulo, SP. São Paulo, Tese de Doutorado, Instituto de Geociências, USP, 803 p.

Juliani C., Beljavskis P., Schorscher H.D. 1986. Petrogênese do Vulcanismo e Aspectos Metalogenéticos Associados: Grupo Serra do Itaberaba na Região do São Roque SP. In: Congresso Brasileiro de Geologia, 34, Goiânia, Anais, 2:730-745.

Juliani C., Martin M.A.B., Clarimundo S. de J. 1997. Os metarcoseos do Morro do Polvilho: implicações para geocronologia e para evolução crustal dos grupos Serra do Itaberaba e São Roque (SP). Anais da Academia Brasileira de Ciencias, 69:441.

Juliani C., Martin M.A.B., Clarimundo S. de J., McReath I., Pertersen Jr. K.J. 1999. Geologia dos Grupos Serra do Itaberaba e São Roque entre o Pico do Jaraguá e Araçarigüama, São Paulo. In: SBG/NSP-NRJ/ES, Simpósio de Geologia do Sudeste, Águas de São Pedro, Boletim de Resumos, 6:26.

Juliani C., Hackspaker P., Dantas E.L., Fetter A.H. 2000. The Mesoproterozoic volcano-sedimentary Serra do Itaberaba Group of the central Ribeira Belt, São Paulo, Brazil: implications for the age of the overlying São Roque Group. Revista Brasileira de Geociências, 30:82-86.

Lazzari M.L. 1987. O Metabasito de Pirapora do Bom Jesus. Dissertação de Mestrado, Instituto de Geociências, Universidade de São Paulo, 84 p.

Le Bas M.J., Le Maitre R.W., Streckeisen A., Zanettin. 1986. A Chemical Classification of Volcanic Rocks Based on Total Alkali-Silica Diagram. Journal of Petrology, 27(3):745-750.

Martin M.A.B. 2000. Geologia e Petrografia e Metamorfismo dos Grupos Serra do Itaberaba e São Roque a Noroeste da Cidade de São Paulo (SP). Dissertação de Mestrado, Instituto de Geociências, USP, 256 p.

McReath I., Jardim de Sá E.F., Fryer B.J. 1981. As Vulcânicas Ácidas Proterozóicas da Região da Bacia do Rio Paramirim - Bahia. Geologia e Recursos Minerais do Estado da Bahia. Secr. de Minas e Energia, 4:121-134.

Moraes L.J. de. 1944. A Serra do Japí, Estado de São Paulo. Boletim da Faculdade de Filosofia, Ciências e Letras Universidade de São Paulo, 45(1):34-40.

Moraes Rego L.F. de. 1931. As estructuras antigas do Brasil. Annaes da Escola de Minas, 27-85.

Moraes Rego L.F. de. 1933. Contribuição ao estudo das formações pré-devonianas de São Paulo. Boletim do Instituto Astronômico e Geographico. São Paulo - SP, 55p.

Oliveira E.P. de. 1925. Analyses de Calcareos. Serviço Geológico e Mineralógico do Brasil. Ministério da Agricultura Indústria e Commercio. Boletim 10:1-45.

Oliveira F de P. 1887. Esboço Geológico da Região Comprehendida entre os Rios Sorocaba e Tieté. Relatório da Província de São Paulo, Commissão Geographica e Geológica. São Paulo, Typographia a Vapor de Jorge Seckler \& Comp., 19 de novembro, p. 26-28.

Oliveira M.A.F de, Melo R.P., Nardy A.J.R., Arab P.B., Trindade I. 2008. New U/Pb Palaeoproterozoic Zircon Age For The Cajamar Metabasite, São Roque Group, Central Ribeira Belt, Southeastern Brazil. In: South Americam Symposium on Isotope Geology, 6, San Carlos de
Bariloche, Argentina, Actas, p.1-4.

Paoliello P.C. 1964. Geologia do Estado de São Paulo - Explanação do Mapa Geológico. Boletim do Instituto Geográfico e Geológico de São Paulo, 41:37-44.

Pearce J.A \& Cann J.R. 1973. Tectonic Setting of Basic Volcanic Rocks Determined Using Trace Element Analyses. Earth and Planetary Science Letters, 19(2):290-300.

Pearce J.A \& Norry M.J. 1979. Petrogenetic Implications of $\mathrm{Ti}, \mathrm{Zr}, \mathrm{Y}$, and $\mathrm{Nb}$ Variations in Volcanic Rocks. Contributions to Mineralogy and Petrology, 69:33-47.

Pearce J.A., Harris N.B.W., Tindle A.G. 1984. Trace Element Discrimination for the Tectonic Interpretation of Granitic Rocks. Journal of Petrology, 25(4):956-983.

Rogers J.W. \& Santosh M. 2002. Configuration of Columbia, a Mesoproterozoic Supercontinent. Gondwana Research, 5(1):5-22.

Schobbenhaus C., Hoppe A., Baumann A., Lork A. 1994. Idade U/Pb do Vulcanismo Rio dos Remédios, Chapada Diamantina, Bahia. In: Congresso Brasileiro de Geologia, 38, Balneário Camboriú (SC), Anais, p. 397-398.

Tassinari C.C.G., Kawashita K., Kikuchi R.K.P. 1985. Estudo Geocronológico nos Metaconglomerados do Grupo São Roque, Estado de São Paulo. In: SBG, Simpósio Regional de Geologia, 10, São Paulo, Boletim de Resumos, 1:201-208.

Tassinari C.C.G., Munhá J.M.U., Correia C.T. 2001. Neoproterozoic Oceans in the Ribeira Belt (southeastern Brazil): The Pirapora do Bom Jesus Ophiolitic Complex. Episodes, 24(4):245-251.

Taylor S. R. \& Mclennan S. M. 1985. The Continental Crust: Its Composition and Evolution. Oxford, Blackwell,234p.

Turra B.B., Campanha G.A.C., Henrique-Pinto R. 2007. Análise de Deformação nos Metaconglomerados do Morro Doce, Grupo São Roque, Faixa Ribeira ao Norte da Cidade de São Paulo. In: Simpósio de Geologia de Minas Gerais, 14, e Simpósio de Geologia do Sudeste, 10, Diamantina (MG), Livro de Resumos, p. 19.

Van Schmus W.R., Tassinari C.C.G., Cordani U.G. 1986. Estudo Geocronológico da Parte Inferior do Grupo São Roque. In: Congresso Brasileiro de Geologia, 34, Goiânia (GO), Anais, 3:1399 - 1406.

Weber W., Siga Jr. O., Sato K., Reis Neto J.M dos, Basei M.A.S., Nutman A.P. 2004. A Formação Água Clara na Região de Araçaíba - SP: Registro U-Pb de Uma Bacia Mesoproterozóica. Geologia USP - Série Científica, 4(1):101-110.

Wedepohl K.H. 1995. The composition of the continental crust. Geochimica et Cosmochimica Acta, 59(7): 12171232.

Vermeesh P. 2006. Tectonic Discrimination Diagrams Revisited. Geochemistry Geophysics Geosystems, 7(6):1-55.

Wernick E., Oliveira M.A.F. de, Kawashita K., Cordani U.G., Delhal J. 1976. Estudo Geocronológico pelo Método Rb/ Sr em Rochas do Bloco Jundiaí e Regiões Adjacentes. Revista Brasileira de Geociências, 6(2):125-135.

Manuscrito ID 16307

Submissão em 09 de dezembro de 2009 Aceite em 15 de setembro de 2010 


\section{Apêndice - II}

(Paleoproterozoic source contributions to the São Roque Group sedimentation: LA-MCICPMS U-Pb dating and Sm-Nd systematics of clasts from metaconglomerates of the Boturuna Formation) 
Paleoproterozoic source contributions to the São Roque Group sedimentation: LAMC-ICPMS U-Pb dating and Sm-Nd systematics of clasts from metaconglomerates of the Boturuna Formation

Contribuições de fontes Paleoproterozoicas para a sedimentação do Grupo São Roque: datação U-Pb LA-MC-ICPMS e sistemática Sm-Nd dos clastos dos metaconglomerados da Formação Boturuna

Título curto: Datação U-Pb de clastos de metaconglomerados do Grupo São Roque

Renato Henrique-Pinto ${ }^{1}$, Valdecir de Assis Janasi ${ }^{1}$, Antonio Simonetti ${ }^{2}$, Colombo Celso Gaeta Tassinari $^{1}$, Larry Michael Heaman ${ }^{3}$

${ }^{1}$ Departamento de Mineralogia e Geotectônica, Instituto de Geociências, Universidade de São Paulo - USP, Rua do Lago 562, CEP 05508-080, São Paulo, SP, BR (renatohp@usp.br; vajanasi@usp.br; ccgtassi@usp.br)

${ }^{2}$ Department of Civil Engineering and Geological Sciences, University of Notre Dame, South Bend, US (antonio.simonetti.3@nd.edu)

${ }^{3}$ Department of Earth \& Atmospheric Sciences, University of Alberta, Edmonton, CA (larry.heaman@ualberta.ca)

Received 14 March 2012; accepted 26 July 2012 
ABSTRACT

The São Roque Group is characterized by volcano-sedimentary sequences, in which deposition probably started in the late Paleoproterozoic. U-Pb dating by LA-MC-ICPMS of zircons extracted from predominantly equigranular monzogranites clasts from Morro Doce and Morro do Polvilho regions, yield paleoproterozoic ages of $2199 \pm 8.5 \mathrm{Ma}$ and $2247 \pm 13 \mathrm{Ma}$, respectively. These represent the ages for the main source of granite for the metaconglomerates from the Boturuna Formation (basal unit of São Roque Group). Its polycyclic history is reinforced by the presence of inherited Archean zircons (2694 $\pm 29 \mathrm{Ma}$ ) found within the clasts. Moreover, these clasts have also been affected by the Neoproterozoic overprinting event as indicated by their lower intercept Concordia ages. Sm-Nd isotope data for the main clast varieties from the Morro Doce metaconglomerates yield $\mathrm{T}_{\mathrm{DM}}$ ages of 2.6 to $2.7 \mathrm{Ga}$, demonstrating that these granites are the recycling products of an Archean crustal component. The metaconglomerate Arkosean framework yields slightly lower $\varepsilon_{\mathrm{Nd}(\mathrm{t})}$ values than those for the clasts, indicating that a younger and/or more primitive source also contributed to the Boturuna Formation.

Keywords: São Roque Group; Metaconglomerates; U-Pb dating; Sm-Nd data; Provenance.

\section{RESUMO}

O Grupo São Roque é caracterizado por uma sequência vulcano-sedimentar com deposição provavelmente iniciada no Paleoproterozoico tardio. Datações U-Pb obtidas por LA-MCICPMS de zircões extraídos das variedades predominantes dos clastos de monzogranitos equigranulares, das regiões do Morro Doce e Morro do Polvilho mostram idades paleoproterozoicas de $2199 \pm 8.5$ Ma e $2247 \pm 13 \mathrm{Ma}$, respectivamente. Estas representam as idades da principal fonte de granito da Formação Boturuna (unidade basal do Grupo São Roque). A história policíclica deste domínio é reforçada pela presença de zircões arqueanos herdados $(2694 \pm 29 \mathrm{Ma})$, encontrados nos clastos. Além disso, tais clastos também foram afetados pelo evento Neoproterozoico, conforme indicado pelo intercepto inferior das idades concórdia. Dados isotópicos Sm-Nd para os principais clastos do metaconglomerado do Morro Doce têm idades $\mathrm{T}_{\mathrm{DM}}$ entre 2,6 a 2,7 Ga, demonstrando que estes granitos são produtos da reciclagem de um componente crustal arqueano. $\mathrm{O}$ arcabouço dos metaconglomerados, quando comparado com os clastos, mostra valores mais baixos de $\varepsilon_{\mathrm{Nd}(t)}$, indicando contribuições de fontes mais jovens e/ou primitivas para a Formação Boturuna.

Palavras-chave: Grupo São Roque; Metaconglomerados; Datação U-Pb; Dados Sm-Nd; Proveniência. 


\section{INTRODUCTION}

The depositional age and geological significance of the São Roque Group (SRG) (Mantiqueira Tectonic Province, in Southeast Brazil) remain the focus of considerable debate in the geological literature. Several meta volcano-sedimentary sequences have been recognized in the so-called São Roque Domain. This includes the Serra do Itaberaba Group, which has been recognized as a medium-grade metamorphic sequence with a depositional age of $\sim 1.5 \mathrm{Ga}$ (Juliani et al., 2000), and is distinct relative to the lower-grade sequences that are commonly grouped into the SRG. The SRG itself is considered by some authors (Juliani, 1993; Martin, 2000) as a younger sequence, in view of its lower-grade metamorphism and proposed erosional contact marked by the presence, in metaconglomerates from its basal sequence (Boturuna Formation), of clasts and volcanic fragments, which are correlated to the Serra do Itaberaba Group (SIG). However, U-Pb zircon dating of acid and basic metavolcanic rocks from the Boturuna Formation has yielded consistently older ages (1790 \pm 14 Ma; van Schmus et al., 1986; $1750 \pm 40 \mathrm{Ma}$; Oliveira et al., 2008), strongly suggesting that SRG in fact corresponds, at least in part, to an older sequence (Henrique-Pinto and Janasi, 2010).

The metaconglomerates study from the SRG basal sequence has a long history, with the pioneering study by Derby (1882), who first documented the occurrence of such rocks in Brazil. A subsequent study by Coutinho (1955) reported a detailed description of the metaconglomerates, which are characterized by pebbles and boulders largely granitic in nature within an arkosean framework. These occur as meter to hectometre-sized lenses within a dominantly psammitic sequence. The intercalated bimodal suite of metavolcanic rocks that was used to determine the age of deposition occurs as thin layers and is characterized by a within-plate geochemical signature (Henrique-Pinto, 2008).

We have reported here the results of LA-MC-ICPMS U-Pb zircon dating of granitic clasts and $\mathrm{Sm}-\mathrm{Nd}$ isotope determinations for granitic and amphibolite clasts, and for the framework of the metaconglomerates. Together with the previously reported geochemical data, these new results are used to aid in elucidating the provenance of the SRG and therefore contribute for understanding its tectonic significance. 


\section{TECTONIC SETTING}

The São Roque Domain is a tectonic block that is located between the highmetamorphic grade Socorro-Guaxupé Nappe to the North (currently interpreted as related to the evolution of the Southern branch of the Brasília Fold Belt), and the Embu Domain to the South (related to the Ribeira Fold Belt), as observed in Figure 1. In the tectonic model of Campos Neto (2000), the São Roque Domain is part of a larger block dominated by meta-volcano-sedimentary sequences metamorphosed to low-to-mediumgrade conditions (the Apiaí-São Roque Domain). When together with the SocorroGuaxupé Nappe, these correspond to a magmatic arc domain developed at the border of an older cratonic nucleus, which is mostly concealed beneath the Phanerozoic Paraná sedimentary basin, the Paranapanema Craton (Mantovani and Brito Neves, 2005).

The first stratigraphic division of the SRG was proposed by Hasui (1976). Subsequently, a two-fold one was proposed, with the basal Boturuna Formation consisting of phyllites with quartzite and metacarbonate intercalations, whereas the upper Piragibu Formation is composed of rhythmic metapsammites succeeded by phyllites that are interbedded with quartzite. This sequence is interpreted to possibly represent turbidity current deposits in a marine environment (Carneiro, 1983; Campos Neto et al., 1983; Dantas, 1990).

Later studies recognized a distinctive volcano-sedimentary sequence in the Serra do Itaberaba region (Coutinho et al., 1982), composed of basic to intermediate tuffs, volcanic and subvolcanic rocks interbedded with chert, banded iron formation, and detrital sediments. This sequence was later defined as SIG (Juliani et al., 1986), and distinguished from the SRG, based on its higher (amphibolite-facies) metamorphic grade, and the presumed existence of an erosional contact. The latter is delineated by the presence of clasts and volcanic fragments from the SIG in metaconglomerates located at SRG base (Juliani, 1993; Martin, 2000). SIG was dated, by Juliani et al. (2000), by U$\mathrm{Pb}$ zircon in metavolcanic rocks at $1395 \pm 10 \mathrm{Ma}$.

A different metavolcano-sedimentary sequence was described in the Pirapora region (Bistrichi, 1982; Bergmann, 1988; Tassinari et al., 2001), which is composed of tholeiitic metabasalts with pillow-lavas (Figueiredo et al., 1982) chemically similar to MORB (Lazzari, 1987; Henrique-Pinto and Janasi, 2010) and associated with pyroclastics and meta-limestones, showing stromatolite structures (Bergmann and 
Fairchild, 1985). Bergmann (1988) interpreted the Pirapora Formation as the representation of passive margin volcanic centers surrounded by stromatolites. U-Pb zircon $(608 \pm 7 \mathrm{Ma})$ and monazite $(628 \pm 9 \mathrm{Ma})$ dates (Hackspacker et al., 1999; 2000) suggest a Neoproterozoic age for this sequence; however, recent $\mathrm{U}-\mathrm{Pb}$ zircon dating for possible correlative metavolcanic rocks in the Cajamar region indicate an age of $1750 \pm$ $40 \mathrm{Ma}$ (Oliveira et al., 2008).

The possibility that the SRG base is older than the overlying layers was stated by Van Schmus et al. (1986), based on U-Pb zircon age of $1790 \pm 14$ Ma obtained for acid metavolcanic rocks, which are characterized by a within-plate geochemical signature from the Morro do Polvilho region (Henrique-Pinto and Janasi, 2010).

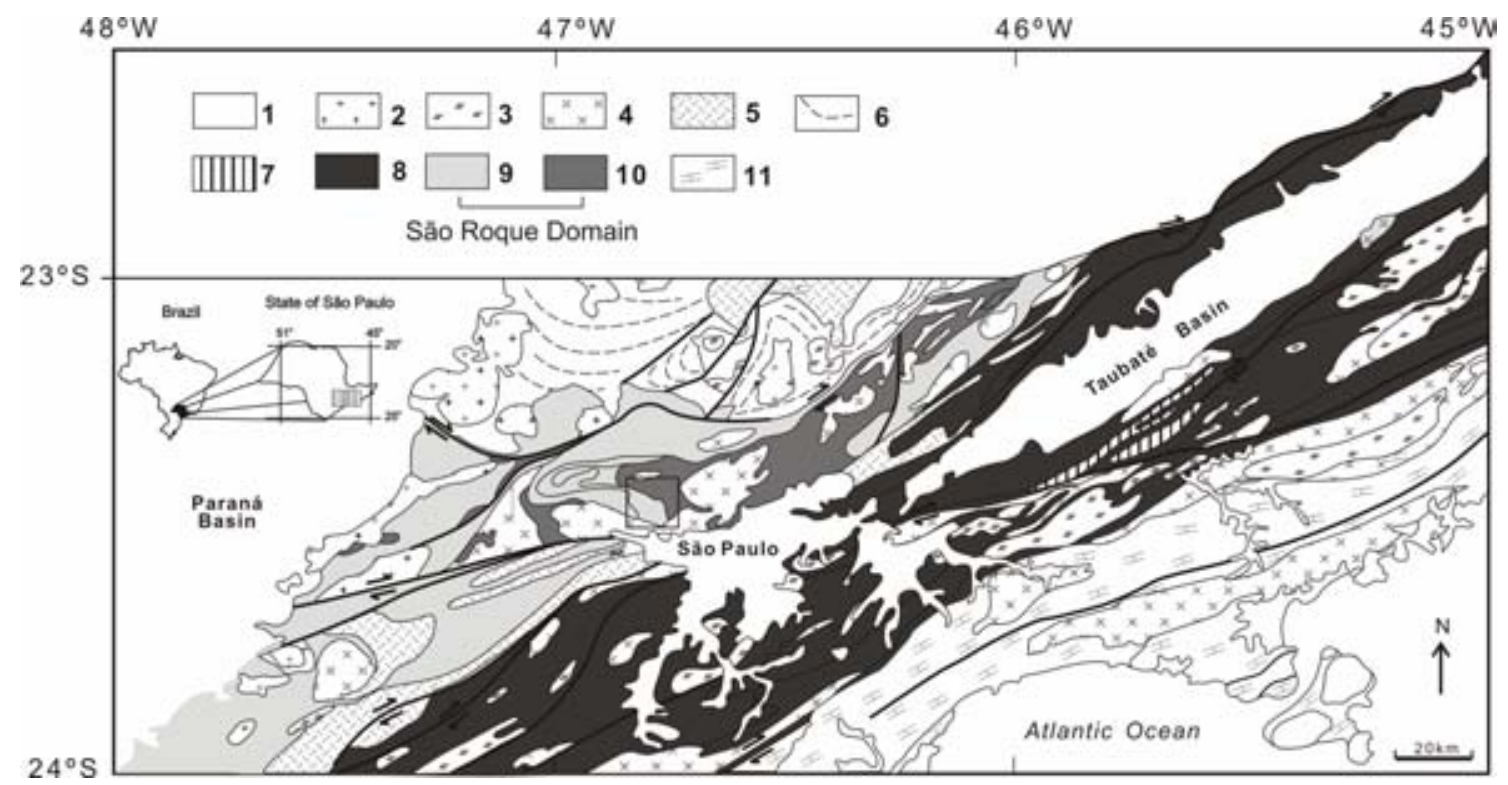

Figure 1. Simplified geotectonic map of the region near the city of São Paulo (modified from Campos Neto, 2000). 1: Phanerozoic cover and intrusive rocks; 2: late and posttectonic granites; 3: (garnet)-(muscovite)-biotite granites; 4: porphyritic biotite granites; 5: porphyritic (hornblende)-biotite granites; 6: Socorro-Guaxupé domain; 7: Paleoproterozoic gneisses (basement to Embu Domain metasupracrustals); 8: Embu Domain metasupracrustal sequences; 9: São Roque Group and Votuverava Formation; 10: Serra do Itaberaba Group; 11: Costeiro complex. The small box shows the location of Figure 2. 


\section{LOCAL GEOLOGY}

A simplified geological map of the study area is presented in Figure 2, where most of the metaconglomerate occurrences from the Boturuna Formation are indicated. The basal unit of the SRG identified by Coutinho (1955) was referred as Morro Doce Formation (Juliani et al., 1999); part of this sequence was also positioned as lower by Cordani et al. (1961) and classified as 'impure metapsammitic' unit (Carneiro, 1983), or 'basal siliciclastic association' (Fernandes da Silva, 2004). However, these studies were conducted in different geographical locations.

The Boturuna Formation crops out predominantly Northwest of the city of São Paulo (Figure 2). It is characterized by the predominance of interfingered metarkoses and polymictic metaconglomerates with pebbles and cobbles encased by hardrecrystallized framework. In topographically higher regions (the Jaraguá Peak), occurrences of metasandstones and feldspathic metasandstones ones are present. Small bodies of metavolcanic rocks are intercalated with metarkoses; those are represented by basic metavolcanic rocks (e.g. small lenses of basaltic trachyandesite within the metarkoses), and porphyritic meta-trachydacite (in the Morro do Polvilho region). The meta-trachydacites define a chemical signature typical of within-plate magmatism, with low mg\#, high Zr, Y, Nb, and low Sr (Henrique-Pinto and Janasi, 2010).

The Jaraguá amphibolite, with an approximate exposure area of $1.5 \times 2.5 \mathrm{~km}$, occurs in apparent discordance in relation to detrital metasediments (Gomes, 1962). It shares the MORB-like signature of the detritus from the Pirapora Formation, like low concentrations of incompatible elements such as $\mathrm{Rb}, \mathrm{Nb}$ and $\mathrm{Th}$ (Henrique-Pinto and Janasi, 2010). Small occurrences of impure metalimestones surrounding the main body further suggest a correlation with the Pirapora Formation.

The occurrences of calc-silicate rocks appearing in the North-central portion of the studied area (Cordani et al., 1963) belong to SIG, as probably do the scattered occurrences of staurolite-mica schist that appear as windows within the area consisting predominantly of metarkoses from the Boturuna Formation.The Southern portion of the study area (Figure 2) is dominated by Neoproterozoic granitic rocks from Itaqui and Cantareira plutons; the small Fazenda Ithayê Granite, intruding the metarkose unit in the center of the area is petrographically similar, being dominated by porphyritic biotite $( \pm$ hornblende) granites. In contrast, the Tico-Tico Granite, part of which appears in the 
extreme North of the study area, is intrusive in SIG, and consists of two mica leucogranites. Tourmaline-bearing pegmatite and aplite dikes are scattered over most of the area.

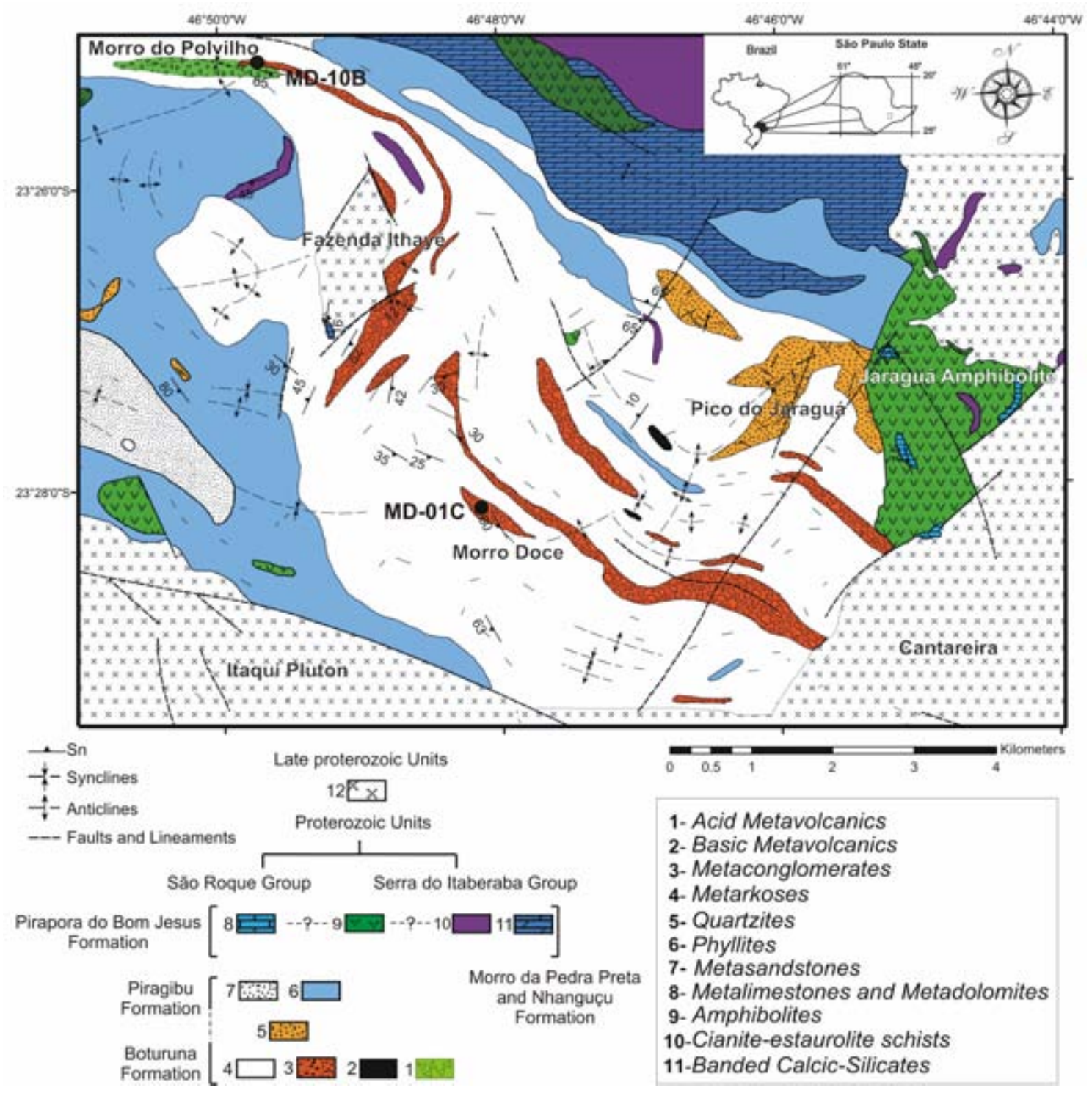

Figure 2. Geological map of São Roque Domain northwest of the city of São Paulo (modified from IPT, 1983).

Tassinari et al. (1985) obtained a $\mathrm{Rb}-\mathrm{Sr}$ isochron age of $1200 \pm 75 \mathrm{Ma}$ for granitic pebbles from a metaconglomerate of Boturuna Formation. The evolution of the $\mathrm{Sr}$ isotopic ratio was used to suggest that the source of pebbles formed at $\sim 2.4 \mathrm{Ga} \mathrm{K}$-Ar ages for groundmass biotite range between 800 to $750 \mathrm{Ma}$, and they were interpreted as representing the last metamorphic event that affected these rocks (Tassinari, 1988). 
It is possible that the basal unit (sensu Coutinho, 1955) was deposited in a deepsea environment (Odman, 1955), which was affected by proximal arkosean terrigenous or even conglomeratic sediments. Petrographic study of granites clasts for SRG metaconglomerates (Henrique-Pinto, 2008; Henrique-Pinto and Janasi, 2010) allowed the identification of four petrographic varieties: porphyritic biotite monzogranite, inequigranular monzogranite, equigranular monzogranite, and inequigranular leucogranite. The clasts appear to be broadly comagmatic, as suggested by their definition of a single geochemical evolution trend consistent with normal differentiation in granitic magmas.

The metarkoses show clear chemical affinities with the granitic pebbles from the metaconglomerate; their REE patterns, although similar to the clasts, are characterized by a smaller negative Eu anomaly suggestive of an additional source. This possibly corresponds to a mafic igneous source as indicated by their higher $\mathrm{Cr} / \mathrm{Th}, \mathrm{Ti} / \mathrm{Zr}$, and $\mathrm{Co} /$ Th ratios (Henrique-Pinto and Janasi, 2010).

\section{ANALYTICAL METHODS}

\section{Zircon separation}

Zircon crystals for $\mathrm{U}-\mathrm{Pb}$ geochronological dating were extracted from two clasts of equigranular muscovite-biotite monzogranite, which represent the most typical variety found in the metaconglomerate at the Morro Doce (MD-01C) and Morro do Polvilho (MD-10B) localities.

The samples were crushed in a steel jaw-crusher and subsequently in a disk mill. The concentrates were obtained in the Mineral Separation Laboratory of Instituto de Geociências, Universidade de São Paulo, in Brazil, by standard procedures involving a vibrating table (Wilfley) and heavy liquids (bromoform and methylene iodide).

Microscopic studies of the heavy mineral concentrates were conducted in transmitted light using a Zeiss Axioplan microscope. The concentrates were then submitted to magnetic separation procedures using a Frantz ${ }^{\mathrm{TM}}$ type isodynamic magnetic separator, initially with $+10^{\circ}$ side and $15^{\circ}$ forward dip. Zircons were concentrated in the nonmagnetic fraction at 1.5 A. The different magnetic fractions of zircons were then split by varying the inclination angle of the separator from $+6^{\circ}$ to 
lower values, until the last sizeable fraction was obtained. Handpicking involved the selection of the least magnetic crystals with well-preserved prismatic faces, vitreous luster, and least amount of inclusions as possible.

\section{LA-ICPMS U-Pb dating}

Isotopic determinations were conducted at the Department of Earth and Atmospheric Sciences, University of Alberta (Edmonton, Canada), by LA-MC-ICPMS using a $\mathrm{Nu}$ Plasma mass spectrometer equipped with three ion counters and 12 Faraday detectors; this instrument was coupled to a Nd:YAG UP213 nm New Wave laser ablation system. The accuracy and precision of analyses were validated by analyses zircon standards BR266 and 91500. A spot size of $20 \mu \mathrm{m}$ was used for the laser ablation runs given in general the high total $\mathrm{Pb}$ contents of the zircons. This resulted in adequate $\mathrm{U}$ and $\mathrm{Pb}$ ion signal intensities and allowed spots to be located in areas free of fractures and inclusions. Details of the analytical protocol employed here are given in Simonetti et al. (2005).

\section{Sm-Nd analyses}

Sm-Nd isotope analyses were performed at the Centro de Pesquisas Geocronológicas (CPGeo), Instituto de Geociências, Universidade de São Paulo, Brazil, following the procedures described by Sato et al. (1995). The Nd isotopic ratios were obtained using a multicollector Finnigan MAT-262 mass spectrometer, whereas the Sm ones were obtained using a single collector VG-354 mass spectrometer. The average ${ }^{143} \mathrm{Nd} /{ }^{144} \mathrm{Nd}$ values measured for the La Jolla and BCR-1 Nd standards during the period of this study are $0.511849 \pm 0.000025$ and $0.512662 \pm 0.000027$ (yearly $1 \sigma$ variation), respectively. The maximum measured errors were $0.09 \%$ for the ${ }^{147} \mathrm{Sm} /{ }^{144} \mathrm{Nd}$ ratio and \pm 0.00002 for ${ }^{143} \mathrm{Nd} /{ }^{144} \mathrm{Nd}\left(2 \sigma\right.$ precision level). $\varepsilon_{\mathrm{Nd}}$ calculations assume present CHUR ratios of ${ }^{143} \mathrm{Nd} /{ }^{144} \mathrm{Nd}=0.512638$ and ${ }^{147} \mathrm{Sm} /{ }^{144} \mathrm{Nd}=0.1967$. The constant used decay was $6.54 \times 10^{-12}$ years $^{-1}$. $\mathrm{T}_{\mathrm{DM}}$ calculations are made using the method of DePaolo (1988). Details of the analytical protocol employed here are given in Sato et al. (1995). 


\section{RESULTS OF LA-ICPMS U-Pb DATING}

\section{Sample MD-01C}

Thirty-nine analyses were conducted for sample MD-01C (Table 1). Eight points are essentially concordant (discordance <3\%) and yield an average date of $2199 \pm 9$ Ma. This is interpreted as the age of magmatic crystallization for this granitic clast. Two analyses from crystal 6b, although discordant, are clearly inherited and define discordia with an upper intercept age of $2694 \pm 29 \mathrm{Ma}$ (lower intercept $\sim$ zero), which is indicative of an Archean inheritance (Figure 3). The remaining analyses define a single discordia and yield an upper intercept age of $2209 \pm 14 \mathrm{Ma}$, which is within uncertainty to the average age (2199 $\pm 9 \mathrm{Ma})$, defined by the concordant crystals. The lower intercept age at $527 \pm 72$ Ma reflects the overprint associated with the Neoproterozoic thermal event (Figure 3).
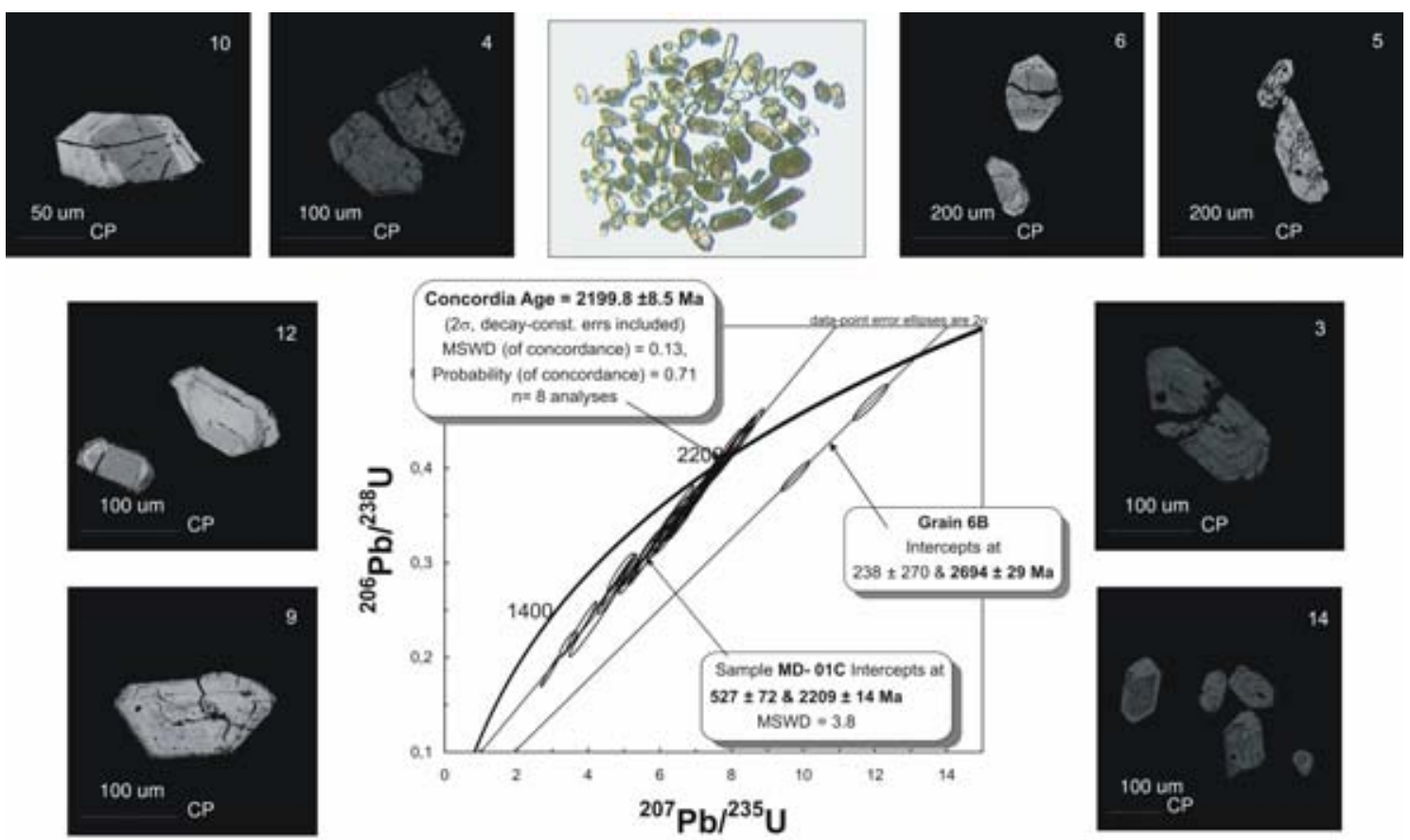

Figure 3. Concordia plot for LA-MC-ICPMS U-Pb zircon dating of sample MD-01C, a biotite monzogranite clast from the Morro Doce region. Backscattering images obtained by scanning electron microscopy with numbers linked to Table 1. 


\section{Sample MD-10B}

Thirty-two analyses were conducted for sample MD-10B (Morro do Polvilho region), of which six were excluded from regression because of for their complex zoning and multiple age domains (Table 2). The remaining 26 points indicate variable degrees of discordance, between 4 and 22\%, and define a discordia with an upper intercept age at $2247 \pm 13 \mathrm{Ma}$; which is interpreted as the magmatic crystallization age for this granite clast. The lower intercept age at $637 \pm 84 \mathrm{Ma}$ once again reflects the overprint associated with the Neoproterozoic thermal event (Figure 4).
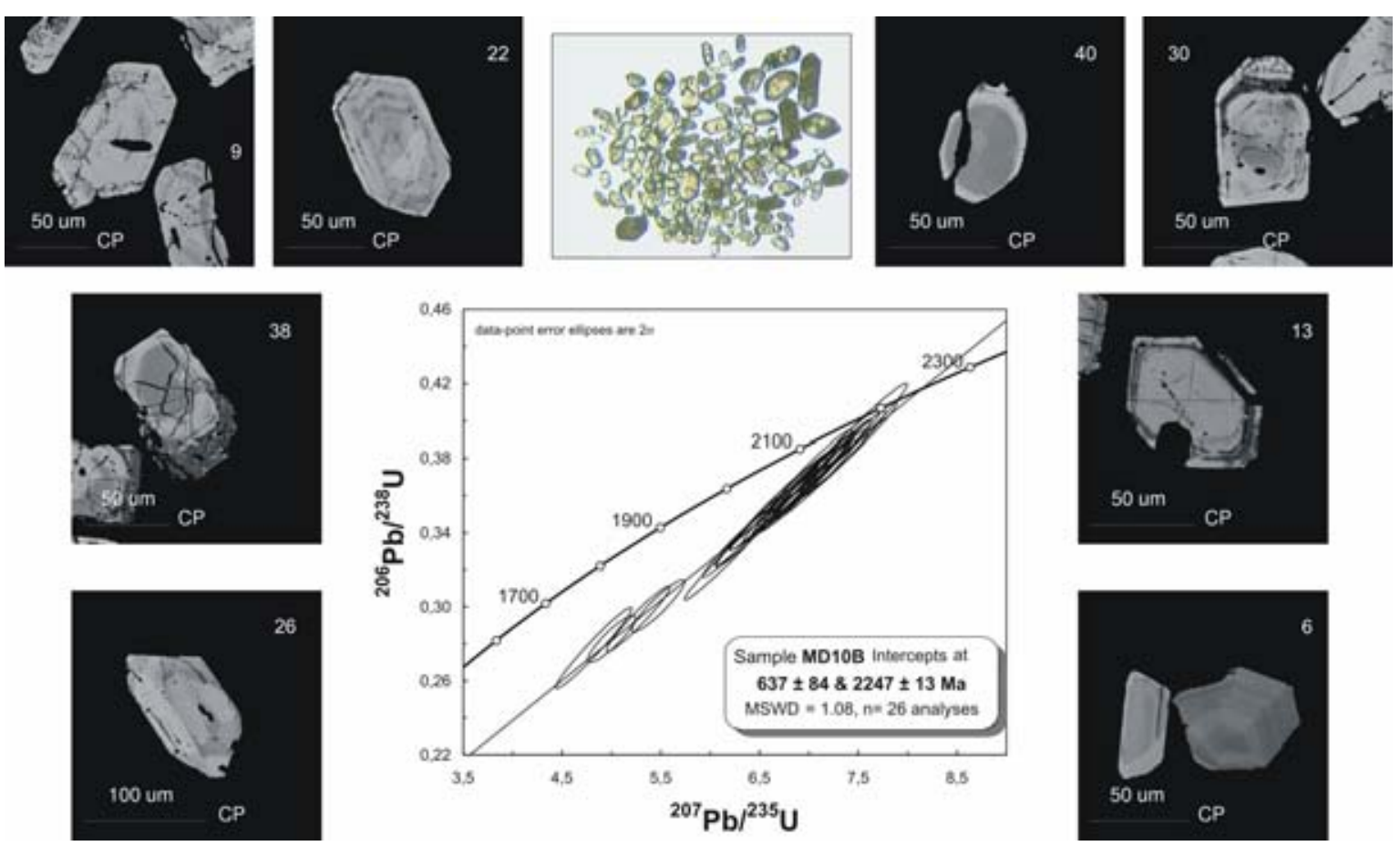

Figure 4. Concordia plot for LA-MC-ICPMS U-Pb zircon dating of sample MD-10B, a biotite monzogranite clast from the Morro do Polvilho region. Backscattering images obtained by scanning electron microscopy with numbers linked to Table 2 . 


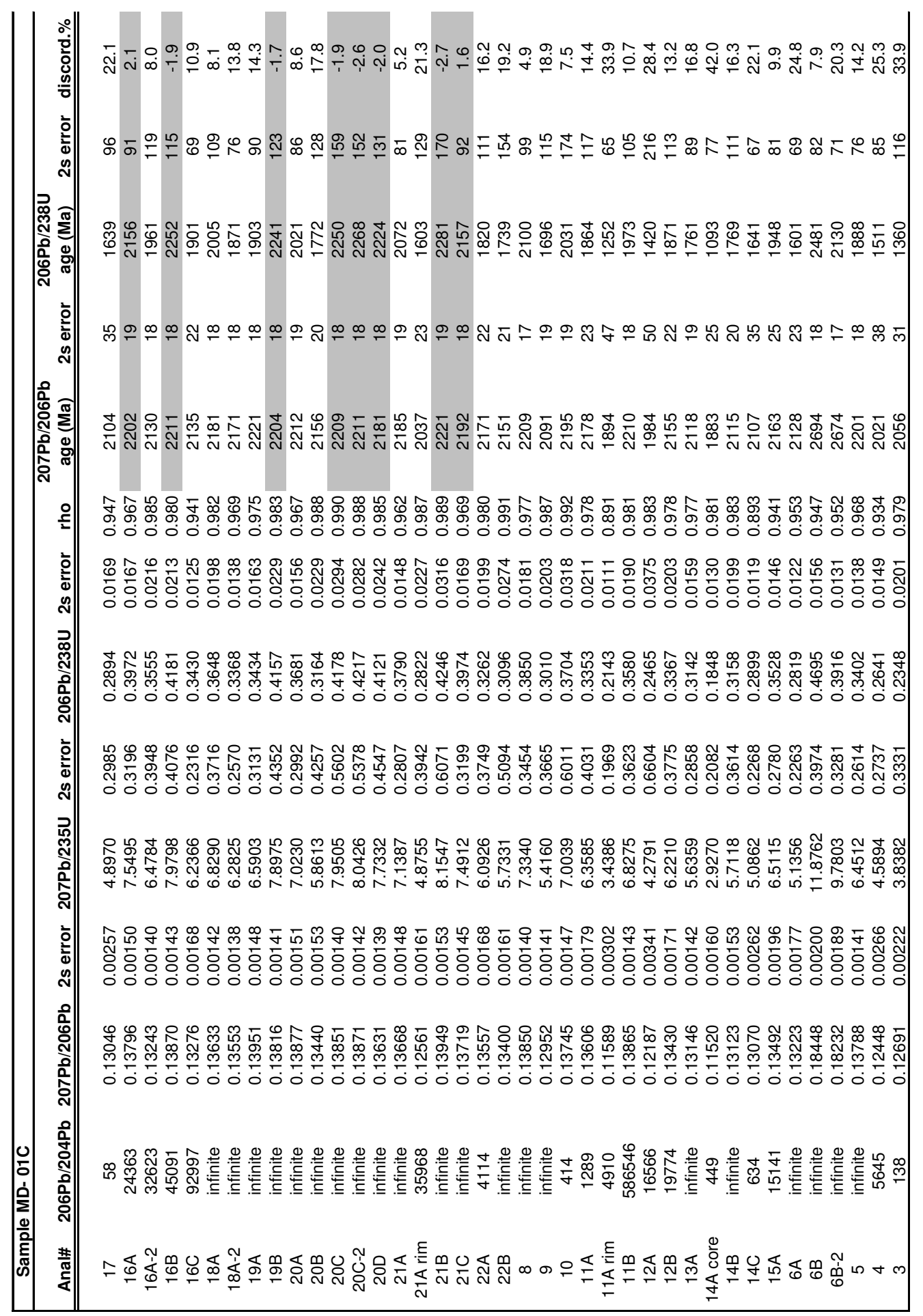

Table 1. U-Pb zircon LA-MC-ICPMS data from biotite monzogranite clast MD-01C (Boturuna Formation, São Roque Group). The grey underlain-data correspond to the concordant results. 


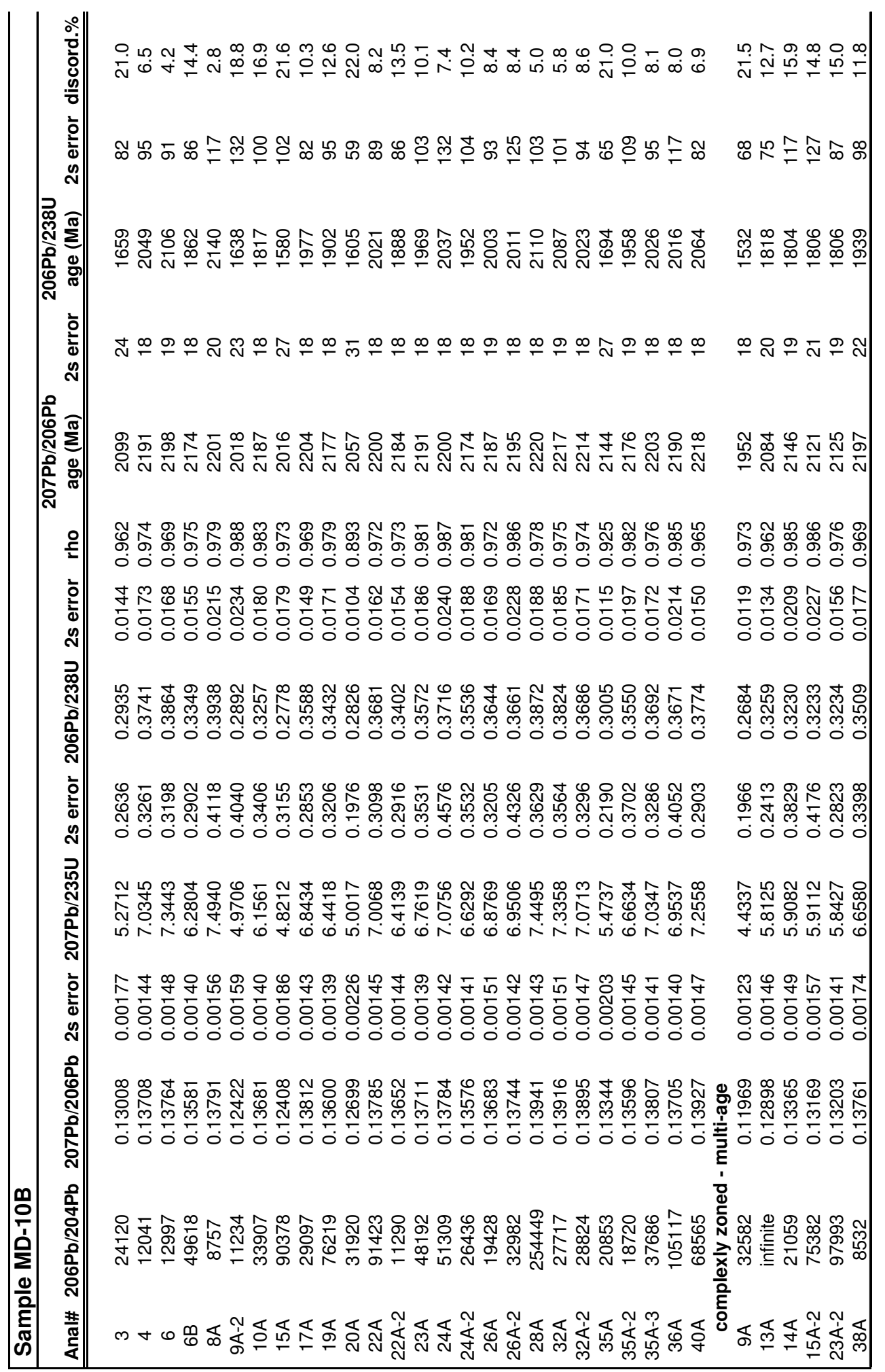

Table 2. U-Pb zircon LA-MC-ICPMS data from biotite monzogranite clast MD-10B (Boturuna Formation, São Roque Group). 
Sm-Nd DATA

$\mathrm{Sm}-\mathrm{Nd}$ isotope data were obtained from six representative samples of the main clast varieties of the Morro Doce metaconglomerate, all from outcrop MD-01. Results are listed in Table 3 and illustrated in Figure 5. Given a 2.2 Ga magmatic crystallization age, $\varepsilon_{\mathrm{Nd}(\mathrm{t})}$ values are all negative and appear to cluster between values from -3.1 to -4.3 ; an exception is the inequigranular granite sample MD-01D that is characterized by a more negative value of -6.7. The metarkose framework is slightly less negative $\left(\varepsilon_{\mathrm{Nd}(\mathrm{t})}=\right.$ -2.3), suggesting contribution from a distinct source, perhaps of mafic character, a feature also suggested by whole-rock chemistry (Henrique-Pinto and Janasi, 2010). Interestingly, the amphibolite clast does not seem to equate to this same source since its $\varepsilon_{\mathrm{Nd}(\mathrm{t})}(-3.6)$ at $\mathrm{t}=2.2 \mathrm{Ga}$ is within the same range for most of the granite clasts.

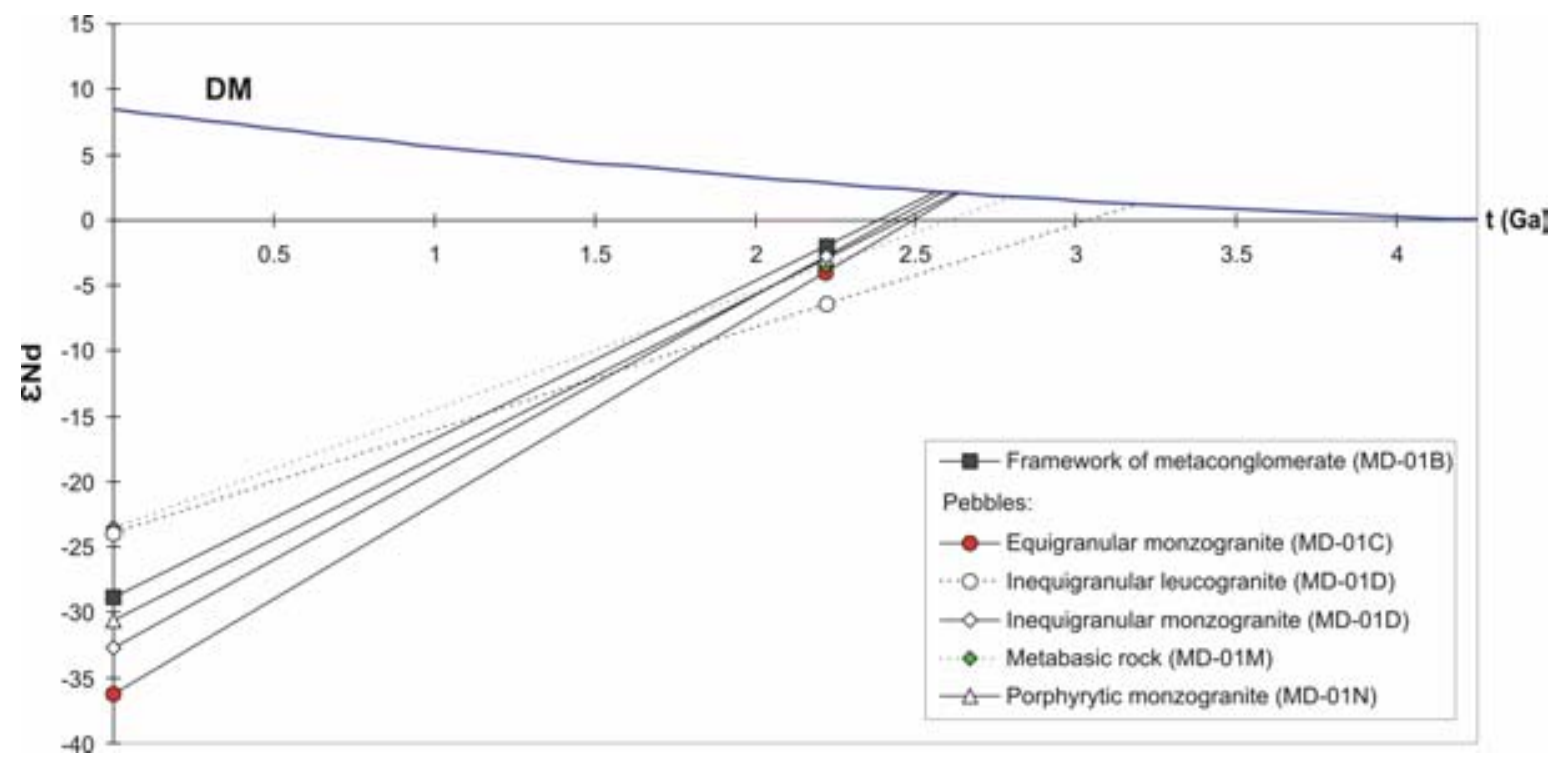

Figure 5. $\varepsilon_{\mathrm{Nd}}$ versus $\mathrm{t}(\mathrm{Ga})$ diagram of main granite clasts of Boturuna Formation. DM: evolution line of the depleted mantle (De Paolo, 1988).

The Sm-Nd $\mathrm{T}_{\mathrm{DM}}$ ages of the granitic clasts and the metarkose framework cluster at 2.6 to $2.7 \mathrm{Ga}$ (Figure 5), combined with the inherited age (2694 $\pm 29 \mathrm{Ma})$ reported in sample MD-01C, reinforces the idea that these granites are products of remelting a $\sim 2.7$ $\mathrm{Ga}$ crustal component. The older $\mathrm{T}_{\mathrm{DM}}$ age (3.2 Ga, Table 3) defined by the inequigranular leucogranite MD-01D can be a reflection of its higher ${ }^{147} \mathrm{Sm} /{ }^{144} \mathrm{Nd}$ ratio (0.135), and may result from LREE fractionation during magma evolution (Henrique- 
Pinto and Janasi, 2010). Hence, this older $\mathrm{T}_{\mathrm{DM}}$ age most probably does not have any geological significance. The ${ }^{147} \mathrm{Sm} /{ }^{144} \mathrm{Nd}$ ratio of the metabasic clast $(0.126)$ is typical for this rock type, its $\mathrm{T}_{\mathrm{DM}}$ age $(2.8 \mathrm{Ga})$ is slightly older than those of the typical granite clasts.

\begin{tabular}{|llccccccccc|}
\hline \multirow{2}{*}{ Samples } & \multicolumn{1}{c}{ Clasts } & $\mathbf{S m}$ & $\mathbf{N d}$ & $\mathbf{1 4 7 5 m} /$ & Error & $\mathbf{1 4 3 N d} /$ & Error & TDM & $\boldsymbol{\varepsilon}_{(\mathbf{0})}$ & $\boldsymbol{\mathcal { E }}_{(\mathbf{t})}$ \\
\cline { 2 - 10 } & & $\mathbf{p p m})$ & $\mathbf{( p p m )}$ & $\mathbf{1 4 4 N d}$ & $\mathbf{1 4 4 N d}$ & & $\mathbf{( G a )}$ & & \\
\hline MD-01B & Metarkose framework & 5.856 & 34.745 & 0.1019 & 0.0006 & 0.511160 & 0.000011 & 2.6 & -28.84 & -2.25 \\
MD-01C & Equigranular granite & 5.752 & 42.047 & 0.0827 & 0.0005 & 0.510779 & 0.000008 & 2.7 & -36.27 & -4.30 \\
MD-01D & Inequigranular leucogranite & 1.900 & 8.514 & 0.1349 & 0.0008 & 0.511409 & 0.000012 & 3.2 & -23.98 & -6.66 \\
MD-01E & Inequigranular granite & 6.005 & 39.859 & 0.0911 & 0.0005 & 0.510961 & 0.000012 & 2.6 & -32.71 & -3.09 \\
MD-01M & Metabasic rock & 1.261 & 6.063 & 0.1257 & 0.0007 & 0.511431 & 0.000014 & 2.8 & -23.55 & \\
MD-01N & Porphyritic granite & 7.629 & 46.601 & 0.0990 & 0.0006 & 0.511068 & 0.000010 & 2.6 & -30.62 & -3.22 \\
\hline
\end{tabular}

$\mathrm{t}=2.2 \mathrm{Ga}$, the crystallization age of the granite clasts;TDM according to DePaolo (1988)

Table 3. Sm-Nd isotope data for clasts and framework of metaconglomerate MD-01 (Boturuna Formation, São Roque Group).

\section{DISCUSSION}

The metaconglomerates from the Boturuna Formation (basal unit of SRG) are part of the detrital sedimentary sequences indicating proximal sources, as identified by the presence of pebbles and boulders supported by an arkosean framework. Thus, these rocks have an excellent potential for characterizing the main source for the SRG.

$\mathrm{U}-\mathrm{Pb}$ dating by LA-MC-ICP-MS of zircons extracted from predominantly equigranular monzogranites clasts within the Morro Doce and Morro do Polvilho regions indicate Paleoproterozoic ages for magmatic crystallization $(2199 \pm 9 \mathrm{Ma}$ and $2247 \pm 13$ Ma, respectively). Even taking into account the $\sim 10 \mathrm{Ma}$ uncertainties associated with each date, the ca. $50 \mathrm{Ma}$ difference between the two ages is suggestive that these clasts, although very similar in petrography and chemistry, are not strictly comagmatic, i.e., do not derive from exactly the same source.

The polycyclic history of the zircons is reinforced by the presence of inherited grains found in the clast MD-01B in the Morro Doce occurrence $(2694 \pm 29 \mathrm{Ma})$. Furthermore, both dated clasts were also affected by a neoproterozoic event, as indicated by lower intercept dates in the 530 to $640 \mathrm{Ma}$ range. Although imprecise, the latter dates can be attributed to the important thermal event of metamorphism and intrusion of large amounts of granitic plutons that affected the Apiaí-São Roque 
Domain and the Socorro-Guaxupé Nappe, which together correspond to the reworked border of the Paranapanema Craton (Campos Neto, 2000).

The ages of the granite clasts are not documented in basement granitic rocks that occur at the Southwestern margin of São Francisco craton, which are typically slightly younger and range between 2020 and $2140 \mathrm{Ma}$ (Campos Neto et al., 2004). Similar ages are found in the basement of Espinhaço Supergroup in Eastern São Francisco Craton (Mineiro Belt; Teixeira et al., 2008). However, correlation with some parts of the São Francisco Craton seems improbable, since the Apiaí-São Roque Domain is thought to belong to a different paleocontinent (Paranapanema). It seems more probable, therefore, that equivalents are present in the basement of the Açungui Supergroup as exposed in the Tigre, Setuva and Betari nuclei, where orthogneisses of similar age are described (Kaulfuss, 2001; Cury et al., 2002; Siga Jr. et al., 2007). Remarkably, the latter are intruded by younger $(\sim 1.75 \mathrm{Ga})$ syenogranitic orthogneisses, which are considered to represent an extensional tectonic event (Kaulfuss, 2001; Siga Jr. et al., 2011) that is possibly equivalent to the one that generated the bimodal metavolcanic sequence of within-plate geochemical signature described in the SRG (Henrique-Pinto and Janasi, 2010).

$\mathrm{Sm}-\mathrm{Nd}$ isotope data from the main clast varieties from the Morro Doce metaconglomerates yield $\mathrm{T}_{\mathrm{DM}}$ ages of 2.6 to $2.7 \mathrm{Ga}$, indicating that these granites are the recycling products of an Archean crust; an interpretation that is corroborated with the presence of an inherited zircon dated at $\sim 2.7 \mathrm{Ga}$. The metaconglomerate arkosean framework yields slightly lower $\varepsilon_{\mathrm{Nd}(\mathrm{t})}$ values compared to the clasts, therefore younger and/or more mafic source may contribute to the Boturuna Formation. This is in agreement with the geochemical signature of the associated metarkoses since a mafic igneous input was identified based on the whole-rock geochemistry (Henrique-Pinto and Janasi, 2010).

\section{REFERENCES}

BERGMANN, M. Caracterização Estratigráfica e Estrutural da Seqüência VulcanoSedimentar do Grupo São Roque na Região de Pirapora do Bom Jesus - Estado de São Paulo. 1988. Dissertação de Mestrado - Instituto de Geociências, Universidade de São Paulo, São Paulo. 
BERGMANN, M.; FAIRCHILD, T.R. Estromatólitos do Grupo São Roque, Proterozóico Superior, Região de Pirapora de Bom Jesus, Estado de São Paulo. Anais da Academia Brasileira de Ciências, v. 57, n. 1, p. 116-117, 1985.

BISTRICHI, C.A. Geologia do Sinclinório de Pirapora, SP. 1982. Dissertação de Mestrado - Instituto de Geociências, Universidade de São Paulo, São Paulo.

CAMPOS NETO, M.C.; BASEI, M.A.S; ARTUR, A.C.; SILVA, M.E.; MACHADO, R.; DIAS NETO, C.M.; FRAGOSO CESAR, A.R.; SOUZA, A.P. Geologia das Folhas

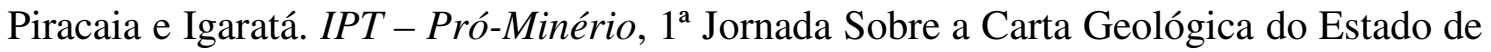
São Paulo em 1: 50,000. 1983, p. 55-76.

CAMPOS NETO, M.C. Orogenic Systems From Southwestern Gondwana: an Approach to Brasiliano-Pan African Cycle and Orogênic Collage in Southeastern Brazil. In: XXXI INTERNATIONAL GEOLOGICAL CONGRESS, 2000. Extended Abstracts, Rio de Janeiro, Brazil, 2000, p. 335-365.

CAMPOS NETO, M.C.; BASEI, M.A.S.; VLACH, S.R.F.; CABY, R.; SZABO, G.A.J.; VASCONCELOS, P. Migração de Orógenos e Superposição de Orogêneses: Um Esboço da Colagem Brasiliana no Sul do Cráton do São Francisco, SE-Brasil. Geologia USP: Série Científica, São Paulo, v. 4, p. 13-40, 2004.

CARNEIRO, C.D.R. Análise Estrutural do Grupo São Roque na Faixa entre o Pico do Jaraguá e a Serra dos Cristais, SP. 1983. Tese (Doutorado) - Instituto de Geociências, Universidade de São Paulo, São Paulo.

CORDANI, U.G.; CAMPOS, A.C.R.; DAVINO, A.; BJÖRNBER, A.J.S. Geologia da Região do Jaraguá. Boletim da Sociedade Brasileira de Geologia, São Paulo, v. 10, n. 20, p. 73-91, 1961.

CORDANI, U.G.; GOMES, C.B.; GIRARDI, V.A.V. Rochas Cálcio-Silicatadas da Região de Perus, SP. Anais da Academia Brasileira de Ciências, v. 35, n. 3, p. 361-372, 1963.

COUTINHO, J.M.V. Metaconglomerado e rochas associadas no Município de São Paulo. Boletim Faculdade de Filosofia Ciências e Letras, Universidade de São Paulo, São Paulo, v. 186, Mineralogia 13, p. 5-56, 1955.

COUTINHO, J.M.V.; RODRIGUES, E.P.; SUEMITSU, A.; JULIANI. C.; BELJAVSKIS, P.; PAULO, T.Y.P. Geologia e Petrologia da Seqüência VulcanoSedimentar do Grupo São Roque na Serra de Itaberaba - SP. In: XXXII CONGRESSO BRASILEIRO DE GEOLOGIA, Salvador, Anais, v. 2, 1982, p. 624-640. 
CURY, L.F.; KAULFUSS, G.A.; SIGA JR., O.; BASEI, M.A.S.; HARARA, O.M.; SATO, K. Idades U-Pb (Zircões) de 1.75 Ga em Granitóides Alcalinos Deformados dos Núcleos Betara e Tigre: Evidências de Regimes Extensionais do Estateriano na Faixa Apiaí. Geologia USP, Série Científica, v. 2, p. 95-108, 2002.

DANTAS, A.S.L. Geologia da Faixa São Roque e Intrusivas Associadas na Região entre São Paulo e Mairiporã, Norte de São Paulo. 1990. Dissertação de Mestrado Instituto de Geociências, Universidade de São Paulo, São Paulo.

DEPAOLO, D.J. Neodymium Isotope Geochemistry. An Introduction. Springer, Berlin, 1988. $187 \mathrm{p}$.

DERBY, O.A. Relatório acerca dos estudos geológicos praticados nos Valles do rio das Velhas e alto S. Francisco. Apresentado ao Conselheiro Manoel de Araújo, 29 de março, 1882. Typographia Nacional, Rio de Janeiro.

FERNANDES DA SILVA, P.C. Litofácies e Prováveis Ambientes de Sedimentação do Grupo São Roque na Região de Votorantim e Salto de Pirapora, SP. Revista do Instituto Geológico, São Paulo, v. 25, n. 1/2, p. 29-48, 2004.

FIGUEIREDO, M.C.H.; BERGMANN, M.; PENALVA, F.; TASSINARI, C.C.G. Ocorrência de pillow-lavas no Grupo São Roque, Estado de São Paulo. Revista Ciências da Terra, v. 2, p. 6-8, 1982.

GOMES, C.B. Contribuição ao Conhecimento dos Anfibolitos da Região do Jaraguá, SP. Boletim Sociedade Brasileira de Geologia, São Paulo, v. 11, n. 1, p. 57-73, 1962.

HACKSPACHER, P.C.; DANTAS, E.L.; GODOY, A.M.; OLIVEIRA, M.A.F.; FETTER, A.; VAN SCHMUS, W.R. Considerations About the Evolution of the Ribeira Belt in the São Paulo State - Brazil, From U/Pb Geochronology in Metavolcanic Rocks of the São Roque Group. In: II SOUTH AMERICAN SYMPOSIUM ON ISOTOPE GEOLOGY. Cordoba, Argentina, Actas, 1999, p. 310-313.

HACKSPACHER, P.C.; DANTAS, E.L.; SPOLADORE, A.; FETTER, A.H.; OLIVEIRA, M.A.F. Evidence for Neoproterozoic back-arc basin development in the Central Ribeira Belt, southeastern Brazil: new geochronological and geochemical constraints from the São Roque-Açungui Groups. Revista Brasileira de Geociências, v. 30, p. 110-114, 2000.

HASUI, Y. Considerações Sobre a Estratigrafia do Pré-Cambriano na Região de São Paulo. Boletim Instituto de Geociências, Universidade de São Paulo, São Paulo, v. 7, p. 107-112, 1976. 
HENRIQUE-PINTO, R. Metaconglomerados e Rochas Associadas do Grupo São

Roque a Noroeste da Cidade de São Paulo: Proveniência e Implicações para a Idade da Sedimentação. 2008. Dissertação de Mestrado - Instituto de Geociências, Universidade de São Paulo, São Paulo.

HENRIQUE-PINTO, R.; JANASI, V.A. Metaconglomerados e Rochas Associadas do Grupo São Roque a Norte da Cidade de São Paulo, Brasil. Revista Brasileira de Geociências, v. 40, n. 3, p. 409-425, 2010.

INSTITUTO DE PESQUISAS TECNOLÓGICAS - IPT. Carta Geológica do Estado de São Paulo em Escala 1:50.000. Secretaria da Indústria, Comércio, Ciência e Tecnologia, Pró-Minério, 1983.

JULIANI, C.; BELJAVSKIS, P.; SCHORSCHER, H.D. Petrogênese do Vulcanismo e Aspectos Metalogenéticos Associados: Grupo Serra do Itaberaba na Região do São Roque - SP. In: XXXIV CONGRESSO BRASILEIRO DE GEOLOGIA, Goiânia. Anais 2, 1986. p. 730-745.

JULIANI, C. Geologia, Petrogênese e Aspectos Metalogenéticos dos Grupos Serra do Itaberaba e São Roque na Região das Serras do Itaberaba e Pedra Branca, NE da Cidade de São Paulo, SP. 1993. 2 v. Tese (Doutorado) - Instituto de Geociências, Universidade de São Paulo, São Paulo.

JULIANI, C.; MARTIN, M.A.B.; CLARIMUNDO, S.J.; MCREATH, I.; PERTERSEN Jr. K.J. Geologia dos Grupos Serra do Itaberaba e São Roque entre o Pico do Jaraguá e Araçarigüama, São Paulo. In: SIMPÓSIO DE GEOLOGIA DO SUDESTE, SBG/NSPNRJ/ES Águas de São Pedro, Boletim de Resumos, 1999. v. 6, p. 26.

JULIANI, C.; HACKSPAKER, P.; DANTAS, E.L.; FETTER, A.H. The Mesoproterozoic volcano-sedimentary Serra do Itaberaba Group of the central Ribeira Belt, São Paulo, Brazil: implications for the age of the overlying São Roque Group. Revista Brasileira de Geociências, v. 30, p. 82-86, 2000.

KAULFUSS, G.A. Geocronologia dos Núcleos de Embasamento Setuva, Betara e Tigre, Norte de Curitiba-Paraná. 2001. Dissertação de Mestrado - Instituto de Geociências, Universidade de São Paulo, São Paulo.

LAZZARI, M.L. O Metabasito de Pirapora do Bom Jesus. 1987. Dissertação de Mestrado - Instituto de Geociências, Universidade de São Paulo, São Paulo. 
MANTOVANI, M.S.M.; BRITO NEVES, B.B. The Paranapanema Lithospheric Block:

Its Importance for Proterozoic (Rodinia, Gondwana) Supercontinent Theories. Gondwana Research, v. 8, p. 303-315, 2005.

MARTIN, M.A.B. Geologia e Petrografia e Metamorfismo dos Grupos Serra do Itaberaba e São Roque a Noroeste da Cidade de São Paulo (SP). 2000. Dissertação de Mestrado - Instituto de Geociências, Universidade de São Paulo, São Paulo.

ODMAN, O.H. A Pre-Cambrian Conglomerate With Pebbles of Deep-Seated Rocks Near São Paulo, Brazil. Engenharia, Mineração e Metalurgia, v. 21, n. 121, p. 32, 1955.

OLIVEIRA, M.A.F.; MELO, R.P.; NARDY, A.J.R.; ARAB, P.B.; TRINDADE, I. New $\mathrm{U} / \mathrm{Pb}$ Palaeoproterozoic Zircon Age For The Cajamar Metabasite, São Roque Group, Central Ribeira Belt, Southeastern Brazil. In: VI SOUTH AMERICAM SYMPOSIUM ON ISOTOPE GEOLOGY. San Carlos de Bariloche, Argentina, 2008. p. 1-4.

SATO, K.; TASSINARI, C.C.G.; KAWASHITA, K.; PETRONILHO, L. Método geocronológico Sm- Nd no IG-USP e suas aplicações. Anais da Academia Brasileira de Ciências, v. 67, n. 3, p. 315-336, 1995.

SIGA Jr O.; BASEI, M.A.S.; PASSARELLI, C.R.; HARARA, O.M.; SATO, K.; CURY, L.F.; PRAZERES FILHO, H.J. Geocronologia das Rochas GnáissicoMigmatíticas e Sienograníticas do Núcleo Setuva (PR): implicações tectônicas. Revista Brasileira de Geociências, v. 37, n. 1, p. 114-128, 2007.

SIGA Jr O.; CURY, L.F.; McREATH, I.; RIBEIRO, L.M.A.L.; SATO, K.; BASEI, M.A.S.; PASSARELLI, C.R. Geology and geochronology of the Betara region in southsoutheastern Brazil: Evidence for possible Statherian (1.80-1.75 Ga) and Calymmian (1.50-1.45 Ga) extension events. Gondwana Research, v. 19, n. 1, p. 260-274, 2011.

SIMONETTI, A.; HEAMAN, L.M.; HARTLAUB, R.P.; CREASER, R.A.; MACHATTIE, T.G. U-Pb Zircon Dating by Laser Ablation-MC-ICP-MS Using a New Multiple Ion Counting Faraday Collector Array. Journal of Analytical Atomic Spectrometry, v. 20, p. 677-686, 2005.

TASSINARI, C.C.G. As Idades das Rochas e dos Eventos Metamórficos da Porção Sudeste do Estado de São Paulo e sua Evolução Crustal. 1988. Tese (Doutorado) Instituto de Geociências, Universidade de São Paulo, São Paulo. 
TASSINARI, C.C.G.; KAWASHITA, K.; KIKUCHI, R.K.P. Estudo Geocronológico nos Metaconglomerados do Grupo São Roque, Estado de São Paulo. In: X SIMPÓSIO REGIONAL DE GEOLOGIA, São Paulo, Boletim de Resumos, 1985, v. 1, p. 201-208. TASSINARI, C.C.G.; MUNHÁ, J.M.U.; CORREIA, C.T. Neoproterozoic Oceans in the Ribeira Belt (southeastern Brazil): The Pirapora do Bom Jesus Ophiolitic Complex. Episodes, v. 24, n. 4), p. 245-251, 2001.

TEIXEIRA, W.; ÁVILA, A.C.; NUNES, L.C. Nd-Sr Isotopic Geochemistry and U-Pb Geocronology of the Fé Granitic Gneiss and Lajedo Granodiorite: Implications for Paleoproterozoic Evolution of the Mineiro Belt, Southern São Francisco Craton, Brazil. Geologia USP: Série Científica, São Paulo, v. 8, n. 1, p. 53-74, 2008.

VAN SCHMUS, W.R.; TASSINARI, C.C.G.; CORDANI, U.G. Estudo Geocronológico da Parte Inferior do Grupo São Roque. In: XXXIV CONGRESSO BRASILEIRO DE GEOLOGIA, 34, Goiânia, Anais, 3 v, 1986, p. 1399-1406. 


\section{Apêndice - III}

(Provenance and sedimentation environments of the São Roque Group, Brazil: contributions from petrography, geochemistry and Sm-Nd isotopic systematics of metasediments) 


\title{
Provenance and sedimentation environments of the São Roque Group, Brazil: contributions from petrography, geochemistry and $\mathrm{Sm}-\mathrm{Nd}$ isotopic systematics of metasediments
}

\begin{abstract}
The São Roque Group corresponds to a Proterozoic sequence deposited in a marine environment consisting of of proximal (metasandstones and meta-felspathic wackes with some volcanic layers; Boturuna Formation) and more distal deposits (metawackes and metamudstones; Piragibu Formation). The main sources are dominantly Archean and Paleoproterozoic, and their compositions vary from granitic (responding for the LREE-rich moderately fractionated REE patterns and subtle negative Eu anomalies) to basic (responding for increases in the contents of $\mathrm{Fe}_{2} \mathrm{O}_{3}, \mathrm{MgO}, \mathrm{V}, \mathrm{Rb}$ and $\mathrm{Cr}$ ) and recycled mature quartzose (present as clasts in metaconglomerates). Sm-Nd isotope data for metamudstones (Piragibu Formation) show four main groups of $\mathrm{T}_{\mathrm{DM}}$ ages at $1.9 \mathrm{Ga}, 2.1 \mathrm{Ga}, 2.4 \mathrm{Ga}$ and $3.0 \mathrm{Ga}$. The positive $\varepsilon_{\mathrm{Nd}(1.75)}$ corresponds to youngest $\mathrm{Sm}-\mathrm{Nd} \mathrm{T}_{\mathrm{DM}}$ ages $(1.88-1.93 \mathrm{Ga})$ characterizing the sedimentation as younger than $\sim 1.9$ Ga. The samples with younger $\mathrm{T}_{\mathrm{DM}}$ must reflect greater contributions from younger sources, possibly including juvenile rocks. The oldest $\mathrm{Sm}-\mathrm{Nd} \mathrm{T}_{\mathrm{DM}}$ age $(3.0 \mathrm{Ga})$ is consistent with the $\mathrm{T}_{\mathrm{DM}}$ typical of granitic clasts from the Boturuna Formation metaconglomerates, which correspond to 2,2 Ga products of crust reworking, and of basement nuclei of the same age in the Apiaí-São Roque Domain. The main group of metamudstones with $\mathrm{Sm}-\mathrm{Nd}_{\mathrm{DM}}$ ages in the 2.2-2.6 Ga range may have as main sources mixtures between the same basement nuclei and rocks with less negative $\varepsilon_{\mathrm{Nd}}$ at $1.75 \mathrm{Ga}$ (the best estimate for their depositional age). The latter may include both the younger sources that are present in the few samples with lower $\mathrm{T}_{\mathrm{DM}}$ and juvenile 2.2-2.4 Ga granitic sources, so far not recognized in the basement nuclei. Similar geochemical behavior, consistent with sediments deposited in passive margin basin, for both formations, suggests that these were coeval, probably with lateral correlation. However, the mudstones (Piragibu Formation) have Ce-depleted REE patterns compatible with clays from open sea, suggesting a more complex paleo-environment, probably with interaction between passive margin basin and additional volcanogenic source related to oceanic island arc.
\end{abstract}

Key words: provenance; São Roque Group; Nd signature; paleo-environment 


\section{Introduction}

The sedimentary provenance study started in the 19th century with the macroscopic investigation of heavy accessory minerals from recent sands. The mineralogical maturity of sands has been investigated since Krynine (1948), Dott (1964) and Folk (1974); initially, the fine-grained quartz-feldspar and lithic fragments (QFL) in sandstones were used to infer provenance and tectonic environments (Dickinson, 1970; Dickinson, 1985 Dickinson and Suczek, 1979).

Although the geochemistry of clastic metasedimentary rocks results from a complex interplay of several variables, including source rock compositions, intensity of weathering, sorting processes during transport and sedimentation, diagenetic reactions and metamorphism, they show a great potential for provenance studies and ensuing inferences for the paleo-environmental sedimentation (Bathia, 1983; Bathia and Taylor, 1981; Cullers et al., 1988; Floyd et al., 1989).

The use of geochemical and isotope tools for provenance has gained impetus in the last decades. It has been demonstrated that the source rocks and tectonic settings of sandstones may be inferred from the behaviour of trace elements with low mobility such as Th, Sc, REE etc (McLennan et al., 1993). When combined with U-Pb dating of detrital zircons it becomes a powerful tool in the study of sedimentary provenance (e.g., Ross et al., 2005).

Provenance studies of fine-grained sediments (shales and mudstones) are especially appealing, since these are the most abundant sedimentary rocks. Due to the difficulties of studying petrographically the fine-grained components, $\mathrm{Sm}-\mathrm{Nd}$ isotope data and traceelement ratios such as $\mathrm{Th} / \mathrm{Sc}$, combined with other isotope systems ( $\mathrm{Rb}-\mathrm{Sr}, \mathrm{Pb}-\mathrm{Pb})$, have proven to be important tools to determine the relative amount of silicic to basic rock contributions, as well as tectonic settings and secular trends in the crustal evolution (McLennan and Hemming, 1991; McLennan et al., 1990; McLennan et al., 1995).

The $\mathrm{Th} / \mathrm{Sc}, \mathrm{La} / \mathrm{Sc}, \mathrm{La} / \mathrm{Lu}$ ratios are higher in acid rocks, while elements as $\mathrm{Cr}, \mathrm{Ni}$, Sc are more concentrated in basic igneous rocks, (Cullers et al., 1987; Cullers and Berendsen, 1988; Cullers and Podkovyrov, 2002). Additionally, the size of the negative Eu anomalies in the provenance appears to be preserved in fine-grained sediments, and thus 
can be used as a provenance tool; for instance, basic igneous rocks contribute with slight or no $\mathrm{Eu}$ anomalies $\left(\mathrm{Eu} / \mathrm{Eu}^{*}\right)$.

The weathering breakdown of biotite, amphibole, pyroxene, olivine and opaque minerals results in clay minerals as smectite-vermiculite, while feldspars usually alter to kaolinite and illite. The intensity of the weathering process can be measured by the relation between Aluminium ("immobile" element) and mobile elements such as $\mathrm{Ca}, \mathrm{Na}$ and $\mathrm{K}$. The effects of chemical weathering can be measured by CIA-indice, with higher values indicating more intense chemical weathering (Nesbitt and Young, 1982 - 1989); Nesbitt et al., 1996; Nesbitt and Markovics, 1997).

Paleo-environmental reconstruction is a challenge for geological processes; however, taking into account the systematical weathering of the crust, which is responsible for the depletion of feldspar and ferromagnesian minerals generating new minerals, many authors have used these properties to study paleo-weathering in several geological sequences, from the Precambrian until the present day (Nesbitt and Young, 1982; Sawyer, 1986; Harnois, 1988; McLennan, 1993; Fedo et al., 1995; Nesbitt et al., 1996; Cullers, 2000; Bauluz et al., 2000; Bahlburg and Dobrzinski, 2009).

This work presents the results of a provenance study of low-grade metamorphic rocks of the Proterozoic São Roque Group (SRG), SE Brazil, using as main tools the petrographic, elemental geochemistry and Sm-Nd isotope geochemistry. Our previous works (Henrique-Pinto \& Janasi, 2010; Henrique-Pinto et al., 2012) dealt with the investigation of the paleoenvironment and provenance of metaconglomerates and associated metarkoses from exposures of the lower stratigraphic unit of the SRG in a restrict area (the Morro Doce region, NW of the city of São Paulo). Here we extend this study to a broader area that encompasses a large portion of the SRG exposures, including samples of meta-sandstones (which are the subject of a parallel provenance study using zircon chemistry and U-Pb dating; Henrique-Pinto et al., in prep.) and metapelitic rocks that make up most of the upper portion of the stratigraphically higher Piragibu Formation.

Even taking into account some ambiguities intrinsic to the use of provenance tools in some of sedimentary rocks, especially those that were subject to metamorphism, we believe our results bring important constraints on the nature of the source areas, intensity of weathering and environmental sedimentation during the deposition of the SRG. 


\section{Geological Setting}

The São Roque Domain in South Brazil is a tectonic block that is located between the high-metamorphic grade Socorro-Guaxupé Nappe (currently interpreted as related to the evolution of the southern branch of the Brasília Fold Belt), in the north, and the Embu Domain (related to the Ribeira Fold Belt), in the south (Fig. 1 -A). In the tectonic model presented by Campos Neto (2000), the São Roque Domain is part of a larger block dominated by meta-volcano-sedimentary sequences metamorphosed in low- to mediumgrade (the Apiaí-São Roque Domain) which, together with the Socorro-Guaxupé Nappe, corresponds to a magmatic arc domain developed at the border of an older cratonic nucleus that is mostly hidden beneath the Phanerozoic Paraná sedimentary basin (the Paranapanema Craton; Mantovani and Brito Neves, 2005).

Hennies et al. (1967) proposed that the Taxaquara Fault (Fig. 1-A) corresponds to an important boundary that separates two domains, São Roque (north) and Cotia (south). Recent studies (Campos Neto, 2000) have shown that the Caucaia Fault divides the Cotia Domain in two portions and can correspond to tectonic limit of higher order, separating the southern the Ribeira Fold Belt strictu sensu (locally represented by the Embu Domain) and the reworked margin of Paranapanema craton in the north (locally represented by the Apiaí Domain, intruded by the Agudos Grandes Granitic Batholith).

Hasui et al. (1976) suggested a two-fold stratigraphic division for the SRG. The basal Boturuna Formation is characterized by the predominance of meta-feldspathic wackes interfingered with polymictic metaconglomerates with pebbles and cobbles encased by metarkose framework (e.g., at the Morro Doce locality) and local metaquartzarenites which sustain some topographically higher regions (e.g., the Jaraguá Peak, near São Paulo Fig. 1-B). Small bodies of metavolcanic rocks occur in the sequence (Carneiro, 1983; Carneiro et al., 1984), as small lenses of basaltic trachyandesite intercalated with the meta-feldspahtic wackes and porphyritic meta-trachydacite, locally associated with metaconglomerates (e.g., in the Morro do Polvilho region). The volcanism in the Boturuna Formation is bimodal and has a within-plate geochemical signature (metatrachydacites with low mg\#, high $\mathrm{Zr}, \mathrm{Y}, \mathrm{Nb}$, and low $\mathrm{Sr}$; Henrique-Pinto and Janasi, 2010). A 1.75-1.80 Ga depositional age seems well established from U-Pb zircon dating

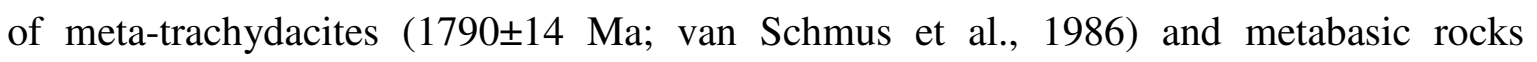


(metamicrogabbro with clinopyroxene relics and preserving an intergranular texture) in

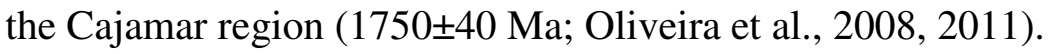

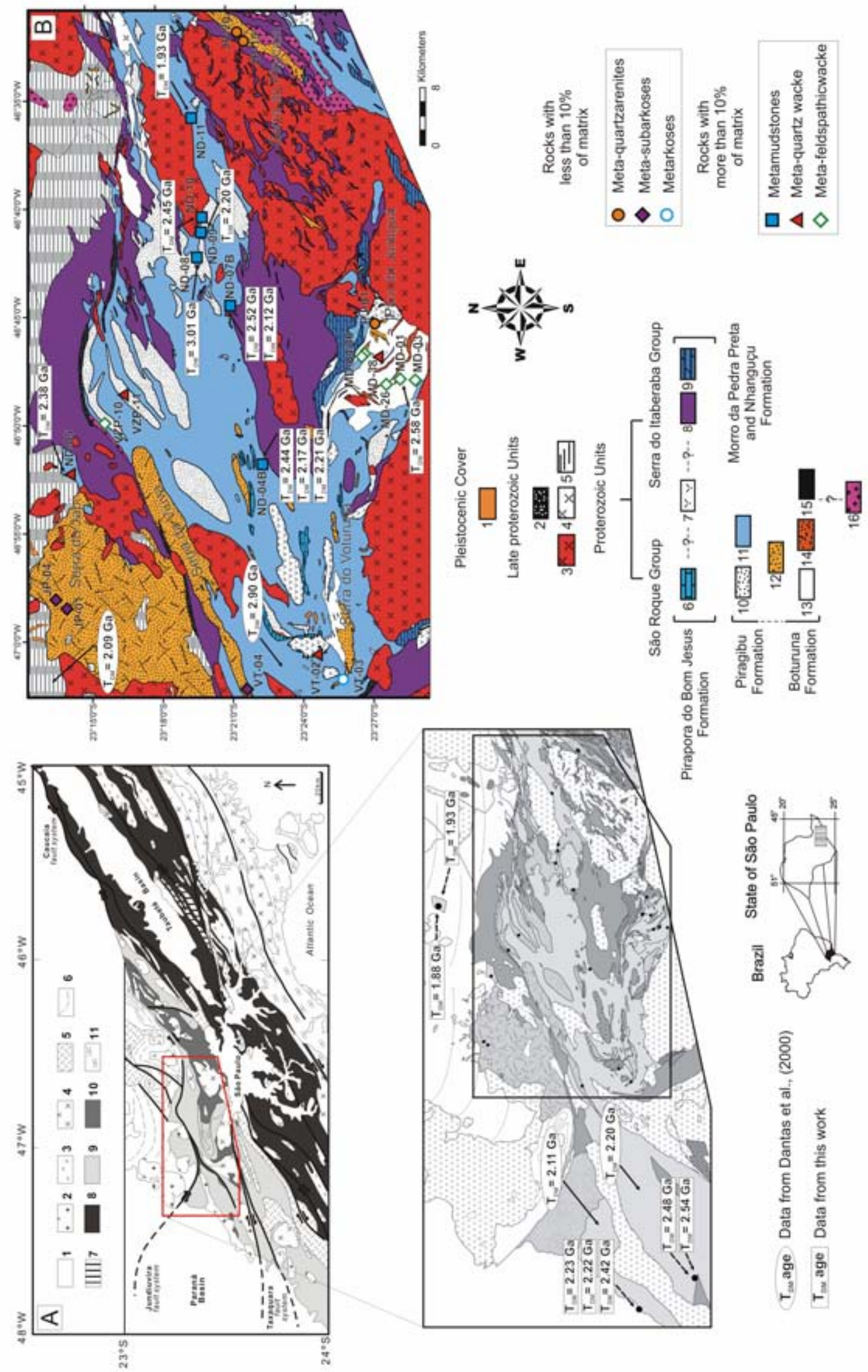


Figure 1: (A)- Regional geological map modified from Campos Neto (2000). 1- Phanerozoic sedimentary and associated Mesozoic intrusive rocks (Paraná Basin); 2- Neoproterozoic late and post-orogenic granites; 3- (Garnet)-(Muscovite)-Biotite Granites; 4- Biotite Porphyritic Granites; 5- (Hornblende) Biotite porphyritic granites; 6- Socorro Guaxupé Domain (with predominance of garnet-bearing migmatites); 7- Embu Domain: basement Paleoproterozoic gneisses; 8- Embu Domain: cover metasupracrustal rocks; 9- Apiaí-São Roque Domain: São Roque and Açungui Groups; 10- Serra do Itaberaba Group; 11- Costeiro Complex. (B)- Geological map of the central part of the São Roque Domain and neighboring southernmost Socorro-Guaxupé Domain. 1- São Paulo Basin (Pleistocene); 2- Neoproterozoic shear zones with milonites and ultramilonites; 3Indiferentiated granites (Neoproterozoic); 4- Qtz Sienites (Neoproterozoic); 5- Socorro-Guaxupé Domain (paragneisses and migmatites); 6- Pirapora do Bom Jesus Formation (Metalimestones and metadolomites); 7= amphibolites, metatuffs and BIFs (Pirapora do Bom Jesus Formation/Serra do Itaberaba Group (?)) ; 8-9- Serra do Itaberaba Group (8= Kyanite-staurolite schists; $9=$ calc-silicate rocks and tremolite marbles); 10-15- São Roque Group (10= metawackes; 11= metamudstones; $12=$ meta-quartzarenites and meta-subarkoses; $13=$ meta-feldspathic wackes and metaquartzwackes; 14= metaconglomerates; 15= acid metavolcanic rocks); 16- Basement (?) orthogneisses. Compiled from IPT (1983), Dantas (1990), Bergmann (1988), Juliani (1993), Neves (2005) and Serviço Geológico do Brasil - CPRM (2006).

The upper Piragibu Formation is composed of a rhythmic sequence with predominance of meta-mudstones interbedded with metawackes, which possibly corresponds to turbidity current deposits in a marine environment (Carneiro, 1983; Campos Neto et al., 1983; Dantas, 1990; Silva, 2004).

Later stratigraphic studies by Coutinho et al. (1982) recognized a distinctive volcano-sedimentary sequence which was recognized as a separate unit named Serra do Itaberaba Group (SIG) by Juliani et al. (1986) on the basis of its higher metamorphic grade (amphibolite-facies) and the proposed existence of an erosive contact marked by the presence of clasts and volcanic fragments derived from it in metaconglomerates from the basal portions of the SRG (Juliani, 1993; Martin, 2000). The SIG is composed of amphibolites, metatuffs, banded iron formation, calc-silicate rocks and tremolite marble (Morro da Pedra Preta Formation), detrital metapelites with predominance of staurolite schists (Nhanguçu Formation) and metapsammites (Pirucaia Formation). A meta-andesite interpreted to be a small intrusion linked to the beginning of sedimentation in the Serra do Itaberaba basin, located stratigraphically above the MORB-like metamafic unit 
(amphibolites and metatuffs), yielded a U-Pb zircon age of 1395 $\pm 10 \mathrm{Ma}$, interpreted as the maximum age of deposition (Juliani et al., 2000). On the light of the above constraints for the SRG, this age suggests that, in spite of the higher metamorphic grade, the SIG was deposited after the SRG Boturuna Fm, and therefore that the clasts found in the latter are not related to the SIG.

Another distinctive meta-volcano-sedimentary sequence is recognized in the Pirapora region (Bistrichi, 1982; Bergmann, 1988), and is dominated by tholeiitic metabasalts chemically similar to MORB (Lazzari, 1987; Tassinari et al., 2001) with local pillow-lava structures (Figueiredo et al., 1982) that are associated with pyroclastic rocks and meta-limestones showing well-preserved stromatolitic structures (Bergmann and Fairchild, 1985). This sequence was named Pirapora do Bom Jesus Formation by Bergmann (1988), who interpreted it as corresponding to passive margin volcanic centers surrounded by stromatolites. U-Pb zircon (608 $\pm 7 \mathrm{Ma})$ and monazite $(628 \pm 9 \mathrm{Ma})$ ages (Hackspacker et al., 1999 and 2000, respectively) were used to infer a Neoproterozoic age for this sequence. This age range ( 625-605 Ma) is coeval with the emplacement of large volumes of granite related to the "syn-orogenic" period of Neoproterozoic evolution (e.g., Agudos Grandes Batholith; Leite et al., 2007), and this led some authors (Hackspacker et al., 2000; Juliani et al., 2000) to interpret the sequence as a back-arc basin. Tassinari et al. (2000) interpreted this sequence as a slice of ophiolite, in view of expressive volume of basic magamatic activities with MORB signature and pillow-lavas structures, associated with maganetite/cromite talco schists mineralization.

The Jaraguá amphibolite body, outcropping in the Morro Doce region (Fig. 1-B), has geochemical affinities with the Pirapora metabasites and field relationships suggestive that it is intrusive into the Boturuna Fm; our unpublished LA-ICPMS U-Pb zircon data suggests a similar Neoproterozoic age.

\section{Sampling and analytical procedures}

The metasedimentary rock samples chosen for geochemical study were collected to assemble material representative of the existing variety in terms of grain size and mineralogical and textural maturity, targeting the best available exposures, in order to avoid, as far as possible, the effects of weathering, which are widespread in the region. 
The chemical analyses were preceded by petrographic studies and modal counting, for which 500 points were counted per thin section (Table 1).

\subsection{Whole-rock chemistry}

Chemical analyses were carried out at the Geoanalitica Core Research Center, Instituto de Geociências, Universidade de São Paulo, Brazil. Samples were crushed in a steel jawcrusher and subsequently in an agate disk mill. The concentration of the trace elements was determined by the previously sprayed compressed material in the form of pressed pellets, the concentration of major elements was quantified by melting the material previously sprayed followed by quenched pellets. Whole-rock major and trace element compositions were obtained by XRF spectrometry following the analytical protocol described in Mori et al. (1999). Rare earth elements (REE) and other trace-elements present in low amounts (typically $<100 \mathrm{ppm}$ ) were measured by inductively coupled plasma mass spectroscopy (ICP-MS) in a Perkin Elmer Plasma Quadrupole MS ELAN 6100DRC, following the analytical protocols described in Navarro et al. (2002). Samples were dissolved in pumps Parr type, in a high temperature $\left(\sim 200^{\circ} \mathrm{C}\right)$ at the oven for approximately five days, with the intention to ensure complete dissolution of ultra-stable minerals (eg., zircon). From $100 \mathrm{mg}$ of sample was added $5 \mathrm{~mL}$ of $\mathrm{HNO}_{3}$ and $15 \mathrm{ml}$ of $\mathrm{HF}$.

\subsection{Sm-Nd analyses}

$\mathrm{Sm}-\mathrm{Nd}$ isotope analyses of the same whole-rock powdered samples analyzed for elemental geochemistry were performed at the Centro de Pesquisas Geocronológicas (CPGeo), Instituto de Geociências, Universidade de São Paulo, Brazil, following the procedures described in Sato et al. (1995). Samples were dissolved in pumps at temperatures of $\sim 160^{\circ} \mathrm{C}$ for a period of ten days. For isotope separation steps were employed conventional cation exchange columns, filled with resin type AG 50 (200-400 mesh) using HCL and water in varying concentrations. The $\mathrm{Nd}$ isotopic ratios were obtained using a multi-collector Finnigan MAT-262 mass spectrometer, whereas the Sm isotopic ratios were obtained using a single collector VG-354 mass spectrometer. The average ${ }^{143} \mathrm{Nd} /{ }^{144} \mathrm{Nd}$ values measured for the La Jolla and BCR-1 Nd standards during the period of this study are $0.511849 \pm 0.000025$ and $0.512662 \pm 0.000027$, respectively. The 
maximum measured errors were $0.09 \%$ for the ${ }^{147} \mathrm{Sm} /{ }^{144} \mathrm{Nd}$ ratio and \pm 0.00002 for

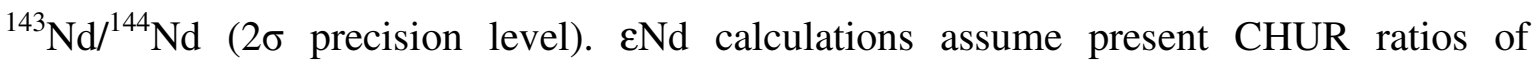
${ }^{143} \mathrm{Nd} /{ }^{144} \mathrm{Nd}=0.512638$ and ${ }^{147} \mathrm{Sm} /{ }^{144} \mathrm{Nd}=0.1967$. The decay constant used was $6.54 \times 10^{-}$ ${ }^{12}$ years $^{-1}$. $\mathrm{T}_{\mathrm{DM}}$ calculations are made using the method of DePaolo (1988). Details of the analytical protocol employed here are given in Sato et al. (1995).

\section{Petrography}

Modal counting allowed the classification of the metasediments (following Dott, 1964; McBride, 1963) in six subtypes (Fig. 2) using the compositional maturity, based on the proportion of quartz, feldspar and lithic fragments and the textural maturity, based on the proportion between framework (grains with sand size) and matrix (grains with silt and clay size).

The samples with greater sedimentary maturity $(<10 \%$ of matrix and $>75 \%$ of quartz) are classified as meta-quartzarenites and meta-subarkoses (Fig. 3A and B, respectively). These rocks in some cases lost the original sedimentary petrofabrics due to metamorfic orverprinting, reflecting the low competence of quartz during deformation.

The lowest compositional maturity (>25\% of feldspars) of metarkoses (Fig. 3-C) and meta-feldspathic wackes (Fig. 4-A) and the presence of angular to rounded plagioclase and alkali-feldspar in similar proportions, indicates that their main sources are of granitic composition; additionally, this sedimentary petrofabrics suggests short transport distances. Additional sources are preserved as lithic fragments of metabasic rocks and intraclasts of quartzarenite rocks, both always in small modal proportions (less than 1\%).

The metamudstones and meta-quartz wackes (Fig. 4-B) are characterized by low textural maturity and, although with more than $40 \%$ matrix, they are of high compositional maturity, with more than $70 \%$ quartz. These sub-types are mostly composed of very fine to fine-grained particles, as sub-angular to rounded grains, and often preserve the original petrofabrics, as in the case of metamudstones, which preserve plane-parallel layering with clay-rich and quartz-rich bands (Fig. 4C). 


\begin{tabular}{|c|c|c|c|c|c|c|c|c|}
\hline & \#Samples & Petrography Classification & quartz & feldspar & fine muscovite & accessory & framework \% & matrix \% \\
\hline \multirow{7}{*}{ ARENITES } & PJ-01 & Meta-quartzarenite & 459 & & 36 & 5 & 92.80 & 7.20 \\
\hline & JP-19 & Meta-quartzarenite & 440 & 25 & 27 & 8 & 94.60 & 5.40 \\
\hline & JP-20 & Meta-quartzarenite & 443 & 22 & 31 & 4 & 93.80 & 6.20 \\
\hline & |JP-01 l l l & Meta-subarkose & 354 & 109 & 28 & 9 & 94.40 & 5.60 \\
\hline & VT-04 & Meta-subarkose & 397 & 43 & 50 & 10 & 90.00 & 10.00 \\
\hline & JP-04 & Meta-subarkose & 356 & 56 & 54 & 34 & 89.20 & 10.80 \\
\hline & VT-03 & Metarkose & 350 & 115 & 30 & 5 & 94.00 & 6.00 \\
\hline \multirow{10}{*}{ WACKES } & MD-03a & Meta-feldspathic wacke & 257 & 106 & 94 & 43 & 81.20 & 18.80 \\
\hline & MD-04a & Meta-feldspathic wacke & 246 & 89 & 164 & 1 & 67.20 & 32.80 \\
\hline & MD-26b & Meta-feldspathic wacke & 258 & 105 & 134 & 3 & 73.20 & 26.80 \\
\hline & MD-36 & Meta-feldspathic wacke & 245 & 80 & 159 & 16 & 68.20 & 31.80 \\
\hline & MD-01b & Meta-feldspathic wacke & 228 & 79 & 193 & 0 & 61.40 & 38.60 \\
\hline & VT - 02 & Meta-feldspathic wacke & 174 & 75 & 251 & 0 & 49.80 & 50.20 \\
\hline & VZP-10 & Meta-feldspathic wacke & 131 & 7 & 329 & 33 & 34.20 & 65.80 \\
\hline & MD-38 & Meta-quartz wacke & 187 & 69 & 224 & 20 & 55.20 & 44.80 \\
\hline & ND-05A & Meta-quartz wacke & 179 & 8 & 302 & 11 & 39.60 & 60.40 \\
\hline & VZP-11 & Meta-quartz wacke & 181 & 3 & 306 & 10 & 38.80 & 61.20 \\
\hline \multirow{9}{*}{ MUDSTONES } & ND-09 & Metamudstone & 105 & 5 & 378 & 12 & 24.40 & 75.60 \\
\hline & ND-07A & Metamudstone & 94 & 7 & 392 & 7 & 21.60 & 78.40 \\
\hline & ND-06B & Metamudstone & 96 & 10 & 380 & 14 & 24.00 & 76.00 \\
\hline & ND-03C & Metamudstone & 117 & 2 & 375 & 6 & 25.00 & 75.00 \\
\hline & ND-03B & Metamudstone & 90 & 1 & 386 & 23 & 22.80 & 77.20 \\
\hline & ND-10 & Metamudstone & 115 & & 375 & 10 & 25.00 & 75.00 \\
\hline & ND-02B & Metamudstone & 70 & 4 & 376 & 50 & 24.80 & 75.20 \\
\hline & ND-08 & Metamudstone & 108 & 6 & 377 & 9 & 24.60 & 75.40 \\
\hline & ND-04A & Metamudstone & 106 & 11 & 375 & 8 & 25.00 & 75.00 \\
\hline
\end{tabular}

Table 1: Modal mineralogy of metasediments of São Roque Group (Counted 500 points per section).

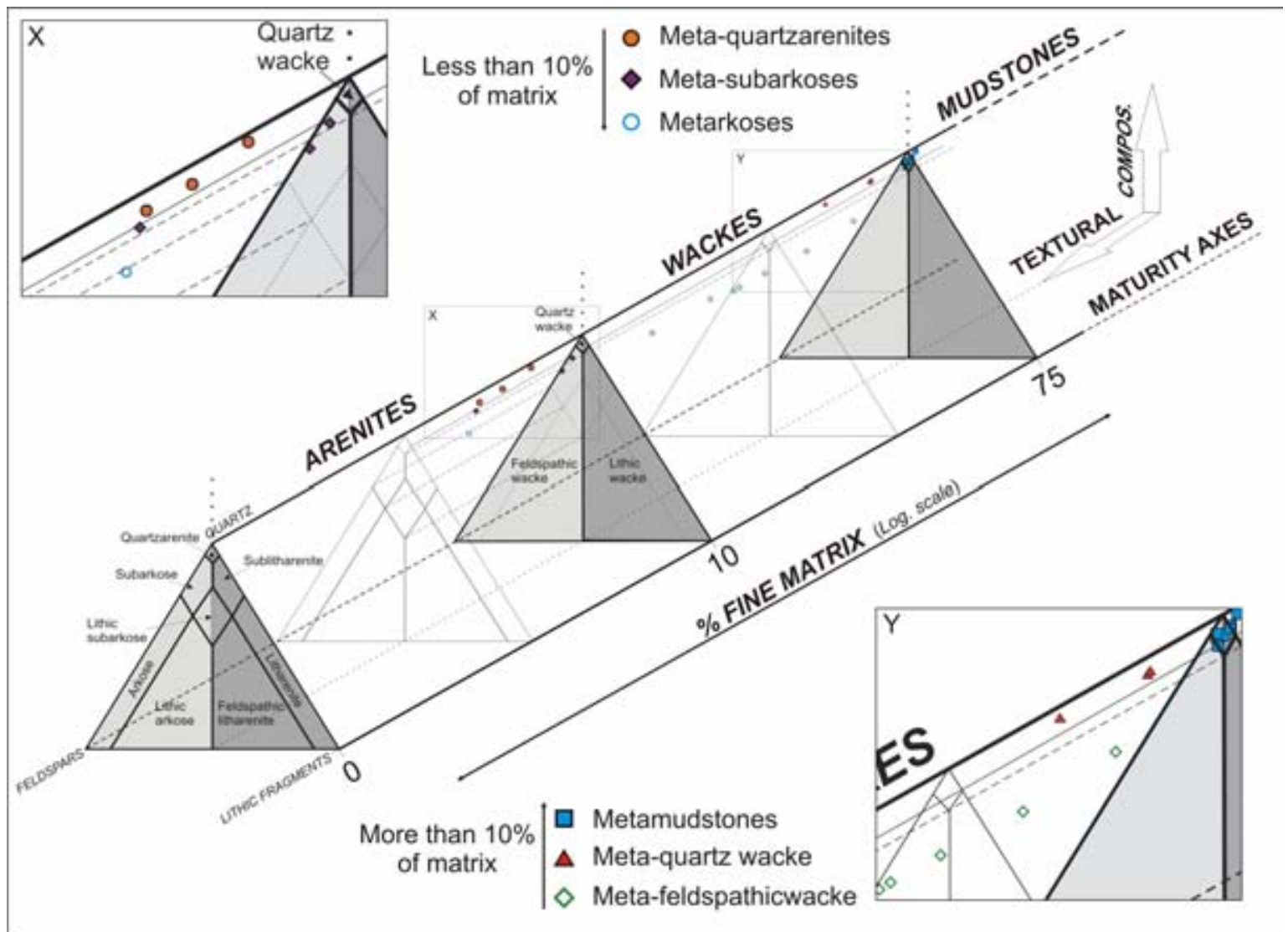

Figure 2: Ternary diagram (QFL) $Q=$ quartz, $F=$ feldspar, $L=$ lithic fragments for São Roque Group metasediments; fields after Dott (1964) and McBride (1963). 


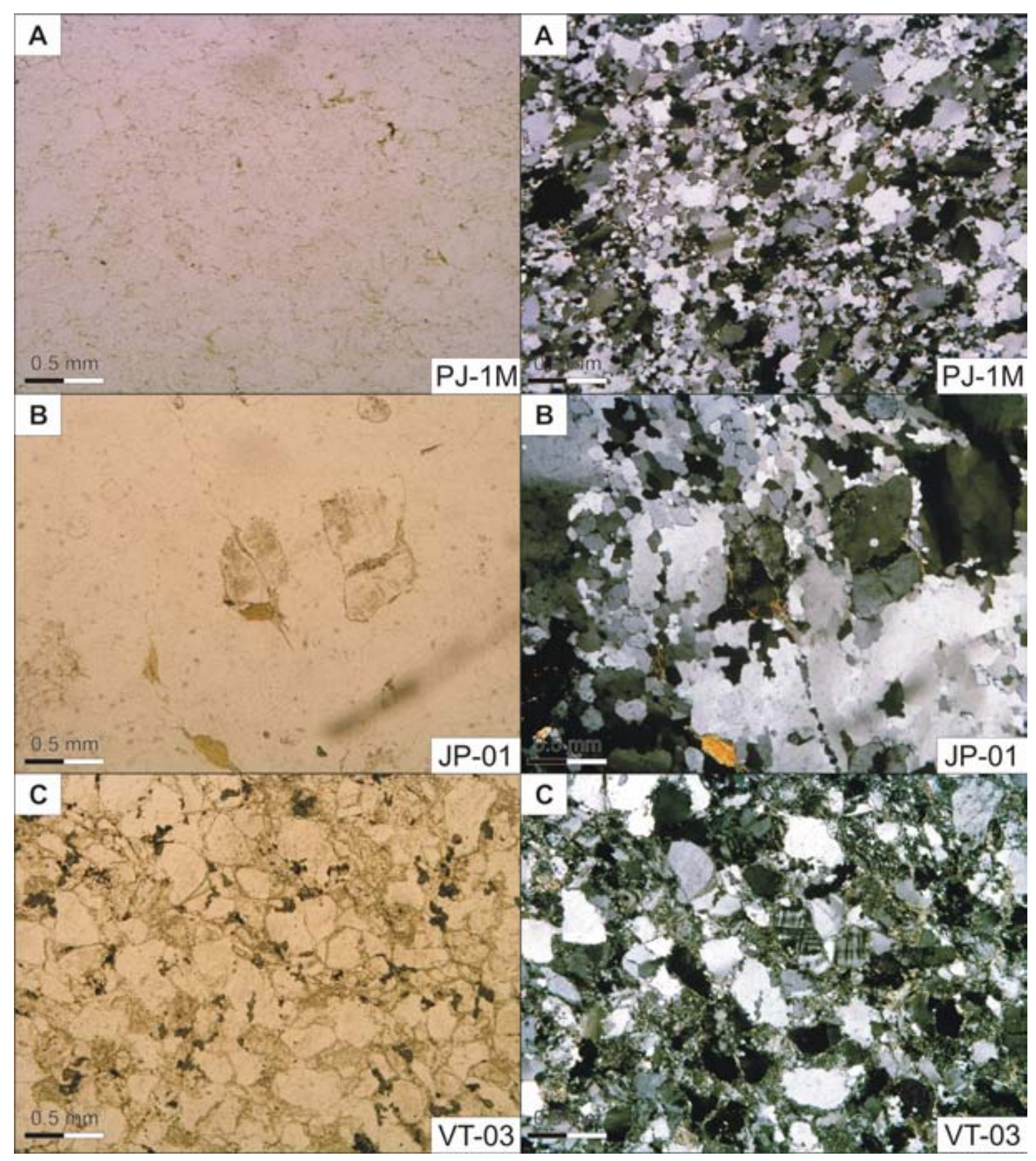

Figure 3: Photomicrographs of São Roque Group metasediments: A- meta-quartzarenites; Bmeta-subarkoses; C- metarkoses (left, parallel polarizers; right, crossed polarizers). 


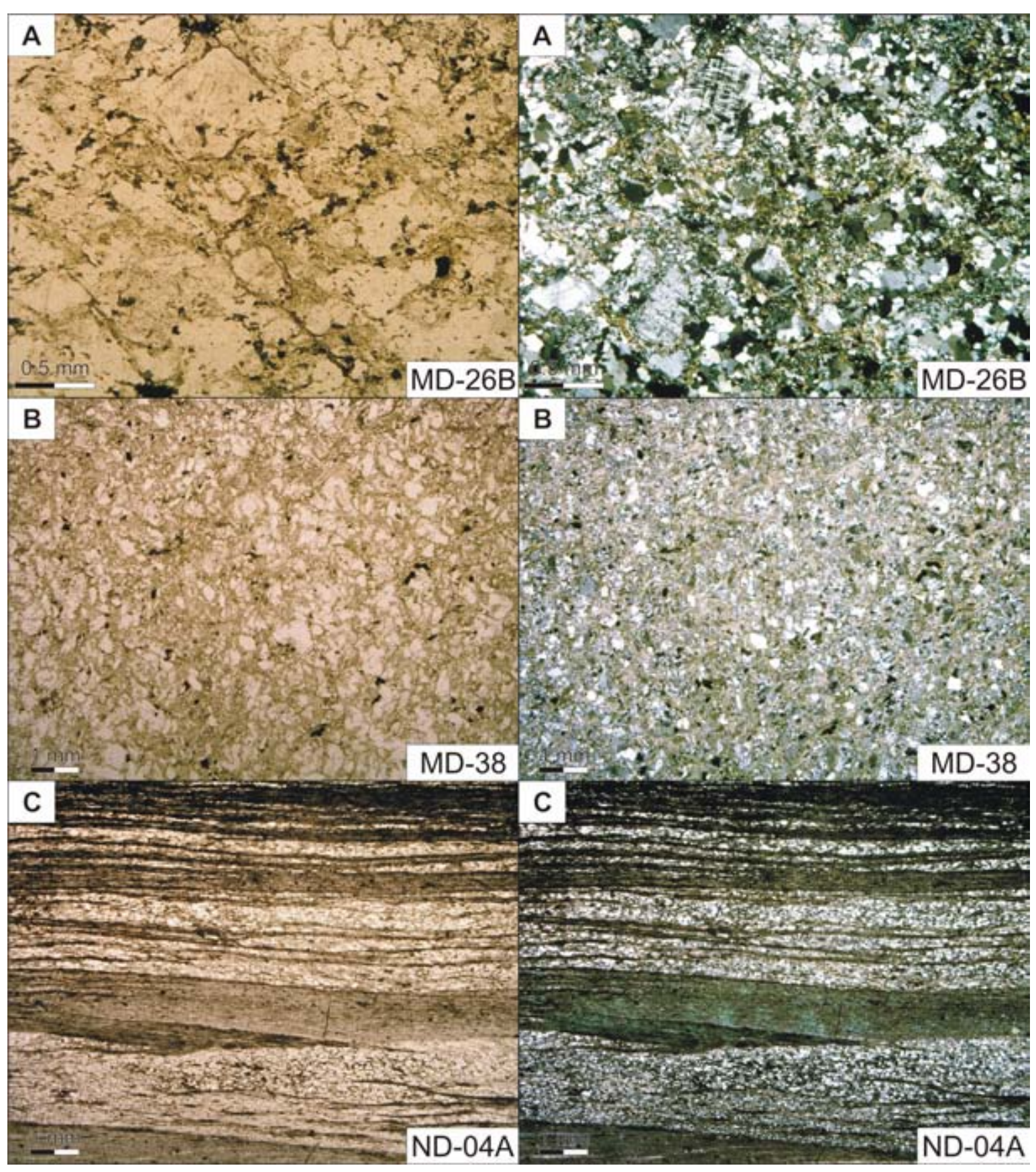

Figure 4: Photomicrographs of São Roque Group metasediments: A- meta-feldspathic wackes; Bmeta-quartz wackes; C- metamudstones (left, parallel polarizers; right, crossed polarizers). 


\section{Geochemistry}

The chemical classification (Herron, 1988) based on major elements shows a distinctive correlation with the petrographic classification, except in the case of metarkoses and meta-feldspathic wackes, which have similar chemical behavior, but different proportions of matrix (Fig. 5).

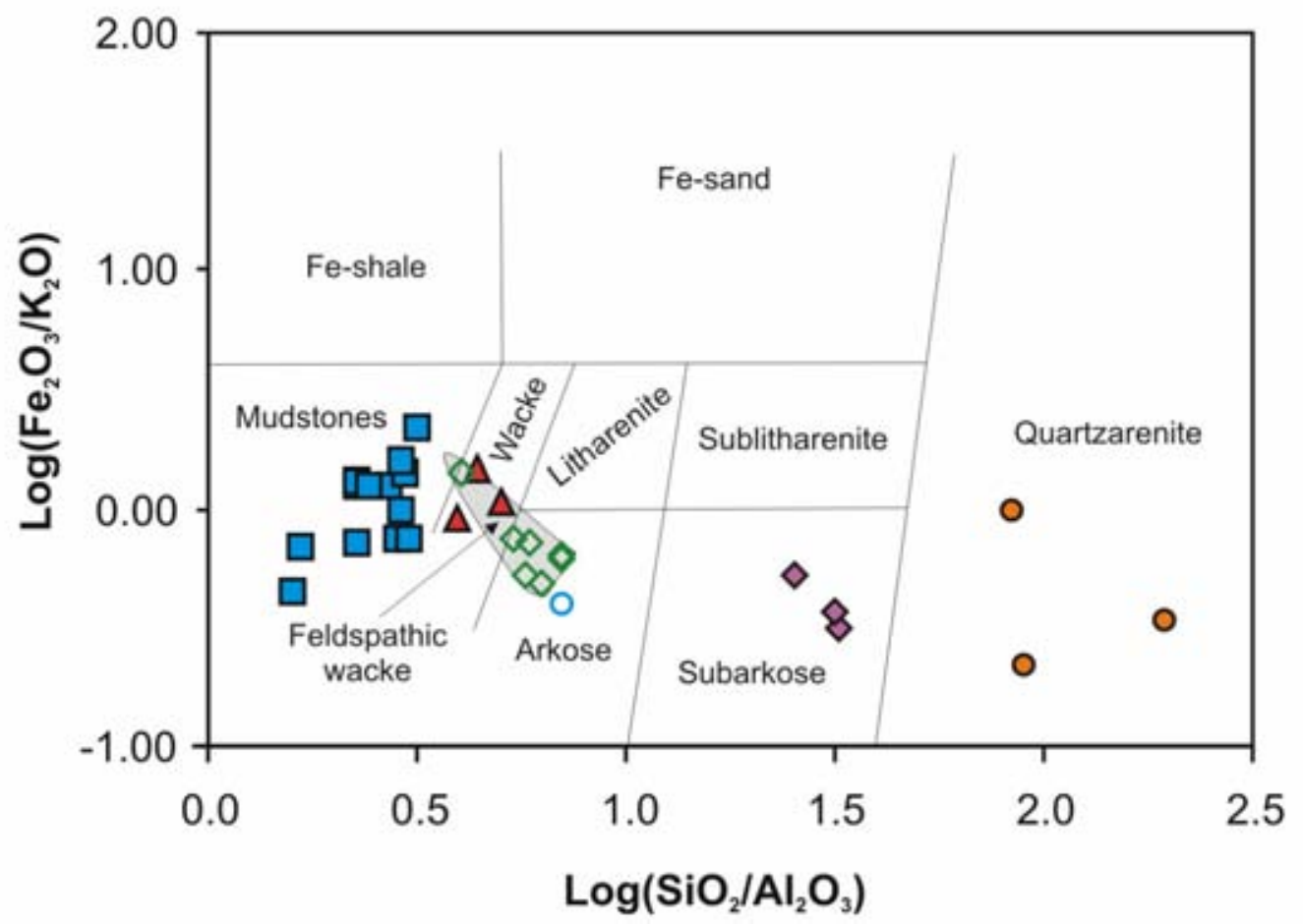

Figure 5: Chemical classification diagram $\left[\log \left(\mathrm{SiO}_{2} / \mathrm{Al}_{2} \mathrm{O}_{3}\right)\right.$ versus $\left.\log \left(\mathrm{Fe}_{2} \mathrm{O}_{3} / \mathrm{K}_{2} \mathrm{O}\right)\right]$ (Herron, 1988) for samples of the São Roque Group. Symbols are the same as in Figure 3.

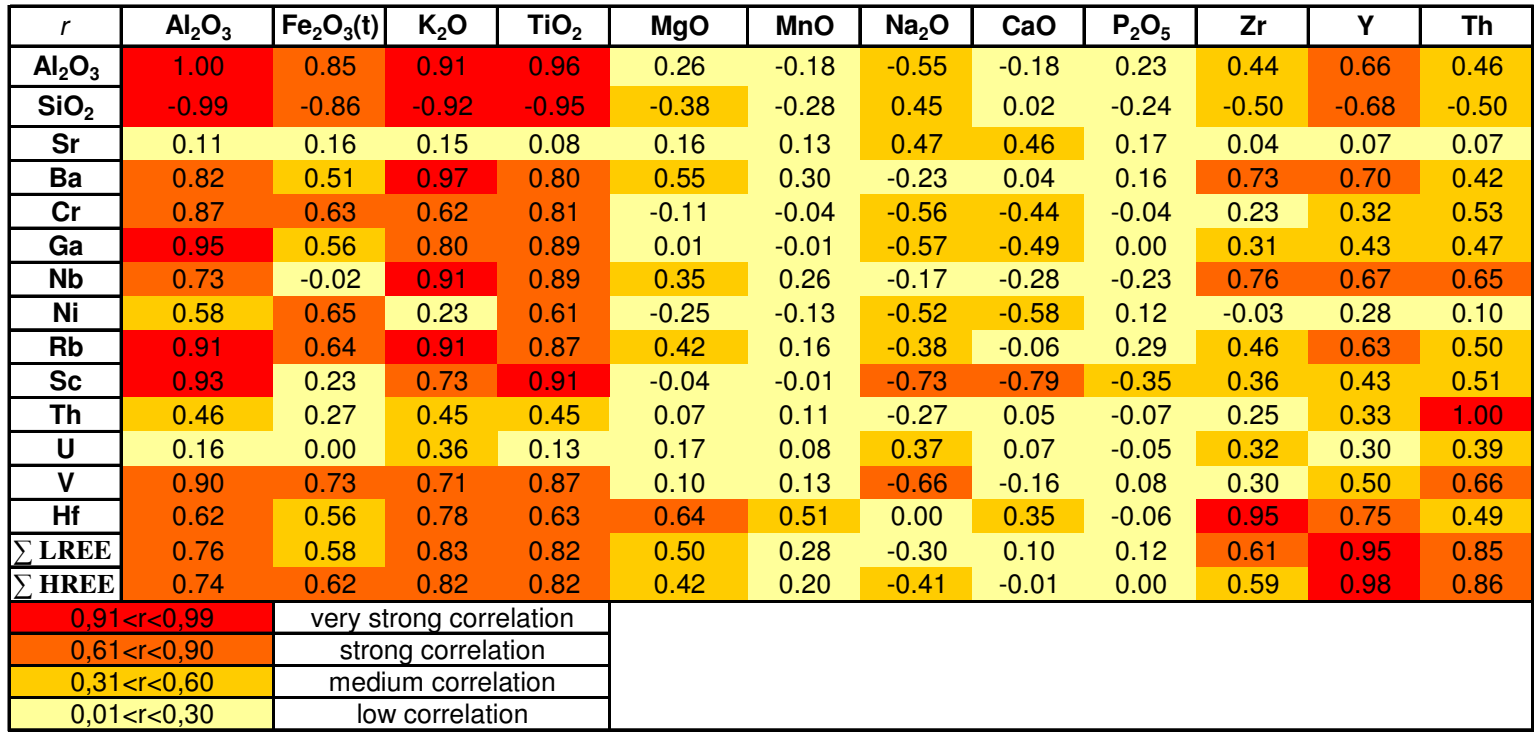


Table 2: Correlation coefficients (r) obtained with geochemical data of metasediments $(n=30)$ for rocks from São Roque Group. The coefficients of linear correlation of Pearson (r) were calculated according to the ratio between the two covariance variables using the product of standard deviations of each one, as described in relation $\left.r=n \sum(x . y)-\left(\sum x\right)-\sum y\right) / v\left[n \cdot \sum x^{2}-\left(\sum x\right)^{2}\right]\left[n . \Sigma y^{2}-\right.$ $\left.(\Sigma \mathrm{y})^{2}\right]$.

\subsection{Potential source-areas and weathering}

The best evidence for the nature of source areas is in the clasts of polymithic metaconglomerates from the base of São Roque Group (Boturuna Formation). The granitic clasts appear to be broadly comagmatic as suggested by their alignment in a single geochemical evolution trend consistent with normal differentiation in granitic magmas (Henrique-Pinto and Janasi, 2010). Pebbles of other rock types are little abundant, but indicate the contributions from different sources, such as amphibolite and quartzite. The source varieties observed in metaconglomerates are in agreement with the trends identified in diagrams of Roser and Korsch (1988) (Fig. 6).

$\mathrm{U}-\mathrm{Pb}$ dating of zircons extracted from the granitic clasts within the metaconglomerates (Henrique-Pinto et al., 2012) indicate a Paleoproterozoic ( 2.2 Ga) age for magmatic crystallization. The nearest potential source areas with similar ages are found in basement nuclei of the Açungui Group (Kaulfuss, 2001; Ribeiro, 2006; Siga Jr. et al., 2007, 2011). The chemical composition of these rocks is similar to the granitic clasts of metaconglomerates (Boturuna Formation) at a given silica content (65-78 wt.\%) (Group 1 in Figs. 9 and 10). Intermediate plutonic rocks (Group 2) are common in these basement nuclei but have not been found in the metaconglomerates studied by Henrique-Pinto et al. (2012).

The chemical index weathering $\left(\mathrm{CIW}=\left[\mathrm{Al}_{2} \mathrm{O}_{3} /\left(\mathrm{Al}_{2} \mathrm{O}_{3}+\mathrm{CaO}+\mathrm{N}_{2} \mathrm{O}\right) * 100\right]\right.$; Harnois, 1988) uses the same parameters of the chemical index of alteration (CIA= $\left[\mathrm{Al}_{2} \mathrm{O}_{3} /\left(\mathrm{Al}_{2} \mathrm{O}_{3}+\mathrm{CaO}+\mathrm{N}_{2} \mathrm{O}+\mathrm{K}_{2} \mathrm{O}\right) * 100\right]$; Nesbitt and Young, 1982), disconsidering $\mathrm{K}_{2} \mathrm{O}$, which may be introduced by $\mathrm{K}$ metasomatism. Some of our samples (mainly the sandstones; Fig. 8) with high $\mathrm{K}_{2} \mathrm{O}$ contents probably were affected by late diagenetic and/or metamorphic processes, and were excluded from Fig. 7B. Samples with secondary calcite were also excluded, since the parameters used to quantify the weathering consider that the sources of $\mathrm{CaO}$ are only silicate minerals.

The index of compositional variability $\mathrm{ICV}=\left[\left(\mathrm{Fe}_{2} \mathrm{O}_{3}+\mathrm{MnO}+\mathrm{MgO}+\mathrm{CaO}+\mathrm{N}_{2} \mathrm{O}\right.\right.$ $\left.+\mathrm{K}_{2} \mathrm{O}+\mathrm{TiO}_{2}\right) / \mathrm{Al}_{2} \mathrm{O}_{3}$ ] (Cox et al., 1995) is used to evaluate the original composition of the 
sources of shales and siltstones, the Figure 7 (A and B) illustrates the weathering of the potential source. The values of this index indicate that the particles that disintegrated from the source suffered sedimentary sorting (diagram A) and were deposited as sands and clays after moderate weathering process (with CIA values between 73 and 87). The main result of this is transformation of feldspar to illite, not reaching the highest degree of weathering with the appearance of kaolinite (Fig. 8).

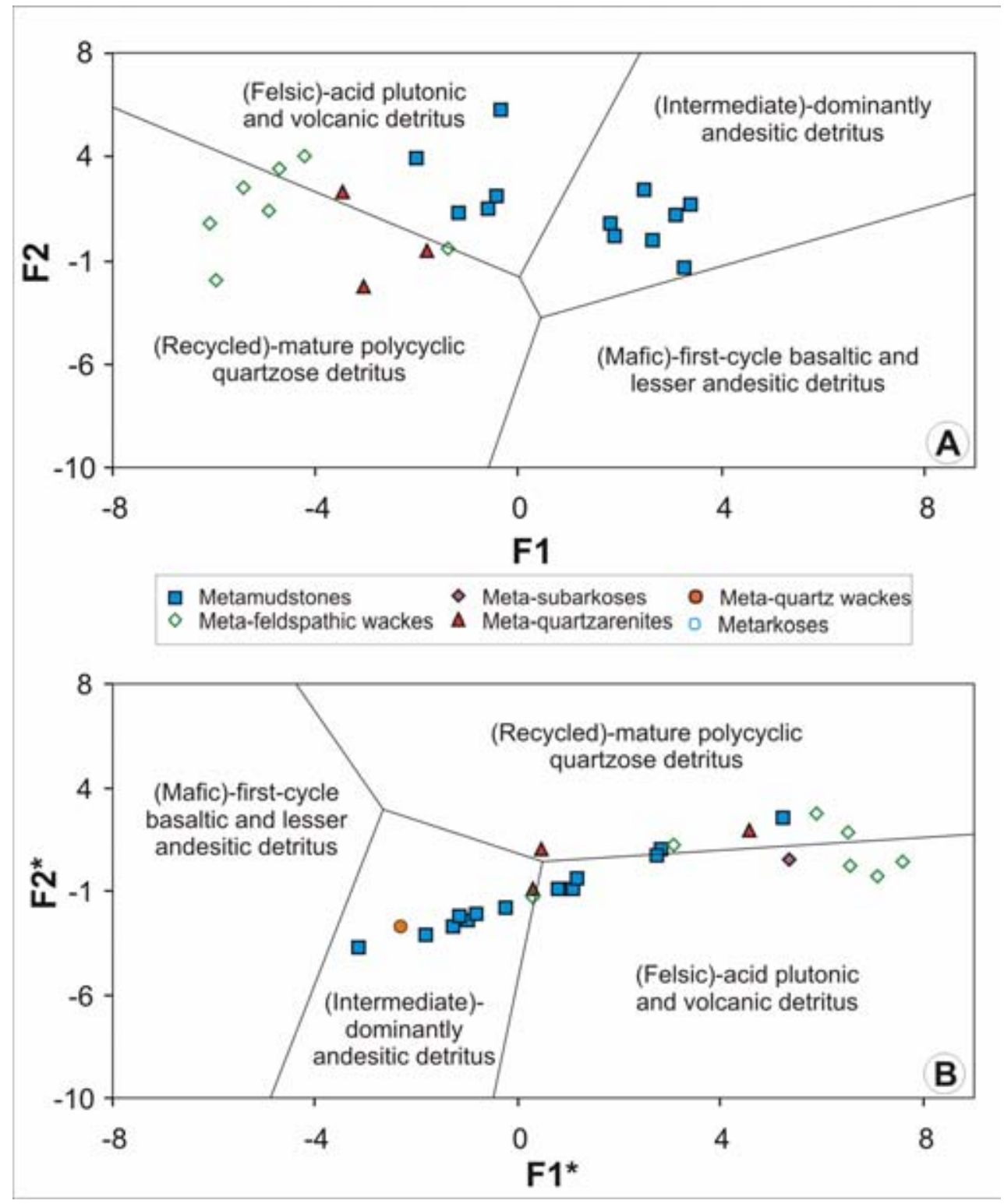

Figure 6: Provenance signatures using discriminant function analysis from Roser and Korsch (1988). The discriminant functions are:

$$
\begin{gathered}
\mathbf{F 1}=\left(-\left(1,773 * \mathrm{TiO}_{2}\right)+\left(0,607 * \mathrm{Al}_{2} \mathrm{O}_{3}\right)+\left(0,76 * \mathrm{Fe}_{2} \mathrm{O}_{3}\right)-(1,5 * \mathrm{MgO})+(0,616 * \mathrm{CaO})+\left(0,509 * \mathrm{Na}_{2} \mathrm{O}\right)-\right. \\
\left.\left(1,224 * \mathrm{~K}_{2} \mathrm{O}\right)-9,09\right) ; \mathbf{F} 2=\left(0,445 * \mathrm{TiO}_{2}\right)+\left(0,07 * \mathrm{Al}_{2} \mathrm{O}_{3}\right)-\left(0,25 * \mathrm{Fe}_{2} \mathrm{O}_{3}\right)- \\
\left.(1,142 * \mathrm{MgO})+(0,438 * \mathrm{CaO})+\left(1,475 * \mathrm{Na}_{2} \mathrm{O}\right)+\left(1,426 * \mathrm{~K}_{2} \mathrm{O}\right)-6,861\right)
\end{gathered}
$$


$\mathbf{F 1} *=\left(\left(\left(30,638 * \mathrm{TiO}_{2}\right) / \mathrm{Al}_{2} \mathrm{O}_{3}\right)-\right.$

$\left(\left(12,541 * \mathrm{Fe}_{2} \mathrm{O}_{3}\right) / \mathrm{Al}_{2} \mathrm{O}_{3}\right)+\left((7,329 * \mathrm{MgO}) / \mathrm{Al}_{2} \mathrm{O}_{3}\right)+\left(\left(12,031 * \mathrm{Na}_{2} \mathrm{O}\right) / \mathrm{Al}_{2} \mathrm{O}_{3}\right)+\left(\left(35,402 * \mathrm{~K}_{2} \mathrm{O}\right) / \mathrm{Al}_{2} \mathrm{O} 3\right)-$ $6,382) ; \mathbf{F} 2 *=\left(\left(\left(56,5 * \mathrm{TiO}_{2}\right) / \mathrm{Al}_{2} \mathrm{O}_{3}\right)-\left(\left(10,879 * \mathrm{Fe}_{2} \mathrm{O}_{3}\right) / \mathrm{Al}_{2} \mathrm{O}_{3}\right)+\left((30,875 * \mathrm{MgO}) / \mathrm{Al}_{2} \mathrm{O}_{3}\right)-\right.$ $\left.\left(\left(5,404 * \mathrm{Na}_{2} \mathrm{O}\right) / \mathrm{Al}_{2} \mathrm{O}_{3}\right)+\left(\left(11,112 * \mathrm{~K}_{2} \mathrm{O}\right) / \mathrm{Al}_{2} \mathrm{O}_{3}\right)-3,89\right)$.
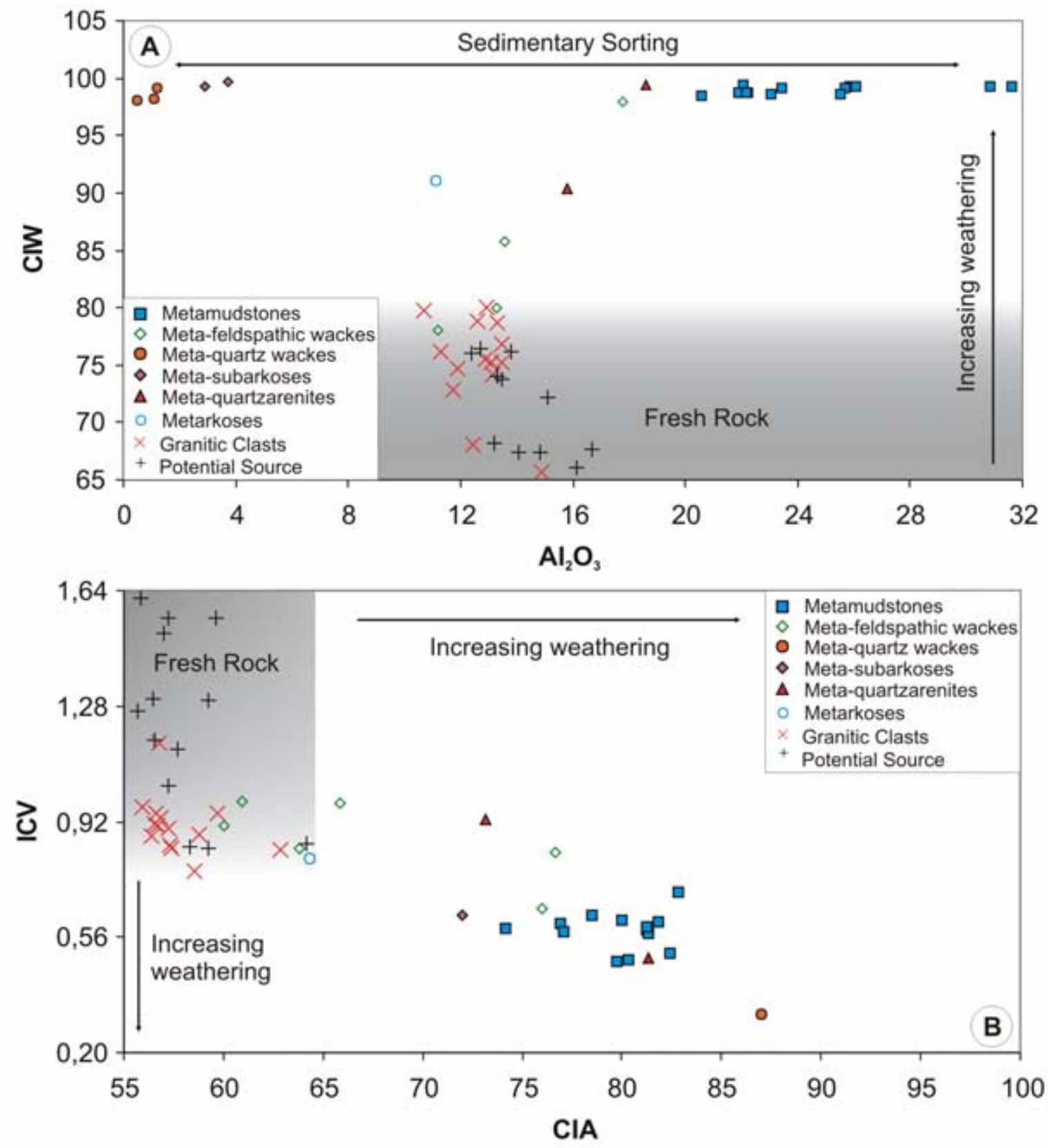

Figure 7: Relationship between weathering intensity and sedimentary sorting: A- CIW (chemical

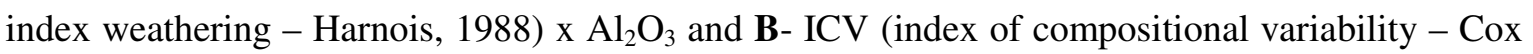
et al., 1995) x CIA (chemical index of alteration - Nesbitt and Young, 1982). 


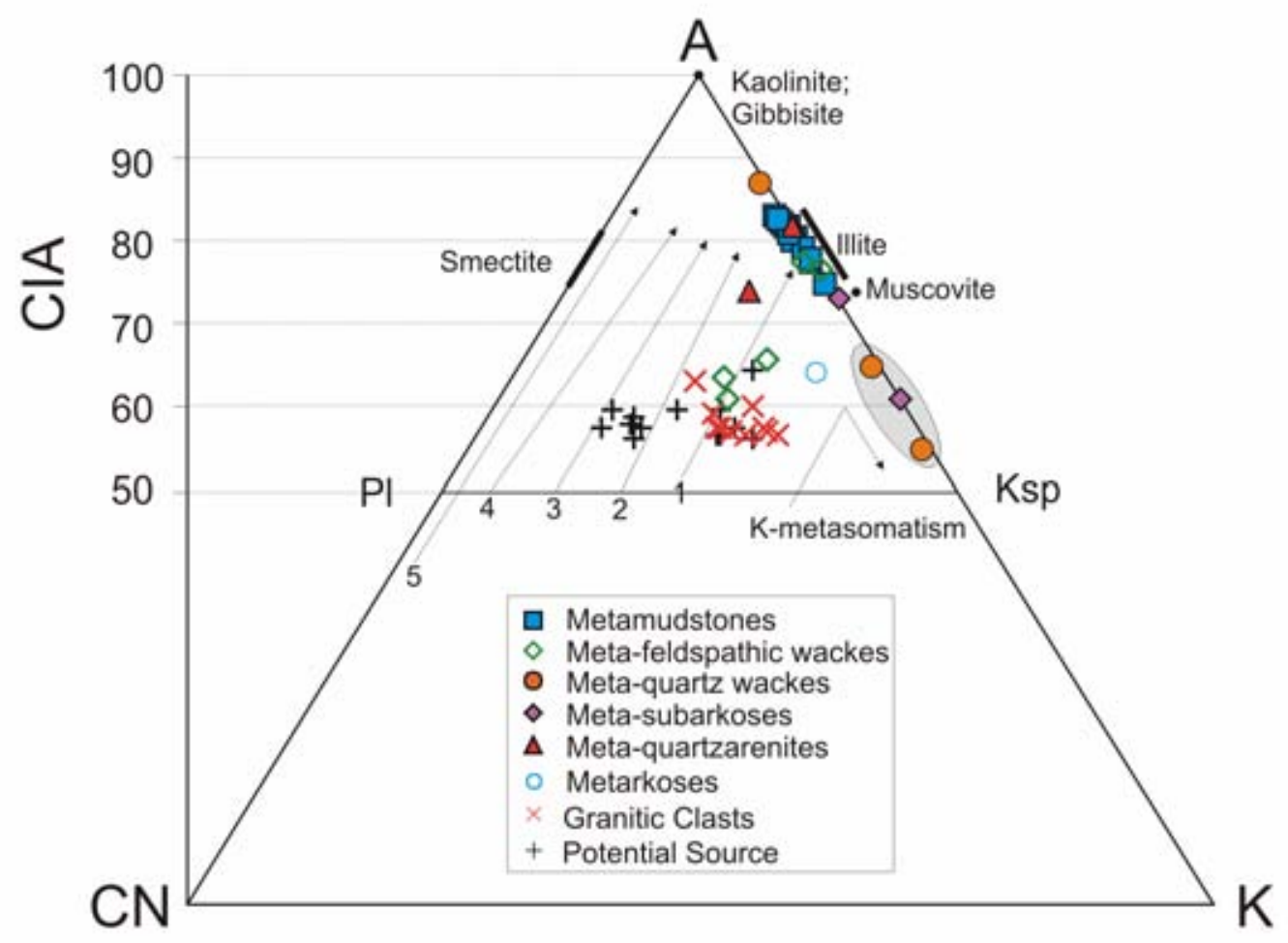

Figure 8: Chemical composition of São Roque metasediments in the A-CN-K diagram (Nesbitt and Young, 1984). 1 - average granitic rocks, 2 - avarage adamellite, 3 - average granodiorite, 4 average tonalite, 5 - average gabbro (trends ploted according to Nesbitt and Young, 1989).

\subsection{Inferences on source areas from elemental geochemistry}

The very strong to strong negative linear correlation of $\mathrm{SiO}_{2}$ with the main oxides $\mathrm{Al}_{2} \mathrm{O}_{3}(r=-0.99), \mathrm{Fe}_{2} \mathrm{O}_{3}(r=-0.86), \mathrm{K}_{2} \mathrm{O}$ ( $\left.r=-0.92\right), \mathrm{TiO}_{2}(r=-0.95)$ (Table 2, Fig. 9) is manly related to sedimentary sorting responsible for the concentration of these elements in the Al-rich clay fraction. The largest scattering of $\mathrm{MgO}$ with small negative linear correlation relative to $\mathrm{SiO}_{2}(r=-0.38)$ could reflect the presence of microlithic fragments of metabasic rocks, found in small proportions in some metawacke samples; this could also respond for the increase of $\mathrm{CaO}$ (up to 0.05 wt.\%). Alternatively, these increases (Table 3) might reflect the presence of dolomite/calcite authigenic cement (not identified in the thin sections) or secondary hydrothermal process. 
Many trace elements as $\mathrm{Cr}(r=0.87), \mathrm{Rb}(r=0.91), \mathrm{Ba}(r=0.82), \mathrm{V}(r=0.90)$ and $\mathrm{Ga}(\mathrm{r}=0.95)$ show very strong to strong positive correlation with $\mathrm{Al}_{2} \mathrm{O}_{3}$, which reflects the preference of these elements in Al-rich sediments for the clay fraction, and their depletion in quartz-rich fractions.

Similarities with source area composition and proximal deposits (meta-feldspathic wackes and metarkoses), with increasing of feldspar, can respond for shifting of $\mathrm{Sr}$, and low values of $\mathrm{V}$ and $\mathrm{Rb}$, compared to metamudstones and metaquartzarenites; nevertheless the possibility of additional Ba-rich sources should not be discarded due to similarities between some metamudstones and intermediate potential sources with high $\mathrm{Ba}$ values (Fig. 10).

The metamudstones are enriched in REE (Fig. 11; Table 4) compared to other metasediments (proximal deposits), displaying more fractionated patterns $\left(\mathrm{La}_{\mathrm{N}} / \mathrm{Yb}_{\mathrm{N}}\right.$ between 15 and 40; $\left.\mathrm{Gd}_{\mathrm{N}} / \mathrm{Yb}_{\mathrm{N}}=2.2-3.0 ; \sum \mathrm{HREE}=10-64 \mathrm{ppm}\right)$ Well-defined negative Ce $\left(\mathrm{Ce} / \mathrm{Ce}^{*}=0.34-0.51\right)$ and $\mathrm{Eu}\left(\mathrm{Eu} / \mathrm{Eu}^{*}=0.64-0.71\right)$ anomalies are common in these rocks, with the exception of one sample (ND-08; with no Ce anomaly and little fractioned, as a result of depletion in light REE).

The immature sediments (metarkoses and meta-feldspathic wackes) show a behavior similar to the inferred sources (granitic clasts), with moderately fractionated REE patterns $\left(\mathrm{La}_{N} / \mathrm{Yb}_{\mathrm{N}}=10-13\right)$, high LREE contents $\left(\sum \mathrm{LREE}=111-183 \mathrm{ppm}\right)$, and subtle negative $\mathrm{Eu}$ anomalies $\left(\mathrm{Eu} / \mathrm{Eu}^{*}=0.69-0.96\right)$. The increase of $\mathrm{Eu}$ sometimes results in positive anomalies $\left(\mathrm{Eu} / \mathrm{Eu}^{*}=1.08-\mathrm{JP}-01\right)$, probably due to feldspar acumulation due to sorting during the sedimentary process (cf. Singh and Rajamani, 2001) and/or to contribution from additional Eu-rich sources (e.g., intermediate potential sources with $\mathrm{Eu} / \mathrm{Eu}^{*}=0.72-1.03-$ Fig. 11). 


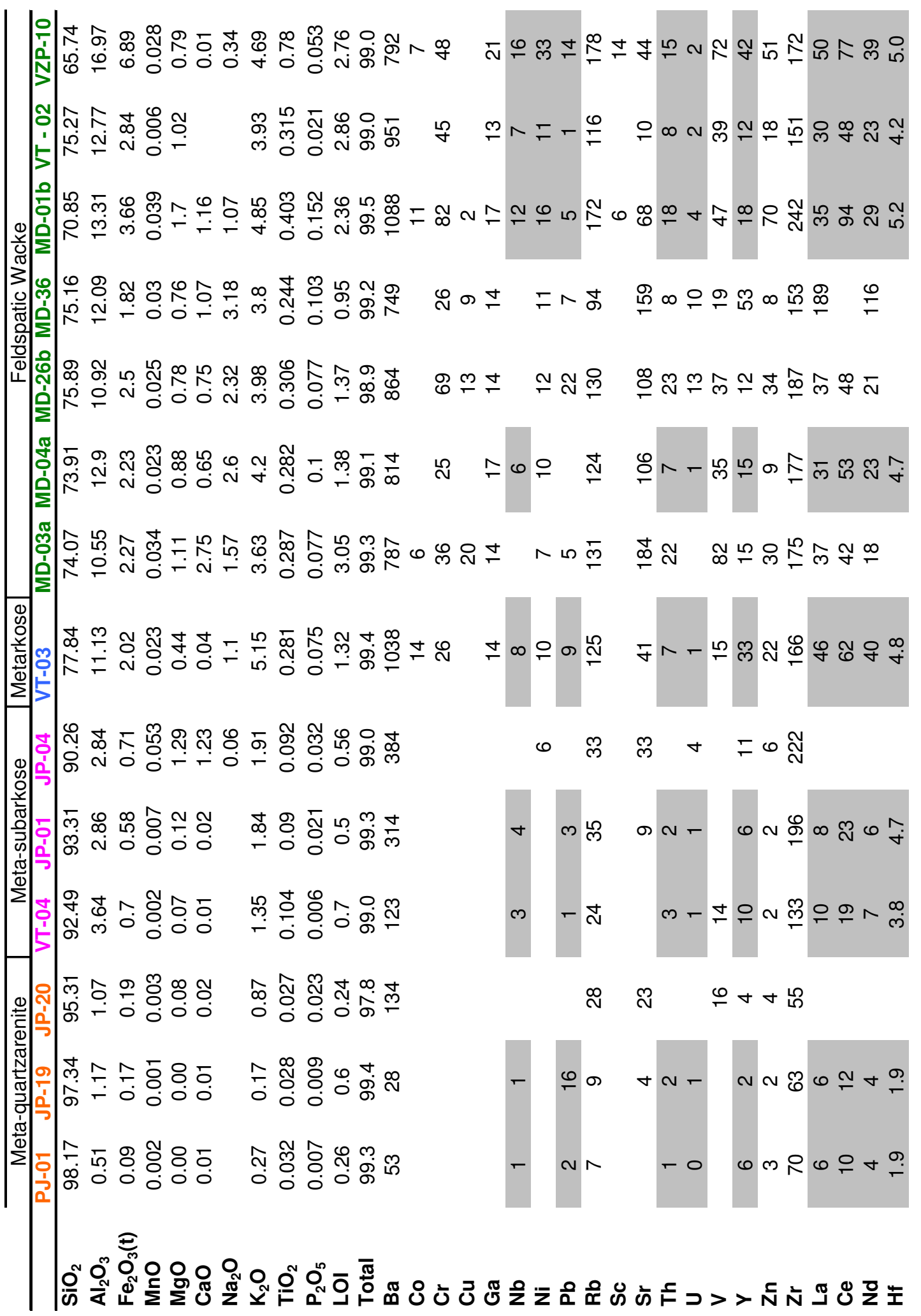

Table 3: Results of chemical analyses (FRX) of metasediments of the São Roque Group. Fields in grey represent analyses obtained by ICPMS. 


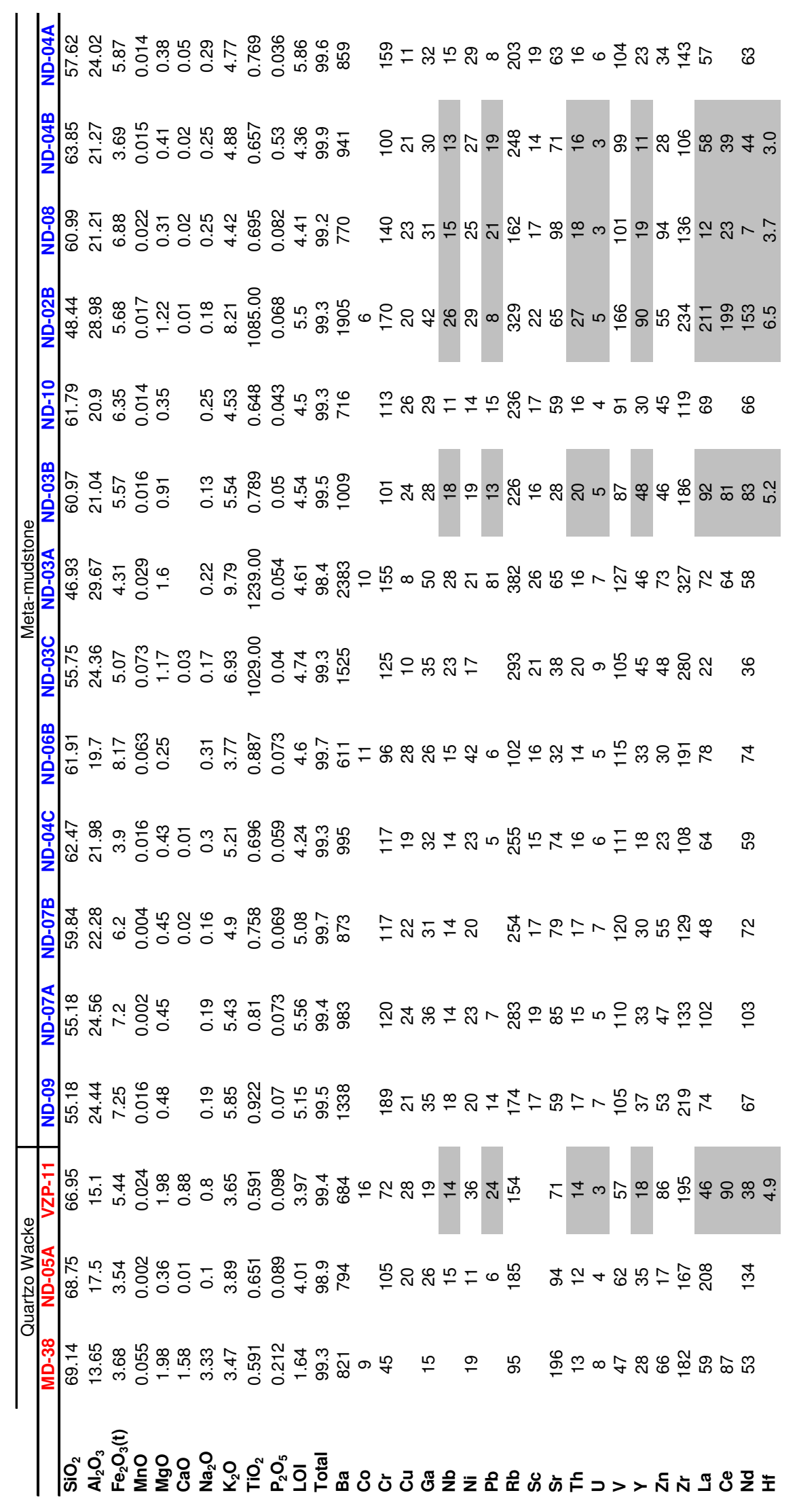

Table 3 continuation: Results of chemical analyses (FRX) of metasediments of the São Roque Group. Fields in grey represent analyses obtained by ICPMS. 

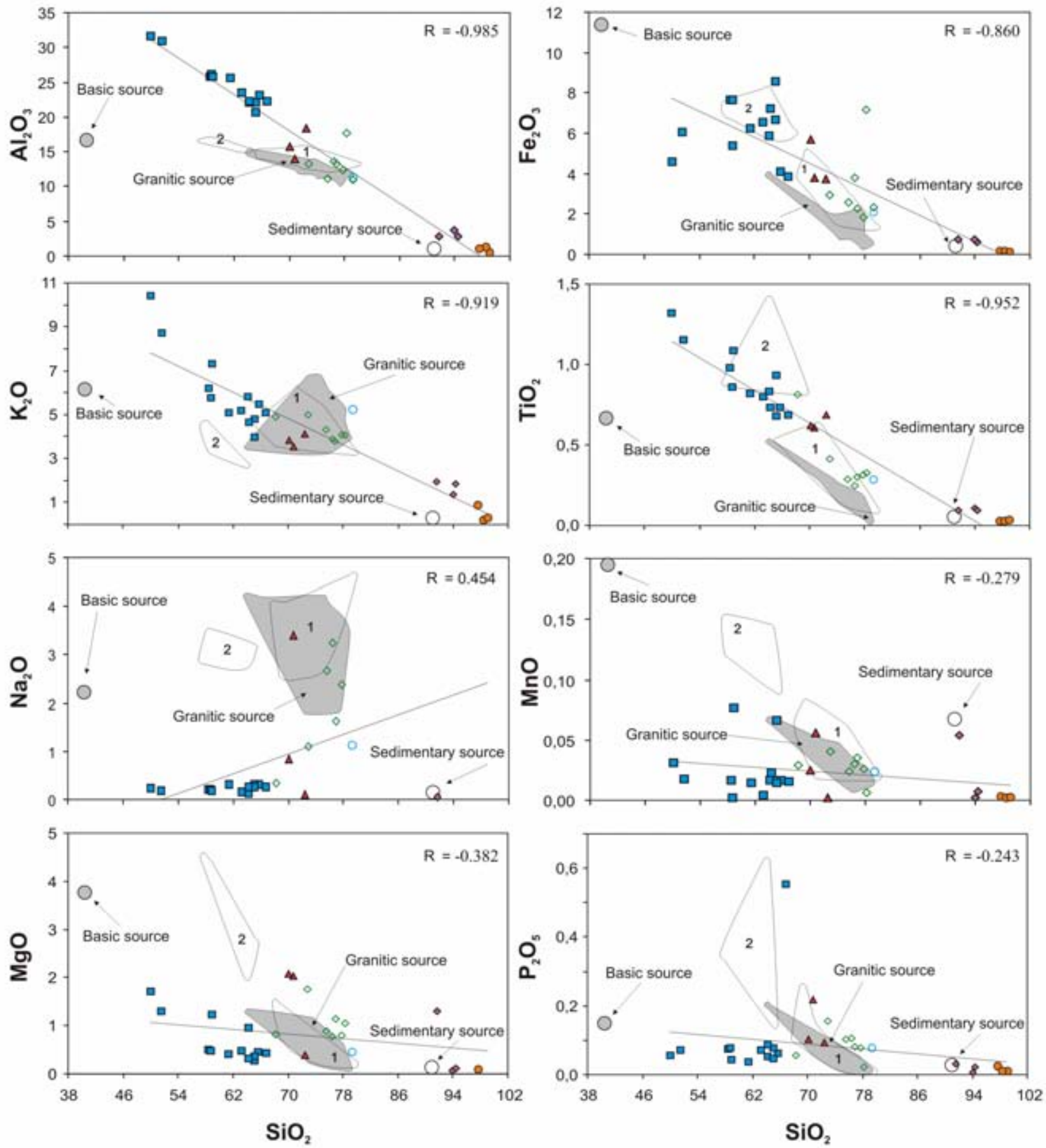

Figure 9: Variation diagrams for major elements versus $\mathrm{SiO}_{2}$ in metasediments of the São Roque Group. 1 - 2 represent potential sources compiled from Kaulfuss (2001); basic, granitic and sedimentary sources represent clasts of polymictic metaconglomerates of São Roque Group (Henique-Pinto, 2008). 

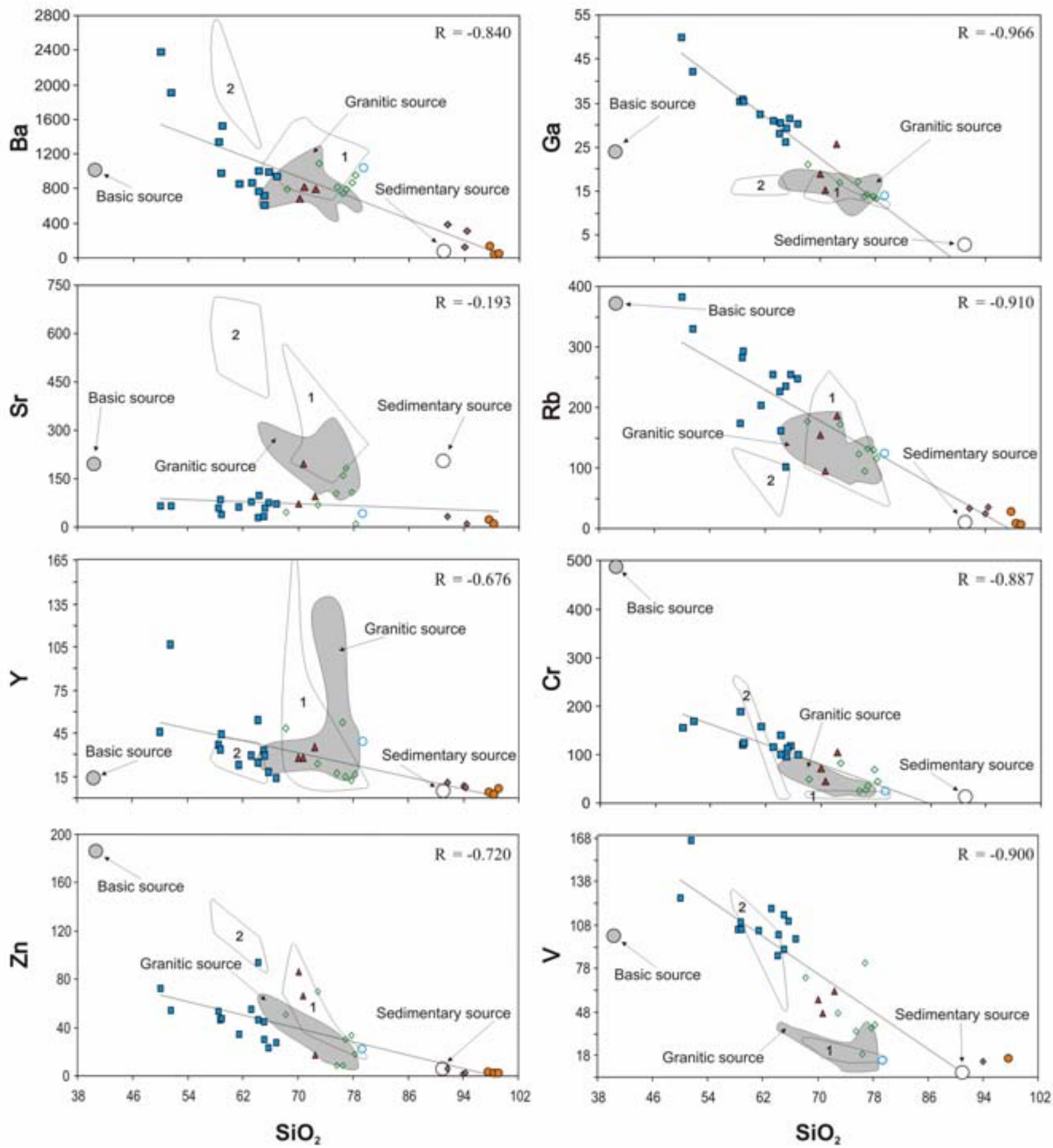

Figure 10: Variation diagrams for trace elements versus $\mathrm{SiO}_{2}$ in metasediments of the São Roque Group. 1 - 2 represent potential granitic sources compiled from Kaulfuss (2001); basic, granitic and sedimentary sources represent clasts of polymictic metaconglomerates from the São Roque Group (Henique-Pinto, 2008). 


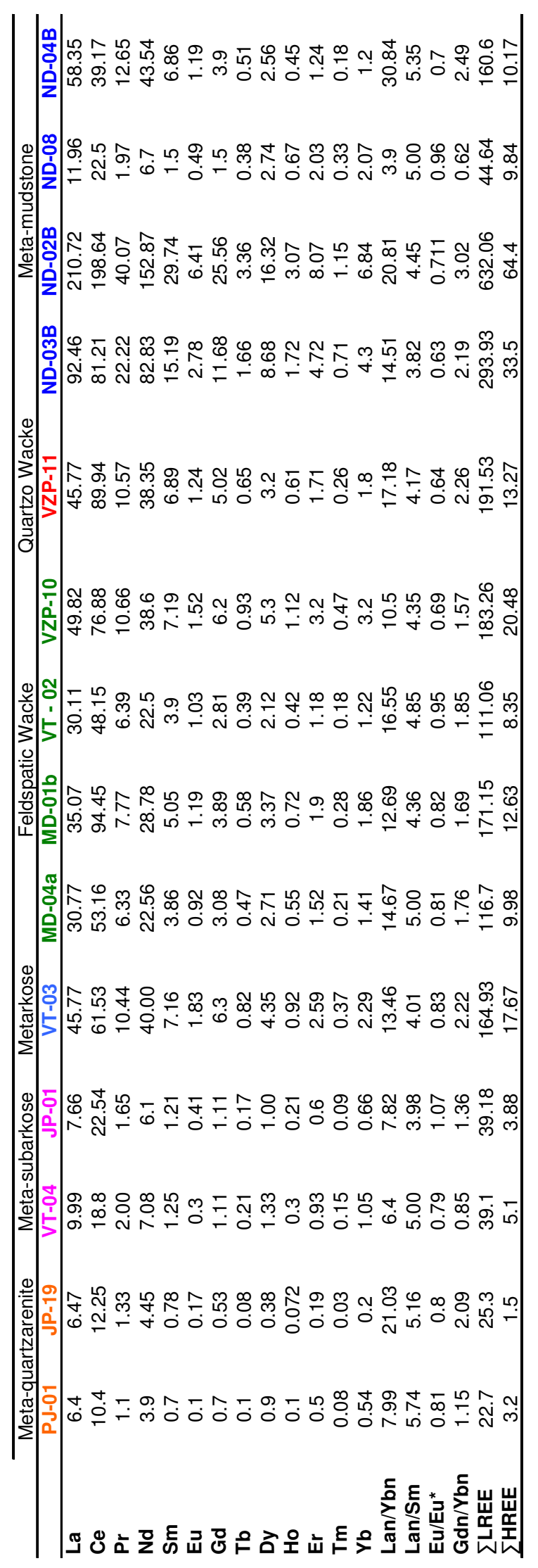

Table 4: Rare earth element data for metasediments of the São Roque Group. 


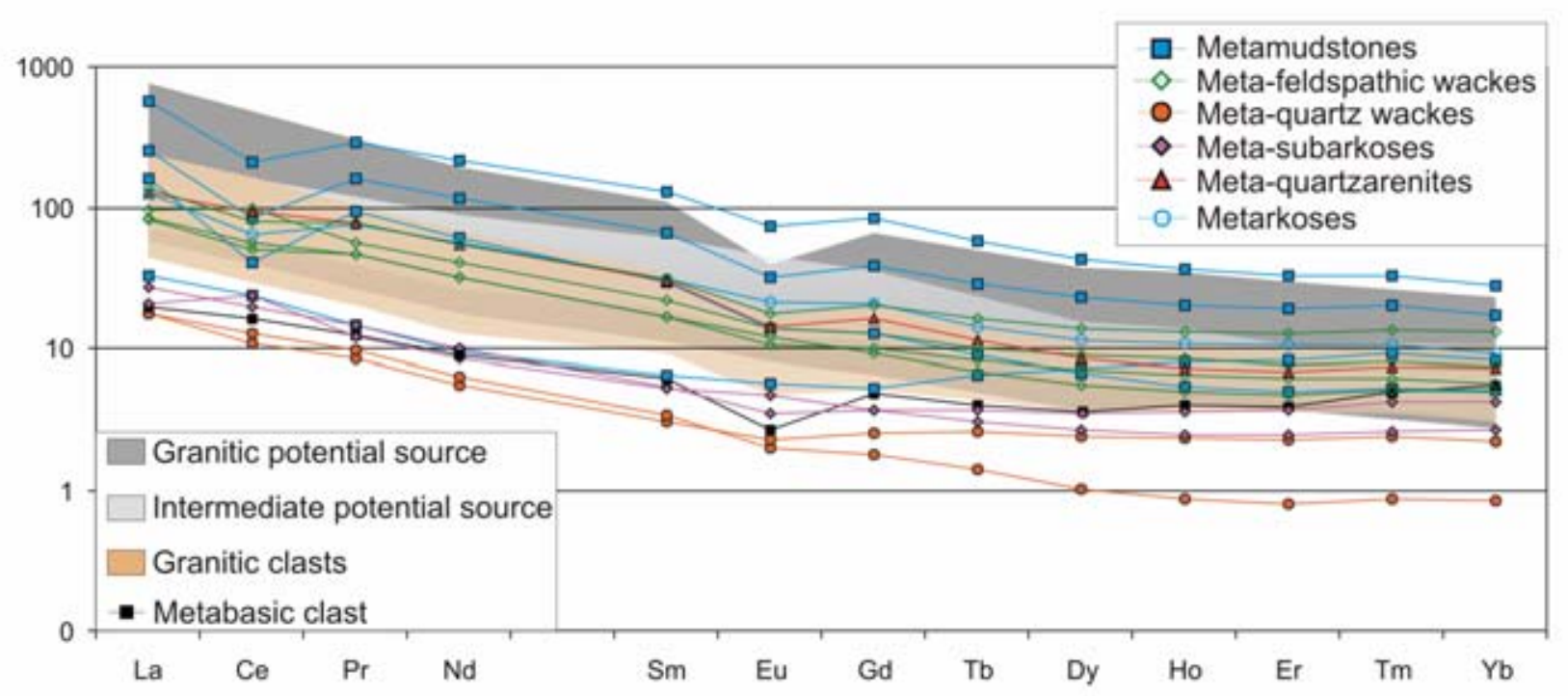

Figure 11: Chondrite-normalized (Taylor and McLennan, 1985) rare-earth element patterns for metasediments of São Roque Group. Granitic and intermediate potential sources compiled of Kaulfuss (2001), clasts of metaconglomerates compiled of Henrique-Pinto et al. (2012).

The quartz-rich metasandstones are depleted in REE and show relatively high $\mathrm{La}_{N} / \mathrm{Sm}_{\mathrm{N}}$ ratios (3.9-5.7), little fractionated patterns $\left(\mathrm{La}_{N} / \mathrm{Yb}_{\mathrm{N}}=6-8\right)$, with the exception of sample JP-19, which is depleted in HREE, resulting in a more fractionated pattern with $\mathrm{La}_{\mathrm{N}} / \mathrm{Yb}_{\mathrm{N}}=21$. Good positive linear correlations between $\sum$ HREE and $\sum \mathrm{LREE}$ with Th ( $r=$ 0.86 and 0.85 , respectively; Table 2) and between Y and REE suggest an important control by heavy minerals as monazite and xenotime (Table 2 ).

\section{Sm-Nd Data from Metamudstones}

Previously available Sm-Nd data for the SRG metasediments are restrict to a few determinations in metapelites by Dantas et al. (2000), indicating Paleoproterozoic to Archean (1.9-2.9 Ga) $\mathrm{T}_{\mathrm{DM}}$, and a systematic survey of $\sim 2.2 \mathrm{Ga}$ old granitic clasts and the framework of a metaconglomerate from the Boturuna Formation (Henrique-Pinto et al., 2012) that yielded Archean $\mathrm{T}_{\mathrm{DM}}$ ages ranging from 2.6 to $3.2 \mathrm{Ga}$.

Our new Sm-Nd isotope data (Table 5) were obtained in 19 representative samples of metamudstones of the Piragibu Formation, part of which corresponds to the samples 
analyzed for major and trace elements. The results span approximately the same range of $\mathrm{T}_{\mathrm{DM}}$ indicated by previous works (1.9-3.0 Ga), and reveal a clear concentration in the 2.12.6 Ga interval, where two peaks are observed (at $\sim 2.2$ and 2.4-2.5 Ga); two other peaks at lower $(\sim 1.9 \mathrm{Ga})$ and older $(\sim 3.0 \mathrm{Ga})$ ages occur (Fig. $12 \mathrm{~A}$ and $\mathrm{B})$.

The oldest $\mathrm{Sm}-\mathrm{Nd} \mathrm{T}_{\mathrm{DM}}$ age $(3.0 \mathrm{Ga})$ obtained in a sample (ND-08) with $\varepsilon_{\mathrm{Nd}(0)}=$ 23.8, although with comparatively high ${ }^{147} \mathrm{Sm} /{ }^{144} \mathrm{Nd}=0.130$, is consistent with the oldest $\mathrm{T}_{\mathrm{DM}}$ ages obtained in the granitic rocks clasts from the Boturuna Formation metaconglomerates (Henrique-Pinto et al., 2012).

The Sm-Nd isotope signatures of the metaconglomerate clasts from the SRG Boturuna Formation (Henrique-Pinto et al., 2012) and from the basement nuclei from the Açungui Group (Kaulfuss, 2001; Siga Jr. et al., 2011) were used to calculate their $\varepsilon_{\mathrm{Nd}}$ at the age inferred for the deposition of the SRG $(\sim 1.75 \mathrm{Ga})$. The $\varepsilon_{\mathrm{Nd}(1.75)}$ values of the clasts (-7 to -10$)$ and the basement nuclei $(-7$ to -13$)$ are more negative compared to all metamudstones ( +2 to -7 ), with the exception of sample ND-08 with $\varepsilon_{\mathrm{Nd}(1.75)}=-9$.

The meta-feldpathic wake from the Boturuna Formation has $\left(\varepsilon_{\mathrm{Nd}(1.75)}=-7\right)$, closer to the clasts, in agreement with its direct association with the metaconglomerates (Fig. 12). The least negative values of the metamudstones require that other sources, younger and/or with least negative $\varepsilon_{\mathrm{Nd}}$ at the age of deposition, were important for the SRG metamudstones.

Only three samples with positive $\varepsilon_{\mathrm{Nd}(1.75)}(+1.4$ to +2.4$)$ were identified among the metamudstones, and they are located either to the north of the Jundiuvira Fault (therefore outside the São Roque Domain, but corresponding to low-grade metamorphic rocks not consistent with the metamorphic grade typical of the Guaxupé Domain; Fig. 1), or in the northeasternmost portion of the studied sector of the São Roque Domain (Mairiporã region). Their positive $\varepsilon_{\mathrm{Nd}(1.75)}$ and corresponding youngest $\mathrm{Sm}-\mathrm{Nd} \mathrm{T}_{\mathrm{DM}}$ ages (1.88-1.93 $\mathrm{Ga}$ ) must reflect greater contributions from younger sources, possibly including juvenile rocks such as the metabasic rocks from the Cajamar region dated at $1.75 \mathrm{Ga}$, which have positive $\varepsilon_{\mathrm{Nd}}$ (Oliveira et al., 2008).

The study of detrital zircons from metampsammitic rocks yields some important clues to the identification of the sources of the SRG sediments (Henrique-Pinto et al., in prep.). Granitic sources seem to be largely predominant for these sediments, which show 
main peaks of zircon ages in the same range as the $\mathrm{Sm}-\mathrm{Nd} \mathrm{T}_{\mathrm{DM}}$, in some cases with a bimodal distribution (2.2 and $2.4 \mathrm{Ga}$ ) (Fig. 12B). This behavior could be explained by the existence of sources with juvenile signature at this age range, therefore with less negative $\varepsilon_{\mathrm{Nd}}(1.75)$ than the metaconglomerate clasts studied by Henrique-Pinto et al. (2012). To our knowledge, such rocks were not documented in the literature so far in the small paleoproterozoic basement nuclei described in the Paranapanema craton. We notice, however, that recent studies have identified rocks with these characteristics in other portions of southeast Brazil, such as the Mineiro Belt in the São Francisco craton (Teixeira et al., 1996; Ávila et al., 2010).

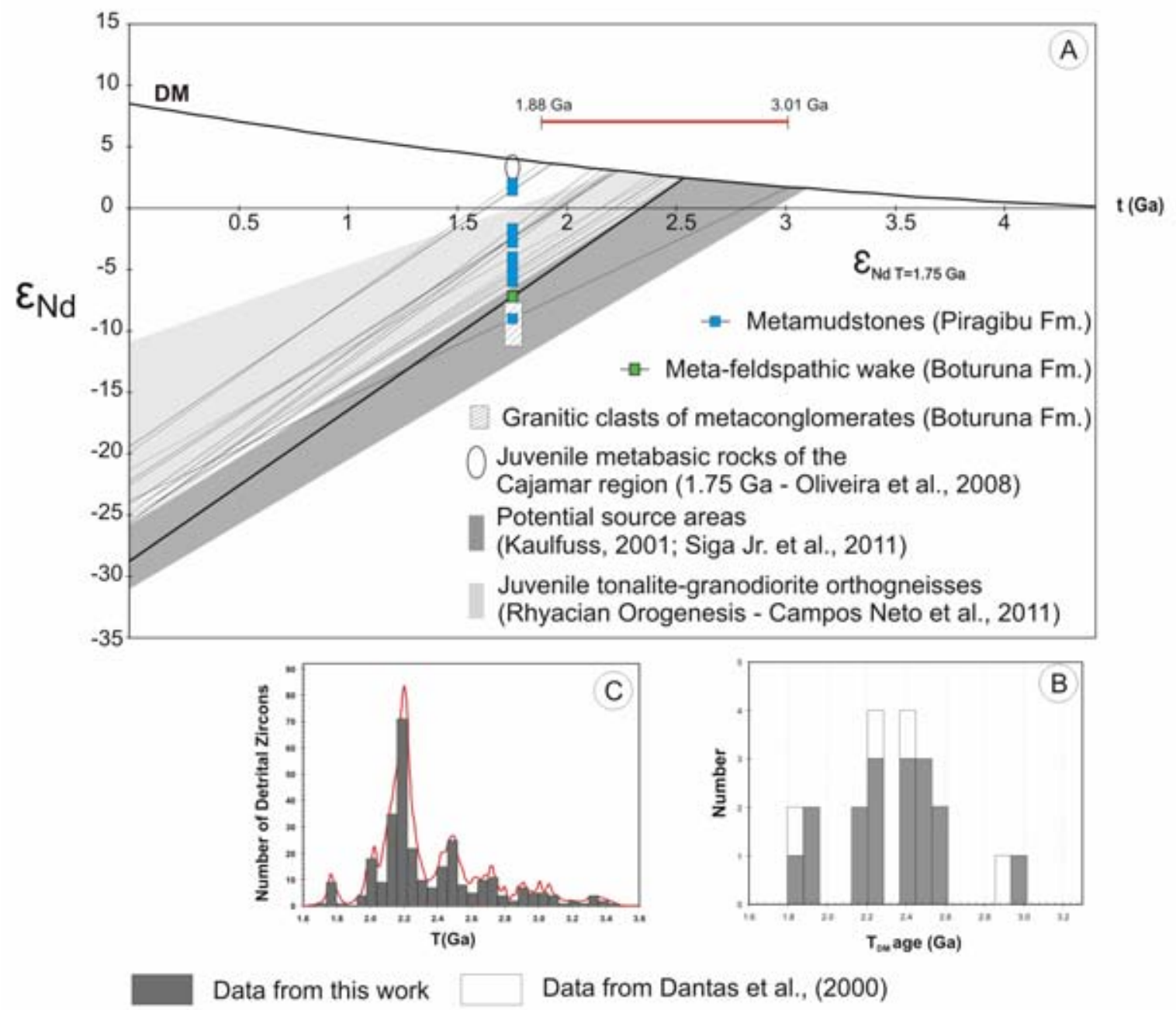

Figure 12: (A) $\varepsilon_{\mathrm{Nd}}$ versus $\mathrm{T}_{\mathrm{DM}}(\mathrm{Ga})$ diagram for metamudstones of Piragibu Formation (include one sample of meta-felspathic wake - Boturuna Formation; Henrique-Pinto et al., 2012), São Roque Group; DM: evolution line of depleted mantle (De Paolo, 1988); (B) histogram with peaks of TDM ages (include samples compiled by Dantas et al., 2000); (C) population of detrital zircons of São Roque Domain. 


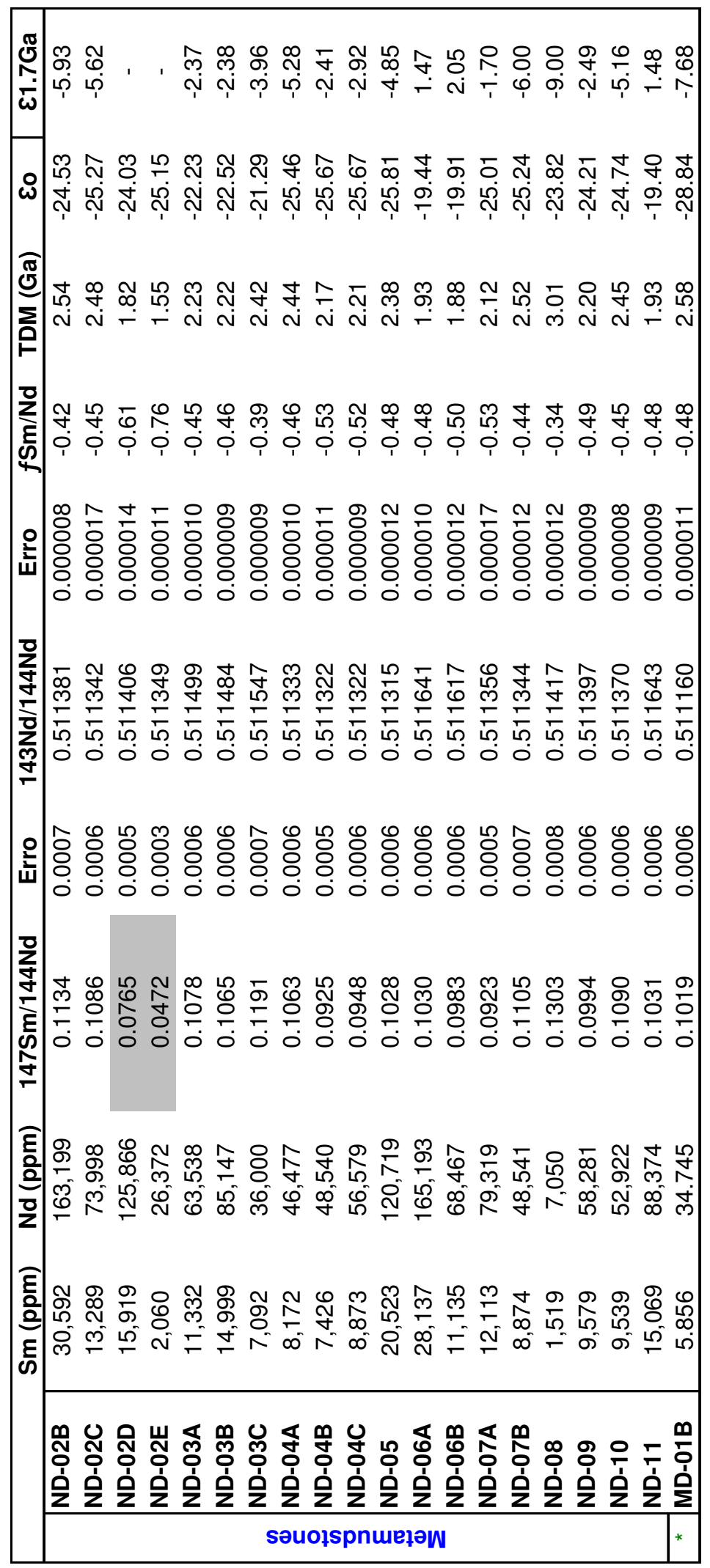

Table 5: Sm-Nd isotope data for metamudstones of Piragibu Formation, São Roque Group. * = Sm-Nd isotope data of meta-feldspathic wake compiled by Henrique-Pinto et al. (2012). Fields in grey represent analyses with low $\mathrm{Sm} / \mathrm{Nd}$ ratios that been excluded of interpretations. 


\section{Tectonic discrimination}

The first attempts to characterize the depositional sedimentary environment from petrographic features of sedimentary rocks were done by Dickinson (1985), who characterized different provenances from the modal proportions of quartz, feldspar and lithic fragments (QFL). The amount of lithic fragments (mainly andesitic volcanic rocks in that example) indicates proximity with an active orogen, and the absence or low abundance of lithic fragments was seen as characteristic of stable cratonic areas (Dickinson, 1985). The QFL model, although a limited method, can be successful in classifying environment types, according to Molinaroli (1991).

The quartz-rich metasandstones probably have provenance from a continental block with sources in stable craton (Fig. 13A) deposited in passive margin environments (Fig. 13B) and the metarkose/meta-feldspathic wakes, characterized by lesser compositional maturity (Fig. 2), can represent uplifted source areas followed by weathering and proximal deposition.

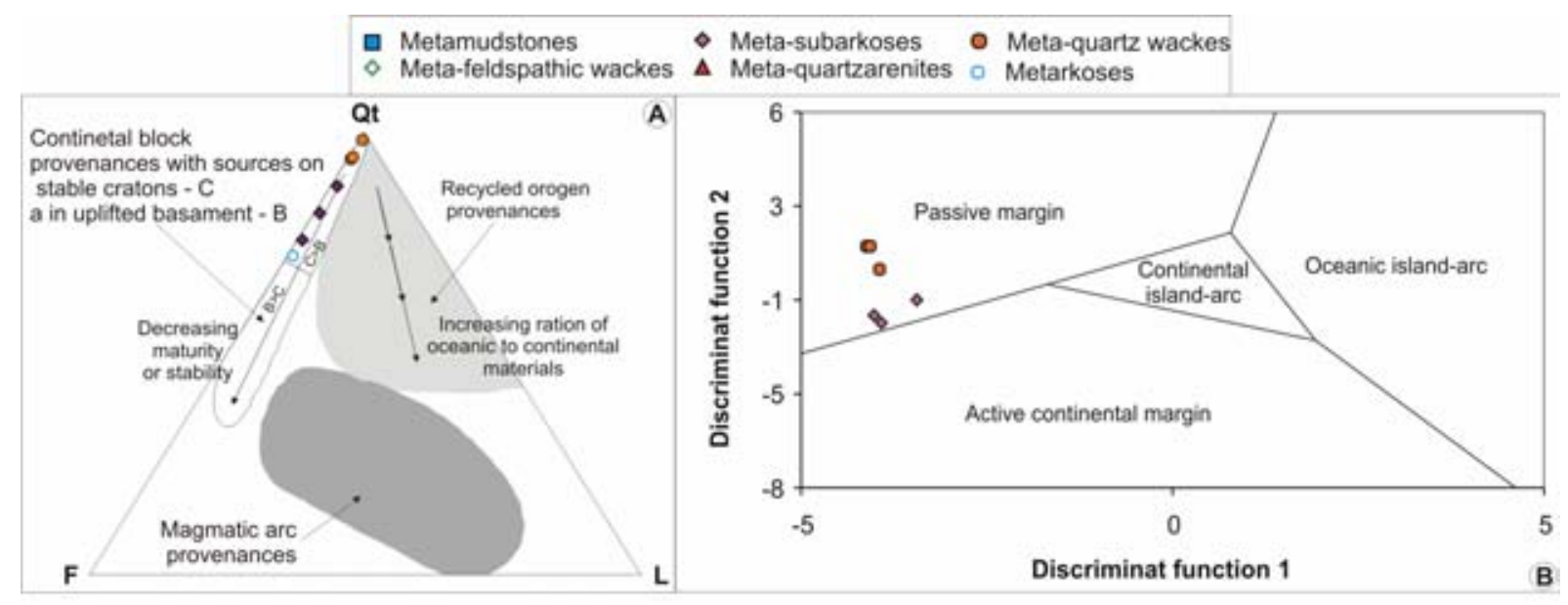

Figure 13: A - Metasandstones of the São Roque Group plotted on standard triangular QFL (quartz-feldspar-lithic fragments) diagrams from Dickinson (1985), showing fields for different types of provenance; B - Discriminant function diagram for sandstones (from Bhatia, 1983). The discriminant functions are as follows: Discriminant function $\mathbf{1}=-0.0447 \mathrm{SiO}_{2}-0.972 \mathrm{TiO}_{2}+$ $0.008 \mathrm{Al}_{2} \mathrm{O}_{3}-0.267 \mathrm{Fe}_{2} \mathrm{O}_{3}+0.208 \mathrm{FeO}-3.082 \mathrm{MnO}+0.140 \mathrm{MgO}+0.195 \mathrm{CaO}+0.719 \mathrm{Na}_{2} \mathrm{O}-$ $0.032 \mathrm{~K}_{2} \mathrm{O}+7.510 \mathrm{P}_{2} \mathrm{O}_{3}+0.303$. Discriminant function $2=-0.421 \mathrm{SiO}_{2}+1.988 \mathrm{TiO}_{2}-0.526$ $\mathrm{Al}_{2} \mathrm{O}_{3}-0.551 \mathrm{Fe}_{2} \mathrm{O}_{3}-1.610 \mathrm{FeO}+2.720 \mathrm{MnO}+0.881 \mathrm{MgO}-0.907 \mathrm{CaO}-0.177 \mathrm{Na}_{2} \mathrm{O}-1.840$ $\mathrm{K}_{2} \mathrm{O}+7.244 \mathrm{P}_{2} \mathrm{O}_{5}+43.57$ 
All set of samples has geochemical behavior compatible with sediments deposited in a passive margin basin, as shown by the discrimination diagram for the provenance signature (Fig. 15; Roser and Korsch, 1988) and the REE pattern (Fig. 14). This is confirmed by Sm-Nd data, that suggest predominatly felsic older Proterozoic sources but with some contribution of mafic crust (Fig. 16 A). On the other hand, metamudstones are Ce-depleted (Fig. 14B and D) as shown by negative Ce anomalies, commonly observed in seawater (Elderfield and Greaves, 1982), which is compatible with clays from open sea environment (Shimizu and Masuda, 1977). This could be an indication that an additional volcanogenic source (Fig. 16 B) related to oceanic island arc could be present during sedimentation time (Fig. 14).
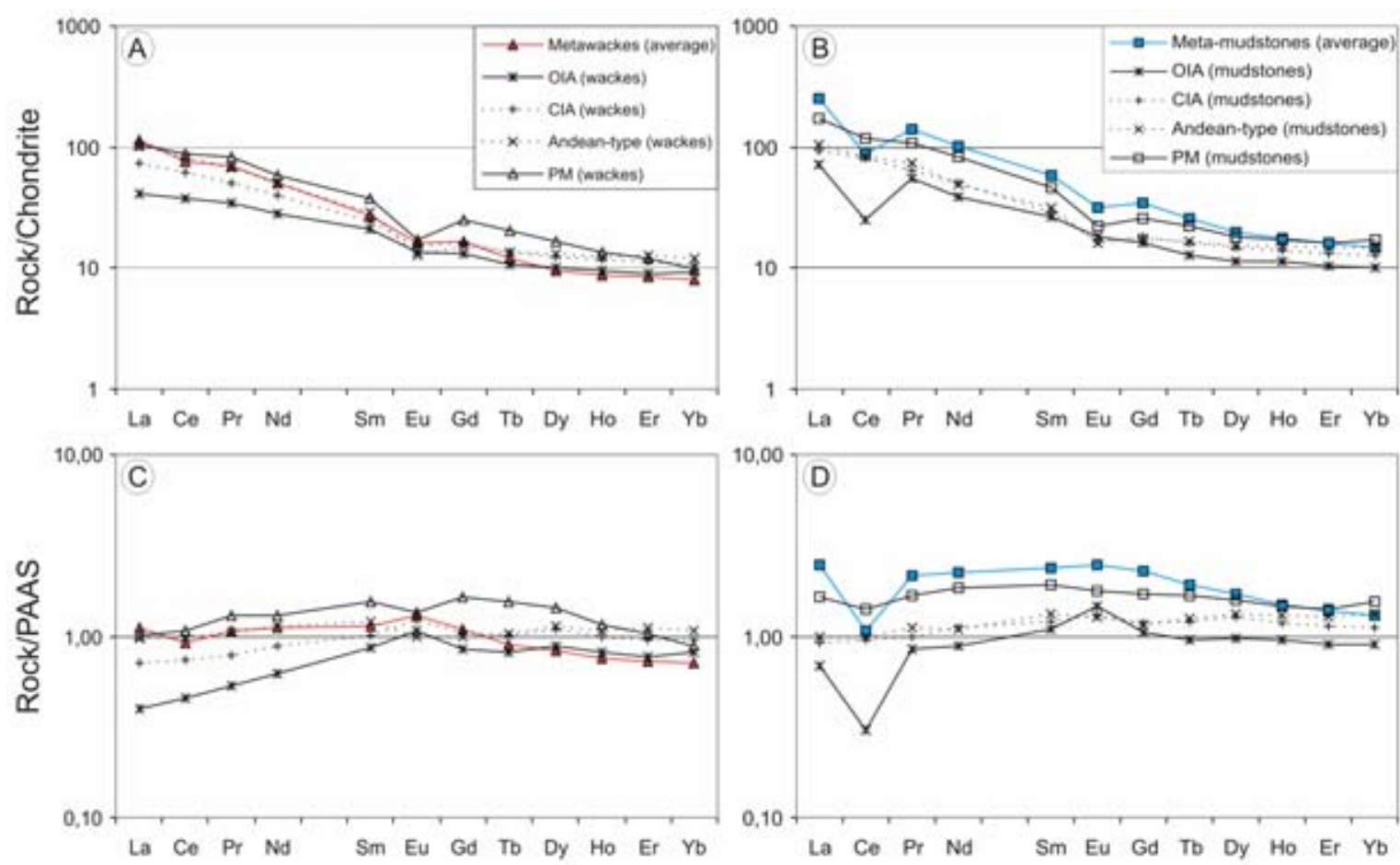

Figure 14: A and B - Chondrite-normalized (Taylor and McLennan, 1985) rare-earth element patterns for average metawackes and metamudstones from the São Roque Group; C and D PAAS-normalized (Taylor and McLennan, 1981) rare-earth element patterns for metasediments of the São Roque Group. PM= Passive Margin; OIA= Oceanic Island Arc; CIA= Continental Island Arc, by Shimizu and Masuda (1977). 

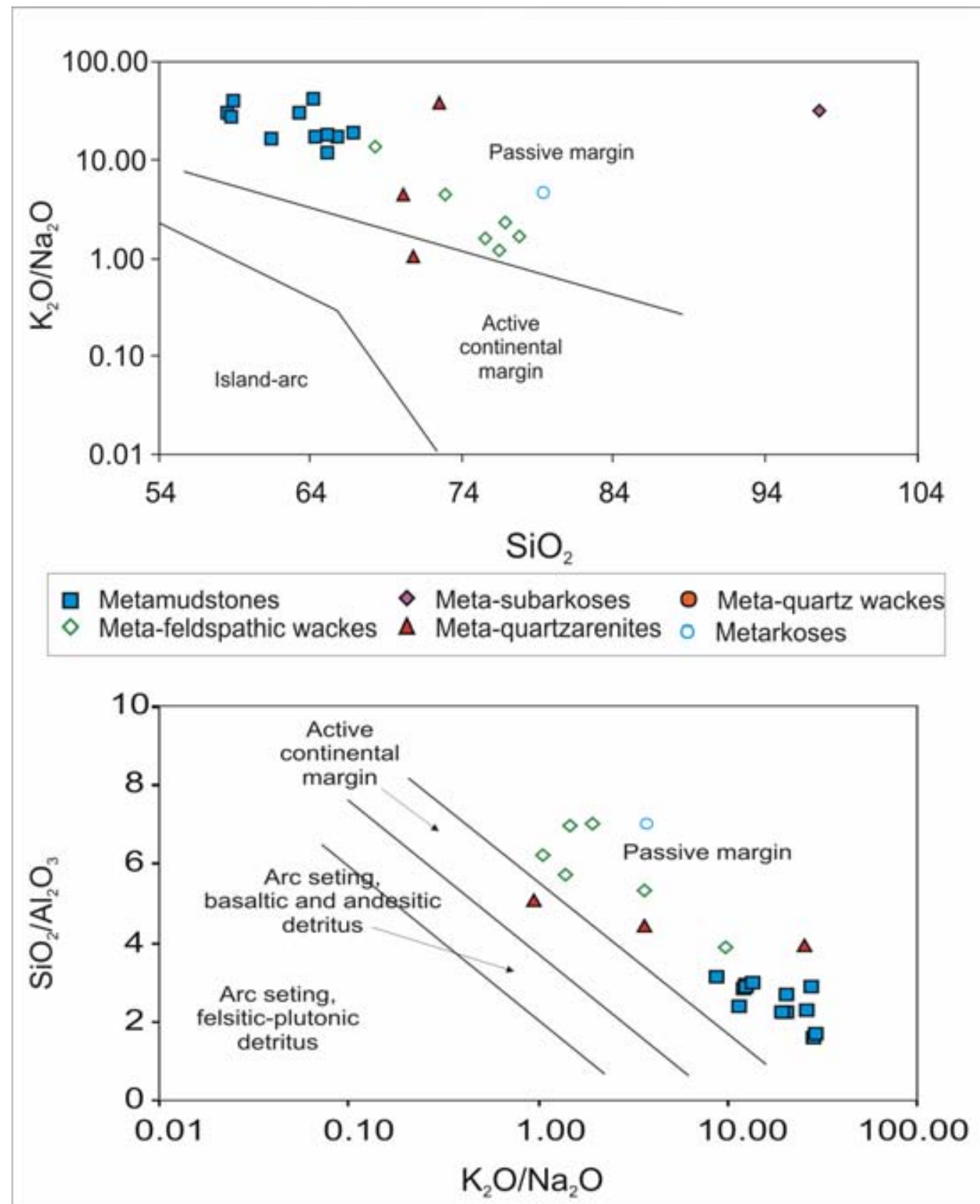

Figure 15: $\mathrm{K}_{2} \mathrm{O} / \mathrm{Na}_{2} \mathrm{O}$ vs. $\mathrm{SiO}_{2}$ and $\mathrm{SiO}_{2} / \mathrm{Al}_{2} \mathrm{O}_{3}$ vs $\mathrm{K}_{2} \mathrm{O} / \mathrm{Na}_{2} \mathrm{O}$ discrimination diagram for the provenance signature of metasediments from São Roque Group according to Roser and Korsch (1988). 

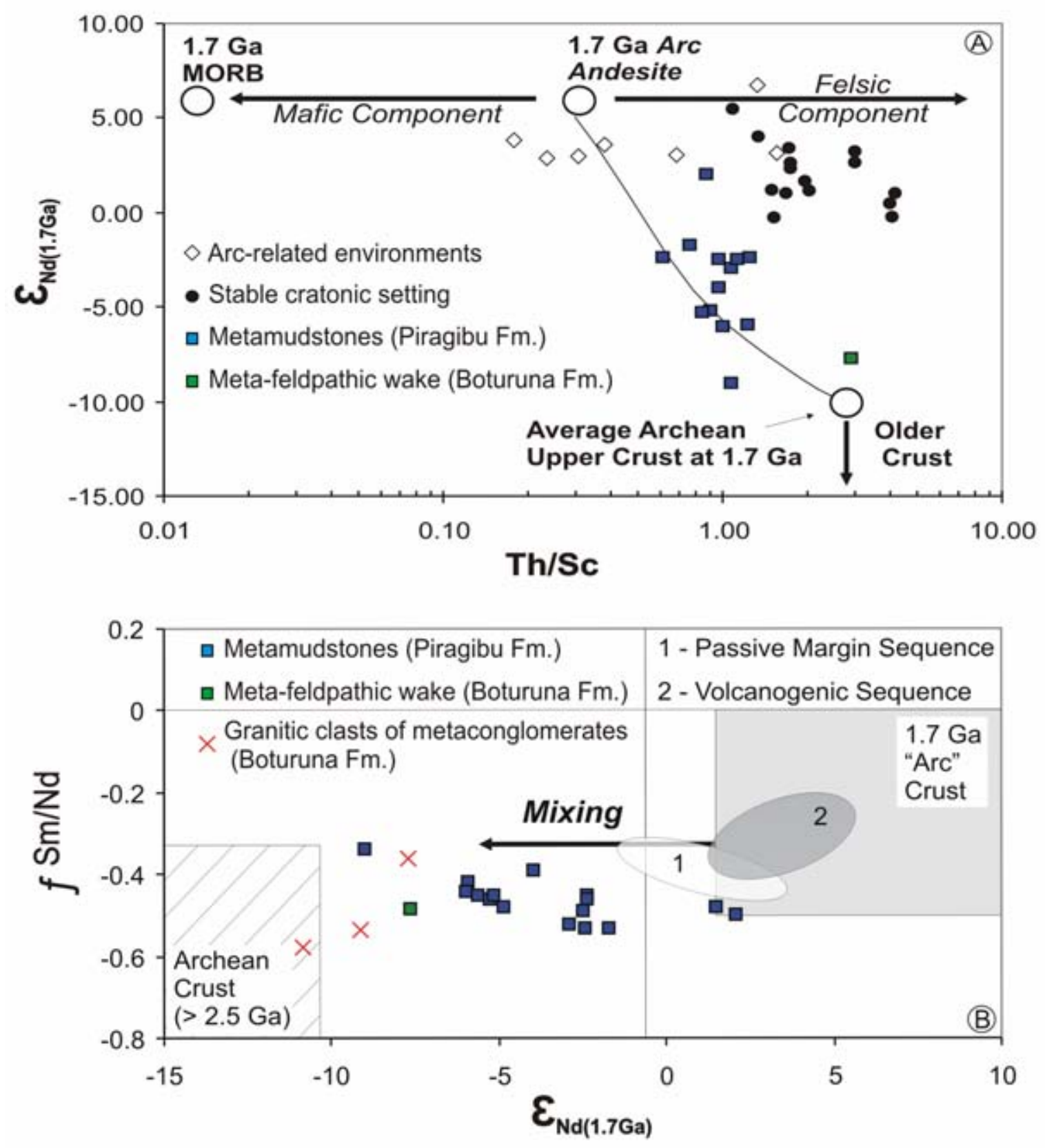

Figure 16: (A) - Plot of $\varepsilon_{\mathrm{Nd}}$ versus $\mathrm{Th} / \mathrm{Sc}$ ratio (McLennan et al., 1990) and (B) - Plot of $f^{\mathrm{Sm} / \mathrm{Nd}}$ versus $\varepsilon_{\mathrm{Nd}}$ (McLennan and Hemming, 1991) for metamudstones of Piragibu Formation, São Roque Group. 


\section{Conclusions}

The modal composition allowed the classification of a diversity of metasediments from the São Roque Group (using the criteria of Dott, 1964 and McBride, 1963) into six subtypes: samples with greater sedimentary maturity classified as meta-quartzarenites and meta-subarkoses; samples with lowest compositional maturity classified as metarkoses and meta-feldspathic wackes; and samples with low textural maturity but with high compositional maturity classified as metamudstones and meta-quartz wackes.

The chemical classification using major elements (Herron, 1988) shows great similarity with the petrographic classification, except in the case of metarkoses and metafeldspathic wackes that have same chemical behavior, in spite of different proportions of matrix. The very strong to strong negative linear correlation of $\mathrm{SiO}_{2}$ with the main major $\left(\mathrm{Al}_{2} \mathrm{O}_{3}, \mathrm{Fe}_{2} \mathrm{O}_{3}, \mathrm{~K}_{2} \mathrm{O}, \mathrm{TiO}_{2}\right)$ and trace $(\mathrm{Cr}, \mathrm{Rb}, \mathrm{Ba}, \mathrm{V}, \mathrm{Ga})$ elements is due to sedimentary sorting responsible for the concentration of these elements in the clay fraction in Al-rich sediments, which are depleted in quartz.

The increase of $\mathrm{Fe}_{2} \mathrm{O}_{3}, \mathrm{MnO}, \mathrm{MgO}, \mathrm{Zn}$ and $\mathrm{Cr}$ in metamudstones may reflect the contribution of basic and intermediate igneous sources; furthermore, this feature also demonstrates the preference of these elements for fine sediments (e.g., clay minerals) and could represent only a sorting sedimentary effect.

The presence of plagioclase and alkali-feldspar in similar proportion in metarkoses and meta-feldspathic wackes from the Boturuna Fm. (in the Morro Doce region) indicates that the main sources of these rocks are of granitic composition, and the preserved sedimentary petrofabrics with sub-euhedral feldspar in the framework suggests proximal deposits with short distance transport. Additional sources are preserved as lithic fragments of metabasic rocks and intraclasts of quartzarenite, but are always present in small modal proportions (less than $1 \%$ ).

The increase of weathering in the source area (measured by the index of chemical variation, ICV) that suffered sedimentary sorting and has been deposited as sands and clays, suggests moderate weathering processes. The transformation of feldspar to illite, therefore not reaching the highest degree of weathering with of the generation of K-poor clay mineral phases as kaolinite, reinforces the idea about moderate weathering processes in the source area as show the CIA values between 73 to 87 . 
Similar geochemical behavior compatible with sediments deposited in passive margin basin from older proterozoic sources between Boturuna Formation (proximal deposits, with peak age of detrital zircons of $2.2 \mathrm{Ga}$, and youngest detrital zircon dated in $1.7 \mathrm{Ga}$ ) and Piragibu Formation (distal deposits, with a $\mathrm{Sm}-\mathrm{Nd} \mathrm{T}_{\mathrm{DM}}$ age between 1.9 to 3.0 $\mathrm{Ga}$ ), suggesting that the sedimentation younger than $\sim 1.9 \mathrm{Ga}$ and, that the deposition of these two units was coeval, possibly with lateral correlation. However, metamudstones (Piragibu Formation) with Ce-depleted REE patterns are compatible with clays from open sea, suggesting a more complex paleo-environment, probably with interaction between passive margin basin and additional volcanogenic source related to oceanic island arc.

The samples with younger $\mathrm{T}_{\mathrm{DM}}$ must reflect greater contributions from younger sources, possibly including juvenile rocks. The oldest $\mathrm{Sm}-\mathrm{Nd} \mathrm{T}_{\mathrm{DM}}$ age $(3.0 \mathrm{Ga})$ is consistent with the $\mathrm{T}_{\mathrm{DM}}$ typical of granitic clasts from the Boturuna Formation metaconglomerates, which correspond to $2,2 \mathrm{Ga}$ products of crust reworking, and of basement nuclei of the same age in the Apiaí-São Roque Domain. The main group of metamudstones with $\mathrm{Sm}-\mathrm{Nd} \mathrm{T}_{\mathrm{DM}}$ ages in the 2.2-2.6 Ga range may have as main sources mixtures between the same basement nuclei and rocks with less negative $\varepsilon_{\mathrm{Nd}}$ at $1.75 \mathrm{Ga}$ (the best estimate for their depositional age). The latter may include both the younger sources that are present in the few samples with lower $\mathrm{T}_{\mathrm{DM}}$ and juvenile 2.2-2.4 Ga granitic sources, so far not recognized in the basement nuclei.

\section{References}

Ávila, C. A; Teixeira, W; Cordani, U.G; Moura, C.A.V; Pereira, R.M. 2010. Rhyacian (2.23-2.20 Ga) juvenile accretion in the southern São Francisco craton, Brazil: Geochemical and isotopic evidence from the Serrinha magmatic suíte, Mineiro belt. Journal of South American Earth Sciences, 29: 464-482.

Bathia. M. R. 1983. Plate tectonics and geochemical composition of sandstones. Journal of Geology. 91:611-627.

Bathia. M. R. and Taylor. S. R. 1981. Trace element geochemistry and sedimentary provinces: a study from the Tasman geosynclines. Australia. Chemical Geology. 33:115-125.

Bathia. M. R. and Crook. K. A. W. 1986. Trace element characteristics of graywackes and tectonic setting discrimination of sedimentary basins. Contributions to Mineralogy and Petrology. 92:181-193. 
Bauluz, B; Mayayo, M. J; Fernandez-Nieto, C; Lopez, J. M. G. 2000. Geochemistry of Precambrian and Paleozoic siliciclastic rocks from the Iberian Range (NE Spain): implications for source-area weathering, sorting, provenance, and tectonic setting. Chemical Geology, 168: 135-150.

Bahlburg, H. and Dobrzinski, N. 2009. A review of the Chemical Index of Alteration (CIA) and its application to the study of Neoproterozoic glacial deposits and climate transitions. The Geological Record of Neoproterozoic Glaciations. Geological Society, London: 1-31.

Bergmann. M. 1988. Caracterização Estratigráfica e Estrutural da Seqüência Vulcano-Sedimentar do Grupo São Roque na Região de Pirapora do Bom Jesus - Estado de São Paulo. Dissertação de Mestrado - Instituto de Geociências USP: 167 p.

Bergmann. M. \& Fairchild. T. R. 1985. Estromatólitos do Grupo São Roque. Proterozóico Superior. Região de Pirapora de Bom Jesus. Estado de São Paulo. Anais da Academia Brasileira de Ciências. 57(1): 116-117.

Bistrichi. C. A. 1982. Geologia do Sinclinório de Pirapora. SP. Dissertação de Mestrado. Instituto de Geociências - USP: 92 p.

Campos Neto. M. da C; Basei. M. A.. S; Artur. A. C; Silva. M. E. da; Machado. R; Dias Neto. C. de M; Fragoso Cesar. A. R; Souza. A. P. 1983. Geologia das Folhas Piracaia e Igaratá. IPT - Pró-Minério. $1^{o}$ Jornada Sobre a Carta Geológica do Estado de São Paulo em 1: 50.000: 55-76.

Campos Neto. M da C. 2000. Orogenic Systems From Southwestern Gondwana: an Approach to Brasiliano-Pan African Cycle and Orogênic Collage in Southeastern Brazil. In: U.G. Cordani. E.J. Milani. A. Thomaz Filho \& D.A. Campos. (Eds.): Tectonic Evolution of South American. In: XXXI International Geological Congress. Rio de Janeiro. Brazil: 335-365.

Carneiro. C.D.R. 1983. Análise Estrutural do Grupo São Roque na Faixa entre o Pico do Jaraguá e a Serra dos Cristais. SP. Tese de Doutoramento. Instituto de Geociências - USP: 155p.

Coutinho. J.M.V; Rodrigues. E de P; Suemitsu. A; Juliani. C; BeljavskiS. P; Paulo de T. Y. P. 1982. Geologia e Petrologia da Seqüência Vulcano-Sedimentar do Grupo São Roque na Serra de Itaberaba - SP. In: XXXII Congresso Brasileiro de Geologia. Salvador - Bahia. Anais. 2: 624-640.

Cox, R; Lowe, D. R. and Cullers. R. L. 1995. The influence of sediment recycling and basement composition on evolution of mudrock chemistry in the southwestern United States. Geochimica et Cosmochimica Acta, 59(14): 2919-2940. 
Cullers, R. L; Barret, T; Carlson, R; Robinson, B. 1987. Rare earth element and mineralogic changes in Holocene soil and stream sediment: a case study in the Wet Mountains, Colorado, USA. Chemical Geology, 63: 275-297.

Cullers, R. L. and Berendsen, P. 1988. The provenance and chemical variation of sandstones associated with the Mid-continental rift system, USA. European Journal of Mineralogy, 10: $987-1002$.

Cullers, R. L. 2000. The geochemistry of shales, siltstones and sandstones of PennsylvanianPermian age, Colorado, USA: implications for provenance and metamorphic studies. Lithos, 51: 181-203.

Cullers, R. and Podkovyrov, N. V. 2002. The source and origin of terrigenous sedimentary rocks in the Mesoproterozoic Ui group, southeastern Russia. Precambrian Research, 117: 157183.

Dantas, A. S. L. 1990. Geologia da Faixa São Roque e Intrusivas Associadas na Região entre São Paulo e Mairiporã. Norte de São Paulo. Dissertação de Mestrado. Instituto de Geociências - USP: 199 p.

Dantas E.L., Hackspacher P., Godoy A.M., Sato K., Pimentel M.M., Oliveira M.A.F., Fetter A. 1999. Characterization of the generating sources of continental crust of the Ribeira Belt through isotope of $\mathrm{Nd}$ in the State of São Paulo, SE of Brazil In: South-American Symposium on Isotope Geology, 2, Villa Carlos Paz, Argentina, Anais, p. 192-195.

Depaolo, D.J. 1988. Neodymium Isotope Geochemistry. An Introduction. Springer, Berlin. 187p.

Dickinson, W.R. 1970. Interpreting detrital modes of greywacke and arkose. Journal of Sedimentary Petrology. 40:695 - 707.

Dickinson, W.R. 1985. Interpreting provenance relations from detrital modes of sandstones. In: G.G. Zuffa (ed.). Provenance of Arenites. by D. Reidel Publishing Company: 333-361.

Dickinson, W. R. and Suczek. C. A. 1979. Plate tectonics and sandstones compositions. AAPG Bulletin, 63: 2164-2182.

Dott. JR. R. H. 1964. Wecke. Graywacke and Matrix - What Approach to Immature Sandstone Classification?. Journal of Sedimentary Petrology. 33(3): 625 - 632.

Elderfield, H. and Greaves. M. J. 1982. The rare earth elements in seawater. Nature, 296: 214-219. 
Fedo, C. M; Nesbitt, H. W; Young, G. M. 1995. Unraveling the effects of potassium metassomatism in sedimentary rocks and paleosols, with implications for paleoweathering conditions and provenance. Geology, Geological Society of America, 23: 921-924.

Figueiredo. M.C.H; Bergmann. M; Penalva. F; Tassinari. C.C.G. 1982. Ocorrência de pillow-lavas no Grupo São Roque. Estado de São Paulo. Revista Ciências da Terra. 2: 6-8.

Floyd, P. A. and Leveridge, B. E. 1987. Tectonic environment of the Devonian Gramscatho basin, south Cornwall: framework mode and geochemical evidence from turbiditic sandstones. Journal of the Geological Society, London, 144:531-542.

Folk, R. L. 1974. Petrology of sedimentary rocks. Hemphill Publishing, Austin, Texas 182 p.

Govindaraju. K. 1995. Working values with confidence limits for twentysix CRPG. ANRT and IWT-GIT geostandards. Geostandards Newsletter. 19: 1-32.

Hackspacher, P.C., Dantas, E.L., Godoy, A.M., Oliveira, M.A.F., Fetter, A., Van Schmus, W.R. Considerations About the Evolution of the Ribeira Belt in the São Paulo State - Brazil, From U/Pb Geochronology in Metavolcanic Rocks of the São Roque Group. In: II SOUTH AMERICAN SYMPOSIUM ON ISOTOPE GEOLOGY, Actas, 1999. p. 310313.

Hackspacher, P.C., Dantas, E.L., Spoladore, A., Fetter, A.H., Oliveira, M.A.F. Evidence for Neoproterozoic back-arc basin development in the Central Ribeira Belt, southeastern Brazil: new geochronological and geochemical constraints from the São Roque-Açungui Groups. Revista Brasileira de Geociências, 30, p. 110-114, 2000.

Harnois, L. 1988. The CIW index: a new chemical index of weathering. Sedimentary Geology, 55: 319-322.

Hasui. Y. 1976. Considerações Sobre a Estratigrafia do Pré-Cambriano na Região de São Paulo. Boletim Instituto de Geociências - USP. 7: 107-112.

Hennies. W.T; Hasui Y; Penalva. F. 1967. O Falhamento Transcorrente de Taxaquara. In: XXI Congresso Brasileiro de Geologia. SBG. Curitiba. Anais. 21: 159-168.

Henrique-Pinto. R. 2008. Metaconglomerados e Rochas Associadas do Grupo São Roque a Noroeste da Cidade de São Paulo: Proveniência e Implicações para a Idade da Sedimentação. Dissertação de Mestrado. Instituto de Geociências. Universidade de São Paulo. 82 p. 
Henrique-Pinto. R. and Janasi. V. A. 2010. Metaconglomerados e Rochas Associadas do Grupo São Roque a Norte da Cidade de São Paulo. Brasil. Revista Brasileira de Geociências. 40(3): 409-425.

Henrique-Pinto. R; Janasi. V. A; Simonetti. A; Tassinari. C. C. G; Heaman. L. M. 2012. Paleoproterozoic source contributions to the São Roque Group sedimentation: LA-MCICPMS U-Pb dating and Sm-Nd systematics of clasts from metaconglomerates of the Boturuna Formation. Geologia USP, 12(3): in press.

Herron, M. M. 1988. Geochemical classification of terrigenous sands and shales from core or $\log$ data. Journal of Sedimentary Research, 58(5): 820-829.

Imai. N; Terashima. S; Itoh. S and Ando. A. 1995. Compilation of Analytical Data for Minor and Trace Elements in Seventeen GSJ Geochemical Reference Samples. "Igneous Rock Series". Geostandards Newsletter. 19: 135-213.

IPT - Instituto de Pesquisas Tecnológicas 1983. Carta Geológica do Estado de São Paulo em Escala 1:50.000. Secretaria da Industria. Comércio. Ciência e Tecnologia - PróMinério.

Juliani. C. 1993. Geologia. Petrogênese e Aspectos Metalogenéticos dos Grupos Serra do Itaberaba e São Roque na Região das Serras do Itaberaba e Pedra Branca. NE da Cidade de São Paulo. SP. São Paulo. Tese de Doutorado. Instituto de Geociências - USP: 803p.

Juliani. C; Beljavskis. P; Schorscher. H. D. 1986. Petrogênese do Vulcanismo e Aspectos Metalogenéticos Associados: Grupo Serra do Itaberaba na Região do São Roque - SP. In: XXXIV Congresso Brasileiro de Geologia. Goiânia. Anais 2: 730-745.

Juliani, C., Hackspaker, P., Dantas, E.L., Fetter, A.H. 2000. The Mesoproterozoic volcanosedimentary Serra do Itaberaba Group of the central Ribeira Belt, São Paulo, Brazil: implications for the age of the overlying São Roque Group. Revista Brasileira de Geociências, 30, p. 82-86.

Kaulfuss. G. A. 2001. Geocronologia dos Núcleos de Embasamento Setuva. Betara e Tigre. Norte de Curitiba-Paraná. Dissertação de Mestrado. Instituto de Geociências - USP: 115p.

Krynine. P.D. 1948. The tourmaline group in sediments. The Journal of Geology. 54 (2) :65-87.

Lazzari, M. L. 1987. O Metabasito de Pirapora do Bom Jesus. Tese Instituto de Geociências, Universidade de São Paulo: 84p.

Leite, R.J., Heaman, L.M., Janasi, V.A., Martins, L., and Creaser, R.A., 2007. The late- to postorogenic transition in the Neoproterozoic Agudos Grandes Granite Batholith (Apiai 
Domain, SE Brazil): Constraints from geology, mineralogy, and U-Pb geochronology. Journal of South American Earth Sciences, 23(2-3): 193-212.

Mantovani, M. S. M. and Brito Neves, B. B. 2005. The Paranapanema Lithospheric Block: Its Importance for Proterozoic (Rodinia, Gondwana) Supercontinent Theories. Gondwana Research, 8, 303-315.

Martin. M. A. B. 2000. Geologia e Petrografia e Metamorfismo dos Grupos Serra do Itaberaba e São Roque a Noroeste da Cidade de São Paulo (SP). Dissertação de Mestrado - Instituto de Geociências -USP: 256p.

McBride, E. F. 1963. A Classification of Common Sandstones. Journal of Sedimentary Petrology, 33(3): 664-669.

McLennan, S. M. and Hemming, S. R. 1991. Samarium/neodymium elemental and isotopic systematics in sedimentary rocks. Geochimica et Cosmochimica Acta, v. 56: 887-898.

McLennan, S. M; Taylor, S. R; McCulloch, M. T; Maynard, J. B. 1990. Geochemical and Nd-Sr isotopic composition of deep-sea turbidites: Crustal evolution and plate tectonic associations. Geochimica et Cosmochimica Acta, v. 54: 2015-2050.

McLennan, S. M; Hemming, S. McDaniel D. K. and Hanson, G. N. 1993. Geochemical approaches to sedimentation, provenance, and tectonics. Geological Society of America, Special Paper, 248: 21-40.

McLennan, S. M; Hemming, S. R; Taylor, S. R; Eriksson, K. A. 1995. Early Proterozoic crustal evolution: Geochemical and $\mathrm{N}-\mathrm{Pb}$ isotopic evidence from metasedimentary rocks, southwestern North America. Geochimica et Cosmochimica Acta, v.59(6): 1153-1177.

Molinaroli, E; Blom. M. and Basu. A. 1991. Methods of provenance determination tested with discriminant function analysis. Journal of Sedimentary Petrology, 61(6): 900-908.

Mori, P. E; Reeves, S; Correia, C.T; Haukka, M. 1999. Development of a fused glass disc XRF facility and comparison with the pressed powder pellet technique at Instituto de Geociências, Universidade de São Paulo. Revista Brasileira de Geociências, 29: 441446.

Navarro, M.S; Ulbrich, H. H. G. J; Andrade, S; Janasi, V.A. 2002. An adaptation of ICP-OES routine determination techniques for the analysis of rare-earth elements by chromatographic separation in geologic materials: tests with reference materials and granitic rock. Journal of Alloys and Compounds, Amsterdam, 344: 40-45.

Nesbitt, H. W. and Young, G. M. 1982. Early Proterozoic climates and plate motions inferred from major element chemistry of lutites. Nature, 299: 715-717. 
Nesbitt, H. W. and Young, G. M. 1989. Formation and Diagenesis of Weathering Profiles. The Journal of Geology, 97(2): 129-147.

Nesbitt, H. W. and Young, G. M. 1996. Petrogenesis of sediments in the absence of chemical weathering: effects of abrasion and sorting on bulk composition and mineralogy. Sedimentology, 43: 341-358.

Nesbitt, H. W; Young, G. M; McLennan, S. M. and Keays, R. R. 1996. Effects of Chemical Weathering and Sorting on the Petrogenesis of Siliciclastic Sediments, with Implications for Provenance Studies. The Journal of Geology, 104(5): 525-542.

Nesbitt, H. W. and Markovics, G. 1997. Weathering of granodioritic crust, long-term storage of elements in weathering profiles, and petrogenesis of siliciclastic sediments. Geochimica et Cosmochimica Acta, 6(8): 1653-1670.

Neves. M. A. 2005. Análise Integrada Aplicada à Exploração de Água Subterrânea na Bacia do Rio Jundiaí (SP). Tese de Doutoramento. Instituto de Geociências e Ciências Exatas. Universidade Estadual Paulista. Rio Claro: 200 p.

Oliveira, M. A. F., Souza, S. C. A., Teixeira, W. and Vasconcelos, P. M. 2003. ${ }^{40} \mathrm{Ar} /{ }^{39} \mathrm{Ar}$ ages of the Aluminio (Serra do Itaberaba group) and Hermida (Itapira group) Amphibolite, central portion of the Ribeira Belt, Brazil: preliminary inferences. In: , Proceedings of: Crustal Evolution Of South America. Short Papers - IV South American Symposium on Isotope Geology. IV South American Symposium on Isotope Geology, Salvador-Bahia, Brazil: 233-236).

Oliveira, M.A.F. de., Melo, R.P., Nardy, A.J.R., Arab, P.B., Trindade, I. 2008. New U/Pb Palaeoproterozoic Zircon Age For The Cajamar Metabasite, São Roque Group, Central Ribeira Belt, Southeastern Brazil. In: VI SOUTH AMERICAM SYMPOSIUM ON ISOTOPE GEOLOGY. San Carlos de Bariloche, Argentina,. p. 1-4.

Oliveira, M.A.F. de., Melo, R.P., Nardy, A.J.R., Arab, P.B. 2011. Caracterização geotermobarométrica dos metabasitos de Cajamar (SP), Grupo São Roque, Cinturão Ribeira. Revista Brasileira de Geociências, 41(3): 375-389.

Ribeiro, L.M de A.L. 2006. Estudo Geocronológico dos Terrenos Granito-Gnáissicos e Seqüências Metavulcanossedimentares da Região do Betara (PR). Dissertação de Mestrado. Instituto de Geociências - USP: 121p.

Roser. B. P. and Korsch. R. J. 1988. Provenance Signatures of Snadstone-Mudstone Suites Determined Using Discriminant Function Analysis of Major-Element Data. Chemical Geology, 67: 119-139. 
Ross, G.M., Patchett, P.J., Hamilton, M., Heaman, L., DeCelles, P.G., Rosenberg, E., and Giovanni, M.K., 2005, Evolution of the Cordilleran orogen (southwestern Alberta, Canada) inferred from detrital mineral geochronology, geochemistry, and $\mathrm{Nd}$ isotopes in the foreland basin. Geological Society of America Bulletin, 117: 747-763.

Sato, K.; Tassinari, C.C.G.; Kawashita, K.; Petronilho, L. Método geocronológico Sm- Nd no IGUSP e suas aplicações. Anais da Academia Brasileira de Ciências, 67(3): 315-336, 1995.

Sawyer, E. W. 1986. The influence of source rock type, chemical weathering and sorting on the geochemistry of clastic sediments from the Quetico mesedimentary belt, Superior Province, Canada. Chemical Geology, 55: 77-95.

Serviço Geológico Do Brasil - CPRM. 2006. Geologia e Recursos Minerais do Estado de São Paulo. Mapas Geológicos Estaduais na Escala 1:750.000. Ministério de Minas e Energia.

Shimizu, H. and Masuda, A. 1977. Cerium in chert as an indication of marine environment of its formation. Nature, 266: 346-348.

Siga Jr. O; Basei. M. A. S; Passarelli. C. R; Harara. O. M; Sato. K; Cury. L. F. \& Prazeres Filho. H. J. dos. 2007. Geocronologia das Rochas Gnáissico-Migmatíticas e Sienograníticas do Núcleo Setuva (PR): implicações tectônicas. Revista Brasileira de Geociências 37(1): 114-128.

Siga Jr, O., Basei, M.A.S., Sato, K., Passarelli, C.R., Nutman, A., McReath, I. \& Prazeres Filho, H.J.d., 2011. Calymmian (1.50-1.45 Ga) magmatic records in Votuverava and Perau sequences, south-southeastern Brazil: Zircon ages and $\mathrm{Nd}-\mathrm{Sr}$ isotopic geochemistry. Journal of South American Earth Sciences, 32(4): 301-308.

Silva, P. C. F. da. 2004. Litofácies e Prováveis Ambientes de Sedimentação do Grupo São Roque na Região de Votorantim e Salto de Pirapora, SP. Revista do Instituto Geológico. São Paulo, 25(1/2), p. 29-48.

Singh, P and Rajamani, V. 2001. REE geochemistry of recent clastic sediments from the Kaveri floodplains, southern India: Implication to source area weathering and sedimentary processes. Geochimica et osmochimica Acta, Vol. 65, nº. 18, pp. 3093-3108.

Tassinari, C.C.G., Munhá, J.M.U., Ribeiro, A., and Correia, C.T., 2001, Neoproterozoic oceans in the Ribeira Belt (southeastern Brazil): The Pirapora do Bom Jesus ophiolitic complex: Episodes, v. 24, p. 245-250. 
Taylor. S. R; McLennan. S. M; Armstrong. R. L. and Tarney, J. 1981. The Composition and Evolution of the Continental Crust: Rare Earth Element Evidence from Sedimentary Rocks (and Discussion). Phil. Trans. R. Soc. Lond. 301(1461): 381-399.

Taylor. S. R. and McLennan. S. M. 1985. The Continental Crust: Its Composition and Evolution. Blackwell.pg 298.

Teixeira, W; Carneiro, M.A; Noce, C.M; Machado, N; Sato, K; Taylor, P.N. 1996. Pb, Sr and Nd isotope constraints on the Archaean evolution of gneissic-granitoid complexes in the southern São Francisco Craton, Brazil. Precambrian Research, 78:151-164.

Van Schmus. W.R; Tassinari. C.C.G; Cordani. U.G. 1986. Estudo Geocronológico da Parte Inferior do Grupo São Roque. In: XXXIV Congresso Brasileiro de Geologia. Goiânia (GO). Anais. 3: 1399 - 1406. 


\section{ANEXO - I}

(Histórico do Conhecimento Geológico sobre o Pré-Cambriano Paulista até o ano de 1955) 


\section{Histórico do Conhecimento Geológico sobre o Pré-Cambriano Paulista até $o$ ano de 1955}

Renato Henrique-Pinto \& Valdecir de Assis Janasi - Instituto de Geociências da Universidade de São Paulo, Departamento de Mineralogia e Geotectônica

São Paulo - SP, Cidade Universitária

Universidade de São Paulo, Instituto de Geociências - rua do Lago 562, CEP - 05508080 .

Endereço eletrônico: renatohp@usp.br 
Segundo Derby, o "primeiro impulso dado à mineração no Brasil (...) foi devido à descoberta das lavras auríferas do Jaraguá”, onde já se anunciava a existência de ouro, desde 1562. No entanto, os primeiros escritos sobre a geologia paulista se dão a partir do "Diário de uma viagem mineralógica pela província de São Paulo no ano 1805", escrito por Martim de Andrada.

Em o "Jornal do Brasil", escrito por Eschwege se encontram anexados os estudos de Varnhagen, sobre parte da capitania de São Paulo. Em "Brasil, novo mundo" publicado em 1824, Eschwege descreve uma cadeia de montanhas que se prolonga de Pernambuco até o Rio Grande do Sul, nomeada de "serra do Espinhaço".

Fundada em abril de 1886, a "Comissão Geographica e Geologica da Província de São Paulo" é responsável por gerar as primeiras cartas topográficas do Estado. Enquanto Francisco Oliveira dedicava-se aos estudos dos granitos e metassedimentos da província de São Paulo, Gonzaga de Campos estudava principalmente os "terrenos horizontaes" da Bacia do Paraná.

Das explorações realizadas nos rios paulistas em 1905, por Florence, aos importantes trabalhos efetuados no sul do estado por Euzébio de Oliveira e Leonardos, 1925 e 1934 respectivamente, muito se somou ao conhecimento da geologia na região. No entanto, coube a Moraes Rego em 1933 a primeira tentativa de reconstituição do paleoambiente sedimentar, admitindo uma origem marinha para a serie de São Roque. Tais considerações foram seguidas por Almeida em 1945 e Coutinho em 1955.

Palavras-chave: Geologia Paulista, Neptunismo, Comissão Geográfica e Geológica, Naturalistas. 
According to Derby, the "first impulse to mining in Brazil (...) was due to the discovery of gold extractions in Jaraguá", where the existence of gold was already announced since 1562. However, the earliest work about São Paulo State's geology came with the "Diary of a mineralogical trip to São Paulo Province in the 1805", written by Martin de Andrada.

Varnhagen's geological studies of part of the captaincy of São Paulo are published in the "Jornal do Brasil", written by Eschwege. In "Brasil, Novo Mundo", published in 1824, Eschwege described mountain ridges that extend from Pernambuco State to Rio Grande do Sul State, and called them "Serra do Espinhaço".

Founded in April 1886, the Geographical and Geological Commission of São Paulo Province was responsible for generating the first topographic maps of the state. While Francisco Oliveira was devoted to the study of granites and metasediments from the Sao Paulo Province, Gonzaga de Campos studied mainly the "horizontal layers" of the Paraná Basin.

From the explorations performed by Florence in the rivers of São Paulo State in $\mathbf{1 9 0 5}$, to the important works realized by Euzébio de Oliveira and Leonardos in the southern area of São Paulo State, 1925 and 1934 respectively, considerable knowledge was achieved on the geology of the region. However, it was Moraes Rego in 1933 who made the first attempt to reconstruct the sedimentary paleoenvironment, assuming a marine origin to the São Roque Series. Such considerations were further developed by Almeida in 1945 and Coutinho in 1955.

Keywords: Geology of São Paulo, Neptunism, Geographical and Geological Commission, Naturalists. 


\section{Prefácio}

A região da cidade de São Paulo e arredores conta com um dos maiores e o mais antigo acervo de estudos geológicos do Brasil, e neste inclui-se o germe da pesquisa geológica brasileira, que cresceu com a necessidade eminente de reerguer a mineração (século XIX), principalmente as minas de ouro, cujo auge da sua produção se dera no século XVIII, atingindo seu máximo entre os anos de 1750 e 1760, tal como se observa na figura 1 (PINTO, 1979).

$O$ advento da primeira Revolução Industrial colocou de maneira imperiosa a necessidade de reajustes profundos para diversos países. Tanto Portugal como Espanha (...), lançaram mão de uma série de reformas no intuito de se equipararem à época e, assim, solucionarem seus problemas de manutenção e exploração dos territórios ultramarinos dentro da nova ordem político-econômica que se configurava. Buscando inspiração no aparato mental contemporâneo, as elites ibéricas introduziram o ideário iluminista, que passou então a subsidiar o programa de reformas (FIGUEIRÔA, 1992).

Não obstante a esta investida, também foram as preocupações com as minas de ferro, que deveriam atender as necessidades emergentes pós Revolução Industrial. O berço da siderurgia no Brasil surgiu com a implantação da fábrica de ferro de São João de Ipanema na província de São Paulo, cuja primeira fundição foi atribuída a Afonso Sardinha, segundo histórico apresentado por Friedrich Ludwig Wilhelm Varnhagen em 1818.

D.Diogo Botelho Entendente das Minas, (...) chegando em S. Paulo em 1609, desiludido de encontrar o Sabarabussú, a serra resplandecente, incentivou o trabalho nas minas de ouro de lavagem e dedicou-se à exploração do ferro em Biraçoyaba; associando-se ao Provedor Mór da Fazenda, Diogo de Quadros e ao cunhado deste, Francisco Lopes Pinto, explorou a mineração de ferro em Santo Amaro, na fabrica construída em 1601, no local chamado Ibirapuera, à margem do rio Jeribatiba (rio Pinheiros) (MARTINS 1943). 
Aluno do Professor Abraham Gottlob Werner, precursor da Teoria Neptunista, José Bonifácio de Andrada e Silva (Figura 2) e seu irmão Martim Francisco Ribeiro de Andrada foram pioneiros autores que, a partir de viagens científicas, fizeram referência à geologia da Província de São Paulo. Estes escritos contêm em sua essência o ideário Neptunista, responsável pela construção dos primeiros alicerces do pensamento geológico no Brasil (Figura 7).

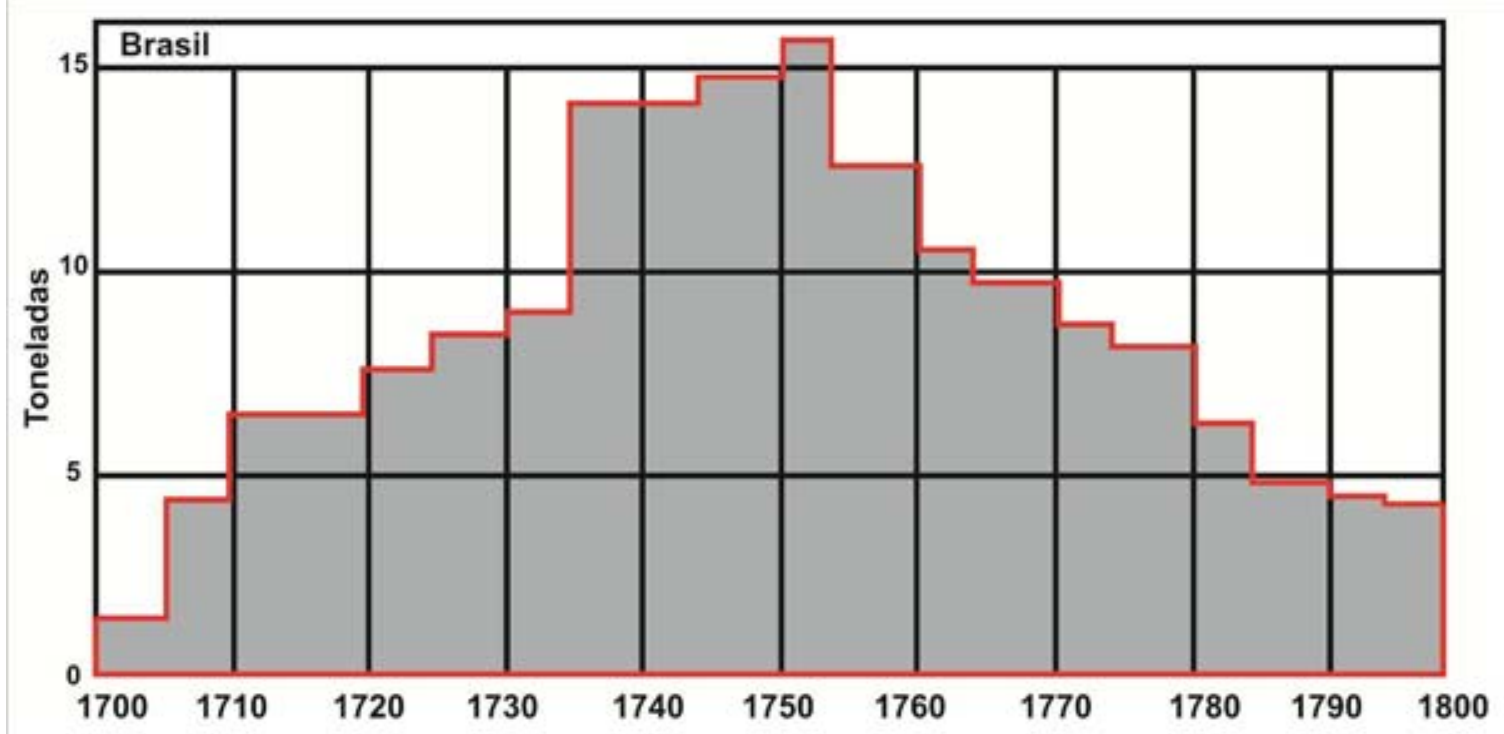

Figura 1: Produção de ouro no Brasil no século XVIII - extraído e modificado de PINTO (1979).

Neptunismo, derivado de Neptuno em alusão ao deus greco-romano dos mares, consistia em uma teoria que defendia que as formações geológicas teriam sido criadas a partir da precipitação e cristalização de minerais nas águas de um oceano primordial. Esta idéia foi bem aceita pela sociedade do século XIX, principalmente por ser consistente com o episódio bíblico do Dilúvio. A teoria que se contrapõe a este modelo foi defendida por James Hutton (1788) em A Theory of the Earth, e foi chamada de Plutonismo, porque defendia a formação das rochas a partir da atividade vulcânica, uma referência a Plutão (o deus romano das profundezas), o que levou a um "debate" geológico que perdurou por muitas décadas, conforme é discutido no capitulo IV do livro Principles of Geology escrito por Charles Lyell em 1835.

(...) em Freyberg, na Saxônia, onde pontificava na famosa Academia o grande mineralogista Abraão Gottlob Werner, de quem ouviu Andrada muitas e proveitosas lições sôbre Orictognosia*, Geognosia** e 
Montanística. Por ter separado da Química a parte referente à Mineralogia Sistemática, constituiu-se Werner o verdadeiro fundador desta. (TAVORA FILHO, 1944).

* ciência que ensina reconhecer e distinguir os minerais e os fósseis

** ramo da ciência geológica que tinha como objeto de estudo a estrutura da Terra Por carta-régia de 15 de abril de 1801 foi criada, na Universidade Coimbra, pelo Príncipe Regente (mais tarde D. João VI), a cadeira de Metalurgia, para a chefia da qual foi designado o nosso patrício. A 18 de maio do mesmo ano foi nomeado membro do Tribunal de Minas, além de receber o título de Intendente Geral das Minas e Metais do Reino (TÁVORA FILHO, 1944).

Já nos “Jornais das Viagens de 1803 e 1804”, Martim Francisco Ribeiro de Andrada, inspetor das Minas e Matas da Capitania de São Paulo, apresentara muitas notas sobre a geologia regional. Martim Francisco, juntamente com seu irmão, José Bonifácio de Andrada e Silva, que a história consagrou como o Patriarca da Independência do Brasil e que os anais da ciência clamam como um dos maiores mineralogistas de seu tempo. (OLIVEIRA; LEONARDOS, 1943).

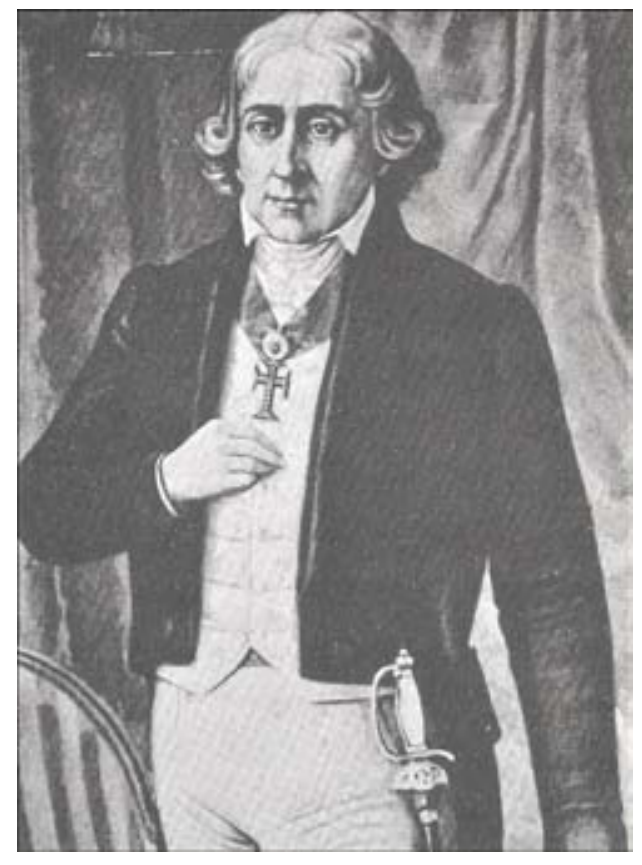

Figura 2: José Bonifácio de Andrada e Silva (1765 - 1838) - extraído de FRANCO (1981) 
A chegada da Família Real ao Brasil no ano de 1808 culminou com o processo de abertura dos portos, facilitando não só o comércio de novos produtos, mas também a criação de instituições vinculadas às ciências geológicas, como a Academia Real Militar e o Museu Real que, em 1844 transformou-se em Museu Nacional (Figura 7). Desta forma, foi permitida a entrada de pesquisadores naturalistas como John Mawe, John Bapt. von Spix, Karl Friedrich Phil. von Martius, M. A. Pissis, Augustin François César Prouvençal de Saint-Hilaire entre outros, que contribuíram substancialmente para a documentação do Brasil daquela época e para a construção da imagem do "novo mundo" no "século das luzes".

O primeiro mapa geológico do território brasileiro foi publicado em o "Jornal do Brasil" (ESCHWEGE, 1818), trabalho que reúne diversos relatos sobre o Brasil, e também inclui estudos realizados por Friedrich Varnhagen na província de São Paulo. Wilhelm Ludwig von Eschwege (Figura 3) e Varnhagen faziam parte do corpo de Engenheiros Militares contratados por José Bonifácio (Figura 7), e cujo reflexo mais nobre de seus estudos foram minuciosas descrições sobre os bens minerais brasileiros, informações que ajudaram a construir o pensamento filosófico sobre a economia e seu desenvolvimento no século XIX.

Segundo Eschwege, o produto total da exploração das minas de diamantes do Brasil, durante oitenta anos, não tinha ainda atingido em 1823 o preço do produto médio de um ano e meio das plantações de açúcar ou de café do mesmo país, embora representasse muito mais trabalho e, portanto, mais valor. Com minas mais ricas, a mesma quantidade de trabalho representaria uma maior quantidade de diamantes, cujo valor baixaria. Se se conseguisse transformar com pouco trabalho o carvão em diamante, o valor deste último desceria talvez abaixo do valor dos tijolos (MARX, 1867). 


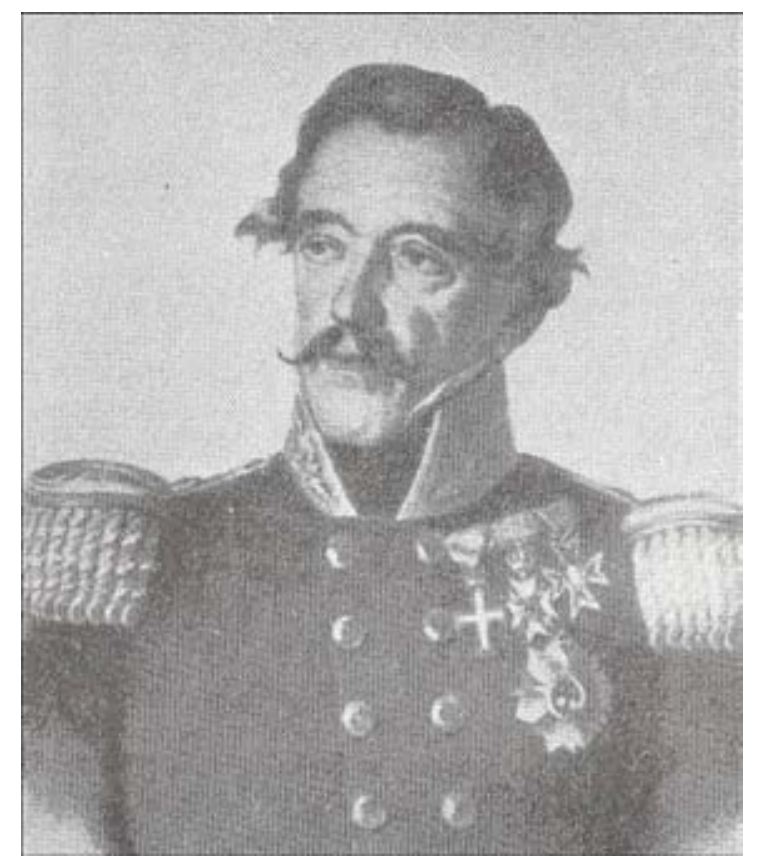

Figura 3: Wilhelm Ludwig von Eschwege (1777 - 1835) - extraído de FIGUEIRÔA (1997).

Para DERBY (1889) a necessidade de novas expansões, onde os trabalhos “geographicos embrionarios não mais podiam satisfazer", levou o governo imperial no ano de 1875, à criação da Comissão Geológica (Figura 7), que foi dirigida por Charles Frederick Hartt (Figura 4), que já havia estado no Brasil como membro da "Expedição Thayer", realizada em 1865 sob a direção de Jean Louis Rodolphe Agassiz. Tal fato marca, segundo Viktor Leinz, a transição da época dos "viajantes estrangeiros" para a das "comissões geológicas" (LEINZ, 1955). Segundo FIGUEIRÔA (1997), este período, inspirado no modelo dos "geological surveys", marca a segunda fase no processo de institucionalização das ciências geológicas no Brasil.

A escola catastrofista/criacionista amplamente difundida por Agassiz, principalmente com a teoria da ação das geleiras na constituição dos Alpes suíços, trouxe para o Brasil a teoria do "drift" (AGASSIZ, 1865), que propunha a existência de depósitos glaciais teoricamente confirmados pela presença dos matacões, posteriormente identificados por Hartt como vestígios da alteração intempérica (FREITAS, 2001).

A teoria neptunista com aspectos catastrofistas constituiu a base geológica na defesa do "dilúvio universal"; trata-se de elementos de grande importância usados para justificar a presença dos sítios arqueológicos "sambaquieiros” no Brasil por Carlos José Frederico Rath (1856 e 1871). Charles Hartt ao romper com a concepção catastrofista 
de seu mestre Agassiz possivelmente inicia uma nova etapa sobre a concepção geológica do solo brasileiro, considerando que as teorias de James Hutton (1788), Charles Lyell (1835), Charles Darwin (1859), entre outros, já assumiam um papel importante e de muita aceitação no mundo científico da época.

O programa administrativo do conselheiro José Fernandes da Costa Pereira, que assumia a pasta da Agricultura, Comércio e Obras Públicas, em 1874, cogitava estabelecer no Brasil a exploração geológica regular e sistemática de seu vasto território. Para consegui-la, convidou o prof. Hartt a elaborar o plano da organização dos trabalhos que deveriam ser encetados nesse novo rumo. Abrangia os seus planos a criação de um Serviço Geológico nos moldes das organizações existentes nas administrações federal e estaduais norte-americanas. (OLIVEIRA; LEONARDOS, 1943).

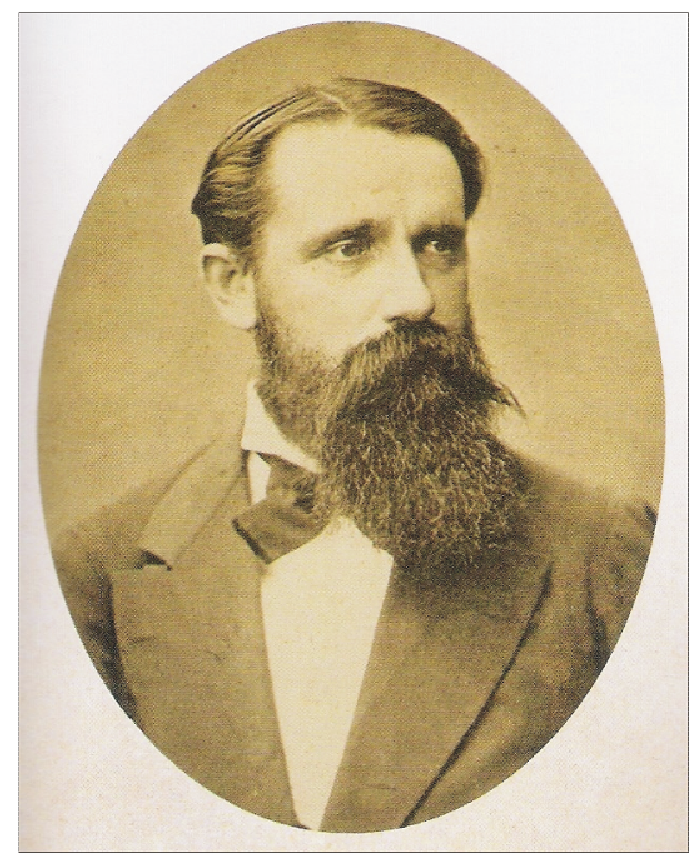

Figura 4: Charles Frederick Hartt (1840 - 1878) - extraído de FREITAS (2001).

O crescimento demográfico paulista culminou com a busca por novas frentes agrícolas e de extração mineral, justificando reformas que incluíram a criação da Comissão Geographica e Geologica em 1886 (Figura 7), por iniciativa do Conselheiro João Alfredo Correia de Oliveira, que convidou Orville Adelbert Derby para dirigi-la. Órgão responsável por gerar as primeiras cartas topográficas do Brasil, e pela expansão do conhecimento geológico para além do "sertão" brasileiro, a Comissão Geográfica e 
Geológica da Província de São Paulo deixou um legado de valor inestimável para o que diz respeito ao entendimento da geologia e geomorfologia do Estado de São Paulo.

Membro da expedição Morgan 1870-1871, que, sob a direção do Prof.

Charles F. Hartt, percorreu grande parte da Amazônia em explorações geológicas, Orville A. Derby, ainda estudante da Universidade de Cornell, com 20 anos de idade, mostrou tão excepcional capacidade como geólogo e como fisiógrafo, que se tornou desde logo o principal geólogo das comissões de Hartt. (OLIVEIRA, 1939).

No Museu Nacional, o prof. Derby ocupou o lugar de diretor da Secção de Geologia e Mineralogia de 1879 a 1891. Nesse período, foi comissionado pelo conselheiro João Alfredo Correia de Oliveira para organizar a Comissão Geográfica e Geológica de São Paulo, que passou a dirigir juntamente com a Secção do Museu. (OLIVEIRA; LEONARDOS, 1943).

$\mathrm{O}$ arcabouço ao qual se agregou a primogênita equipe da comissão em São Paulo, contava com o petrógrafo Eugen Hussak, os engenheiros de minas Luiz Felippe Gonzaga de Campos e Francisco de Paula Oliveira, além de Antonio Ave Lallemant, Axel Frick, Augusto de Abreu Lacerda, Alberto Loefregn, João Frederico Washington de Aguiar e Theodoro Fernandes Sampaio (Figura 5). Em fase posterior incorporou-se o químico Guilherme Florence e o engenheiro Joviano Pacheco.

Como primeiro Diretor da Comissão imprimiu-lhe um tal ritmo de trabalho que, ao exonerar-se, em 1905, deixava pela primeira vez no Brasil uma grande área rigorosamente cartografada em folhas na escala 1:100.000, que ainda hoje são fundamentais. (LAMEGO, 1951). 


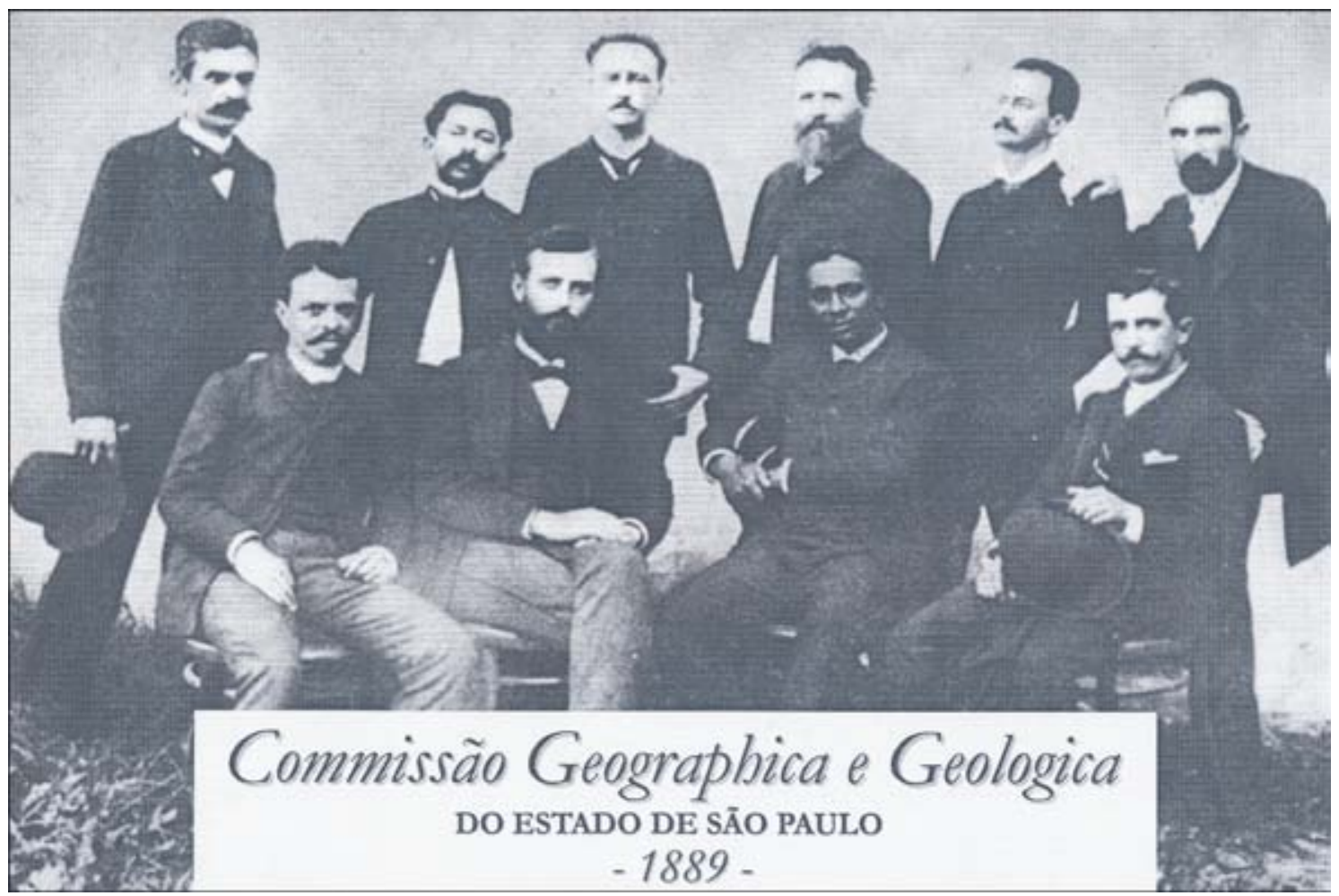

Figura 5: Commissão Geographica e Geologica do Estado de São Paulo em 1889. Segundo plano da esquerda para a direita: Ave Lallemant, Luiz Felippe Gonzaga de Campos, Eugenio Hussack, Axel Frick, Augusto de Abreu Lacerda, Alberto Löfgren; Primeiro plano da esquerda para a direita: Francisco de Paula Oliveira, Orville Adelbert Derby, Theodoro Fernandes Sampaio, João Frederico Washington de Aguiar. - extraído de FITTIPALDI \& GUTJAHR (2006).

Fundado no governo de Afonso Pena em 1907, o Serviço Geológico e Mineralógico do Brasil teve como primeiro diretor Orville Adelbert Derby (Figura 6). Antes de deixar a comissão, Derby ainda participou da criação do Museu Paulista em 1901 (Figura 7), seus trabalhos não se voltam apenas para os aspectos físicos do Brasil, e sim, resgatam informações sobre a história da geologia, geografia e do povo brasileiro. Como mostram os trabalhos de DERBY (1889 op. cit.) e DERBY (188?) em "As investigações Geologicas do Brasil" publicadas por A. de Lapparent, porém com data desconhecida.

Assim, no dia 10 de janeiro de 1907, o Decreto $n^{o}$ 6.323, do Ministro da Indústria, Viação e Obras Públicas (criado pela Lei $n^{o} 23$, de outrubro de 1891), fundava o Serviço Geológico e Mineralógico do Brasil - SGMB, tendo como seu primeiro diretor Orville Adelbert Derby que prontamente, 
buscou para seu auxiliar Luiz Felipe Gonzaga de Campos, (...), bem como Francisco de Paula Oliveira (1857-1935) e Euzébio Paulo de Oliveira (1883-1939), que auxiliara Israel Cook White (1848-1927) na Comissão do Carvão. (TOSATTO, 2001).

(...) o Museu Paulista foi o último espaço institucional para a história Natural a surgir (...). Sua origem esteve ligada à Comissão Geográfica e Geológica de São Paulo da qual se desmembrou (FIGUEIRÔA, 1992).

A São Paulo não prestou Orville Derby unicamente os inestimáveis serviços que no terreno da geologia, da mineralogia, da paleontologia, da geografia e a geodesia o apontam à gratidão do Estado e à benemerência da cultura e da civilização brasileira. (TAUNAY 1951).

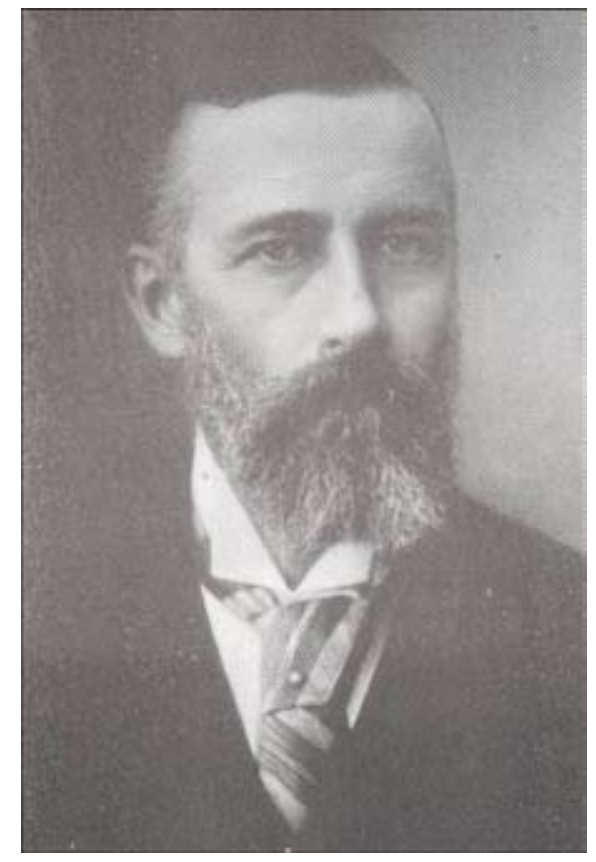

Figura 6: Orville Adelbert Derby (1851 - 1915) - extraído de FIGUEIRÔA (1997)

A disputa "ciência pura" x "ciência aplicada", que segundo FIGUEIRÔA (1992; 1997) repercutiu no afastamento de Orville Derby da Comissão Geográfica e Geológica de São Paulo em 1905, marca a terceira fase no processo de institucionalização das ciências geológicas no Brasil.

A Escola Politécnica de São Paulo criada em 1893 defendia principalmente os interesses da elite paulista cujo objetivo principal era o "crescimento" das atividades ligadas à construção civil, mineração e agricultura, e para isso era importante a formação de mão de obra especializada (ciência aplicada), sendo considerada na visão 
dos engenheiros, principalmente na do positivista Francisco Bhering, os trabalhos da Comissão como de pouco valor social. O afastamento de Derby reflete em uma queda acentuada no número de trabalhos de geologia publicados em São Paulo e no Brasil, assim como mostra a figura 7 .

O fato é que toda a despesa fixada pelo governo do Estado de São Paulo sofrera um corte generalizado, em média de quinze por cento. No entanto no caso particular da Comissão, essa redução praticamente inviabilizava seu funcionamento... Tudo isso levou Orville Derby, ainda na chefia da instituição, a queixar-se ao Secretário Carlos José Botelho, acreditando ver no corte das verbas a continuidade da campanha difamatória movida nos últimos anos por professores da Escola Politécnica de São Paulo.

Havia também o aspecto profissional: valendo-se de discursos com tom enfaticamente nativista que atacaram Derby..., o "grupo de engenheiros nacionais", como se autodenominaram Bhering e seus defensores, na verdade procurava defender um mercado de trabalho que se ampliava $e$ especializava, num processo de afirmação social da categoria profissional dos engenheiros... (FIGUEIRÔA, 1997)

Segundo FIGUEIRÔA (1997) o ano da revolução de 1930 que marca o fim da "República Velha" é tido como um marco na história contemporânea brasileira, e foi precedido pelos "movimentos militares de 1922 e 1924 (tenentismo) e a marcha da Coluna Prestes", além da superprodução de café e a quebra da bolsa de Nova York em 1929. Este período de mudanças na história brasileira culminou com transformações em diversas instituições e na extinção da Comissão Geográfica e Geológica em 1931 (figura 7). 


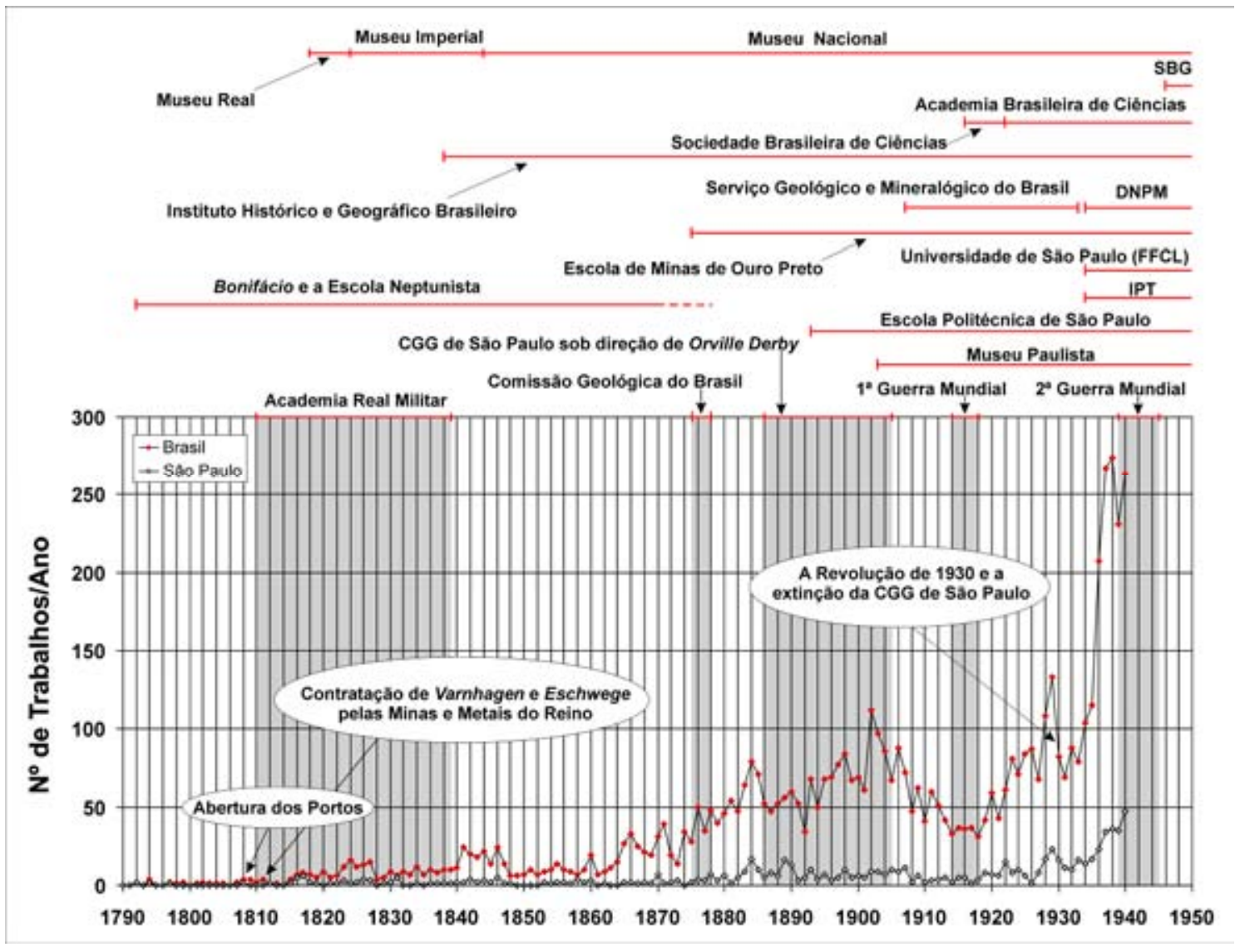

Figura 7: Quadro Cronológico de Publicações sobre a Geologia do Brasil de 1790 a 1940, situando os principais eventos e instituições (principalmente paulistas) responsáveis por grande parte destas publicações. CGG = Comissão Geográfica e Geológica; DNPM = Departamento Nacional de Produção Mineral; FFCL = Faculdade de Filosofia Ciências e Letras; IPT = Instituto de Pesquisa Tecnológica; SBG = Sociedade Brasileira de Geologia. Número de trabalhos/ano compilado de BRANNER (1903); GONSALVES (1928); IGLESIAS (1943).

Tornou-se um marco para o estudo do Pré-Cambriano paulista o Professor da Escola Politécnica de São Paulo, Luiz Flores de Moraes Rego; sua influência ainda ecoa viva nos pensamentos geológicos atuais, e seus trabalhos são considerados em muitos aspectos ainda modernos. Estes se tornaram as bases para os estudos efetuados pelos últimos naturalistas do Brasil, como Fernando Flavio Marques de Almeida (figura 9), Aziz Nacib Ab’Sáber, Setembrino Petri (figura 9), Othon Henry Leonardos (figura 10) e José Moacyr Vianna Coutinho (figura 10). Estes pesquisadores vivenciaram o momento da Teoria da Tectônica de Placas, cujas bases e idéias já tinham sido 
publicadas por Alfred Wegener em 1929, mas que somente após a segunda Grande Guerra conquistou em definitivo o espaço de aceitação nas ciências geológicas.

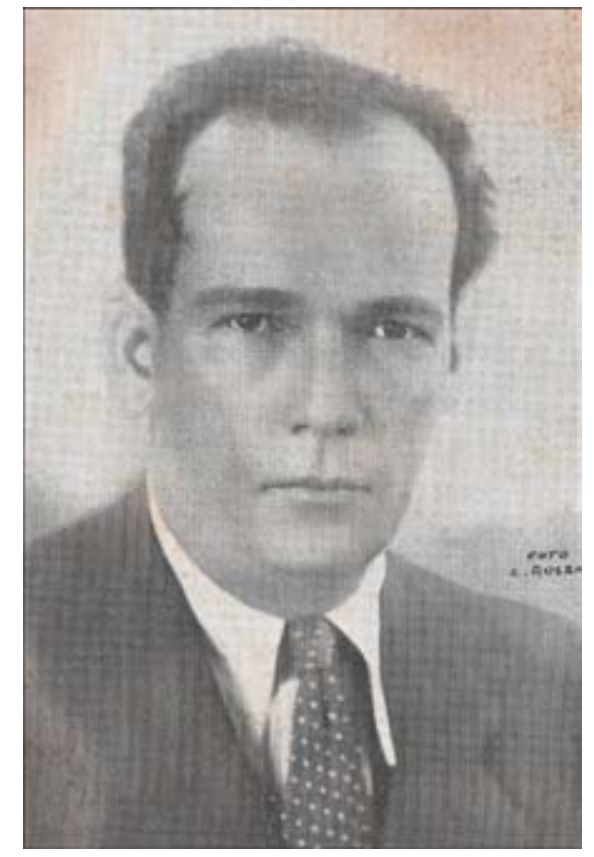

Figura 8: Luiz Flores de Moraes Rego (1896 - 1940) - extraído de MORAES REGO (1936)

A personalidade de Luís Flores de Morais Rêgo (...) após palmilhar quase todo Brasil, fixou atividade em São Paulo, em 1928, no Instituto Astronômico e Geográfico. Em 1931 foi convidado a lecionar na Escola Politécnica de São Paulo onde permaneceu como catedrático de Geologia e Mineralogia até sua morte em 25-6-1940. (LEONARDOS, 1955). 


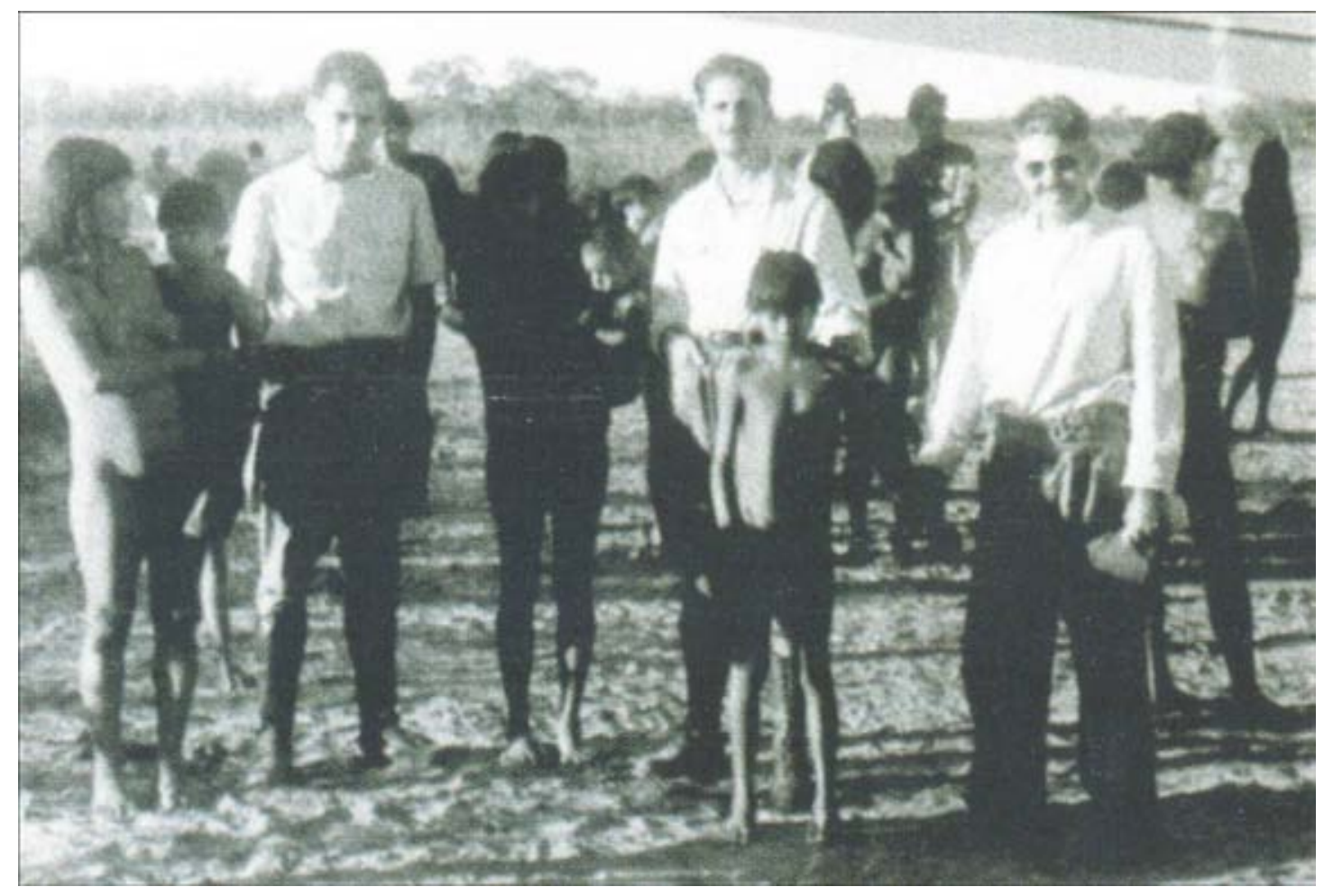

Figura 9: Da esquerda para a direita, Setembrino Petri, Octavio Barbosa (1907 - 1997), Fernando Flavio Marques de Almeida entre os índios Kalapalos (Barra do Garça Estado de Goiás em 1947) - extraído de PETRI \& CAMPOS (2004).

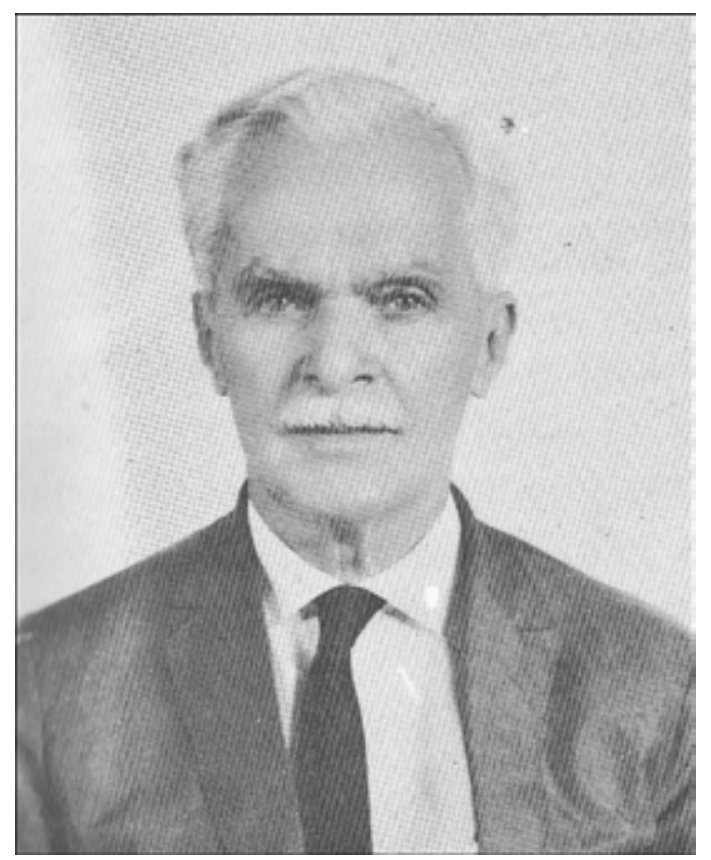

Figura 10: Othon Henry Leonardos - extraído de FRANCO (1981). 


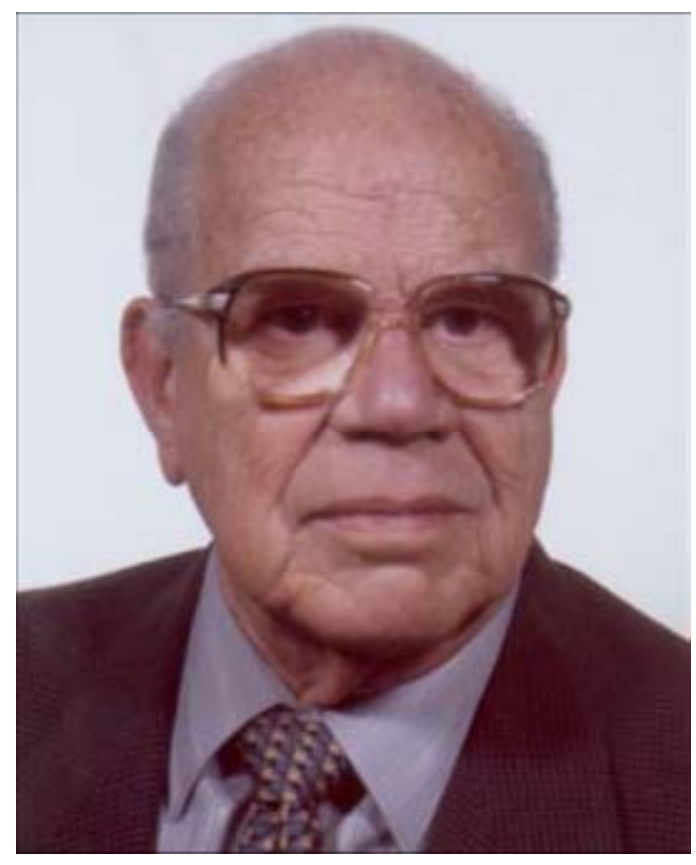

Figura 11: José Moacyr Vianna Coutinho - extraído de Academia Brasileira de Ciências (arquivo HTML, http://www.abc.org.br/resultado.php3?codigo=jcoutinho).

Tomando como referência os três principais períodos históricos pautados por FIGUEIRÔA (1992; 1997), consideramos que a criação da CAGE - Campanha Nacional de Formação de Geólogos, que introduz as primeiras escolas brasileiras de geologia, inicia o quarto período no processo de institucionalização das ciências geológicas no Brasil.

Em 1955, o Dr. Juscelino Kubitschek, Presidente da República, através do Ministro da Educação e Cultura, o também mineiro e médico, Dr. Clóvis Salgado, compôs uma comissão de 10 membros, presidida pelo engenheiro civil Othon Henry Leonardos, para os estudos de implantação dos cursos de geologia no Brasil (...), No final de 1956, aquela comissão concluiu os trabalhos, com a proposta de criação, já em 1957, de 4 cursos superiores, com 4 anos de duração (tempo integral) e procurando reunir os melhores profissionais disponíveis, no Brasil e no exterior, de forma a se alcançar padrões internacionais. Disto resultou a CAGE, responsável pela criação e inicio em abril dos cursos de Recife, Ouro Preto, São Paulo e Porto Alegre. (BARROSO 1996). 


\section{A Geologia de São Paulo no século XIX: o alicerce neptunista}

Segundo o retrospecto histórico dos trabalhos geográficos e geológicos efetuados na província de São Paulo, escrito por Orville Adelbert Derby, o primeiro impulso dado à mineração no Brasil, "foi devido à descoberta das lavras auríferas do Jaraguá, perto da capital de São Paulo" (DERBY, 1889). Este foi o local da primeira descoberta de ouro no Brasil, segundo uma carta de Braz Cubas, datada de 1562, onde já se anunciava a existência de ouro a "30 léguas de Santos".

Affonço Sardinha, e seu filho do mesmo nome, foram, os que tiveram a gloria de descobrir ouro de lavagem nas Serras Jaguámimbába e de Jaraguá (em S. Paulo) na de Ivuturuna (em Parnahiba) e Birácoyaba (no sertão do Rio Sorocaba) ouro, prata, e ferro, pelos annos de 1597. (LEME, 1772).

Em cartas enviadas a von Eschwege, Friedrich Ludwig Wilhelm Varnhagen também atribui a Affonso Sardinha a descoberta do minério de ferro em "Araçoiaba", que Francisco Ignacio Ferreira (1885) afirma ter sido do descoberta em 1578. Já as primeiras lavagens de ouro da Serra do Jaraguá começaram a ser exploradas em 1590; tais minas de ouro, segundo Francisco de Paula Oliveira (1892), são também referenciadas por Jean de Laet, na sua obra, "História do Novo Mundo", em 1640.

A febre do ouro propagava-se por toda a parte e de Portugal partiam os navios conduzindo aventureiros e ferramentas para o novo Perú brazileiro (OLIVEIRA, 1892).

No histórico apresentado por Othon Henry Leonardos, coube a D. Francisco de Souza, em 1609 o primeiro registro sobre as minas de prata na Capitania de São Vicente (LEONARDOS, 1934). No entanto, um dos primeiros registros sobre a geologia brasileira encontram-se em "Diamantes do Brasil”, escrito por José Bonifácio em 1797, enquanto a propósito da geologia paulista, seu irmão Martim de Andrada introduz a literatura geológica em língua portuguesa no Brasil, a partir de o "Diário de uma viagem mineralógica pela província de São Paulo no ano 1805”.

(...) seguiu D. Francisco de Souza para S. Vicente e em maio de 1599 já se encontrava em S. Paulo, (...) ao chegar, dirigiu-se logo em seguida para Araçoyaba ou Biraçoyaba (Montanha que encobre o sol), a fim de tomar conhecimento pessoal dos tão falados depósitos minerais, e onde Afonso Sardinha já instalará fornos de fundir ferro. (...) Em 1601, visitou as minas 
de Jaraguá e Vuturuna, onde só fazia a mineração de ouro de lavagem. (MARTINS, 1943).

A transferência da Família Real portuguesa em 1808, que culminou com a abertura dos portos brasileiros, trouxe um progresso quanto aos registros geológicos do Brasil Colonial. Muitos viajantes naturalistas contribuíram para a construção da imagem da America do Sul na Europa Ilustrada, e registros sobre a geologia da Província de São Paulo encontram-se nos trabalhos de Mawe (1811), Saint-Hilaire (1822), Spix \& Martius (1823) e M. A. Pissis (1848).

"Os mapas mais antigos do Brasil" foram estudados por Derby e revelam os registros embrionários sobre a cartografia brasileira (DERBY, 1886; 1897; 1898). No entanto, o primeiro mapa geológico do território brasileiro foi publicado no "Jornal do Brasil" (ESCHWEGE, 1818), trabalho que reúne diversos relatos sobre o Brasil, e também inclui estudos realizados por Friedrich L. W. Varnhagen na província de São Paulo.

Até a entrada do porto de Santos, a costa é formada por granito, que freqüentemente passa para gnaisse (...), em algumas regiões encontra-se granada disseminada (...). Ultrapassando, porém, o cume da serra em direção ao interior, encontra-se (...) xisto argiloso de transição, xisto silicoso (...) e rocha calcária primária, branca e granulada.

Sobe-se a serra entre dois cumes (...), e bem em cima chega-se ao platô, que prossegue (...) até além da cidade de São Paulo, que é delimitada pela segunda serra (denominada geralmente Serra da Mantiqueira), que tem direção de leste para oeste.

Varnhagen também relata um pouco da história do ferro em São João de Ipanema, e na Serra de "Araçoiaba", onde a implantação da primeira fundição foi atribuída a Afonso Sardinha, e atribuiu como origem do ouro primário da serra do Jaraguá, cuja lavagem era executada em aluviões sobrepostos a "xistos argilosos, gnaisses e granitos", relação com um "vieiro de limonita", provável "rocha matriz" encontrada ao "pé do Morro".

Martim de Andrada e seu irmão José Bonifácio de Andrada e Silva partiram de Santos ao interior de São Paulo, em 1820, lá descreveram o ponto mais elevado chamado de Monserrat.

A rocha é composta de gnais, que passa por vezes ao verdadeiro granito (...) sobre este gnais, aparece, de vez em quando, o xisto argiloso primitivo, 
que se transforma em algumas partes em micaxisto. (ANDRADA e SILVA \& ANDRADA, 1820)

Em "O Quadro Geognóstico do Brasil” publicado em 1822 e "Brasil, novo mundo" publicado em 1824, Eschwege descreve uma cadeia de montanhas chamada em algumas regiões de "serra da Mantiqueira", que sustenta na sua linha de cumeada um dos pontos mais altos do Brasil.

Esta se prolonga através da província de Minas Gerais em direção ao norte, através da Bahia e de Pernambuco, e em direção sul, através de São Paulo e o Rio Grande do Sul. Dei a essa cadeia o nome de serra do Espinhaço (ESCHWEGE, 1824).

Os esquemas estratigráficos de Eschwege, Varnhagen, assim como dos irmãos Andradas, foram baseados nos modelos europeus, como por exemplo, aquele proposto em 1787 por Abraham Gottlieb Werner, professor da Academia de Minas de Freiberg na Alemanha.

A Primeira Formação Primitiva é formada pelo embasamento cristalino, a Segunda Formação Primitiva corresponde às seqüências supracrustais dobradas (representadas pelos Supergrupos Rio das Velhas, Minas e Espinhaço), a Terceira ou de Transição abrange essencialmente o atual Grupo Bambui e uma quarta subdivisão reúne depósitos superficiais como aluviões e coberturas terciárias e quaternárias. Percebe-se que suas idéias a respeito da geologia do Brasil são fortemente influenciadas pela escola netunista de Werner (RENGER, 2005).

Possivelmente ao discordar da teoria catastrófica e criacionista de seu mestre Jean Louis Agassiz, Charles Hartt abre caminho para a filosofia de James Hutton, assim como mostra a primeira tese de geologia do país intitulada "Rochas Plutonicas do Brazil" de Oscar Nerval de Gouvêa (1880).

Muitas e mui diversas têm sido as hypotheses formuladas sobre o estado da massa central ou nucleolar do nosso planeta, e difficil, senão impossível, será fundamentar qualquer asserção verdadeiramente positiva sobre um facto que, por sua mesma natureza, não se presta a uma observação directa... Deixemos, portanto, a cada um a liberdade de engendrar as mais phantasticas ficções, para com ellas povoar o centro da terra. Limitemo-nos a admirar essas exaltadas imaginações, que, a exemplo de Leslio, impressionadas pelo accrescimo de densidade, attribuida ás camadas 
profundas da crosta terrestre, não encontraram a menor difficuldade em figurar logo uma enorme caverna central, cheia de um fluido luminoso por compressão, dotada de temperatura uniforme, e onde dous novos astros, Plutão e Proserpina, deviam gyrar em orbitas prescriptas. (GOUVÊA, 1880)

\section{A Geologia Paulista e os Últimos “Geólogos Naturalistas” do Brasil}

Após a criação da Comissão Geológica pelo governo imperial, dirigida por Charles Hartt, que em 1870 (cinco anos antes da criação da Comissão), escreve importantes contribuições sobre a Província de São Paulo (HARTT, 1870); seu discípulo Derby, em 1878, estuda parte da Província do Paraná, que foi por muito tempo conhecida como "região diamantífera": sendo pequenas as "pedras preciosas ahi achadas, conquanto de boa qualidade e côr".

As series metamorphicas não crystallinas compostas de quartzitos (itacolumito, itabirito, jacutinga), schistos talcosos e marmores (...), caracteristicos do interior das provincias da Bahia e Minas Gerais, estendendo-se em uma zona continua em direcção ao sul, provavelmente até o Rio Grande do Sul, apresentando em toda parte os mesmos caracteres esssenciaes. (DERBY, 1878)

Tais associações também são propostas em estudos praticados por Derby em 1882, nos vales do rio das Velhas e alto São Francisco. São comparados também, mármores associados a "schistos vermelhos da região de Assunguy", com equivalentes descritos perto de Sorocaba, em São Paulo.

O mais interessante é um bloco de conglomerado metamorphoseado contendo seixos redondos do tamanho de um punho (...), unidas por um cimento silicoso. (DERBY, 1882)

Fundada em abril de 1886, a Comissão Geographica e Geologica da Província de São Paulo foi responsável por gerar as primeiras cartas topográficas do estado. Em um "esboço geológico" da região compreendida entre os rios Sorocaba e Tietê, Francisco de Paula Oliveira, em 1887, separa geologicamente a região da província em quatro séries:

A série de "schistos metamorphicos" intercalada à série "gneissica" (caracterizada por PISSIS (1848); HARTT (1870) e DERBY (1880)), a série 
"sedimentaria não metamorphisada" e a série de "rochas eruptivas composta principalmente de granitos de varios typos", onde aparecem as cadeias de montanhas da serra de São Francisco, São Roque e Itaqui. Estas serras são constituídas de uma rocha "granítica amphibolica", conhecida como "olho de sapo" e por "granitos a turmalinas e a granadas das pedreiras de Cayeiras".

Não resta duvida que o granito de Caieiras é eruptivo e posterior não somente aos micaschistos como também aos schistos argillosos (...). Ainda, porém, não me foi possível determinar a relação dos schistos argillosos com os micaschistos. (OLIVEIRA, 1887)

Coube a Oliveira o pioneirismo no que diz respeito ao estudo mais detalhado dos granitos do Estado de São Paulo, como o granito do Tico-Tico, Pirituba, Itaqui, Sorocaba, Salto de Itu e granitos com "lepidolitha" como o de Perus. Já quanto à gênese do ouro na região do Jaraguá OLIVEIRA (1888; 1892), atribui a "grossos veieiros que atravessam os micaschistos em diversas direcções e que são encontrados in situ perto do morro Ururuqueçava ou morro Doce".

Em extensas e detalhadas secções, percorrendo principalmente as linhas férreas do estado, Luiz Felippe Gonzaga de Campos em 1888, caracteriza os "schistos inclinados (...) e grandes massas de granito", como constituintes da serrania de São Roque, São Francisco e Paranapiacaba, que "prolongam-se até cerca da cidade de Castro".

Na primeira edição da Revista do Instituto Histórico e Geográfico de São Paulo em 1895, Derby caracteriza o sistema de cordilheiras da Serra da Mantiqueira em São Paulo, a partir do conjunto Serra da Cantareira, como um "macisso composto", e a Serra do Jaraguá, como "pico ou montanha isolada". Em 1898 as montanhas ao redor da cidade de São Paulo, são descritas como "xistos antigos em posição inclinada", cortados por granitos que passam "subterraneamente, por baixo do distrito urbano".

Guilherme Florence em "Notas geológicas sobre o rio Tieté", através das explorações realizadas pela Comissão Geográfica e Geológica nos rios paulistas em 1905, percorre desde a cabeceira até o Salto de Itu. O rio, neste trajeto, atravessa "schistos argillosos (phyllites) fortemente inclinados", "calcareo" incluído nos "schistos", gabros, quartzitos e "schistos amphibolicos".

Em 1925, Euzébio Paulo de Oliveira, filho primogênito de Francisco de Paula Oliveira, provavelmente introduz na literatura o nome "serie de São Roque", ao descrever metacalcários do Estado de São Paulo, porém o termo “camadas de São 
Roque" já era consagrado na geologia paulista por Gonzaga de Campos como unidade litoestratigráfica.

O Dr. Euzébio de Oliveira denominou as formações análogas do Estado do Paraná de Serie de Assunguy. O Dr. Gonzaga de Campos já havia proposto para suas homologas em S. Paulo a denominação Serie de S. Roque (MORAES REGO, 1930).

Em 1927, Euzébio de Oliveira define como "serie de Assunguy", na região do Estado do Paraná, seqüências de rochas constituídas "especialmente de schistos argillosos, pouco metamorphisados (...), calcareos, e algum quartzito”, outrora estudados por Pissis (1848), Rath (1856) e Derby (1878).

Luiz Flores de Moraes Rego em "As estructuras antigas do Brasil" e "Ensaio sobre as montanhas do Brasil e sua genesis" no ano de 1931, chamou de Pré-Brasilides as "estruturas diastroficas" que se anexaram a "escudos arqueanos", para dar origem à "grande molhe continental chamada Brasilia". A esta se "haviam de juntar outras estruturas, chamada de Brasilides, já paleozóicas", dando origem à “Terra Gondwana”.

Moraes Rego compara o conjunto serie São Roque, em São Paulo, serie Assunguy, no Paraná, serie de Brusque, em Santa Catarina, com as camadas descritas no vale do Rio das Mortes em Minas Gerais.

As estruturas metamórficas de Minas se prolongam para sul. São terras constituídas de formações mais ou menos sincrônicas da serie de Minas (...), que se continuam até Sta. Catharina.

O grande trabalho realizado por Moraes Rego em 1943 foi pioneiro no que diz respeito às primeiras tentativas de reconstituição do paleoambiente sedimentar, admitindo então para estes depósitos uma origem marinha.

Para Othon Henry Leonardos em 1934, na série de São Roque encontram-se formações principalmente "metamorfizadas na mesozona, muito semelhante à da série de Minas", definida por Derby em 1906. Leonardos chama de "formação Iporanga", "filitos acetinados, folhelhos ardosianos", e "conglomerados fluviais encontrados ao longo da Ribeira de Iguape".

Os conglomerados, que se acham encaixados nos filitos acetinados, encerram seixos de quartzitos, quartzo filonar, filitos com magnetita, eruptivas ácidas sericitizadas e cloritaxistos, ligados por um cimento sericítico. (LEONARDOS, 1934) 
Avelino Ignácio de Oliveira e Leonardos em 1943 apontaram para a "série São Roque e sua homóloga paranaense, série Assungui”, semelhanças estruturais e litológicas com a série Minas atribuindo à série de São Roque uma predominância de membros filíticos, "outrora chamados de xistos argilosos e talcosos". A busca sobre a continuidade entre as formações do Pré-cambriano paranaense e paulista também foi alvo de estudo em uma seção geológica realizada por Moraes Rego \& Almeida (1946) de Capela da Ribeira a Curitiba.

Hipótese da existência de registros de vida na série de São Roque, já havia sido levantada por Theodoro Knecht em 1934, com a descrição de uma "suposta" concha fóssil chamada de Pteropodes, que aparece no "cambriano inferior". No entanto, exames microscópicos efetuados por Viktor Leinz em 1937, mostraram tratar-se de pseudomorfos de cordieritas.

A primeira descoberta de estruturas "sem dúvida fósseis", feita no précambriano sul-americano, coube a Fernando Flavio Marques de Almeida em 1944 e 1945, que atribui para a série Assunguí, a série Minas e "suas congêneres", uma origem a partir de "mares epicontinentais", com fósseis pré-cambrianos referentes ao gênero “Collenia Itapevensis".

Os quartzitos da serra do Japi são comparados aos do morro do Boturuna e Jaraguá por Luciano Jacques de Moraes, em 1944. Já o Morro Doce, descrito por Aziz Nacib Ab'Sáber em 1947, encontra-se "esculpido em um feixe de chistos e filitos menos resistentes" em relação aos quartzitos do Jaraguá, cuja orientação $E$ - $W$, "escapa completamente ao sentido clássico $N E-S W$ que geralmente se dá para as formações proterozóicas paulista".

O batólito desnudado da Cantareira seria, no caso, o maior responsável pela orientação local E-W das estruturas do Jaraguá.

O trabalho de Mores Rego \& Souza Santos (1938) em parte é retomado por Almeida em 1955 que identifica estruturas retilíneas (falhas) com aproximadamente 15,4 quilômetros de extensão, "indo pelo menos desde o morro Doce..., às nascentes do corrego do Horto". No mesmo ano, José Moacyr Vianna Coutinho relata a primeira inspeção científica realizada por Otávio Barbosa e Fernando de Almeida em 1953, das então recentes escavações herdadas da construção da Rodovia Anhanguera. Esta inspeção permitiu o reconhecimento de metaconglomerados polimíticos. Coutinho refere-se à importância do achado, descrevendo estas rochas como "um dos primeiros conglomerados polimíticos metamorfizados encontrados entre as rochas pré-devonianas 
brasileiras". Ao fazer uma comparação com outros metaconglomerados do Brasil, Coutinho atribui semelhanças petrográficas e cronoestratigráficas aos descritos por Leonardos na região de Iporanga, e que Otavio Barbosa em 1948, insere na "serie Açunguí’.

\section{Reflexões}

O Pico do Jaraguá descrito como a primeira ocorrência de ouro do Brasil, e que em Tupi-Guarani significa "o senhor do vale", vale este representado como a bacia sedimentar de São Paulo, e que do qual talvez fora possível uma esplêndida visada desde os tempos pré-colombianos. Talvez, junto com as primeiras descrições feitas por Pero Uaaz de Camjnha popularmente chamado de Pero Vaz de Caminha, que chamou de "grandes bareiras delas vermelhas e delas bramcas", referindo-se às grandes barreiras (Grupo Barreiras) compostas por rochas de cores variegadas da costa brasileira (CAMJNHA, 1500), o Jaraguá, possa representar um dos primeiros elementos documentados da fisiografia e geologia do Brasil.

São Paulo foi o berço da produção aurífera e da siderurgia no Brasil, principalmente através as lavras do Jaraguá, Voturuna e Ribeira de Iguape, além da primeira fabrica de ferro de São João de Ipanema, o que entre outros fatores permitiu fixação das primeiras vilas e províncias brasileiras, como é o caso de São Vicente, Santos e São Paulo. Destas partiram as bandeiras paulistas na conquista do sertão brasileiro, o que acarretou na descoberta das Minas Gerais, proporcionando para a coroa portuguesa uma produção que atingiu com o seu auge mais de 15 toneladas de ouro por volta do ano de 1750 .

A busca em reerguer a mineração e as necessidades emergentes pós Revolução Industrial, segundo FIGUEIRÔA (1992), levou Portugal a subsidiar o programa de reformas que buscou "inspiração no aparato mental contemporâneo" influenciado pelo "ideário iluminista". As filosofias geológicas fruto deste momento na Europa, afloraram com raízes na mineralogia, que teve como grande precursor Abraham Gottlob Werner responsável pela divulgação da teoria Neptunista e de quem recebeu José Bonifácio de Andrada e Silva, seus ensinamentos. Financiado pela coroa portuguesa, Bonifácio, após estudar em diversos países europeus foi nomeado membro do Tribunal de Minas. Como Intendente Geral das Minas e Metais do Reino, foi responsável pela contratação dos engenheiros militares como Friedrich Ludwig Wilhelm Varnhagen e Wilhelm Ludwig von Eschwege. 
A escola neptunista/criacionista difundida por Bonifácio e outros muitos viajantes naturalistas são marcas notórias nos trabalhos da época. Charles Frederick Hartt ao discordar da teoria catastrófica e criacionista de seu mestre Jean Louis Agassiz, possivelmente inicia uma nova etapa sobre a concepção geológica do solo brasileiro, considerando que naquele momento, as teorias de James Hutton, Charles Lyell, Charles Darwin, entre outros, já assumiam um papel importante e de muita aceitação no mundo científico.

Membro da expedição "Morgan" 1870-1871, aos 20 anos de idade, Orville Adelbert Derby começava a trilhar uma das mais lisonjeadas carreiras da geologia brasileira, levando muitos até os dias de hoje, o considerarem como "pai de geologia brasileira". Sob influência de Charles Hartt, foi montada nos modelos da curta história da Comissão Geológica do Brasil, a Comissão Geográfica e Geológica da Província de São Paulo, que, em quase duas décadas de existência, transformou os estudos "geográficos embrionários" em verdadeiras bases, que são fundamentais até os dias de hoje. Vale lembrar que as primeiras cartas topográficas, o reconhecimento e a discriminação de diversas unidades geológicas, como por exemplo: as Formações Devonianas da Bacia do Paraná, ou mesmo as "camadas de São Roque" de Luiz Felippe Gonzaga de Campos, além do primeiro microscópio petrográfico do Brasil trazido por Eugenio Hussack, figuram entre as primazias do legado da Comissão.

Muitos pesquisadores formados pela Escola de Minas de Ouro Preto, criada em 1876 por Claude Henri Gorceix, fizeram parte do arcabouço da primogênita Comissão paulista e também ocuparam cargos em importantes instituições nacionais como: $\mathrm{O}$ Museu Nacional do Rio de Janeiro, Serviço Geológico e Mineralógico do Brasil, Academia Brasileira de Ciências, e em São Paulo, o Museu Paulista, Escola Politécnica e a Faculdade de Filosofia Ciências e Letras da Universidade de São Paulo, entre outras.

A partir do final dos anos 30 do século XX houve uma explosão de trabalhos de geologia, ultrapassando a marca de mais de 250 trabalhos ao ano, graças aos esforços de grandes pesquisadores como Luiz Flores de Moraes Rego, Setembrino Petri, Othon Henry Leonardos, José Moacyr Vianna Coutinho e Fernando Flavio Marques de Almeida.

Até Segunda Guerra Mundial a humanidade não conhecia tão profundamente as partículas atômicas, principalmente os isótopos, que começaram a ser empregados na datação dos eventos terrestres após a década de 1950, assim como a Tectônica de Placas, que mudou o modo de entender os processos geológicos. Isto enobrece os 
trabalhos anteriores a esta época, e dá luz a uma expansão incognoscível sobre o tema, considerando que muitas e importantes questões vieram com os anos que sucederam a estes trabalhos, principalmente após a criação da CAGE, que criou as primeiras escolas da geologia erguidas sobre um sólido alicerce, construído pelos últimos geólogos naturalistas do Brasil, marcando então, a quarta fase no processo nacional de institucionalização das ciências geológicas. Por isso, encerramos aqui este histórico que é dedicado aos pioneiros estudos relacionados às rochas do Pré-cambriano paulista, sobre as quais segundo Martim de Andrada (1805), “obrou a mão inexorável do volúvel tempo".

\section{Referências}

AB'SÁBER, A. N. 1947. Geomorfologia da Região do Jaraguá, em São Paulo. Anais da Associação dos Geógrafos Brasileiros, p. 32- 40.

AGASSIZ, J. L. R. 1865. On the drift in Brazil, and on decomposed rocks under the drift. The American Journal of Science and Arts, New Haven: Editors, 20 series, XL. p. 389-390.

ALMEIDA, F. F. M. de. 1944. Collenia Itapevensis sp. n. - um fóssil pré-cambriano do Estado de São Paulo. Faculdade de Filosofia, Ciências e Letras, Universidade de São Paulo, Boletim 1, nº 45, p. 89-106.

ALMEIDA, F. F. M. de. 1945. A Vida Pré-Cambriana. Geologia e Metalurgia. Boletim 1, p. 81-90.

ALMEIDA, F. F. M. de. 1955. As Camadas de São Paulo e a Tectônica da Serra da Cantareira. Boletim da Sociedade Brasileira de Geologia, v. 2, nº 4, p. 23-40.

ALMEIDA, F. F. M. de. 1957. Novas Ocorrências de Fósseis no Pré-Cambriano Brasileiro. Anais da Academia Brasileira de Ciências, v. 29, nº 1, p. 63-72.

ANDRADA e SILVA, J. B. de. 1797. Diamonds of Brazil. A Journal of Natural Philosophy, Chemistry and the Arts. v. 1, n 4, p. 24-26.

ANDRADA, M. F. R. de. 1805. Diário de uma Viagem Mineralógica pela Província de São Paulo no Ano de 1805. (transcrição) Boletim Paulista de Geografia. São Paulo, outubro de 1954 , v. 18 , p. $35-42$.

ANDRADA e SILVA, J. B. de. \& ANDRADA, M. F. R de. 1820. Viagem mineralógica na Província de São Paulo (Primeira Parte). (transcrição) Boletim Paulista de Geografia. São Paulo, 16 de março, 1954, p. 66-74. 
BARBOSA. O. 1948. A Chamada Série Ribeira. Mineração e Metalurgia. Setembrooutubro, v.13, nº 75 , p. 187-188.

BARROSO, J. A. 1996. Os 40 anos da CAGE - Campanha Nacional de Formação de Geólogos, os cursos no Brasil e, em particular, no Rio de Janeiro. Anuário do Instituto de Geociências, n 19, p. 143-156.

BRANNER, J. C. 1903. A Bibliography of the Geology, Mineralogy and Paleontology of Brazil. Archivos do Museu Nacional, Rio de Janeiro, v. XII. P. 197-309.

CAMJNHA, P. U. de. 1500. Carta a El Rei D. Manuel. Ortografia original copiada do original que existe no Arc. Nac. da Tôrre do Tombo - Portugal, gav. 8, maç. 2, $\mathrm{n}^{\mathrm{o}} 8$. Arquivo da Internet por: wikisource.org.

COUTINHO, J. M. V. 1955. Metaconglomerado e rochas associadas no Município de São Paulo. Boletim Faculdade de Filosofia. Ciências e Letras da Universidade de São Paulo, Mineralogia 13, no 186, p. 5-56.

DARWIN, C. 1859. The Origin of Species by means of natural selection, or the preservation of favoured races in the struggle for life. John Murray, Albemarle Street, London. 502 p.

DERBY, O. A. 1878. A Geologia da Região Diamantifera da Provincia do Paraná no Brasil. Archivos do Museu Nacional, v. 3, p. 89-98.

DERBY, O. A. 1880. On the age of the Brazilian gneiss series; Discovery of Eozoon. American Journal Science. 3rd, v.XIX (W. N. CXIX), New Haven. p. 324-325.

DERBY, O. A. 1882. Relatório acerca dos estudos geológicos praticados nos Valles do rio das Velhas e alto S. Francisco. Apresentado ao Conselheiro Manoel de Araújo, 29 de março. Typographia Nacional. Rio de Janeiro.

DERBY, O. A. 1886. Os mapas mais antigos do Brasil. Revista do Instituto Histórico e Geográfico. Transcrição - 1902, v.7, nº 53, p. 38-62.

DERBY, O. A. 1889. Retrospecto Histórico dos Trabalhos Geográficos e Geológicos (Efetuados na Província de São Paulo). In: Revista do Instituto Geográfico e Geológico de São Paulo, julho a dezembro de 1949 (transcrição). v. 7, nº 3-4, p. 283-300.

DERBY, O. A. 1895. A denominação "Serra da Mantiqueira". Revista do Instituto Historico e Geografico de São Paulo, v. 1, p. 1-15.

DERBY, O. A. 1897. Um Mapa Antigo de Partes das Capitanias de S. Paulo, Minas Gerais e Rio de Janeiro. Revista do Instituto Histórico e Geográfico de São Paulo, v. 2, p. 197-219. 
DERBY, O. A. 1898. A Estrada de S. Paulo ao Rio Grande do Sul no século passado. Revista do Instituto Histórico e Geográfico de São Paulo, v. 3, p. 173-199.

DERBY, O. A. 189?. As Investigações Geologicas do Brasil. In: Resumo de Geologia por Lapparent, A. de. Rio de Janeiro. H. Garnier. p. 312-333.

DERBY, O. A. 1898. Geologia do Sudeste Paulista. Boletim da Agricultura, Secretaria da Agricultura, 1951. p. 3-4.

DERBY, O. A. 1906. The Serra do Espinhaço, Brazil. Journal of Geology, v. 14, nº 5, p. 374-401.

ESCHWEGE, W. L. von. 1818. Jornal do Brasil. Tradução Friedrich E. Renger, Tarcísia Lobo Ribeiro e Günter Augustin, 2002. Centro de Estudos Históricos e Culturais. Fundação João Pinheiro. Belo Horizonte. 408p.

ESCHWEGE, W. L. von. 1824. Brasil, novo mundo. Tradução Domício de Figueiredo Murta, 1996. Centro de Estudos Históricos e Culturais. Fundação João Pinheiro. Belo Horizonte. 410p.

FERREIRA, F. I. 1885. Diccionario Geographico das Minas do Brazil - concatenação de noticias, informações e descripções sobre as minas, extrahidas de documentos officiaes, memorias, historias, revistas, diccionarios, cartas geographicas, roteiros, viagens, explorações de rios, ditas de estradas de ferro e outras. Imprensa Nacional, Rio de Janeiro. 754 p.

FIGUEIRÔA, S. F. de M; VIEIRA, P. C; BOCHICCHIO, V. R. 1985. Um Século de Pesquisas em Geociências. Secretaria de Agricultura e Abastecimento, Coordenadoria da Pesquisa de Recursos Naturais, Instituto Geológico. São Paulo. 96 p.

FIGUEIRÔA, S. F. de M. 1992. Ciência na Busca do Eldorado: A institucionalização das ciências geológicas no Brasil, 1808 - 1907. Tese de Doutoramento - Faculdade de Filosofia, Letras e Ciências Humanas, Universidade de São Paulo. 171 p.

FIGUEIRÔA, S. F. de M. 1997. As Ciências Geológicas no Brasil: uma História Social e Institucional, 1875 - 1934. São Paulo: Hucitec.

FITTIPALDI, F. C; GUTJAHR, M. R. 2006. Os 120 anos de criação da Comissão Geographica e Geologica 1886 - 2006. Instituto Geológico de São Paulo, Secretaria de Estado do Meio Ambiente.

FLORENCE, G. 1905. Notas geológicas sobre o rio Tieté. Comissão Geographica e Geológica de São Paulo - Exploração do Rio Tietê, $3^{\circ}$ Edição - 1930. p. 10-16. 
FRANCO, R. R. 1981. A Mineralogia e a Petrologia no Brasil. In: História das Ciências no Brasil. Coordenadores - Ferri, M. G \& Motoyama, S. Editora da Universidade de São Paulo - EDUSP, São Paulo. p. 1-42.

FREITAS, M. V. de. 2001. Hartt- expedições pelo Brasil imperial, 1865-1878. São Paulo, Metalivros. 244p.

GONSALVES, A. D. 1928. Bibliographia de Geologia, Mineralogia e Peleontologia do Brasil. Serviço Geológico e Mineralógico do Brasil, Ministério da Agricultura, Indústria e Comércio, Officinas Typographicas do Serviço de Informações do Ministério da Agricultura, Rio de Janeiro, Boletim n ${ }^{\circ}$ 27. 205p.

GONZAGA DE CAMPOS, L. F. Secção Geológica. Relatório apresentado ao Dr. Orville A. Derby. 1888. Commisão Geographica e Geológica da Província de São Paulo. Typographia a Vapor de Jorge Seckler \& Comp. - São Paulo, 15 de Dezembro. p. 21-34.

GOUVÊA, O. N. 1880. Rochas Plutonicas do Brazil. These de Concurso a uma das vagas da primeira secção do curso de sciencias physicas e naturaes apresentada á Congregação da Escola Polytechnica, Typographia Universal de E. \& H. Laemmert, Rio de Janeiro. 67 p.

HARTT, F. C. 1870. “Geology and Physical Geography of Brazil”. Tradução de Edgar Süssekind de Mendonça e Elias Dolianiti: Companhia Editora Nacional. 1941, nº 200, p. 543-549.

HUTTUN, J. 1788. Theory of the Earth; or an investigation of the Laws observable in the Composition, Dissolution, and Restoration of Land up the Globe. Transactions of the Royal Society of Edinburgh, vol. I, part II, p. 209-304.

IGLESIAS, D. 1943. Bibliografia e Índice da Geologia do Brasil, 1641-1940. Departamento Nacional da Produção Mineral, Divisão de Geologia e Mineralogia, Boletim no $111,323 \mathrm{p}$.

KNECHT, T. 1934. Occorencia de Suppostos Fosseis na Serie de S. Roque em Araçaeiro, S. Paulo. Mineração e Metalurgia. v.I, nº 6, p. 250.

LEINZ, V. 1937. Natureza dos supostos fósseis de Araçaeiro, S. Paulo. Mineração e Metalurgia, v. II, nº 7, p. 36.

LEINZ, V. 1955. A Geologia e a Paleontologia no Brasil. In: As Ciências no Brasil Obra organizada e publicada sob a direção de Fernando de Azevedo. Edições Melhoramentos, p. $245-261$. 
LAMEGO, A. R. 1951. Derby, o Sábio Incompreendido. In: Orville A. Derby 1851-1951 Alguns aspectos da sua obra. Rio de Janeiro: DGM/DNPM. p. 83-88.

LEME, P. T. de A. P. 1772. Informações sobre as minas de S. Paulo e dos sertões da sua capitania desde o anno de 1597 até o presente 1772. Revista do Instituto Histórico e Geográfico do Brasil. Publicata do ano de 1901. n 44, p. 1-84

LEONARDOS, H. O. 1934. Chumbo e Prata no Estado de São Paulo. Serviço de Fomento da Produção Mineral. Boletim 6, p. 3-43.

LEONARDOS, H. O. 1955. A Mineralogia e a Petrografia no Brasil. In: As Ciências no Brasil - Obra organizada e publicada sob a direção de Fernando de Azevedo. Edições Melhoramentos, p. $267-313$.

LYELL, C. 1835. Principles of Geology: being an inquiry how far the former changes of the earth's surface are referable to causes now in operation. John Murray, Albemarle Street, London, vol. I. 406 p.

MARTINS, F. P. 1943. A Propósito de Afonso Sardinha. Revista do Arquivo Municipal. Prefeitura do Município de São Paulo, XCII. p. 99-111.

MARX, K. 1867. O Capital. Fonte da Presente Transcrição: Centelha - Promoção do Livro, SARL, Coimbra, 1974. Tradução de: J. Teixeira Martins e Vital Moreira. Transcrição de: Alexandre Linares. HTML por José Braz para Marxists Internet Archive. MAWE, J. 1812. Viagens ao Interior do Brasil. Tradução de Selena Benevides Viana. São Paulo. Editora da Universidade de São Paulo.

MORAES, L. J. de. 1944. A Serra do Japí, Estado de São Paulo. Faculdade de Filosofia, Ciências e Letras da Universidade de São Paulo. Boletim 1, nº 45. p. 34-40.

MORAES REGO, L. F. de. 1930. A Geologia do Petróleo no Estado de S. Paulo. Serviço Geológico e Mineralógico do Brasil. Rio de Janeiro, Boletim 46, p. 1-70.

MORAES REGO, L. F. de. 1931. As estructuras antigas do Brasil. Annaes da Escola de Minas, p. 27-85.

MORAES REGO, L. F. de. 1931. Ensaio sobre as montanhas do Brasil e sua genesis. Revista do Club Militar. Rio de Janeiro: p. 83-118.

MORAES REGO, L. F. de. 1943. A Geologia do Estado de São Paulo. Separata do Boletim do Departamento de Estradas e Rodagem, v. 3, n 3, p. 538-556.

MORAES REGO, L. F. de. 1936. O Vale do São Francisco (Ensaio de Monografia Geográfica). Originais deste trabalho foram publicados na Revista do Museu Paulista com reedição em 1945, Editora Renascença S. A., São Paulo. 245p. 
MORAES REGO, L. F. de. \& SOUZA SANTOS. T. D. de. 1938. Contribuição para o estudo dos Granitos da Serra da Cantareira. Instituto de Pesquisas Technologicas de S. Paulo. Boletim 18: 1-162.

MORAES REGO, L. F. de. \& ALMEIDA, F. F. M. de. 1946. Seção Geologica de Capela da Ribeira a Curitiba. Escola Politécnica de Universidade de São Paulo, Separata de Geologia e Metalurgia, São Paulo, Brasil, no 3, p. 5 a 30.

OLIVEIRA, A. I. de. \& LEONARDOS, O. H. 1943. Geologia do Brasil. Serviço de Informação Agrícola, Ministério da Agricultura. Rio de Janeiro. Serie didática 2.

OLIVEIRA, E. P. de. 1925. Analyses de Calcareos. Serviço Geológico e Mineralógico do Brasil. Ministério da Agricultura Industria e Commercio. Boletim 10, p. 1-45.

OLIVEIRA, E. P. de. 1927. Geologia e Recursos Mineraes do Estado do Paraná. Serviço geológico e Mineralógico do Brasil. Monographia.

OLIVEIRA, E. P. 1939. "Orville A. Derby (1851-1915)". Transcrito da Revista Brasileira de Geografia, ano I, $\mathrm{n}^{\circ}$ 4, outubro de 1939. In: Orville A. Derby 1851-1951 Alguns aspectos da sua obra. Rio de Janeiro: DGM/DNPM. 1951. p. 13-15.

OLIVEIRA, F. de P. 1887. Esboço Geológico da Região Comprehendida entre os Rios Sorocaba e Tieté. Relatório da Província de São Paulo, Commissão Geographica e Geológica. Typographia a Vapor de Jorge Seckler \& Comp. - São Paulo, 19 de novembro. p. 26-28.

OLIVEIRA, F. de P. 1888. Relatório da Província de São Paulo, enviado ao Sr. Adalbert Orville Derby. Comissão Geographica e Geológica de São Paulo. 10 de dezembro, p. $35-42$.

OLIVEIRA, F. de P. 1892. Ouro em São Paulo. Contribuição para o estudo da mineração no Brazil. Imprensa da Casa da Moeda - Republica dos Estados Unidos do Brazil.

PETRI, S \& CAMPOS, D. de A. 2004. A Contribuição de Fernando Flávio Marques de Almeida para a Pesquisa Paleontológica no Brasil. In: V. Mantesso-Neto., Bartorelli, A., Carneiro, C.D.R. \& Brito Neves, B.B. (Organizadores): Geologia do Continente SulAmericano: Evolução da obra de Fernando Flávio Marques de Almeida. São Paulo, Beca Prod. Culturais, Capitulo XX: 347-353.

PINTO, V. N. 1979. O Ouro Brasileiro e o Comércio Anglo-Português. Edt. Brasiliana. PISSIS, M. A. 1848. Mémoire Sur La Position Geologique Des Terrains De La Partie Australe Du Brésil. Academie des Sciences, Paris.

RATH, C. J. F. 1856. Fragmentos geológicos e geographicos etc para a parte physica da estatística das províncias de S. Paulo e Paraná. Exploradas a próprias expensas do autor, 
começados no anno de 1845. Typographia Imparcial, de Joaquim Roberto de Azevedo Marques. 78 p.

RATH, C. J. F. 1871. Notícia ethonologica sobre um povo que já habitou a costa do Brasil, bem como seu interior, antes do dilúvio universal. Revista do Instituto Histórico Geographico e Ethonographico do Brasil. Tomo XXXIV, Parte Primeira. p. 287-298.

RENGER, F. E. 2005. O "Quadro Geognóstico do Brasil” de Wilhelm Ludwig Von Eschwege: Breves Comentários à sua Visão da Geologia no Brasil. Geonomos v. 13, nº 1-2, p. 91- 95 .

SAINT-HILAIRE, A. de. 1822. II Viagem à Província de São Paulo e resumo da viagem ao Brasil, Província Cisplatina e Missões do Paraguai. Biblioteca Histórica Brasileira. Tradução Rubens Borba de Moraes.

SPIX, J. B.; MARTIUS, C. F. P. 1823. Viagem pelo Brasil. Tradução brasileira promovida pelo Instituto Histórico e Geográfico Brasileiro para a comemoração do seu centenário. 1938. Imprensa Nacional, Rio de Janeiro.

TAUNAY. A. de E. 1951. Derby e a História do Brasil. In: Orville A. Derby 1851-1951 Alguns aspectos da sua obra. Rio de Janeiro: DGM/DNPM. p. 51-52.

TAVORA FILHO, E. 1944. José Bonifácio Cientista, Professor e Técnico. Conferência lida na sala "José Bonifácio de Andrada e Silva" da Faculdade Nacional de Filosofia, no dia 26 de Agosto de 1943. Coleção Estudos Brasileiros, Rio de Janeiro.

TOSATTO, P. 2001. Orville A. Derby. "O Pai da Geologia do Brasil". Departamento Nacional de Produção Mineral - DNPM (Museu de Ciências da Terra); CPRM - Serviço Geológico do Brasil. Rio de Janeiro.

WEGENER, A. 1929. The Origen of Continents and Oceans. Translated by John Biram in 1966. Dover Publications, Inc. 247p. 
ANEXO - II

(Fotos de Campo) 

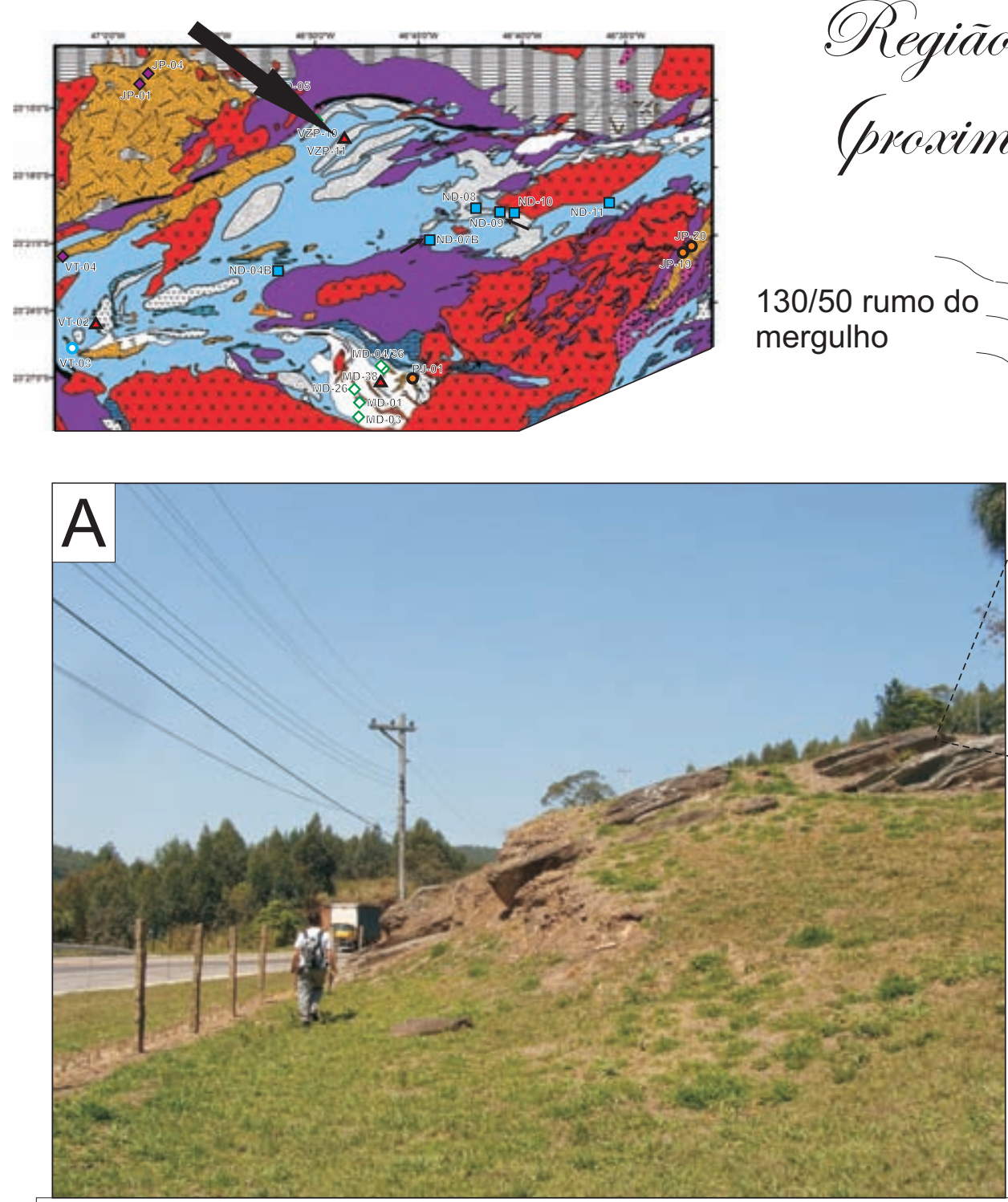

Metawakes e metasiltitos (A) nas proximidades de Varzea Paulista. A exposição encontra-se preservada de alteração intempérica com a presença de "filitos" cinzas fortemente crenulados (B). Por vezes afetado por zonas de cisalhamento $(C)$, relacionadas ao sistema de falhas Jundiuvira.

$130 / 50$ rumo do mergulho

\section{Regiāo com exposisão de metawakes e metasillitos} (proximidades de Oárzea OPuulista)
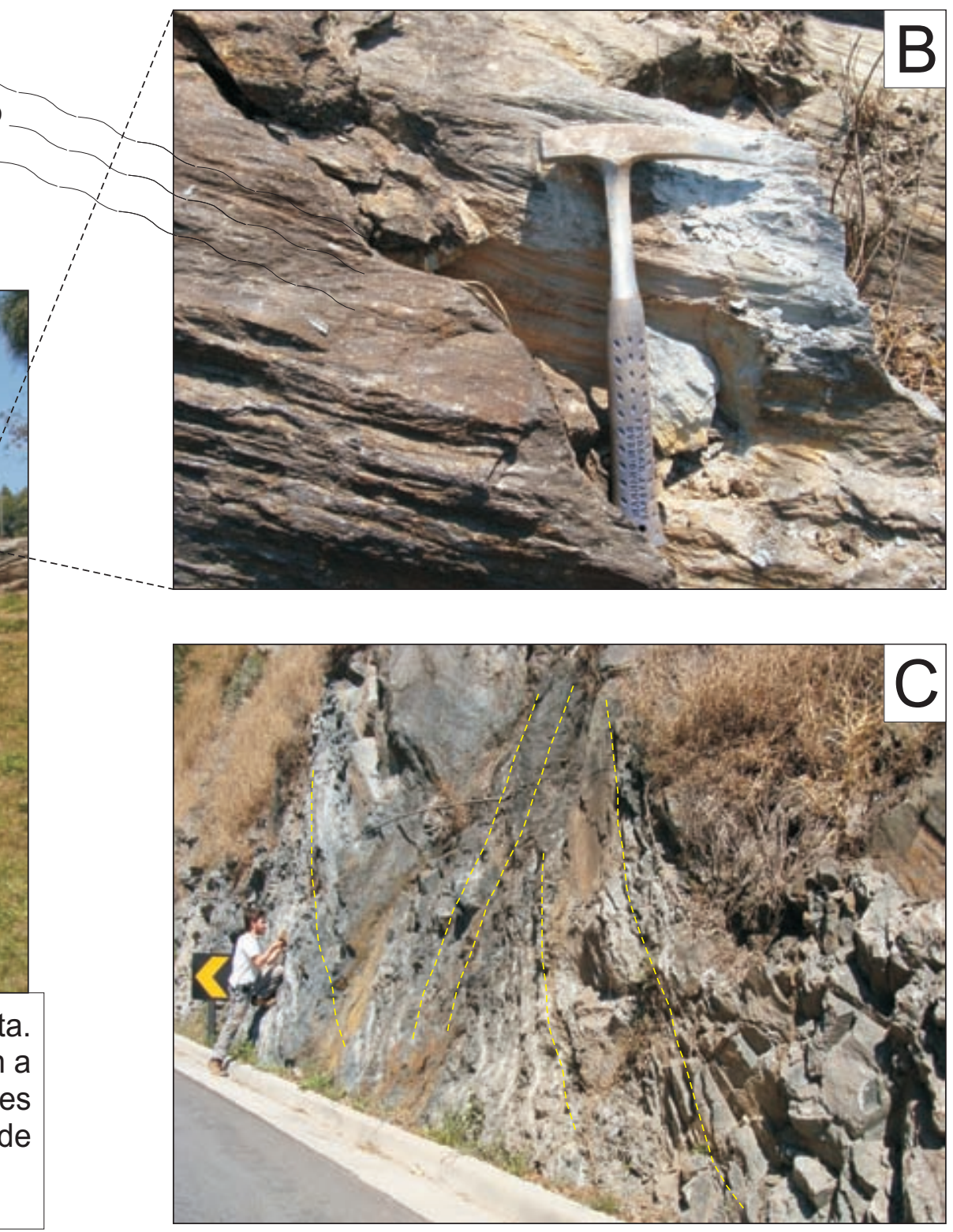


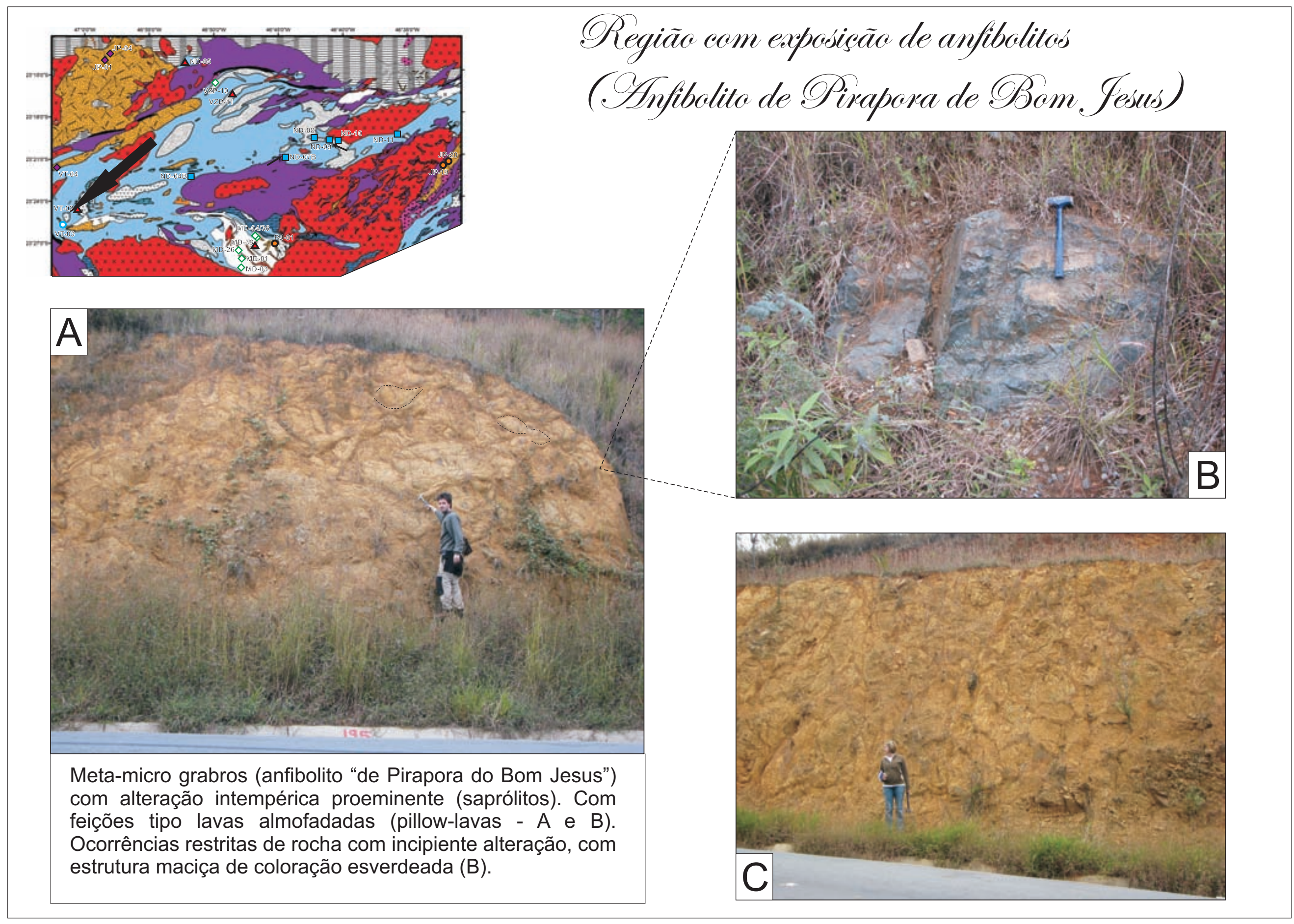




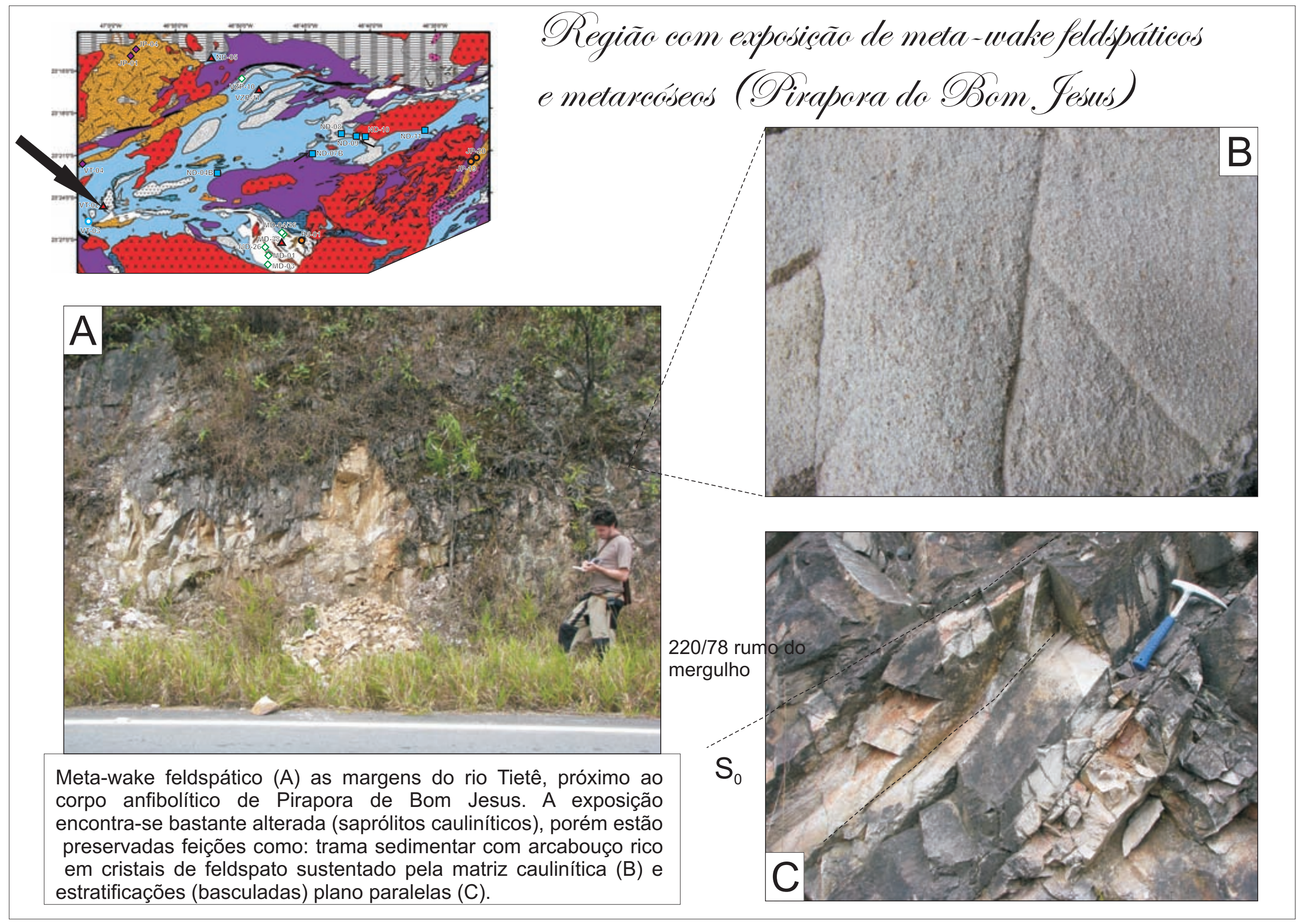




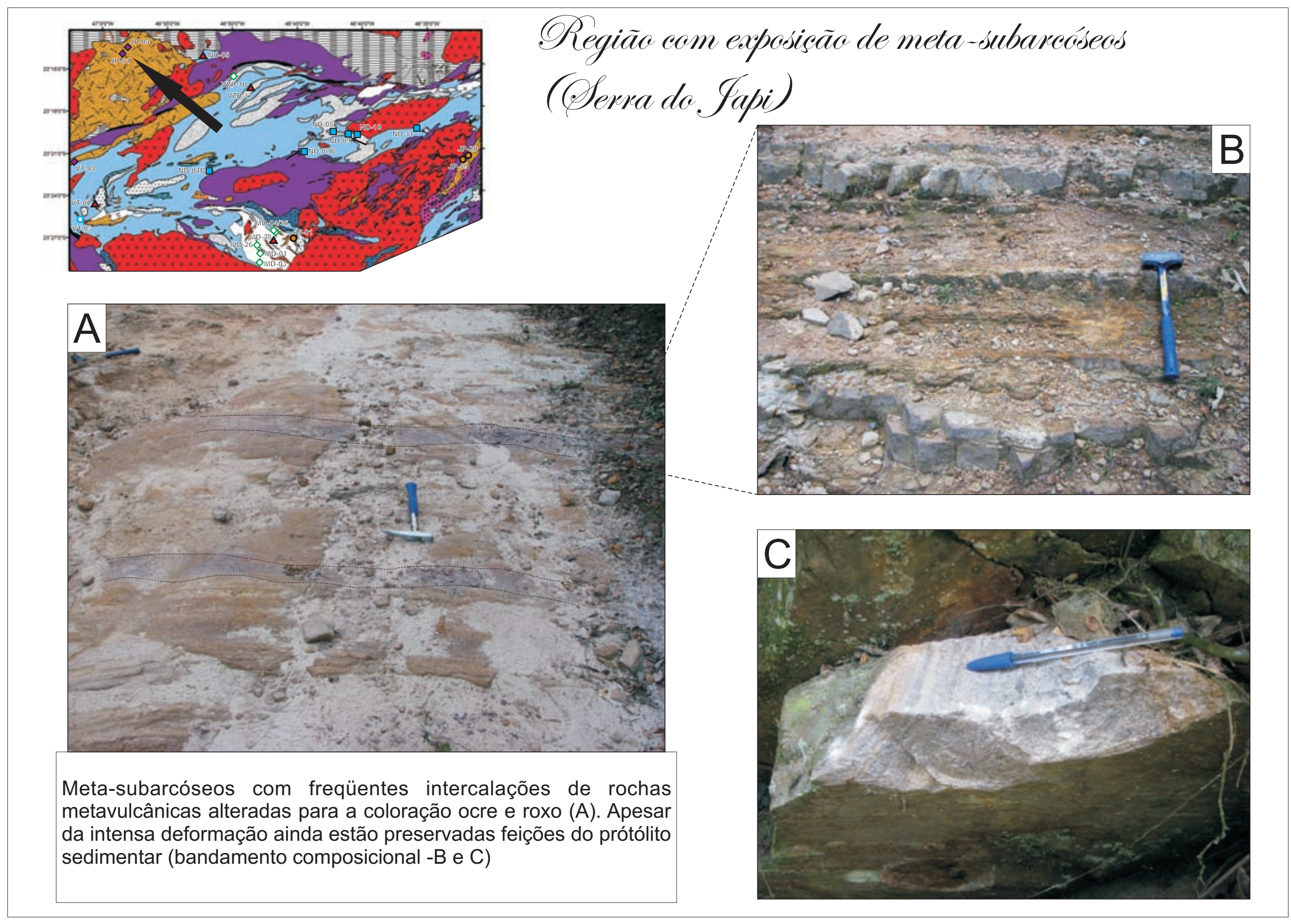




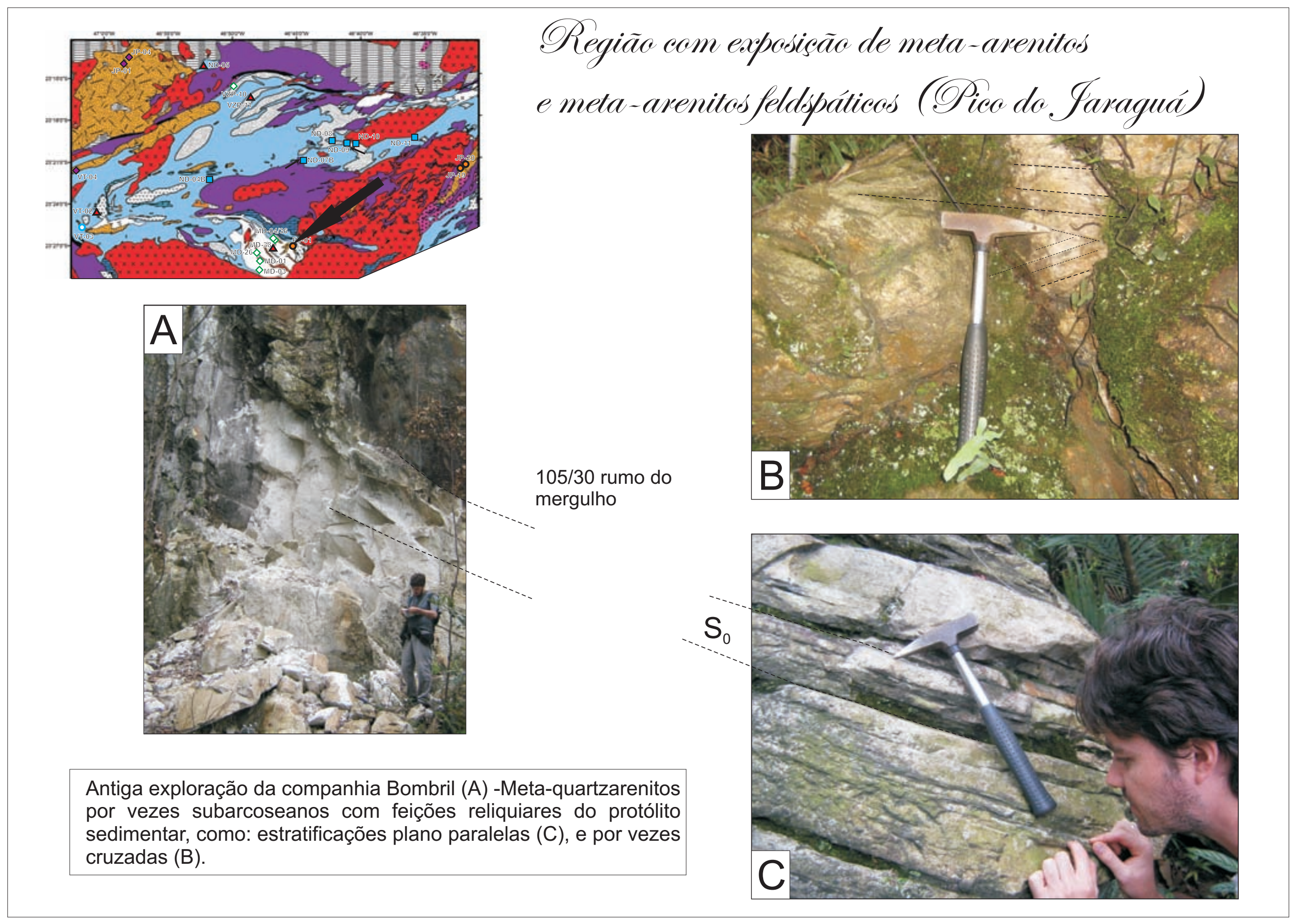




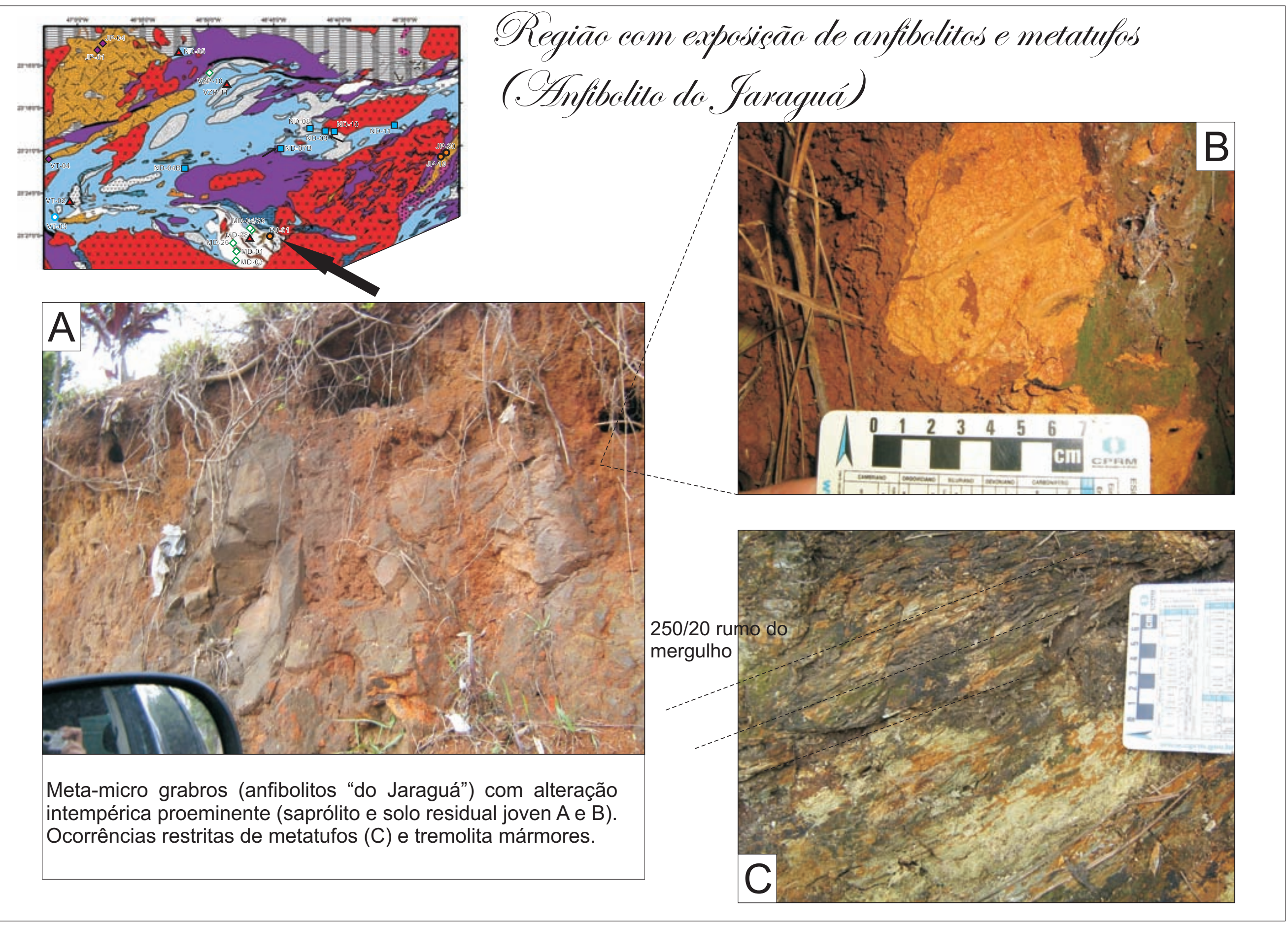




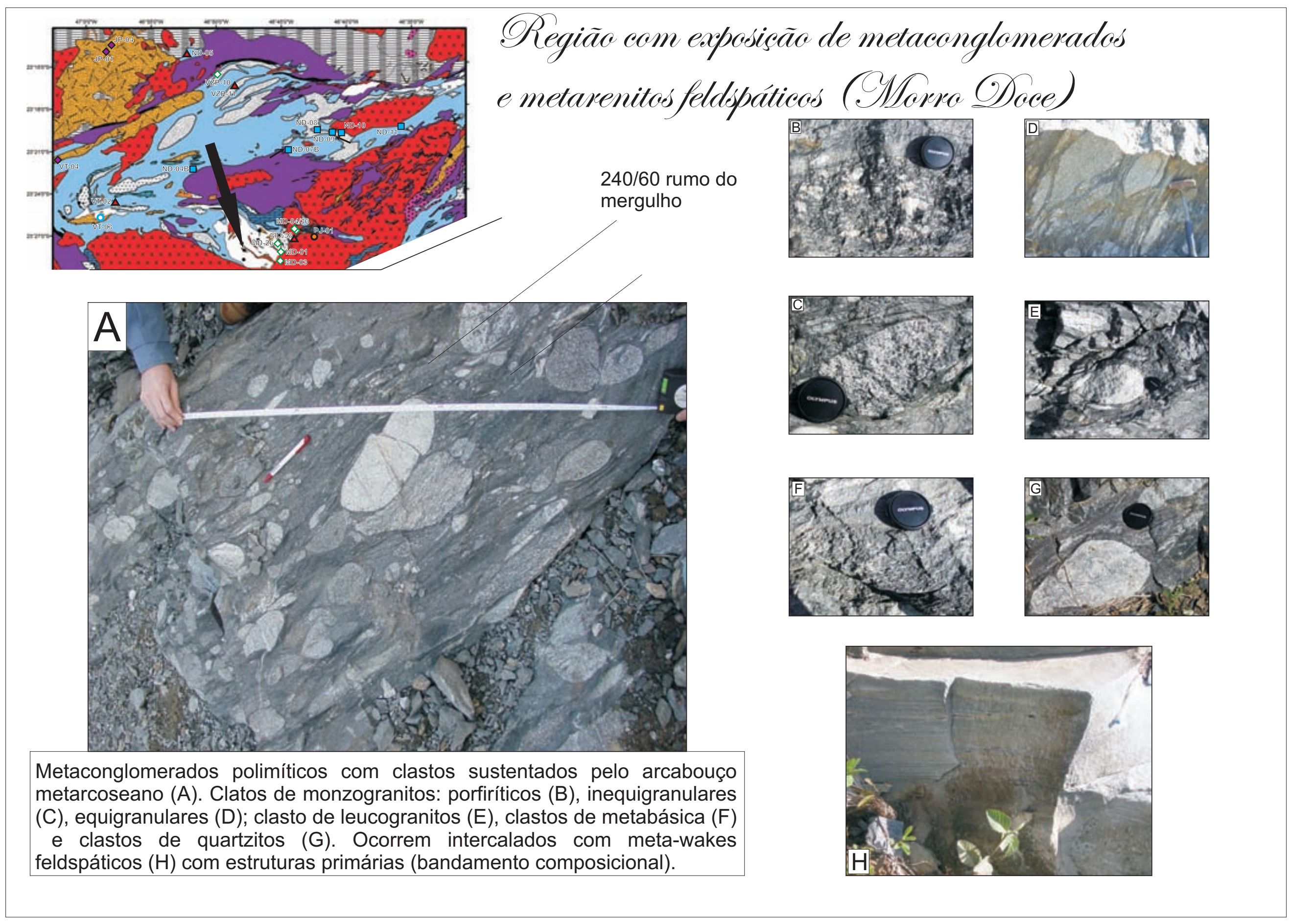




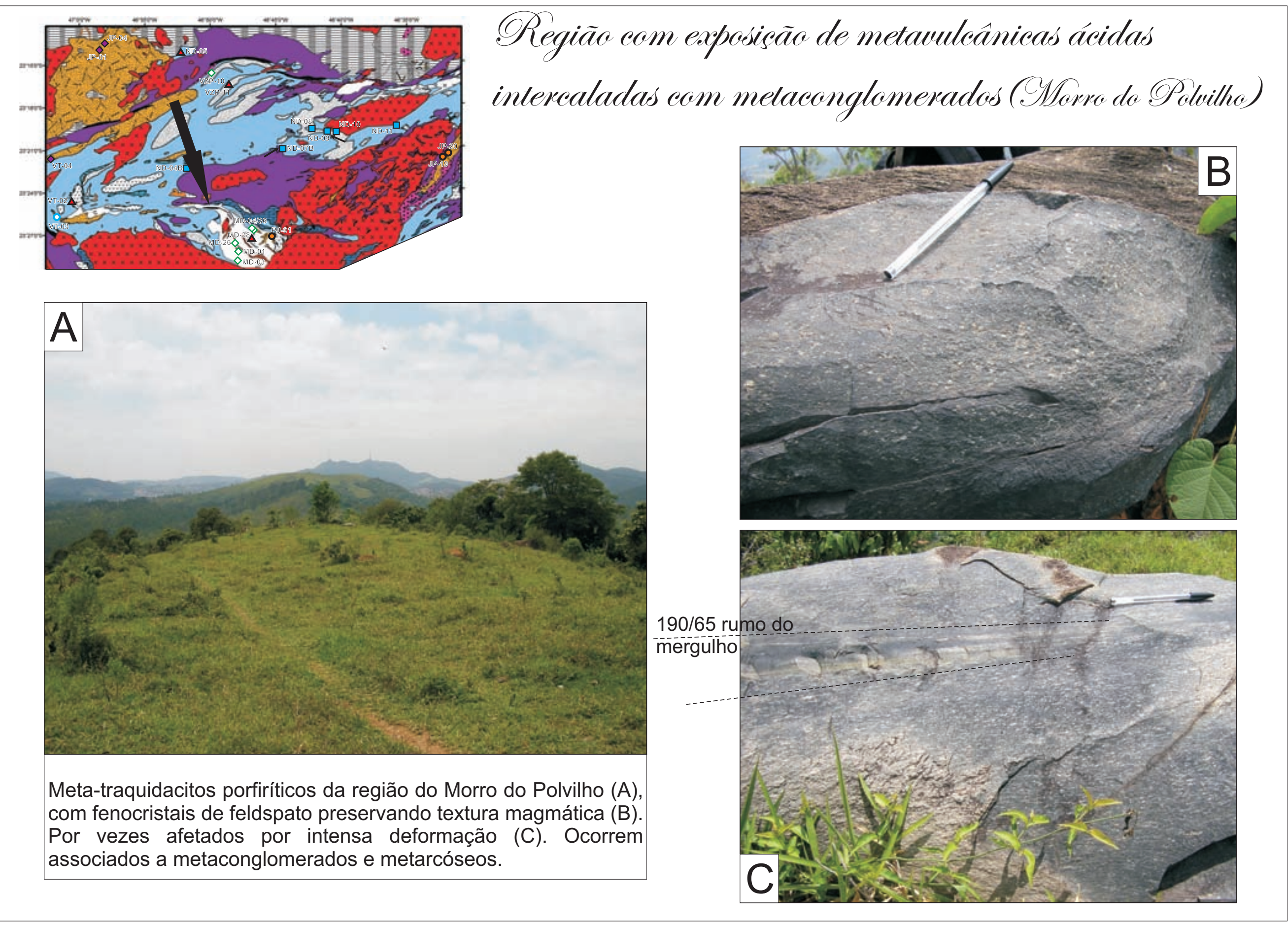


ANEXO - III

(Fotomicrografias) 


\section{Fotomicrografias de Pecsōes Delgadas}

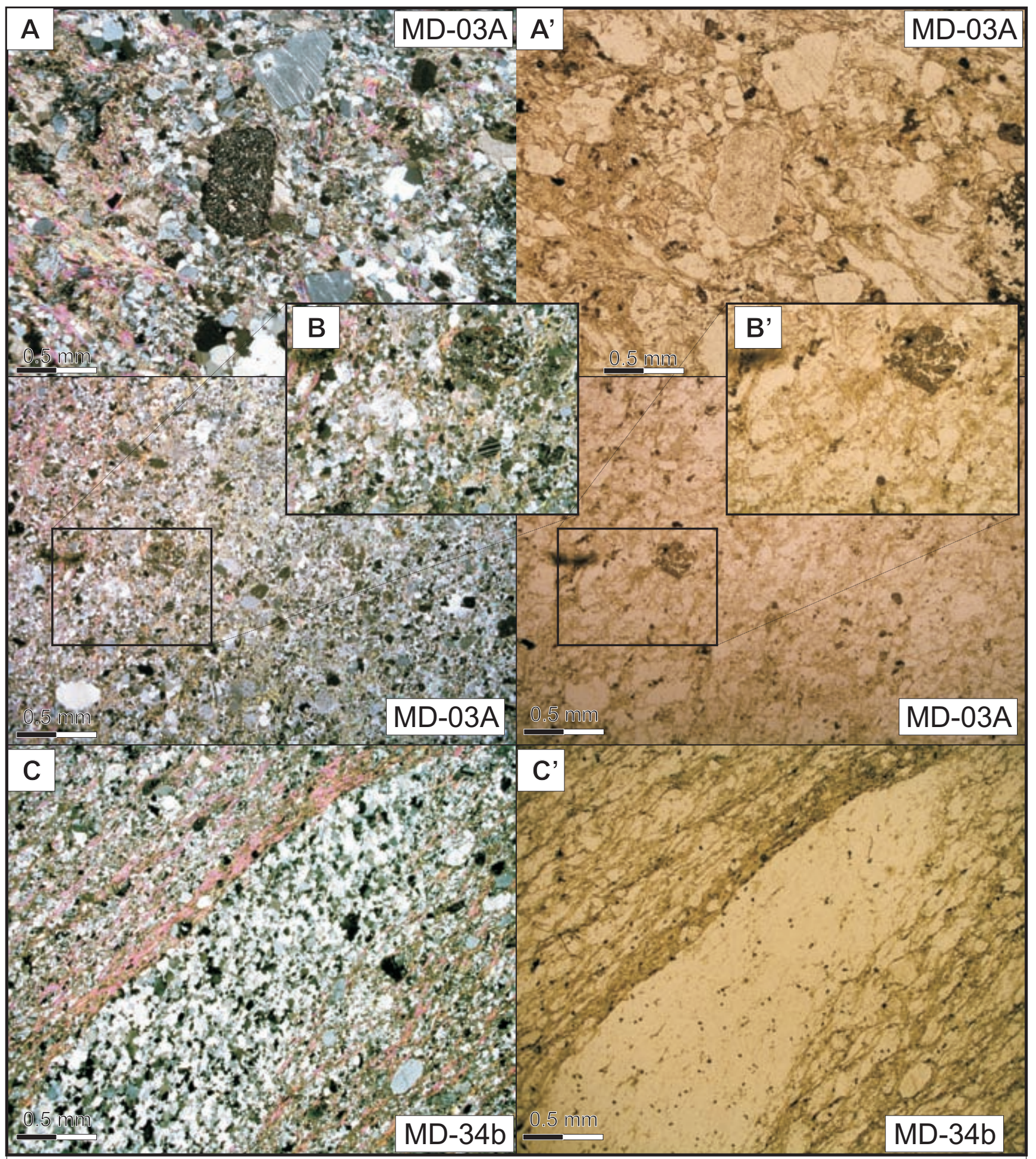

Fotomicrografias de secções delgadas de metassedimentos do Grupo São Roque com feições da petrotrama sedimentar preservadas: Meta-wake feldspáticos e metarcóseos com a presença de fragmentos líticos (menos que 1\%). A e B - fragmentos de rochas metabásicas; C - fragmentos de quartzitos (intraclastos?). Polarizadores paralelos - lado direito, polarizadores cruzados - lado esquerdo. 


\section{Fotomicrografias de Pecsões Delgadas}

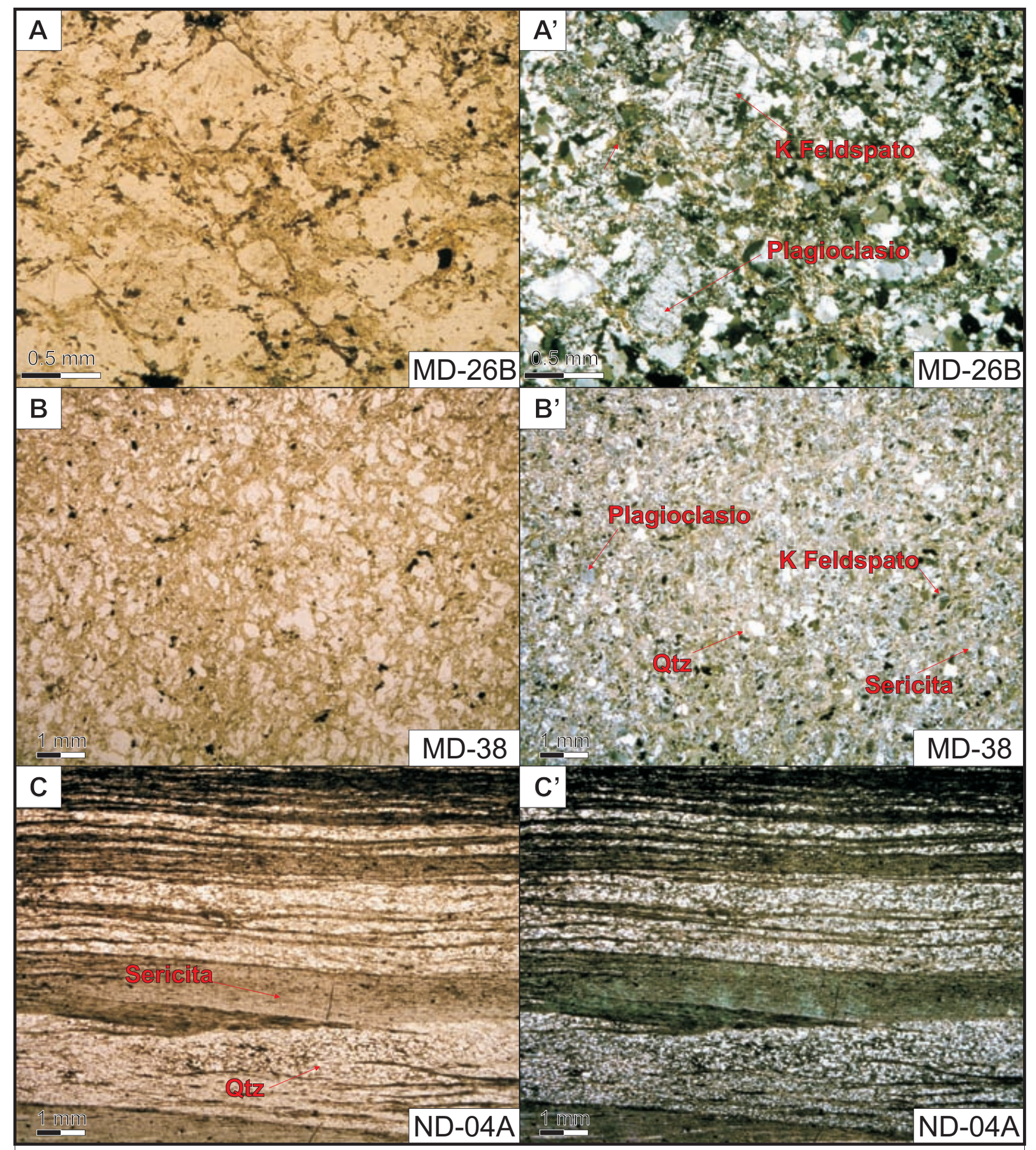

Fotomicrografias de secções delgadas de metassedimentos do Grupo São Roque com feições da petrotrama sedimentar preservadas: A- meta-wake feldspático; B- meta-quartzo wake; C- metasiltito (polarizadores paralelos - lado esquerdo, polarizadores cruzados lado direito) 


\section{Fotomicrografias de Pecsões Delgadas}

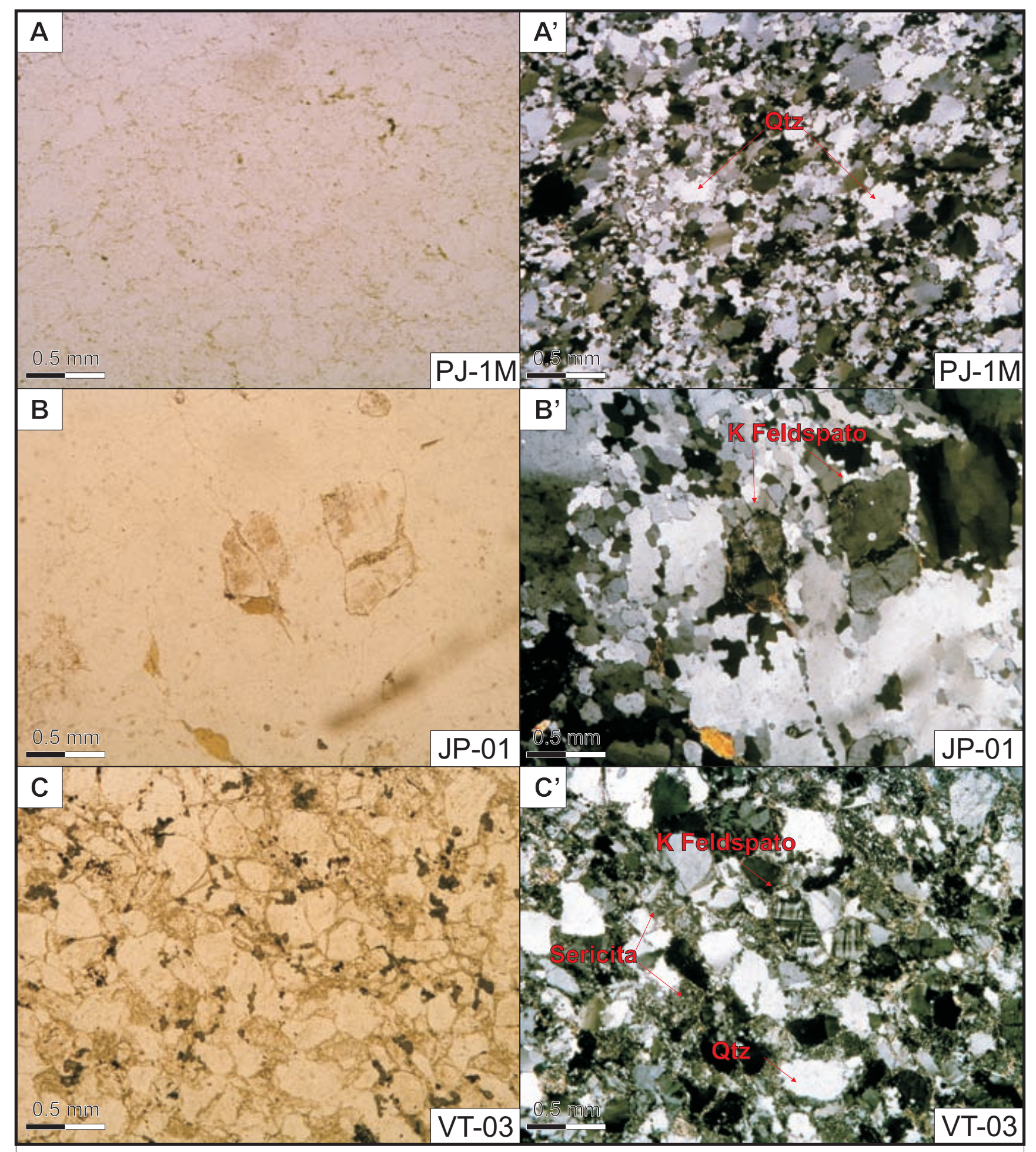

Fotomicrografias de secções delgadas de metassedimentos do Grupo São Roque com feições da petrotrama sedimentar parcialmente preservadas: A- meta-quartzo arenito; Bmeta-subarcóseo; C- metarcóseo (polarizadores paralelos - lado esquerdo, polarizadores cruzados - lado direito) 


\section{Fotomicrografias de Pecsões Delgadas}

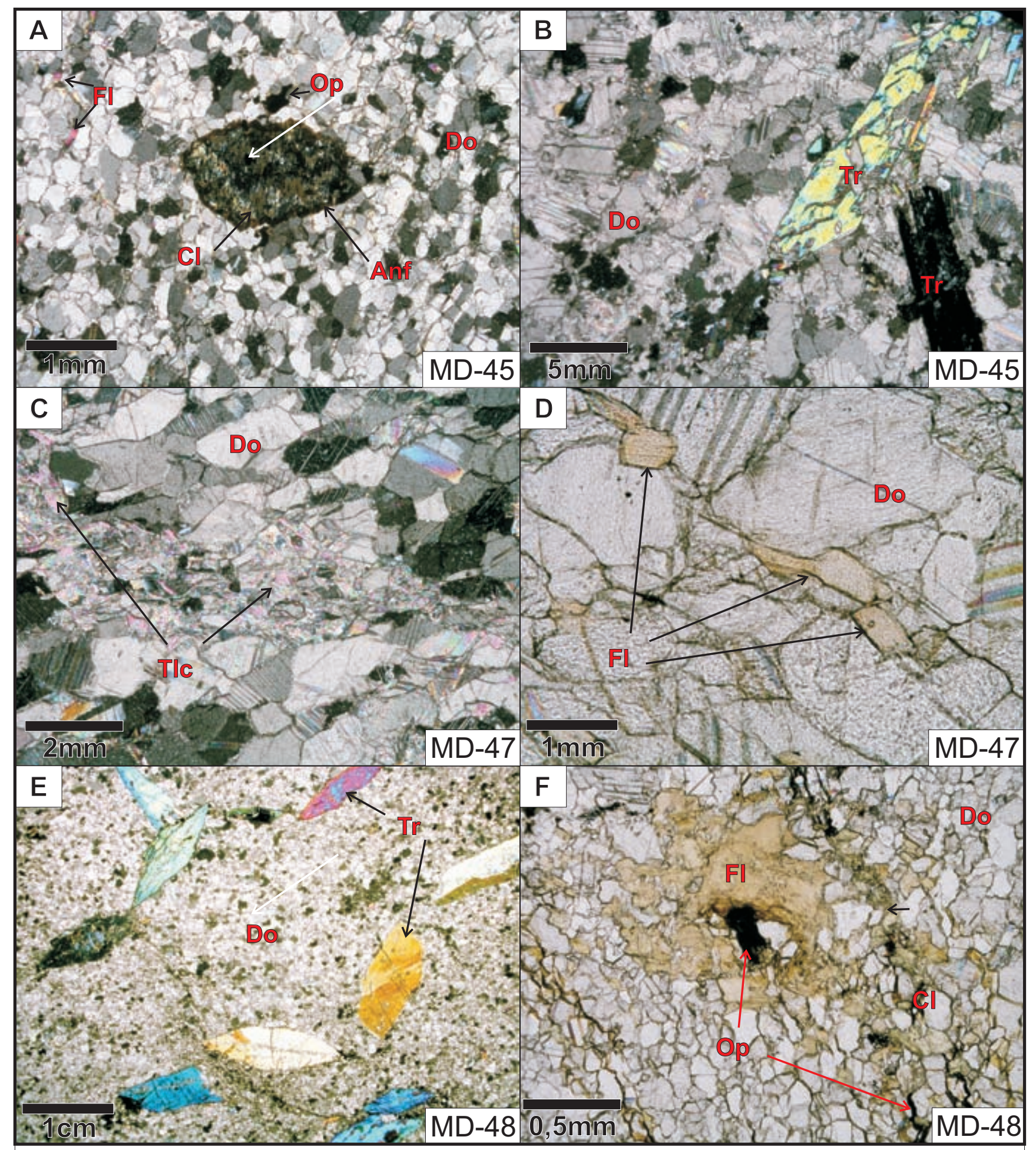

Fotomicrografias de secções delgadas de meta-dolomitos impuros associados aos anfibolitos do Jaraguá, provavelmente parte do Grupo Serra do Itaberaba, ao julgar pela paragenêse de mais alto grau metamórfico. $\mathrm{Do}=$ dolomita, $\mathrm{Tr}=$ tremolita, $\mathrm{Fl}=$ flogopita e $\mathrm{Op}=$ opaco (metamorfismo progressivo); $\mathrm{Cl}=$ clorita e Tlc=talco (retrometamorfismo). 


\section{Ofotomicrografias de Minerais. Pesados}

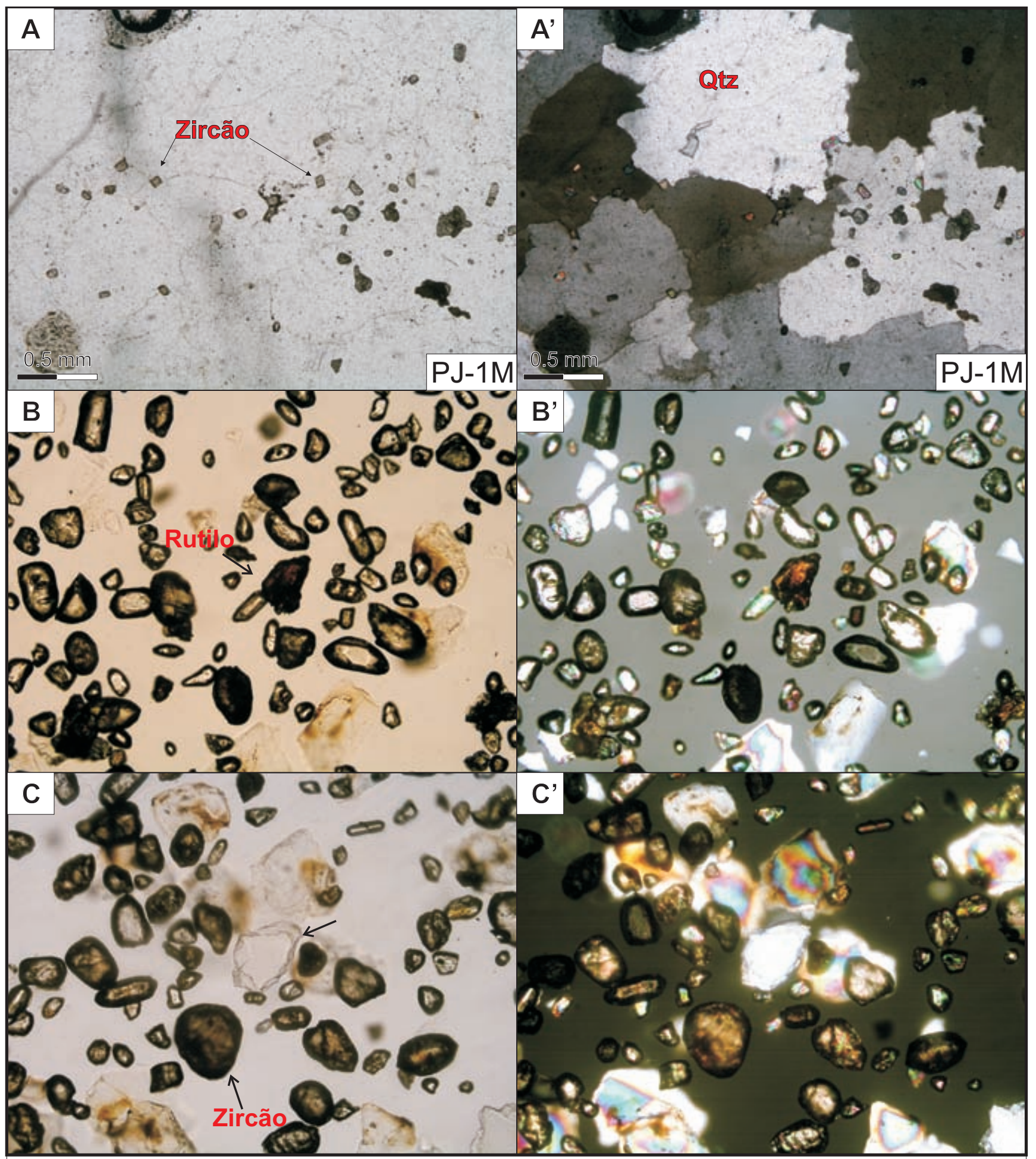

B e C -Secção delgada de grãos detríticos pesados extraídos de meta-quartzo arenitos da Serra do Japi, fração granulométrica de 0,125 a 0,25 mm (areia fina) -A, B e C polarizadores paralelos; A', B' e C' polarizadores cruzados. Em (A e A') fotomicrografias mostrando "linha de pesados" com zircões marcando antiga estratificação sedimentar 


\section{Potomicrografias de Minerais. Pesados}

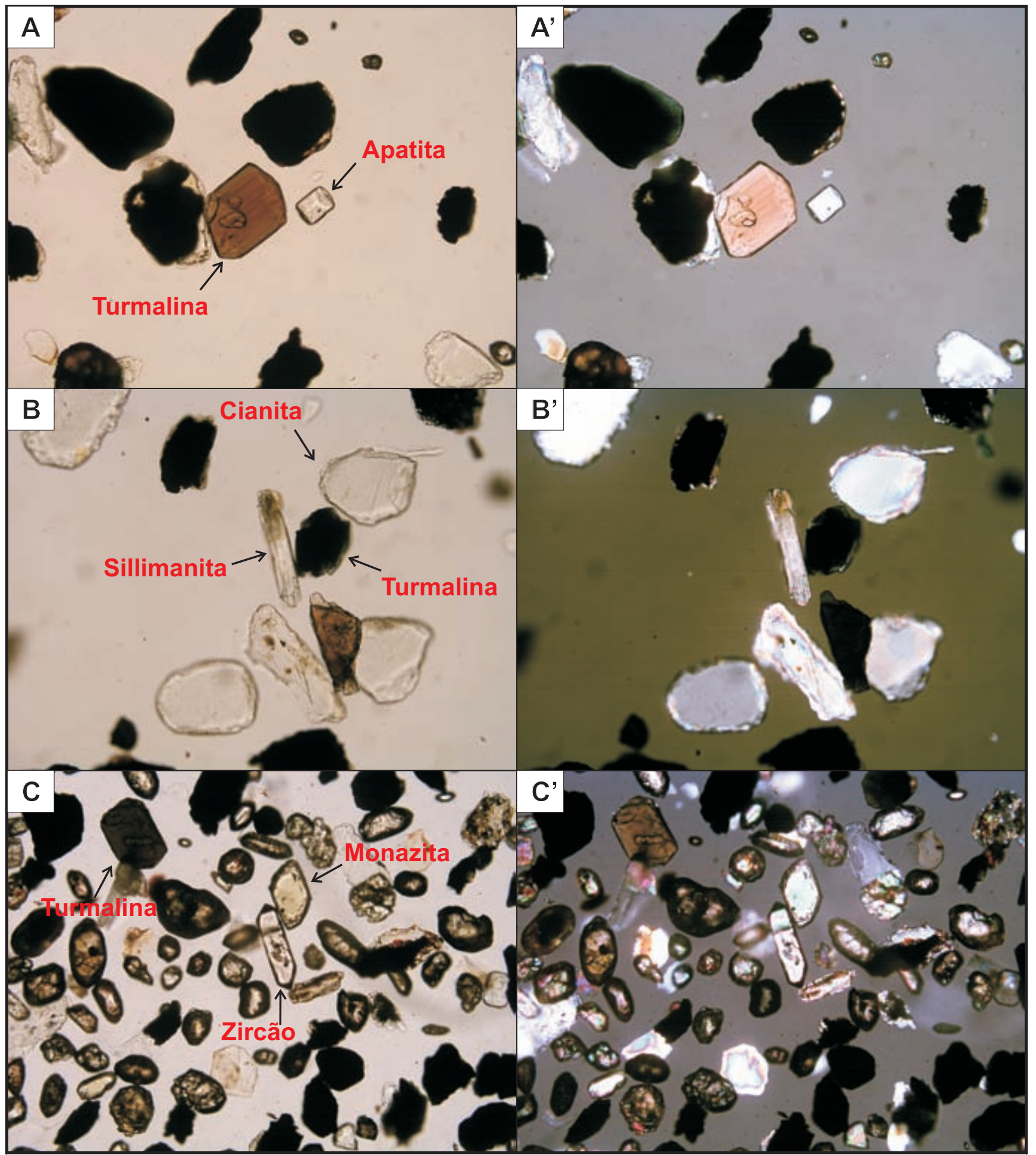

Secção delgada de grãos detríticos pesados extraídos de meta-quartzo arenitos da Serra do Pirucaia, fração granulométrica de 0,125 a 0,25 mm (areia fina) - A, B e C polarizadores paralelos; A', B' e C' polarizadores cruzados. 


\section{Potomicrografias de Minerais. Pesados}

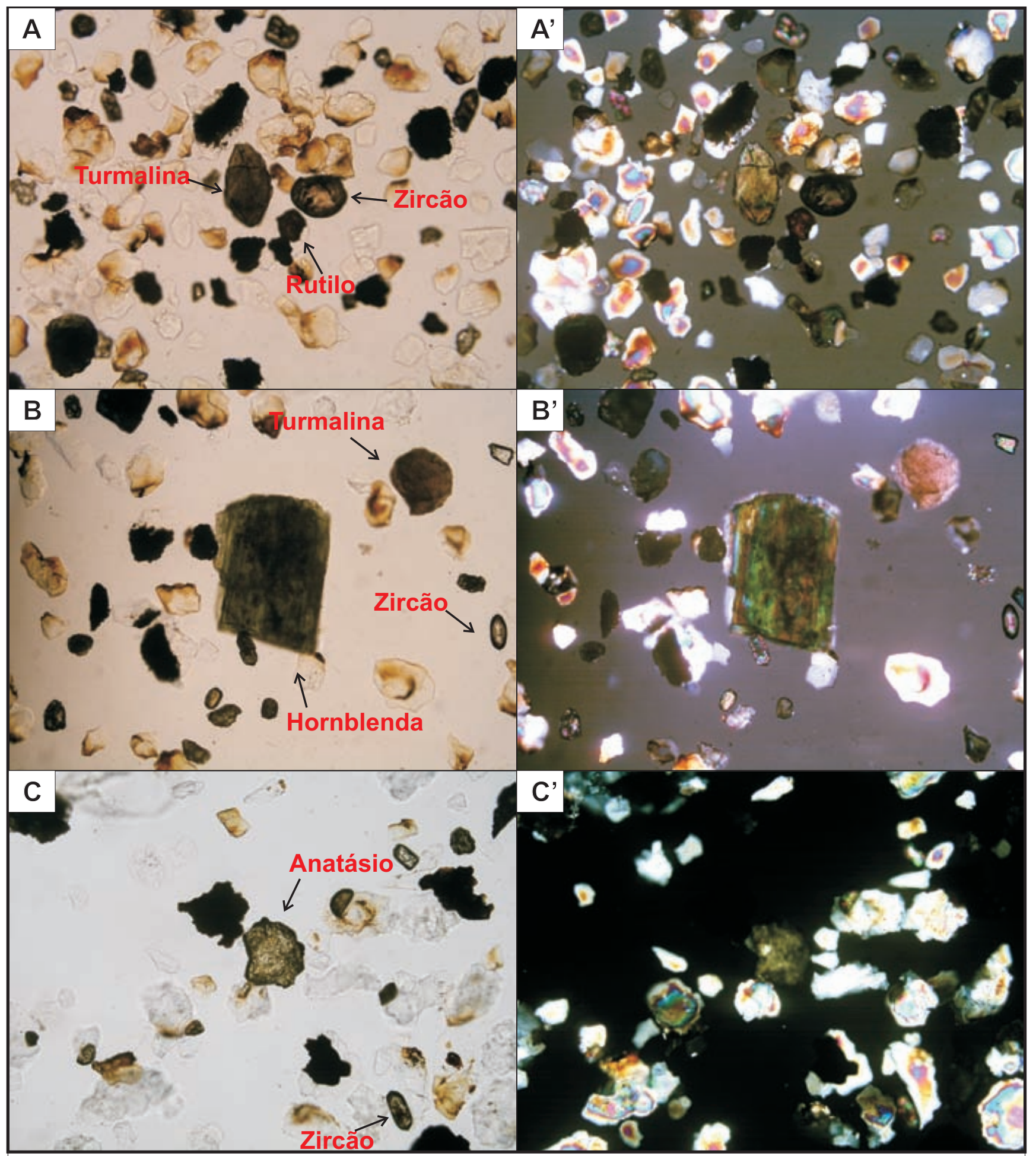

Secção delgada de grãos detríticos pesados extraídos de meta-quartzo arenitos do Pico do Jaraguá, fração granulométrica de 0,125 a $0,25 \mathrm{~mm}$ (areia fina) - A, B e C polarizadores paralelos; A', B' e C' polarizadores cruzados. 
ANEXO - IV

(Zircões) 


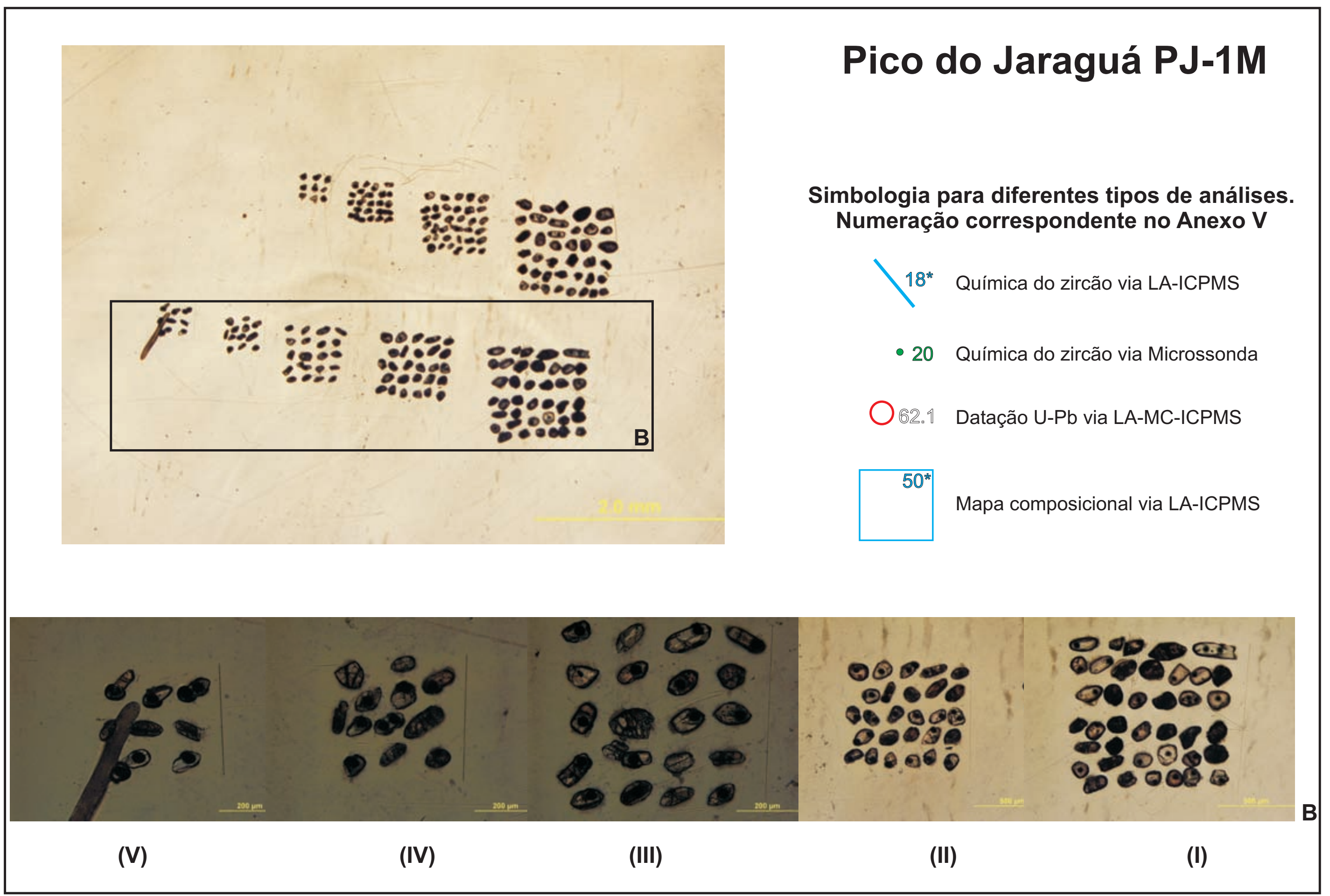




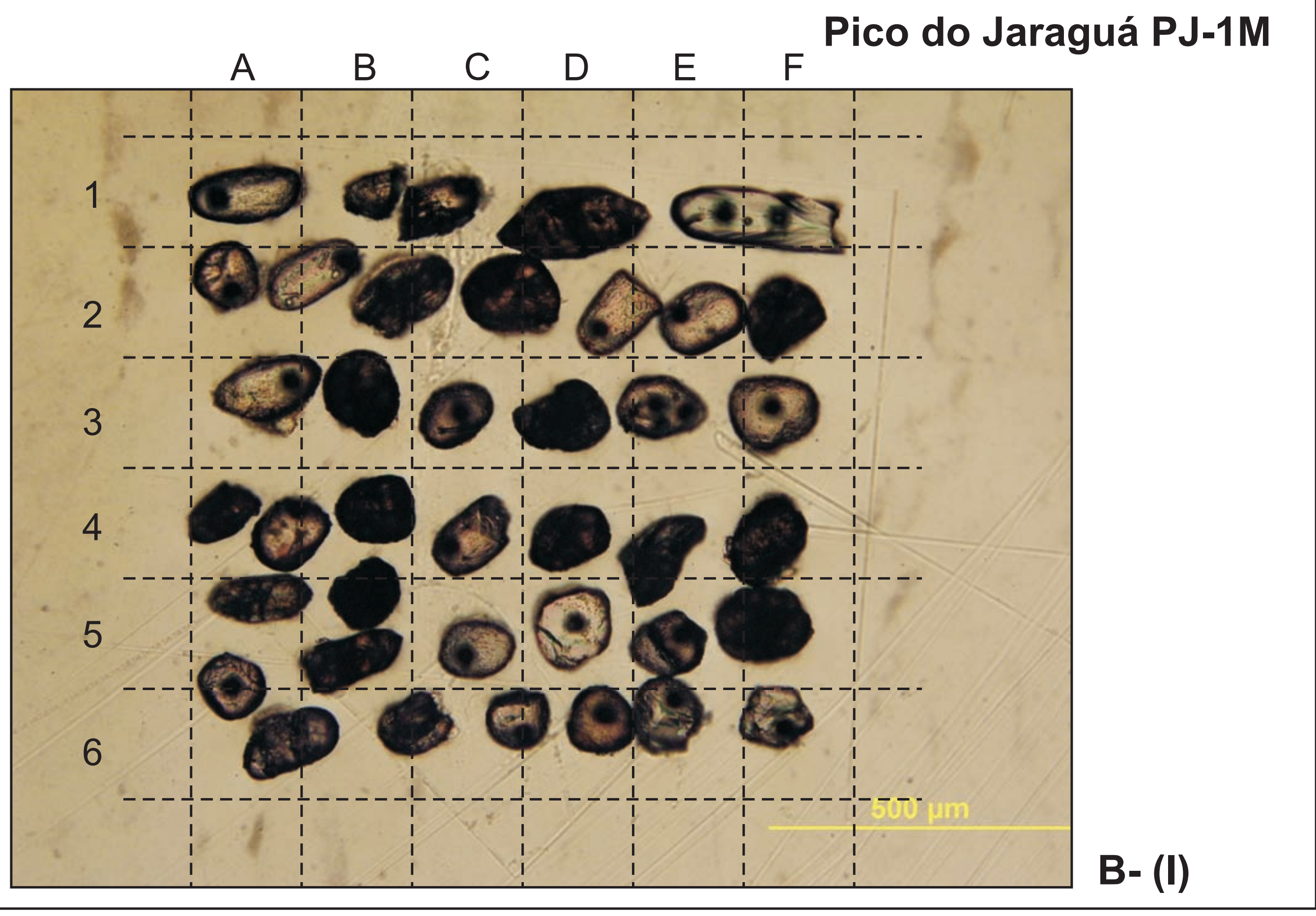




\section{Pico do Jaraguá PJ-1M}

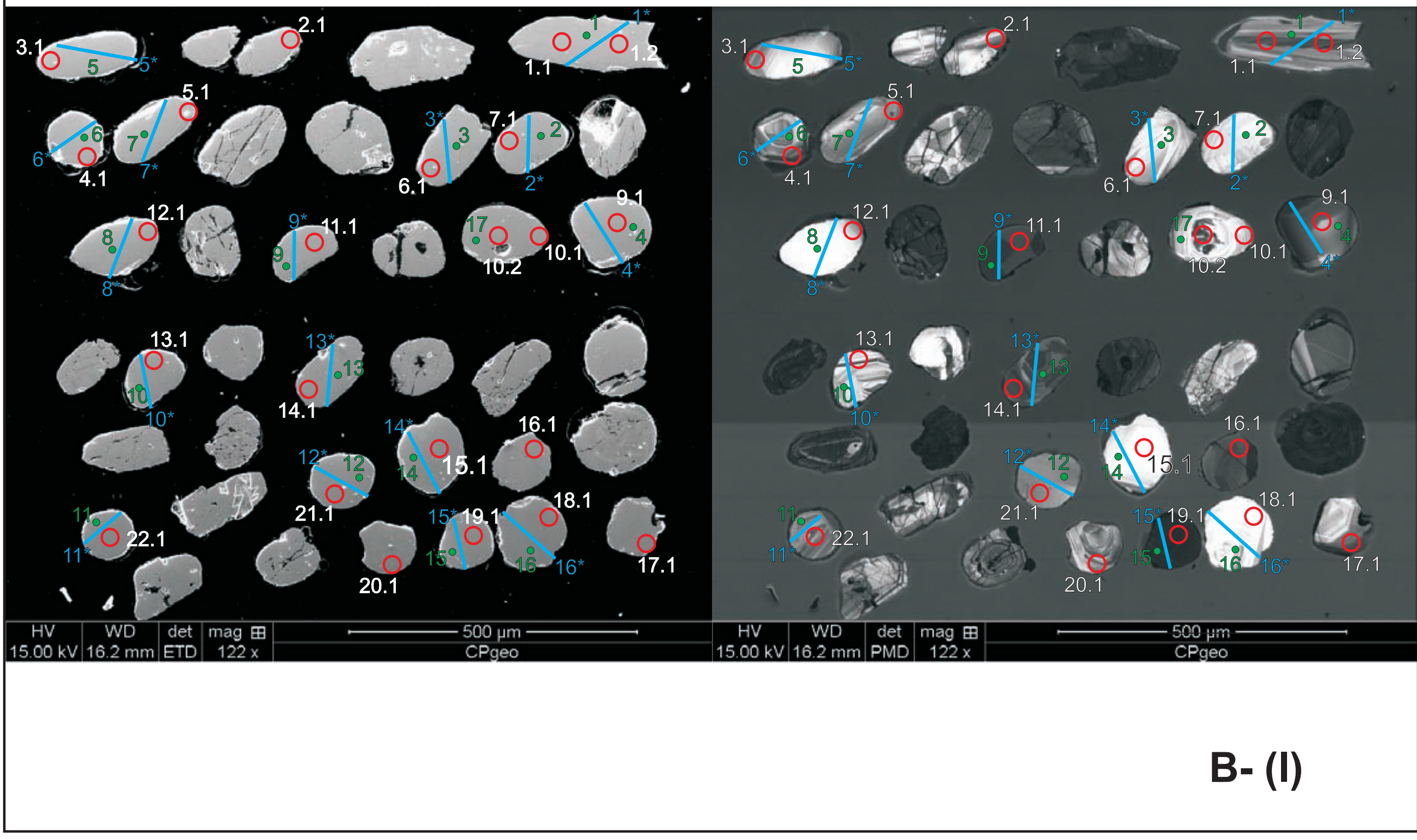


Pico do Jaraguá PJ-1M

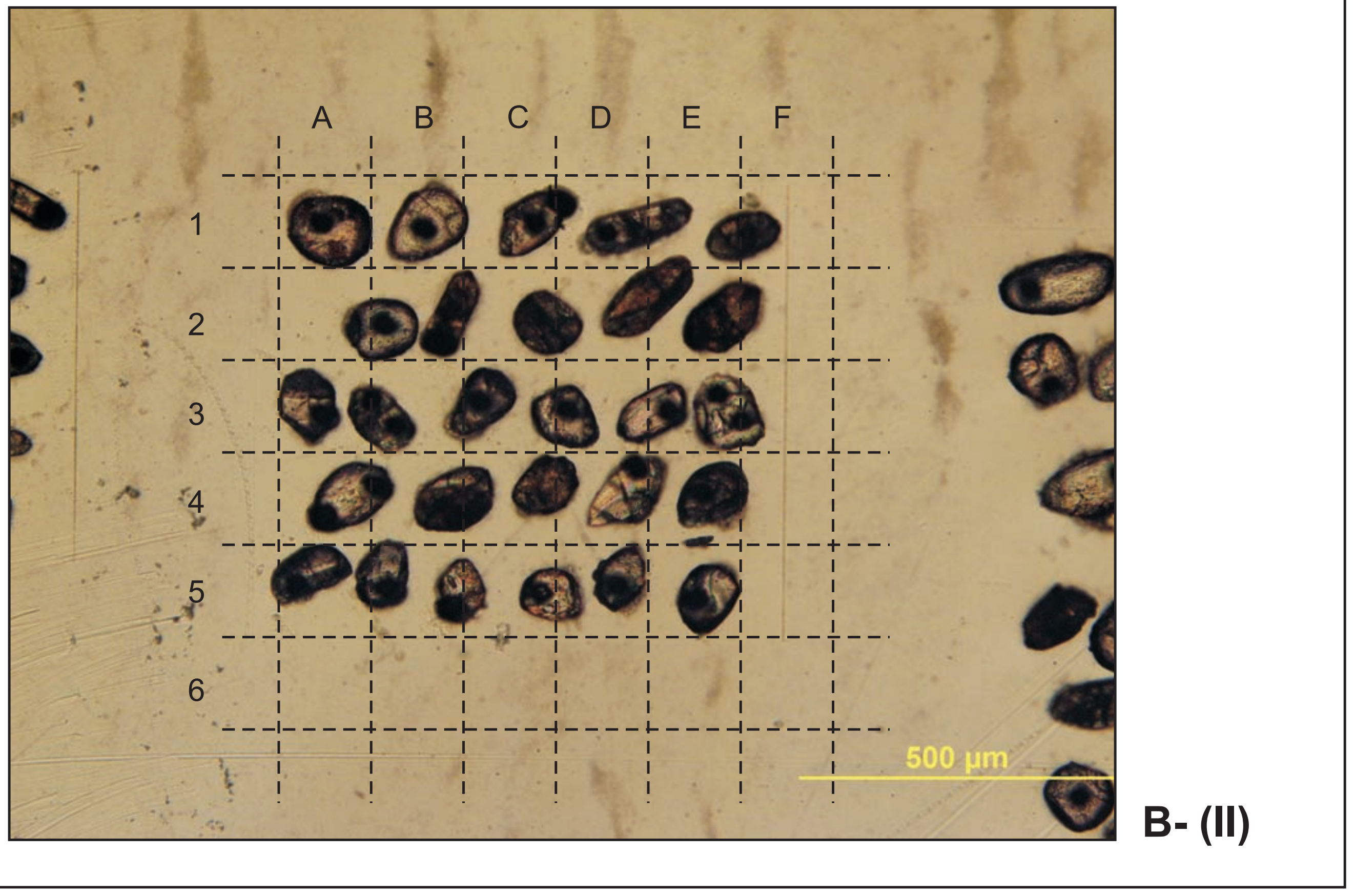




\section{Pico do Jaraguá PJ-1M}

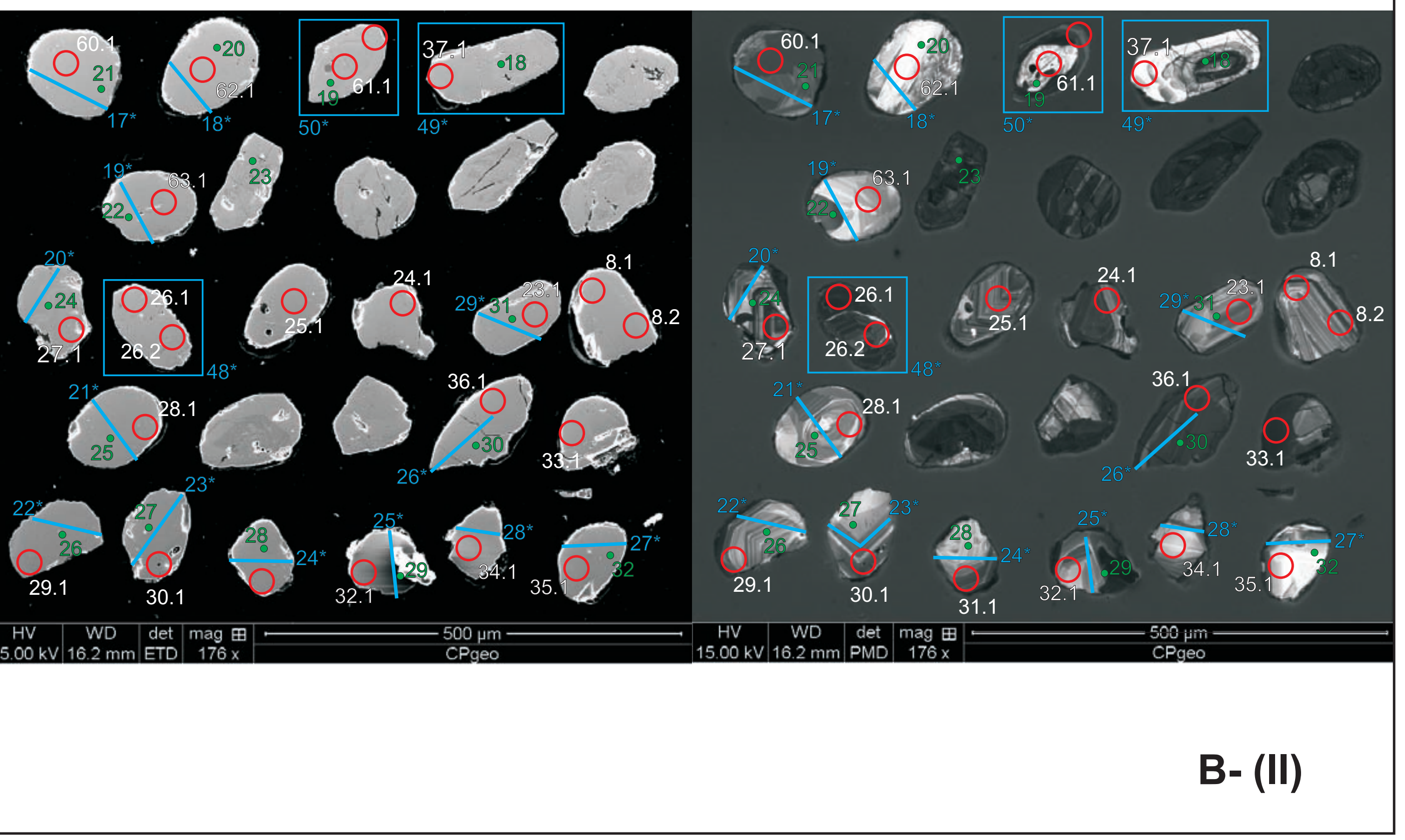




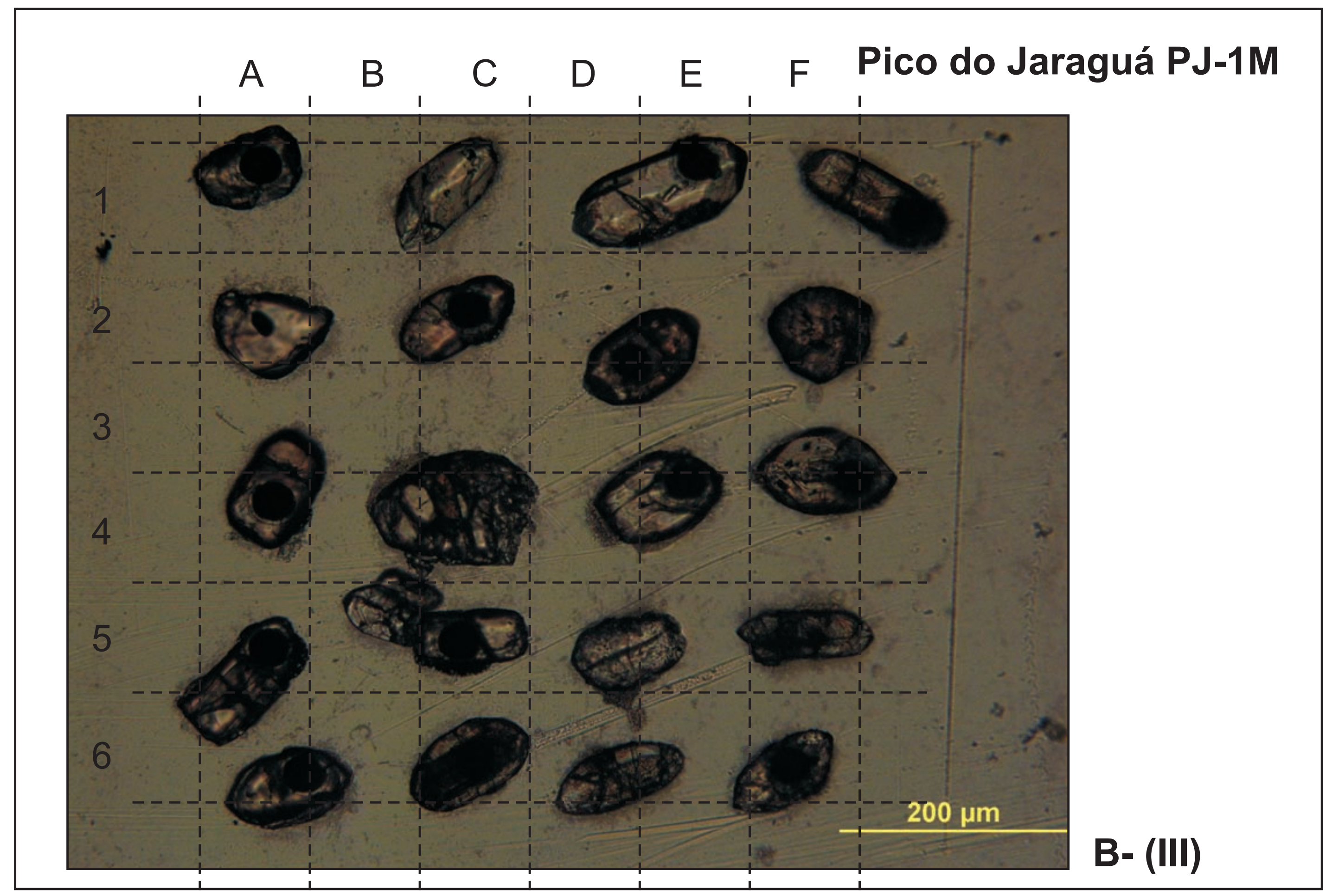




\section{Pico do Jaraguá PJ-1M}

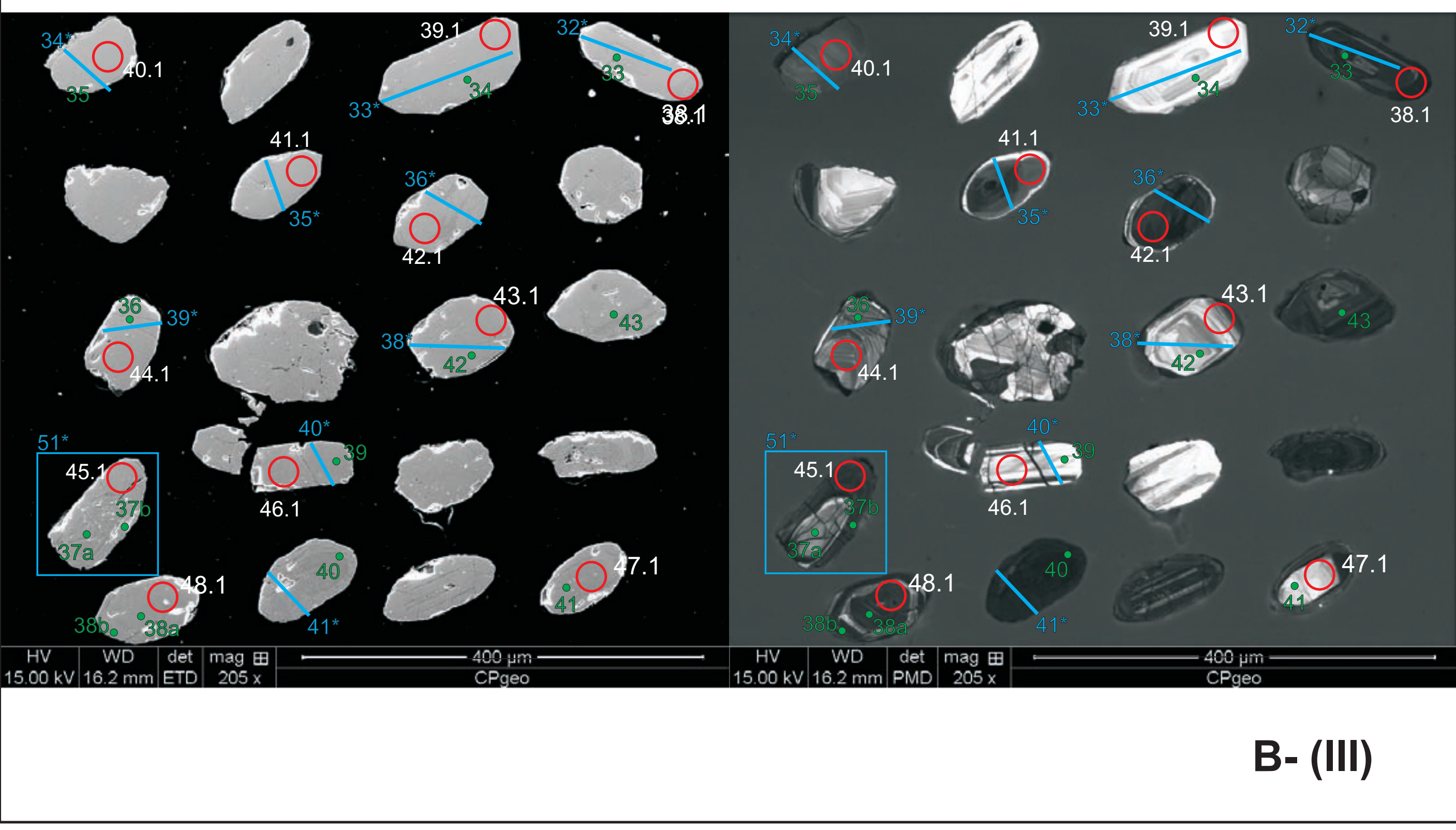


Pico do Jaraguá PJ-1M

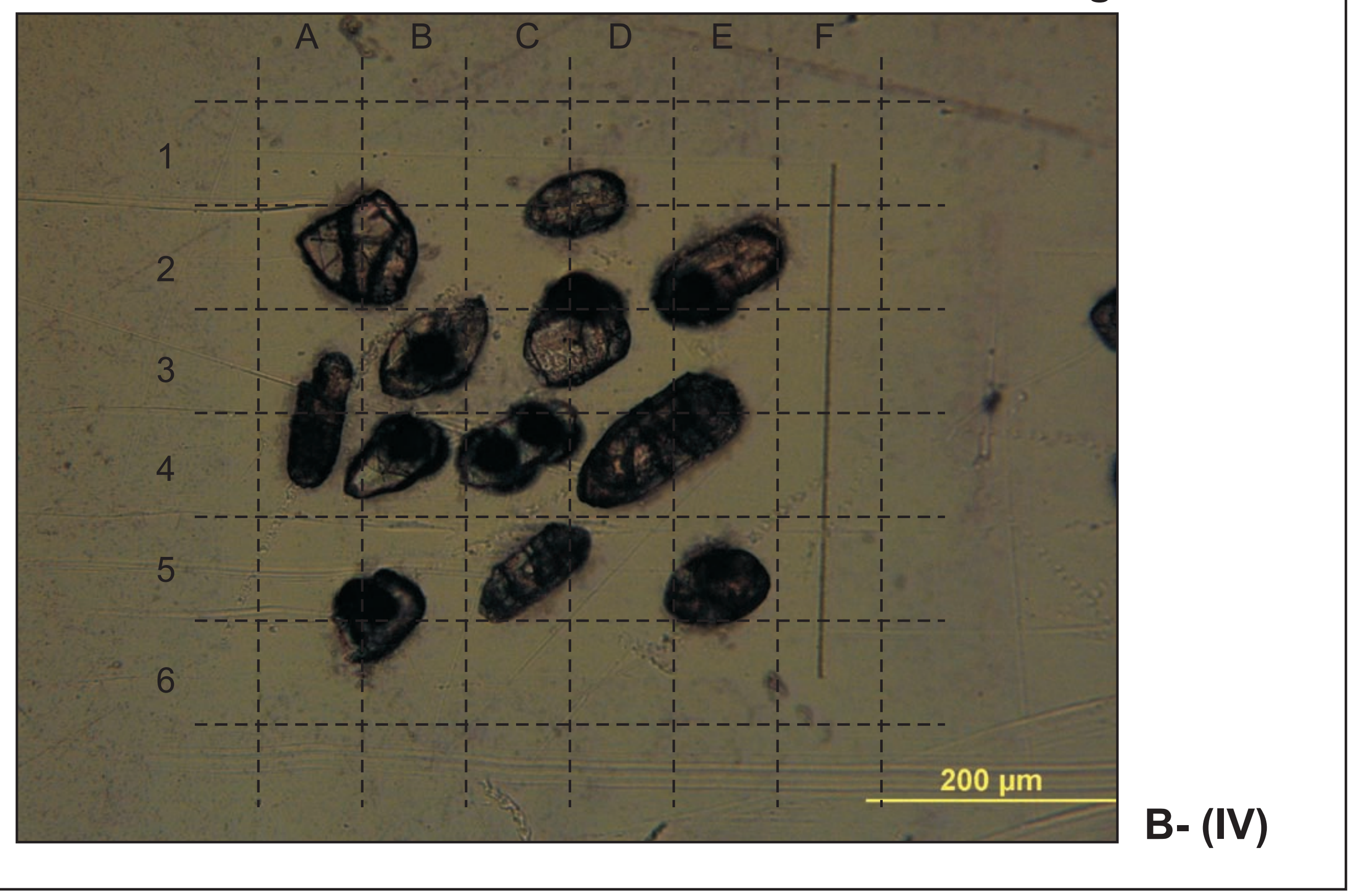


Pico do Jaraguá PJ-1M

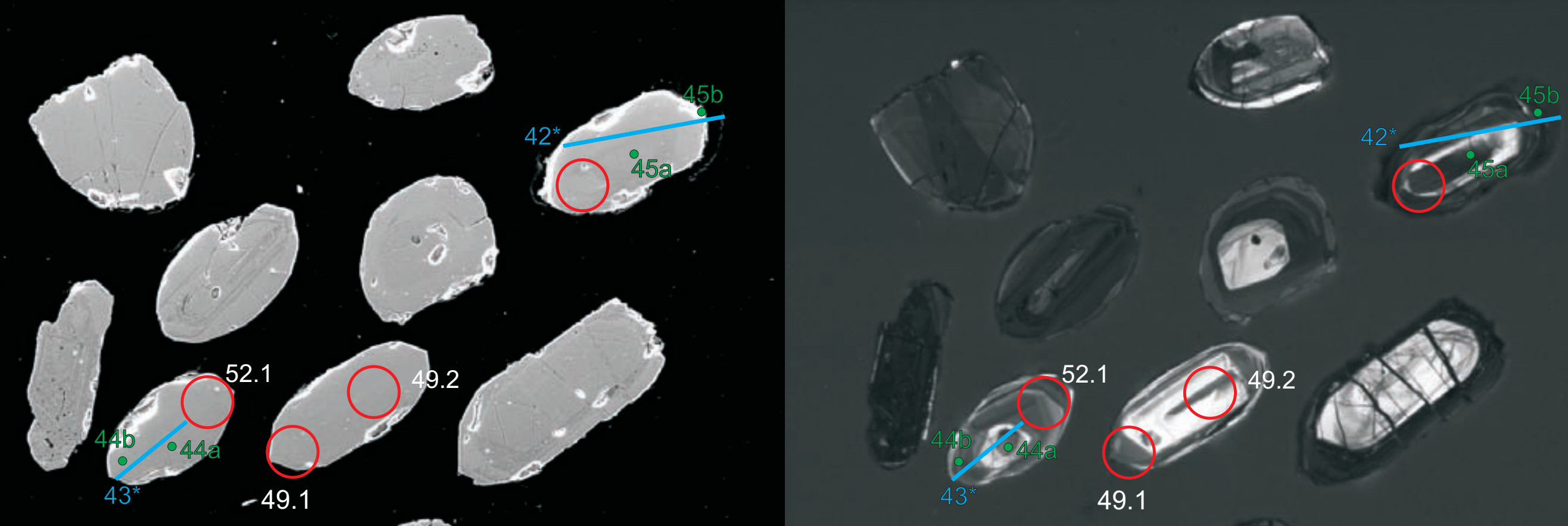


Pico do Jaraguá PJ-1M

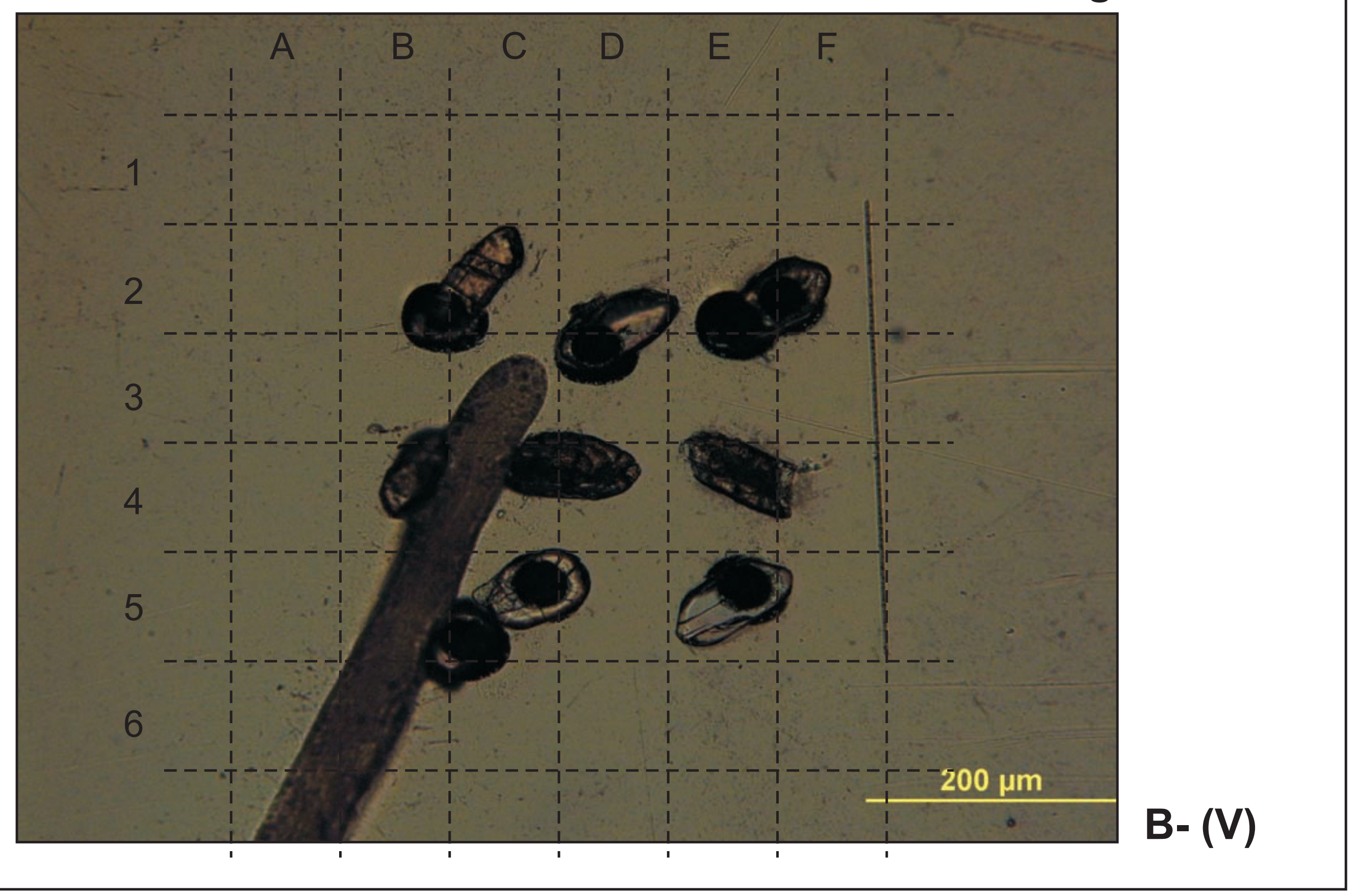




\section{Pico do Jaraguá PJ-1M}

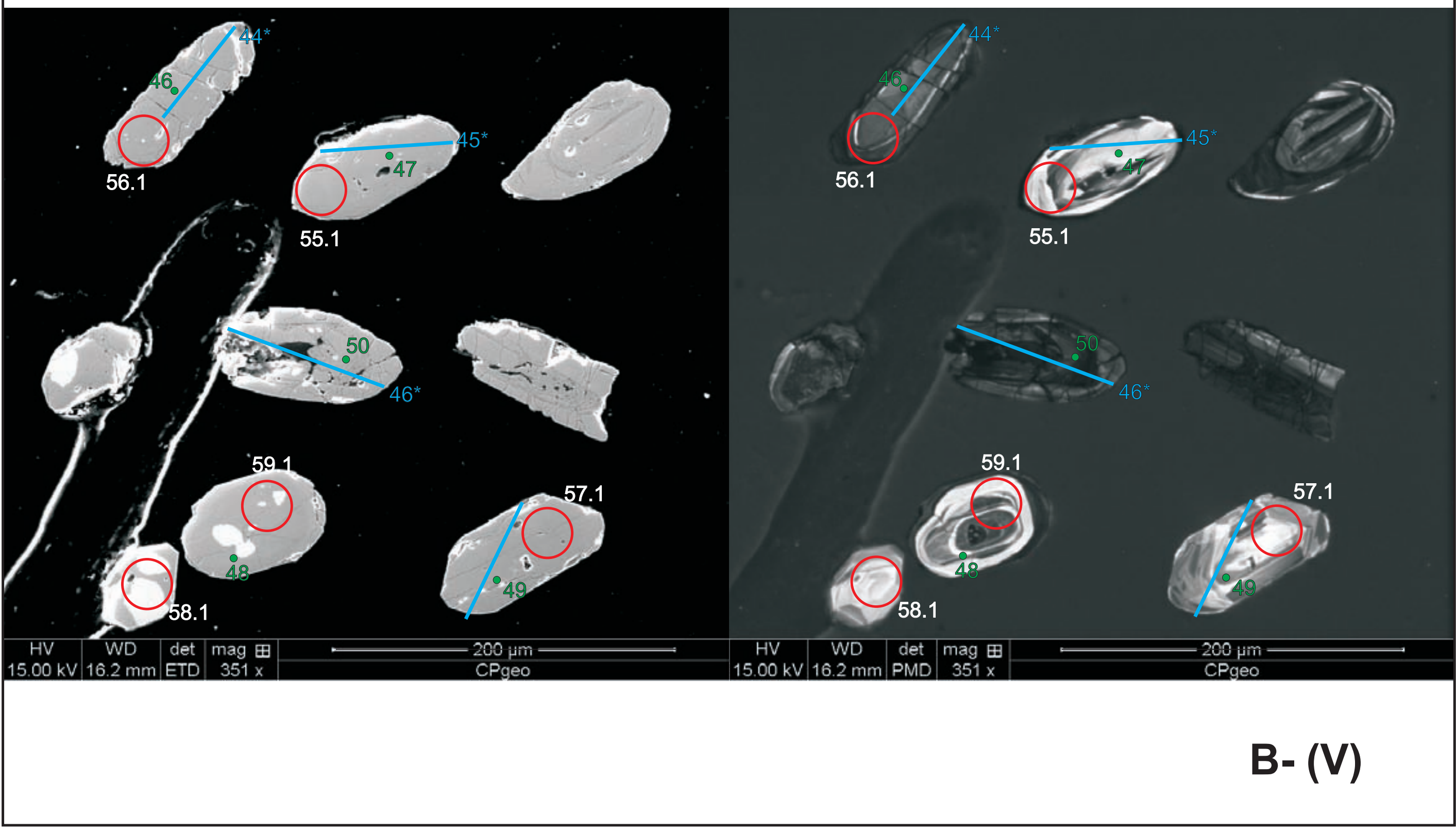




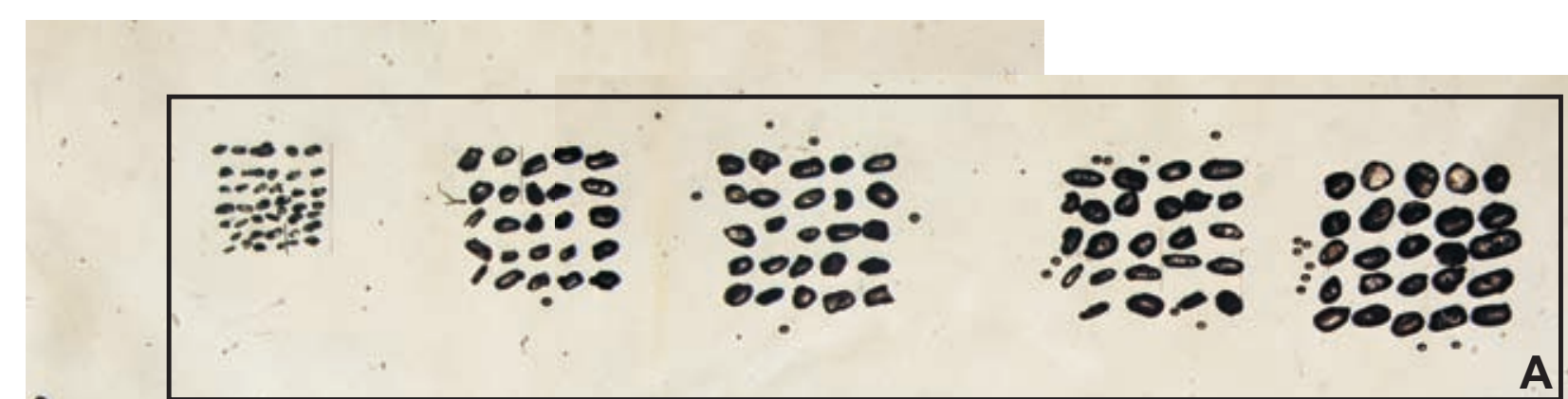

-

$\because \because: 0^{\circ}$

00000000

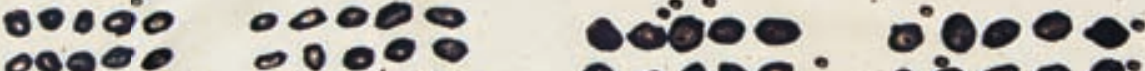

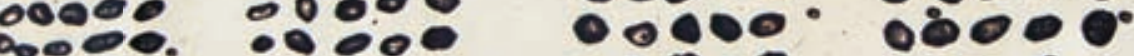

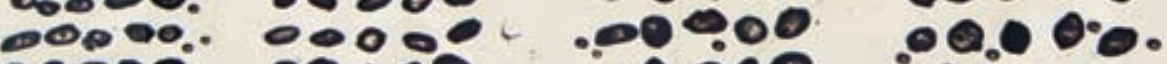

0000.1000

$\because \cdot$

80008

\section{Serra do Japi JP-01}

Simbologia para diferentes tipos de análises. Numeração correspondente no Anexo V

18* Química do zircão via LA-ICPMS

- 20 Química do zircão via Microssonda

62.1 Datação U-Pb via LA-MC-ICPMS

$50^{*}$

- 0 요 0 - 000 - 0900 - 8890 0000 $\therefore 80 \%$

(V)
2000 $00 \Leftrightarrow$ 000 Q 000 - 000

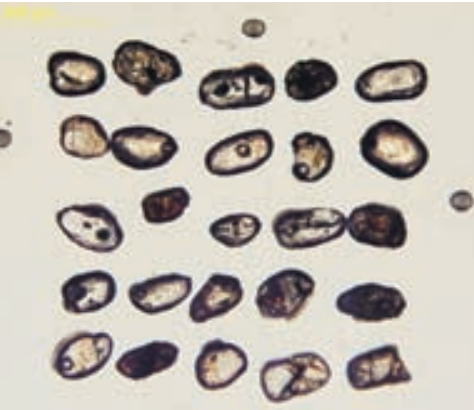

(III)

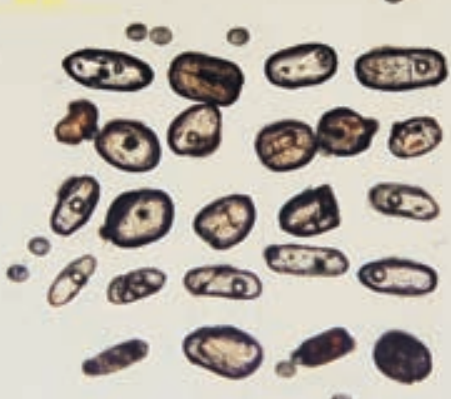

(II)

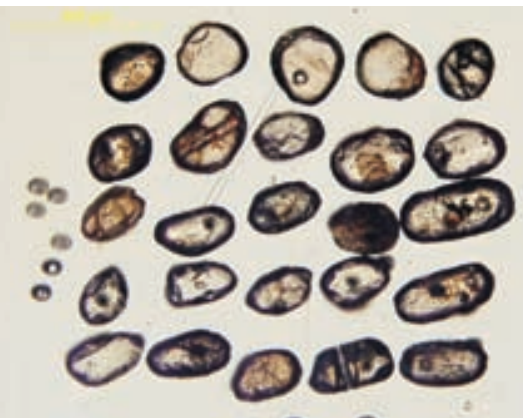

(l) 


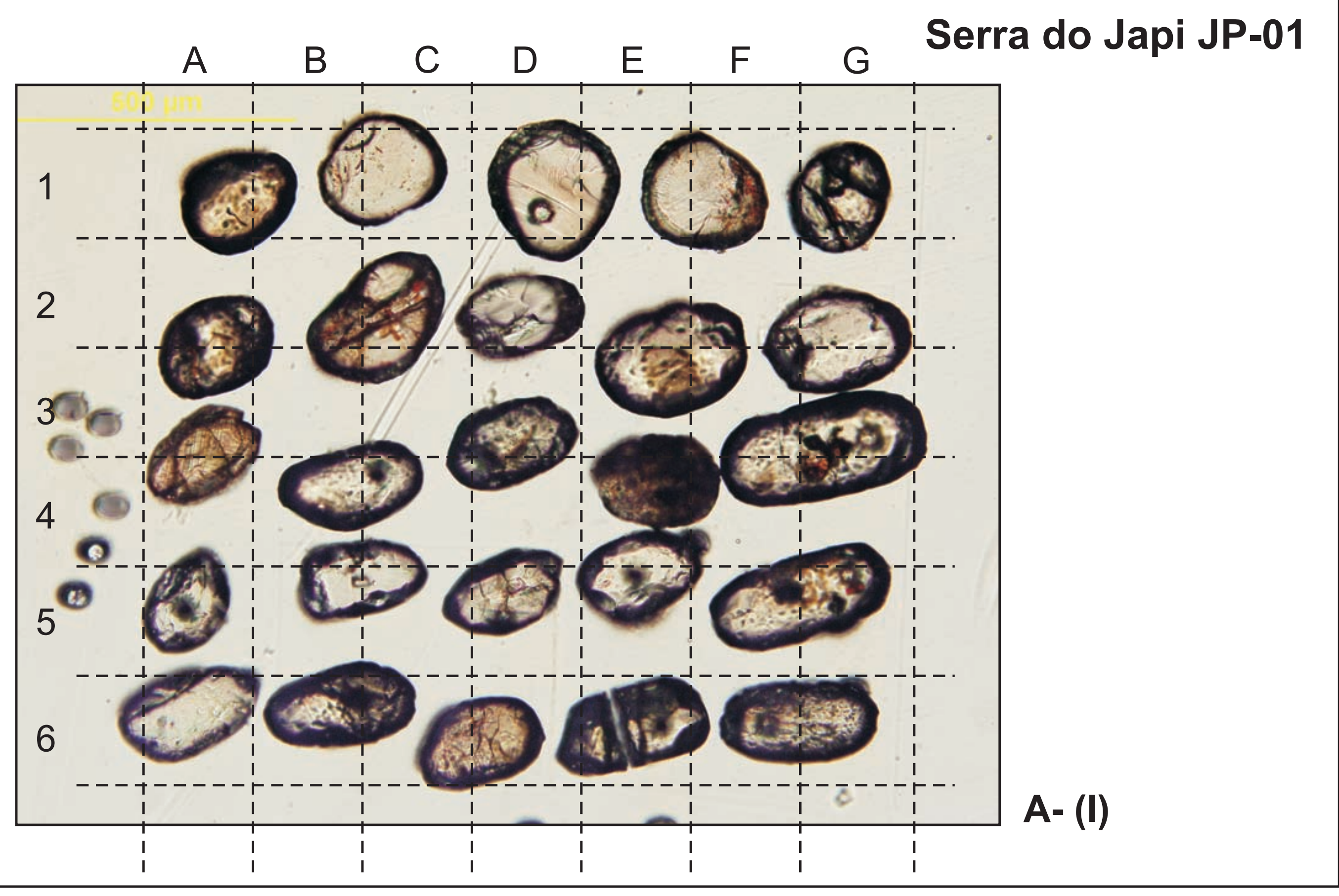




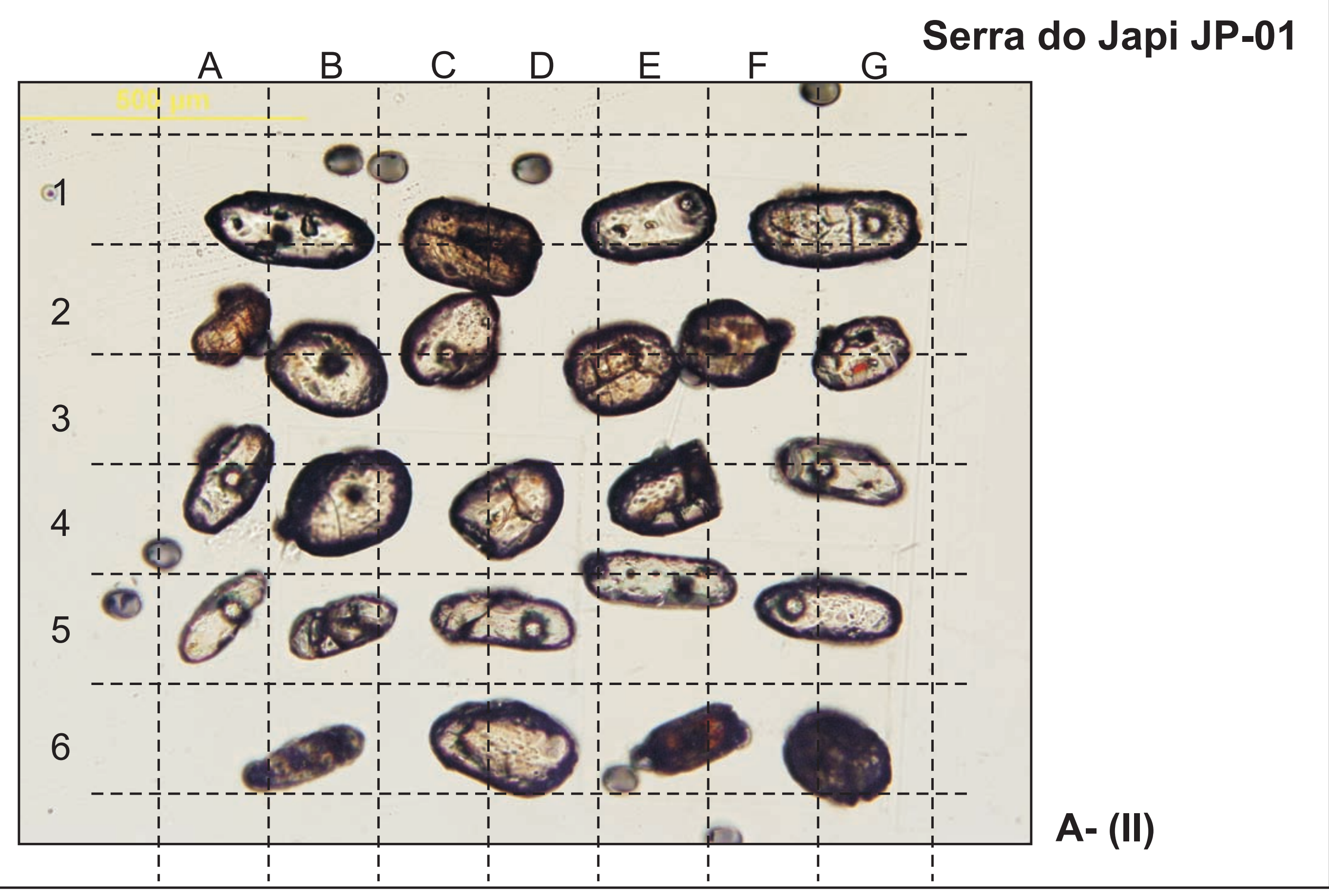




\section{Serra do Japi JP-01}

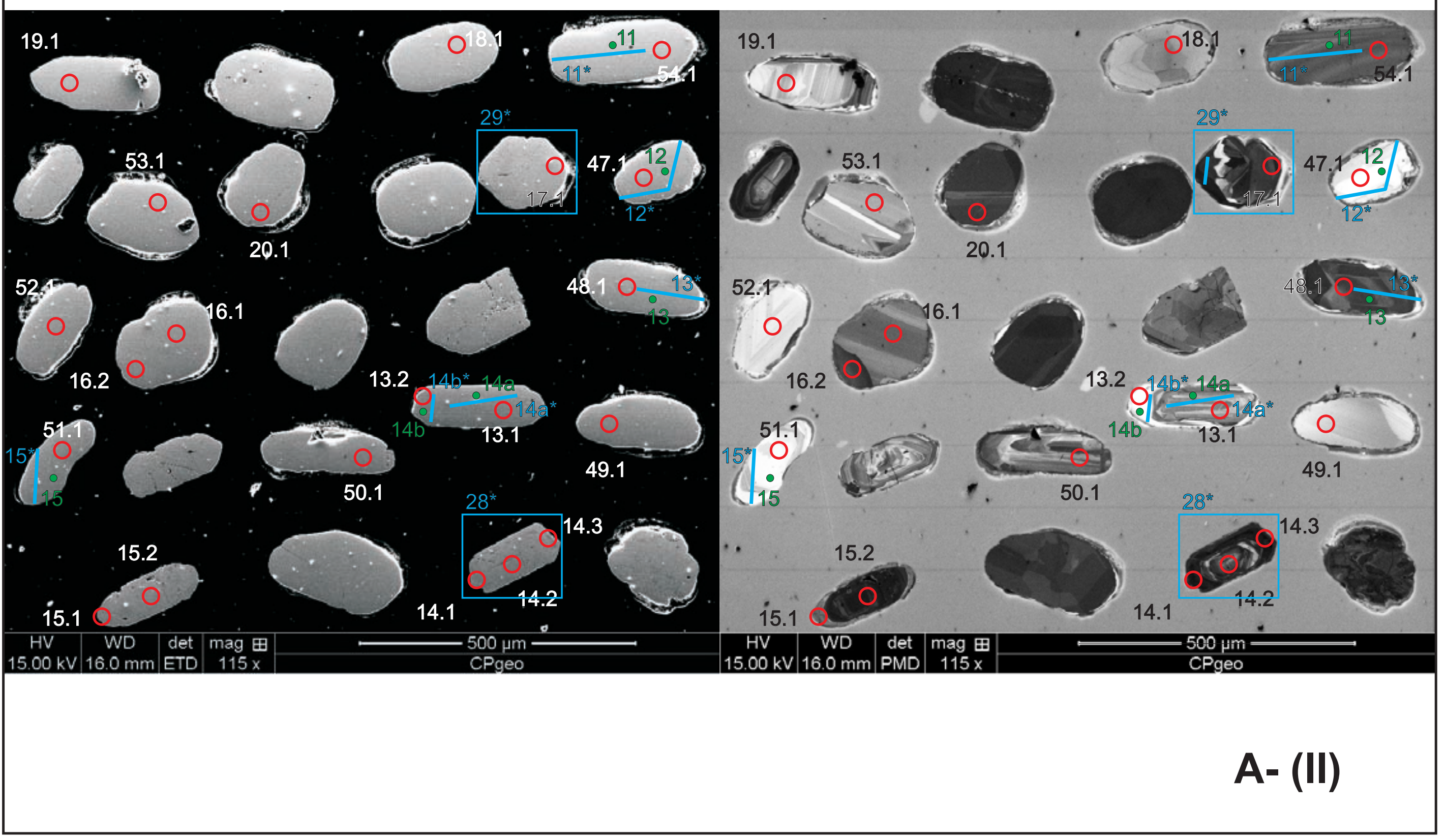




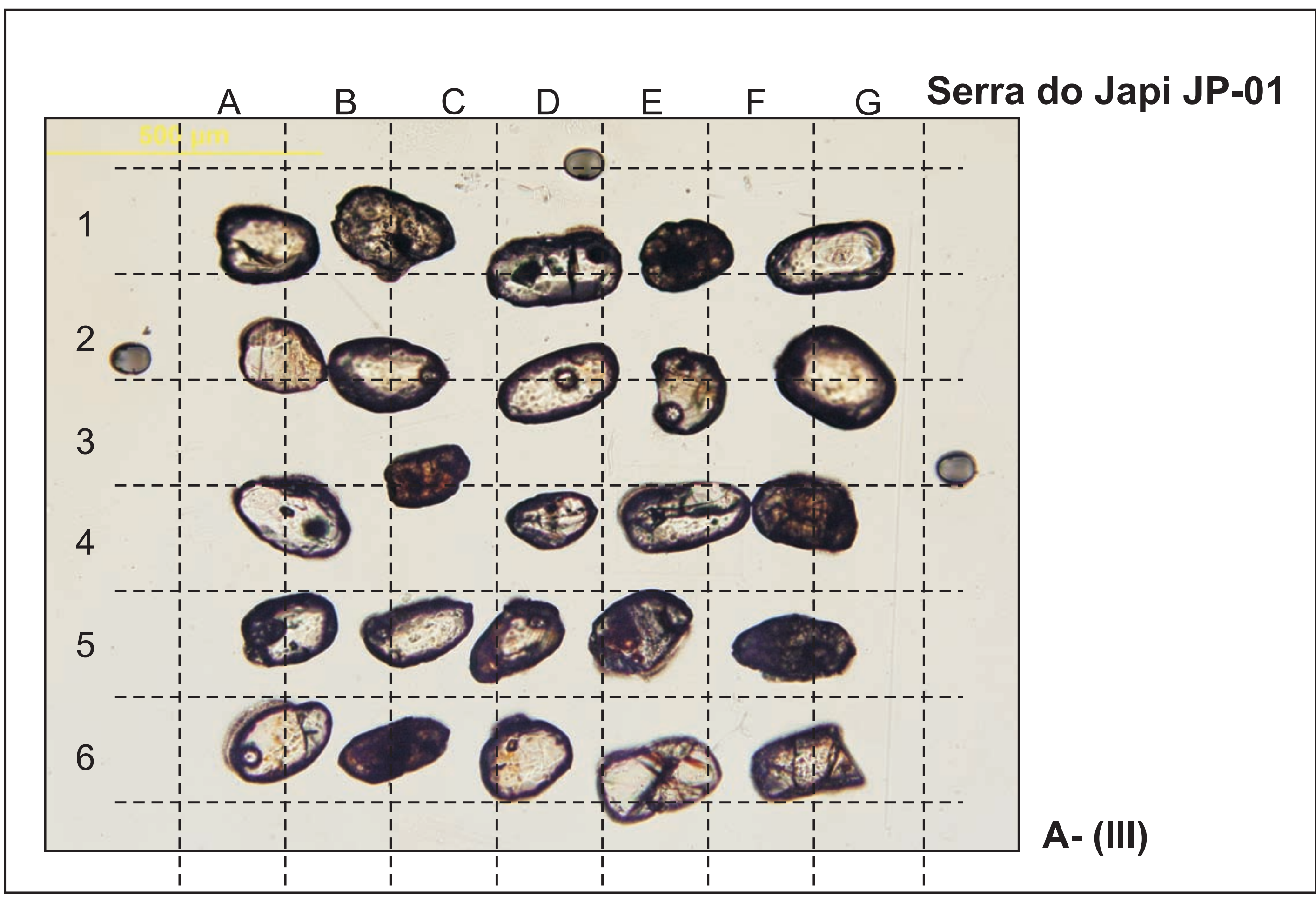




\section{Serra do Japi JP-01}

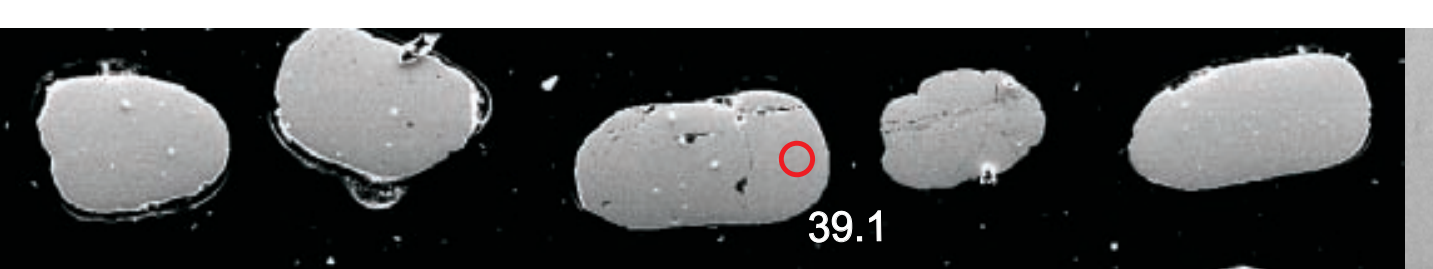

00

0000

0000 2"0.90 57.1 HV WD $\quad$ det $\operatorname{mag} \boxplus$ $15.00 \mathrm{kV} 16.0 \mathrm{~mm}$ ETD $115 \mathrm{x}$

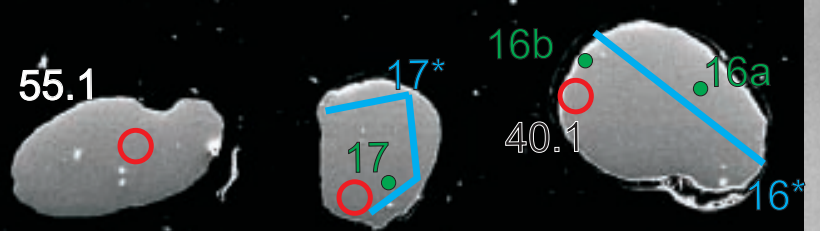

$P_{20}^{43.1}$
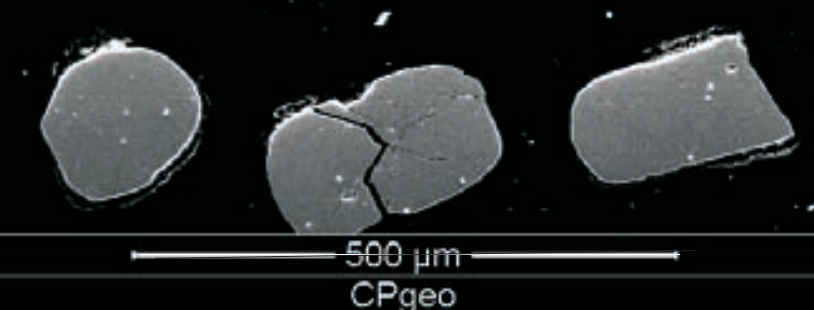
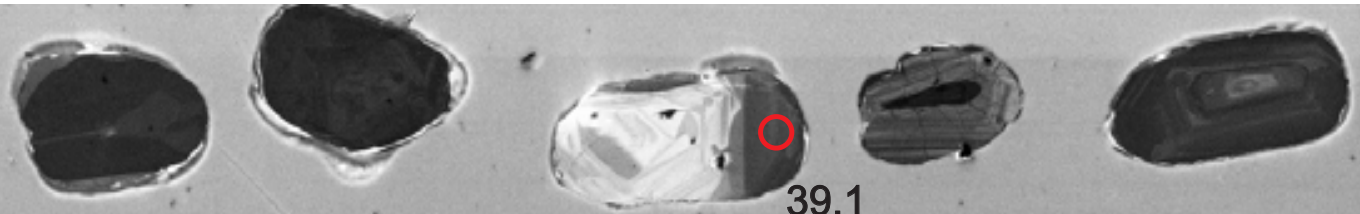

39.1

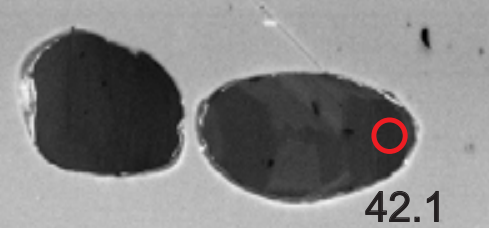

55.1

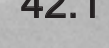

$18^{*} \cdot \begin{array}{r}18 \\ 44.1\end{array}$

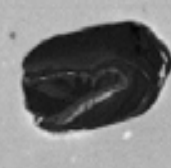

a)

56.1
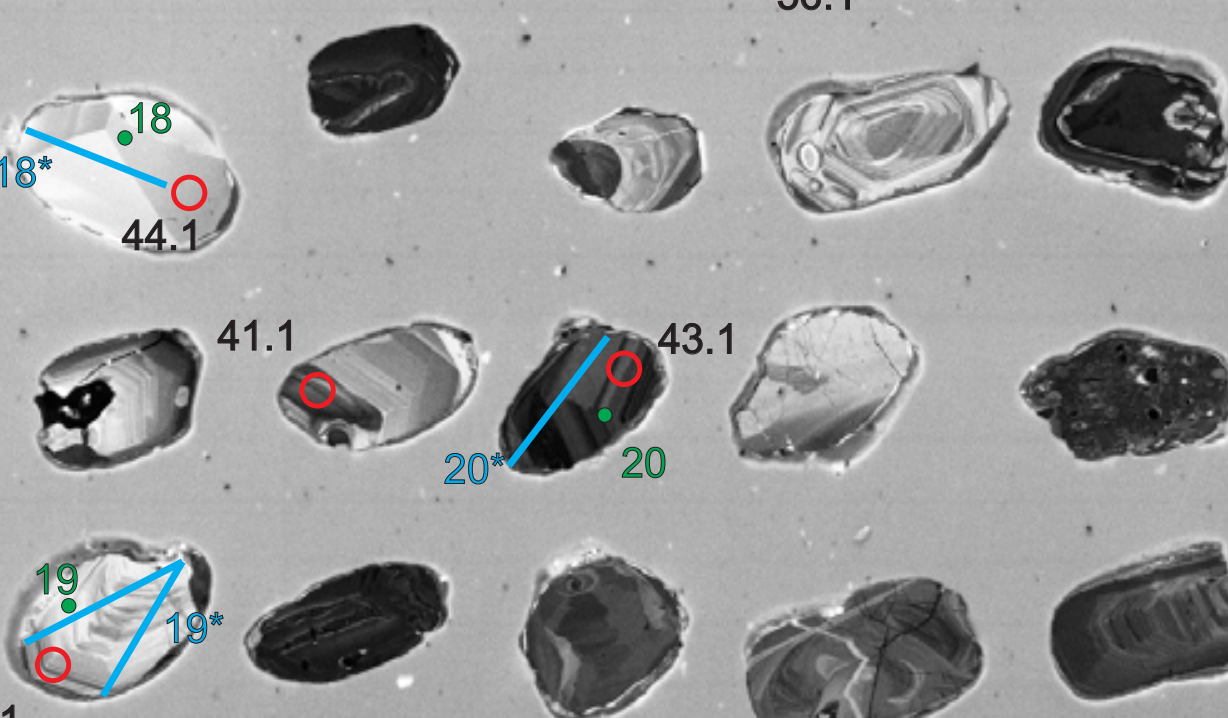

57.1

det mag $\rightarrow$

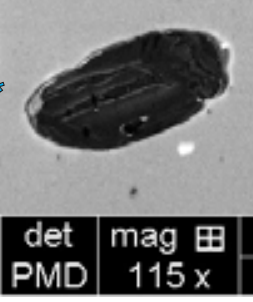

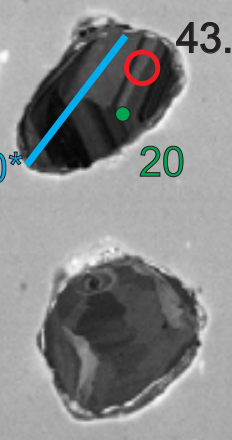

20

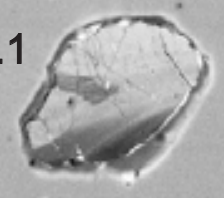

a)

$500 \mu \mathrm{m}$
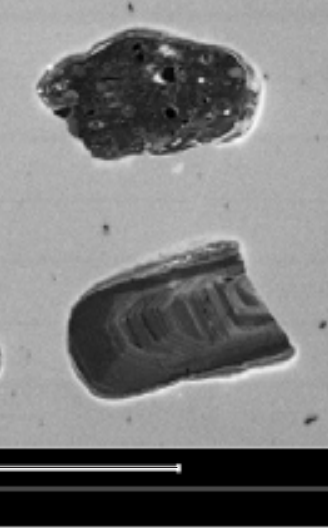

A- (III) 
Serra do Japi JP-01

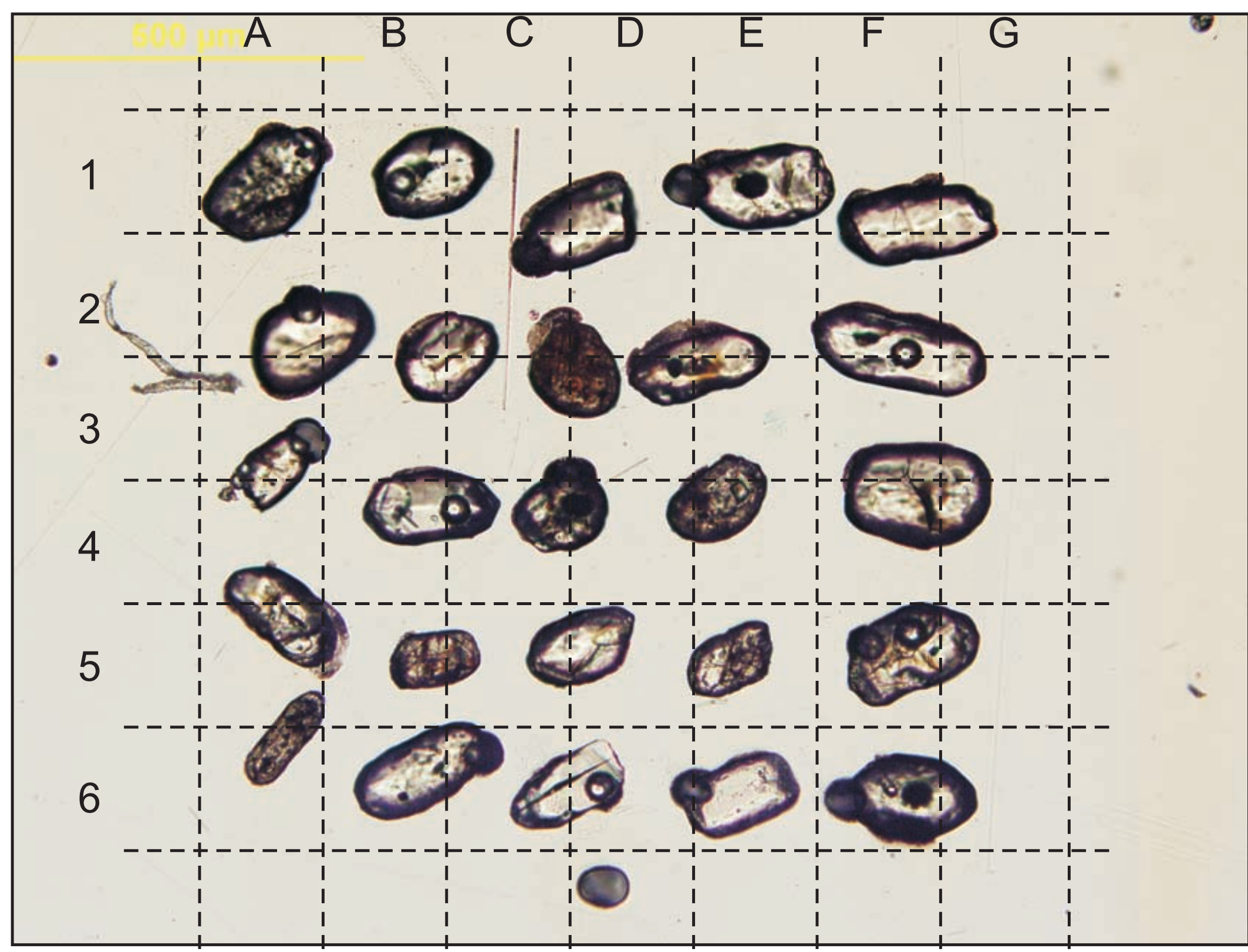

A- (IV) 


\section{Serra do Japi JP-01}

\section{Q.}

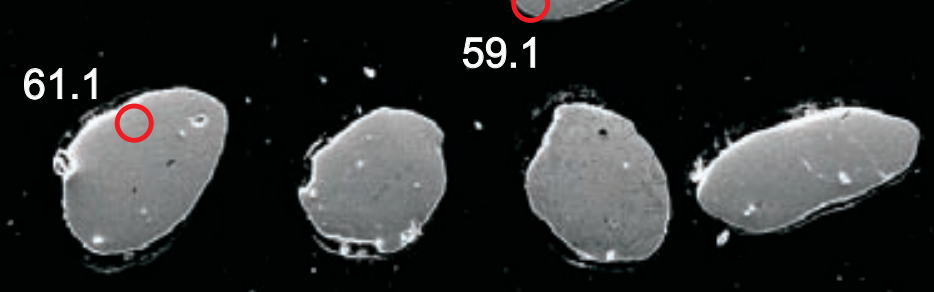

$0^{641} 0^{6021} \bigcirc$

$+000^{0.62} 0^{053}$

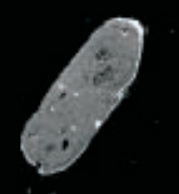

\begin{tabular}{l|c|c|c|} 
HV & WD & det & mag $\boxplus$
\end{tabular}

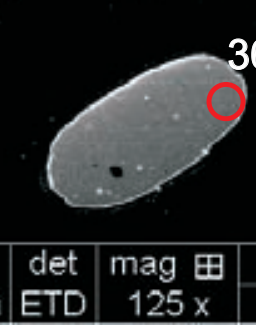

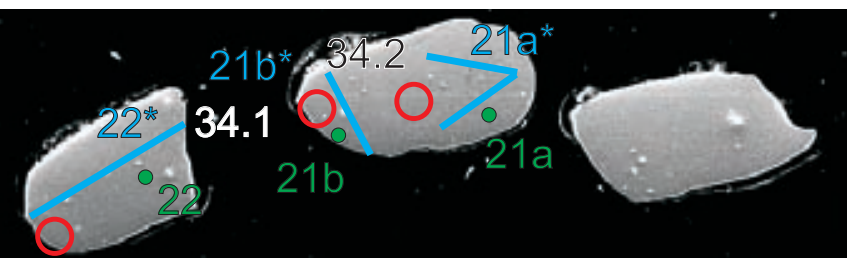

58.1

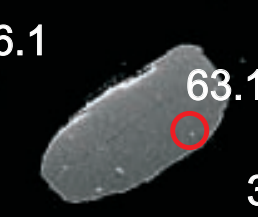

37.1
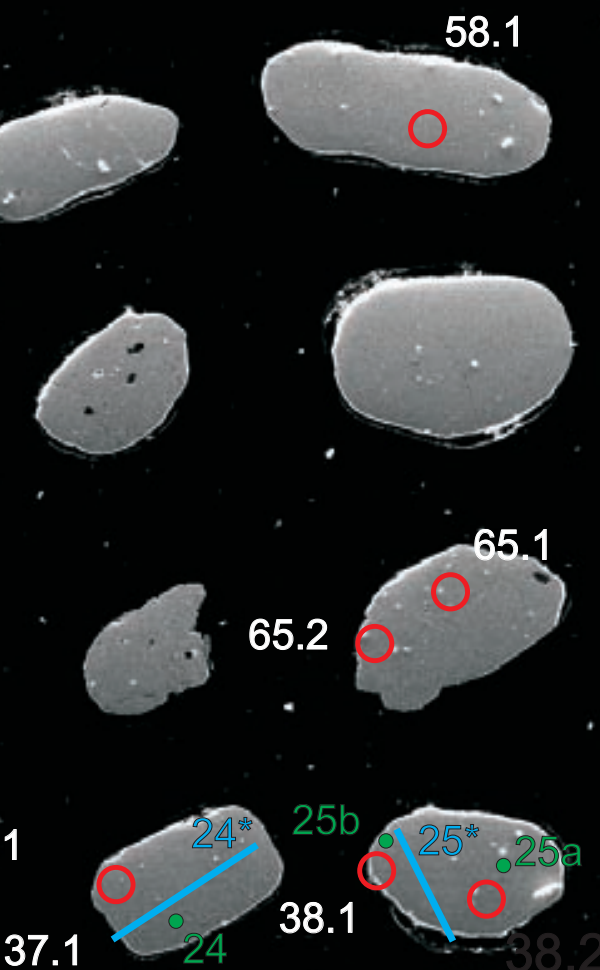
$500 \mu \mathrm{m}$
CPgeo
60.1
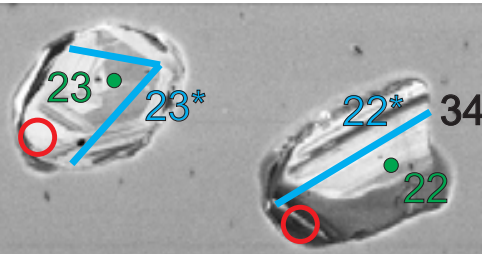

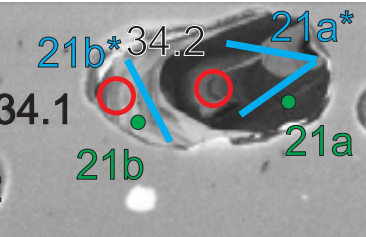

59.1

61.1
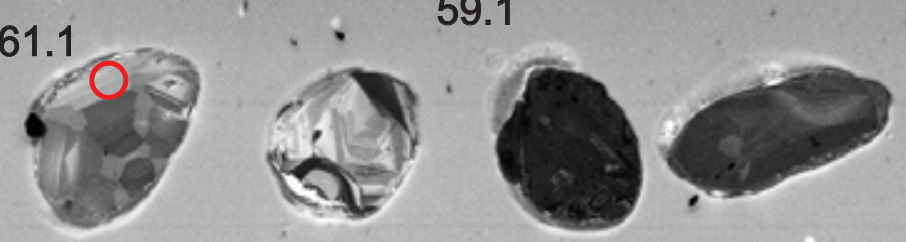

$\frac{58.1}{0}$

$20^{64.1}$

$\left(1.0^{62.1}\right.$

35.1
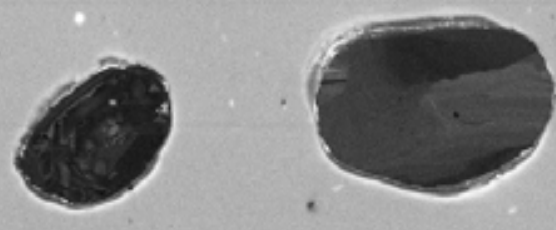

5

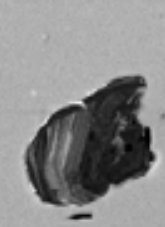

65.2

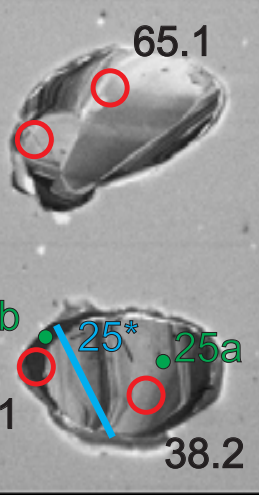

\begin{tabular}{l|l|l|l} 
HV & WD & det & mag $\boxplus$
\end{tabular} 15.00 kV 16.0 mm PMD $125 \mathrm{x}$

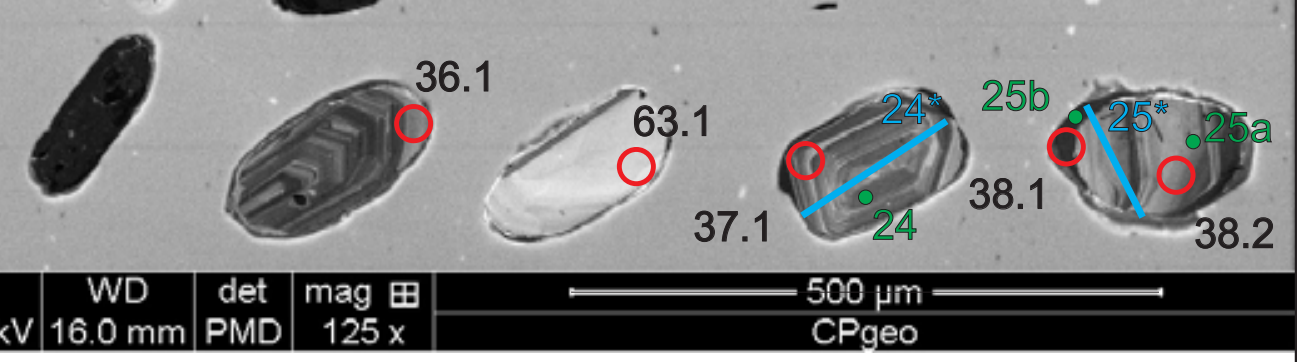

A- (IV) 
Serra do Japi JP-01

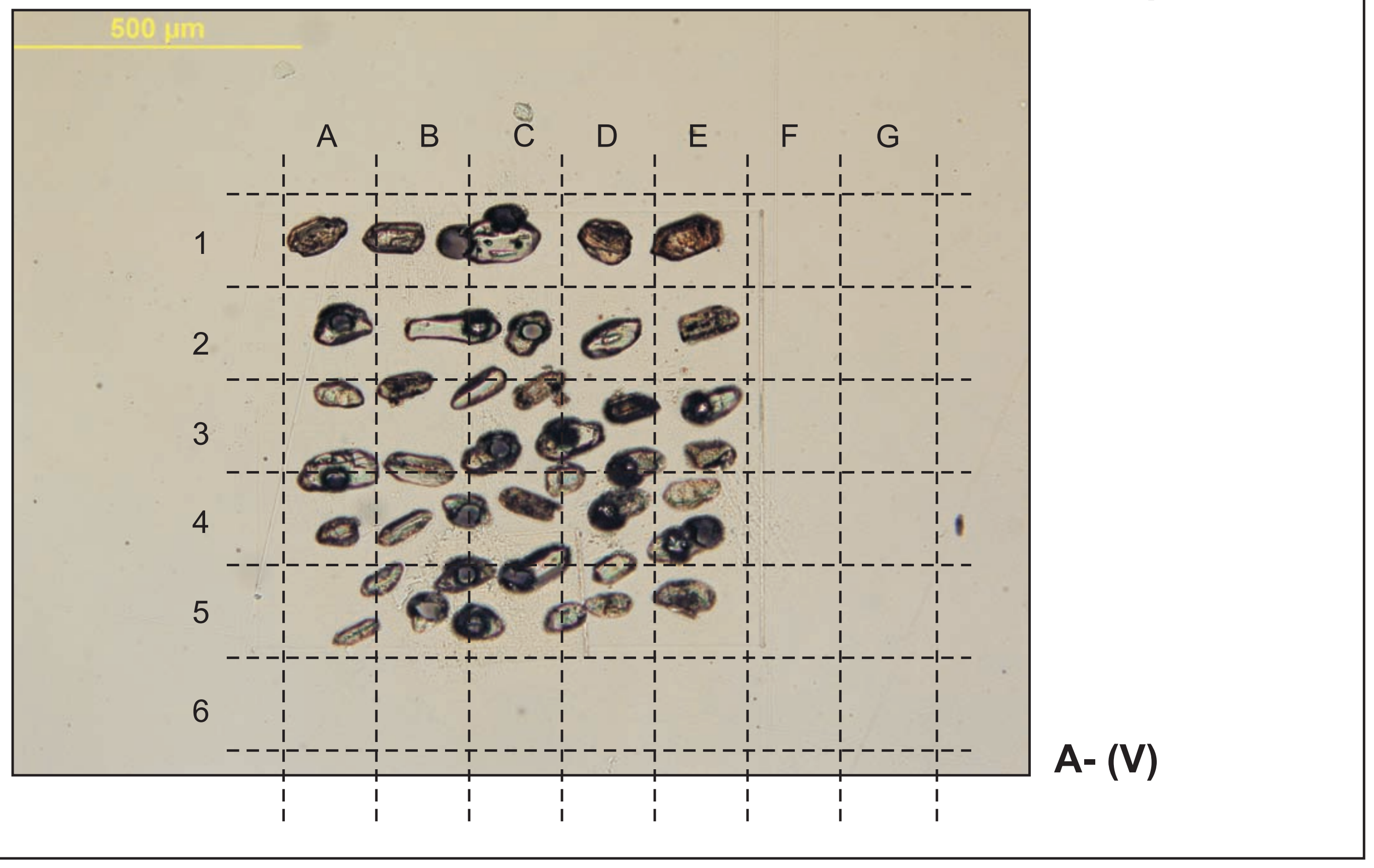




\section{Serra do Japi JP-01}

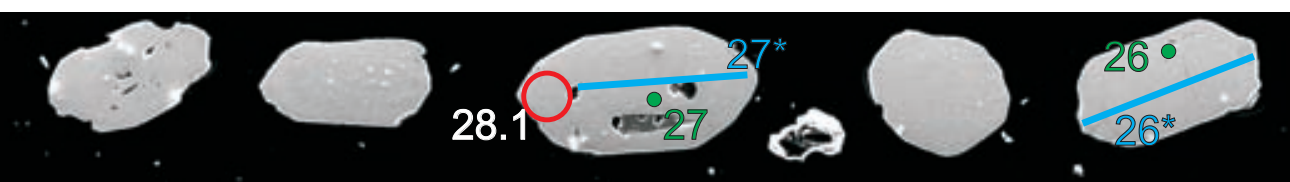

200

0

2ais

$\infty \infty$

$0^{20}$

30.1

$\overbrace{33.1}^{0.1}$

$\mathrm{HV}$

WD det $\mathrm{mag}$ it 15.00 kV $16.0 \mathrm{~mm}$ ETD $170 \mathrm{x}$

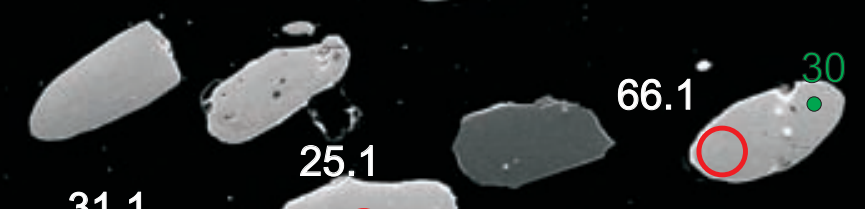
$25.1>0$

32.10 .03 .10

$$
\frac{22.2}{22.1}
$$

$\therefore 2$

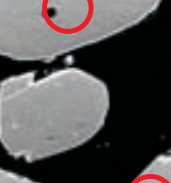

68.1 $0^{67.1}$ 0.

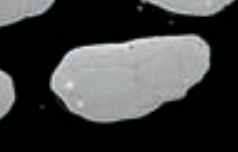
$500 \mu \mathrm{m}$
CPgeo
(1) (ल)

29.1

(103) 27.1 (2)
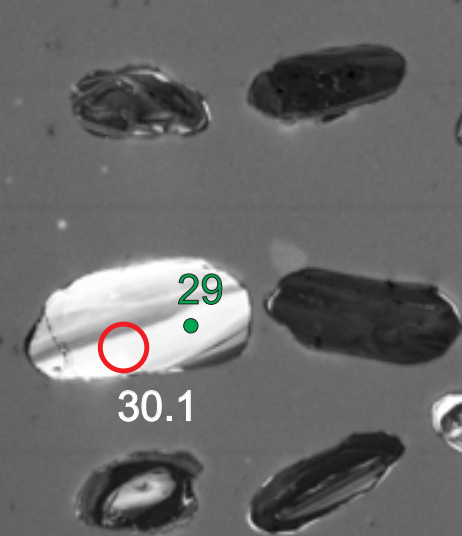

31.1

(20)

(1) 67.1

${ }^{66.1} 0^{\circ}$

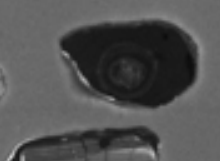

(a)

33.1

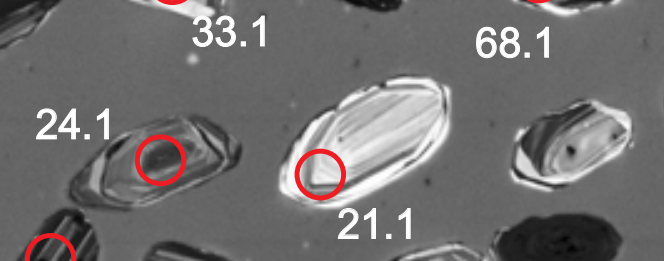

(3)

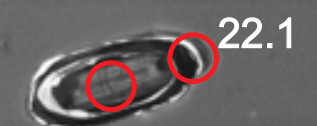

32.1

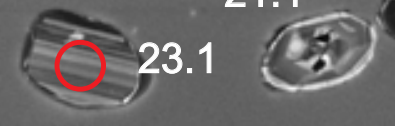

HV WD det mag $\mathrm{m}$
$15.00 \mathrm{kV}$
$16.0 \mathrm{~mm}$ PMD $170 \mathrm{x}$

$500 \mu \mathrm{m}$
$\mathrm{CPgeo}$

A- (V) 


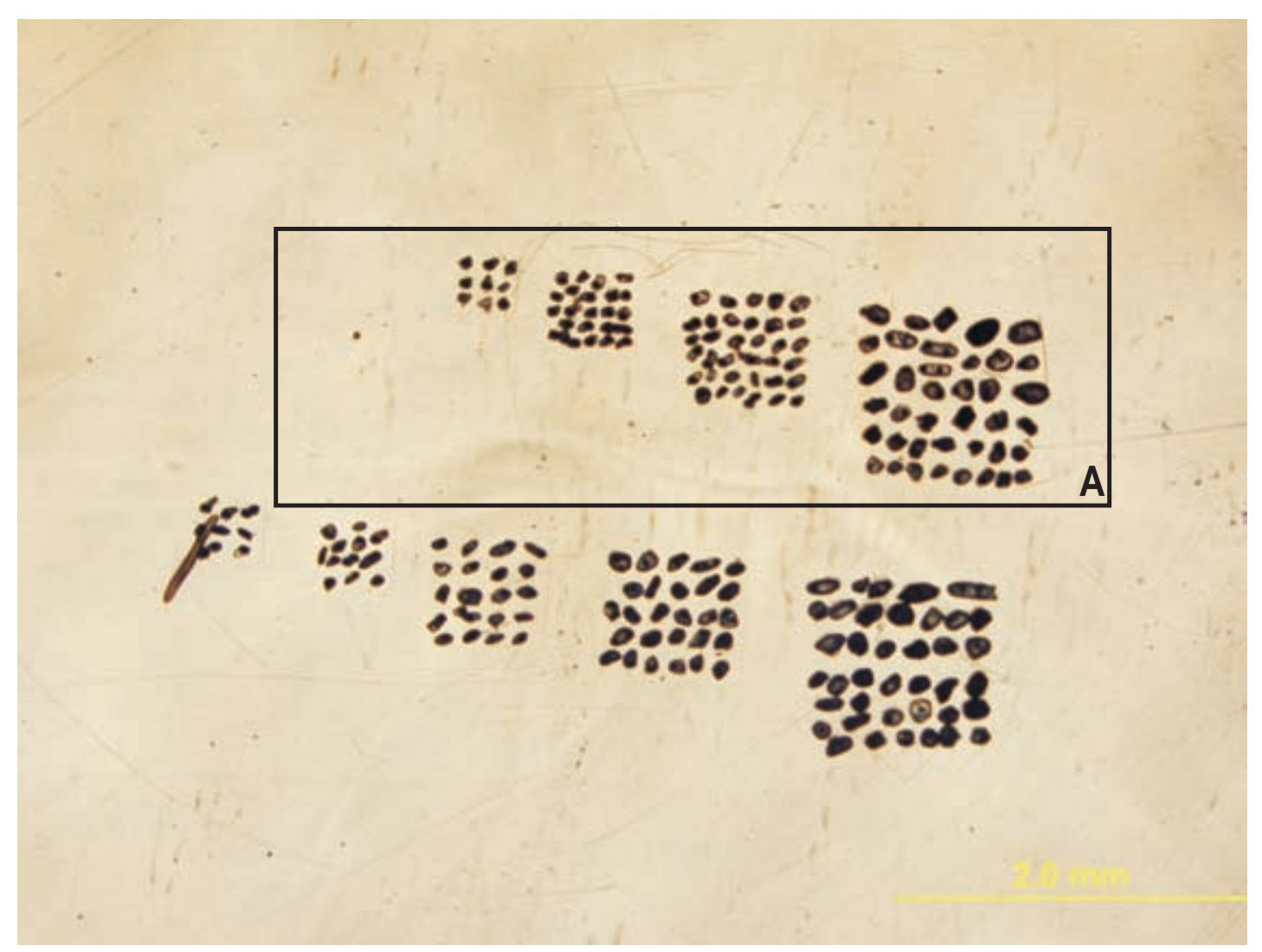

\section{Serra da Viúva VT-04}

Simbologia para diferentes tipos de análises. Numeração correspondente no Anexo V

18* Química do zircão via LA-ICPMS

- 20 Química do zircão via Microssonda

62.1 Datação U-Pb via LA-MC-ICPMS

Mapa composicional via LA-ICPMS

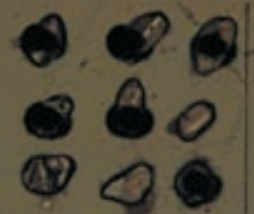

(IV)

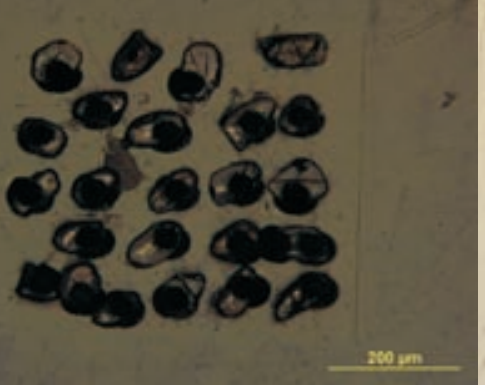

(III)

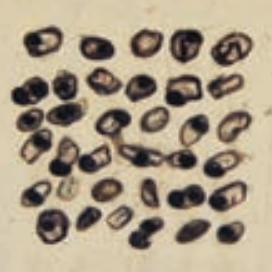

(II)

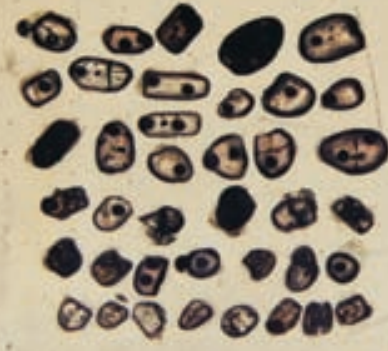

A

(l) 


\section{Serra da Viúva VT-04}

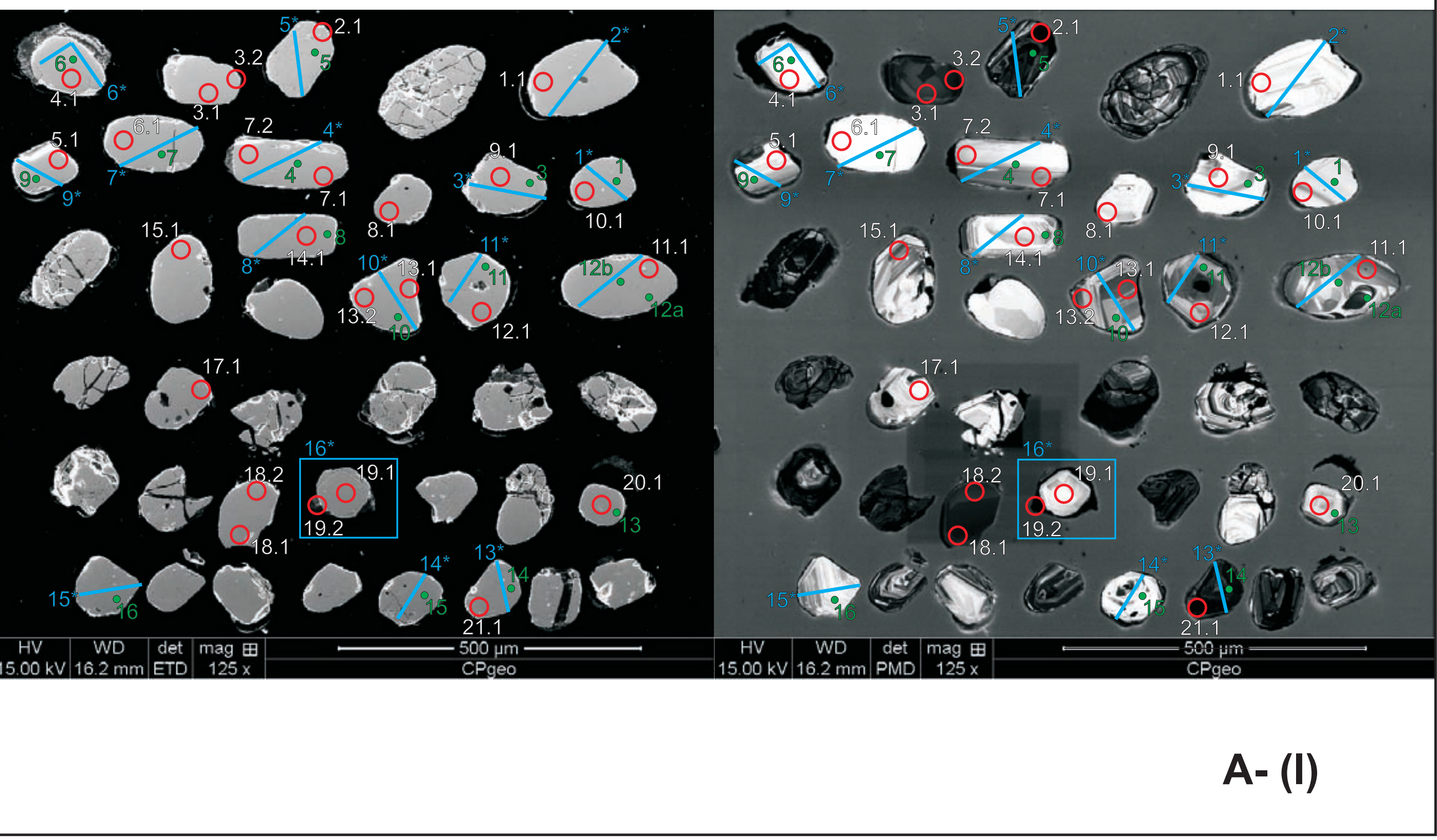




\section{Serra da Viúva VT-04}

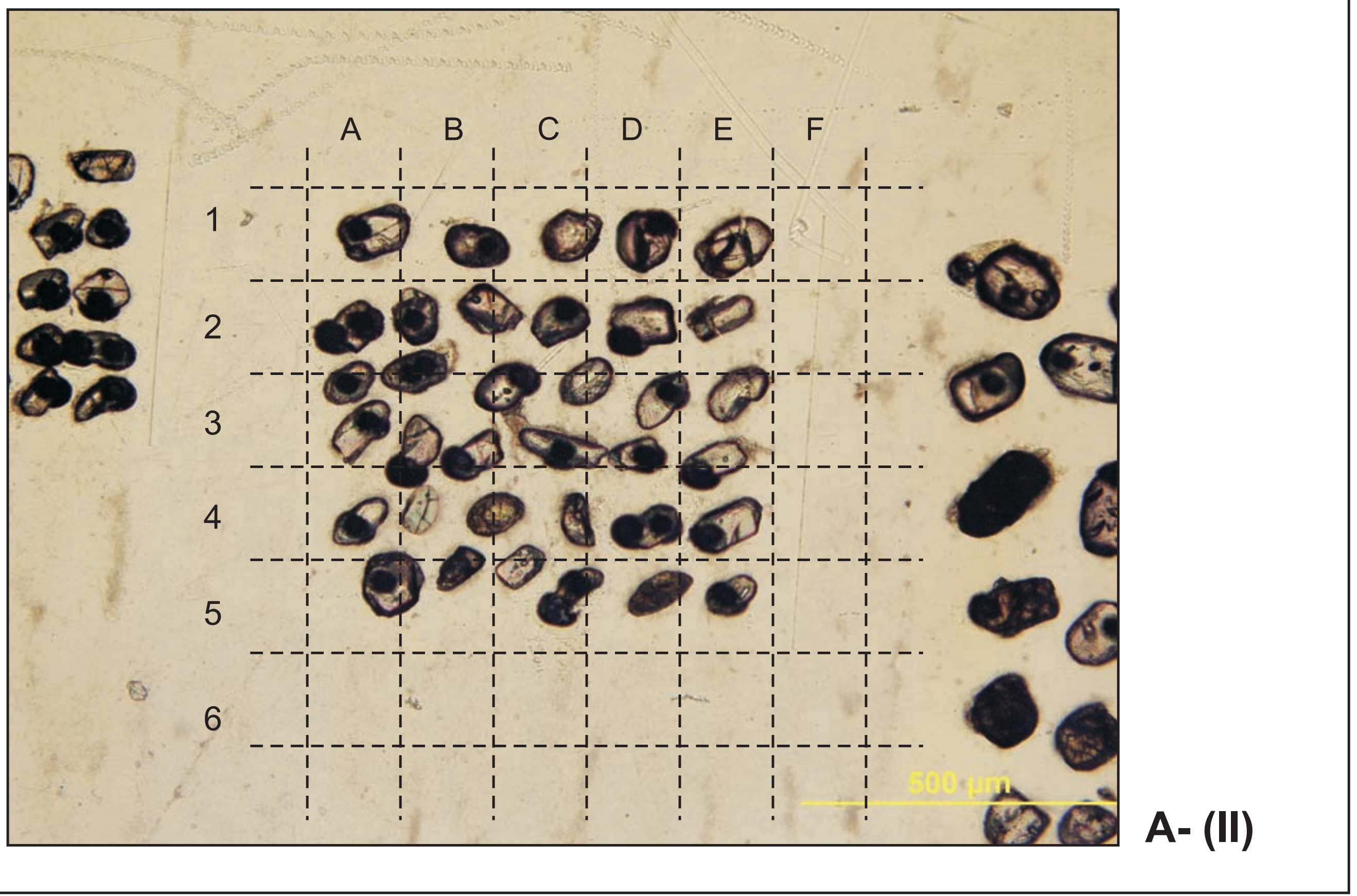




\section{Serra da Viúva VT-04}

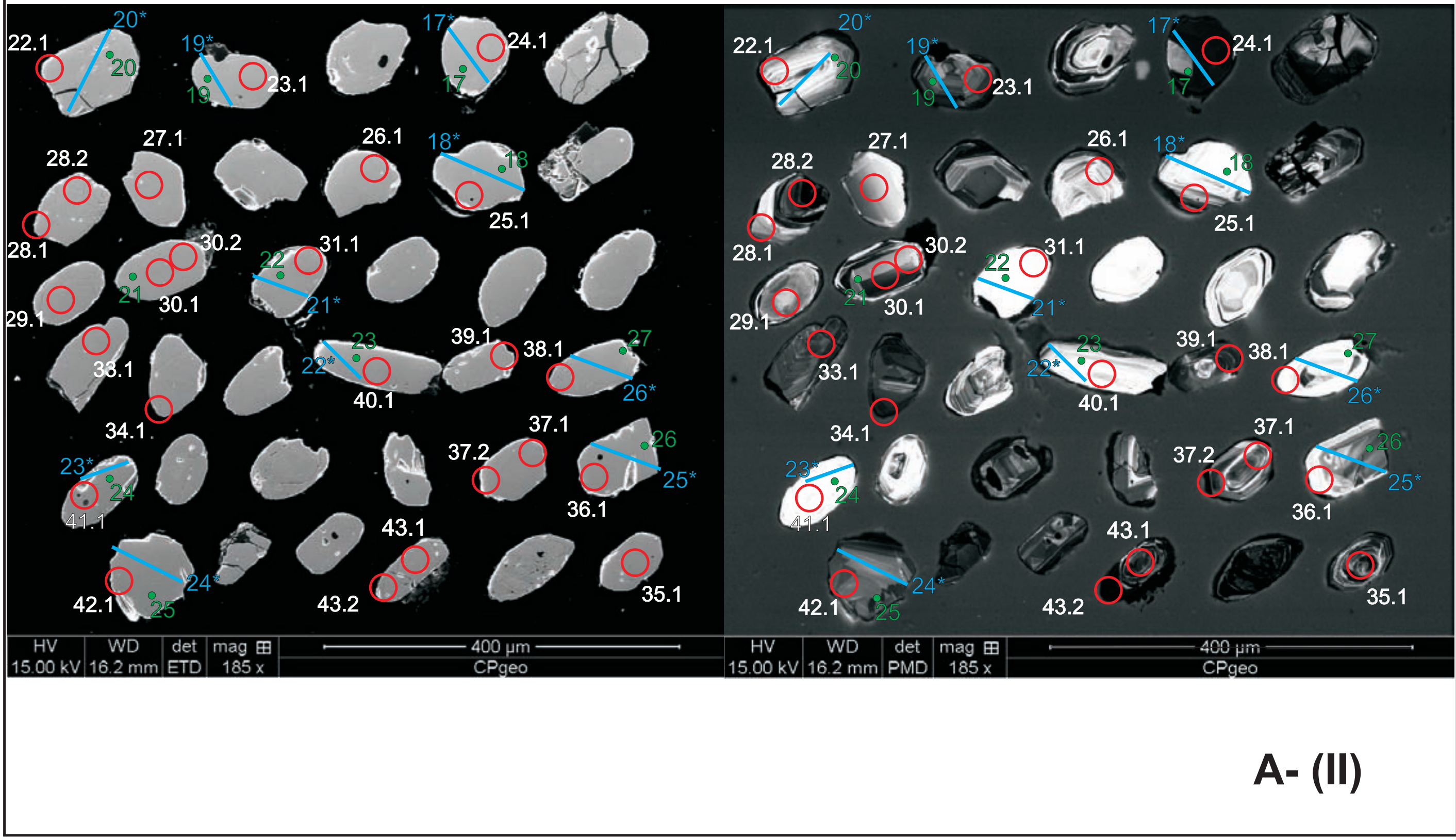


Serra da Viúva VT-04

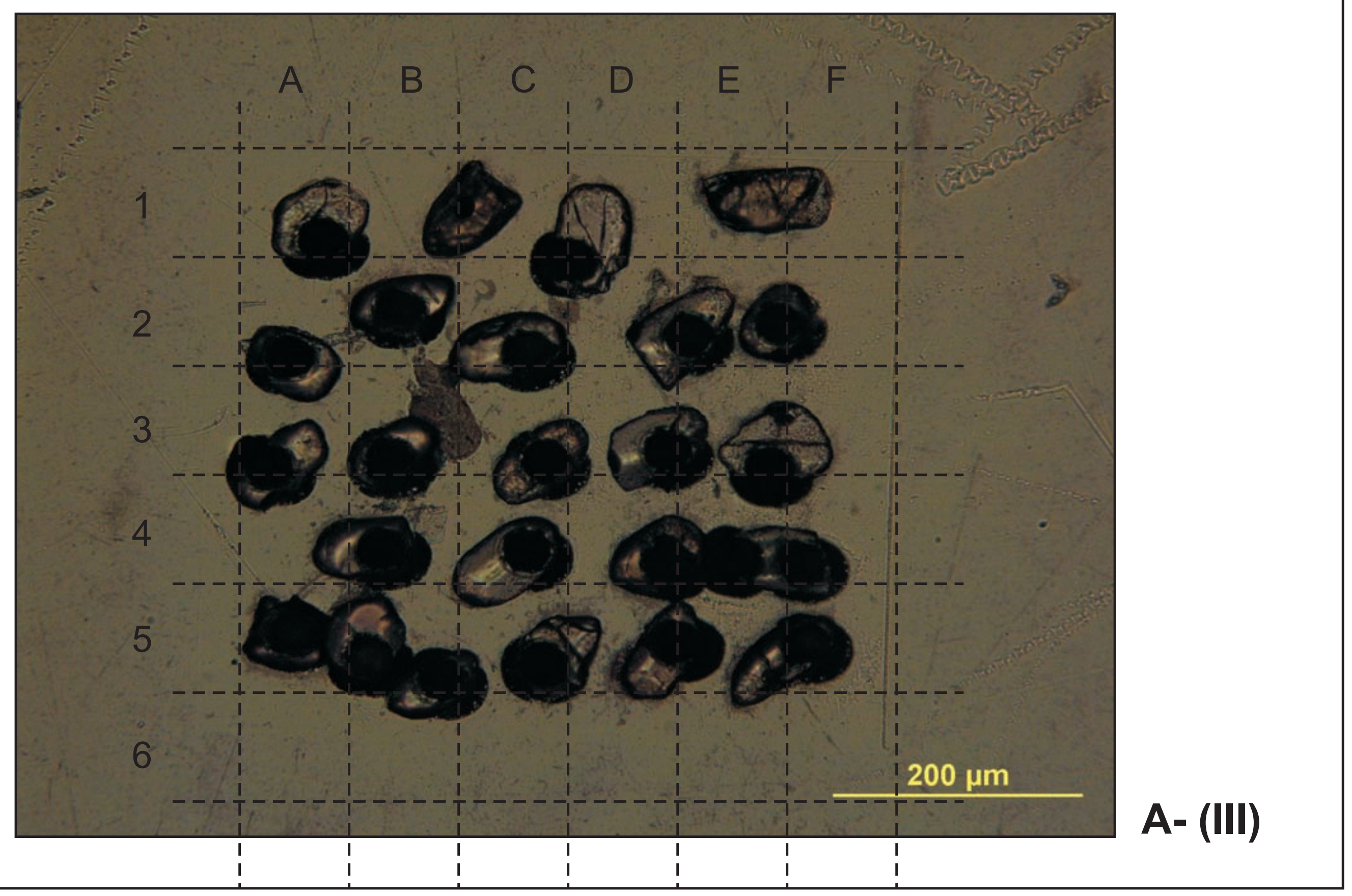




\section{Serra da Viúva VT-04}

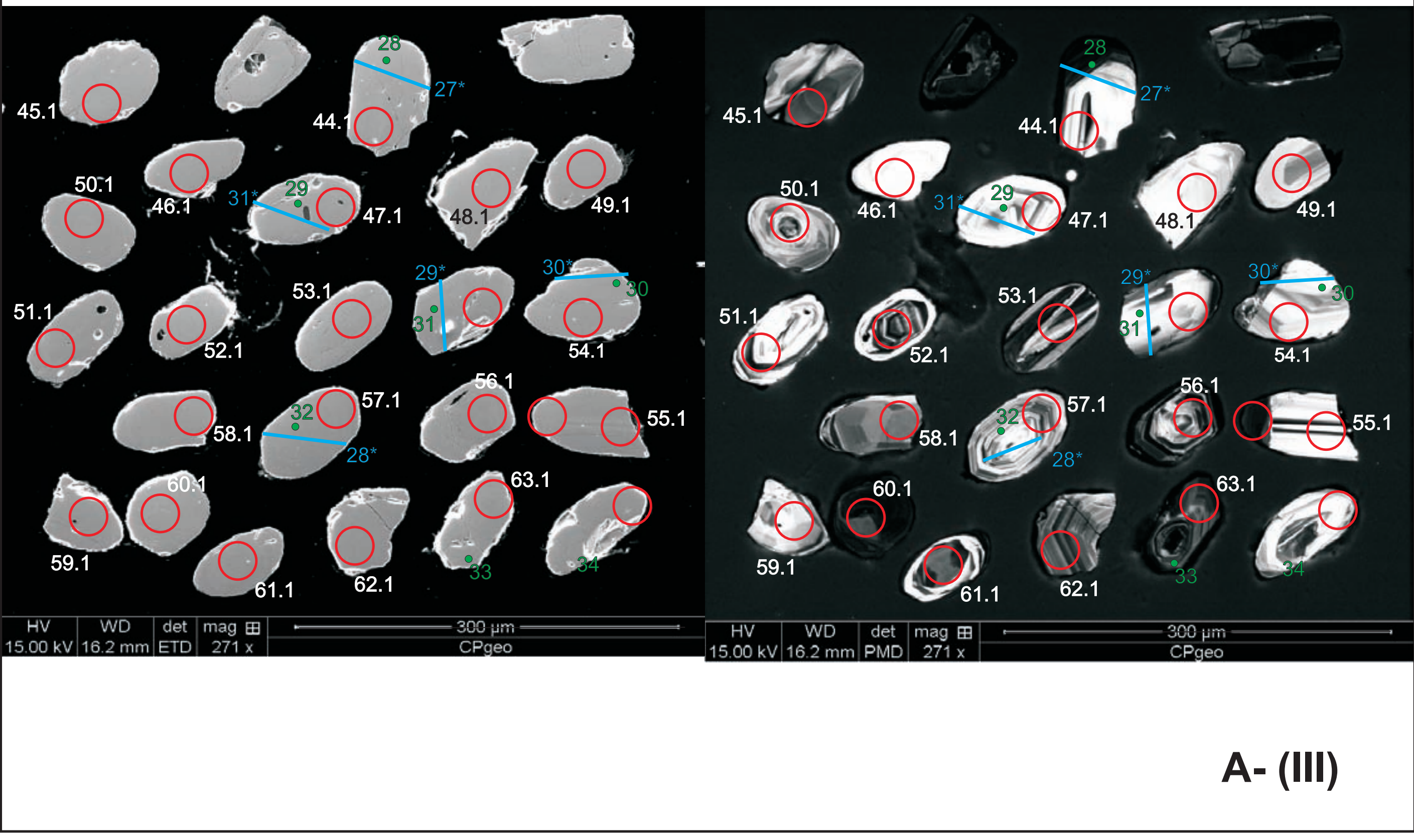


Serra da Viúva VT-04

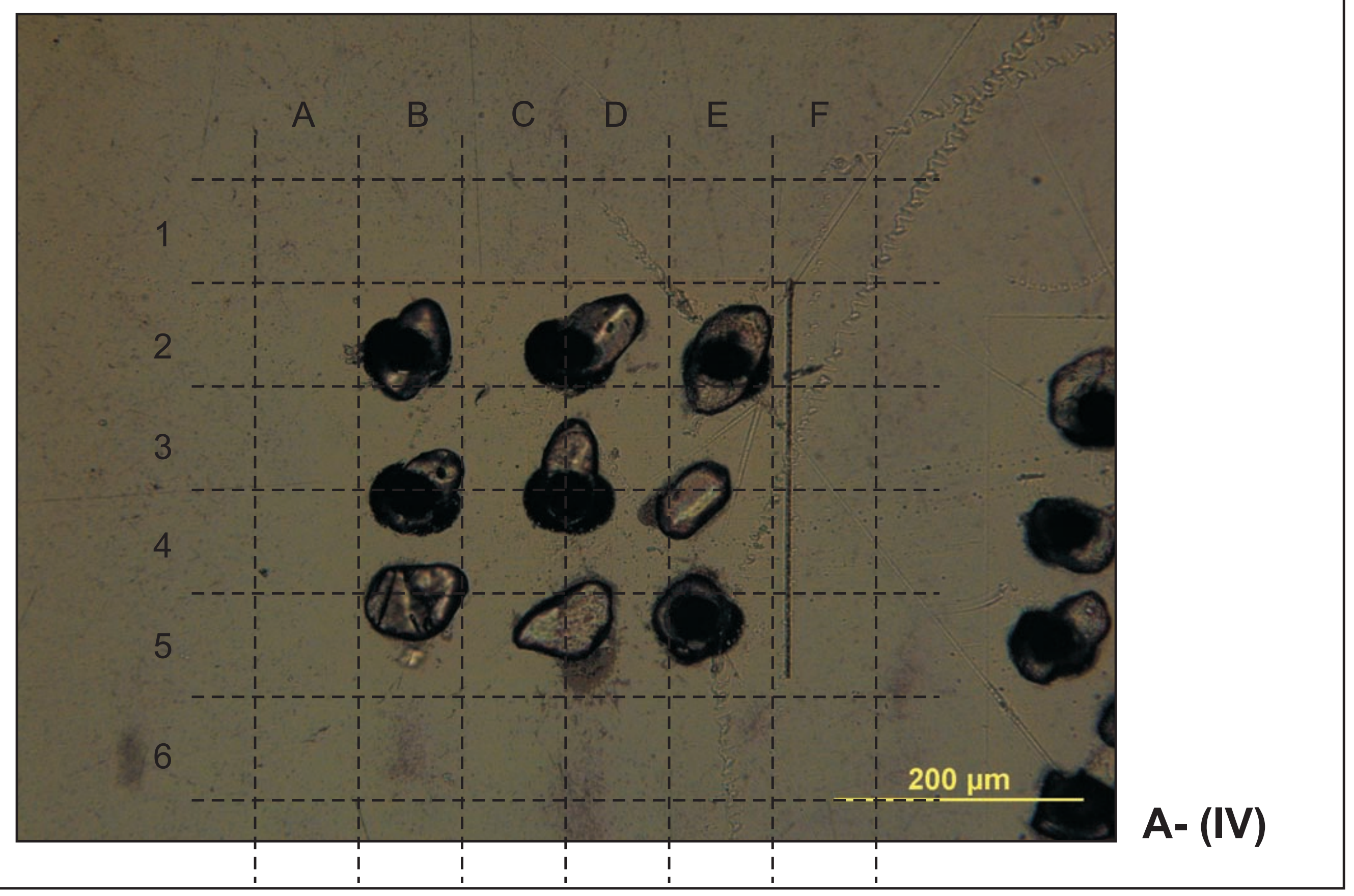



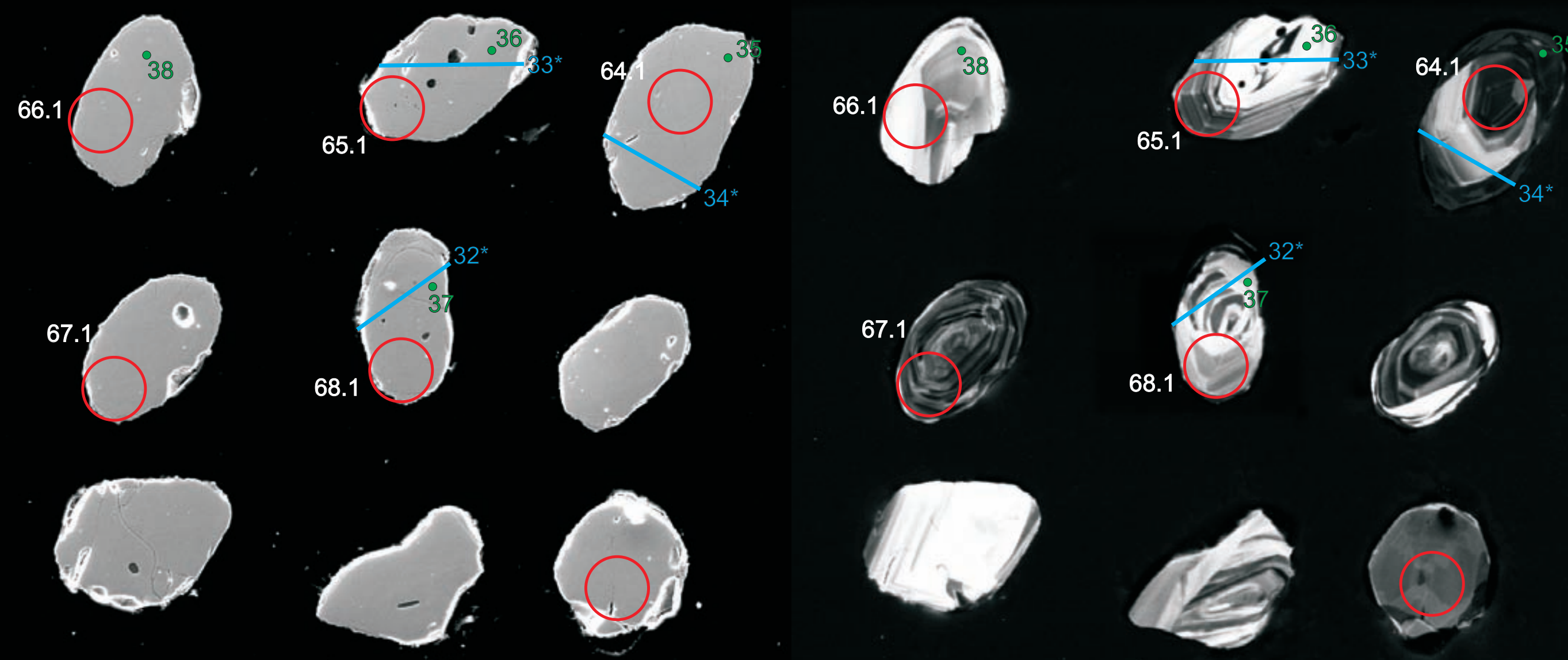


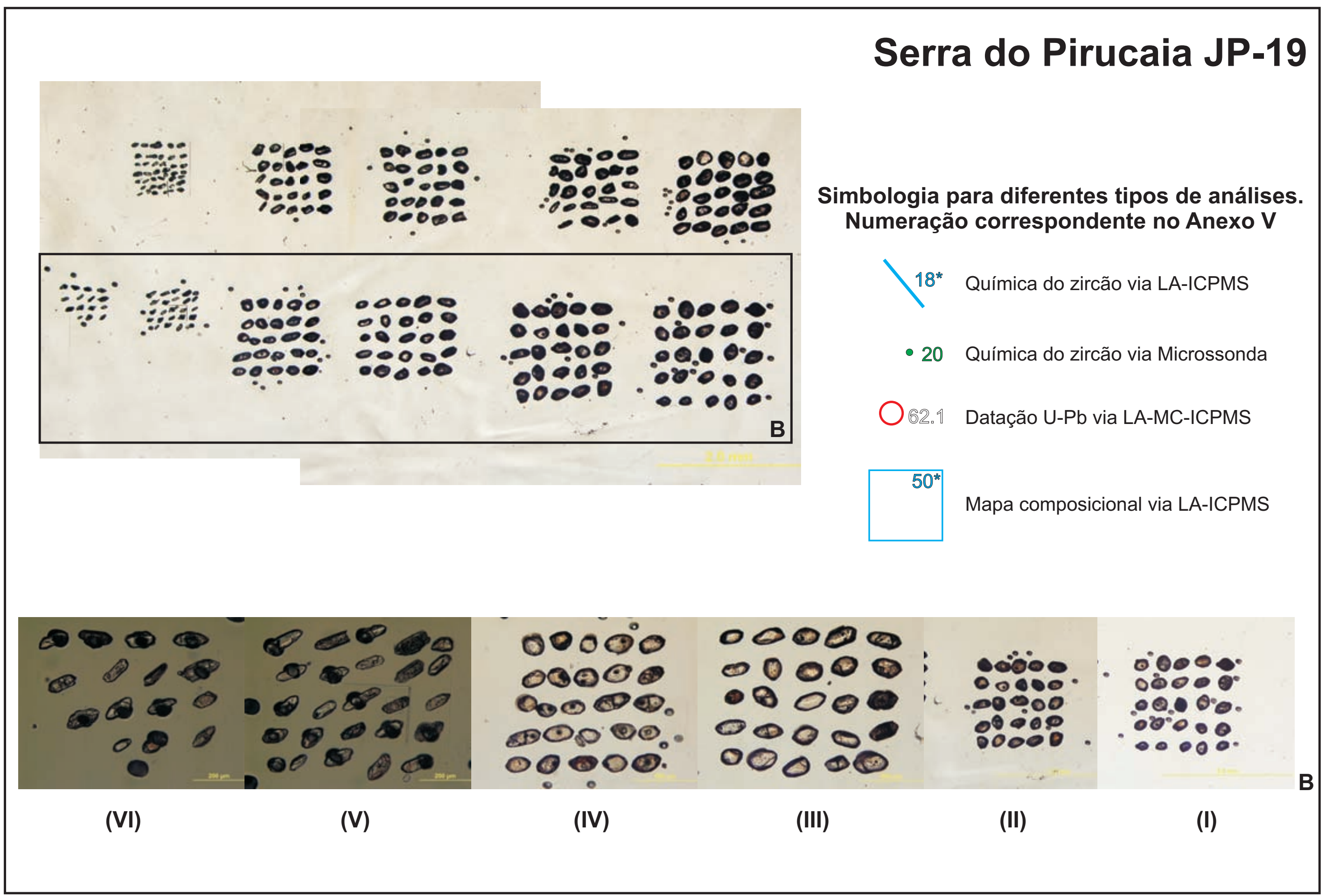




\section{Serra do Pirucaia JP-19}

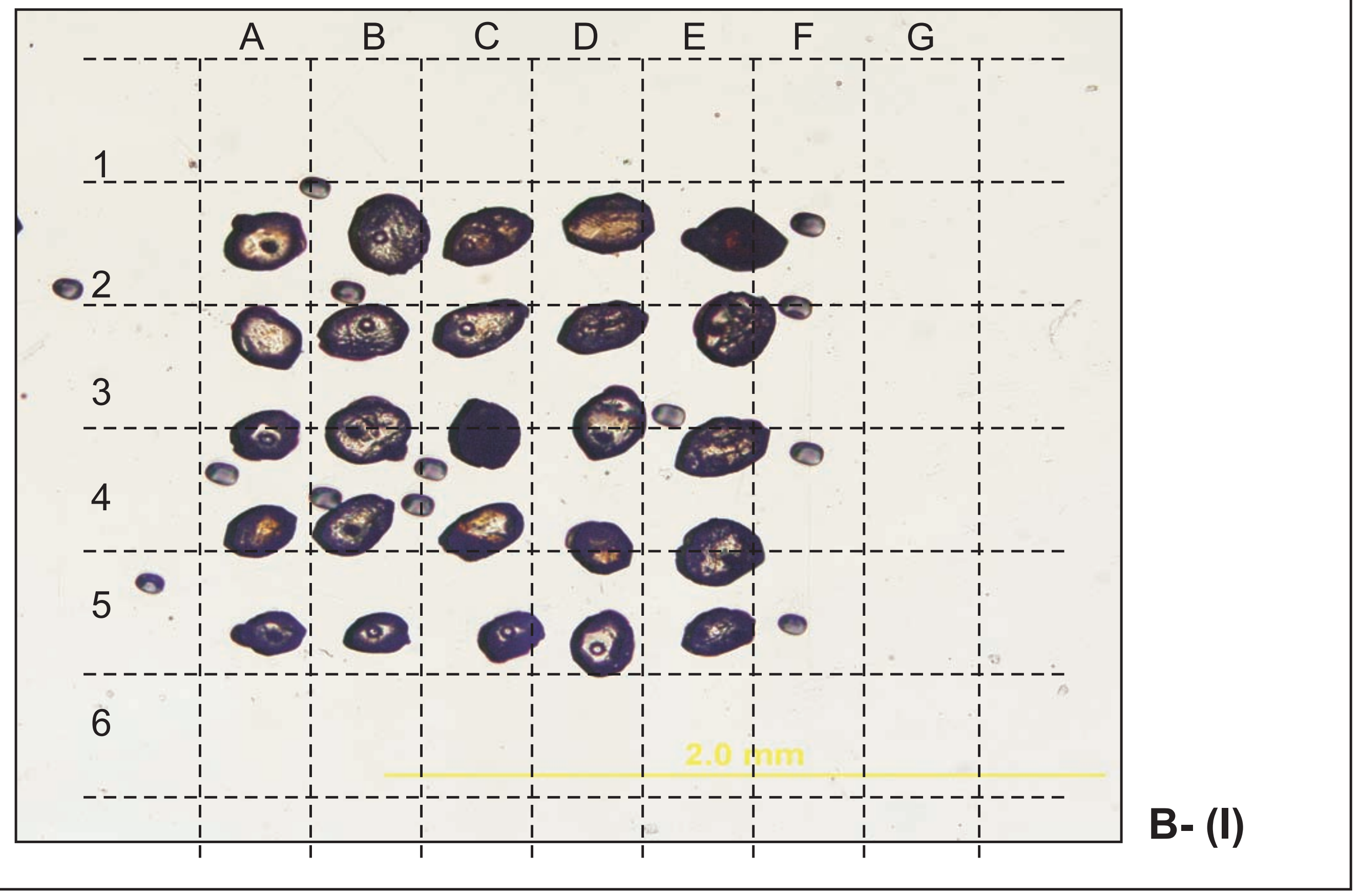




\section{Serra do Pirucaia JP-19}

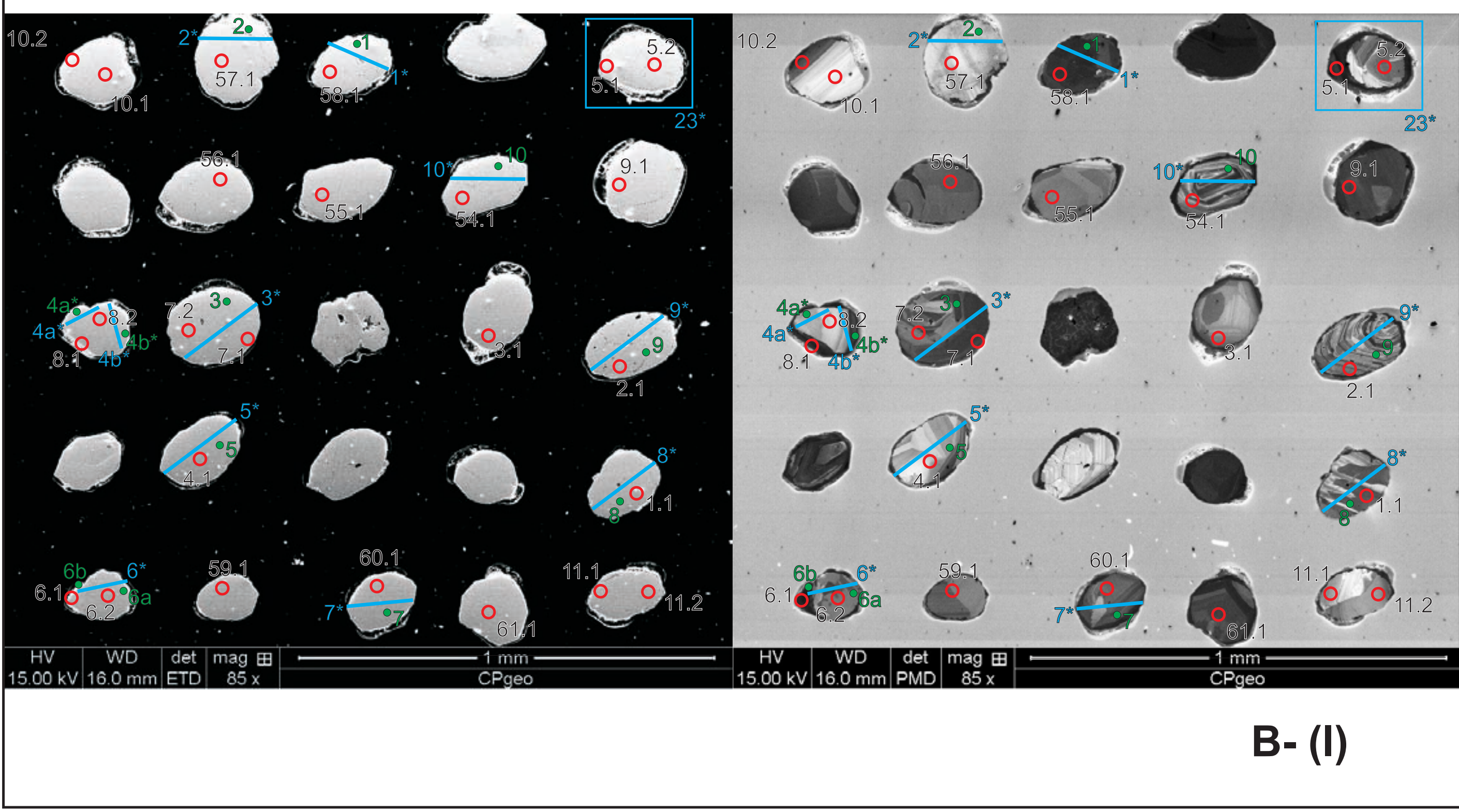


Serra do Pirucaia JP-19

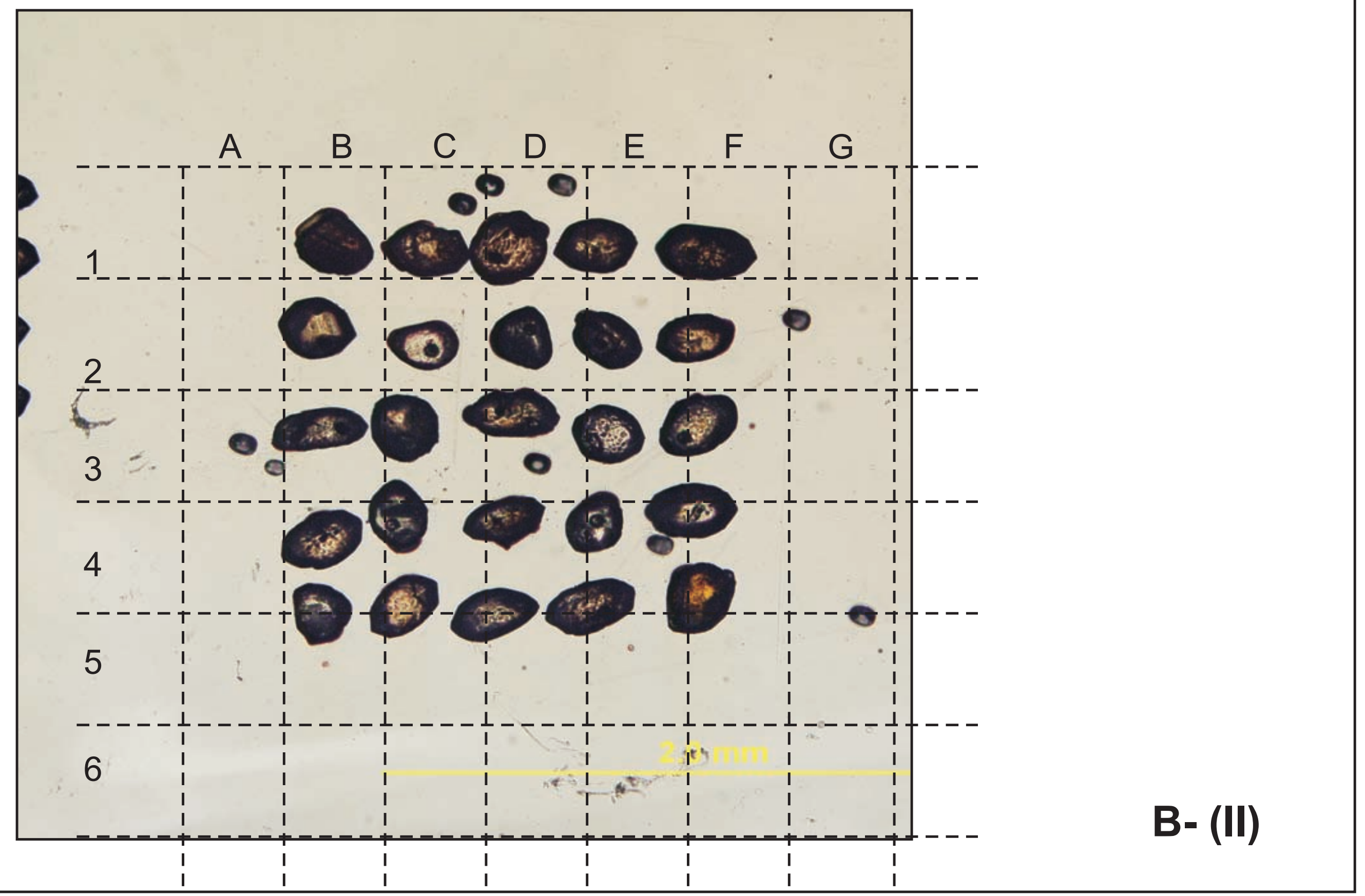




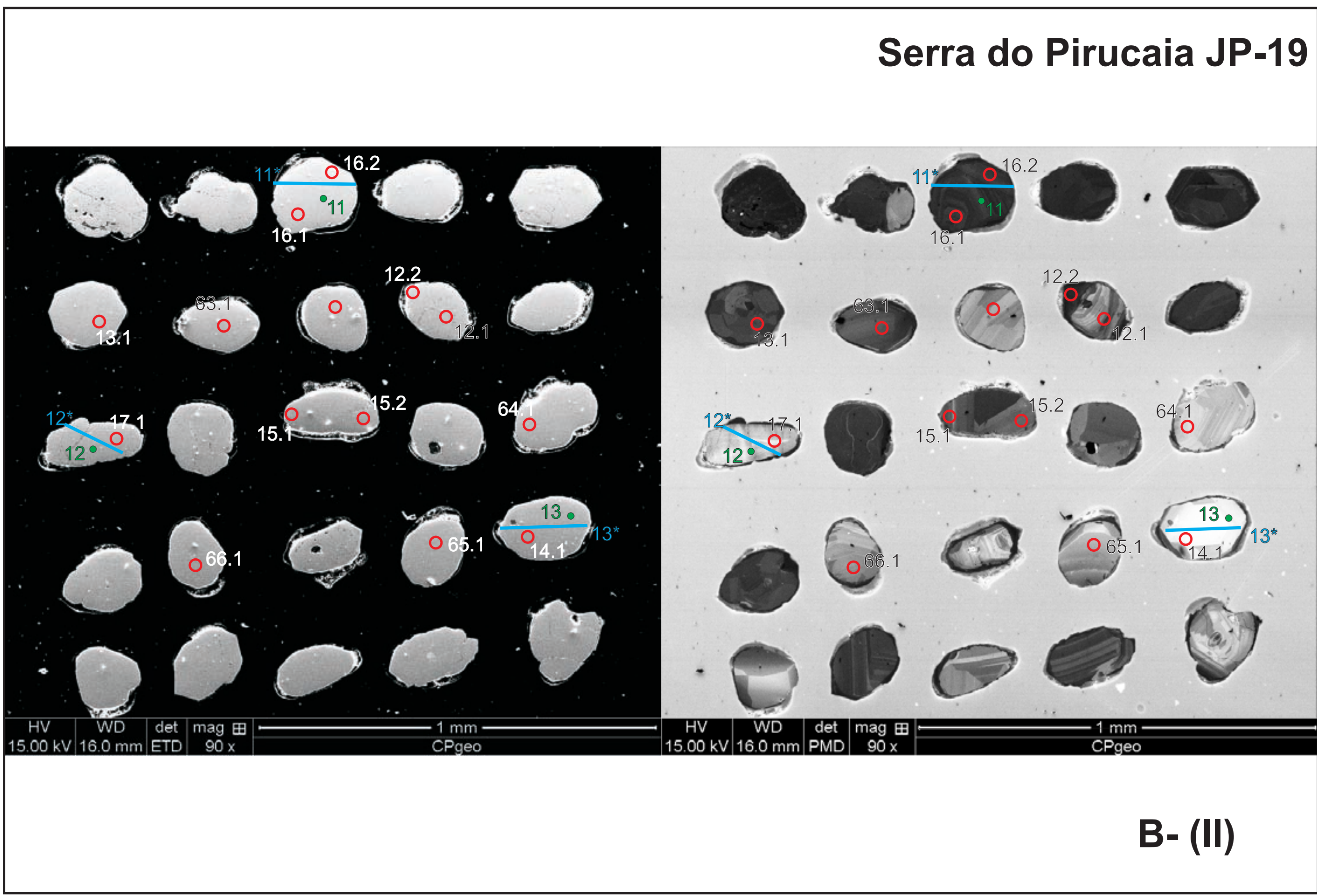




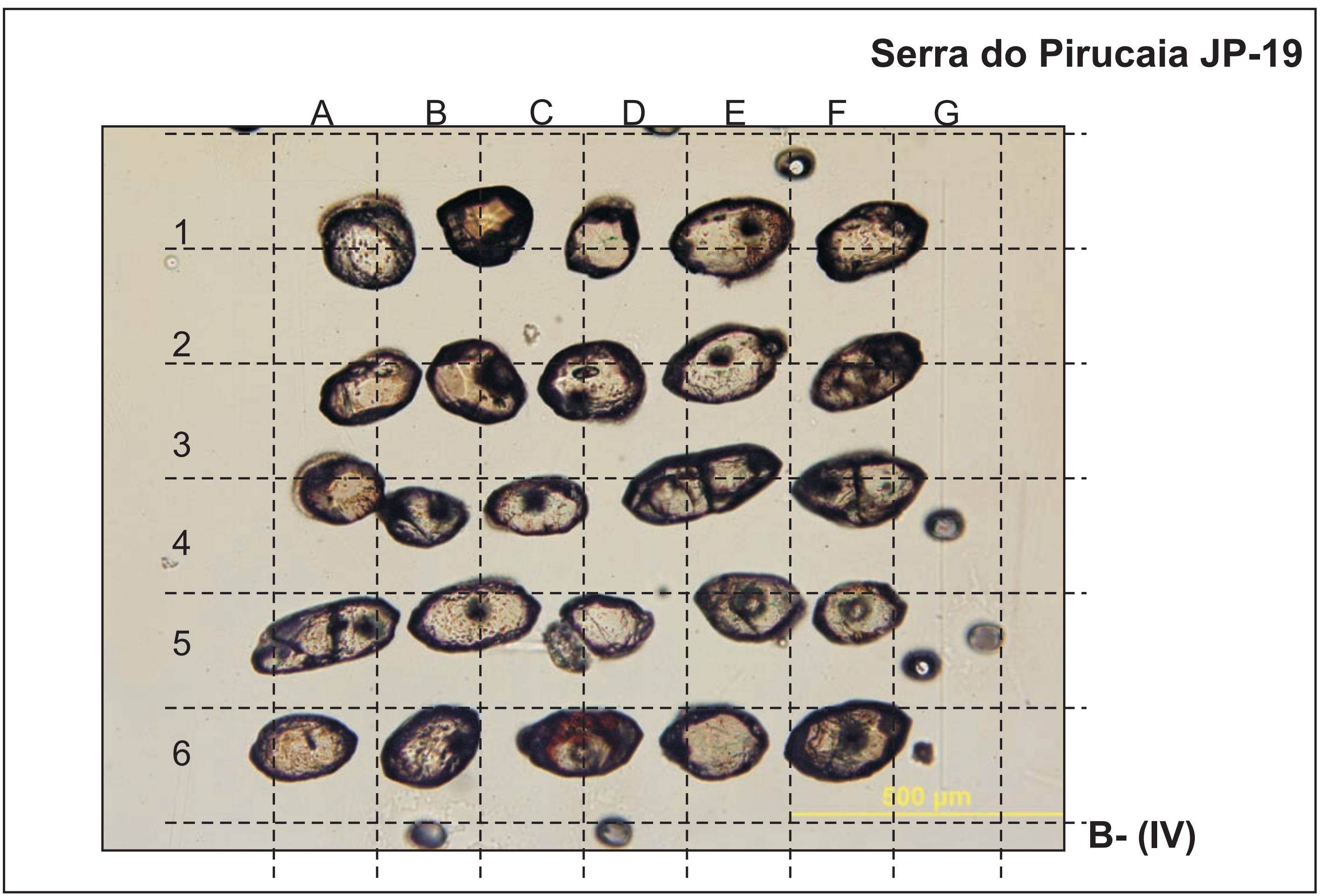




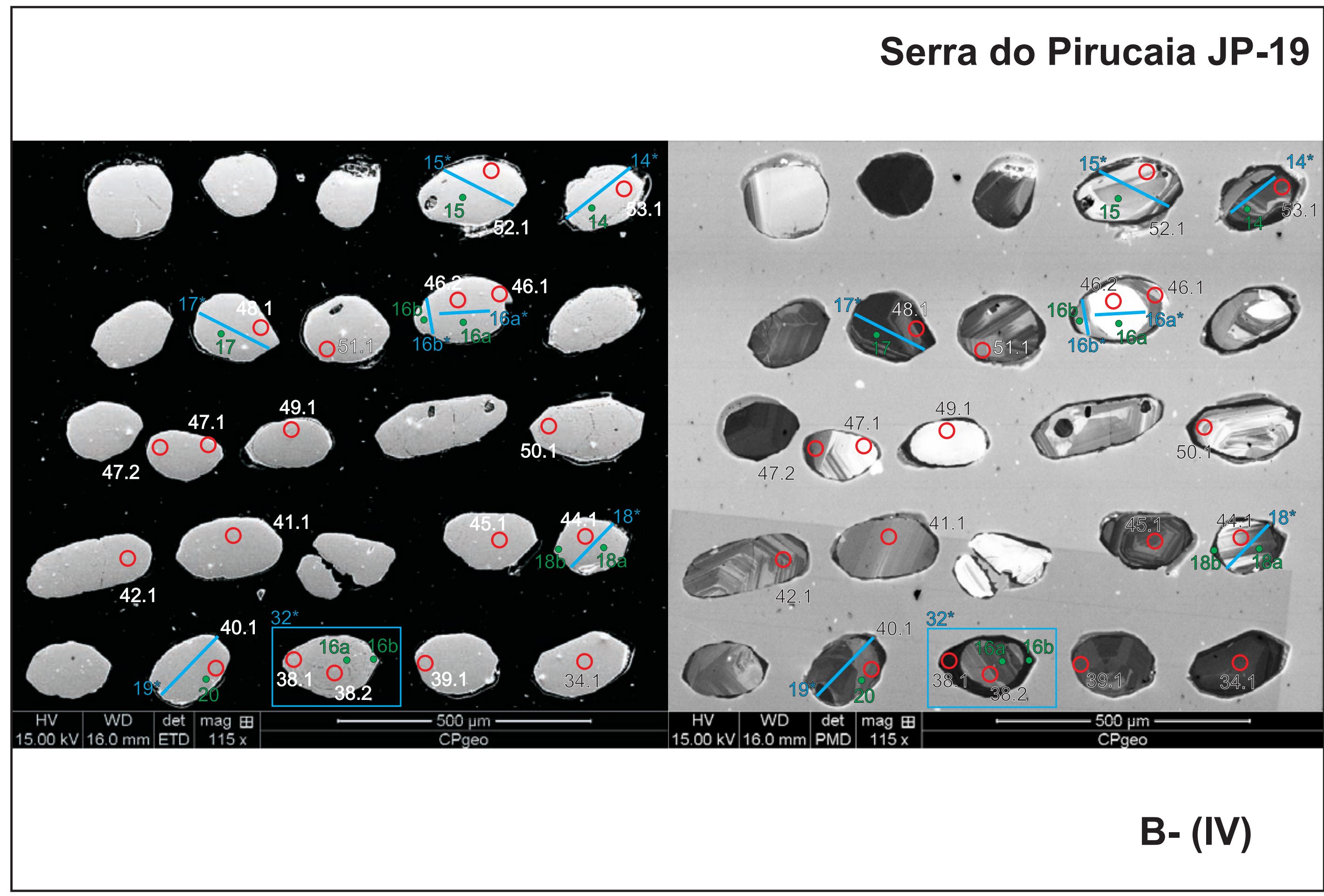


Serra do Pirucaia JP-19

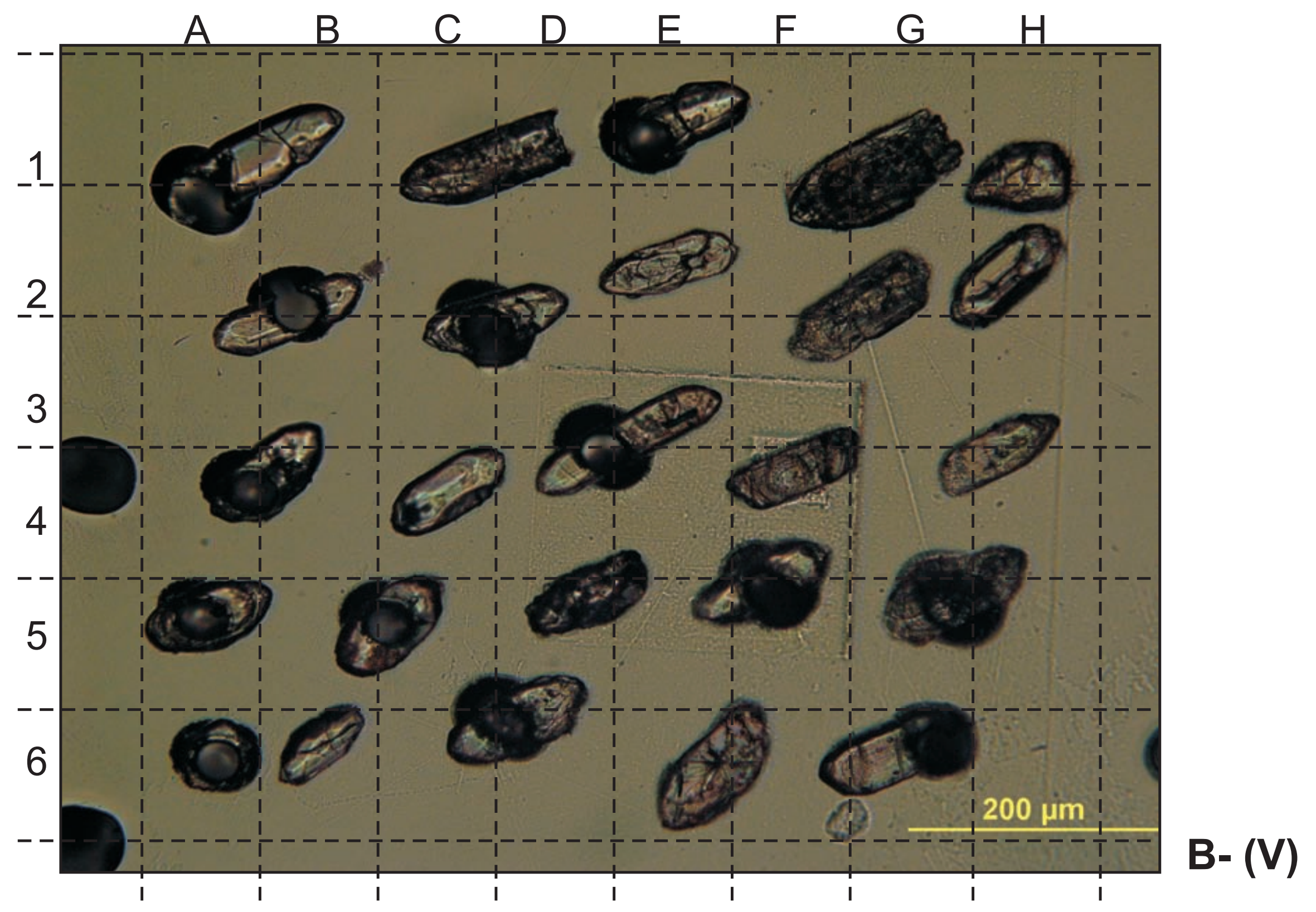




\section{Serra do Pirucaia JP-19}

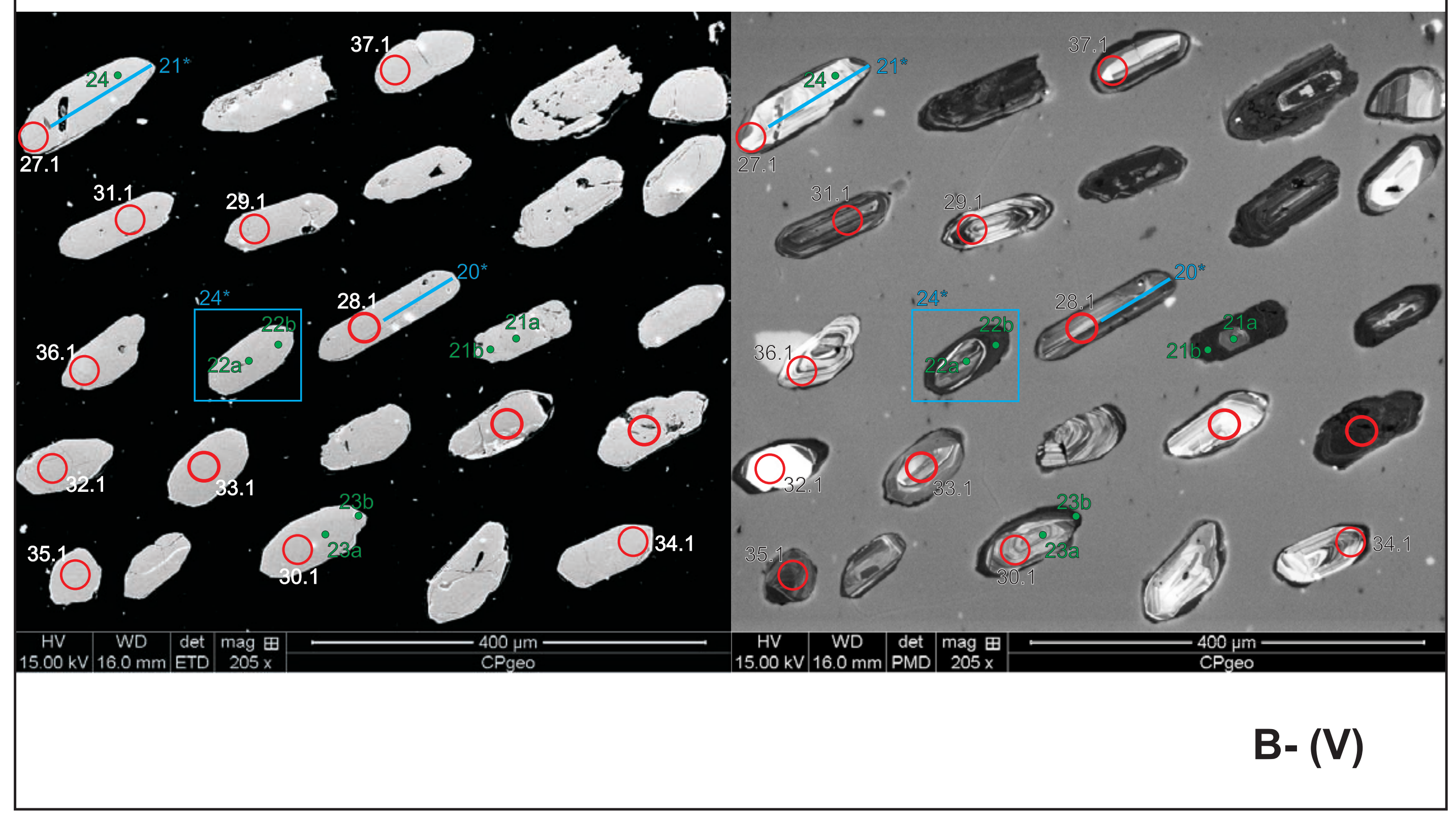




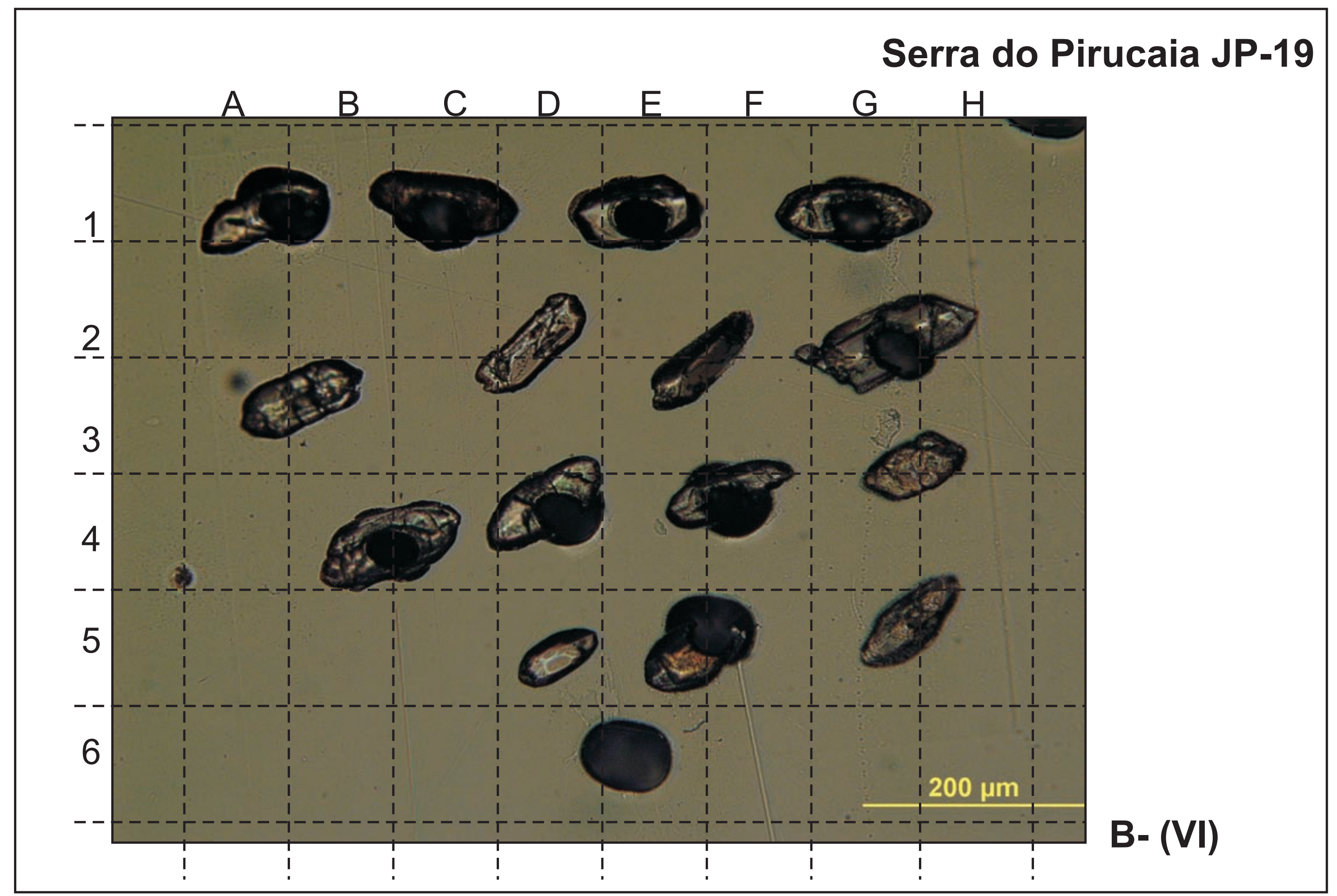




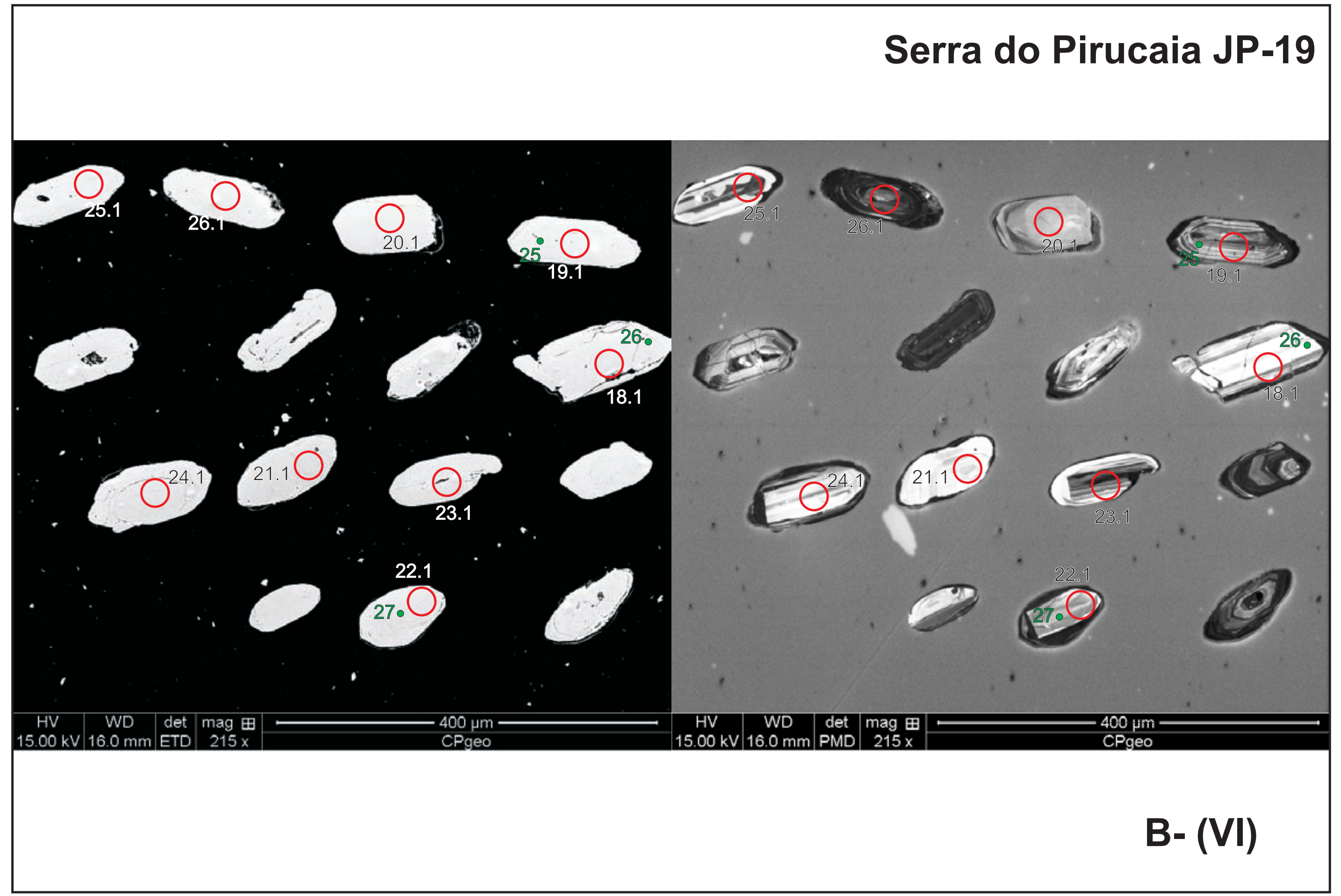




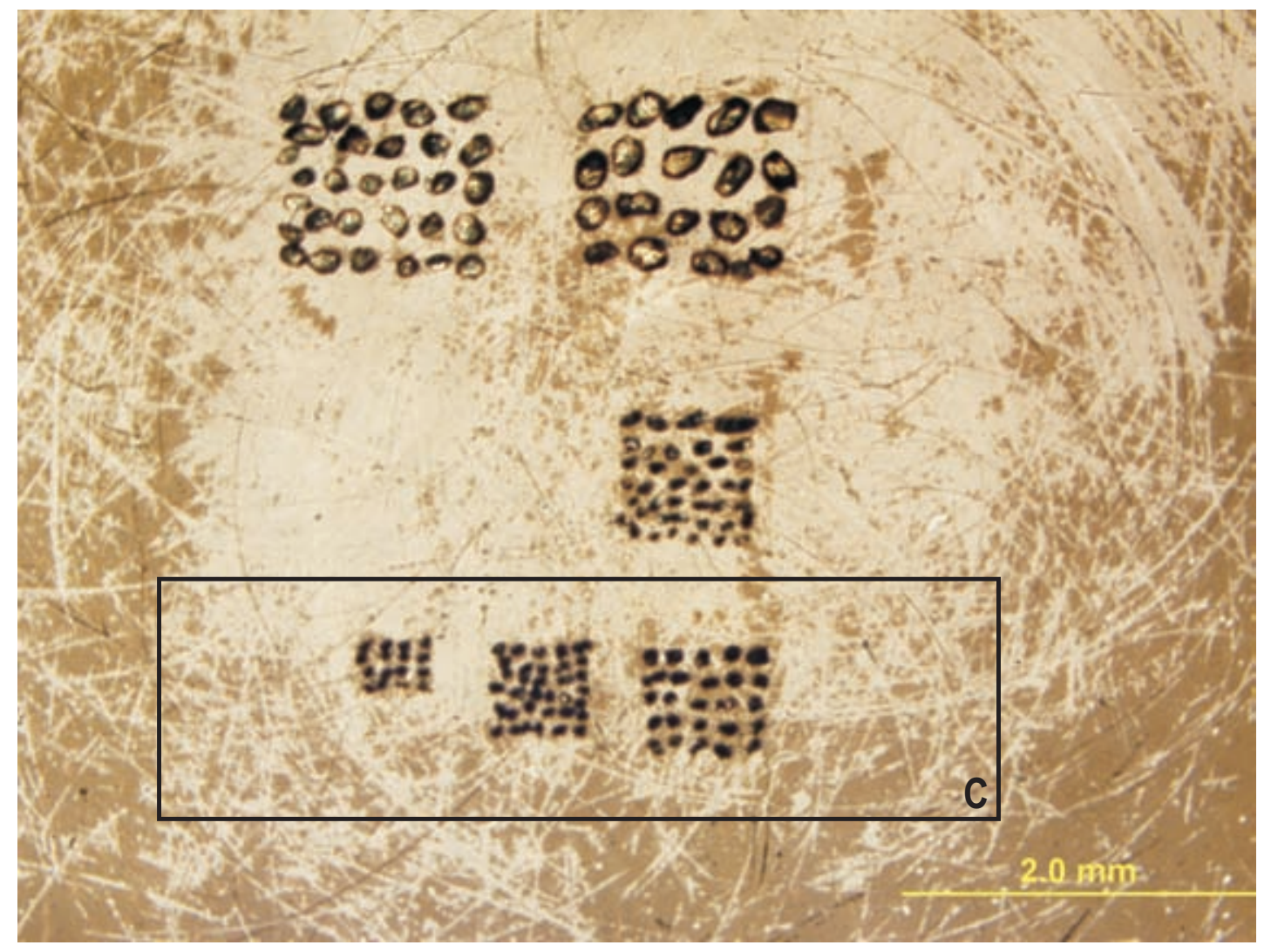

\section{Serra da Voturuna VT-03}

Simbologia para diferentes tipos de análises. Numeração correspondente no Anexo V

$18^{*}$ Química do zircão via LA-ICPMS

- 20 Química do zircão via Microssonda

(52.1 Datação U-Pb via LA-MC-ICPMS

50* Mapa composicional via LA-ICPMS

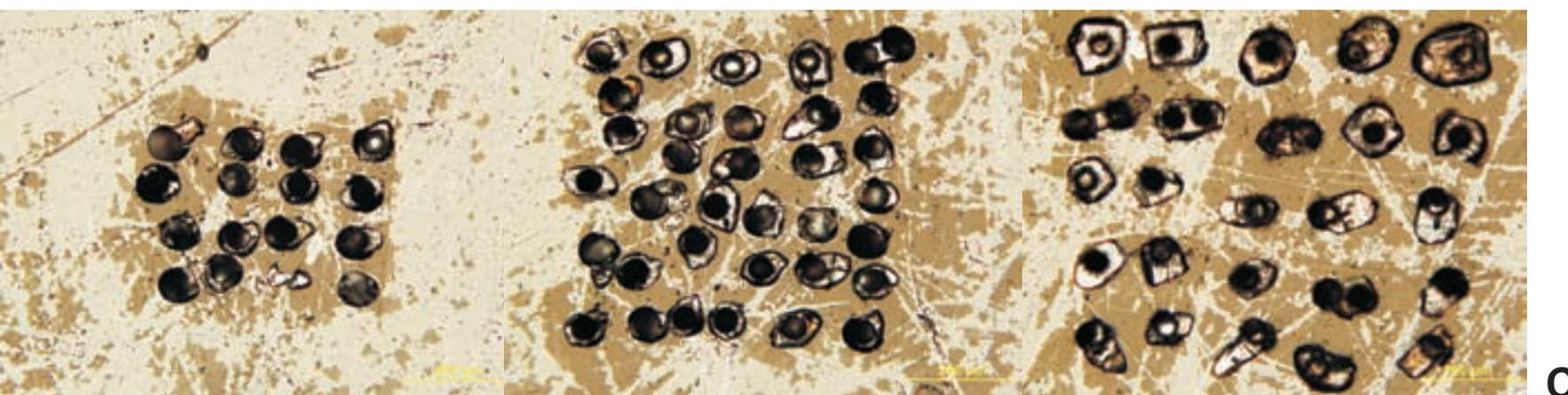

(III)

(II)

(I) 


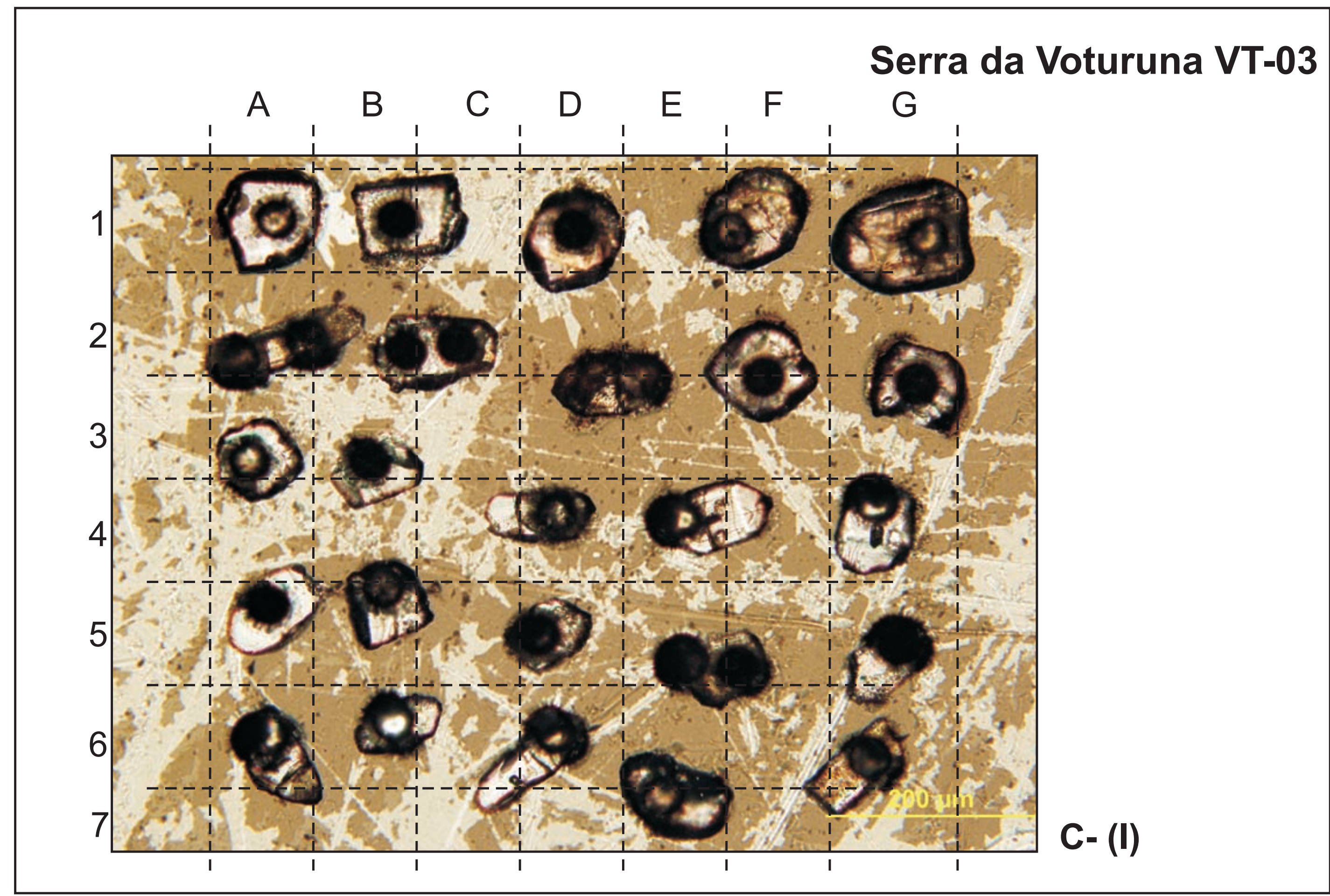




\section{Serra da Voturuna VT-03}

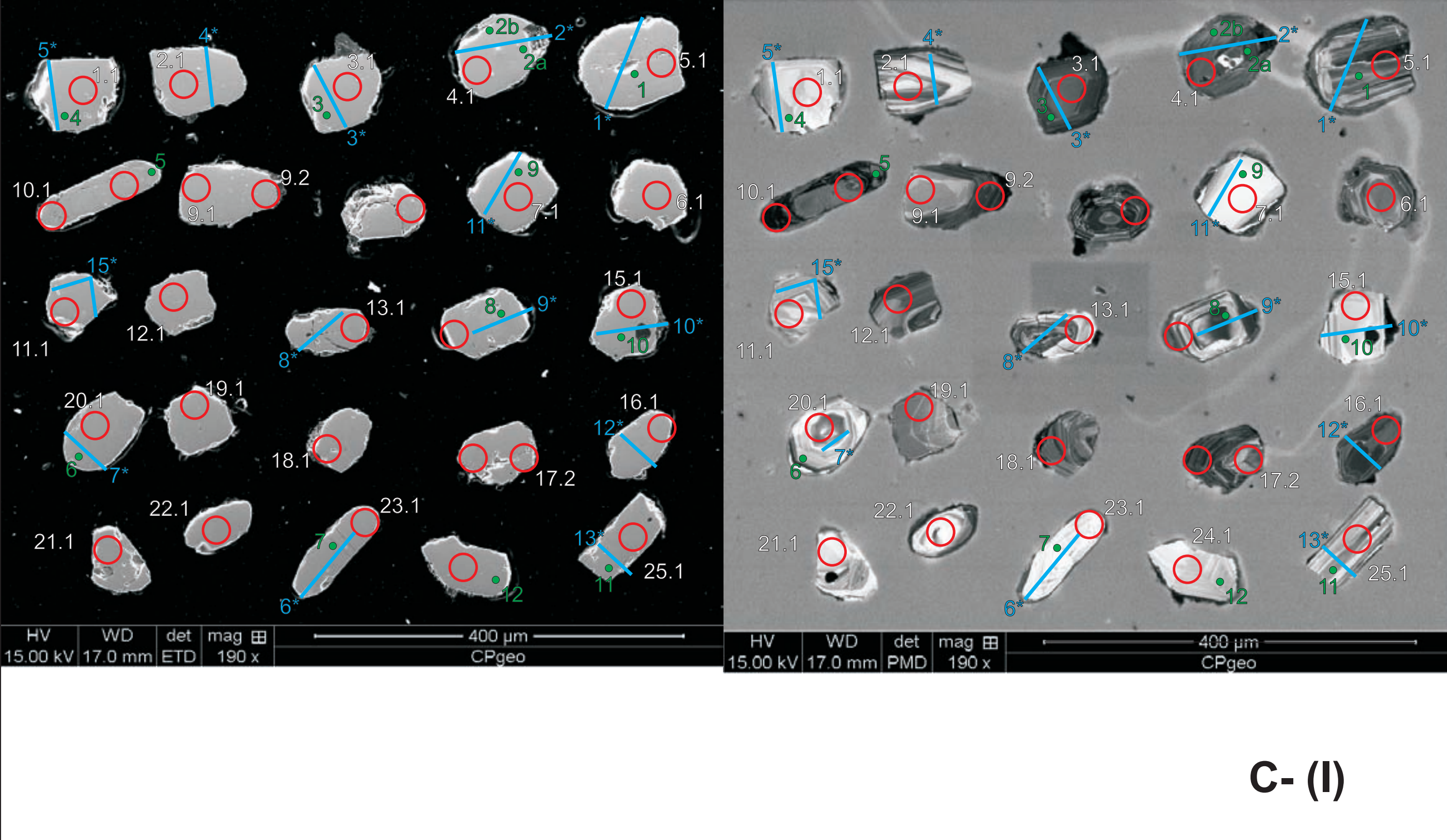




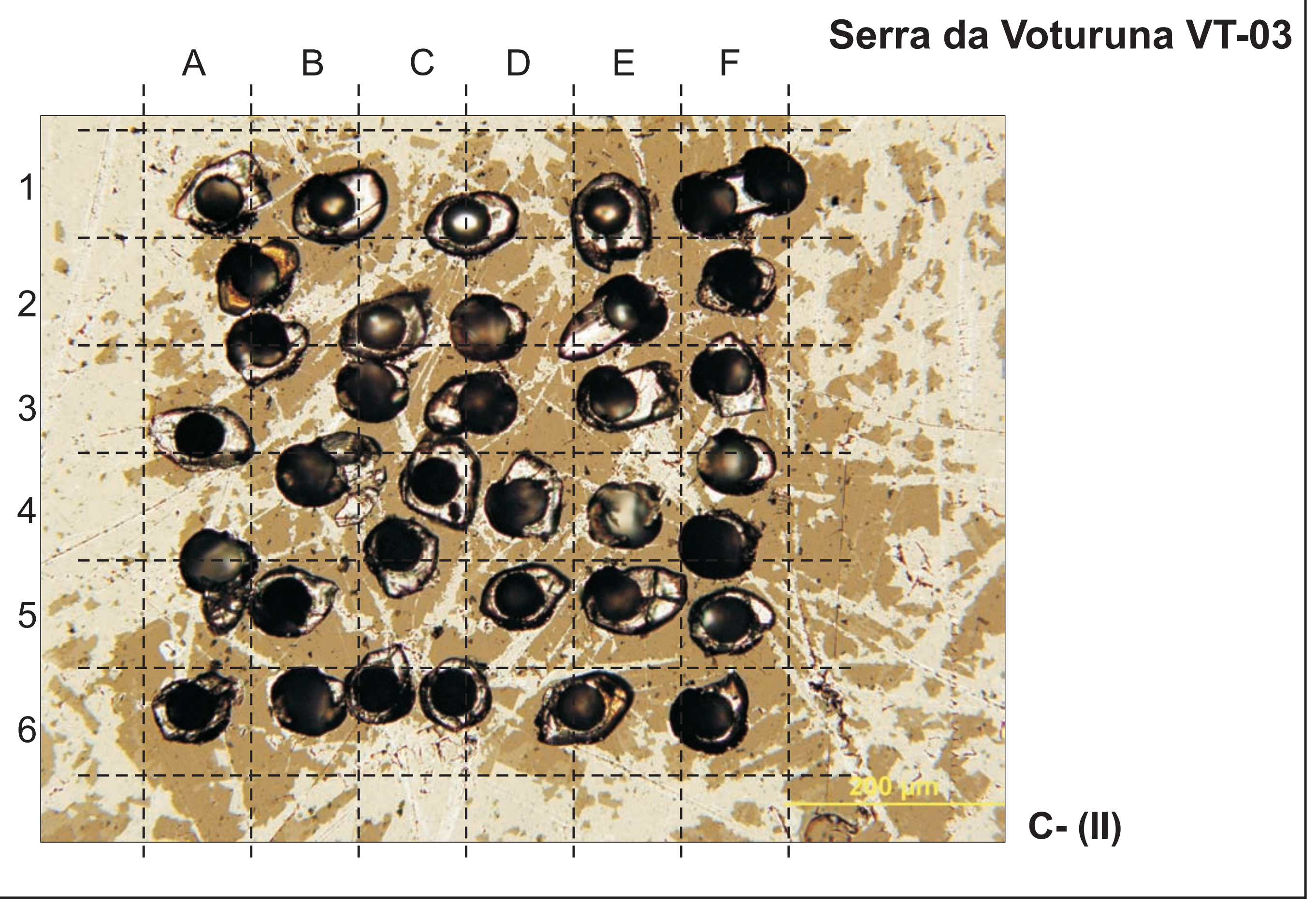




\section{Serra da Voturuna VT-03}

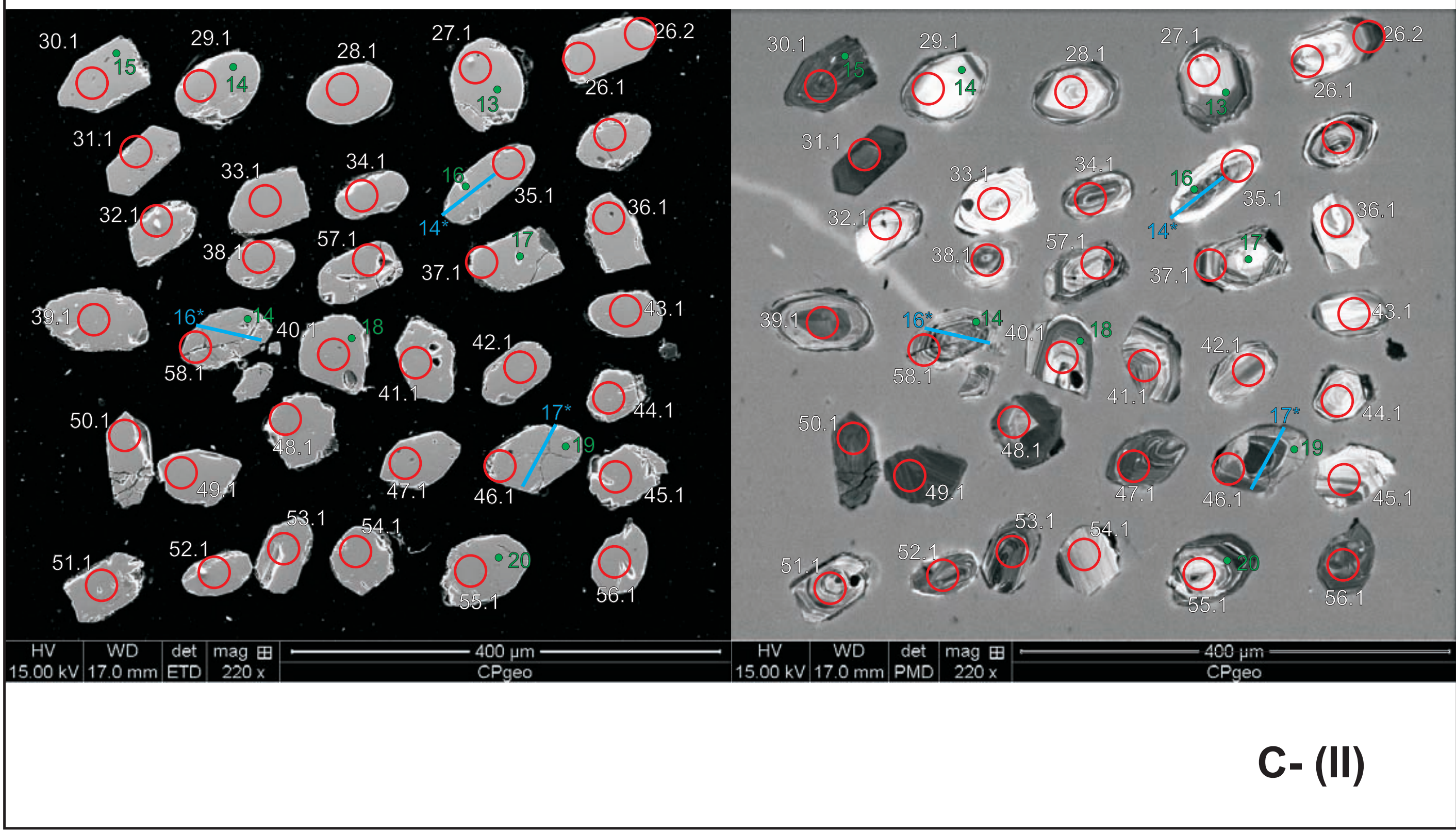




\section{Serra da Voturuna VT-03}

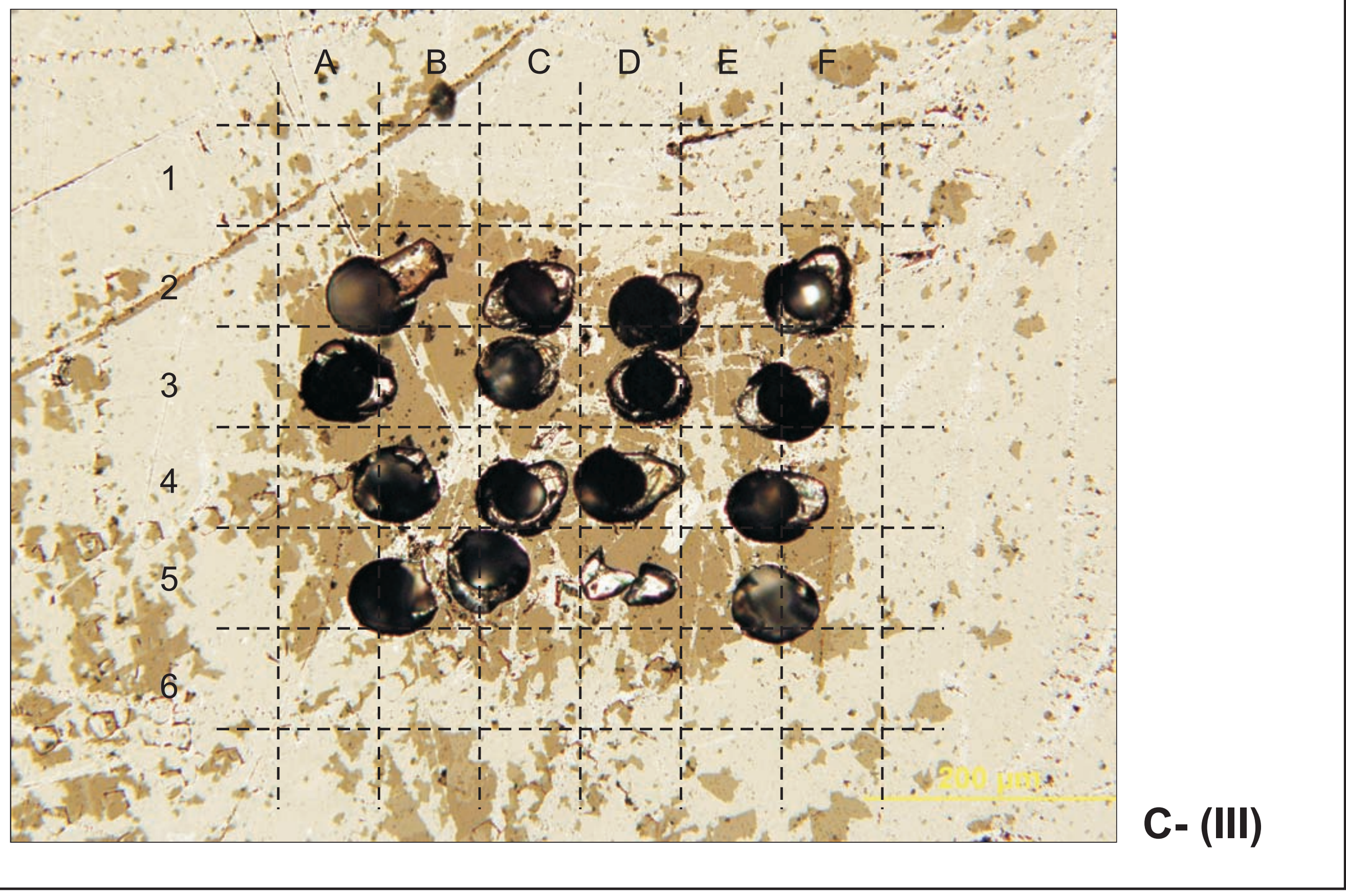




\section{Serra da Voturuna VT-03}

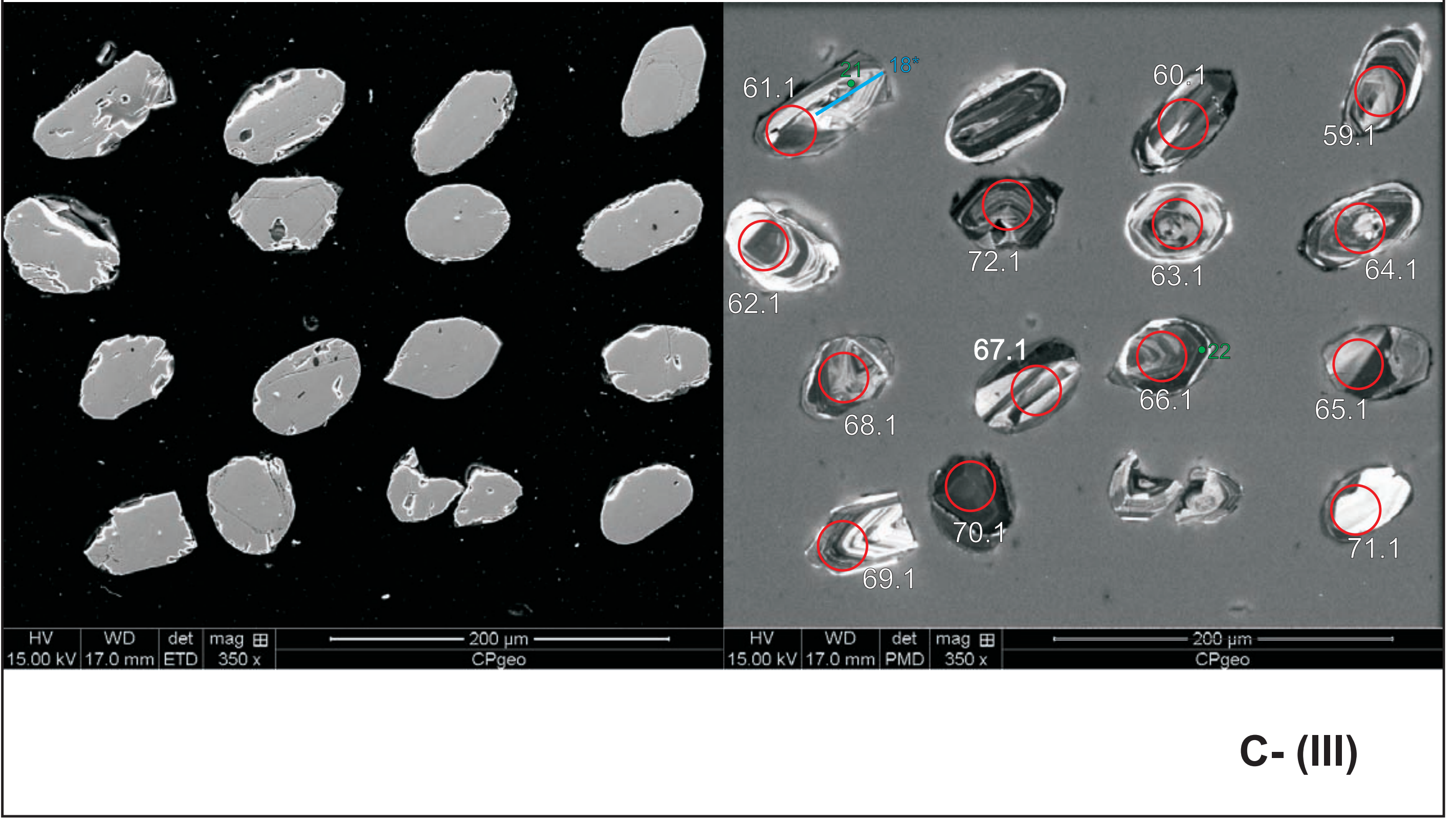




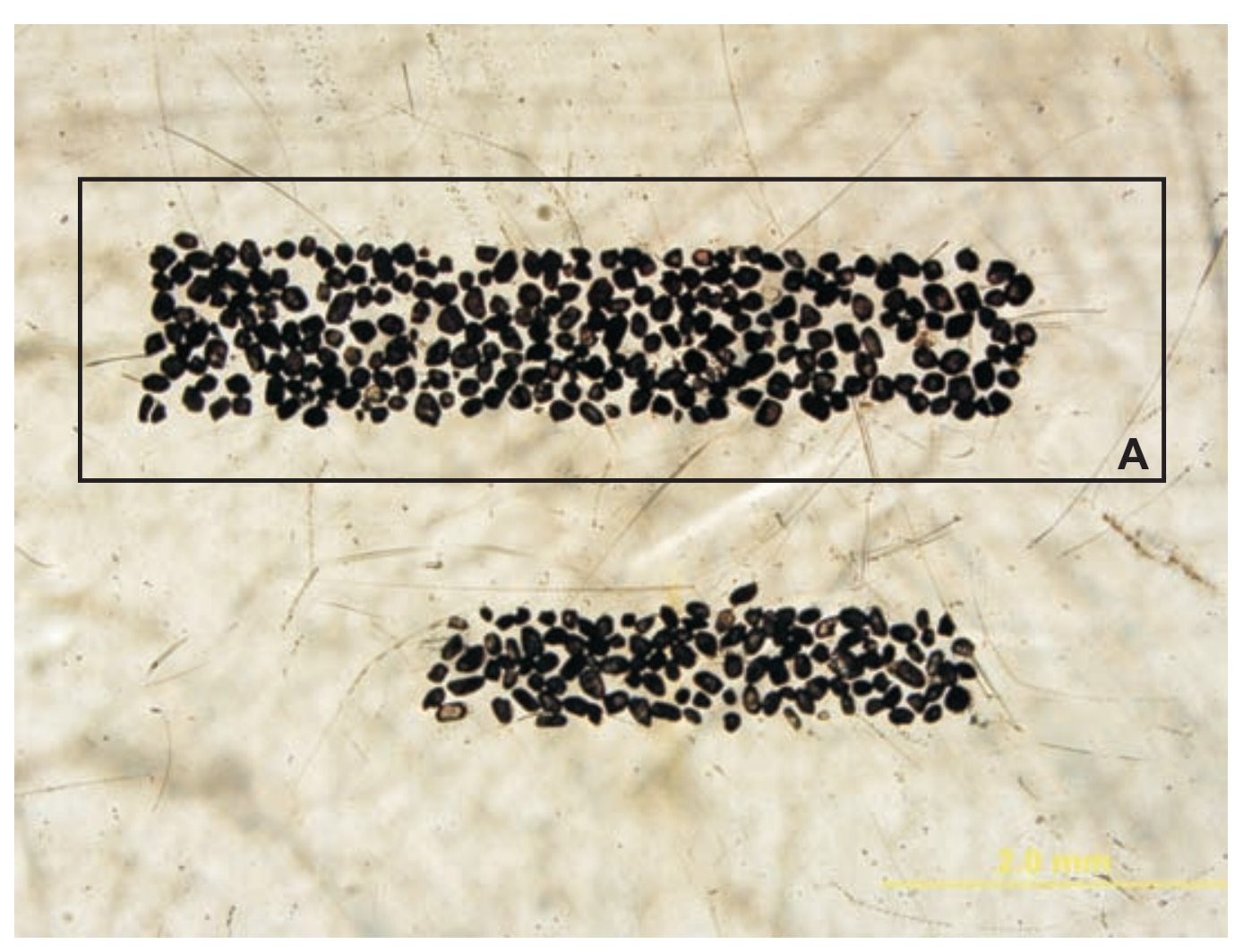

\section{Voturuna meta-wake feldspático VT-02}

Simbologia para diferentes tipos de análises. Numeração correspondente no Anexo V

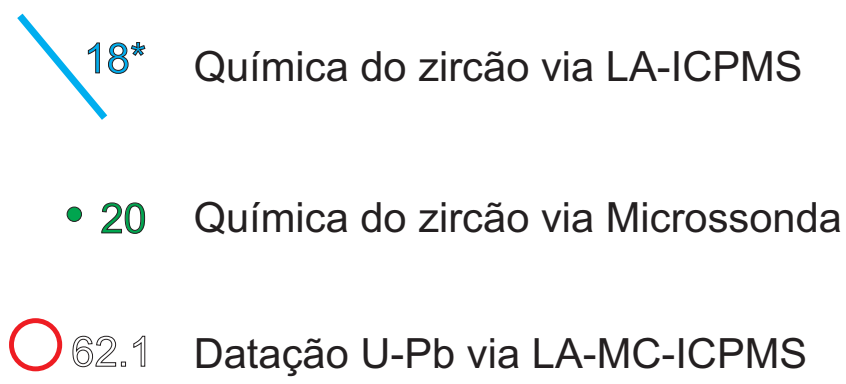

Mapa composicional via LA-ICPMS

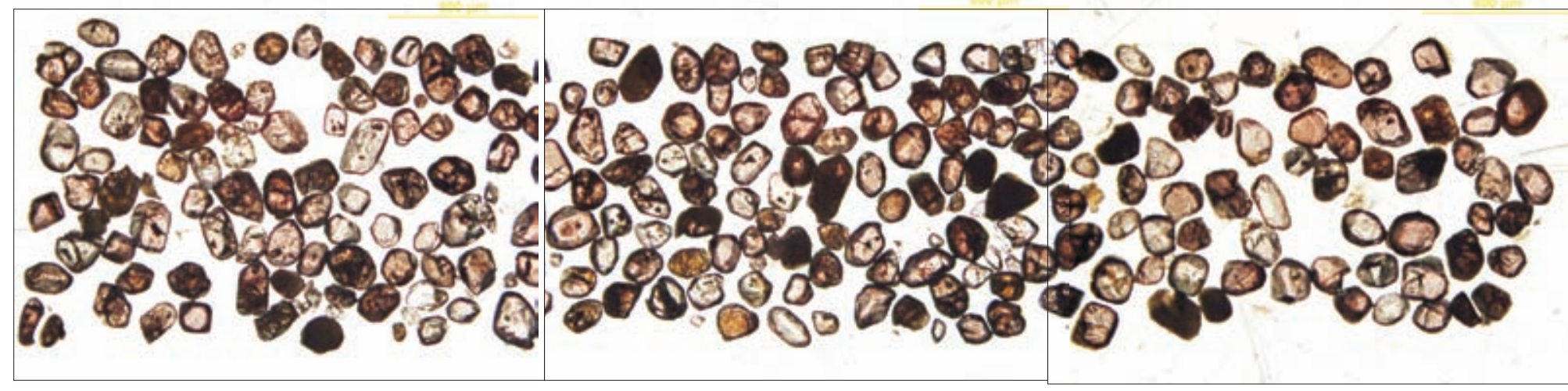

A

(III)

(II)

(I) 


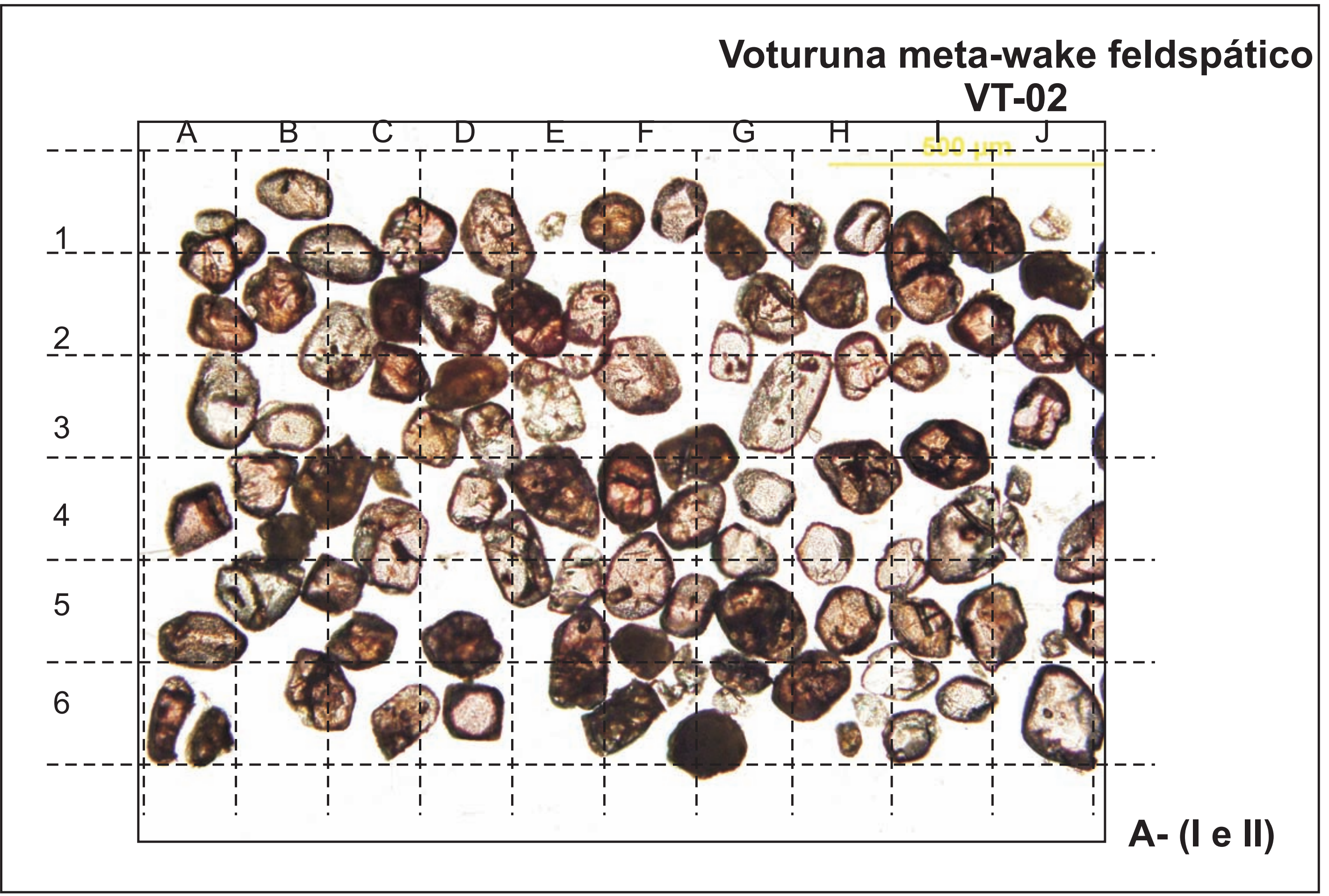




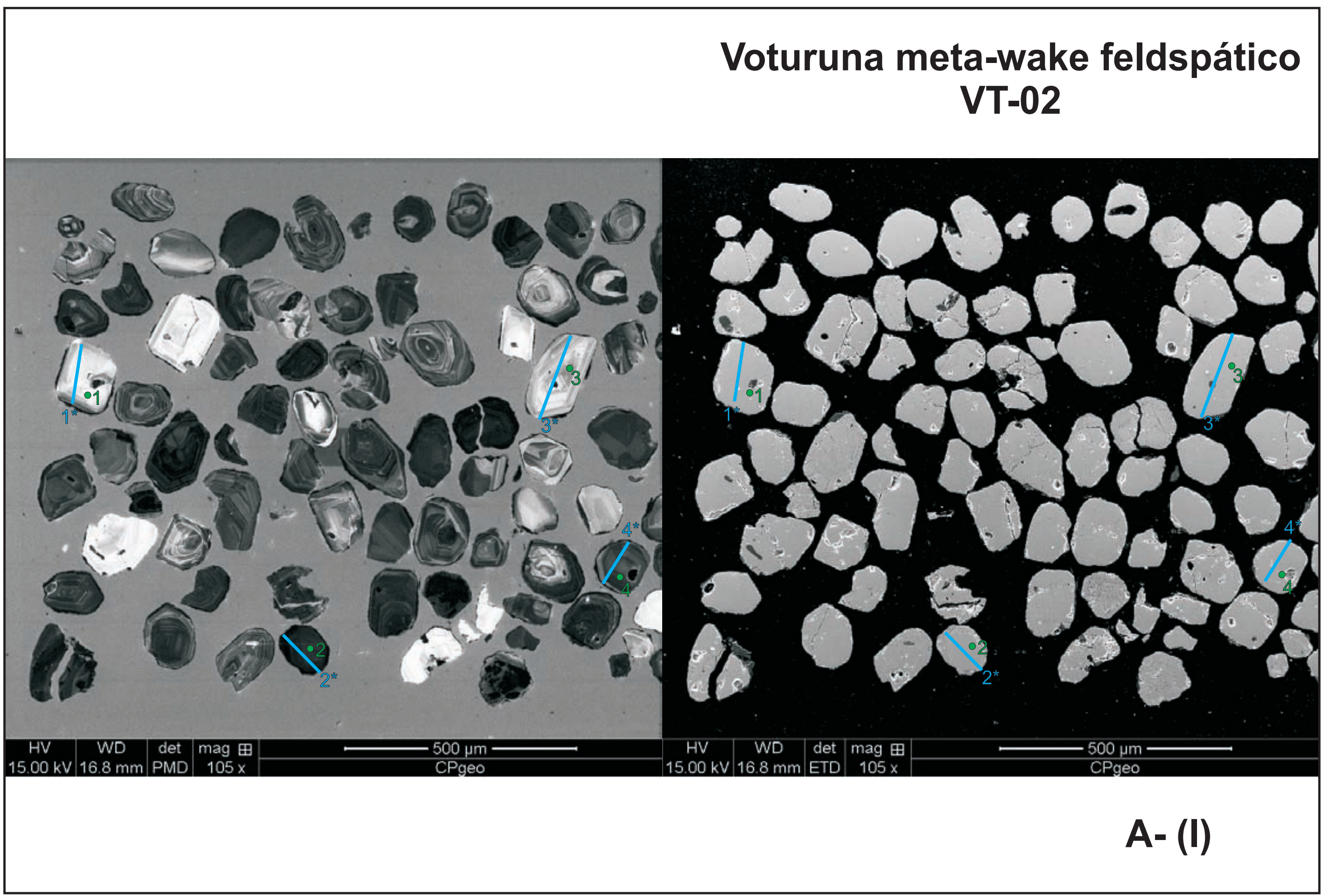




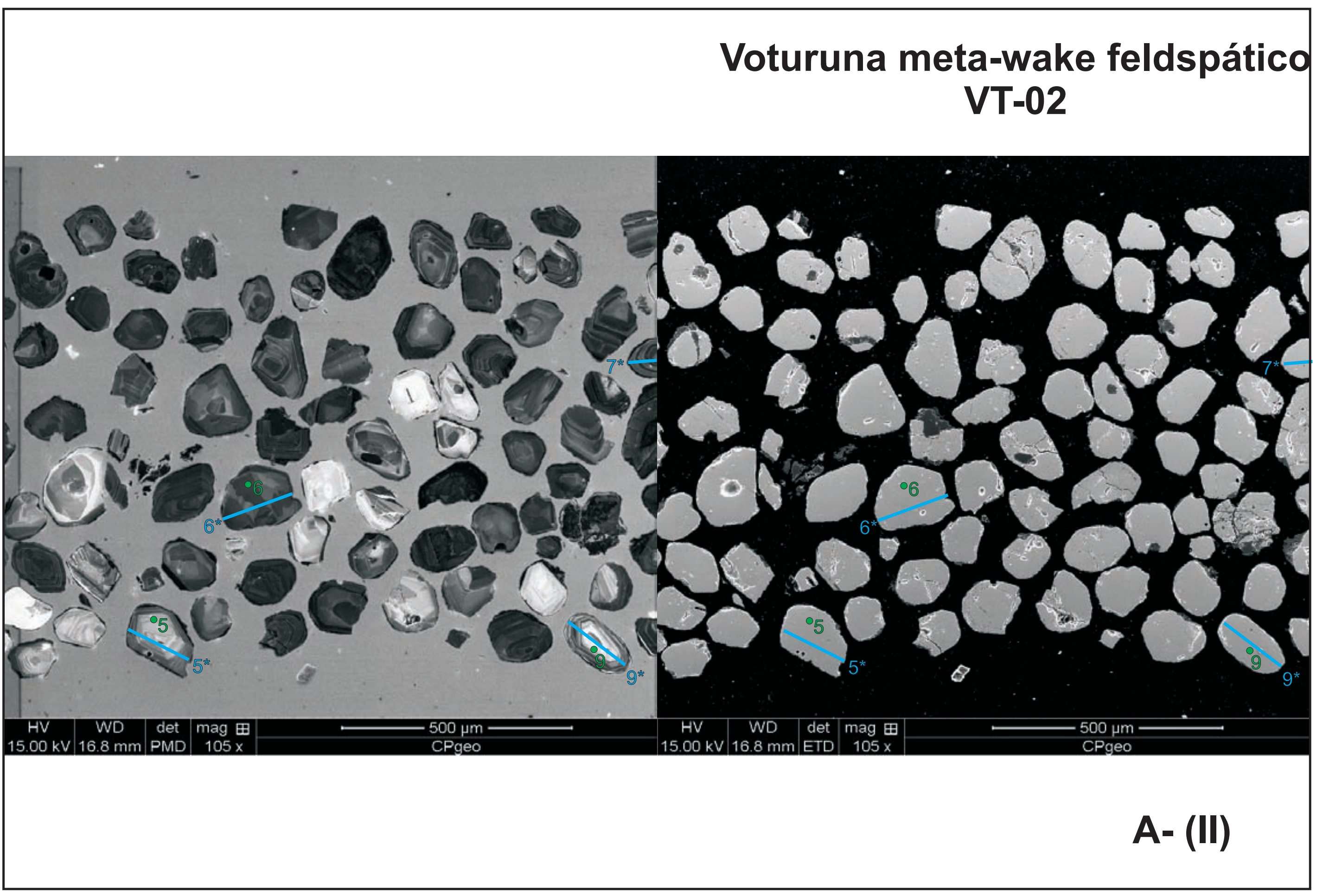




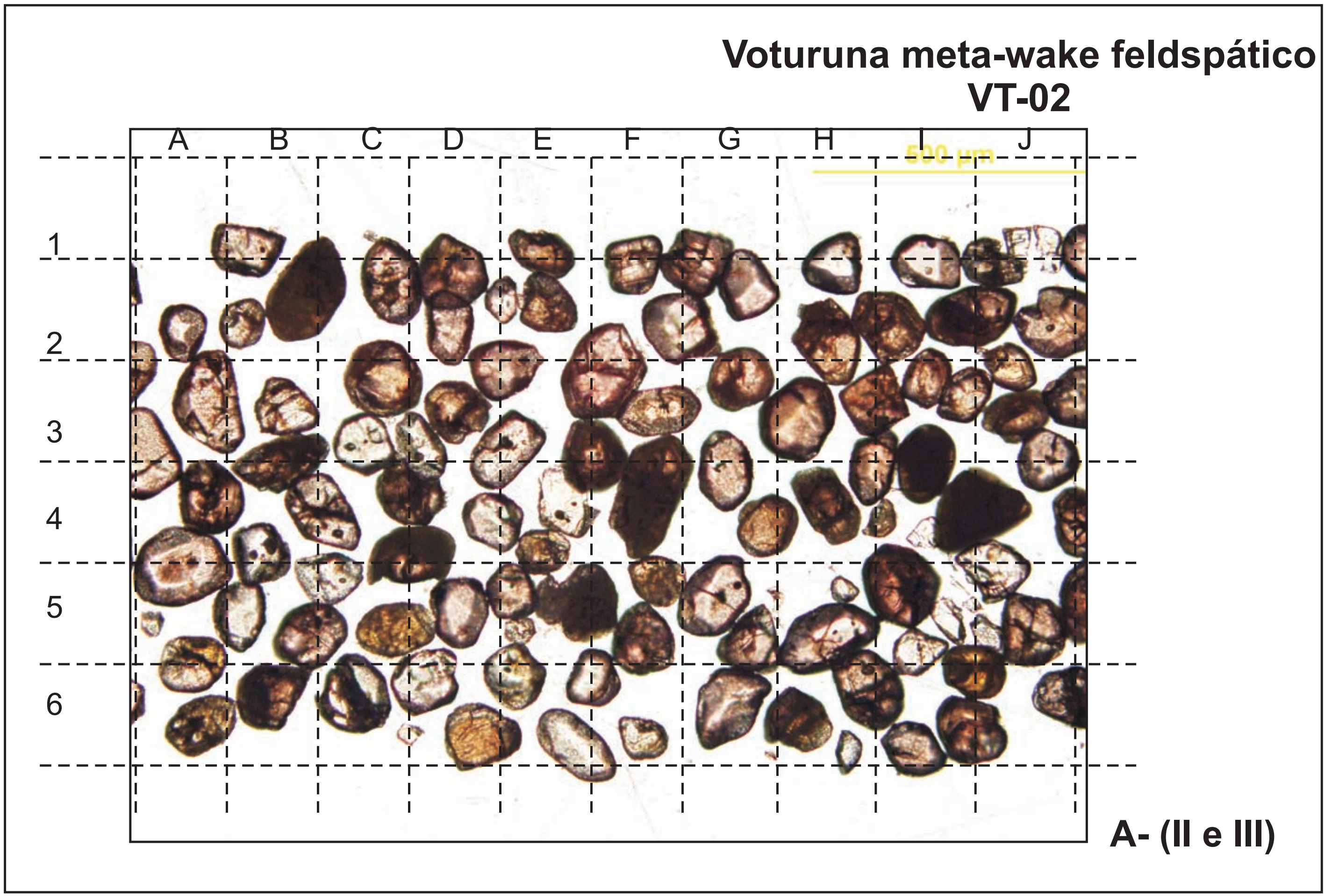




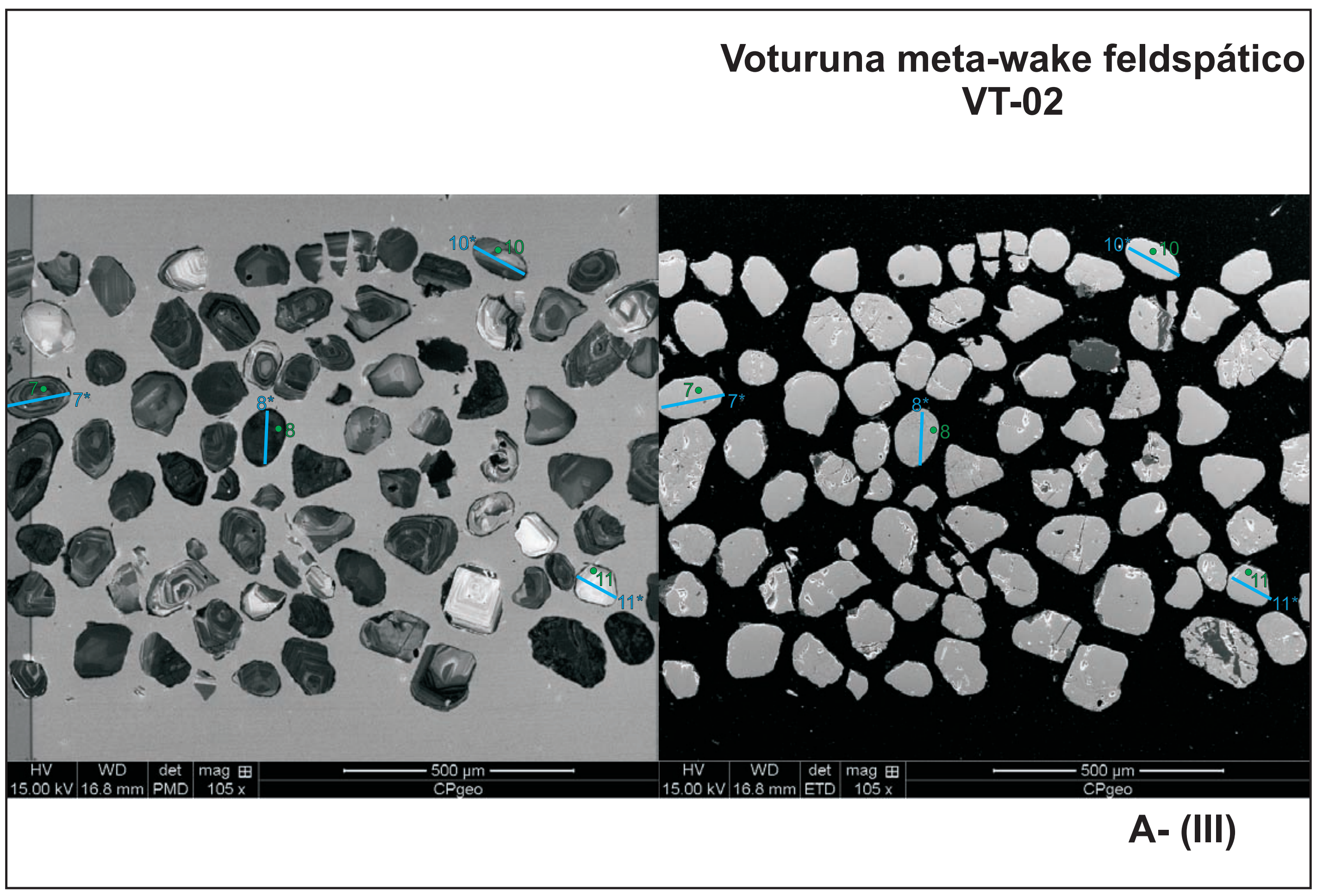




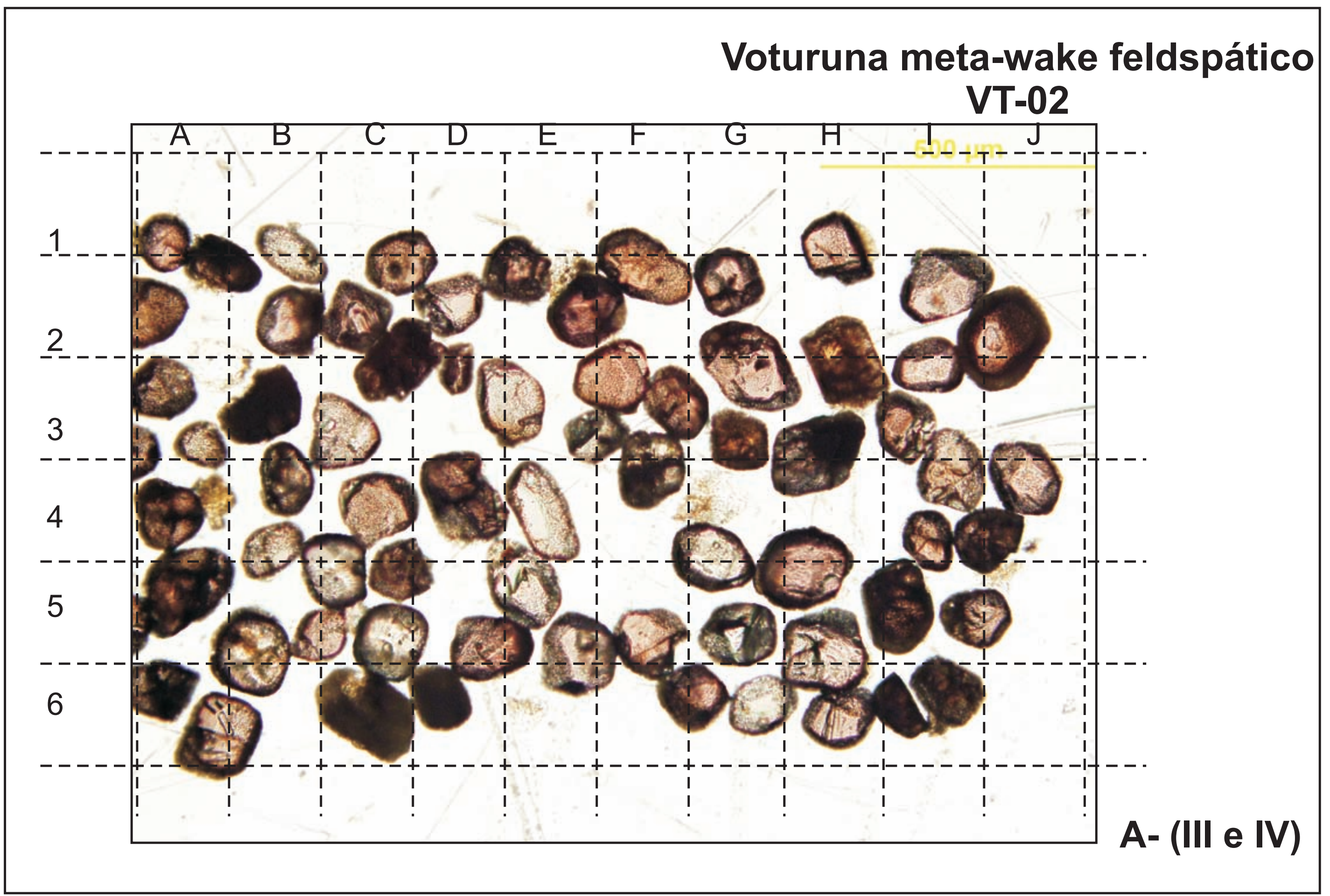




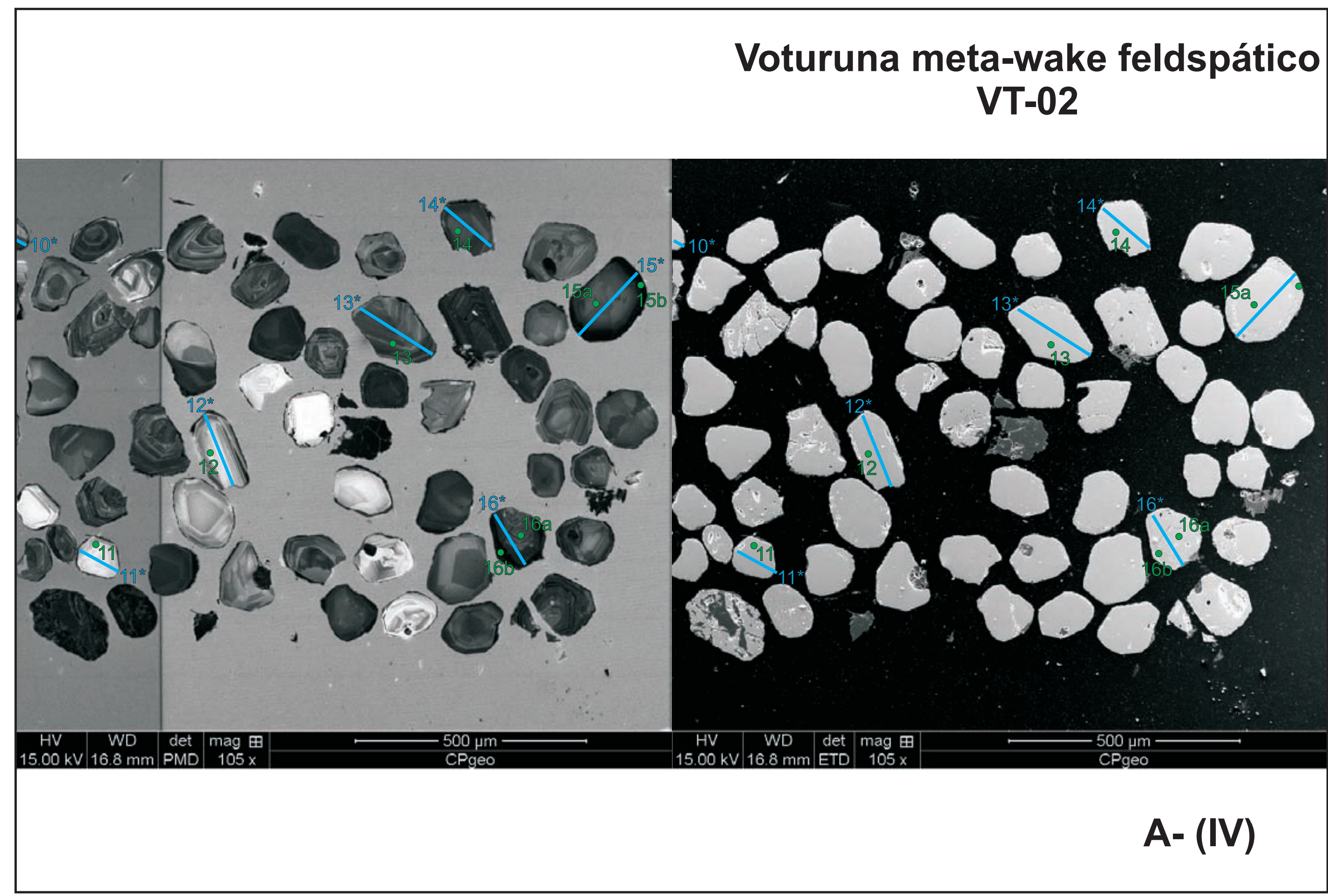


ANEXO - V

(Tabelas) 


\begin{tabular}{|c|c|c|c|c|c|c|c|c|c|c|}
\hline Ponto & UTM E & UTM N & Rocha & Sn & Lineação & $\mathrm{Sn}+1$ & Eixo de Dobra & Veio de Qtz & Clivagem & Fraturamento \\
\hline MD $01 \mathrm{~A}-\mathrm{P}$ & 316059 & 7403271 & Metaconglomerado & $240 / 60$ & & & & & & \\
\hline MD-02A & 314103 & 7399759 & Granito porfirítico & & & & & & & \\
\hline MD $03 \mathrm{~A}-\mathrm{E}$ & 315987 & 7402046 & Metaconglomerado e rochas metabásicas & & & & & & & \\
\hline MD $04 \mathrm{~A}$ & 318084 & 7405836 & Metarenitos feldspáticos & & & & & & & \\
\hline MD $05 \mathrm{~A}-\mathrm{B}$ & 313267 & 7408894 & Blocos de Metavulcânica Ácida e metaconglomerados & $188 / 60$ & & & & $010 / 50$ & & \\
\hline MD 06 & 313394 & 7408756 & Metavulcânica ácida & $202 / 68$ & & & & & $185 / 25$ & \\
\hline MD 07 & 313324 & 7408822 & Blocos de Metaconglomerado & & & & & & & \\
\hline MD 08 & 313233 & 7408727 & Metavulcânica ácida & $190 / 65$ & & & & & & \\
\hline MD 09 & 313071 & 7408790 & Metavulcânica ácida & $190 / 65$ & & & & & & \\
\hline MD 10 & 313021 & 7408821 & Metaconglomerado & $175 / 75$ & & & & & & \\
\hline MD 11 & 312965 & 7408850 & Metaconglomerado & $184 / 85$ & & & $270 / 30$ & & & \\
\hline MD 12 & 312985 & 7408872 & Metavulcânica ácida & $180 / 48$ & & & & $194 / 80$ & $194 / 80$ & \\
\hline MD 13 & 312812 & 7408793 & Metavulcânica ácida & & & & & & & \\
\hline MD 14 & 313092 & 7408849 & Metaconglomerado alterado & 172/78 & & & & & & \\
\hline MD 15 & 313164 & 7408827 & Metavulcânica ácida alterada & $206 / 40$ & & & & & & \\
\hline MD 16 & 313012 & 7407350 & Granada gnaisse & $168 / 45$ & & & & & & \\
\hline MD 17 & 312147 & 7404919 & Metasiltito & $234 / 80$ & & & & & & \\
\hline MD 18 & 313428 & 7405205 & Metasiltito & $219 / 30$ & & & & & $220 / 55$ & \\
\hline MD 19 & 313821 & 7404829 & Metarenitos com intercalações de metabásicas & $294 / 45$ & & & & & & \\
\hline MD 20 & 314754 & 7404111 & Metarenitos com intrusões de pegmatitos com turmalina & $212 / 35$ & & & & $38 / 60$ & $138 / 85$ & $38 / 80$ \\
\hline MD 21 & 315174 & 7404058 & Filitos com intercalações de metarenitos & $202 / 25$ & & & & & & \\
\hline MD 22 & 313524 & 7409931 & Granada xistos e metabásicas & & & & & & & \\
\hline MD 23 & 315982 & 7402010 & Metaconglomerado & $240 / 63$ & $120 / 70$ & & & & & \\
\hline MD 24 & 314643 & 7406817 & Hornblenda-granito porfirítico $\mathrm{IC}=15$ & & & & & & & \\
\hline MD 25 & 315041 & 7406129 & Metaconglomerado & & & & & & & \\
\hline MD 26 & 315737 & 7404189 & Metarcoseos com seixos esparços & $45 / 30$ & & $105 / 60$ & & & & \\
\hline MD 27 & 315807 & 7404067 & Metarcoseos com seixos esparços & & & & & & & \\
\hline MD 28 & 314620 & 7406744 & Hornblenda-granito porfirítico $\mathrm{IC}=15$ & & & & & & & \\
\hline MD 29 & 314043 & 7405629 & Filito com intercalações ócres e calciossilicática & $95 / 16$ & & & & & & \\
\hline MD 30 & 314153 & 7405396 & Granito alterado & & & & & & & \\
\hline MD 31 & 314272 & 7405324 & Filito xistoso com brilho sedoso & $120 / 52$ & & & & & & \\
\hline MD 32 & 314257 & 7405214 & Granito porfirítico & & & & & & & \\
\hline MD 33 & 314737 & 7405860 & Metarcoseo alterado & $140 / 12$ & & & & & & \\
\hline MD 34 & 315361 & 7404981 & Metaconglomerado & $168 / 30$ & & & & & & \\
\hline MD 35 & 314814 & 7404769 & Metarcoseo alterado com seixos esparços & $100 / 42$ & & & & & & \\
\hline MD 36 & 318034 & 7405904 & Metarcoseo + grosso com granulos & $20 / 65$ & & & & & $213 / 85$ & \\
\hline MD 37 & 317759 & 7405720 & Metarcoseo alterado & $195 / 65$ & & & & & $155 / 20$ & \\
\hline MD 38 & 317881 & 7404626 & Metarcoseo & $305 / 10$ & & $215 / 44$ & & & $275 / 88$ & \\
\hline MD 39 & 318221 & 7404154 & Metavulcânica básica & & & & & & & \\
\hline MD 40 & 323851 & 7399868 & Granito porfirítico & & & & & & & \\
\hline MD 41 & 323134 & 7400868 & Granito porfirítico & $90 / 48$ & & & & & & \\
\hline MD 42 & 321574 & 7403101 & Sienogranito porfirítico IC-8 & & & & & & & \\
\hline MD 43 & 321162 & 7404204 & Anfibolito com brilho sedoso & & & & & & & \\
\hline MD 44 & 321023 & 7404635 & Anfibolito com brilho sedoso & & & & & & & \\
\hline MD 45 & 320890 & 7405283 & Mármore & $180 / 43$ & & & & & & \\
\hline MD 46 & 320857 & 7405442 & Anfibolito grosso & & & & & & & \\
\hline MD 47 & 320812 & 7405324 & Mármore & $135 / 77$ & & & & & & \\
\hline MD 48 & 321083 & 7404086 & Mármore & $255 / 72$ & & & & & & \\
\hline JP 01 & 298021 & 7429527 & Metarenito com grãos sub-arredondados & $185 / 65$ & & & & & & \\
\hline
\end{tabular}

Tabela 1: Dados e nomenclaturas de campo (notações de estruturas apresentadas como rumo do mergulho). 


\begin{tabular}{|c|c|c|c|c|c|c|c|c|c|c|}
\hline Ponto & UTM E & UTM N & Rocha & Sn & Lineação & $\mathrm{Sn}+1$ & Eixo de Dobra & Veio de Qtz & Clivagem & Fraturamento \\
\hline JP 02 & 298230 & 7429764 & Metarenito feldspático com muscovita & & & & & & $310 / 30$ & \\
\hline JP 03 & 298302 & 7429835 & Metarenito com bandamento composicional & $330 / 10$ & & $342 / 80$ & & & & \\
\hline JP 04 & 298532 & 7430139 & Metarenito & & & $182 / 65$ & & & & \\
\hline JP 05 & 302287 & 7428910 & Metarenito com grão detríticos máficos & $220 / 10$ & $150 / 06$ & & & & & $150 / 89$ \\
\hline JP 06 & 302265 & 7429006 & Metarenito & $196 / 32$ & & & & & & $100 / 65$ \\
\hline JP 07 & 301951 & 7428235 & Metarenito feldspático com muscovita & & & & & & & \\
\hline JP 08 & 301719 & 7428908 & Metarenito intercalado com metarcoseo e metabásica & $198 / 38$ & & & & & & \\
\hline JP 09 & 301708 & 7429153 & Metarenito e rochas metabásicas & $180 / 37$ & & & & & & \\
\hline JP 10 & 301478 & 7429505 & Metarenito arcoseano com muscovita & $190 / 48$ & & & & & & \\
\hline VT 01 & 292553 & 7408407 & Calciossilicática e anfibolitos com pillow-lavas & $115 / 83$ & & & & & & \\
\hline VT 02 & 294391 & 7409507 & Metavulcânica ácida & $220 / 78$ & $135 / 15$ & & & & $80 / 89$ & \\
\hline VT 03 & 292403 & 7407618 & Metarenito feldspático & & & & & & & \\
\hline VT 04 & 291762 & 7415086 & Metarenito com intercalação de filito e metarenito & $130 / 75$ & & & & & & \\
\hline JP 11 & 303052 & 7429963 & Titanita granito equigranular & & & & & & & \\
\hline JP 12 & 295905 & 7433290 & Orto e Paragnaisses & $200 / 80$ & $180 / 20$ & & & & & $95 / 55$ \\
\hline JP 13 & 304906 & 7430461 & Gnaisses e Granitos & $235 / 68$ & & & $240 / 40$ & $340 / 85$ & & \\
\hline JP 14 & 305247 & 7430189 & Titanita granito & & & & & & & \\
\hline JP 15 & 309845 & 7425847 & biotita granito inequigranular fino a médio $I C=5-7$ & & & & & & & \\
\hline JP 16 & 300090 & 7437772 & biotita granito inequigranular foliado (granada?) & & & & & & & \\
\hline JP 17 & 337097 & 7428085 & Migmatito & $340 / 80$ & $265 / 30$ & & $320 / 50$ & & & \\
\hline JP 18 & 337635 & 7424344 & Quatzo sienito milonítico & & & & & & & \\
\hline JP 19 & 343185 & 7415800 & Metarenito felspático alterado & & & & & & & \\
\hline JP 20 & 343014 & 7415629 & Metarenito & & & & & & & \\
\hline VZP01 & 310866 & 7432470 & Metarenito Solo Residual Jovem & $35 / 55$ & & & & & & \\
\hline VZP02 & 312470 & 7431320 & Xisto Saprólito & $165 / 60$ & & & & & & \\
\hline VZP03 & 312604 & 7431270 & Biotita Xisto & $90 / 80$ & & & $145 / 40$ & & & \\
\hline VZP05 & 313199 & 7431281 & Metarenito arcoseano & & & & & & & \\
\hline VZP06 & 311497 & 7430290 & Gnaisse migmatítico (Solo residual maduro) & & & & & & & \\
\hline VZP08 & 311862 & 7429682 & Muscovita-biotita xisto (saprólito) & & & & & & & \\
\hline VZP09 & 312102 & 7429017 & Muscovita-biotita xisto (saprólito) & & & & & & & \\
\hline VZP10 & 312545 & 7426369 & Filito arenoso & $130 / 50$ & & & & & $195 / 75$ & \\
\hline VZP11 & 314842 & 7424797 & Metarenito fino & $110 / 75$ & & & & & $150 / 70$ & \\
\hline VZP12 & 316671 & 7428912 & Filito (alterado) & & & & & & & \\
\hline VZP13 & 316219 & 7430960 & Metarenito arcoseano & & & & & & & \\
\hline VZP15 & 315858 & 7431340 & Paragnaisse (saprólito) & $010 / 55$ & & & & & & \\
\hline VZP16 & 315259 & 7432125 & Paragnaisse (solo residual jovem) & & & & & & & \\
\hline VZP17 & 312101 & 7432541 & Biotita xisto & $040 / 75$ & & & & & & \\
\hline VZP18 & 312294 & 7432888 & Paragnaisse & $060 / 35$ & & & & & & \\
\hline ND-02A & 262379 & 7379746 & (Filto) Metasiltito & & & & & & & \\
\hline ND-02B & 262380 & 7397747 & (Filto) Metasiltito & & & & & & & \\
\hline ND-02C & 262381 & 7397748 & (Filto) Metasiltito & & & & & & & \\
\hline ND-02D & 262382 & 7397749 & (Filto) Metasiltito & & & & & & & \\
\hline ND-02E & 262383 & 7397750 & (Filto) Metasiltito & & & & & & & \\
\hline ND-03A & 257520 & 7406260 & (Filto) Metasiltito & & & & & & & \\
\hline ND-03B & 257521 & 7406261 & (Filto) Metasiltito & & & & & & & \\
\hline ND-03C & 257522 & 7406262 & (Filto) Metasiltito & & & & & & & \\
\hline ND-04A & 309626 & 7413919 & (Filto) Metasiltito & & & & & & & \\
\hline ND-04B & 309627 & 7413920 & (Filto) Metasiltito & & & & & & & \\
\hline ND-04C & 309628 & 7413921 & (Filto) Metasiltito & & & & & & & \\
\hline
\end{tabular}




\begin{tabular}{|c|c|c|c|c|c|c|c|c|}
\hline Ponto & UTM E & UTM N & Rocha & Sn & Lineação & $S n+1$ & Eixo de Dobra Veio de Qtz & Clivagem Fraturamento \\
\hline ND-05 & 308570 & 7428999 & (Filto) Metasiltito & & & & & \\
\hline ND-06A & 319165 & 7436854 & (Filto) Metasiltito & & & & & \\
\hline ND-06B & 319896 & 7437539 & (Filto) Metasiltito & & & & & \\
\hline ND-07A & 321771 & 7416457 & (Filto) Metasiltito & & & & & \\
\hline ND-08 & 325858 & 7419151 & (Filto) Metasiltito & & & & & \\
\hline ND-09 & 327737 & 7418835 & (Filto) Metasiltito & & & & & \\
\hline ND-10 & 328703 & 7418754 & (Filto) Metasiltito & & & & & \\
\hline ND-11 & 336534 & 7419704 & (Filto) Metasiltito & & & & & \\
\hline PJ-01M & 319737 & 7405016 & (Quartzito) Metarenito & & & & & \\
\hline PJ-01 & 320563 & 7404931 & Colúvio com blocos de quarztzitos & & & & & \\
\hline PJ-02 & 320498 & 7404940 & Colúvio com blocos de quarztzitos & & & & & \\
\hline PJ-03 & 321305 & 7405313 & Anfibolito alterado & & & & & \\
\hline PJ-04 & 320756 & 7405164 & Metatufo de coloração verde (crenulado) & $250 / 20$ & & & & \\
\hline PJ-05 & 320658 & 7404975 & Anfibolito alterado & $030 / 15$ & & & & $95 / 10$ \\
\hline PJ-06 & 320637 & 7404933 & Anfibolito alterado & & & & & $95 / 10$ \\
\hline PJ-07 & 320618 & 7405031 & Anfibolito alterado & & & & & \\
\hline PJ-08 & 320617 & 7405062 & Anfibolito alterado & & & & & \\
\hline PJ-09 & 320585 & 7405072 & Anfibolito alterado em contato com a Formação São Paulo & & & & & \\
\hline PJ-10 & 320474 & 7405062 & Solo residual maduro (fragmentos de quartzitos) & & & & & \\
\hline PJ-11 & 320516 & 7405078 & Colúvio com blocos de quarztzitos & & & & & \\
\hline PJ-12 & 320608 & 7405048 & (Quartzito) Metarenito & $340 / 55$ & & $345 / 25$ & & \\
\hline PJ-13 & 320560 & 7404987 & Solo residual maduro (fragmentos de quartzitos) & & & & & \\
\hline PJ-14 & 320525 & 7405177 & (Quartzito) Metarenito & & & & & 90/subvertical \\
\hline PJ-15 & 320548 & 7405247 & (Quartzito) Metarenito & $105 / 30$ & & $168 / 80$ & & \\
\hline PJ-16 & 320541 & 7405138 & (Quartzito) Metarenito & $010 / 35$ & & $190 / 35$ & & \\
\hline
\end{tabular}




\begin{tabular}{|c|c|c|c|c|c|c|c|c|c|c|c|c|c|c|}
\hline & \multicolumn{3}{|c|}{ Meta-quartzo arenitos } & \multicolumn{3}{|c|}{ Meta-subarcóseos } & Metarcóseos & \multicolumn{7}{|c|}{ Meta-wake feldspáticos } \\
\hline & $\mathrm{PJ}=01$ & JP-19 & $J P=20$ & VT-04 & JP-01 & JP-04 & VT-03 & MD-03a & MD-04a & MD-26b & MD-36 & MD-01b & VT - 02 & VZP-10 \\
\hline $\mathrm{SiO}_{2}$ & 98.17 & 97.34 & 95.31 & 92.49 & 93.31 & 90.26 & 77.84 & 74.07 & 73.91 & 75.89 & 75.16 & 70.85 & 75.27 & 65.74 \\
\hline $\mathrm{Al}_{2} \mathrm{O}_{3}$ & 0.51 & 1.17 & 1.07 & 3.64 & 2.86 & 2.84 & 11.13 & 10.55 & 12.9 & 10.92 & 12.09 & 13.31 & 12.77 & 16.97 \\
\hline $\mathrm{Fe}_{2} \mathrm{O}_{3}(\mathrm{t})$ & 0.09 & 0.17 & 0.19 & 0.7 & 0.58 & 0.71 & 2.02 & 2.27 & 2.23 & 2.5 & 1.82 & 3.66 & 2.84 & 6.89 \\
\hline MnO & 0.002 & 0.001 & 0.003 & 0.002 & 0.007 & 0.053 & 0.023 & 0.034 & 0.023 & 0.025 & 0.03 & 0.039 & 0.006 & 0.028 \\
\hline $\mathrm{MgO}$ & 0.00 & 0.00 & 0.08 & 0.07 & 0.12 & 1.29 & 0.44 & 1.11 & 0.88 & 0.78 & 0.76 & 1.7 & 1.02 & 0.79 \\
\hline $\mathrm{CaO}$ & 0.01 & 0.01 & 0.02 & 0.01 & 0.02 & 1.23 & 0.04 & 2.75 & 0.65 & 0.75 & 1.07 & 1.16 & & 0.01 \\
\hline $\mathrm{Na}_{2} \mathrm{O}$ & & & & & & 0.06 & 1.1 & 1.57 & 2.6 & 2.32 & 3.18 & 1.07 & & 0.34 \\
\hline $\mathrm{K}_{2} \mathrm{O}$ & 0.27 & 0.17 & 0.87 & 1.35 & 1.84 & 1.91 & 5.15 & 3.63 & 4.2 & 3.98 & 3.8 & 4.85 & 3.93 & 4.69 \\
\hline $\mathrm{TiO}_{2}$ & 0.032 & 0.028 & 0.027 & 0.104 & 0.09 & 0.092 & 0.281 & 0.287 & 0.282 & 0.306 & 0.244 & 0.403 & 0.315 & 0.78 \\
\hline $\mathbf{P}_{2} \mathbf{O}_{5}$ & 0.007 & 0.009 & 0.023 & 0.006 & 0.021 & 0.032 & 0.075 & 0.077 & 0.1 & 0.077 & 0.103 & 0.152 & 0.021 & 0.053 \\
\hline LOI & 0.26 & 0.6 & 0.24 & 0.7 & 0.5 & 0.56 & 1.32 & 3.05 & 1.38 & 1.37 & 0.95 & 2.36 & 2.86 & 2.76 \\
\hline Total & 99.3 & 99.4 & 97.8 & 99.0 & 99.3 & 99.0 & 99.4 & 99.3 & 99.1 & 98.9 & 99.2 & 99.5 & 99.0 & 99.0 \\
\hline $\mathrm{Ba}$ & 53 & 28 & 134 & 123 & 314 & 384 & 1038 & 787 & 814 & 864 & 749 & 1088 & 951 & 792 \\
\hline Co & & & & & & & 14 & 6 & & & & 11 & & 7 \\
\hline $\mathrm{Cr}$ & & & & & & & 26 & 36 & 25 & 69 & 26 & 82 & 45 & 48 \\
\hline $\mathrm{Cu}$ & & & & & & & & 20 & & 13 & 9 & 2 & & \\
\hline Ga & & & & & & & 14 & 14 & 17 & 14 & 14 & 17 & 13 & 21 \\
\hline $\mathrm{Nb}$ & 1 & 1 & & 3 & 4 & & 8 & & 6 & & & 12 & 7 & 16 \\
\hline $\mathrm{Ni}$ & & & & & & 6 & 10 & 7 & 10 & 12 & 11 & 16 & 11 & 33 \\
\hline $\mathrm{Pb}$ & 2 & 16 & & 1 & 3 & & 9 & 5 & & 22 & 7 & 5 & 1 & 14 \\
\hline $\mathbf{R b}$ & 7 & 9 & 28 & 24 & 35 & 33 & 125 & 131 & 124 & 130 & 94 & 172 & 116 & 178 \\
\hline Sc & & & & & & & & & & & & 6 & & 14 \\
\hline Sr & & 4 & 23 & & 9 & 33 & 41 & 184 & 106 & 108 & 159 & 68 & 10 & 44 \\
\hline Th & 1 & 2 & & 3 & 2 & & 7 & 22 & 7 & 23 & 8 & 18 & 8 & 15 \\
\hline $\mathbf{U}$ & 0 & 1 & & 1 & 1 & 4 & 1 & & 1 & 13 & 10 & 4 & 2 & 2 \\
\hline V & & & 16 & 14 & & & 15 & 82 & 35 & 37 & 19 & 47 & 39 & 72 \\
\hline $\mathbf{Y}$ & 6 & 2 & 4 & 10 & 6 & 11 & 33 & 15 & 15 & 12 & 53 & 18 & 12 & 42 \\
\hline $\mathrm{Zn}$ & 3 & 2 & 4 & 2 & 2 & 6 & 22 & 30 & 9 & 34 & 8 & 70 & 18 & 51 \\
\hline $\mathrm{Zr}$ & 70 & 63 & 55 & 133 & 196 & 222 & 166 & 175 & 177 & 187 & 153 & 242 & 151 & 172 \\
\hline La & 6 & 6 & & 10 & 8 & & 46 & 37 & 31 & 37 & 189 & 35 & 30 & 50 \\
\hline $\mathrm{Ce}$ & 10 & 12 & & 19 & 23 & & 62 & 42 & 53 & 48 & & 94 & 48 & 77 \\
\hline Nd & 4 & 4 & & 7 & 6 & & 40 & 18 & 23 & 21 & 116 & 29 & 23 & 39 \\
\hline $\mathrm{Hf}$ & 1.9 & 1.9 & & 3.8 & 4.7 & & 4.8 & & 4.7 & & & 5.2 & 4.2 & 5.0 \\
\hline
\end{tabular}

Tabela 2: Geoquímica de metassedimentos do Grupo São Roque obtidos através de FRX. Campos em cinza representam teores obtidos via ICP-MS. 


\begin{tabular}{|c|c|c|c|c|c|c|c|c|c|c|c|c|c|c|c|c|}
\hline & \multicolumn{3}{|c|}{ Meta-quartzo wakes } & \multicolumn{13}{|c|}{ Metassiltitos } \\
\hline & MD-38 & ND-05A & VZP-11 & ND-09 & ND-07A & ND-07B & ND-04C & ND-06B & ND-03C & ND-03A & ND-03B & ND-10 & ND-02B & ND-08 & ND-04B & ND-04A \\
\hline $\mathrm{SiO}_{2}$ & 69.14 & 68.75 & 66.95 & 55.18 & 55.18 & 59.84 & 62.47 & 61.91 & 55.75 & 46.93 & 60.97 & 61.79 & 48.44 & 60.99 & 63.85 & 57.62 \\
\hline $\mathrm{Al}_{2} \mathrm{O}_{3}$ & 13.65 & 17.5 & 15.1 & 24.44 & 24.56 & 22.28 & 21.98 & 19.7 & 24.36 & 29.67 & 21.04 & 20.9 & 28.98 & 21.21 & 21.27 & 24.02 \\
\hline $\mathrm{Fe}_{2} \mathrm{O}_{3}(\mathrm{t})$ & 3.68 & 3.54 & 5.44 & 7.25 & 7.2 & 6.2 & 3.9 & 8.17 & 5.07 & 4.31 & 5.57 & 6.35 & 5.68 & 6.88 & 3.69 & 5.87 \\
\hline $\mathrm{MnO}$ & 0.055 & 0.002 & 0.024 & 0.016 & 0.002 & 0.004 & 0.016 & 0.063 & 0.073 & 0.029 & 0.016 & 0.014 & 0.017 & 0.022 & 0.015 & 0.014 \\
\hline MgO & 1.98 & 0.36 & 1.98 & 0.48 & 0.45 & 0.45 & 0.43 & 0.25 & 1.17 & 1.6 & 0.91 & 0.35 & 1.22 & 0.31 & 0.41 & 0.38 \\
\hline $\mathrm{CaO}$ & 1.58 & 0.01 & 0.88 & & & 0.02 & 0.01 & & 0.03 & & & & 0.01 & 0.02 & 0.02 & 0.05 \\
\hline $\mathrm{Na}_{2} \mathrm{O}$ & 3.33 & 0.1 & 0.8 & 0.19 & 0.19 & 0.16 & 0.3 & 0.31 & 0.17 & 0.22 & 0.13 & 0.25 & 0.18 & 0.25 & 0.25 & 0.29 \\
\hline $\mathrm{K}_{2} \mathrm{O}$ & 3.47 & 3.89 & 3.65 & 5.85 & 5.43 & 4.9 & 5.21 & 3.77 & 6.93 & 9.79 & 5.54 & 4.53 & 8.21 & 4.42 & 4.88 & 4.77 \\
\hline $\mathrm{TiO}_{2}$ & 0.591 & 0.651 & 0.591 & 0.922 & 0.81 & 0.758 & 0.696 & 0.887 & 1029.00 & 1239.00 & 0.789 & 0.648 & 1085.00 & 0.695 & 0.657 & 0.769 \\
\hline $\mathrm{P}_{2} \mathrm{O}_{5}$ & 0.212 & 0.089 & 0.098 & 0.07 & 0.073 & 0.069 & 0.059 & 0.073 & 0.04 & 0.054 & 0.05 & 0.043 & 0.068 & 0.082 & 0.53 & 0.036 \\
\hline LOI & 1.64 & 4.01 & 3.97 & 5.15 & 5.56 & 5.08 & 4.24 & 4.6 & 4.74 & 4.61 & 4.54 & 4.5 & 5.5 & 4.41 & 4.36 & 5.86 \\
\hline Total & 99.3 & 98.9 & 99.4 & 99.5 & 99.4 & 99.7 & 99.3 & 99.7 & 99.3 & 98.4 & 99.5 & 99.3 & 99.3 & 99.2 & 99.9 & 99.6 \\
\hline $\mathrm{Ba}$ & 821 & 794 & 684 & 1338 & 983 & 873 & 995 & 611 & 1525 & 2383 & 1009 & 716 & 1905 & 770 & 941 & 859 \\
\hline Co & 9 & & 16 & & & & & 11 & & 10 & & & 6 & & & \\
\hline $\mathrm{Cr}$ & 45 & 105 & 72 & 189 & 120 & 117 & 117 & 96 & 125 & 155 & 101 & 113 & 170 & 140 & 100 & 159 \\
\hline $\mathrm{Cu}$ & & 20 & 28 & 21 & 24 & 22 & 19 & 28 & 10 & 8 & 24 & 26 & 20 & 23 & 21 & 11 \\
\hline Ga & 15 & 26 & 19 & 35 & 36 & 31 & 32 & 26 & 35 & 50 & 28 & 29 & 42 & 31 & 30 & 32 \\
\hline $\mathrm{Nb}$ & & 15 & 14 & 18 & 14 & 14 & 14 & 15 & 23 & 28 & 18 & 11 & 26 & 15 & 13 & 15 \\
\hline $\mathrm{Ni}$ & 19 & 11 & 36 & 20 & 23 & 20 & 23 & 42 & 17 & 21 & 19 & 14 & 29 & 25 & 27 & 29 \\
\hline $\mathrm{Pb}$ & & 6 & 24 & 14 & 7 & & 5 & 6 & & 81 & 13 & 15 & 8 & 21 & 19 & 8 \\
\hline $\mathbf{R b}$ & 95 & 185 & 154 & 174 & 283 & 254 & 255 & 102 & 293 & 382 & 226 & 236 & 329 & 162 & 248 & 203 \\
\hline Sc & & & & 17 & 19 & 17 & 15 & 16 & 21 & 26 & 16 & 17 & 22 & 17 & 14 & 19 \\
\hline $\mathrm{Sr}$ & 196 & 94 & 71 & 59 & 85 & 79 & 74 & 32 & 38 & 65 & 28 & 59 & 65 & 98 & 71 & 63 \\
\hline Th & 13 & 12 & 14 & 17 & 15 & 17 & 16 & 14 & 20 & 16 & 20 & 16 & 27 & 18 & 16 & 16 \\
\hline $\mathbf{U}$ & 8 & 4 & 3 & 7 & 5 & 7 & 6 & 5 & 9 & 7 & 5 & 4 & 5 & 3 & 3 & 6 \\
\hline V & 47 & 62 & 57 & 105 & 110 & 120 & 111 & 115 & 105 & 127 & 87 & 91 & 166 & 101 & 99 & 104 \\
\hline $\mathbf{Y}$ & 28 & 35 & 18 & 37 & 33 & 30 & 18 & 33 & 45 & 46 & 48 & 30 & 90 & 19 & 11 & 23 \\
\hline $\mathrm{Zn}$ & 66 & 17 & 86 & 53 & 47 & 55 & 23 & 30 & 48 & 73 & 46 & 45 & 55 & 94 & 28 & 34 \\
\hline $\mathrm{Zr}$ & 182 & 167 & 195 & 219 & 133 & 129 & 108 & 191 & 280 & 327 & 186 & 119 & 234 & 136 & 106 & 143 \\
\hline La & 59 & 208 & 46 & 74 & 102 & 48 & 64 & 78 & 22 & 72 & 92 & 69 & 211 & 12 & 58 & 57 \\
\hline $\mathrm{Ce}$ & 87 & & 90 & & & & & & & 64 & 81 & & 199 & 23 & 39 & \\
\hline Nd & 53 & 134 & 38 & 67 & 103 & 72 & 59 & 74 & 36 & 58 & 83 & 66 & 153 & 7 & 44 & 63 \\
\hline Hf & & & 4.9 & & & & & & & & 5.2 & & 6.5 & 3.7 & 3.0 & \\
\hline
\end{tabular}

Tabela 2 (continuação): Geoquímica de metassedimentos do Grupo São Roque obtidos através de FRX. Campos em cinza representam teores obtidos via ICP-MS. 


\begin{tabular}{|c|c|c|c|c|c|c|c|c|c|c|c|c|c|c|}
\hline & \multicolumn{2}{|c|}{ Meta-quartzo arenitos } & \multicolumn{2}{|c|}{ Meta-subarcóseos } & \multirow{2}{*}{$\begin{array}{c}\text { Metarcóseos } \\
\text { VT-03 } \\
\end{array}$} & \multicolumn{4}{|c|}{ Meta-wake feldspáticos } & \multirow{2}{*}{$\begin{array}{c}\text { Meta-quartzo wackes } \\
\text { VZP-11 } \\
\end{array}$} & \multicolumn{4}{|c|}{ Metassiltitos } \\
\hline & $\begin{array}{l}\mathrm{PJ}-01 \\
\end{array}$ & JP-19 & $\begin{array}{l}\text { VT-04 } \\
\end{array}$ & JP-01 & & MD-04a & MD-01b & VT - 02 & VZP-10 & & ND-03B & ND-02B & ND-08 & ND-04B \\
\hline La & 6.4 & 6.47 & 9.99 & 7.66 & 45.77 & 30.77 & 35.07 & 30.11 & 49.82 & 45.77 & 92.46 & 210.72 & 11.96 & 58.35 \\
\hline $\mathrm{Ce}$ & 10.4 & 12.25 & 18.8 & 22.54 & 61.53 & 53.16 & 94.45 & 48.15 & 76.88 & 89.94 & 81.21 & 198.64 & 22.5 & 39.17 \\
\hline $\mathrm{Pr}$ & 1.1 & 1.33 & 2.00 & 1.65 & 10.44 & 6.33 & 7.77 & 6.39 & 10.66 & 10.57 & 22.22 & 40.07 & 1.97 & 12.65 \\
\hline Nd & 3.9 & 4.45 & 7.08 & 6.1 & 40.00 & 22.56 & 28.78 & 22.5 & 38.6 & 38.35 & 82.83 & 152.87 & 6.7 & 43.54 \\
\hline Sm & 0.7 & 0.78 & 1.25 & 1.21 & 7.16 & 3.86 & 5.05 & 3.9 & 7.19 & 6.89 & 15.19 & 29.74 & 1.5 & 6.86 \\
\hline Eu & 0.1 & 0.17 & 0.3 & 0.41 & 1.83 & 0.92 & 1.19 & 1.03 & 1.52 & 1.24 & 2.78 & 6.41 & 0.49 & 1.19 \\
\hline Gd & 0.7 & 0.53 & 1.11 & 1.11 & 6.3 & 3.08 & 3.89 & 2.81 & 6.2 & 5.02 & 11.68 & 25.56 & 1.5 & 3.9 \\
\hline Tb & 0.1 & 0.08 & 0.21 & 0.17 & 0.82 & 0.47 & 0.58 & 0.39 & 0.93 & 0.65 & 1.66 & 3.36 & 0.38 & 0.51 \\
\hline Dy & 0.9 & 0.38 & 1.33 & 1.00 & 4.35 & 2.71 & 3.37 & 2.12 & 5.3 & 3.2 & 8.68 & 16.32 & 2.74 & 2.56 \\
\hline Ho & 0.1 & 0.072 & 0.3 & 0.21 & 0.92 & 0.55 & 0.72 & 0.42 & 1.12 & 0.61 & 1.72 & 3.07 & 0.67 & 0.45 \\
\hline Er & 0.5 & 0.19 & 0.93 & 0.6 & 2.59 & 1.52 & 1.9 & 1.18 & 3.2 & 1.71 & 4.72 & 8.07 & 2.03 & 1.24 \\
\hline Tm & 0.08 & 0.03 & 0.15 & 0.09 & 0.37 & 0.21 & 0.28 & 0.18 & 0.47 & 0.26 & 0.71 & 1.15 & 0.33 & 0.18 \\
\hline Yb & 0.54 & 0.2 & 1.05 & 0.66 & 2.29 & 1.41 & 1.86 & 1.22 & 3.2 & 1.8 & 4.3 & 6.84 & 2.07 & 1.2 \\
\hline Lan/Ybn & 7.99 & 21.03 & 6.4 & 7.82 & 13.46 & 14.67 & 12.69 & 16.55 & 10.5 & 17.18 & 14.51 & 20.81 & 3.9 & 30.84 \\
\hline Lan/Sm & 5.74 & 5.16 & 5.00 & 3.98 & 4.01 & 5.00 & 4.36 & 4.85 & 4.35 & 4.17 & 3.82 & 4.45 & 5.00 & 5.35 \\
\hline $\mathrm{Eu} / \mathrm{Eu}^{\star}$ & 0.81 & 0.8 & 0.79 & 1.07 & 0.83 & 0.81 & 0.82 & 0.95 & 0.69 & 0.64 & 0.63 & 0.711 & 0.96 & 0.7 \\
\hline Gdn/Ybn & 1.15 & 2.09 & 0.85 & 1.36 & 2.22 & 1.76 & 1.69 & 1.85 & 1.57 & 2.26 & 2.19 & 3.02 & 0.62 & 2.49 \\
\hline$\sum$ LREE & 22.7 & 25.3 & 39.1 & 39.18 & 164.93 & 116.7 & 171.15 & 111.06 & 183.26 & 191.53 & 293.93 & 632.06 & 44.64 & 160.6 \\
\hline$\sum$ HREE & 3.2 & 1.5 & 5.1 & 3.88 & 17.67 & 9.98 & 12.63 & 8.35 & 20.48 & 13.27 & 33.5 & 64.4 & 9.84 & 10.17 \\
\hline
\end{tabular}

Tabela 3: Elementos de Terras Raras de metassedimentos do Grupo São Roque obtidos via ICP-MS. 


\begin{tabular}{|c|c|c|c|c|c|c|c|c|c|c|c|c|}
\hline & \multicolumn{12}{|c|}{ Meta-wake feldspáticos da região de Pirapora de Bom Jesus } \\
\hline Microssonda no & VT02 1 & VT02 2 & VT02 3 & VT02 4 & VT02 5 & VT02 6 & VT02 7 & VT02 8 & VT02 9 & VT02 10 & VT02 11 & VT02 12 \\
\hline $\mathrm{U}-\mathrm{Pb}$ n은 & - & - & - & - & - & - & - & - & - & - & - & - \\
\hline Idades $207 \mathrm{~Pb} / 206 \mathrm{~Pb}$ & - & - & - & - & - & - & - & - & - & - & - & - \\
\hline LA-ICPMS no & $1 \mathrm{a}$ & $2 a$ & $3 a$ & $4 b$ & $5 b$ & $6 b$ & $7 a$ & $8 b$ & $9 a$ & $10 b$ & $11 b$ & $12 a$ \\
\hline Feições & nucleo & nucleo & nucleo & borda & borda & borda & nucleo & borda & nucleo & borda & borda & nucleo \\
\hline $\mathrm{SiO}_{2}$ & 32.521 & 32.293 & 32.433 & 32.241 & 32.146 & 31.789 & 32.439 & 30.725 & 32.584 & 32.660 & 32.254 & 32.065 \\
\hline $\mathrm{ZrO}_{2}$ & 65.544 & 65.332 & 65.434 & 65.043 & 65.796 & 65.799 & 65.446 & 61.715 & 65.748 & 65.294 & 65.606 & 65.762 \\
\hline $\mathrm{HfO}_{2}$ & 1.266 & 1.301 & 1.249 & 1.754 & 1.382 & 1.349 & 1.210 & 1.246 & 1.198 & 1.536 & 1.218 & 1.162 \\
\hline $\mathrm{P}_{2} \mathrm{O}_{5}$ & 0.084 & 0.055 & 0.066 & 0.106 & 0.075 & 0.104 & 0.044 & 0.019 & 0.058 & 0.086 & 0.088 & 0.080 \\
\hline $\mathrm{ThO}_{2}$ & 0.068 & 0.026 & 0.024 & 0.070 & 0.000 & 0.092 & 0.053 & 0.087 & 0.018 & 0.000 & 0.018 & 0.043 \\
\hline $\mathrm{Al}_{2} \mathrm{O}_{3}$ & 0.042 & 0.009 & 0.011 & 0.011 & 0.010 & 0.004 & 0.000 & 0.042 & 0.006 & 0.000 & 0.006 & 0.014 \\
\hline $\mathrm{La}_{2} \mathrm{O}_{3}$ & 0.035 & 0.000 & 0.000 & 0.000 & 0.071 & 0.000 & 0.000 & 0.000 & 0.000 & 0.016 & 0.038 & 0.000 \\
\hline $\mathrm{Ce}_{2} \mathrm{O}_{3}$ & 0.000 & 0.000 & 0.005 & 0.006 & 0.008 & 0.000 & 0.064 & 0.016 & 0.000 & 0.042 & 0.000 & 0.031 \\
\hline $\mathrm{MgO}$ & 0.007 & 0.022 & 0.012 & 0.023 & 0.002 & 0.000 & 0.020 & 0.013 & 0.025 & 0.007 & 0.018 & 0.021 \\
\hline $\mathrm{CaO}$ & 0.007 & 0.011 & 0.000 & 0.000 & 0.015 & 0.006 & 0.000 & 0.039 & 0.002 & 0.000 & 0.012 & 0.000 \\
\hline $\mathrm{FeO}$ & 0.000 & 0.000 & 0.027 & 0.000 & 0.011 & 0.000 & 0.038 & 0.662 & 0.000 & 0.000 & 0.057 & 0.016 \\
\hline $\mathrm{Na}_{2} \mathrm{O}$ & 0.000 & 0.000 & 0.000 & 0.000 & 0.000 & 0.000 & 0.000 & 0.000 & 0.000 & 0.000 & 0.000 & 0.000 \\
\hline Total & 99.574 & 99.049 & 99.261 & 99.254 & 99.516 & 99.143 & 99.314 & 94.564 & 99.639 & 99.641 & 99.315 & 99.194 \\
\hline
\end{tabular}

Tabela 4: Dados de química de zircão de metassedimentos do Domínio São Roque, obtidos via Microssonda Eletrônica. 


\begin{tabular}{|c|c|c|c|c|c|c|c|c|c|c|c|c|}
\hline & \multicolumn{6}{|c|}{ Meta-wake feldspáticos da região de Pirapora de Bom Jesus } & \multicolumn{6}{|c|}{ Meta-subarcóseos de região da Serra do Japi } \\
\hline Microssonda no & VT02 13 & VT02 14 & VT02 15 a & VT02 $15 \mathrm{~b}$ & VT02 16 a & VT02 $16 \mathrm{~b}$ & JP01 1 & JP01 2 & JP01 3 & JP01 4 & JP01 5 & JP01 6 \\
\hline $\mathrm{U}-\mathrm{Pb} \mathrm{n}^{\circ}$ & - & - & - & - & - & - & 4.1 & 45.1 & 11.2 & 6.1 & 9.2 & - \\
\hline Idades $207 \mathrm{~Pb} / 206 \mathrm{~Pb}$ & - & - & - & - & - & - & 2.4 & 2.0 & 1.7 & 2.0 & 1.9 & - \\
\hline LA-ICPMS no & $13 b$ & $14 a$ & $15 a$ & $15 b$ & $16 a$ & $16 \mathrm{~b}$ & $1 \mathrm{a}$ & $2 a$ & $3 a$ & $4 a$ & $5 b$ & - \\
\hline Feições & borda & nucleo & nucleo & borda & nucleo & borda & nucleo & nucleo & nucleo & nucleo & borda & borda \\
\hline $\mathrm{SiO}_{2}$ & 32.153 & 32.066 & 31.786 & 27.290 & 32.332 & 26.822 & 32.364 & 32.363 & 32.062 & 32.287 & 32.523 & 32.112 \\
\hline $\mathrm{ZrO}_{2}$ & 64.734 & 65.354 & 65.130 & 54.525 & 65.012 & 52.156 & 65.560 & 64.777 & 64.817 & 65.358 & 65.024 & 65.187 \\
\hline $\mathrm{HfO}_{2}$ & 1.173 & 1.168 & 1.146 & 1.345 & 1.341 & 2.080 & 1.170 & 1.402 & 1.835 & 1.309 & 1.615 & 1.220 \\
\hline $\mathrm{P}_{2} \mathrm{O}_{5}$ & 0.089 & 0.082 & 0.065 & 0.377 & 0.026 & 0.765 & 0.087 & 0.098 & 0.063 & 0.052 & 0.084 & 0.128 \\
\hline $\mathrm{ThO}_{2}$ & 0.097 & 0.003 & 0.022 & 0.143 & 0.049 & 0.326 & 0.000 & 0.000 & 0.077 & 0.068 & 0.047 & 0.026 \\
\hline $\mathrm{Al}_{2} \mathrm{O}_{3}$ & 0.000 & 0.019 & 0.015 & 0.713 & 0.000 & 1.322 & 0.003 & 0.000 & 0.000 & 0.014 & 0.016 & 0.010 \\
\hline $\mathrm{La}_{2} \mathrm{O}_{3}$ & 0.000 & 0.008 & 0.003 & 0.008 & 0.074 & 0.051 & 0.012 & 0.000 & 0.000 & 0.000 & 0.000 & 0.000 \\
\hline $\mathrm{Ce}_{2} \mathrm{O}_{3}$ & 0.059 & 0.006 & 0.000 & 0.080 & 0.000 & 0.304 & 0.000 & 0.000 & 0.000 & 0.064 & 0.036 & 0.019 \\
\hline $\mathrm{MgO}$ & 0.001 & 0.014 & 0.000 & 0.089 & 0.008 & 0.064 & 0.016 & 0.012 & 0.012 & 0.012 & 0.006 & 0.011 \\
\hline $\mathrm{CaO}$ & 0.000 & 0.000 & 0.000 & 1.047 & 0.008 & 1.300 & 0.000 & 0.000 & 0.000 & 0.000 & 0.000 & 0.000 \\
\hline $\mathrm{FeO}$ & 0.000 & 0.027 & 0.049 & 1.625 & 0.030 & 1.473 & 0.008 & 0.000 & 0.000 & 0.033 & 0.033 & 0.041 \\
\hline $\mathrm{Na}_{2} \mathrm{O}$ & 0.000 & 0.000 & 0.000 & 0.000 & 0.000 & 0.000 & 0.000 & 0.000 & 0.000 & 0.000 & 0.000 & 0.000 \\
\hline Total & 98.306 & 98.747 & 98.216 & 87.242 & 98.880 & 86.663 & 99.220 & 98.652 & 98.866 & 99.197 & 99.384 & 98.754 \\
\hline
\end{tabular}

Tabela 4: Dados de química de zircão de metassedimentos do Domínio São Roque, obtidos via Microssonda Eletrônica. 


\begin{tabular}{|c|c|c|c|c|c|c|c|c|c|c|c|c|}
\hline & \multicolumn{12}{|c|}{ Meta-subarcóseos de região da Serra do Japi } \\
\hline Microssonda no & \begin{tabular}{|ll}
$J P 0111$ \\
\end{tabular} & \begin{tabular}{|ll}
$J P 0112$ \\
\end{tabular} & JP01 13 & JP01 14 a & JP01 $14 \mathrm{~b}$ & JP01 15 & JP01 16 a & JP01 $16 \mathrm{~b}$ & JP01 17 & JP01 18 & JP01 19 & JP01 20 \\
\hline U-Pb no & 54.1 & 47.1 & 48.1 & 13.1 & 13.2 & 51.1 & - & 40.1 & - & 44.1 & - & 43.1 \\
\hline Idades $207 \mathrm{~Pb} / 206 \mathrm{~Pb}$ & 2.9 & 2.1 & 2.0 & 2.6 & 1.9 & 3.4 & - & $?$ & - & $?$ & - & $?$ \\
\hline LA-ICPMS no & $11 b$ & $12 a$ & $13 a$ & $14 a$ & $14 b$ & $15 a$ & $16 a$ & $16 b$ & $17 \mathrm{a}$ & $18 \mathrm{~b}$ & $19 a$ & $20 a$ \\
\hline Feições & borda & nucleo & nucleo & nucleo & borda & nucleo & nucleo & borda & nucleo & borda & nucleo & nucleo \\
\hline $\mathrm{SiO}_{2}$ & 32.176 & 32.391 & 32.380 & 32.447 & 33.392 & 32.918 & 32.587 & 32.653 & 32.295 & 32.446 & 32.469 & 32.061 \\
\hline $\mathrm{ZrO}_{2}$ & 64.988 & 65.351 & 65.061 & 65.664 & 65.435 & 65.536 & 65.693 & 65.801 & 65.272 & 65.459 & 65.409 & 64.492 \\
\hline $\mathrm{HfO}_{2}$ & 1.295 & 1.296 & 1.244 & 1.376 & 1.250 & 1.678 & 1.340 & 1.177 & 1.496 & 0.906 & 1.426 & 1.675 \\
\hline $\mathrm{P}_{2} \mathrm{O}_{5}$ & 0.206 & 0.125 & 0.029 & 0.039 & 0.108 & 0.098 & 0.032 & 0.064 & 0.102 & 0.108 & 0.112 & 0.045 \\
\hline $\mathrm{ThO}_{2}$ & 0.087 & 0.084 & 0.091 & 0.106 & 0.000 & 0.020 & 0.062 & 0.000 & 0.037 & 0.027 & 0.093 & 0.016 \\
\hline $\mathrm{Al}_{2} \mathrm{O}_{3}$ & 0.000 & 0.016 & 0.016 & 0.001 & 0.029 & 0.000 & 0.003 & 0.003 & 0.000 & 0.000 & 0.012 & 0.008 \\
\hline $\mathrm{La}_{2} \mathrm{O}_{3}$ & 0.016 & 0.005 & 0.000 & 0.000 & 0.026 & 0.023 & 0.021 & 0.000 & 0.000 & 0.058 & 0.000 & 0.000 \\
\hline $\mathrm{Ce}_{2} \mathrm{O}_{3}$ & 0.000 & 0.014 & 0.000 & 0.000 & 0.000 & 0.000 & 0.000 & 0.000 & 0.000 & 0.078 & 0.000 & 0.000 \\
\hline $\mathrm{MgO}$ & 0.027 & 0.008 & 0.000 & 0.000 & 0.017 & 0.010 & 0.012 & 0.030 & 0.000 & 0.008 & 0.007 & 0.018 \\
\hline $\mathrm{CaO}$ & 0.000 & 0.000 & 0.010 & 0.000 & 0.000 & 0.000 & 0.000 & 0.000 & 0.000 & 0.000 & 0.000 & 0.000 \\
\hline $\mathrm{FeO}$ & 0.003 & 0.000 & 0.000 & 0.000 & 0.000 & 0.044 & 0.060 & 0.019 & 0.016 & 0.003 & 0.057 & 0.011 \\
\hline $\mathrm{Na}_{2} \mathrm{O}$ & 0.000 & 0.000 & 0.000 & 0.000 & 0.000 & 0.000 & 0.000 & 0.000 & 0.000 & 0.000 & 0.000 & 0.000 \\
\hline Total & 98.798 & 99.290 & 98.831 & 99.633 & 100.257 & 100.327 & 99.810 & 99.747 & 99.218 & 99.093 & 99.585 & 98.326 \\
\hline
\end{tabular}

Tabela 4: Dados de química de zircão de metassedimentos do Domínio São Roque, obtidos via Microssonda Eletrônica. 


\begin{tabular}{|c|c|c|c|c|c|c|c|c|c|c|c|c|}
\hline & \multicolumn{12}{|c|}{ Meta-subarcóseos de região da Serra do Japi } \\
\hline Microssonda no & JP01 21 a & JP01 $21 \mathrm{~b}$ & JP01 22 & JP01 23 & JP01 24 & JP01 25 a & JP01 $25 \mathrm{~b}$ & JP01 26 & JP01 27 & JP01 28 & JP01 29 & JP0130 \\
\hline U-Pb no & 34.2 & 34.1 & - & - & - & 38.2 & 38.1 & - & - & - & 30.1 & 66.1 \\
\hline Idades $207 \mathrm{~Pb} / 206 \mathrm{~Pb}$ & $?$ & $?$ & - & - & - & $?$ & $?$ & - & - & - & 2.2 & 2.1 \\
\hline LA-ICPMS no & $21 a$ & $21 b$ & $22 a$ & $23 a$ & $24 a$ & $25 a$ & $25 b$ & $26 b$ & $27 a$ & - & - & - \\
\hline Feições & nucleo & borda & nucleo & nucleo & nucleo & nucleo & borda & metamítico & nucleo & nucleo & borda & borda \\
\hline $\mathrm{SiO}_{2}$ & 31.839 & 32.416 & 32.095 & 31.824 & 32.322 & 32.364 & 32.373 & 32.155 & 32.326 & 32.539 & 32.275 & 32.162 \\
\hline $\mathrm{ZrO}_{2}$ & 64.489 & 65.655 & 64.649 & 64.467 & 64.823 & 65.331 & 65.186 & 64.615 & 65.692 & 65.784 & 65.538 & 64.860 \\
\hline $\mathrm{HfO}_{2}$ & 1.238 & 1.385 & 1.310 & 1.059 & 1.402 & 1.387 & 1.563 & 1.605 & 1.623 & 1.348 & 1.244 & 1.281 \\
\hline $\mathrm{P}_{2} \mathrm{O}_{5}$ & 0.097 & 0.080 & 0.071 & 0.098 & 0.029 & 0.047 & 0.078 & 0.104 & 0.059 & 0.075 & 0.065 & 0.044 \\
\hline $\mathrm{ThO}_{2}$ & 0.062 & 0.054 & 0.057 & 0.098 & 0.000 & 0.031 & 0.000 & 0.069 & 0.060 & 0.022 & 0.046 & 0.000 \\
\hline $\mathrm{Al}_{2} \mathrm{O}_{3}$ & 0.030 & 0.008 & 0.014 & 0.001 & 0.009 & 0.006 & 0.024 & 0.008 & 0.010 & 0.001 & 0.014 & 0.004 \\
\hline $\mathrm{La}_{2} \mathrm{O}_{3}$ & 0.046 & 0.000 & 0.000 & 0.000 & 0.023 & 0.000 & 0.000 & 0.000 & 0.063 & 0.015 & 0.000 & 0.000 \\
\hline $\mathrm{Ce}_{2} \mathrm{O}_{3}$ & 0.000 & 0.000 & 0.028 & 0.053 & 0.000 & 0.000 & 0.000 & 0.000 & 0.000 & 0.000 & 0.000 & 0.028 \\
\hline $\mathrm{MgO}$ & 0.018 & 0.020 & 0.003 & 0.013 & 0.010 & 0.008 & 0.021 & 0.008 & 0.021 & 0.010 & 0.013 & 0.005 \\
\hline $\mathrm{CaO}$ & 0.000 & 0.000 & 0.002 & 0.000 & 0.000 & 0.000 & 0.000 & 0.000 & 0.000 & 0.003 & 0.000 & 0.000 \\
\hline $\mathrm{FeO}$ & 0.014 & 0.014 & 0.066 & 0.082 & 0.085 & 0.000 & 0.005 & 0.011 & 0.074 & 0.036 & 0.038 & 0.000 \\
\hline $\mathrm{Na}_{2} \mathrm{O}$ & 0.000 & 0.000 & 0.000 & 0.000 & 0.000 & 0.000 & 0.000 & 0.000 & 0.000 & 0.000 & 0.000 & 0.000 \\
\hline Total & 97.833 & 99.632 & 98.295 & 97.695 & 98.703 & 99.174 & 99.250 & 98.575 & 99.928 & 99.833 & 99.233 & 98.384 \\
\hline
\end{tabular}

Tabela 4: Dados de química de zircão de metassedimentos do Domínio São Roque, obtidos via Microssonda Eletrônica. 
Meta-quartzo arenitos de região da Serra do Pirucaia

\begin{tabular}{|c|c|c|c|c|c|c|c|c|c|c|c|c|}
\hline & \multicolumn{12}{|c|}{ Meta-quartzo arenitos de região da Serra do Pirucaia } \\
\hline Microssonda no & JP191 & \begin{tabular}{|l|l}
$J P 192$ \\
\end{tabular} & JP19 3 & JP19 4 a & JP19 4 b & JP19 5 & JP19 6 a & JP19 6 b & JP19 7 & JP19 8 & JP19 9 & JP1910 \\
\hline U-Pb no & 58.1 & 57.1 & 7.1 & 8.2 & 8.1 & 4.1 & 6.2 & 6.1 & 60.1 & 1.1 & 2.1 & 54.1 \\
\hline Idades $207 \mathrm{~Pb} / 206 \mathrm{~Pb}$ & 2.0 & 2.4 & 2.1 & 2.1 & 0.6 & 3.0 & 2.1 & 0.6 & 2.1 & 2.8 & 2.2 & 2.1 \\
\hline LA-ICPMS no & $1 \mathrm{a}$ & $2 a$ & $3 b$ & $4 a$ & $4 \mathrm{~b}$ & $5 a$ & $6 a$ & $6 b$ & $7 a$ & $8 b$ & $9 b$ & $10 b$ \\
\hline Feições & nucleo & nucleo & borda & nucleo & borda & nucleo & nucleo & borda & nucleo & borda & borda & borda \\
\hline $\mathrm{SiO}_{2}$ & 31.063 & 32.214 & 32.007 & 32.489 & 31.312 & 32.490 & 32.432 & 37.504 & 33.327 & 32.627 & 32.310 & 32.567 \\
\hline $\mathrm{ZrO}_{2}$ & 63.287 & 65.041 & 64.335 & 65.384 & 63.027 & 65.264 & 64.844 & 60.200 & 64.989 & 65.025 & 65.288 & 64.800 \\
\hline $\mathrm{HfO}_{2}$ & 1.532 & 1.517 & 1.549 & 1.769 & 1.567 & 1.274 & 1.430 & 1.565 & 1.007 & 1.268 & 1.350 & 1.393 \\
\hline $\mathrm{P}_{2} \mathrm{O}_{5}$ & 0.291 & 0.108 & 0.137 & 0.174 & 0.111 & 0.061 & 0.097 & 0.097 & 0.045 & 0.076 & 0.064 & 0.019 \\
\hline $\mathrm{ThO}_{2}$ & 0.161 & 0.089 & 0.000 & 0.027 & 0.000 & 0.049 & 0.061 & 0.038 & 0.030 & 0.045 & 0.015 & 0.056 \\
\hline $\mathrm{Al}_{2} \mathrm{O}_{3}$ & 0.290 & 0.000 & 0.080 & 0.009 & 0.024 & 0.008 & 0.001 & 0.007 & 0.009 & 0.011 & 0.023 & 0.006 \\
\hline $\mathrm{La}_{2} \mathrm{O}_{3}$ & 0.000 & 0.049 & 0.033 & 0.000 & 0.068 & 0.031 & 0.013 & 0.000 & 0.086 & 0.000 & 0.007 & 0.025 \\
\hline $\mathrm{Ce}_{2} \mathrm{O}_{3}$ & 0.026 & 0.000 & 0.012 & 0.000 & 0.016 & 0.000 & 0.000 & 0.016 & 0.000 & 0.000 & 0.023 & 0.028 \\
\hline $\mathrm{MgO}$ & 0.017 & 0.021 & 0.026 & 0.024 & 0.000 & 0.015 & 0.018 & 0.007 & 0.024 & 0.014 & 0.017 & 0.003 \\
\hline $\mathrm{CaO}$ & 0.044 & 0.000 & 0.000 & 0.000 & 0.000 & 0.000 & 0.000 & 0.001 & 0.002 & 0.006 & 0.000 & 0.000 \\
\hline $\mathrm{FeO}$ & 0.418 & 0.046 & 0.066 & 0.000 & 0.052 & 0.066 & 0.000 & 0.097 & 0.019 & 0.038 & 0.112 & 0.038 \\
\hline $\mathrm{Na}_{2} \mathrm{O}$ & 0.000 & 0.000 & 0.000 & 0.000 & 0.000 & 0.000 & 0.000 & 0.000 & 0.000 & 0.000 & 0.000 & 0.000 \\
\hline Total & 97.129 & 99.085 & 98.245 & 99.876 & 96.177 & 99.258 & 98.896 & 99.532 & 99.538 & 99.110 & 99.209 & 98.935 \\
\hline
\end{tabular}

Tabela 4: Dados de química de zircão de metassedimentos do Domínio São Roque, obtidos via Microssonda Eletrônica. 
Meta-quartzo arenitos de região da Serra do Pirucaia

\begin{tabular}{|c|c|c|c|c|c|c|c|c|c|c|c|c|}
\hline & \multicolumn{12}{|c|}{ Meta-quartzo arenitos de região da Serra do Pirucaia } \\
\hline Microssonda no & \begin{tabular}{|l|l}
$J P 1911$ \\
\end{tabular} & \begin{tabular}{|l|l|l}
$J P 19$ & 12 \\
\end{tabular} & JP19 13 & JP19 14 & JP1915 & JP19 16 a & JP19 16 b & JP19 17 & JP19 18 a & JP19 $18 \mathrm{~b}$ & JP19 19 a & JP19 $19 \mathrm{~b}$ \\
\hline U-Pb n은 & 16.1 & 17.1 & 14.1 & 53.1 & 52.1 & 46.2 & 46.1 & 48.1 & 44.1 & - & 38.2 & 38.1 \\
\hline Idades 207Pb/206Pb & 3.0 & 2.4 & 2.3 & 2.9 & 2.2 & 2.3 & 2.2 & 2.1 & 2.5 & - & 1.9 & 0.7 \\
\hline LA-ICPMS no & $11 a$ & $12 b$ & $13 b$ & $14 \mathrm{~b}$ & $15 a$ & $16 a$ & $16 b$ & $17 \mathrm{~b}$ & $18 a$ & $18 \mathrm{~b}$ & 22 mapa & 22 mapa \\
\hline Feições & nucleo & borda & borda & borda & nucleo & nucleo & borda & borda & nucleo & borda & nucleo & borda \\
\hline $\mathrm{SiO}_{2}$ & 32.718 & 32.490 & 32.241 & 32.656 & 32.858 & 32.466 & 32.659 & 32.658 & 32.604 & 32.699 & 32.527 & 32.320 \\
\hline $\mathrm{ZrO}_{2}$ & 64.500 & 65.587 & 64.546 & 65.103 & 65.181 & 65.459 & 65.186 & 65.435 & 65.472 & 65.377 & 65.349 & 64.211 \\
\hline $\mathrm{HfO}_{2}$ & 1.692 & 1.149 & 1.165 & 1.214 & 1.207 & 1.495 & 1.647 & 1.556 & 1.283 & 1.573 & 1.365 & 1.947 \\
\hline $\mathrm{P}_{2} \mathrm{O}_{5}$ & 0.079 & 0.053 & 0.046 & 0.097 & 0.049 & 0.074 & 0.085 & 0.097 & 0.094 & 0.098 & 0.037 & 0.145 \\
\hline $\mathrm{ThO}_{2}$ & 0.009 & 0.011 & 0.053 & 0.123 & 0.000 & 0.000 & 0.050 & 0.000 & 0.000 & 0.000 & 0.107 & 0.037 \\
\hline $\mathrm{Al}_{2} \mathrm{O}_{3}$ & 0.004 & 0.009 & 0.000 & 0.000 & 0.010 & 0.011 & 0.000 & 0.007 & 0.002 & 0.000 & 0.002 & 0.007 \\
\hline $\mathrm{La}_{2} \mathrm{O}_{3}$ & 0.000 & 0.012 & 0.000 & 0.000 & 0.000 & 0.000 & 0.000 & 0.000 & 0.043 & 0.000 & 0.046 & 0.030 \\
\hline $\mathrm{Ce}_{2} \mathrm{O}_{3}$ & 0.031 & 0.000 & 0.000 & 0.031 & 0.011 & 0.000 & 0.000 & 0.000 & 0.033 & 0.000 & 0.000 & 0.017 \\
\hline $\mathrm{MgO}$ & 0.033 & 0.009 & 0.020 & 0.010 & 0.001 & 0.012 & 0.005 & 0.012 & 0.026 & 0.018 & 0.027 & 0.005 \\
\hline $\mathrm{CaO}$ & 0.000 & 0.000 & 0.000 & 0.000 & 0.000 & 0.000 & 0.000 & 0.000 & 0.000 & 0.006 & 0.000 & 0.000 \\
\hline $\mathrm{FeO}$ & 0.000 & 0.000 & 0.014 & 0.016 & 0.000 & 0.000 & 0.000 & 0.000 & 0.033 & 0.041 & 0.068 & 0.000 \\
\hline $\mathrm{Na}_{2} \mathrm{O}$ & 0.000 & 0.000 & 0.000 & 0.000 & 0.000 & 0.000 & 0.000 & 0.000 & 0.000 & 0.000 & 0.000 & 0.000 \\
\hline Total & 99.066 & 99.320 & 98.085 & 99.250 & 99.317 & 99.517 & 99.632 & 99.765 & 99.590 & 99.812 & 99.528 & 98.719 \\
\hline
\end{tabular}

Tabela 4: Dados de química de zircão de metassedimentos do Domínio São Roque, obtidos via Microssonda Eletrônica. 


\begin{tabular}{|c|c|c|c|c|c|c|c|c|c|c|c|}
\hline & \multicolumn{11}{|c|}{ Meta-quartzo arenitos de região da Serra do Pirucaia } \\
\hline Microssonda no & JP19 20 & JP19 21 a & JP19 21 b & JP19 22 a & JP19 22 b & JP19 23 a & JP19 23 b & JP19 24 & JP19 25 & JP19 26 & JP19 27 \\
\hline U-Pb no & 40.1 & - & - & - & - & 30.1 & - & 27.1 & 19.1 & 18.1 & 22.1 \\
\hline Idades $207 \mathrm{~Pb} / 206 \mathrm{~Pb}$ & 2.1 & - & - & - & - & 2.5 & - & 1.9 & 2.1 & 2.0 & 2.6 \\
\hline LA-ICPMS no & $19 b$ & - & - & 24 mapa & 24 mapa & - & - & $21 a$ & - & - & - \\
\hline Feições & borda & nucleo & borda & nucleo & borda & nucleo & borda & nucleo & nucleo & nucleo & nucleo \\
\hline $\mathrm{SiO}_{2}$ & 32.465 & 32.424 & 32.916 & 32.381 & 32.338 & 32.758 & 30.738 & 32.590 & 34.800 & 32.262 & 32.507 \\
\hline $\mathrm{ZrO}_{2}$ & 65.098 & 65.240 & 64.068 & 65.416 & 65.362 & 64.587 & 62.017 & 65.331 & 63.215 & 64.278 & 65.054 \\
\hline $\mathrm{HfO}_{2}$ & 1.438 & 1.155 & 1.937 & 1.512 & 1.405 & 1.178 & 1.912 & 1.221 & 1.371 & 0.945 & 0.918 \\
\hline $\mathrm{P}_{2} \mathrm{O}_{5}$ & 0.183 & 0.048 & 0.106 & 0.122 & 0.020 & 0.065 & 0.258 & 0.064 & 0.091 & 0.092 & 0.060 \\
\hline $\mathrm{ThO}_{2}$ & 0.087 & 0.005 & 0.074 & 0.028 & 0.000 & 0.000 & 0.000 & 0.066 & 0.070 & 0.000 & 0.064 \\
\hline $\mathrm{Al}_{2} \mathrm{O}_{3}$ & 0.000 & 0.032 & 0.086 & 0.002 & 0.000 & 0.000 & 0.066 & 0.005 & 0.022 & 0.008 & 0.029 \\
\hline $\mathrm{La}_{2} \mathrm{O}_{3}$ & 0.000 & 0.020 & 0.002 & 0.064 & 0.000 & 0.008 & 0.000 & 0.000 & 0.000 & 0.033 & 0.000 \\
\hline $\mathrm{Ce}_{2} \mathrm{O}_{3}$ & 0.000 & 0.000 & 0.055 & 0.000 & 0.026 & 0.000 & 0.000 & 0.000 & 0.000 & 0.000 & 0.030 \\
\hline $\mathrm{MgO}$ & 0.018 & 0.010 & 0.002 & 0.003 & 0.016 & 0.000 & 0.000 & 0.024 & 0.010 & 0.018 & 0.022 \\
\hline $\mathrm{CaO}$ & 0.000 & 0.000 & 0.000 & 0.001 & 0.000 & 0.000 & 0.030 & 0.000 & 0.000 & 0.000 & 0.000 \\
\hline $\mathrm{FeO}$ & 0.014 & 0.000 & 0.060 & 0.000 & 0.046 & 0.030 & 0.000 & 0.008 & 0.060 & 0.019 & 0.066 \\
\hline $\mathrm{Na}_{2} \mathrm{O}$ & 0.000 & 0.000 & 0.000 & 0.000 & 0.000 & 0.000 & 0.000 & 0.000 & 0.000 & 0.000 & 0.000 \\
\hline Total & 99.303 & 98.934 & 99.306 & 99.529 & 99.213 & 98.626 & 95.021 & 99.309 & 99.639 & 97.655 & 98.750 \\
\hline
\end{tabular}

Tabela 4: Dados de química de zircão de metassedimentos do Domínio São Roque, obtidos via Microssonda Eletrônica. 


\begin{tabular}{|c|c|c|c|c|c|c|c|c|c|c|c|c|}
\hline & \multicolumn{12}{|c|}{ Metarcóseos da região da Serra do Voturuna } \\
\hline Microssonda no & VT03 1 & VT03 2 a & VT03 2 b & VT03 3 & VT03 4 & VT03 5 & VT03 6 & \begin{tabular}{|l|l} 
VT03 7 \\
\end{tabular} & VT03 8 & VT03 9 & VT03 10 & VT0311 \\
\hline U-Pb no & 5.1 & - & 4.1 & 3.1 & 1.1 & 10.1 & 20.1 & 23.1 & - & 7.1 & 15.1 & 25.1 \\
\hline Idades $207 \mathrm{~Pb} / 206 \mathrm{~Pb}$ & 3.0 & - & 2.2 & 2.1 & 2.2 & 1.6 & 2.4 & 2.4 & - & 2.5 & 2.2 & 2.5 \\
\hline LA-ICPMS no & $1 \mathrm{a}$ & $2 a$ & $2 \mathrm{~b}$ & $3 a$ & $5 a$ & - & $7 a$ & $6 b$ & $9 a$ & $11 a$ & $12 b$ & $13 a$ \\
\hline Feições & nucleo & nucleo & borda & nucleo & nucleo & borda & nucleo & borda & nucleo & nucleo & borda & nucleo \\
\hline $\mathrm{SiO}_{2}$ & 32.602 & 32.063 & 32.418 & 32.512 & 32.543 & 28.887 & 32.321 & 32.557 & 32.345 & 32.562 & 32.383 & 32.444 \\
\hline $\mathrm{ZrO}_{2}$ & 65.082 & 64.139 & 65.508 & 65.573 & 65.221 & 58.601 & 65.094 & 65.387 & 64.908 & 65.419 & 65.556 & 64.980 \\
\hline $\mathrm{HfO}_{2}$ & 1.270 & 1.549 & 1.428 & 1.289 & 1.230 & 1.668 & 1.563 & 1.164 & 1.389 & 1.280 & 0.958 & 1.243 \\
\hline $\mathrm{P}_{2} \mathrm{O}_{5}$ & 0.152 & 0.103 & 0.115 & 0.084 & 0.100 & 0.211 & 0.078 & 0.092 & 0.041 & 0.063 & 0.117 & 0.004 \\
\hline $\mathrm{ThO}_{2}$ & 0.027 & 0.092 & 0.000 & 0.076 & 0.077 & 0.063 & 0.073 & 0.018 & 0.057 & 0.026 & 0.000 & 0.049 \\
\hline $\mathrm{Al}_{2} \mathrm{O}_{3}$ & 0.005 & 0.038 & 0.035 & 0.000 & 0.000 & 0.264 & 0.001 & 0.023 & 0.006 & 0.009 & 0.002 & 0.004 \\
\hline $\mathrm{La}_{2} \mathrm{O}_{3}$ & 0.000 & 0.000 & 0.000 & 0.000 & 0.000 & 0.046 & 0.000 & 0.007 & 0.000 & 0.000 & 0.000 & 0.000 \\
\hline $\mathrm{Ce}_{2} \mathrm{O}_{3}$ & 0.016 & 0.000 & 0.000 & 0.000 & 0.000 & 0.097 & 0.000 & 0.000 & 0.000 & 0.000 & 0.000 & 0.000 \\
\hline $\mathrm{MgO}$ & 0.000 & 0.026 & 0.016 & 0.016 & 0.001 & 0.060 & 0.002 & 0.017 & 0.016 & 0.021 & 0.020 & 0.017 \\
\hline $\mathrm{CaO}$ & 0.000 & 0.000 & 0.002 & 0.000 & 0.000 & 0.788 & 0.005 & 0.003 & 0.000 & 0.003 & 0.000 & 0.003 \\
\hline $\mathrm{FeO}$ & 0.000 & 0.088 & 0.055 & 0.000 & 0.000 & 1.536 & 0.008 & 0.107 & 0.000 & 0.041 & 0.000 & 0.000 \\
\hline $\mathrm{Na}_{2} \mathrm{O}$ & 0.000 & 0.000 & 0.000 & 0.000 & 0.000 & 0.000 & 0.000 & 0.000 & 0.000 & 0.000 & 0.000 & 0.000 \\
\hline Total & 99.154 & 98.098 & 99.577 & 99.550 & 99.172 & 92.221 & 99.145 & 99.375 & 98.762 & 99.424 & 99.036 & 98.744 \\
\hline
\end{tabular}

Tabela 4: Dados de química de zircão de metassedimentos do Domínio São Roque, obtidos via Microssonda Eletrônica. 


\begin{tabular}{|c|c|c|c|c|c|c|c|c|c|c|c|}
\hline & \multicolumn{11}{|c|}{ Metarcóseos da região da Serra do Voturuna } \\
\hline Microssonda no & VT03 12 & VT0313 & VT03 14 & VT03 15 & VT03 16 & VT03 17 & |VT03 18 & \begin{tabular}{|l|l} 
VT03 19 \\
\end{tabular} & VT03 20 & VT03 21 & VT03 22 \\
\hline $\mathrm{U}-\mathrm{Pb} \mathrm{n}^{\circ}$ & 24.1 & 27.1 & 29.1 & 30.1 & 35.1 & 37.1 & 40.1 & 46.1 & 55.1 & 61.1 & 66.1 \\
\hline Idades $207 \mathrm{~Pb} / 206 \mathrm{~Pb}$ & 1.7 & 2.9 & 2.5 & 2.0 & 2.9 & 2.5 & 2.5 & 2.0 & 2.3 & 2.2 & 2.7 \\
\hline LA-ICPMS no & - & - & - & - & $14 a$ & - & - & $17 \mathrm{~b}$ & - & $20 b$ & - \\
\hline Feições & nucleo & borda & borda & borda & nucleo & borda & nucleo & borda & nucleo & borda & nucleo \\
\hline $\mathrm{SiO}_{2}$ & 32.460 & 32.110 & 32.374 & 32.062 & 32.233 & 32.451 & 32.375 & 32.432 & 32.446 & 32.375 & 31.562 \\
\hline $\mathrm{ZrO}_{2}$ & 65.171 & 64.730 & 65.209 & 64.186 & 64.877 & 64.864 & 64.721 & 64.899 & 64.572 & 64.551 & 63.459 \\
\hline $\mathrm{HfO}_{2}$ & 1.574 & 1.544 & 1.494 & 1.248 & 1.312 & 1.717 & 1.453 & 1.285 & 1.561 & 1.195 & 1.239 \\
\hline $\mathbf{P}_{2} \mathbf{O}_{5}$ & 0.062 & 0.063 & 0.077 & 0.126 & 0.266 & 0.047 & 0.034 & 0.110 & 0.043 & 0.074 & 0.137 \\
\hline $\mathrm{ThO}_{2}$ & 0.004 & 0.000 & 0.000 & 0.058 & 0.045 & 0.000 & 0.009 & 0.054 & 0.041 & 0.041 & 0.001 \\
\hline $\mathrm{Al}_{2} \mathrm{O}_{3}$ & 0.007 & 0.010 & 0.000 & 0.010 & 0.000 & 0.011 & 0.000 & 0.002 & 0.010 & 0.016 & 0.042 \\
\hline $\mathrm{La}_{2} \mathrm{O}_{3}$ & 0.008 & 0.000 & 0.025 & 0.000 & 0.041 & 0.000 & 0.000 & 0.010 & 0.079 & 0.000 & 0.000 \\
\hline $\mathrm{Ce}_{2} \mathrm{O}_{3}$ & 0.006 & 0.003 & 0.020 & 0.000 & 0.000 & 0.009 & 0.037 & 0.000 & 0.000 & 0.000 & 0.016 \\
\hline $\mathrm{MgO}$ & 0.000 & 0.003 & 0.023 & 0.016 & 0.017 & 0.000 & 0.014 & 0.011 & 0.022 & 0.032 & 0.016 \\
\hline $\mathrm{CaO}$ & 0.000 & 0.009 & 0.000 & 0.000 & 0.006 & 0.000 & 0.015 & 0.002 & 0.000 & 0.008 & 0.020 \\
\hline $\mathrm{FeO}$ & 0.057 & 0.000 & 0.014 & 0.320 & 0.000 & 0.000 & 0.022 & 0.025 & 0.101 & 0.000 & 0.255 \\
\hline $\mathrm{Na}_{2} \mathrm{O}$ & 0.000 & 0.000 & 0.000 & 0.000 & 0.000 & 0.000 & 0.000 & 0.000 & 0.000 & 0.000 & 0.000 \\
\hline Total & 99.349 & 98.472 & 99.236 & 98.026 & 98.797 & 99.099 & 98.680 & 98.830 & 98.875 & 98.292 & 96.747 \\
\hline
\end{tabular}

Tabela 4: Dados de química de zircão de metassedimentos do Domínio São Roque, obtidos via Microssonda Eletrônica. 


\begin{tabular}{|c|c|c|c|c|c|c|c|c|c|c|c|c|}
\hline & \multicolumn{12}{|c|}{ Meta-subarcóseos da região da Serra da Viúva } \\
\hline Microssonda no & VT04 1 & VT04 2 & VT04 3 & VT04 4 & VT04 5 & VT04 6 & VT04 7 & VT04 8 & VT04 9 & VT0410 & VT04 11 & VT04 12 a \\
\hline U-Pb no & 10.1 & 1.1 & 9.1 & 7.2 & - & 4.1 & 6.1 & 14.1 & 5.1 & 13.1 & 12.1 & - \\
\hline Idades $207 \mathrm{~Pb} / 206 \mathrm{~Pb}$ & 2.9 & 2.2 & 2.4 & 2.5 & - & 2.2 & 1.8 & 2.2 & 2.2 & 1.8 & 2.2 & - \\
\hline LA-ICPMS no & $1 \mathrm{~b}$ & $2 b$ & $3 a$ & $4 a$ & $5 a$ & $6 b$ & $7 b$ & $8 a$ & $9 a$ & $10 \mathrm{~b}$ & $11 b$ & $12 a$ \\
\hline Feições & borda & borda & nucleo & nucleo & nucleo & borda & borda & nucleo & nucleo & borda & borda & nucleo \\
\hline $\mathrm{SiO}_{2}$ & 32.723 & 32.669 & 32.517 & 32.388 & 32.330 & 32.639 & 32.651 & 32.089 & 32.867 & 32.067 & 32.177 & 32.364 \\
\hline $\mathrm{ZrO}_{2}$ & 65.481 & 65.191 & 65.060 & 64.787 & 64.777 & 65.531 & 65.379 & 64.595 & 65.403 & 64.058 & 65.307 & 64.822 \\
\hline $\mathrm{HfO}_{2}$ & 1.308 & 1.159 & 1.310 & 1.033 & 1.360 & 1.223 & 1.372 & 1.147 & 1.284 & 1.700 & 1.069 & 1.532 \\
\hline $\mathrm{P}_{2} \mathrm{O}_{5}$ & 0.061 & 0.094 & 0.117 & 0.075 & 0.123 & 0.074 & 0.052 & 0.082 & 0.080 & 0.109 & 0.073 & 0.086 \\
\hline $\mathrm{ThO}_{2}$ & 0.095 & 0.003 & 0.014 & 0.118 & 0.046 & 0.079 & 0.000 & 0.005 & 0.000 & 0.000 & 0.037 & 0.014 \\
\hline $\mathrm{Al}_{2} \mathrm{O}_{3}$ & 0.001 & 0.016 & 0.011 & 0.008 & 0.021 & 0.000 & 0.008 & 0.008 & 0.004 & 0.022 & 0.023 & 0.006 \\
\hline $\mathrm{La}_{2} \mathrm{O}_{3}$ & 0.033 & 0.023 & 0.010 & 0.000 & 0.000 & 0.000 & 0.000 & 0.008 & 0.061 & 0.000 & 0.010 & 0.013 \\
\hline $\mathrm{Ce}_{2} \mathrm{O}_{3}$ & 0.000 & 0.000 & 0.030 & 0.000 & 0.000 & 0.028 & 0.000 & 0.000 & 0.002 & 0.003 & 0.066 & 0.000 \\
\hline $\mathrm{MgO}$ & 0.033 & 0.004 & 0.013 & 0.000 & 0.034 & 0.022 & 0.013 & 0.015 & 0.006 & 0.025 & 0.003 & 0.009 \\
\hline $\mathrm{CaO}$ & 0.000 & 0.000 & 0.000 & 0.002 & 0.003 & 0.000 & 0.000 & 0.000 & 0.000 & 0.000 & 0.000 & 0.000 \\
\hline $\mathrm{FeO}$ & 0.038 & 0.027 & 0.000 & 0.000 & 0.047 & 0.000 & 0.000 & 0.049 & 0.025 & 0.000 & 0.000 & 0.057 \\
\hline $\mathrm{Na}_{2} \mathrm{O}$ & 0.000 & 0.000 & 0.000 & 0.000 & 0.000 & 0.000 & 0.000 & 0.000 & 0.000 & 0.000 & 0.000 & 0.000 \\
\hline Total & 99.773 & 99.186 & 99.082 & 98.411 & 98.741 & 99.596 & 99.475 & 97.998 & 99.732 & 97.984 & 98.765 & 98.903 \\
\hline
\end{tabular}

Tabela 4: Dados de química de zircão de metassedimentos do Domínio São Roque, obtidos via Microssonda Eletrônica. 


\begin{tabular}{|c|c|c|c|c|c|c|c|c|c|c|c|c|}
\hline & \multicolumn{12}{|c|}{ Meta-subarcóseos da região da Serra da Viúva } \\
\hline Microssonda $\mathrm{n}^{\circ}$ & VT04 12 b & VT04 13 & VT04 14 & VT04 15 & VT04 16 & VT04 17 & VT04 18 & VT04 19 & VT04 20 & VT04 21 & VT04 22 & VT04 23 \\
\hline U-Pb no & 11.1 & 20.1 & 21.1 & - & - & 24.1 & - & 23.1 & 22.1 & 30.2 & 31.1 & 40.1 \\
\hline Idades $207 \mathrm{~Pb} / 206 \mathrm{~Pb}$ & 2.5 & 2.5 & 1.8 & - & - & 2.7 & - & 2.2 & 2.2 & 3.3 & 1.8 & 2.2 \\
\hline LA-ICPMS no & $12 b$ & - & $13 b$ & $14 a$ & $15 a$ & $17 b$ & $18 a$ & $19 b$ & $20 b$ & - & $21 b$ & $22 a$ \\
\hline Feições & borda & nucleo & borda & nucleo & nucleo & borda & nucleo & borda & borda & borda & borda & nucleo \\
\hline $\mathrm{SiO}_{2}$ & 32.415 & 31.969 & 32.217 & 32.437 & 32.441 & 32.774 & 32.591 & 32.673 & 32.542 & 32.246 & 32.774 & 32.517 \\
\hline $\mathrm{ZrO}_{2}$ & 64.856 & 64.170 & 64.775 & 64.509 & 65.628 & 65.157 & 65.032 & 65.307 & 65.149 & 64.783 & 65.008 & 65.167 \\
\hline $\mathrm{HfO}_{2}$ & 1.075 & 1.294 & 1.152 & 1.418 & 1.176 & 1.786 & 1.293 & 1.100 & 1.422 & 1.521 & 1.231 & 1.302 \\
\hline $\mathrm{P}_{2} \mathrm{O}_{5}$ & 0.108 & 0.078 & 0.071 & 0.078 & 0.066 & 0.083 & 0.046 & 0.072 & 0.092 & 0.037 & 0.053 & 0.112 \\
\hline $\mathrm{ThO}_{2}$ & 0.079 & 0.061 & 0.053 & 0.037 & 0.000 & 0.053 & 0.000 & 0.043 & 0.000 & 0.100 & 0.042 & 0.018 \\
\hline $\mathrm{Al}_{2} \mathrm{O}_{3}$ & 0.012 & 0.000 & 0.017 & 0.019 & 0.014 & 0.015 & 0.000 & 0.000 & 0.000 & 0.029 & 0.016 & 0.002 \\
\hline $\mathrm{La}_{2} \mathrm{O}_{3}$ & 0.003 & 0.000 & 0.003 & 0.000 & 0.002 & 0.000 & 0.000 & 0.012 & 0.000 & 0.030 & 0.043 & 0.000 \\
\hline $\mathrm{Ce}_{2} \mathrm{O}_{3}$ & 0.000 & 0.064 & 0.000 & 0.094 & 0.000 & 0.072 & 0.011 & 0.000 & 0.019 & 0.062 & 0.000 & 0.042 \\
\hline $\mathrm{MgO}$ & 0.016 & 0.019 & 0.022 & 0.014 & 0.012 & 0.014 & 0.011 & 0.009 & 0.020 & 0.017 & 0.016 & 0.014 \\
\hline $\mathrm{CaO}$ & 0.000 & 0.000 & 0.002 & 0.000 & 0.000 & 0.000 & 0.000 & 0.000 & 0.000 & 0.000 & 0.000 & 0.000 \\
\hline $\mathrm{FeO}$ & 0.088 & 0.060 & 0.000 & 0.000 & 0.019 & 0.000 & 0.000 & 0.025 & 0.027 & 0.459 & 0.088 & 0.000 \\
\hline $\mathrm{Na}_{2} \mathrm{O}$ & 0.000 & 0.000 & 0.000 & 0.000 & 0.000 & 0.000 & 0.000 & 0.000 & 0.000 & 0.000 & 0.000 & 0.000 \\
\hline Total & 98.652 & 97.715 & 98.312 & 98.606 & 99.358 & 99.954 & 98.984 & 99.241 & 99.271 & 99.284 & 99.271 & 99.174 \\
\hline
\end{tabular}

Tabela 4: Dados de química de zircão de metassedimentos do Domínio São Roque, obtidos via Microssonda Eletrônica. 


\begin{tabular}{|c|c|c|c|c|c|c|c|c|c|c|c|c|}
\hline & \multicolumn{12}{|c|}{ Meta-subarcóseos da região da Serra da Viúva } \\
\hline Microssonda no & VT04 24 & VT04 25 & VT04 26 & VT04 27 & VT04 28 & VT04 29 & VT04 30 & VT04 31 & VT04 32 & VT04 33 & VT04 34 & VT04 35 \\
\hline $\mathrm{U}-\mathrm{Pb} \mathrm{n}^{\circ}$ & 41.1 & 42.1 & 36.1 & 38.1 & 44.1 & 47.1 & 54.1 & - & 57.1 & 63.1 & - & 64.1 \\
\hline Idades $207 \mathrm{~Pb} / 206 \mathrm{~Pb}$ & 2.3 & 2.2 & 1.8 & 2.3 & 2.0 & 2.2 & 2.3 & - & 2.2 & 2.3 & - & 2.3 \\
\hline LA-ICPMS no & $23 b$ & $24 a$ & $25 b$ & $26 b$ & $27 a$ & $31 b$ & $30 b$ & $29 b$ & $28 b$ & - & - & $34 a$ \\
\hline Feições & borda & nucleo & borda & borda & nucleo & borda & borda & borda & borda & borda & nucleo & nucleo \\
\hline $\mathrm{SiO}_{2}$ & 32.610 & 32.449 & 32.327 & 32.312 & 32.290 & 32.480 & 32.188 & 32.178 & 32.246 & 32.259 & 31.721 & 32.321 \\
\hline $\mathrm{ZrO}_{2}$ & 65.293 & 64.901 & 64.703 & 64.016 & 64.286 & 64.400 & 64.501 & 64.354 & 63.630 & 64.379 & 63.725 & 64.581 \\
\hline $\mathrm{HfO}_{2}$ & 1.355 & 1.388 & 1.218 & 1.325 & 1.253 & 1.027 & 1.101 & 1.282 & 1.380 & 1.152 & 1.550 & 1.324 \\
\hline $\mathrm{P}_{2} \mathrm{O}_{5}$ & 0.134 & 0.046 & 0.027 & 0.163 & 0.083 & 0.114 & 0.048 & 0.041 & 0.095 & 0.078 & 0.207 & 0.086 \\
\hline $\mathrm{ThO}_{2}$ & 0.062 & 0.026 & 0.041 & 0.027 & 0.000 & 0.000 & 0.000 & 0.000 & 0.088 & 0.080 & 0.072 & 0.127 \\
\hline $\mathrm{Al}_{2} \mathrm{O}_{3}$ & 0.026 & 0.006 & 0.004 & 0.000 & 0.019 & 0.014 & 0.016 & 0.000 & 0.024 & 0.000 & 0.062 & 0.021 \\
\hline $\mathrm{La}_{2} \mathrm{O}_{3}$ & 0.000 & 0.035 & 0.000 & 0.040 & 0.000 & 0.056 & 0.002 & 0.007 & 0.000 & 0.000 & 0.000 & 0.036 \\
\hline $\mathrm{Ce}_{2} \mathrm{O}_{3}$ & 0.094 & 0.002 & 0.108 & 0.051 & 0.020 & 0.000 & 0.000 & 0.000 & 0.000 & 0.000 & 0.020 & 0.000 \\
\hline $\mathrm{MgO}$ & 0.005 & 0.000 & 0.015 & 0.006 & 0.016 & 0.012 & 0.013 & 0.027 & 0.001 & 0.000 & 0.008 & 0.015 \\
\hline $\mathrm{CaO}$ & 0.000 & 0.000 & 0.000 & 0.000 & 0.000 & 0.000 & 0.000 & 0.000 & 0.000 & 0.000 & 0.017 & 0.000 \\
\hline $\mathrm{FeO}$ & 0.047 & 0.000 & 0.000 & 0.000 & 0.000 & 0.000 & 0.000 & 0.003 & 0.000 & 0.000 & 0.074 & 0.005 \\
\hline $\mathrm{Na}_{2} \mathrm{O}$ & 0.000 & 0.000 & 0.000 & 0.000 & 0.000 & 0.000 & 0.000 & 0.000 & 0.000 & 0.000 & 0.000 & 0.000 \\
\hline Total & 99.626 & 98.853 & 98.443 & 97.940 & 97.967 & 98.103 & 97.869 & 97.892 & 97.464 & 97.948 & 97.456 & 98.516 \\
\hline
\end{tabular}

Tabela 4: Dados de química de zircão de metassedimentos do Domínio São Roque, obtidos via Microssonda Eletrônica. 


\begin{tabular}{|c|c|c|c|c|c|c|c|c|c|c|c|c|}
\hline & \multicolumn{3}{|c|}{ Serra da Viúva } & \multicolumn{9}{|c|}{ Meta-quartzo arenitos da região do Pico do Jaraguá } \\
\hline Microssonda $\mathrm{n}^{\circ}$ & VT04 36 & VT04 37 & VT04 38 & PJ1M 1 & PJ1M 2 & PJ1M 3 & PJ1M 4 & PJ1M 5 & PJ1M 6 & PJ1M 7 & PJ1M 8 & PJ1M 9 \\
\hline $\mathrm{U}-\mathrm{Pb} \mathrm{n}^{\circ}$ & - & 68.1 & - & 1.1 & - & 6.1 & 9.1 & - & 4.1 & - & 12.1 & 11.1 \\
\hline Idades $207 \mathrm{~Pb} / 206 \mathrm{~Pb}$ & - & 3.1 & - & 0.6 & - & 2.1 & 2.7 & - & 2.1 & - & 2.2 & 2.5 \\
\hline LA-ICPMS no & $33 a$ & $32 b$ & - & $1 b$ & $2 a$ & $3 a$ & $4 a$ & $5 a$ & $6 b$ & $7 a$ & $8 a$ & $9 a$ \\
\hline Feições & nucleo & borda & nucleo & borda & nucleo & nucleo & nucleo & nucleo & borda & nucleo & nucleo & nucleo \\
\hline $\mathrm{SiO}_{2}$ & 32.582 & 32.498 & 32.397 & 31.917 & 31.991 & 32.383 & 32.179 & 32.588 & 32.513 & 32.594 & 32.400 & 32.325 \\
\hline $\mathrm{ZrO}_{2}$ & 64.978 & 65.036 & 65.020 & 64.380 & 65.124 & 64.491 & 64.368 & 65.184 & 65.278 & 65.311 & 65.301 & 64.948 \\
\hline $\mathrm{HfO}_{2}$ & 1.137 & 1.358 & 1.272 & 1.527 & 1.268 & 1.093 & 1.670 & 1.514 & 1.305 & 1.543 & 1.311 & 1.296 \\
\hline $\mathrm{P}_{2} \mathrm{O}_{5}$ & 0.053 & 0.026 & 0.101 & 0.264 & 0.109 & 0.085 & 0.074 & 0.086 & 0.071 & 0.084 & 0.083 & 0.126 \\
\hline $\mathrm{ThO}_{2}$ & 0.115 & 0.083 & 0.000 & 0.031 & 0.077 & 0.014 & 0.076 & 0.005 & 0.043 & 0.022 & 0.000 & 0.046 \\
\hline $\mathrm{Al}_{2} \mathrm{O}_{3}$ & 0.035 & 0.002 & 0.002 & 0.016 & 0.006 & 0.000 & 0.010 & 0.007 & 0.000 & 0.010 & 0.005 & 0.022 \\
\hline $\mathrm{La}_{2} \mathrm{O}_{3}$ & 0.012 & 0.008 & 0.000 & 0.012 & 0.043 & 0.003 & 0.005 & 0.000 & 0.000 & 0.086 & 0.000 & 0.000 \\
\hline $\mathrm{Ce}_{2} \mathrm{O}_{3}$ & 0.000 & 0.017 & 0.000 & 0.000 & 0.000 & 0.003 & 0.005 & 0.000 & 0.009 & 0.072 & 0.000 & 0.000 \\
\hline $\mathrm{MgO}$ & 0.022 & 0.014 & 0.020 & 0.016 & 0.020 & 0.003 & 0.032 & 0.008 & 0.000 & 0.000 & 0.027 & 0.006 \\
\hline $\mathrm{CaO}$ & 0.000 & 0.000 & 0.000 & 0.000 & 0.000 & 0.000 & 0.000 & 0.000 & 0.000 & 0.008 & 0.000 & 0.000 \\
\hline $\mathrm{FeO}$ & 0.016 & 0.000 & 0.000 & 0.000 & 0.000 & 0.000 & 0.000 & 0.000 & 0.000 & 0.000 & 0.022 & 0.085 \\
\hline $\mathrm{Na}_{2} \mathrm{O}$ & 0.000 & 0.000 & 0.000 & 0.000 & 0.000 & 0.000 & 0.000 & 0.000 & 0.000 & 0.000 & 0.000 & 0.000 \\
\hline Total & 98.950 & 99.042 & 98.812 & 98.163 & 98.638 & 98.075 & 98.419 & 99.392 & 99.219 & 99.730 & 99.149 & 98.854 \\
\hline
\end{tabular}

Tabela 4: Dados de química de zircão de metassedimentos do Domínio São Roque, obtidos via Microssonda Eletrônica. 


\begin{tabular}{|c|c|c|c|c|c|c|c|c|c|c|c|c|}
\hline & \multicolumn{12}{|c|}{ Meta-quartzo arenitos da região do Pico do Jaraguá } \\
\hline Microssonda no & PJ1M 10 & PJ1M 11 & PJ1M 12 & PJ1M 13 & PJ1M 14 & PJ1M 15 & PJ1M 16 & PJ1M 17 & PJ1M 18 & PJ1M 19 & PJ1M 20 & PJ1M 21 \\
\hline U-Pb no & - & 22.1 & 21.1 & - & 15.1 & 19.1 & - & 10.1 & - & 61.1 & 62.1 & 60.1 \\
\hline Idades $207 \mathrm{~Pb} / 206 \mathrm{~Pb}$ & - & 2.5 & 2.2 & - & 2.5 & 2.4 & - & 3.1 & - & 3.2 & $?$ & 2.2 \\
\hline LA-ICPMS no & $10 a$ & $11 \mathrm{a}$ & $12 b$ & $13 a$ & $14 a$ & $15 a$ & $16 a$ & - & 49 mapa & 50 mapa & $18 a$ & $17 b$ \\
\hline Feições & nucleo & nucleo & borda & nucleo & nucleo & nucleo & nucleo & nucleo & nucleo & nucleo & nucleo & borda \\
\hline $\mathrm{SiO}_{2}$ & 32.470 & 32.101 & 31.729 & 31.631 & 32.402 & 32.192 & 32.368 & 32.620 & 32.461 & 32.578 & 32.516 & 32.456 \\
\hline $\mathrm{ZrO}_{2}$ & 65.848 & 64.460 & 64.139 & 64.300 & 64.662 & 64.196 & 64.441 & 65.104 & 64.376 & 64.599 & 65.236 & 65.056 \\
\hline $\mathrm{HfO}_{2}$ & 1.096 & 1.466 & 1.118 & 1.375 & 1.462 & 1.585 & 1.093 & 1.531 & 1.471 & 1.801 & 1.161 & 1.496 \\
\hline $\mathrm{P}_{2} \mathrm{O}_{5}$ & 0.097 & 0.102 & 0.058 & 0.199 & 0.049 & 0.047 & 0.109 & 0.073 & 0.064 & 0.086 & 0.053 & 0.091 \\
\hline $\mathrm{ThO}_{2}$ & 0.038 & 0.000 & 0.000 & 0.054 & 0.000 & 0.053 & 0.019 & 0.050 & 0.008 & 0.076 & 0.057 & 0.000 \\
\hline $\mathrm{Al}_{2} \mathrm{O}_{3}$ & 0.015 & 0.006 & 0.014 & 0.000 & 0.001 & 0.016 & 0.006 & 0.001 & 0.007 & 0.025 & 0.025 & 0.015 \\
\hline $\mathrm{La}_{2} \mathrm{O}_{3}$ & 0.000 & 0.000 & 0.000 & 0.000 & 0.000 & 0.000 & 0.021 & 0.002 & 0.013 & 0.043 & 0.068 & 0.000 \\
\hline $\mathrm{Ce}_{2} \mathrm{O}_{3}$ & 0.000 & 0.000 & 0.000 & 0.008 & 0.000 & 0.000 & 0.000 & 0.011 & 0.000 & 0.000 & 0.000 & 0.000 \\
\hline $\mathrm{MgO}$ & 0.016 & 0.007 & 0.023 & 0.018 & 0.005 & 0.016 & 0.014 & 0.001 & 0.010 & 0.011 & 0.000 & 0.006 \\
\hline $\mathrm{CaO}$ & 0.000 & 0.000 & 0.000 & 0.000 & 0.000 & 0.000 & 0.000 & 0.000 & 0.000 & 0.000 & 0.000 & 0.000 \\
\hline $\mathrm{FeO}$ & 0.022 & 0.063 & 0.014 & 0.003 & 0.000 & 0.126 & 0.074 & 0.000 & 0.079 & 0.055 & 0.082 & 0.118 \\
\hline $\mathrm{Na}_{2} \mathrm{O}$ & 0.000 & 0.000 & 0.000 & 0.000 & 0.000 & 0.000 & 0.000 & 0.000 & 0.000 & 0.000 & 0.000 & 0.000 \\
\hline Total & 99.602 & 98.205 & 97.095 & 97.588 & 98.581 & 98.231 & 98.145 & 99.393 & 98.489 & 99.274 & 99.198 & 99.238 \\
\hline
\end{tabular}

Tabela 4: Dados de química de zircão de metassedimentos do Domínio São Roque, obtidos via Microssonda Eletrônica. 
Meta-quartzo arenitos da região do Pico do Jaraguá

\begin{tabular}{|c|c|c|c|c|c|c|c|c|c|c|c|c|}
\hline & \multicolumn{12}{|c|}{ Meta-quartzo arenitos da região do Pico do Jaraguá } \\
\hline Microssonda no & PJ1M 22 & PJ1M 23 & PJ1M 24 & PJ1M 25 & PJ1M 26 & PJ1M 27 & PJ1M 28 & PJ1M 29 & PJ1M 30 & PJ1M 31 & PJ1M 32 & PJ1M 33 \\
\hline U-Pb no & - & - & - & 28.1 & 29.1 & - & - & - & 36.1 & 23.1 & 35.1 & - \\
\hline Idades 207Pb/206Pb & - & - & - & 2.7 & 2.2 & - & - & - & 2.2 & 2.2 & 2.5 & - \\
\hline LA-ICPMS no $^{\circ}$ & $19 b$ & - & $20 b$ & $21 a$ & $22 a$ & $23 a$ & $24 a$ & $25 b$ & $26 b$ & $29 a$ & $27 b$ & $32 a$ \\
\hline Feições & borda & metamítico & borda & nucleo & nucleo & nucleo & nucleo & borda & borda & nucleo & borda & nucleo \\
\hline $\mathrm{SiO}_{2}$ & 32.616 & 29.363 & 32.433 & 32.522 & 32.343 & 32.323 & 32.242 & 32.241 & 32.463 & 32.555 & 32.395 & 31.981 \\
\hline $\mathrm{ZrO}_{2}$ & 65.142 & 61.402 & 64.324 & 64.267 & 64.983 & 64.831 & 65.292 & 64.440 & 65.120 & 64.977 & 64.244 & 64.397 \\
\hline $\mathrm{HfO}_{2}$ & 1.231 & 1.699 & 1.244 & 1.685 & 1.251 & 1.301 & 1.196 & 1.536 & 1.464 & 1.044 & 1.467 & 1.827 \\
\hline $\mathrm{P}_{2} \mathrm{O}_{5}$ & 0.053 & 1.131 & 0.045 & 0.202 & 0.096 & 0.105 & 0.105 & 0.094 & 0.042 & 0.034 & 0.064 & 0.239 \\
\hline $\mathrm{ThO}_{2}$ & 0.065 & 0.266 & 0.087 & 0.016 & 0.054 & 0.033 & 0.000 & 0.118 & 0.058 & 0.019 & 0.000 & 0.018 \\
\hline $\mathrm{Al}_{2} \mathrm{O}_{3}$ & 0.008 & 0.611 & 0.022 & 0.007 & 0.004 & 0.001 & 0.009 & 0.008 & 0.003 & 0.008 & 0.000 & 0.089 \\
\hline $\mathrm{La}_{2} \mathrm{O}_{3}$ & 0.000 & 0.079 & 0.000 & 0.000 & 0.000 & 0.000 & 0.005 & 0.015 & 0.005 & 0.015 & 0.056 & 0.086 \\
\hline $\mathrm{Ce}_{2} \mathrm{O}_{3}$ & 0.014 & 0.128 & 0.000 & 0.000 & 0.000 & 0.033 & 0.067 & 0.000 & 0.000 & 0.000 & 0.022 & 0.005 \\
\hline $\mathrm{MgO}$ & 0.027 & 0.022 & 0.009 & 0.014 & 0.015 & 0.023 & 0.018 & 0.000 & 0.036 & 0.000 & 0.019 & 0.016 \\
\hline $\mathrm{CaO}$ & 0.007 & 0.295 & 0.000 & 0.003 & 0.001 & 0.006 & 0.000 & 0.004 & 0.000 & 0.003 & 0.000 & 0.013 \\
\hline $\mathrm{FeO}$ & 0.000 & 0.831 & 0.071 & 0.000 & 0.033 & 0.038 & 0.011 & 0.000 & 0.060 & 0.005 & 0.000 & 0.202 \\
\hline $\mathrm{Na}_{2} \mathrm{O}$ & 0.000 & 0.000 & 0.000 & 0.000 & 0.000 & 0.000 & 0.000 & 0.000 & 0.000 & 0.000 & 0.000 & 0.000 \\
\hline Total & 99.163 & 95.827 & 98.235 & 98.716 & 98.780 & 98.694 & 98.945 & 98.456 & 99.251 & 98.660 & 98.267 & 98.873 \\
\hline
\end{tabular}

Tabela 4: Dados de química de zircão de metassedimentos do Domínio São Roque, obtidos via Microssonda Eletrônica. 


\begin{tabular}{|c|c|c|c|c|c|c|c|c|c|c|c|c|}
\hline & \multicolumn{12}{|c|}{ Meta-quartzo arenitos da região do Pico do Jaraguá } \\
\hline Microssonda no & PJ1M 34 & PJ1M 35 & PJ1M 36 & PJ1M 37 a & PJ1M 37 b & PJ1M 38 a & PJ1M 38 b & PJ1M 39 & PJ1M 40 & PJ1M 41 & PJ1M 42 & PJ1M 43 \\
\hline U-Pb no & - & 40.1 & - & - & 45.1 & 48.1 & - & 46.1 & - & 47.1 & - & - \\
\hline Idades 207Pb/206Pb & - & 2.2 & - & - & 2.0 & 2.8 & - & 2.9 & - & 2.7 & - & - \\
\hline LA-ICPMS no & $33 a$ & $34 a$ & $39 b$ & 51 mapa & 51 mapa & - & - & $40 a$ & $41 b$ & - & $38 a$ & $37 a$ \\
\hline Feições & nucleo & nucleo & borda & nucleo & borda & nucleo & borda & nucleo & metamítico & nucleo & nucleo & nucleo \\
\hline $\mathrm{SiO}_{2}$ & 32.702 & 32.692 & 32.627 & 32.235 & 32.288 & 32.223 & 32.589 & 32.441 & 23.202 & 32.230 & 32.318 & 32.571 \\
\hline $\mathrm{ZrO}_{2}$ & 65.079 & 65.601 & 65.122 & 64.484 & 64.513 & 64.705 & 65.257 & 65.022 & 50.946 & 65.020 & 64.889 & 64.698 \\
\hline $\mathrm{HfO}_{2}$ & 1.184 & 0.977 & 1.178 & 1.417 & 1.946 & 1.547 & 1.419 & 1.151 & 1.353 & 1.358 & 1.258 & 1.533 \\
\hline $\mathrm{P}_{2} \mathrm{O}_{5}$ & 0.043 & 0.071 & 0.061 & 0.269 & 0.134 & 0.166 & 0.105 & 0.108 & 2.431 & 0.131 & 0.055 & 0.043 \\
\hline $\mathrm{ThO}_{2}$ & 0.000 & 0.061 & 0.069 & 0.114 & 0.000 & 0.060 & 0.056 & 0.000 & 0.081 & 0.000 & 0.031 & 0.098 \\
\hline $\mathrm{Al}_{2} \mathrm{O}_{3}$ & 0.000 & 0.000 & 0.006 & 0.087 & 0.024 & 0.030 & 0.025 & 0.015 & 1.342 & 0.022 & 0.024 & 0.023 \\
\hline $\mathrm{La}_{2} \mathrm{O}_{3}$ & 0.000 & 0.000 & 0.038 & 0.000 & 0.000 & 0.000 & 0.000 & 0.058 & 0.000 & 0.068 & 0.008 & 0.000 \\
\hline $\mathrm{Ce}_{2} \mathrm{O}_{3}$ & 0.000 & 0.000 & 0.000 & 0.000 & 0.000 & 0.011 & 0.000 & 0.000 & 0.125 & 0.005 & 0.000 & 0.005 \\
\hline $\mathrm{MgO}$ & 0.003 & 0.009 & 0.001 & 0.012 & 0.023 & 0.005 & 0.014 & 0.030 & 0.026 & 0.000 & 0.002 & 0.010 \\
\hline $\mathrm{CaO}$ & 0.000 & 0.000 & 0.000 & 0.015 & 0.000 & 0.000 & 0.006 & 0.000 & 0.438 & 0.002 & 0.000 & 0.000 \\
\hline $\mathrm{FeO}$ & 0.000 & 0.000 & 0.090 & 0.200 & 0.000 & 0.038 & 0.000 & 0.027 & 8.448 & 0.000 & 0.000 & 0.005 \\
\hline $\mathrm{Na}_{2} \mathrm{O}$ & 0.000 & 0.000 & 0.000 & 0.000 & 0.000 & 0.000 & 0.000 & 0.000 & 0.000 & 0.000 & 0.000 & 0.000 \\
\hline Total & 99.011 & 99.411 & 99.192 & 98.833 & 98.928 & 98.785 & 99.471 & 98.852 & 88.392 & 98.836 & 98.585 & 98.986 \\
\hline
\end{tabular}

Tabela 4: Dados de química de zircão de metassedimentos do Domínio São Roque, obtidos via Microssonda Eletrônica. 


\begin{tabular}{|c|c|c|c|c|c|c|c|c|c|}
\hline & \multicolumn{9}{|c|}{ Meta-quartzo arenitos da região do Pico do Jaraguá } \\
\hline Microssonda no & PJ1M 44 a & PJ1M 44 b & PJ1M 45 a & PJ1M 45 b & PJ1M 46 & PJ1M 47 & PJ1M 48 & PJ1M 49 & PJ1M 50 \\
\hline U-Pb no & - & 52.1 & - & - & 56.1 & - & 59.1 & 57.1 & - \\
\hline Idades $207 \mathrm{~Pb} / 206 \mathrm{~Pb}$ & - & 3.3 & - & - & 2.0 & - & 2.1 & 2.0 & - \\
\hline LA-ICPMS no & $43 a$ & $43 b$ & $42 a$ & $42 b$ & $44 \mathrm{~b}$ & $45 a$ & - & $47 a$ & $46 a$ \\
\hline Feições & nucleo & borda & nucleo & borda & borda & nucleo & nucleo & nucleo & nucleo \\
\hline $\mathrm{SiO}_{2}$ & 32.606 & 32.666 & 32.100 & 31.868 & 32.483 & 32.460 & 32.770 & 32.376 & 32.062 \\
\hline $\mathrm{ZrO}_{2}$ & 65.371 & 65.165 & 64.606 & 64.323 & 64.965 & 65.107 & 65.316 & 64.633 & 64.842 \\
\hline $\mathrm{HfO}_{2}$ & 1.505 & 1.491 & 1.574 & 1.608 & 1.068 & 1.325 & 1.657 & 1.462 & 1.625 \\
\hline $\mathrm{P}_{2} \mathrm{O}_{5}$ & 0.057 & 0.122 & 0.159 & 0.212 & 0.111 & 0.059 & 0.025 & 0.039 & 0.061 \\
\hline $\mathrm{ThO}_{2}$ & 0.093 & 0.052 & 0.000 & 0.016 & 0.004 & 0.000 & 0.051 & 0.062 & 0.095 \\
\hline $\mathrm{Al}_{2} \mathrm{O}_{3}$ & 0.009 & 0.010 & 0.042 & 0.070 & 0.011 & 0.000 & 0.012 & 0.020 & 0.008 \\
\hline $\mathrm{La}_{2} \mathrm{O}_{3}$ & 0.010 & 0.000 & 0.000 & 0.059 & 0.000 & 0.017 & 0.056 & 0.000 & 0.000 \\
\hline $\mathrm{Ce}_{2} \mathrm{O}_{3}$ & 0.000 & 0.034 & 0.000 & 0.017 & 0.000 & 0.003 & 0.000 & 0.006 & 0.034 \\
\hline $\mathrm{MgO}$ & 0.009 & 0.010 & 0.022 & 0.008 & 0.014 & 0.006 & 0.031 & 0.031 & 0.014 \\
\hline $\mathrm{CaO}$ & 0.000 & 0.000 & 0.026 & 0.021 & 0.000 & 0.000 & 0.000 & 0.011 & 0.000 \\
\hline $\mathrm{FeO}$ & 0.066 & 0.033 & 0.200 & 0.227 & 0.000 & 0.025 & 0.000 & 0.003 & 0.030 \\
\hline $\mathrm{Na}_{2} \mathrm{O}$ & 0.000 & 0.000 & 0.000 & 0.000 & 0.000 & 0.000 & 0.000 & 0.000 & 0.000 \\
\hline Total & 99.726 & 99.583 & 98.729 & 98.429 & 98.656 & 99.002 & 99.918 & 98.643 & 98.771 \\
\hline
\end{tabular}

Tabela 4: Dados de química de zircão de metassedimentos do Domínio São Roque, obtidos via Microssonda Eletrônica. 


\begin{tabular}{|c|c|c|c|c|c|c|c|c|c|c|c|c|}
\hline & \multicolumn{12}{|c|}{ Meta-subarcóseos de região da Serra do Japi } \\
\hline LA-ICPMS no & $1 \mathrm{a}$ & $2 a$ & $3 a$ & $5 a$ & $6 \mathrm{a}$ & $7 \mathrm{a}$ & $8 \mathrm{a}$ & $10 a$ & $11 \mathrm{a}$ & $12 \mathrm{a}$ & $13 a$ & $14 a$ \\
\hline U-Pb no & 4.10 & 45.10 & 11.20 & 9.10 & 2.10 & 5.10 & 8.10 & 10.10 & 54.10 & 47.10 & 48.10 & 13.10 \\
\hline Idades $207 \mathrm{~Pb} / 206 \mathrm{P}$ & 2.42 & 2.06 & 1.76 & 1.58 & 3.07 & 2.64 & 2.51 & 2.02 & 2.93 & 2.12 & 2.06 & 2.62 \\
\hline Feições & núcleo & núcleo & núcleo & núcleo & núcleo & núcleo & núcleo & núcleo & núcleo & núcleo & núcleo & núcleo \\
\hline$\overline{\mathrm{Si}}$ & 200727.68 & 145020.00 & 110915.30 & 146820.25 & 157521.73 & 180624.91 & 185125.53 & 155021.38 & 192126.50 & 184025.38 & 174524.07 & 170523.52 \\
\hline $\mathrm{Zr}$ & 535000.00 & 401000.00 & 300500.00 & 387300.00 & 442900.00 & 473700.00 & 477500.00 & 428900.00 & 507800.00 & 481000.00 & 454100.00 & 451900.00 \\
\hline $\mathrm{Hf}$ & 9890.00 & 9900.00 & 9950.00 & 9860.00 & 9910.00 & 9825.00 & 10010.00 & 9930.00 & 9977.00 & 9990.00 & 9950.00 & 9910.00 \\
\hline Sc & 818.00 & 614.00 & 437.00 & 621.00 & 676.00 & 712.00 & 709.00 & 652.00 & 918.00 & 730.00 & 660.00 & 637.00 \\
\hline $\mathrm{Ca}$ & 570.32 & 410.23 & 883.49 & 638.36 & 936.52 & 890.50 & 1409.79 & 634.35 & 2494.39 & 1100.61 & 959.53 & 1440.80 \\
\hline $\mathbf{Y}$ & 521.00 & 380.50 & 920.00 & 638.00 & 975.00 & 815.00 & 1535.00 & 643.00 & 2786.00 & 875.00 & 1030.00 & 1586.00 \\
\hline $\mathbf{P}$ & 210.10 & 131.50 & 133.60 & 185.70 & 264.70 & 308.00 & 206.30 & 163.50 & 792.99 & 367.00 & 174.20 & 207.20 \\
\hline $\mathrm{Yb}$ & 156.70 & 103.00 & 363.00 & 199.90 & 304.00 & 248.30 & 438.00 & 163.50 & 1078.00 & 265.90 & 252.00 & 413.00 \\
\hline Al & 23.80 & 21.64 & 19.45 & 14.02 & 339.98 & 119.99 & 24.80 & 16.08 & 50.00 & 19.70 & 23.90 & 18.80 \\
\hline $\mathrm{Fe}$ & 4.70 & 46.50 & 3.94 & 1.25 & 190.00 & 5.50 & 11.10 & 2.98 & 7.80 & 3.40 & 6.90 & 2.96 \\
\hline $\mathrm{Na}$ & 2.83 & 5.68 & 6.44 & 3.45 & 6.30 & 6.50 & 3.75 & 3.05 & 5.90 & 4.00 & 5.82 & 1.93 \\
\hline Mg & 0.06 & 0.11 & 0.03 & 0.05 & 96.01 & 0.47 & 0.06 & 0.05 & 3.50 & 0.13 & 0.06 & 0.19 \\
\hline $\mathrm{Pb}$ & 13.09 & 72.50 & 58.00 & 28.01 & 16.50 & 14.94 & 83.60 & 36.50 & 32.07 & 6.97 & 48.20 & 25.90 \\
\hline $\mathrm{Sr}$ & 0.63 & 0.55 & 0.94 & 0.66 & 0.90 & 0.98 & 1.16 & 0.64 & 2.11 & 1.17 & 0.84 & 1.06 \\
\hline La & 0.01 & 0.04 & 0.02 & 0.02 & 0.02 & 0.04 & 0.11 & 0.02 & 0.02 & 0.06 & 0.03 & 0.03 \\
\hline $\mathrm{Ce}$ & 9.85 & 18.34 & 19.85 & 30.34 & 14.66 & 51.60 & 35.18 & 18.63 & 14.85 & 25.63 & 9.88 & 9.49 \\
\hline $\mathrm{Pr}$ & 0.09 & 0.07 & 0.07 & 0.05 & 0.03 & 0.11 & 0.27 & 0.10 & 0.05 & 0.15 & 0.22 & 0.17 \\
\hline Nd & 1.47 & 1.12 & 1.09 & 1.06 & 0.75 & 1.95 & 4.23 & 1.71 & 1.22 & 2.29 & 3.86 & 3.63 \\
\hline Sm & 3.00 & 2.22 & 2.28 & 2.72 & 2.28 & 3.94 & 8.08 & 3.36 & 4.56 & 4.15 & 6.80 & 7.29 \\
\hline Eu & 0.59 & 0.56 & 0.15 & 0.43 & 0.43 & 1.00 & 1.72 & 0.38 & 2.15 & 1.05 & 0.18 & 1.22 \\
\hline Gd & 13.06 & 10.67 & 11.94 & 14.13 & 16.60 & 19.20 & 37.80 & 16.10 & 38.93 & 20.25 & 30.50 & 39.60 \\
\hline Th & 61.20 & 364.80 & 353.50 & 141.00 & 54.50 & 55.70 & 325.00 & 193.00 & 102.80 & 28.60 & 243.00 & 98.00 \\
\hline Dy & 45.50 & 34.59 & 67.90 & 55.20 & 86.30 & 76.20 & 141.00 & 58.10 & 229.40 & 79.60 & 104.00 & 154.90 \\
\hline Ho & 16.17 & 11.78 & 28.26 & 20.38 & 33.20 & 27.70 & 50.10 & 20.30 & 99.40 & 29.72 & 35.50 & 56.00 \\
\hline Er & 71.60 & 50.66 & 145.30 & 90.00 & 146.40 & 118.30 & 216.60 & 87.50 & 478.90 & 127.30 & 142.00 & 229.60 \\
\hline $\mathbf{U}$ & 92.60 & 502.30 & 487.00 & 136.70 & 79.80 & 88.90 & 462.00 & 281.00 & 385.50 & 32.30 & 424.00 & 161.70 \\
\hline Lu & 27.88 & 18.24 & 67.90 & 37.70 & 55.20 & 43.10 & 75.60 & 31.20 & 191.70 & 47.40 & 42.40 & 68.60 \\
\hline $\mathrm{Ta}$ & 0.69 & 0.81 & 7.26 & 1.60 & 0.97 & 1.81 & 2.21 & 1.91 & 0.74 & 1.21 & 1.08 & 1.71 \\
\hline $\mathrm{Nb}$ & 22.74 & 17.39 & 28.97 & 19.29 & 20.16 & 23.19 & 23.72 & 21.04 & 23.30 & 22.87 & 19.69 & 21.80 \\
\hline Ga & 0.38 & 0.62 & 0.70 & 1.02 & 0.66 & 1.77 & 1.25 & 0.66 & 0.52 & 0.89 & 0.39 & 0.42 \\
\hline $\mathrm{Tb}$ & 4.07 & 3.17 & 4.92 & 4.81 & 6.52 & 6.50 & 12.20 & 5.18 & 16.67 & 6.71 & 9.40 & 13.56 \\
\hline $\mathrm{Tm}$ & 15.89 & 10.78 & 36.58 & 20.68 & 33.00 & 26.30 & 47.20 & 18.26 & 110.20 & 28.47 & 29.30 & 46.80 \\
\hline
\end{tabular}

Tabela 5: Dados de química de zircão de metassedimentos do Domínio São Roque, obtidos via LA-Q-ICPMS. Campos em cinza representam cristais com assínaturas de zircões de gabros tipo MORB. 


\begin{tabular}{|c|c|c|c|c|c|c|c|c|c|c|c|c|}
\hline & \multicolumn{12}{|c|}{ Meta-subarcóseos de região da Serra do Japi } \\
\hline LA-ICPMS no & $14 \mathrm{~b}$ & $15 a$ & $16 \mathrm{a}$ & $17 \mathrm{a}$ & $17 \mathrm{~b}$ & $18 \mathrm{a}$ & $19 a$ & $20 a$ & $21 b$ & $22 a$ & $22 b$ & $23 a$ \\
\hline U-Pb no & 13.20 & 51.10 & - & - & 56.10 & 44.10 & 57.10 & 43.10 & 34.10 & - & 59.10 & - \\
\hline Idades 207Pb/206Р & 1.92 & 3.44 & - & - & 2.32 & $?$ & - & $?$ & $?$ & - & 2.65 & - \\
\hline Feições & borda & núcleo & núcleo & núcleo & borda & núcleo & núcleo & núcleo & borda & núcleo & borda & núcleo \\
\hline$\overline{\mathrm{Si}}$ & 174124.02 & 186125.67 & 172823.84 & 157521.73 & 165622.84 & 182725.20 & 157321.70 & 145520.07 & 166722.99 & 176724.37 & 142519.66 & 183825.35 \\
\hline $\mathrm{Zr}$ & 464000.00 & 521000.00 & 481000.00 & 441000.00 & 429000.00 & 522000.00 & 430000.00 & 390000.00 & 467000.00 & 489000.00 & 388000.00 & 498000.00 \\
\hline $\mathrm{Hf}$ & 9900.00 & 9930.00 & 9980.00 & 9820.00 & 10000.00 & 9970.00 & 10010.00 & 9950.00 & 10060.00 & 9884.00 & 10070.00 & 9970.00 \\
\hline Sc & 693.00 & 832.00 & 740.00 & 770.00 & 769.00 & 794.00 & 634.00 & 567.00 & 673.00 & 712.00 & 544.00 & 724.00 \\
\hline $\mathrm{Ca}$ & 676.38 & 618.34 & 249.14 & 902.50 & 1891.05 & 606.34 & 689.38 & 495.28 & 613.34 & 1070.60 & 557.31 & 730.41 \\
\hline $\mathbf{Y}$ & 677.00 & 640.00 & 204.40 & 978.00 & 1994.00 & 613.00 & 730.00 & 477.00 & 648.00 & 1174.00 & 562.00 & 508.00 \\
\hline $\mathbf{P}$ & 272.00 & 192.00 & 87.90 & 491.00 & 651.99 & 220.60 & 219.00 & 149.00 & 151.60 & 217.60 & 137.00 & 158.00 \\
\hline $\mathrm{Yb}$ & 223.00 & 175.00 & 49.20 & 288.00 & 497.00 & 129.70 & 218.40 & 149.00 & 168.10 & 290.00 & 155.00 & 130.00 \\
\hline Al & 19.70 & 15.82 & 21.00 & 42.90 & 248.39 & 23.30 & 62.00 & 78.00 & 20.50 & 16.91 & 16.50 & 539.98 \\
\hline $\mathrm{Fe}$ & 2.60 & 0.90 & 30.60 & 2.70 & 463.00 & 5.70 & 11.50 & 119.00 & 3.90 & 1.04 & 2.70 & 5.10 \\
\hline $\mathrm{Na}$ & 2.90 & 2.64 & 3.26 & 3.03 & 11.40 & 2.69 & 4.10 & 6.60 & 3.54 & 4.00 & 3.80 & 25.00 \\
\hline Mg & 0.17 & 0.05 & 0.14 & 0.16 & 0.66 & 0.16 & 2.70 & 0.20 & 0.19 & 0.21 & 0.17 & 0.38 \\
\hline $\mathrm{Pb}$ & 11.65 & 12.02 & 11.09 & 8.15 & 12.68 & 17.90 & 25.00 & 24.60 & 15.74 & 20.41 & 20.03 & 11.50 \\
\hline $\mathrm{Sr}$ & 0.72 & 0.70 & 0.43 & 0.86 & 1.88 & 0.59 & 1.40 & 0.71 & 0.65 & 0.87 & 0.61 & 0.91 \\
\hline La & 0.02 & 0.01 & 0.02 & 0.01 & 3.43 & 0.05 & 4.60 & 1.54 & 0.01 & 0.07 & 0.07 & 0.03 \\
\hline $\mathrm{Ce}$ & 12.40 & 12.44 & 5.06 & 6.10 & 121.20 & 58.70 & 33.00 & 42.00 & 9.21 & 10.91 & 12.11 & 6.70 \\
\hline $\mathrm{Pr}$ & 0.05 & 0.07 & 0.04 & 0.03 & 4.39 & 0.32 & 1.00 & 1.91 & 0.08 & 0.25 & 0.23 & 0.07 \\
\hline Nd & 0.95 & 1.25 & 0.72 & 0.78 & 30.30 & 5.16 & 4.30 & 11.20 & 1.44 & 3.64 & 1.96 & 1.27 \\
\hline Sm & 2.33 & 2.62 & 1.57 & 2.54 & 31.10 & 7.59 & 3.06 & 4.50 & 3.26 & 6.78 & 2.46 & 2.06 \\
\hline Eu & 0.37 & 0.77 & 0.60 & 0.30 & 15.63 & 2.53 & 0.40 & 1.54 & 0.18 & 0.61 & 0.22 & 0.26 \\
\hline Gd & 13.70 & 14.70 & 6.69 & 16.50 & 80.00 & 26.90 & 14.54 & 11.10 & 15.92 & 33.30 & 12.90 & 11.80 \\
\hline Th & 58.10 & 36.80 & 62.30 & 37.70 & 90.00 & 98.60 & 121.00 & 130.00 & 84.00 & 78.10 & 85.80 & 58.10 \\
\hline Dy & 60.10 & 56.20 & 16.90 & 88.30 & 250.00 & 67.00 & 62.10 & 37.90 & 60.30 & 115.70 & 49.10 & 44.90 \\
\hline Ho & 22.40 & 20.40 & 5.65 & 33.40 & 75.20 & 20.77 & 23.62 & 14.80 & 21.65 & 40.20 & 18.60 & 16.60 \\
\hline Er & 99.40 & 87.90 & 23.90 & 148.50 & 284.70 & 78.30 & 105.30 & 66.60 & 91.30 & 163.80 & 78.90 & 69.60 \\
\hline $\mathbf{U}$ & 176.10 & 54.10 & 313.00 & 98.00 & 166.10 & 62.60 & 89.20 & 438.00 & 168.00 & 64.60 & 119.00 & 78.10 \\
\hline Lu & 37.00 & 33.90 & 9.52 & 51.70 & 79.40 & 21.90 & 40.00 & 26.80 & 29.80 & 49.60 & 27.50 & 23.70 \\
\hline $\mathrm{Ta}$ & 1.80 & 0.75 & 0.65 & 0.44 & 0.57 & 0.92 & 1.41 & 3.54 & 2.13 & 0.62 & 1.40 & 0.49 \\
\hline $\mathrm{Nb}$ & 22.60 & 22.31 & 20.72 & 18.99 & 20.90 & 23.40 & 21.30 & 21.94 & 24.60 & 21.97 & 18.90 & 21.50 \\
\hline Ga & 0.38 & 0.45 & 0.17 & 0.22 & 4.78 & 2.00 & 1.37 & 1.54 & 0.34 & 0.42 & 0.40 & 0.38 \\
\hline $\mathrm{Tb}$ & 4.91 & 4.87 & 1.71 & 6.83 & 26.41 & 7.06 & 5.03 & 3.27 & 5.26 & 10.35 & 4.07 & 3.87 \\
\hline $\mathrm{Tm}$ & 22.30 & 18.50 & 5.09 & 31.40 & 58.30 & 14.88 & 23.58 & 15.10 & 18.89 & 33.91 & 17.10 & 14.50 \\
\hline
\end{tabular}

Tabela 5: Dados de química de zircão de metassedimentos do Domínio São Roque, obtidos via LA-Q-ICPMS. Campos em cinza representam cristais com assínaturas de zircões de gabros tipo MORB. 


\begin{tabular}{|c|c|c|c|c|c|c|c|c|c|c|c|c|}
\hline & \multicolumn{7}{|c|}{ Meta-subarcóseos de região da Serra do Japi } & \multicolumn{5}{|c|}{ Meta-quartzo arenitos da região do Pico do Jaraguá } \\
\hline LA-ICPMS no & $23 b$ & $24 a$ & $25 a$ & $27 a$ & mapa & mapa & mapa & $?$ & $2 a$ & $3 a$ & $4 a$ & $5 a$ \\
\hline U-Pb no & 60.10 & 37.10 & 38.20 & 28.10 & 14.20 & 17.10 & $?$ & $?$ & 7.10 & 6.10 & 9.10 & 3.10 \\
\hline Idades 207Pb/206P & 2.09 & - & $?$ & 2.18 & 3.17 & 1.98 & $?$ & $?$ & 2.24 & 2.11 & 2.74 & 2.07 \\
\hline Feições & borda & núcleo & núcleo & núcleo & mapa & mapa & mapa & núcleo & núcleo & núcleo & núcleo & núcleo \\
\hline$\overline{\mathrm{Si}}$ & 193126.64 & 177324.46 & 150620.77 & 177024.42 & 156121.53 & 166622.98 & 127717.61 & 145920.13 & 128217.68 & 136118.77 & 97613.46 & 107214.79 \\
\hline $\mathrm{Zr}$ & 511000.00 & 481100.00 & 415000.00 & 486000.00 & 460000.00 & 470000.00 & 364000.00 & 421000.00 & 458000.00 & 497000.00 & 357000.00 & 417000.00 \\
\hline $\mathrm{Hf}$ & 10030.00 & 9970.00 & 9910.00 & 9850.00 & 9950.00 & 9940.00 & 9750.00 & 9980.00 & 9890.00 & 10000.00 & 9940.00 & 9950.00 \\
\hline Sc & 748.00 & 679.00 & 599.00 & 747.00 & 651.00 & 668.00 & 504.00 & 587.00 & 710.00 & 729.00 & 515.00 & 663.00 \\
\hline $\mathrm{Ca}$ & 1293.72 & 974.54 & 366.20 & 2501.39 & 511.29 & 823.46 & 441.25 & 550.31 & 593.33 & 902.50 & 580.32 & 911.51 \\
\hline $\mathbf{Y}$ & 1422.00 & 1064.00 & 366.40 & 794.00 & 542.00 & 949.00 & 492.00 & 530.00 & 570.00 & 932.00 & 604.00 & 970.00 \\
\hline $\mathbf{P}$ & 223.60 & 174.00 & 122.40 & 809.99 & 139.30 & 141.70 & 74.20 & 149.00 & 194.60 & 185.00 & 132.40 & 210.30 \\
\hline Yb & 314.00 & 258.00 & 106.70 & 261.00 & 151.50 & 231.00 & 160.00 & 140.00 & 185.70 & 243.00 & 244.00 & 217.00 \\
\hline Al & 379.98 & 18.80 & 32.00 & 3899.82 & 23.10 & 14.90 & 21.50 & 58.00 & 18.40 & 16.10 & 12.13 & 12.58 \\
\hline $\mathrm{Fe}$ & 120.00 & 5.10 & 4.00 & 20.60 & 8.70 & 1.30 & 11.60 & 21.00 & 1.23 & 0.01 & 5.90 & 0.77 \\
\hline $\mathrm{Na}$ & 33.00 & 2.74 & 5.10 & 21.20 & 17.10 & 3.90 & 9.50 & 11.70 & 1.07 & 1.10 & 0.51 & 0.74 \\
\hline Mg & 100.01 & 0.06 & 0.06 & 4.50 & 1.60 & 0.31 & 1.80 & 23.00 & 0.13 & 0.12 & 0.47 & 0.17 \\
\hline $\mathrm{Pb}$ & 29.50 & 24.90 & 15.31 & 34.50 & 11.59 & 10.12 & 8.68 & 14.50 & 8.51 & 8.93 & 33.00 & 22.90 \\
\hline $\mathrm{Sr}$ & 0.99 & 0.80 & 0.52 & 4.70 & 0.62 & 0.75 & 0.69 & 0.62 & 0.66 & 0.77 & 0.70 & 0.71 \\
\hline La & 0.12 & 0.03 & 0.06 & 2.80 & 0.05 & 0.02 & 0.03 & 0.04 & 0.01 & 0.03 & 0.01 & 0.02 \\
\hline $\mathrm{Ce}$ & 11.26 & 11.42 & 14.32 & 39.00 & 8.10 & 10.76 & 8.80 & 5.10 & 13.26 & 5.04 & 18.76 & 16.51 \\
\hline $\mathrm{Pr}$ & 0.62 & 0.26 & 0.06 & 1.10 & 0.10 & 0.18 & 0.06 & 0.15 & 0.07 & 0.28 & 0.07 & 0.16 \\
\hline Nd & 9.36 & 4.59 & 0.72 & 6.60 & 1.72 & 3.71 & 1.13 & 2.07 & 1.14 & 5.22 & 1.20 & 3.74 \\
\hline Sm & 13.23 & 7.47 & 1.13 & 5.50 & 2.90 & 6.51 & 1.32 & 3.00 & 2.48 & 8.50 & 2.33 & 8.02 \\
\hline Eu & 1.21 & 0.42 & 0.11 & 1.48 & 0.22 & 0.73 & 0.23 & 0.30 & 0.43 & 0.73 & 0.46 & 0.71 \\
\hline Gd & 51.30 & 34.10 & 6.46 & 19.10 & 14.08 & 29.80 & 8.40 & 13.30 & 12.66 & 34.20 & 10.56 & 35.40 \\
\hline Th & 142.60 & 126.70 & 74.60 & 160.00 & 64.10 & 48.90 & 50.40 & 60.00 & 42.50 & 48.40 & 136.30 & 129.00 \\
\hline Dy & 151.20 & 108.70 & 29.70 & 67.20 & 50.30 & 94.70 & 38.20 & 50.00 & 52.30 & 106.00 & 49.00 & 114.00 \\
\hline Ho & 48.70 & 37.00 & 11.54 & 25.60 & 18.11 & 33.00 & 14.87 & 16.90 & 18.72 & 34.50 & 19.35 & 36.20 \\
\hline $\mathrm{Er}$ & 186.90 & 147.80 & 51.80 & 114.50 & 78.60 & 130.90 & 75.00 & 73.00 & 83.30 & 133.00 & 93.10 & 137.20 \\
\hline $\mathbf{U}$ & 136.00 & 212.00 & 186.50 & 186.00 & 105.00 & 78.60 & 220.00 & 78.00 & 73.30 & 81.90 & 213.90 & 45.50 \\
\hline Lu & 53.30 & 42.90 & 19.48 & 50.90 & 28.50 & 42.60 & 31.70 & 25.00 & 30.80 & 38.30 & 44.10 & 34.70 \\
\hline $\mathrm{Ta}$ & 0.47 & 2.16 & 1.13 & 0.81 & 1.28 & 0.84 & 1.72 & 1.14 & 0.51 & 0.94 & 0.84 & 0.60 \\
\hline $\mathrm{Nb}$ & 22.10 & 25.18 & 18.92 & 21.70 & 22.39 & 22.50 & 18.80 & 20.25 & 19.23 & 22.20 & 15.53 & 18.30 \\
\hline Ga & 0.72 & 0.47 & 0.48 & 1.83 & 0.30 & 0.54 & 0.22 & 0.26 & 0.50 & 0.33 & 0.64 & 0.68 \\
\hline $\mathrm{Tb}$ & 14.97 & 10.08 & 2.34 & 5.92 & 4.48 & 8.65 & 3.05 & 4.20 & 4.39 & 9.90 & 3.93 & 10.70 \\
\hline Tm & 37.10 & 29.70 & 11.05 & 26.30 & 16.39 & 26.80 & 16.86 & 15.30 & 18.57 & 26.10 & 22.66 & 25.50 \\
\hline
\end{tabular}

Tabela 5: Dados de química de zircão de metassedimentos do Domínio São Roque, obtidos via LA-Q-ICPMS. Campos em cinza representam cristais com assínaturas de zircões de gabros tipo MORB. 


\begin{tabular}{|c|c|c|c|c|c|c|c|c|c|c|c|c|}
\hline & \multicolumn{12}{|c|}{ Meta-quartzo arenitos da região do Pico do Jaraguá } \\
\hline LA-ICPMS no & $6 \mathrm{~b}$ & $7 a$ & $8 a$ & $9 a$ & $9 \mathrm{~b}$ & $10 \mathrm{a}$ & $11 \mathrm{a}$ & $11 \mathrm{~b}$ & $12 b$ & $13 a$ & $13 b$ & $14 a$ \\
\hline U-Pb no & 4.10 & 5.10 & 12.10 & 11.10 & - & 13.10 & 22.10 & - & 21.10 & - & 14.10 & 15.10 \\
\hline Idades 207Pb/206Р & 2.10 & 2.11 & 2.21 & 2.47 & - & 2.94 & 2.54 & - & 2.22 & - & 2.21 & 2.52 \\
\hline Feições & núcleo & núcleo & núcleo & núcleo & borda & núcleo & núcleo & borda & núcleo & núcleo & borda & núcleo \\
\hline$\overline{\mathrm{Si}}$ & 121516.76 & 129817.90 & 124917.23 & 124917.23 & 125017.24 & 139219.20 & 117916.26 & 133018.35 & 129417.85 & 129467.86 & 122016.83 & 118716.37 \\
\hline $\mathrm{Zr}$ & 464000.00 & 436000.00 & 465000.00 & 436000.00 & 417000.00 & 502000.00 & 423000.00 & 438000.00 & 488000.00 & 449500.00 & 431000.00 & 431000.00 \\
\hline $\mathrm{Hf}$ & 9850.00 & 9900.00 & 9800.00 & 9890.00 & 10275.00 & 9850.00 & 9920.00 & 10740.00 & 9890.00 & 9950.00 & 9700.00 & 9890.00 \\
\hline Sc & 660.00 & 627.00 & 691.00 & 660.00 & 603.50 & 757.00 & 592.00 & 630.00 & 752.00 & 708.00 & 660.00 & 656.00 \\
\hline $\mathrm{Ca}$ & 584.33 & 661.37 & 713.40 & 906.51 & 980.55 & 452.25 & 611.34 & 550.31 & 883.49 & 1213.68 & 1020.57 & 366.20 \\
\hline $\mathbf{Y}$ & 591.00 & 675.00 & 728.00 & 944.00 & 958.00 & 448.00 & 604.00 & 505.00 & 899.00 & 1321.50 & 1139.00 & 350.00 \\
\hline $\mathbf{P}$ & 132.50 & 104.00 & 302.00 & 275.90 & 294.00 & 202.90 & 180.00 & 230.00 & 140.40 & 508.00 & 507.00 & 88.10 \\
\hline $\mathrm{Yb}$ & 158.00 & 191.20 & 236.00 & 317.30 & 306.00 & 114.10 & 200.40 & 200.00 & 269.00 & 447.50 & 440.00 & 120.00 \\
\hline Al & 14.66 & 14.90 & 30.00 & 15.00 & 60.35 & 41.20 & 14.81 & 71.00 & 16.00 & 15.70 & 32.00 & 14.84 \\
\hline $\mathrm{Fe}$ & 2.20 & 14.90 & 2.50 & 9.40 & 91.00 & 5.20 & 3.90 & 84.00 & 1.74 & 2.05 & 29.00 & 2.50 \\
\hline $\mathrm{Na}$ & 3.50 & 1.32 & 1.70 & 2.01 & 11.70 & 3.80 & 2.36 & 22.00 & 3.05 & 1.84 & 11.90 & 1.40 \\
\hline Mg & 0.40 & 0.36 & 0.66 & 0.73 & 5.10 & 1.03 & 0.25 & 2.30 & 0.35 & 0.38 & 3.00 & 0.16 \\
\hline $\mathrm{Pb}$ & 16.77 & 20.70 & 4.74 & 94.50 & 75.50 & 15.23 & 12.20 & 10.60 & 21.20 & 71.45 & 44.50 & 5.46 \\
\hline $\mathrm{Sr}$ & 0.63 & 0.66 & 0.72 & 0.87 & 1.12 & 0.56 & 0.67 & 1.15 & 0.88 & 1.06 & 1.07 & 0.55 \\
\hline La & 0.02 & 0.03 & 0.01 & 0.06 & 0.65 & 0.04 & 0.02 & 1.90 & 0.05 & 0.08 & 0.29 & 0.01 \\
\hline $\mathrm{Ce}$ & 9.77 & 7.68 & 22.00 & 76.00 & 79.50 & 22.60 & 8.36 & 18.00 & 3.41 & 61.70 & 47.50 & 7.72 \\
\hline $\mathrm{Pr}$ & 0.12 & 0.10 & 0.11 & 0.21 & 0.87 & 0.07 & 0.03 & 1.60 & 0.32 & 0.38 & 0.59 & 0.05 \\
\hline Nd & 2.19 & 1.70 & 1.93 & 3.78 & 7.90 & 1.66 & 0.57 & 7.00 & 4.74 & 6.11 & 4.90 & 1.11 \\
\hline $\mathrm{Sm}$ & 3.99 & 3.36 & 3.66 & 6.54 & 7.95 & 3.16 & 1.40 & 4.10 & 6.90 & 9.51 & 7.10 & 2.20 \\
\hline Eu & 0.21 & 0.21 & 0.97 & 0.86 & 1.52 & 1.32 & 0.19 & 1.40 & 0.87 & 2.68 & 1.60 & 0.76 \\
\hline Gd & 16.40 & 16.24 & 16.40 & 25.62 & 27.55 & 13.18 & 9.47 & 11.40 & 26.70 & 36.75 & 27.80 & 8.80 \\
\hline Th & 93.20 & 106.00 & 24.40 & 418.00 & 389.00 & 65.70 & 51.50 & 55.00 & 110.40 & 346.50 & 218.00 & 24.80 \\
\hline Dy & 56.20 & 62.70 & 69.50 & 90.90 & 97.35 & 42.50 & 50.50 & 44.00 & 92.30 & 137.40 & 111.00 & 29.10 \\
\hline Ho & 19.60 & 22.77 & 25.20 & 31.26 & 33.07 & 13.48 & 19.94 & 16.60 & 32.01 & 47.90 & 38.30 & 10.40 \\
\hline Er & 81.50 & 95.10 & 109.90 & 135.00 & 136.00 & 54.60 & 91.00 & 75.30 & 133.60 & 202.85 & 179.20 & 47.30 \\
\hline $\mathbf{U}$ & 123.40 & 139.20 & 25.70 & 388.00 & 341.55 & 93.00 & 124.10 & 125.00 & 148.70 & 244.50 & 180.00 & 45.90 \\
\hline Lu & 25.10 & 30.10 & 39.10 & 52.60 & 55.00 & 19.40 & 33.20 & 35.40 & 45.90 & 69.55 & 65.00 & 22.20 \\
\hline $\mathrm{Ta}$ & 0.93 & 0.64 & 0.92 & 2.35 & 2.41 & 0.67 & 1.76 & 1.54 & 0.34 & 1.72 & 1.81 & 0.32 \\
\hline $\mathrm{Nb}$ & 21.17 & 19.31 & 21.54 & 22.99 & 21.35 & 22.36 & 20.91 & 22.70 & 20.90 & 24.45 & 23.00 & 18.36 \\
\hline Ga & 0.44 & 0.29 & 0.76 & 2.65 & 3.05 & 0.79 & 0.29 & 0.63 & 0.26 & 2.23 & 1.59 & 0.26 \\
\hline $\mathrm{Tb}$ & 5.16 & 5.33 & 5.74 & 8.05 & 8.70 & 4.00 & 3.76 & 4.40 & 8.32 & 11.70 & 9.30 & 2.62 \\
\hline $\mathrm{Tm}$ & 16.50 & 19.99 & 24.06 & 30.91 & 30.65 & 11.78 & 20.14 & 17.93 & 28.60 & 44.35 & 42.60 & 11.04 \\
\hline
\end{tabular}

Tabela 5: Dados de química de zircão de metassedimentos do Domínio São Roque, obtidos via LA-Q-ICPMS. Campos em cinza representam cristais com assínaturas de zircões de gabros tipo MORB. 


\begin{tabular}{|c|c|c|c|c|c|c|c|c|c|c|c|c|}
\hline & & & & & eta-quartzo & arenitos da $r$ & egião do Picc & do Jaraguá & & & & \\
\hline LA-ICPMS no & $15 a$ & $16 a$ & $\overline{17 a}$ & $17 \mathrm{~b}$ & $18 a$ & $18 b$ & $19 a$ & $19 \mathrm{~b}$ & $20 b$ & $22 a$ & $23 a$ & $24 a$ \\
\hline U-Pb no & 19.10 & 18.10 & - & 60.10 & 62.10 & - & 63.10 & - & 27.10 & 29.10 & 30.10 & - \\
\hline Idades 207Pb/206 & 2.44 & 1.77 & - & 2.20 & 2.77 & - & 2.16 & - & 2.72 & 2.20 & 3.39 & - \\
\hline Feições & núcleo & núcleo & núcleo & borda & núcleo & borda & núcleo & borda & borda & núcleo & núcleo & núcleo \\
\hline$\overline{\mathrm{Si}}$ & 100413.85 & 129717.89 & 116516.07 & 112015.45 & 128617.74 & 124417.16 & 117716.24 & 63408.75 & 98663.61 & 127817.63 & 105214.51 & 112915.57 \\
\hline $\mathrm{Zr}$ & 352000.00 & 499000.00 & 430000.00 & 426000.00 & 463000.00 & 462000.00 & 425000.00 & 229000.00 & 370000.00 & 490000.00 & 397000.00 & 437000.00 \\
\hline $\mathrm{Hf}$ & 9900.00 & 9980.00 & 9730.00 & 9900.00 & 9790.00 & 9910.00 & 9935.00 & 9820.00 & 10055.00 & 10030.00 & 9872.00 & 9790.00 \\
\hline Sc & 525.00 & 725.00 & 643.00 & 624.00 & 708.00 & 697.00 & 611.00 & 323.00 & 661.00 & 733.00 & 552.80 & 621.00 \\
\hline $\mathrm{Ca}$ & 496.28 & 637.36 & 731.41 & 2431.36 & 1290.72 & 1560.87 & 1438.80 & 950.53 & 1419.29 & 646.36 & 2038.14 & 924.52 \\
\hline $\mathbf{Y}$ & 498.00 & 682.00 & 808.00 & 860.00 & 1400.00 & 1484.00 & 1574.00 & 800.00 & 1525.00 & 656.00 & 2221.00 & 996.00 \\
\hline $\mathbf{P}$ & 101.80 & 162.10 & 244.00 & 1849.98 & 235.00 & 449.00 & 335.50 & 490.00 & 744.49 & 195.00 & 441.00 & 256.80 \\
\hline $\mathrm{Yb}$ & 200.30 & 188.00 & 246.00 & 210.00 & 436.00 & 392.00 & 434.00 & 252.00 & 570.50 & 213.00 & 650.00 & 322.00 \\
\hline Al & 28.00 & 21.10 & 18.10 & 3499.84 & 17.50 & 269.99 & 80.60 & 319.99 & 232.19 & 17.40 & 20.90 & 17.70 \\
\hline $\mathrm{Fe}$ & 308.00 & 1.40 & 9.80 & 780.00 & 6.50 & 244.00 & 85.55 & 430.00 & 226.80 & 4.00 & 13.20 & 10.60 \\
\hline $\mathrm{Na}$ & 8.50 & 3.60 & 4.60 & 103.99 & 15.10 & 55.00 & 6.90 & 45.00 & 54.14 & 4.00 & 3.20 & 3.70 \\
\hline $\mathbf{M g}$ & 20.20 & 0.27 & 0.55 & 26.00 & 1.23 & 12.60 & 2.70 & 14.10 & 7.08 & 1.02 & 0.50 & 0.75 \\
\hline $\mathrm{Pb}$ & 27.60 & 4.21 & 24.20 & 990.00 & 36.10 & 29.30 & 48.40 & 12.20 & 6.07 & 18.90 & 19.31 & 16.30 \\
\hline $\mathrm{Sr}$ & 0.69 & 0.64 & 0.82 & 243.00 & 1.19 & 2.56 & 1.55 & 1.65 & 2.17 & 0.76 & 1.55 & 0.92 \\
\hline La & 0.04 & 0.03 & 0.09 & 38.00 & 0.02 & 4.80 & 2.34 & 7.40 & 4.10 & 0.02 & 0.02 & 0.02 \\
\hline $\mathrm{Ce}$ & 6.99 & 7.08 & 16.10 & 118.00 & 26.70 & 63.00 & 29.00 & 68.00 & 30.94 & 12.94 & 21.99 & 15.40 \\
\hline Pr & 0.03 & 0.20 & 0.23 & 14.90 & 0.23 & 6.00 & 2.01 & 9.00 & 3.81 & 0.07 & 0.07 & 0.07 \\
\hline Nd & 0.41 & 3.35 & 2.91 & 71.00 & 4.20 & 33.00 & 11.79 & 51.00 & 18.61 & 1.40 & 1.55 & 1.37 \\
\hline $\mathrm{Sm}$ & 1.10 & 4.76 & 4.20 & 24.70 & 7.30 & 17.90 & 9.06 & 19.00 & 8.74 & 2.90 & 4.92 & 3.10 \\
\hline Eu & 0.34 & 0.57 & 0.53 & 8.90 & 1.72 & 7.10 & 1.48 & 8.10 & 3.38 & 0.65 & 0.80 & 0.19 \\
\hline Gd & 7.07 & 20.90 & 20.50 & 56.00 & 35.00 & 57.00 & 37.75 & 46.00 & 31.65 & 14.80 & 36.80 & 17.40 \\
\hline Th & 129.30 & 28.80 & 127.00 & 177.00 & 182.00 & 218.00 & 207.50 & 180.00 & 86.40 & 103.10 & 64.40 & 68.90 \\
\hline Dy & 38.90 & 69.20 & 78.40 & 132.00 & 144.00 & 169.00 & 154.45 & 115.00 & 144.70 & 61.40 & 210.00 & 87.90 \\
\hline Ho & 15.62 & 23.70 & 27.50 & 32.90 & 50.60 & 53.10 & 54.75 & 31.00 & 54.25 & 22.78 & 82.10 & 34.10 \\
\hline $\mathrm{Er}$ & 76.70 & 97.40 & 116.60 & 122.00 & 216.00 & 205.00 & 233.50 & 112.00 & 244.00 & 97.40 & 360.00 & 152.50 \\
\hline $\mathbf{U}$ & 660.00 & 43.80 & 213.10 & 298.00 & 211.00 & 227.00 & 317.50 & 491.00 & 161.35 & 138.70 & 133.90 & 132.00 \\
\hline Lu & 35.70 & 31.30 & 40.90 & 42.60 & 69.00 & 62.00 & 65.70 & 48.10 & 98.70 & 37.20 & 105.00 & 52.50 \\
\hline $\mathrm{Ta}$ & 1.65 & 0.71 & 2.32 & 1.40 & 0.83 & 0.87 & 2.56 & 3.70 & 2.50 & 0.62 & 6.37 & 1.99 \\
\hline $\mathrm{Nb}$ & 16.56 & 22.40 & 22.90 & 21.60 & 22.10 & 22.60 & 24.50 & 13.00 & 21.25 & 22.70 & 40.00 & 22.25 \\
\hline $\mathrm{Ga}$ & 0.21 & 0.37 & 0.62 & 6.70 & 0.95 & 2.92 & 1.36 & 3.70 & 1.46 & 0.48 & 0.77 & 0.54 \\
\hline $\mathrm{Tb}$ & 2.92 & 6.17 & 7.03 & 13.90 & 11.70 & 17.80 & 13.03 & 12.90 & 11.92 & 5.15 & 14.97 & 6.93 \\
\hline $\mathrm{Tm}$ & 18.41 & 19.50 & 25.20 & 24.50 & 44.50 & 42.60 & 46.25 & 23.60 & 57.35 & 22.10 & 72.00 & 33.60 \\
\hline
\end{tabular}

Tabela 5: Dados de química de zircão de metassedimentos do Domínio São Roque, obtidos via LA-Q-ICPMS. Campos em cinza representam cristais com assínaturas de zircões de gabros tipo MORB. 


\begin{tabular}{|c|c|c|c|c|c|c|c|c|c|c|c|c|}
\hline & \multicolumn{12}{|c|}{ Meta-quartzo arenitos da região do Pico do Jaraguá } \\
\hline LA-ICPMS no & $24 \mathrm{~b}$ & $25 a$ & $25 b$ & $26 a$ & $27 a$ & $27 \mathrm{~b}$ & $28 \mathrm{a}$ & $29 a$ & $30 a$ & $32 a$ & $32 b$ & $33 b$ \\
\hline U-Pb no & 31.10 & 32.10 & - & 36.10 & - & 35.10 & 34.10 & 23.10 & $?$ & - & 38.10 & 39.10 \\
\hline Idades 207Pb/206 & 2.69 & 2.48 & - & 2.21 & - & 2.51 & 2.36 & 2.19 & $?$ & - & 2.12 & 2.22 \\
\hline Feições & borda & núcleo & borda & núcleo & núcleo & borda & núcleo & núcleo & borda & núcleo & borda & borda \\
\hline$\overline{\mathrm{Si}}$ & 112015.45 & 109615.12 & 114915.85 & 106214.65 & 114815.84 & 105514.55 & 130518.00 & 123016.97 & 99833.77 & 90912.54 & 96513.31 & 117716.24 \\
\hline $\mathrm{Zr}$ & 401000.00 & 394000.00 & 405000.00 & 404900.00 & 420000.00 & 397000.00 & 421000.00 & 478000.00 & 355000.00 & 367000.00 & 363000.00 & 473000.00 \\
\hline $\mathrm{Hf}$ & 10530.00 & 9960.00 & 9900.00 & 9813.00 & 9780.00 & 9610.00 & 10060.00 & 9870.00 & 9870.00 & 9900.00 & 10030.00 & 9860.00 \\
\hline Sc & 590.00 & 568.00 & 600.00 & 574.40 & 609.00 & 600.00 & 618.00 & 708.00 & 513.00 & 546.00 & 634.00 & 691.00 \\
\hline $\mathrm{Ca}$ & 1420.79 & 770.43 & 641.36 & 1480.83 & 358.20 & 710.40 & 599.33 & 799.45 & 2221.24 & 347.19 & 1750.98 & 854.48 \\
\hline $\mathbf{Y}$ & 1500.00 & 805.00 & 636.00 & 1492.50 & 362.00 & 590.00 & 579.00 & 857.00 & 1530.00 & 320.00 & 1270.00 & 832.00 \\
\hline $\mathbf{P}$ & 500.00 & 235.00 & 320.00 & 547.00 & 116.60 & 420.00 & 233.00 & 170.00 & 1719.99 & 181.00 & 1849.98 & 502.00 \\
\hline $\mathrm{Yb}$ & 461.00 & 281.00 & 234.00 & 443.50 & 115.00 & 141.00 & 264.00 & 246.00 & 340.00 & 67.50 & 248.00 & 195.20 \\
\hline Al & 159.99 & 14.09 & 75.00 & 752.97 & 14.00 & 269.99 & 24.90 & 14.74 & 1329.94 & 64.00 & 1229.94 & 333.98 \\
\hline $\mathrm{Fe}$ & 1120.01 & 8.40 & 580.00 & 288.20 & 1.90 & 240.00 & 3.10 & 3.40 & 1660.01 & 136.00 & 2390.01 & 1680.01 \\
\hline $\mathrm{Na}$ & 37.60 & 1.96 & 37.00 & 47.22 & 2.06 & 59.99 & 6.60 & -0.35 & 135.99 & 8.10 & 178.98 & 63.99 \\
\hline $\mathbf{M g}$ & 9.80 & 0.34 & 12.50 & 29.66 & 0.30 & 8.20 & 1.14 & 0.16 & 38.00 & 5.10 & 25.60 & 3.90 \\
\hline $\mathrm{Pb}$ & 29.00 & 31.10 & 17.00 & 66.25 & 5.32 & 9.90 & 12.40 & 13.30 & 47.20 & 15.68 & 45.90 & 19.10 \\
\hline $\mathrm{Sr}$ & 3.00 & 0.82 & 1.29 & 2.59 & 0.49 & 1.66 & 0.76 & 0.79 & 6.60 & 0.62 & 4.16 & 1.14 \\
\hline La & 6.50 & 0.03 & 1.40 & 3.72 & 0.01 & 4.60 & 0.01 & 0.01 & 51.00 & 1.50 & 53.90 & 4.70 \\
\hline $\mathrm{Ce}$ & 56.00 & 42.30 & 31.60 & 69.75 & 11.36 & 39.00 & 21.50 & 10.06 & 260.00 & 12.00 & 297.00 & 43.10 \\
\hline $\mathrm{Pr}$ & 5.30 & 0.07 & 1.30 & 4.89 & 0.03 & 5.00 & 0.07 & 0.13 & 34.00 & 1.30 & 36.00 & 3.80 \\
\hline Nd & 34.00 & 1.15 & 6.30 & 31.70 & 0.59 & 25.00 & 0.67 & 2.56 & 157.00 & 5.50 & 162.00 & 26.30 \\
\hline Sm & 12.00 & 2.58 & 4.20 & 14.70 & 1.43 & 12.50 & 1.38 & 4.88 & 41.00 & 2.15 & 38.50 & 14.30 \\
\hline Eu & 3.70 & 0.51 & 1.14 & 5.29 & 0.42 & 4.30 & 0.51 & 0.73 & 17.10 & 0.32 & 13.70 & 4.48 \\
\hline Gd & 45.00 & 14.80 & 13.30 & 43.60 & 7.99 & 29.00 & 8.50 & 24.10 & 90.00 & 9.22 & 91.00 & 36.40 \\
\hline Th & 150.00 & 139.90 & 103.00 & 435.50 & 24.90 & 330.00 & 51.00 & 70.70 & 650.00 & 86.00 & 314.00 & 397.00 \\
\hline Dy & 177.00 & 69.40 & 54.30 & 152.25 & 29.00 & 75.00 & 46.20 & 88.40 & 199.00 & 30.30 & 169.00 & 102.70 \\
\hline Ho & 60.00 & 26.37 & 21.50 & 49.55 & 11.36 & 19.30 & 17.90 & 30.60 & 52.00 & 9.17 & 41.90 & 28.80 \\
\hline $\mathrm{Er}$ & 219.00 & 119.70 & 91.10 & 215.85 & 51.40 & 81.00 & 86.90 & 128.60 & 175.00 & 38.10 & 141.00 & 112.20 \\
\hline $\mathbf{U}$ & 230.00 & 191.90 & 217.00 & 394.30 & 46.40 & 126.00 & 109.00 & 146.90 & 860.00 & 531.00 & 942.00 & 126.00 \\
\hline Lu & 83.00 & 47.50 & 40.40 & 76.15 & 21.60 & 25.70 & 50.80 & 41.10 & 49.20 & 11.10 & 41.90 & 35.30 \\
\hline $\mathrm{Ta}$ & 2.87 & 2.74 & 2.53 & 3.23 & 0.47 & 0.53 & 0.75 & 0.76 & 4.37 & 0.98 & 0.89 & 0.66 \\
\hline $\mathrm{Nb}$ & 24.50 & 23.50 & 21.40 & 26.49 & 19.10 & 19.30 & 20.60 & 22.60 & 25.80 & 17.40 & 18.90 & 23.82 \\
\hline $\mathrm{Ga}$ & 2.70 & 1.45 & 1.29 & 3.16 & 0.37 & 1.47 & 0.67 & 0.43 & 13.20 & 0.52 & 14.50 & 2.15 \\
\hline $\mathrm{Tb}$ & 15.90 & 5.49 & 4.70 & 13.70 & 2.43 & 7.80 & 3.28 & 7.77 & 22.10 & 2.90 & 20.90 & 10.40 \\
\hline $\mathrm{Tm}$ & 46.20 & 27.90 & 22.85 & 45.70 & 11.24 & 15.40 & 22.80 & 26.20 & 34.10 & 7.51 & 26.70 & 21.55 \\
\hline
\end{tabular}

Tabela 5: Dados de química de zircão de metassedimentos do Domínio São Roque, obtidos via LA-Q-ICPMS. Campos em cinza representam cristais com assínaturas de zircões de gabros tipo MORB. 


\begin{tabular}{|c|c|c|c|c|c|c|c|c|c|c|c|c|}
\hline & \multicolumn{12}{|c|}{ Meta-quartzo arenitos da região do Pico do Jaraguá } \\
\hline LA-ICPMS no & $33 a$ & $34 a$ & $35 b$ & $35 a$ & $36 \mathrm{~b}$ & $36 a$ & $37 a$ & $38 a$ & $39 a$ & $40 a$ & $42 a$ & $43 a$ \\
\hline U-Pb no & - & 40.10 & 41.10 & - & 42.10 & - & - & 43.10 & 44.10 & 46.10 & - & 52.10 \\
\hline Idades 207Pb/206 & - & 2.22 & 2.70 & - & 2.36 & - & - & 2.71 & 3.35 & 2.92 & - & 3.31 \\
\hline Feições & núcleo & núcleo & borda & núcleo & borda & núcleo & núcleo & núcleo & núcleo & núcleo & núcleo & núcleo \\
\hline$\overline{\mathrm{Si}}$ & 131918.19 & 140019.31 & 172023.73 & 177024.42 & 103014.21 & 123917.09 & 151420.88 & 161822.32 & 190026.21 & 191026.35 & 167023.04 & 132818.32 \\
\hline $\mathrm{Zr}$ & 505300.00 & 487000.00 & 463000.00 & 464000.00 & 326000.00 & 341000.00 & 449300.00 & 494000.00 & 498000.00 & 519000.00 & 426000.00 & 404000.00 \\
\hline $\mathrm{Hf}$ & 9920.00 & 9630.00 & 9690.00 & 10200.00 & 9680.00 & 10060.00 & 9980.00 & 10020.00 & 9940.00 & 10120.00 & 10090.00 & 10010.00 \\
\hline Sc & 751.00 & 742.00 & 685.00 & 636.00 & 489.00 & 484.00 & 640.00 & 682.00 & 670.00 & 741.00 & 702.00 & 550.00 \\
\hline $\mathrm{Ca}$ & 913.51 & 505.28 & 2681.49 & 790.44 & 4122.30 & 1460.81 & 840.47 & 1080.60 & 920.51 & 1290.72 & 1400.78 & 911.51 \\
\hline $\mathbf{Y}$ & 1003.00 & 510.00 & 1830.00 & 860.00 & 3060.00 & 1221.00 & 930.00 & 1320.00 & 1050.00 & 1600.00 & 1070.00 & 1023.00 \\
\hline $\mathbf{P}$ & 210.00 & 169.00 & 1899.98 & 210.00 & 4369.96 & 1299.99 & 490.00 & 261.10 & 296.00 & 321.00 & 1009.99 & 390.00 \\
\hline $\mathrm{Yb}$ & 248.00 & 165.00 & 371.00 & 253.00 & 750.00 & 370.00 & 157.00 & 355.00 & 295.00 & 307.00 & 211.00 & 365.00 \\
\hline Al & 22.70 & 19.00 & 1519.93 & 48.00 & 3699.83 & 919.96 & 220.99 & 22.00 & 86.00 & 22.40 & 679.97 & 163.99 \\
\hline $\mathrm{Fe}$ & 29.00 & 1.00 & 1390.01 & 47.00 & 4080.02 & 1650.01 & 680.00 & 13.60 & 58.00 & 27.00 & 3090.02 & 166.00 \\
\hline $\mathrm{Na}$ & 7.90 & 10.20 & 249.98 & 6.10 & 509.96 & 119.99 & 42.00 & 3.29 & 34.80 & 3.00 & 113.99 & 70.29 \\
\hline $\mathbf{M g}$ & 0.62 & 0.56 & 22.20 & 1.35 & 29.00 & 25.50 & 11.30 & 2.03 & 4.20 & 1.29 & 18.90 & 7.60 \\
\hline $\mathrm{Pb}$ & 18.13 & 24.90 & 64.00 & 63.00 & 49.00 & 24.40 & 102.00 & 13.50 & 58.40 & 12.00 & 118.00 & 16.50 \\
\hline $\mathrm{Sr}$ & 0.87 & 0.68 & 4.20 & 1.02 & 14.40 & 5.36 & 1.46 & 1.14 & 1.36 & 1.02 & 20.00 & 1.32 \\
\hline La & 0.29 & 0.02 & 51.00 & 1.32 & 131.00 & 40.50 & 7.70 & 0.08 & 1.00 & 0.15 & 40.00 & 5.00 \\
\hline $\mathrm{Ce}$ & 20.68 & 11.30 & 270.00 & 20.20 & 730.00 & 212.00 & 111.00 & 5.95 & 37.20 & 19.90 & 159.00 & 30.90 \\
\hline $\mathrm{Pr}$ & 0.50 & 0.02 & 35.00 & 0.82 & 106.00 & 27.10 & 5.20 & 0.24 & 1.02 & 0.87 & 19.50 & 4.31 \\
\hline Nd & 7.48 & 1.14 & 160.00 & 4.70 & 510.00 & 128.00 & 31.10 & 2.77 & 6.70 & 15.10 & 96.00 & 28.00 \\
\hline Sm & 10.05 & 1.56 & 47.00 & 3.08 & 130.00 & 32.50 & 17.80 & 5.69 & 6.30 & 22.30 & 32.80 & 9.20 \\
\hline Eu & 1.87 & 0.54 & 18.00 & 0.76 & 55.00 & 14.20 & 5.40 & 0.92 & 2.20 & 4.50 & 8.40 & 3.68 \\
\hline Gd & 38.90 & 11.40 & 97.00 & 14.20 & 267.00 & 77.00 & 52.30 & 31.60 & 30.00 & 79.00 & 65.00 & 25.30 \\
\hline Th & 106.30 & 113.00 & 620.00 & 249.00 & 493.00 & 320.00 & 658.00 & 57.30 & 215.00 & 44.90 & 113.00 & 185.00 \\
\hline Dy & 109.60 & 42.30 & 222.00 & 63.00 & 390.00 & 136.00 & 107.00 & 123.00 & 92.00 & 186.00 & 126.00 & 85.90 \\
\hline Ho & 36.00 & 16.30 & 60.00 & 26.10 & 93.00 & 39.10 & 30.60 & 45.00 & 32.70 & 53.00 & 35.00 & 31.50 \\
\hline $\mathrm{Er}$ & 142.00 & 72.40 & 220.00 & 113.00 & 332.00 & 148.00 & 107.00 & 191.00 & 145.00 & 195.00 & 122.00 & 152.00 \\
\hline $\mathbf{U}$ & 69.30 & 212.00 & 760.00 & 380.00 & 1300.00 & 736.00 & 441.00 & 99.50 & 268.00 & 80.00 & 492.00 & 231.00 \\
\hline Lu & 42.80 & 27.60 & 60.70 & 46.80 & 136.00 & 74.10 & 27.30 & 62.40 & 50.80 & 49.10 & 34.10 & 75.10 \\
\hline $\mathrm{Ta}$ & 0.59 & 0.65 & 2.22 & 2.40 & 17.20 & 16.50 & 1.07 & 1.29 & 1.89 & 1.53 & 1.03 & 2.26 \\
\hline $\mathrm{Nb}$ & 23.53 & 22.90 & 25.00 & 22.70 & 29.00 & 23.90 & 21.95 & 23.00 & 24.60 & 25.30 & 21.40 & 20.00 \\
\hline $\mathrm{Ga}$ & 0.90 & 0.36 & 15.50 & 0.66 & 41.00 & 10.60 & 4.19 & 0.27 & 1.34 & 1.12 & 8.00 & 1.61 \\
\hline $\mathrm{Tb}$ & 10.51 & 3.55 & 25.00 & 5.00 & 53.00 & 17.40 & 12.20 & 10.40 & 8.70 & 20.40 & 15.10 & 7.79 \\
\hline $\mathrm{Tm}$ & 27.30 & 16.10 & 43.30 & 27.00 & 72.00 & 34.80 & 20.00 & 40.00 & 32.50 & 36.60 & 24.70 & 35.50 \\
\hline
\end{tabular}

Tabela 5: Dados de química de zircão de metassedimentos do Domínio São Roque, obtidos via LA-Q-ICPMS. Campos em cinza representam cristais com assínaturas de zircões de gabros tipo MORB. 


\begin{tabular}{|c|c|c|c|c|c|c|c|c|c|c|c|c|}
\hline & \multicolumn{3}{|c|}{ Pico do Jaraguá } & \multicolumn{9}{|c|}{ Meta-quartzo arenitos de região da Serra do Pirucaia } \\
\hline LA-ICPMS no & $45 a$ & $47 \mathrm{~b}$ & $\overline{47 a}$ & $1 \mathrm{a}$ & $2 a$ & $3 a$ & $4 a$ & $5 a$ & $5 b$ & $7 a$ & $8 a$ & $9 a$ \\
\hline U-Pb no & 55.10 & - & 57.10 & 58.10 & 57.10 & 7.10 & 8.20 & 4.10 & - & 60.10 & 1.10 & 2.10 \\
\hline Idades 207Pb/206月 & 2.61 & - & 2.03 & 2.02 & 2.42 & 2.21 & 2.14 & 3.01 & - & 2.17 & 2.85 & 2.23 \\
\hline Feições & núcleo & borda & núcleo & núcleo & núcleo & núcleo & núcleo & núcleo & borda & núcleo & núcleo & núcleo \\
\hline Si & 173023.86 & 184025.38 & 192026.48 & 136118.77 & 140419.37 & 129917.92 & 132918.33 & 160622.15 & 143819.84 & 189626.15 & 141919.57 & 164522.69 \\
\hline $\mathrm{Zr}$ & 456000.00 & 479000.00 & 495000.00 & 384000.00 & 406600.00 & 372800.00 & 372100.00 & 461000.00 & 411000.00 & 562000.00 & 405700.00 & 480000.00 \\
\hline $\mathrm{Hf}$ & 9850.00 & 9920.00 & 10010.00 & 9940.00 & 9880.00 & 10025.00 & 10090.00 & 9981.00 & 9930.00 & 10090.00 & 9990.00 & 10100.00 \\
\hline Sc & 617.00 & 606.00 & 653.00 & 553.00 & 587.00 & 557.30 & 581.00 & 694.00 & 598.00 & 788.00 & 570.00 & 707.00 \\
\hline $\mathrm{Ca}$ & 1040.58 & 530.30 & 430.24 & 760.42 & 449.25 & 1071.60 & 838.47 & 866.48 & 335.19 & 399.22 & 415.23 & 628.35 \\
\hline $\mathbf{Y}$ & 1240.00 & 408.00 & 440.00 & 850.00 & 491.00 & 1221.00 & 937.00 & 977.00 & 353.00 & 446.00 & 444.00 & 650.00 \\
\hline $\mathbf{P}$ & 226.00 & 248.00 & 175.00 & 280.00 & 180.70 & 482.00 & 411.60 & 255.00 & 133.00 & 110.00 & 107.00 & 191.00 \\
\hline Yb & 360.00 & 75.80 & 85.00 & 140.00 & 141.80 & 337.00 & 267.20 & 210.00 & 93.20 & 212.00 & 134.00 & 170.00 \\
\hline Al & 24.00 & 95.00 & 46.00 & 126.99 & 16.30 & 45.00 & 23.67 & 14.66 & 17.20 & 24.30 & 133.99 & 589.97 \\
\hline $\mathrm{Fe}$ & 24.30 & 79.00 & 3.40 & 55.00 & 2.32 & 17.90 & 2.34 & 2.30 & 18.40 & 31.70 & 44.00 & 58.00 \\
\hline $\mathrm{Na}$ & 5.40 & 35.00 & 44.00 & 17.40 & 2.88 & 5.45 & 1.41 & 3.40 & 3.31 & 5.80 & 19.00 & 13.00 \\
\hline Mg & 1.83 & 2.90 & 3.35 & 7.80 & 0.05 & 2.00 & 0.11 & 0.05 & 0.08 & 0.11 & 13.00 & 8.10 \\
\hline $\mathrm{Pb}$ & 24.20 & 28.70 & 35.40 & 33.30 & 22.82 & 35.40 & 18.01 & 53.80 & 22.20 & 30.70 & 21.00 & 29.70 \\
\hline Sr & 0.88 & 1.42 & 0.83 & 0.76 & 0.57 & 0.97 & 0.79 & 0.78 & 0.52 & 0.65 & 0.68 & 0.81 \\
\hline La & 0.08 & 1.90 & 0.24 & 0.07 & 0.02 & 0.01 & 0.01 & 0.02 & 0.01 & 0.00 & 0.19 & 0.50 \\
\hline $\mathrm{Ce}$ & 19.70 & 64.10 & 67.20 & 6.55 & 12.36 & 4.72 & 22.50 & 24.46 & 15.50 & 4.18 & 25.60 & 23.80 \\
\hline Pr & 0.34 & 2.10 & 0.90 & 0.24 & 0.05 & 0.10 & 0.06 & 0.15 & 0.03 & 0.06 & 0.33 & 0.60 \\
\hline Nd & 5.20 & 11.90 & 8.40 & 3.90 & 0.80 & 1.65 & 1.11 & 2.90 & 0.42 & 0.70 & 2.93 & 5.00 \\
\hline Sm & 8.90 & 7.00 & 9.30 & 12.40 & 1.34 & 4.11 & 3.14 & 5.93 & 1.13 & 1.10 & 3.61 & 6.65 \\
\hline Eu & 0.56 & 2.40 & 2.60 & 6.90 & 0.23 & 0.15 & 0.19 & 1.25 & 0.24 & 0.39 & 1.46 & 1.83 \\
\hline Gd & 38.00 & 16.80 & 25.70 & 51.00 & 7.50 & 24.74 & 20.22 & 29.90 & 6.70 & 4.78 & 12.50 & 21.80 \\
\hline Th & 105.00 & 262.00 & 177.00 & 183.00 & 106.00 & 186.20 & 89.80 & 198.00 & 90.60 & 167.00 & 100.00 & 200.00 \\
\hline Dy & 130.00 & 41.00 & 54.00 & 109.00 & 34.40 & 110.50 & 87.10 & 99.60 & 27.60 & 24.90 & 38.50 & 64.50 \\
\hline Ho & 45.00 & 12.30 & 14.70 & 27.90 & 14.35 & 41.10 & 31.96 & 33.30 & 10.60 & 11.64 & 13.40 & 20.70 \\
\hline Er & 186.00 & 42.30 & 50.00 & 91.00 & 67.50 & 179.30 & 134.80 & 129.30 & 46.90 & 67.00 & 59.80 & 85.60 \\
\hline $\mathbf{U}$ & 148.00 & 198.00 & 127.00 & 770.00 & 114.60 & 333.00 & 121.10 & 110.50 & 121.00 & 386.00 & 306.00 & 372.00 \\
\hline Lu & 56.90 & 12.60 & 14.20 & 23.30 & 27.40 & 62.80 & 51.00 & 39.30 & 18.45 & 50.90 & 27.40 & 32.00 \\
\hline Ta & 1.57 & 1.38 & 1.12 & 1.81 & 1.11 & 1.85 & 1.03 & 0.79 & 0.87 & 0.47 & 0.92 & 0.89 \\
\hline $\mathrm{Nb}$ & 22.30 & 22.40 & 23.00 & 17.20 & 20.03 & 19.72 & 19.26 & 21.16 & 19.12 & 24.61 & 19.23 & 23.27 \\
\hline $\mathrm{Ga}$ & 0.81 & 2.66 & 2.05 & 0.35 & 0.40 & 0.23 & 0.72 & 0.82 & 0.52 & 0.16 & 0.88 & 1.02 \\
\hline Tb & 11.70 & 4.10 & 5.90 & 13.10 & 2.71 & 9.23 & 7.27 & 9.18 & 2.32 & 1.81 & 3.61 & 6.40 \\
\hline $\mathrm{Tm}$ & 41.00 & 8.70 & 9.90 & 16.60 & 14.88 & 38.00 & 28.61 & 24.90 & 9.92 & 17.70 & 13.20 & 17.90 \\
\hline
\end{tabular}

Tabela 5: Dados de química de zircão de metassedimentos do Domínio São Roque, obtidos via LA-Q-ICPMS. Campos em cinza representam cristais com assínaturas de zircões de gabros tipo MORB. 


\begin{tabular}{|c|c|c|c|c|c|c|c|c|c|c|c|c|}
\hline & & & & & ta-quartzo & arenitos de r & gião da Serr & do Pirucaia & & & & \\
\hline LA-ICPMS no & $10 a$ & $11 a$ & $12 a$ & $13 a$ & $14 a$ & $15 a$ & $16 a$ & $16 \mathrm{~b}$ & $17 a$ & $18 a$ & $19 a$ & $20 a$ \\
\hline U-Pb no & 54.10 & 16.10 & 17.10 & 14.10 & 53.10 & 52.10 & 46.20 & 46.10 & 48.10 & 44.10 & 40.10 & 28.10 \\
\hline Idades 207Pb/206 & 2.15 & 3.00 & 2.41 & 2.29 & 2.94 & 2.17 & 2.33 & 2.16 & 2.05 & 2.55 & 2.11 & 2.22 \\
\hline Feições & núcleo & núcleo & núcleo & núcleo & núcleo & núcleo & núcleo & borda & núcleo & núcleo & núcleo & núcleo \\
\hline$\overline{\mathrm{Si}}$ & 151120.84 & 125117.26 & 182025.10 & 182625.19 & 183025.24 & 175524.21 & 140419.37 & 132018.21 & 136018.76 & 226931.30 & 146920.26 & 203028.00 \\
\hline $\mathrm{Zr}$ & 436000.00 & 362000.00 & 522000.00 & 531000.00 & 519000.00 & 517000.00 & 388000.00 & 356000.00 & 380000.00 & 561000.00 & 396300.00 & 493000.00 \\
\hline $\mathrm{Hf}$ & 10020.00 & 10100.00 & 10060.00 & 10160.00 & 10050.00 & 10110.00 & 10040.00 & 10160.00 & 10080.00 & 10120.00 & 10060.00 & 10110.00 \\
\hline Sc & 702.00 & 628.00 & 731.00 & 757.00 & 793.00 & 775.00 & 604.00 & 536.00 & 537.00 & 770.00 & 596.90 & 732.00 \\
\hline $\mathrm{Ca}$ & 1450.81 & 395.22 & 808.45 & 340.19 & 1550.86 & 1179.66 & 334.19 & 334.19 & 791.44 & 3261.82 & 984.55 & 2091.17 \\
\hline$Y$ & 1422.00 & 434.00 & 920.00 & 365.00 & 1800.00 & 1352.00 & 366.00 & 347.00 & 890.00 & 3520.00 & 1128.00 & 1940.00 \\
\hline $\mathbf{P}$ & 235.00 & 133.10 & 189.00 & 112.60 & 230.00 & 169.00 & 215.00 & 112.00 & 191.40 & 678.99 & 456.00 & 669.99 \\
\hline $\mathrm{Yb}$ & 414.00 & 101.40 & 257.40 & 126.60 & 549.00 & 319.00 & 107.00 & 148.00 & 271.50 & 840.00 & 296.70 & 560.00 \\
\hline Al & 84.00 & 20.60 & 98.00 & 26.42 & 32.20 & 100.00 & 58.40 & 13.80 & 26.60 & 149.99 & 40.60 & 269.99 \\
\hline $\mathrm{Fe}$ & 16.60 & 36.70 & 9.80 & 0.30 & 3.56 & 2.20 & 3.90 & 4.80 & 3.90 & 52.00 & 26.80 & 180.00 \\
\hline $\mathrm{Na}$ & 12.30 & 4.33 & 23.40 & 1.15 & 4.40 & 3.23 & 2.00 & 1.50 & 6.10 & 119.99 & 5.99 & 9.30 \\
\hline $\mathbf{M g}$ & 0.95 & 0.58 & 4.00 & 0.20 & 0.37 & 0.20 & 0.52 & 0.19 & 0.23 & 410.02 & 3.90 & 2.94 \\
\hline $\mathrm{Pb}$ & 40.00 & 18.17 & 21.50 & 5.97 & 70.60 & 34.50 & 5.63 & 22.10 & 49.50 & 90.90 & 45.60 & 144.00 \\
\hline $\mathrm{Sr}$ & 1.28 & 0.53 & 0.89 & 0.55 & 1.30 & 1.39 & 0.56 & 0.56 & 1.15 & 2.52 & 0.93 & 90.00 \\
\hline La & 1.40 & 0.02 & 0.07 & 0.00 & 0.05 & 0.67 & 0.01 & 0.01 & 0.03 & 0.25 & 0.09 & 3.10 \\
\hline $\mathrm{Ce}$ & 17.40 & 1.95 & 17.84 & 3.81 & 57.20 & 28.30 & 5.42 & 12.37 & 41.30 & 49.40 & 25.05 & 33.00 \\
\hline $\mathrm{Pr}$ & 0.54 & 0.04 & 0.24 & 0.03 & 0.20 & 1.02 & 0.02 & 0.02 & 0.05 & 1.00 & 0.18 & 0.94 \\
\hline Nd & 5.30 & 0.66 & 3.69 & 0.60 & 3.06 & 13.54 & 0.61 & 0.36 & 0.86 & 15.10 & 2.32 & 9.90 \\
\hline Sm & 8.27 & 2.59 & 5.44 & 1.11 & 5.40 & 16.22 & 1.39 & 1.15 & 2.35 & 25.30 & 4.98 & 13.50 \\
\hline Eu & 1.36 & 0.28 & 0.54 & 0.45 & 2.92 & 2.49 & 0.11 & 0.16 & 0.47 & 4.63 & 0.52 & 2.21 \\
\hline Gd & 38.10 & 14.82 & 23.50 & 5.84 & 30.30 & 53.90 & 8.60 & 5.50 & 14.41 & 114.00 & 24.70 & 58.50 \\
\hline Th & 218.00 & 71.50 & 116.70 & 30.70 & 267.00 & 153.60 & 23.70 & 94.00 & 267.60 & 355.00 & 236.00 & 504.00 \\
\hline Dy & 135.20 & 41.30 & 81.60 & 24.70 & 141.00 & 139.20 & 32.40 & 25.60 & 70.00 & 366.00 & 105.60 & 196.00 \\
\hline Ho & 48.20 & 12.95 & 30.52 & 9.98 & 55.10 & 45.40 & 11.68 & 10.66 & 27.48 & 124.40 & 36.84 & 66.60 \\
\hline $\mathrm{Er}$ & 210.20 & 52.90 & 134.00 & 49.50 & 254.00 & 181.50 & 52.70 & 53.40 & 126.70 & 506.00 & 155.10 & 276.00 \\
\hline $\mathbf{U}$ & 377.00 & 707.00 & 141.90 & 59.60 & 370.00 & 120.70 & 25.11 & 134.10 & 688.00 & 246.00 & 442.00 & 540.00 \\
\hline Lu & 77.40 & 19.12 & 47.00 & 27.17 & 111.10 & 60.90 & 20.90 & 30.60 & 52.30 & 137.80 & 49.30 & 87.40 \\
\hline $\mathrm{Ta}$ & 0.86 & 1.25 & 0.77 & 0.29 & 1.41 & 0.53 & 0.20 & 0.78 & 5.92 & 2.28 & 1.29 & 1.46 \\
\hline $\mathrm{Nb}$ & 20.61 & 17.08 & 25.49 & 24.01 & 27.56 & 23.86 & 18.30 & 17.00 & 28.30 & 33.70 & 20.94 & 24.80 \\
\hline $\mathrm{Ga}$ & 0.71 & 0.10 & 0.71 & 0.12 & 1.75 & 1.25 & 0.19 & 0.29 & 1.24 & 1.70 & 0.80 & 1.67 \\
\hline $\mathrm{Tb}$ & 12.05 & 4.33 & 7.08 & 1.99 & 10.97 & 14.00 & 2.79 & 2.03 & 5.44 & 33.90 & 8.84 & 17.70 \\
\hline $\mathrm{Tm}$ & 45.10 & 10.76 & 28.41 & 11.67 & 56.70 & 36.10 & 11.20 & 13.10 & 28.79 & 96.60 & 32.71 & 55.50 \\
\hline
\end{tabular}

Tabela 5: Dados de química de zircão de metassedimentos do Domínio São Roque, obtidos via LA-Q-ICPMS. Campos em cinza representam cristais com assínaturas de zircões de gabros tipo MORB. 


\begin{tabular}{|c|c|c|c|c|c|c|c|c|c|c|c|c|}
\hline & Serra Piruc. & \multicolumn{11}{|c|}{ Meta-subarcóseos da região da Serra da Viúva } \\
\hline LA-ICPMS no & $21 a$ & $1 \mathrm{~b}$ & $2 \mathrm{~b}$ & $3 a$ & $3 b$ & $4 a$ & $4 \mathrm{~b}$ & $5 b$ & $5 a$ & $6 a$ & $7 a$ & $8 a$ \\
\hline U-Pb no & 27.10 & 10.10 & 1.10 & 9.10 & - & 7.20 & 7.10 & 2.10 & - & 4.10 & 6.10 & 14.10 \\
\hline Idades 207Pb/206 & 1.94 & 2.89 & 2.21 & 2.42 & - & 2.53 & 2.49 & 1.74 & - & 2.24 & 1.77 & 2.25 \\
\hline Feições & núcleo & núcleo & núcleo & núcleo & borda & núcleo & borda & borda & núcleo & núcleo & núcleo & núcleo \\
\hline$\overline{\mathrm{Si}}$ & 178424.61 & 160422.13 & 167723.13 & 154021.24 & 153921.23 & 197627.26 & 193426.68 & 151020.83 & 150520.76 & 168923.30 & 157921.78 & 167723.13 \\
\hline $\mathrm{Zr}$ & 512000.00 & 481000.00 & 472600.00 & 423000.00 & 464000.00 & 554000.00 & 544000.00 & 411000.00 & 448000.00 & 509000.00 & 480150.00 & 481000.00 \\
\hline $\mathrm{Hf}$ & 10060.00 & 9880.00 & 9903.00 & 10150.00 & 9850.00 & 9770.00 & 9710.00 & 10100.00 & 10020.00 & 10090.00 & 9905.00 & 9920.00 \\
\hline Sc & 706.00 & 770.00 & 648.00 & 669.00 & 707.00 & 936.00 & 888.00 & 668.00 & 700.00 & 705.00 & 688.50 & 701.00 \\
\hline $\mathrm{Ca}$ & 617.34 & 581.32 & 534.30 & 955.53 & 822.46 & 2151.20 & 3101.73 & 1730.96 & 2521.41 & 438.74 & 549.81 & 719.40 \\
\hline $\mathbf{Y}$ & 726.00 & 693.00 & 618.00 & 1112.00 & 959.00 & 2570.00 & 3810.00 & 1870.00 & 1230.00 & 497.50 & 654.50 & 875.00 \\
\hline $\mathbf{P}$ & 147.90 & 186.50 & 148.60 & 418.00 & 295.00 & 257.00 & 332.00 & 450.00 & 592.00 & 158.70 & 156.70 & 224.00 \\
\hline $\mathrm{Yb}$ & 167.00 & 192.00 & 172.70 & 343.00 & 326.00 & 672.00 & 970.00 & 600.00 & 442.00 & 172.00 & 157.00 & 227.00 \\
\hline Al & 16.14 & 15.18 & 53.00 & 57.50 & 16.20 & 21.10 & 1899.91 & 229.99 & 77.00 & 28.85 & 21.00 & 19.60 \\
\hline $\mathrm{Fe}$ & 1.90 & 4.90 & 2.96 & 26.60 & 2.20 & 10.20 & 2000.01 & 1580.01 & 358.00 & 5.40 & 2.28 & 11.20 \\
\hline $\mathrm{Na}$ & 4.10 & 2.05 & 12.00 & 4.59 & 1.97 & 17.00 & 10.60 & 57.00 & 14.60 & 2.45 & 2.69 & 2.80 \\
\hline $\mathbf{M g}$ & 0.57 & 0.34 & 0.38 & 2.10 & 0.31 & 0.87 & 740.04 & 12.30 & 3.10 & 0.48 & 0.40 & 0.96 \\
\hline $\mathrm{Pb}$ & 16.10 & 16.88 & 11.96 & 19.30 & 21.70 & 24.90 & 42.60 & 37.10 & 30.40 & 7.71 & 3.84 & 11.80 \\
\hline $\mathrm{Sr}$ & 0.69 & 0.71 & 0.71 & 1.31 & 0.90 & 1.67 & 2.27 & 4.20 & 2.34 & 0.67 & 0.65 & 0.91 \\
\hline La & 0.04 & 0.02 & 0.03 & 0.47 & 0.03 & 0.07 & 0.10 & 3.20 & 3.16 & 0.08 & 0.02 & 0.07 \\
\hline $\mathrm{Ce}$ & 11.63 & 11.65 & 12.87 & 46.90 & 41.20 & 16.80 & 22.90 & 61.00 & 31.00 & 16.25 & 6.32 & 18.60 \\
\hline $\mathrm{Pr}$ & 0.22 & 0.07 & 0.13 & 1.29 & 0.16 & 0.56 & 0.60 & 5.60 & 2.50 & 0.13 & 0.16 & 0.18 \\
\hline Nd & 3.39 & 1.38 & 2.38 & 10.10 & 2.77 & 9.56 & 11.10 & 38.00 & 16.80 & 1.46 & 2.93 & 2.66 \\
\hline Sm & 5.06 & 3.49 & 4.18 & 9.00 & 5.09 & 18.80 & 24.90 & 26.00 & 11.00 & 2.25 & 4.77 & 4.94 \\
\hline Eu & 0.35 & 1.20 & 0.34 & 3.36 & 1.41 & 6.12 & 8.00 & 12.50 & 4.70 & 0.89 & 0.70 & 0.87 \\
\hline Gd & 22.00 & 18.80 & 18.57 & 32.80 & 24.00 & 83.50 & 123.00 & 72.00 & 37.00 & 10.67 & 20.00 & 22.00 \\
\hline Th & 84.40 & 64.50 & 62.10 & 114.00 & 102.80 & 113.00 & 197.00 & 239.00 & 177.00 & 41.45 & 26.20 & 59.20 \\
\hline Dy & 68.70 & 65.50 & 61.00 & 110.80 & 83.80 & 274.00 & 401.00 & 179.00 & 119.00 & 40.20 & 63.80 & 82.00 \\
\hline Ho & 23.30 & 23.08 & 21.68 & 37.80 & 31.20 & 93.50 & 136.00 & 62.40 & 41.00 & 15.03 & 22.10 & 29.30 \\
\hline $\mathrm{Er}$ & 95.50 & 98.20 & 88.20 & 153.40 & 138.50 & 373.00 & 546.00 & 258.00 & 177.00 & 70.15 & 90.90 & 123.50 \\
\hline $\mathbf{U}$ & 111.90 & 98.10 & 67.50 & 85.70 & 67.70 & 131.00 & 238.00 & 649.00 & 447.00 & 48.80 & 31.25 & 66.80 \\
\hline Lu & 30.50 & 35.40 & 29.71 & 67.30 & 65.90 & 112.70 & 163.00 & 112.00 & 81.00 & 34.25 & 28.35 & 43.90 \\
\hline $\mathrm{Ta}$ & 0.80 & 0.60 & 0.65 & 0.87 & 1.27 & 0.90 & 1.35 & 3.56 & 1.29 & 0.46 & 0.48 & 0.84 \\
\hline $\mathrm{Nb}$ & 24.52 & 23.70 & 23.95 & 22.50 & 25.50 & 27.96 & 29.90 & 27.70 & 23.90 & 25.05 & 23.54 & 24.84 \\
\hline Ga & 0.46 & 0.37 & 0.39 & 1.48 & 1.23 & 0.70 & 1.66 & 2.70 & 1.30 & 0.49 & 0.26 & 0.55 \\
\hline $\mathrm{Tb}$ & 6.37 & 5.85 & 5.49 & 10.37 & 7.41 & 25.90 & 38.80 & 18.30 & 11.00 & 3.48 & 5.81 & 7.21 \\
\hline $\mathrm{Tm}$ & 18.80 & 20.60 & 18.16 & 34.80 & 32.00 & 75.30 & 112.00 & 59.10 & 43.00 & 16.45 & 18.00 & 25.30 \\
\hline
\end{tabular}

Tabela 5: Dados de química de zircão de metassedimentos do Domínio São Roque, obtidos via LA-Q-ICPMS. Campos em cinza representam cristais com assínaturas de zircões de gabros tipo MORB. 


\begin{tabular}{|c|c|c|c|c|c|c|c|c|c|c|c|c|}
\hline & \multicolumn{12}{|c|}{ Meta-subarcóseos da região da Serra da Viúva } \\
\hline LA-ICPMS no & $8 b$ & $9 a$ & $9 \mathrm{~b}$ & $10 \mathrm{a}$ & $11 \mathrm{a}$ & $12 \mathrm{a}$ & $13 a$ & $13 b$ & $14 \mathrm{~b}$ & $14 a$ & $15 b$ & $15 a$ \\
\hline U-Pb no & - & 5.10 & - & 13.10 & 12.10 & - & - & 21.10 & - & - & - & - \\
\hline Idades 207Pb/206月 & - & 2.21 & - & 1.77 & 2.21 & - & - & 1.77 & - & - & - & - \\
\hline Feições & borda & núcleo & borda & núcleo & núcleo & núcleo & núcleo & borda & borda & núcleo & borda & núcleo \\
\hline$\overline{\mathrm{Si}}$ & 146420.19 & 158521.86 & 152020.97 & 129917.92 & 194326.80 & 176224.30 & 156821.63 & 148120.43 & 125017.24 & 159622.02 & 146020.14 & 154921.37 \\
\hline $\mathrm{Zr}$ & 426000.00 & 474000.00 & 440000.00 & 381000.00 & 529000.00 & 511000.00 & 441000.00 & 421000.00 & 415000.00 & 446000.00 & 433000.00 & 453000.00 \\
\hline $\mathrm{Hf}$ & 9890.00 & 9850.00 & 10440.00 & 9950.00 & 9860.00 & 9840.00 & 9880.00 & 9920.00 & 9860.00 & 9920.00 & 9600.00 & 9940.00 \\
\hline Sc & 612.00 & 684.00 & 610.00 & 555.00 & 812.00 & 724.00 & 656.00 & 651.00 & 642.00 & 710.00 & 595.00 & 611.00 \\
\hline $\mathrm{Ca}$ & 770.43 & 942.53 & 1000.56 & 500.28 & 1610.90 & 806.45 & 1340.75 & 2031.13 & 2091.17 & 404.23 & 1250.70 & 626.35 \\
\hline $\mathbf{Y}$ & 751.00 & 1106.00 & 1070.00 & 586.00 & 1790.00 & 956.00 & 1490.00 & 2120.00 & 1880.00 & 464.00 & 1290.00 & 725.00 \\
\hline $\mathbf{P}$ & 121.40 & 138.50 & 140.00 & 233.70 & 303.00 & 282.00 & 382.00 & 540.00 & 599.99 & 157.00 & 379.00 & 163.20 \\
\hline $\mathrm{Yb}$ & 207.00 & 283.00 & 296.00 & 168.30 & 472.00 & 235.00 & 389.00 & 580.00 & 280.00 & 151.00 & 299.00 & 218.10 \\
\hline Al & 22.90 & 15.80 & 30.00 & 32.00 & 759.96 & 25.50 & 141.99 & 449.98 & 449.98 & 17.09 & 269.99 & 16.13 \\
\hline $\mathrm{Fe}$ & 23.30 & 1.14 & 16.00 & 6.00 & 169.00 & 1.40 & 508.00 & 2210.01 & 860.01 & 6.60 & 105.00 & 10.20 \\
\hline $\mathrm{Na}$ & 8.90 & 3.47 & 19.00 & 2.25 & 32.00 & 1.04 & 22.90 & 167.99 & 68.99 & 1.60 & 24.00 & 2.79 \\
\hline $\mathbf{M g}$ & 3.90 & 0.35 & 13.00 & 0.87 & 28.10 & 0.25 & 4.75 & 18.20 & 14.20 & 0.29 & 7.10 & 1.41 \\
\hline $\mathrm{Pb}$ & 14.20 & 14.20 & 19.10 & 15.30 & 33.60 & 37.50 & 40.40 & 43.00 & 9.50 & 6.67 & 9.87 & 9.90 \\
\hline $\mathrm{Sr}$ & 0.72 & 0.90 & 0.98 & 0.67 & 2.22 & 0.79 & 2.55 & 9.10 & 6.30 & 0.73 & 2.50 & 0.79 \\
\hline La & 0.05 & 0.02 & 0.12 & 0.01 & 1.42 & 0.07 & 5.20 & 6.60 & 7.30 & 0.00 & 2.10 & 0.01 \\
\hline $\mathrm{Ce}$ & 16.80 & 10.06 & 14.70 & 4.41 & 34.00 & 43.50 & 66.80 & 97.00 & 106.00 & 7.24 & 46.00 & 11.44 \\
\hline $\mathrm{Pr}$ & 0.09 & 0.19 & 0.35 & 0.09 & 3.09 & 0.42 & 4.32 & 8.00 & 15.30 & 0.04 & 5.10 & 0.05 \\
\hline Nd & 1.46 & 3.63 & 3.30 & 1.69 & 24.30 & 6.50 & 28.10 & 53.00 & 134.00 & 0.96 & 32.00 & 0.90 \\
\hline Sm & 2.93 & 6.82 & 6.40 & 3.64 & 19.10 & 9.40 & 20.80 & 39.00 & 87.00 & 1.81 & 24.00 & 2.27 \\
\hline Eu & 0.40 & 1.11 & 1.49 & 0.09 & 6.90 & 2.52 & 8.70 & 17.00 & 30.00 & 0.56 & 7.90 & 0.17 \\
\hline Gd & 17.30 & 32.00 & 32.70 & 15.07 & 65.00 & 33.70 & 62.00 & 111.00 & 131.00 & 9.80 & 55.00 & 13.87 \\
\hline Th & 76.00 & 73.70 & 98.00 & 99.70 & 210.00 & 162.00 & 276.00 & 423.00 & 160.00 & 30.90 & 130.00 & 51.30 \\
\hline Dy & 67.20 & 110.90 & 107.00 & 56.60 & 183.00 & 94.60 & 162.00 & 259.00 & 212.00 & 39.60 & 142.00 & 63.70 \\
\hline Ho & 25.10 & 38.00 & 36.40 & 20.39 & 60.90 & 30.80 & 50.60 & 74.00 & 55.00 & 14.20 & 43.00 & 24.27 \\
\hline $\mathrm{Er}$ & 110.00 & 155.30 & 146.00 & 85.90 & 249.00 & 121.90 & 202.00 & 293.00 & 182.00 & 66.20 & 168.00 & 108.20 \\
\hline $\mathbf{U}$ & 106.00 & 91.10 & 135.20 & 124.10 & 296.00 & 112.30 & 399.00 & 697.00 & 370.00 & 79.00 & 172.00 & 103.40 \\
\hline Lu & 42.40 & 50.90 & 57.00 & 30.20 & 84.30 & 41.30 & 70.70 & 91.40 & 35.00 & 30.10 & 48.40 & 38.70 \\
\hline $\mathrm{Ta}$ & 0.92 & 0.41 & 0.44 & 0.49 & 0.69 & 1.19 & 1.56 & 2.22 & 0.24 & 0.21 & 1.69 & 1.48 \\
\hline $\mathrm{Nb}$ & 22.05 & 22.50 & 21.70 & 18.94 & 27.10 & 26.71 & 23.50 & 39.00 & 21.40 & 21.80 & 24.40 & 24.92 \\
\hline $\mathrm{Ga}$ & 0.61 & 0.32 & 0.43 & 0.17 & 1.79 & 1.32 & 2.56 & 4.30 & 5.90 & 0.21 & 2.50 & 0.31 \\
\hline $\mathrm{Tb}$ & 5.60 & 9.90 & 9.80 & 4.93 & 18.00 & 9.35 & 16.90 & 26.90 & 29.00 & 3.26 & 15.80 & 5.02 \\
\hline $\mathrm{Tm}$ & 23.40 & 32.80 & 31.00 & 18.44 & 52.30 & 25.60 & 43.40 & 59.50 & 35.00 & 14.70 & 34.90 & 23.37 \\
\hline
\end{tabular}

Tabela 5: Dados de química de zircão de metassedimentos do Domínio São Roque, obtidos via LA-Q-ICPMS. Campos em cinza representam cristais com assínaturas de zircões de gabros tipo MORB. 


\begin{tabular}{|c|c|c|c|c|c|c|c|c|c|c|c|c|}
\hline & \multicolumn{12}{|c|}{ Meta-subarcóseos da região da Serra da Viúva } \\
\hline LA-ICPMS no & $17 a$ & $18 \mathrm{~b}$ & $\overline{18 a}$ & $19 \mathrm{~b}$ & $19 a$ & $20 a$ & $21 a$ & $22 a$ & $23 a$ & $24 a$ & $24 b$ & $25 a$ \\
\hline U-Pb no & 24.10 & 25.10 & - & 23.10 & - & 22.10 & 31.10 & 40.10 & 41.10 & 42.10 & - & - \\
\hline Idades 207Pb/206月 & 2.75 & 1.81 & - & 2.21 & - & 2.20 & 1.77 & 2.19 & 2.24 & 2.19 & - & - \\
\hline Feições & núcleo & borda & núcleo & borda & núcleo & núcleo & núcleo & núcleo & núcleo & núcleo & borda & núcleo \\
\hline$\overline{\mathrm{Si}}$ & 143519.79 & 157021.66 & 158021.79 & 145020.00 & 185025.52 & 164522.69 & 173823.97 & 193026.62 & 185025.52 & 190026.21 & 181525.04 & 168023.17 \\
\hline $\mathrm{Zr}$ & 390000.00 & 441000.00 & 474000.00 & 426000.00 & 504000.00 & 461000.00 & 508000.00 & 528000.00 & 449000.00 & 514000.00 & 464500.00 & 473000.00 \\
\hline $\mathrm{Hf}$ & 9870.00 & 9840.00 & 9870.00 & 9850.00 & 10070.00 & 9950.00 & 10350.00 & 9950.00 & 10250.00 & 10110.00 & 9950.00 & 9730.00 \\
\hline Sc & 568.00 & 638.00 & 698.00 & 681.00 & 795.00 & 685.00 & 744.00 & 750.00 & 664.00 & 780.00 & 681.50 & 689.00 \\
\hline $\mathrm{Ca}$ & 178.10 & 960.54 & 622.35 & 561.31 & 715.40 & 674.38 & 760.42 & 900.50 & 573.32 & 681.38 & 648.36 & 1402.78 \\
\hline $\mathbf{Y}$ & 88.00 & 974.00 & 637.00 & 568.00 & 709.00 & 716.00 & 780.00 & 788.00 & 506.00 & 611.00 & 666.50 & 1726.00 \\
\hline $\mathbf{P}$ & 83.20 & 226.00 & 125.00 & 210.00 & 206.00 & 170.70 & 154.00 & 223.00 & 224.00 & 189.00 & 193.00 & 140.00 \\
\hline $\mathrm{Yb}$ & 6.71 & 237.00 & 179.00 & 139.00 & 194.00 & 272.00 & 207.00 & 274.00 & 169.00 & 223.00 & 221.50 & 408.00 \\
\hline Al & 85.00 & 2399.89 & 47.00 & 40.00 & 26.60 & 17.50 & 19.40 & 21.00 & 17.40 & 17.60 & 37.00 & 31.20 \\
\hline $\mathrm{Fe}$ & 8.10 & 300.00 & 8.00 & 47.00 & 6.20 & 2.70 & 1.40 & 10.70 & 4.50 & & 14.05 & 7.10 \\
\hline $\mathrm{Na}$ & 5.70 & 43.00 & 12.20 & 8.10 & 7.60 & 3.21 & 3.80 & 30.00 & 8.80 & 8.00 & 34.00 & 7.00 \\
\hline $\mathbf{M g}$ & 1.82 & 64.00 & 0.64 & 1.20 & 0.77 & 1.59 & 0.42 & 2.50 & 3.00 & 0.83 & 5.15 & 17.00 \\
\hline $\mathrm{Pb}$ & 23.50 & 7.30 & 6.62 & 20.80 & 32.20 & 12.10 & 6.90 & 11.40 & 12.00 & 23.90 & 23.55 & 37.10 \\
\hline $\mathrm{Sr}$ & 0.36 & 2.59 & 0.70 & 0.78 & 0.73 & 0.91 & 0.80 & 0.85 & 0.72 & 0.61 & 0.87 & 1.29 \\
\hline La & 0.06 & 2.53 & 0.06 & 0.26 & 0.06 & 0.01 & 0.23 & 0.01 & 0.05 & 0.01 & 0.07 & 0.10 \\
\hline $\mathrm{Ce}$ & 3.51 & 43.10 & 7.63 & 14.40 & 13.30 & 25.00 & 9.57 & 11.29 & 20.00 & 13.30 & 15.10 & 10.90 \\
\hline $\mathrm{Pr}$ & 0.29 & 5.43 & 0.11 & 0.56 & 0.44 & 0.04 & 0.22 & 0.07 & 0.03 & 0.06 & 0.19 & 0.75 \\
\hline Nd & 2.15 & 35.70 & 1.87 & 4.80 & 6.20 & 0.92 & 3.49 & 1.17 & 0.85 & 1.26 & 2.06 & 11.62 \\
\hline Sm & 2.42 & 20.80 & 3.41 & 5.50 & 8.70 & 2.23 & 6.10 & 3.02 & 1.85 & 2.69 & 3.75 & 15.90 \\
\hline Eu & 0.20 & 8.70 & 0.36 & 1.03 & 1.16 & 0.92 & 0.82 & 0.42 & 0.50 & 0.49 & 0.65 & 0.68 \\
\hline Gd & 6.54 & 59.00 & 17.60 & 18.10 & 29.50 & 13.30 & 27.40 & 19.30 & 10.50 & 14.00 & 17.10 & 64.00 \\
\hline Th & 86.80 & 89.00 & 42.60 & 132.00 & 154.00 & 58.00 & 44.60 & 49.90 & 51.70 & 104.00 & 117.00 & 243.00 \\
\hline Dy & 8.38 & 117.00 & 57.00 & 54.80 & 78.00 & 56.30 & 78.00 & 72.30 & 41.90 & 51.60 & 59.00 & 186.00 \\
\hline Ho & 1.86 & 35.10 & 21.10 & 19.20 & 24.40 & 21.80 & 26.50 & 26.10 & 15.70 & 19.11 & 22.20 & 60.30 \\
\hline $\mathrm{Er}$ & 5.28 & 126.00 & 90.20 & 75.70 & 97.00 & 101.10 & 104.00 & 114.60 & 70.60 & 88.30 & 102.50 & 234.00 \\
\hline $\mathbf{U}$ & 248.00 & 158.00 & 62.80 & 205.00 & 174.00 & 99.10 & 50.00 & 88.00 & 35.90 & 176.00 & 200.50 & 181.40 \\
\hline Lu & 1.25 & 39.50 & 31.50 & 24.60 & 31.70 & 49.60 & 34.50 & 40.10 & 29.60 & 35.50 & 34.70 & 70.80 \\
\hline $\mathrm{Ta}$ & 0.87 & 0.83 & 0.84 & 0.66 & 0.55 & 1.09 & 0.66 & 1.64 & 0.67 & 1.04 & 0.96 & 0.68 \\
\hline $\mathrm{Nb}$ & 16.10 & 20.10 & 20.50 & 17.10 & 20.80 & 20.00 & 22.00 & 24.30 & 18.50 & 21.80 & 20.50 & 19.40 \\
\hline $\mathrm{Ga}$ & 0.23 & 3.54 & 0.33 & 0.84 & 0.64 & 0.93 & 0.42 & 0.42 & 0.75 & 0.49 & 0.57 & 0.80 \\
\hline $\mathrm{Tb}$ & 1.24 & 13.70 & 5.26 & 4.90 & 7.60 & 4.52 & 7.70 & 6.02 & 3.37 & 4.63 & 4.85 & 17.70 \\
\hline Tm & 0.92 & 26.60 & 18.80 & 15.70 & 21.10 & 25.30 & 22.40 & 26.50 & 16.60 & 21.20 & 21.40 & 46.80 \\
\hline
\end{tabular}

Tabela 5: Dados de química de zircão de metassedimentos do Domínio São Roque, obtidos via LA-Q-ICPMS. Campos em cinza representam cristais com assínaturas de zircões de gabros tipo MORB. 


\begin{tabular}{|c|c|c|c|c|c|c|c|c|c|c|c|c|}
\hline & \multicolumn{12}{|c|}{ Meta-subarcóseos da região da Serra da Viúva } \\
\hline LA-ICPMS no & $25 b$ & $26 a$ & $27 \mathrm{~b}$ & $27 a$ & $28 a$ & $28 b$ & $29 a$ & $30 a$ & $30 b$ & $31 \mathrm{a}$ & $32 a$ & $33 a$ \\
\hline U-Pb no & 36.10 & 38.10 & - & 44.10 & - & 57.10 & ? & 54.10 & - & 47.10 & 68.10 & - \\
\hline Idades 207Pb/206月 & 1.79 & 2.30 & - & 1.98 & - & 2.22 & $?$ & 2.31 & - & 2.24 & 3.12 & - \\
\hline Feições & borda & núcleo & borda & núcleo & núcleo & borda & núcleo & núcleo & borda & núcleo & núcleo & núcleo \\
\hline$\overline{\mathrm{Si}}$ & 172023.73 & 204028.14 & 157021.66 & 177824.53 & 158021.79 & 154521.31 & 222030.62 & 212029.24 & 227031.31 & 200027.59 & 174024.00 & 183025.24 \\
\hline $\mathrm{Zr}$ & 513000.00 & 446000.00 & 438000.00 & 526000.00 & 469000.00 & 469500.00 & 496000.00 & 551000.00 & 543000.00 & 539000.00 & 460000.00 & 545000.00 \\
\hline $\mathrm{Hf}$ & 10055.00 & 9500.00 & 10010.00 & 10040.00 & 10030.00 & 10015.00 & 10100.00 & 9810.00 & 9780.00 & 9560.00 & 9800.00 & 9890.00 \\
\hline Sc & 745.00 & 619.00 & 596.00 & 742.00 & 681.00 & 671.00 & 711.00 & 773.00 & 770.00 & 930.00 & 800.00 & 770.00 \\
\hline $\mathrm{Ca}$ & 1430.80 & 520.29 & 511.29 & 501.28 & 1156.64 & 571.32 & 843.47 & 843.47 & 960.54 & 1440.80 & 1160.65 & 527.29 \\
\hline$Y$ & 1580.00 & 610.00 & 557.00 & 514.00 & 1370.00 & 602.50 & 860.00 & 799.00 & 914.00 & 1600.00 & 1222.00 & 613.00 \\
\hline $\mathbf{P}$ & 161.50 & 166.00 & 109.00 & 176.00 & 187.00 & 169.60 & 191.00 & 228.00 & 288.00 & 400.00 & 314.00 & 140.00 \\
\hline $\mathrm{Yb}$ & 359.50 & 250.00 & 168.00 & 148.00 & 533.00 & 253.80 & 201.00 & 239.00 & 278.00 & 522.00 & 475.00 & 153.00 \\
\hline Al & 6083.72 & 78.00 & 15.20 & 25.60 & 14.20 & 27.50 & 20.50 & 23.80 & 100.00 & 20.90 & 45.90 & 35.00 \\
\hline $\mathrm{Fe}$ & 1335.01 & 20.00 & 25.00 & 0.70 & 3.50 & 10.20 & & 5.00 & 155.00 & 4.80 & 10.70 & 5.80 \\
\hline $\mathrm{Na}$ & 52.15 & 14.60 & 2.60 & 13.00 & 2.20 & 8.25 & 5.60 & 18.00 & 35.30 & 14.60 & 8.40 & 12.80 \\
\hline Mg & 191.36 & 6.60 & 0.52 & 1.63 & 0.32 & 0.85 & 0.70 & 3.90 & 7.20 & 3.49 & 1.38 & 0.65 \\
\hline $\mathrm{Pb}$ & 27.30 & 13.20 & 23.10 & 11.00 & 27.00 & 14.96 & 18.20 & 14.20 & 15.90 & 27.40 & 21.40 & 15.20 \\
\hline $\mathrm{Sr}$ & 2.28 & 0.87 & 0.56 & 0.63 & 1.23 & 0.86 & 0.77 & 0.98 & 1.99 & 1.51 & 1.14 & 0.62 \\
\hline La & 0.89 & 0.13 & 0.01 & 0.02 & 0.01 & 0.11 & 0.02 & 0.03 & 0.95 & 0.05 & 0.39 & 0.06 \\
\hline $\mathrm{Ce}$ & 18.60 & 29.00 & 25.10 & 22.10 & 26.80 & 14.75 & 17.40 & 7.65 & 16.60 & 41.20 & 21.70 & 19.10 \\
\hline $\mathrm{Pr}$ & 1.68 & 0.14 & 0.09 & 0.08 & 0.15 & 0.29 & 0.58 & 0.11 & 1.82 & 0.25 & 1.03 & 0.30 \\
\hline Nd & 16.80 & 1.70 & 1.16 & 1.58 & 2.22 & 1.94 & 9.60 & 1.62 & 10.60 & 4.59 & 9.40 & 5.00 \\
\hline Sm & 18.40 & 1.83 & 1.92 & 2.79 & 4.31 & 2.95 & 12.90 & 3.80 & 12.20 & 8.80 & 7.60 & 7.30 \\
\hline Eu & 2.69 & 1.09 & 0.20 & 0.72 & 1.83 & 1.06 & 2.30 & 0.31 & 5.60 & 2.37 & 2.40 & 1.66 \\
\hline Gd & 60.25 & 15.40 & 11.10 & 14.30 & 26.10 & 11.65 & 42.60 & 18.60 & 32.00 & 38.80 & 26.70 & 24.30 \\
\hline Th & 205.00 & 73.00 & 139.00 & 57.60 & 134.00 & 84.65 & 84.50 & 64.70 & 72.00 & 134.00 & 101.00 & 72.30 \\
\hline Dy & 165.50 & 52.00 & 44.00 & 46.60 & 108.20 & 45.95 & 101.00 & 70.30 & 90.50 & 139.00 & 107.00 & 59.90 \\
\hline Ho & 55.05 & 16.90 & 16.90 & 16.44 & 44.10 & 17.35 & 30.10 & 26.90 & 32.00 & 53.80 & 43.80 & 18.90 \\
\hline $\mathrm{Er}$ & 218.50 & 72.00 & 75.00 & 69.60 & 208.00 & 89.85 & 115.10 & 112.00 & 125.80 & 242.00 & 205.00 & 78.20 \\
\hline $\mathbf{U}$ & 167.50 & 121.00 & 375.00 & 97.00 & 179.00 & 151.20 & 113.20 & 148.00 & 252.00 & 142.00 & 146.00 & 96.00 \\
\hline Lu & 59.70 & 48.00 & 29.80 & 26.10 & 100.10 & 51.60 & 32.80 & 40.80 & 41.40 & 95.00 & 89.00 & 25.40 \\
\hline $\mathrm{Ta}$ & 0.75 & 1.01 & 2.21 & 1.00 & 1.02 & 0.76 & 0.64 & 1.19 & 2.42 & 1.03 & 1.13 & 0.88 \\
\hline $\mathrm{Nb}$ & 20.08 & 19.40 & 19.40 & 21.50 & 21.30 & 18.65 & 20.40 & 22.90 & 25.00 & 24.30 & 19.10 & 22.30 \\
\hline Ga & 2.36 & 1.23 & 0.97 & 0.91 & 0.89 & 0.60 & 0.84 & 0.33 & 1.02 & 1.54 & 1.04 & 0.72 \\
\hline Tb & 16.15 & 5.00 & 3.76 & 4.30 & 8.61 & 3.81 & 10.40 & 5.94 & 8.10 & 12.20 & 8.60 & 5.80 \\
\hline $\mathrm{Tm}$ & 42.80 & 21.30 & 17.20 & 15.60 & 50.70 & 23.90 & 23.10 & 24.00 & 28.00 & 55.40 & 48.10 & 16.90 \\
\hline
\end{tabular}

Tabela 5: Dados de química de zircão de metassedimentos do Domínio São Roque, obtidos via LA-Q-ICPMS. Campos em cinza representam cristais com assínaturas de zircões de gabros tipo MORB. 


\begin{tabular}{|c|c|c|c|c|c|c|c|c|c|c|c|c|}
\hline & \multicolumn{3}{|c|}{ Serra da Viúva } & \multicolumn{9}{|c|}{ Metarcóseos da região da Serra do Voturuna } \\
\hline LA-ICPMS no & $33 b$ & $34 a$ & $34 b$ & $1 \mathrm{~b}$ & $1 \mathrm{a}$ & $2 a$ & $3 a$ & $3 b$ & $4 a$ & $5 a$ & $6 b$ & $6 a$ \\
\hline U-Pb no & 65.10 & 64.10 & - & - & 5.10 & - & 3.10 & - & 2.10 & 1.10 & 23.10 & - \\
\hline Idades 207Pb/206Я & 2.21 & 2.26 & - & - & 3.02 & - & 2.18 & - & 2.48 & 2.21 & 2.44 & - \\
\hline Feições & borda & núcleo & borda & borda & núcleo & núcleo & núcleo & borda & núcleo & núcleo & borda & núcleo \\
\hline$\overline{\mathrm{Si}}$ & 176024.28 & 203028.00 & 203028.00 & 158021.79 & 129017.79 & 143919.85 & 202827.97 & 189626.15 & 141819.56 & 277038.21 & 205028.28 & 198027.31 \\
\hline $\mathrm{Zr}$ & 484000.00 & 546000.00 & 480000.00 & 386000.00 & 365000.00 & 360000.00 & 516000.00 & 447000.00 & 367000.00 & 573000.00 & 502000.00 & 516000.00 \\
\hline $\mathrm{Hf}$ & 10150.00 & 9810.00 & 10200.00 & 10010.00 & 9650.00 & 9950.00 & 10180.00 & 9930.00 & 10090.00 & 10440.00 & 9740.00 & 9910.00 \\
\hline Sc & 730.00 & 794.00 & 730.00 & 630.00 & 502.00 & 650.00 & 718.00 & 676.00 & 507.00 & 863.00 & 790.00 & 759.00 \\
\hline $\mathrm{Ca}$ & 845.47 & 510.28 & 540.30 & 1330.74 & 450.25 & 535.30 & 800.45 & 630.35 & 318.18 & 1020.57 & 1460.81 & 760.42 \\
\hline $\mathbf{Y}$ & 828.50 & 469.00 & 520.00 & 1220.00 & 420.00 & 534.00 & 880.00 & 697.40 & 349.00 & 970.00 & 1590.00 & 784.00 \\
\hline $\mathbf{P}$ & 178.00 & 163.00 & 200.00 & 425.00 & 140.00 & 163.00 & 234.00 & 220.00 & 87.00 & 309.00 & 540.00 & 219.00 \\
\hline Yb & 206.50 & 158.00 & 163.00 & 436.00 & 127.00 & 190.00 & 266.00 & 211.00 & 107.00 & 271.00 & 426.00 & 266.00 \\
\hline Al & 2349.89 & 32.00 & 50.00 & 349.98 & 149.99 & 759.96 & 22.40 & 19.90 & 13.50 & 25.70 & 2239.90 & 25.10 \\
\hline $\mathrm{Fe}$ & 241.00 & 9.00 & 300.00 & 410.00 & 39.00 & 309.00 & & 53.00 & 2.50 & 3.80 & 320.00 & 3.20 \\
\hline $\mathrm{Na}$ & 67.99 & 22.30 & 46.00 & 125.99 & 12.60 & 37.90 & 5.10 & 24.00 & 2.20 & 4.70 & 44.00 & 10.50 \\
\hline Mg & 49.75 & 12.00 & 6.60 & 26.90 & 7.20 & 67.00 & 1.04 & 1.70 & 1.61 & 3.00 & 170.01 & 0.99 \\
\hline $\mathrm{Pb}$ & 26.05 & 22.30 & 18.50 & 39.20 & 13.60 & 12.00 & 40.20 & 34.10 & 6.32 & 15.70 & 31.50 & 9.85 \\
\hline $\mathrm{Sr}$ & 2.02 & 0.69 & 1.48 & 12.30 & 1.80 & 3.35 & 0.88 & 1.14 & 0.65 & 0.85 & 3.35 & 0.74 \\
\hline La & 1.16 & 0.04 & 8.00 & 5.90 & 1.70 & 2.15 & 0.03 & 0.06 & 0.00 & 0.02 & 0.22 & 0.03 \\
\hline $\mathrm{Ce}$ & 36.50 & 9.40 & 14.20 & 51.00 & 19.00 & 13.90 & 15.40 & 17.20 & 4.62 & 17.10 & 23.20 & 10.90 \\
\hline $\mathrm{Pr}$ & 2.55 & 0.09 & 1.30 & 6.90 & 2.20 & 2.39 & 0.18 & 0.15 & 0.01 & 0.15 & 0.38 & 0.07 \\
\hline Nd & 18.05 & 1.38 & 13.00 & 39.00 & 12.00 & 15.70 & 2.70 & 2.12 & 0.31 & 3.62 & 4.80 & 1.06 \\
\hline Sm & 16.10 & 2.16 & 9.00 & 19.30 & 6.20 & 8.30 & 4.90 & 4.72 & 0.87 & 7.00 & 6.90 & 2.86 \\
\hline Eu & 5.70 & 0.53 & 2.50 & 8.20 & 2.20 & 3.50 & 0.71 & 0.59 & 0.16 & 1.37 & 1.68 & 0.63 \\
\hline Gd & 45.05 & 9.40 & 16.40 & 40.60 & 17.00 & 21.30 & 21.70 & 14.60 & 6.50 & 27.50 & 35.50 & 15.80 \\
\hline Th & 142.50 & 81.00 & 109.00 & 149.00 & 53.00 & 35.70 & 188.00 & 179.00 & 27.80 & 64.50 & 130.00 & 41.70 \\
\hline Dy & 97.50 & 38.30 & 46.00 & 108.00 & 31.00 & 53.00 & 75.10 & 60.00 & 26.90 & 96.00 & 139.00 & 64.90 \\
\hline Ho & 28.55 & 13.80 & 15.40 & 38.50 & 11.60 & 16.20 & 27.80 & 21.90 & 10.40 & 31.90 & 50.00 & 26.00 \\
\hline $\mathrm{Er}$ & 105.50 & 66.10 & 70.00 & 174.00 & 49.00 & 68.00 & 119.00 & 95.10 & 46.00 & 132.00 & 218.00 & 112.50 \\
\hline $\mathbf{U}$ & 155.00 & 165.00 & 510.00 & 499.00 & 133.00 & 325.00 & 294.00 & 330.00 & 104.00 & 142.00 & 208.00 & 94.40 \\
\hline Lu & 34.30 & 28.40 & 30.50 & 86.00 & 24.00 & 45.80 & 42.80 & 37.20 & 20.60 & 41.90 & 71.00 & 44.30 \\
\hline $\mathrm{Ta}$ & 0.98 & 0.54 & 0.80 & 1.26 & 0.60 & 0.92 & 1.14 & 1.06 & 0.57 & 0.55 & 1.50 & 0.86 \\
\hline $\mathrm{Nb}$ & 23.70 & 24.00 & 18.60 & 18.80 & 18.00 & 19.20 & 23.80 & 21.80 & 16.38 & 25.40 & 24.80 & 23.80 \\
\hline Ga & 2.65 & 0.25 & 0.64 & 2.98 & 1.01 & 1.24 & 0.75 & 0.55 & 0.15 & 0.81 & 1.74 & 0.42 \\
\hline Tb & 11.25 & 3.37 & 4.40 & 10.80 & 3.40 & 6.00 & 6.63 & 4.93 & 2.35 & 8.90 & 11.90 & 5.55 \\
\hline Tm & 21.55 & 16.10 & 17.50 & 42.00 & 11.30 & 17.10 & 26.40 & 21.90 & 10.90 & 31.70 & 46.10 & 25.00 \\
\hline
\end{tabular}

Tabela 5: Dados de química de zircão de metassedimentos do Domínio São Roque, obtidos via LA-Q-ICPMS. Campos em cinza representam cristais com assínaturas de zircões de gabros tipo MORB. 


\begin{tabular}{|c|c|c|c|c|c|c|c|c|c|c|c|c|}
\hline & \multicolumn{12}{|c|}{ Metarcóseos da região da Serra do Voturuna } \\
\hline LA-ICPMS no & $7 a$ & $8 a$ & $8 b$ & $9 a$ & $9 b$ & $10 a$ & $11 \mathrm{~b}$ & $11 \mathrm{a}$ & $12 \mathrm{a}$ & $16 \mathrm{~b}$ & $16 a$ & $17 \mathrm{~b}$ \\
\hline U-Pb no & 20.10 & - & 13.10 & - & $?$ & 15.10 & - & 7.10 & 16.10 & - & 58.10 & 46.10 \\
\hline Idades 207Pb/206 & 2.44 & - & 2.16 & - & $?$ & 2.21 & - & 2.50 & 3.00 & - & 1.41 & 1.95 \\
\hline Feições & núcleo & núcleo & borda & núcleo & borda & núcleo? & borda & núcleo & núcleo & borda & núcleo & borda \\
\hline$\overline{\mathrm{Si}}$ & 172323.77 & 163022.48 & 191026.35 & 174924.13 & 156521.59 & 157021.66 & 173023.86 & 183525.31 & 174024.00 & 180024.83 & 178424.61 & 207028.55 \\
\hline $\mathrm{Zr}$ & 437000.00 & 481000.00 & 475000.00 & 477000.00 & 441000.00 & 425000.00 & 490000.00 & 479000.00 & 501000.00 & 427000.00 & 454000.00 & 501000.00 \\
\hline Hf & 9990.00 & 9930.00 & 9970.00 & 10070.00 & 10275.00 & 9930.00 & 10700.00 & 10015.00 & 10030.00 & 10000.00 & 10220.00 & 9900.00 \\
\hline Sc & 633.00 & 700.00 & 673.00 & 684.00 & 606.50 & 596.00 & 730.00 & 675.00 & 686.00 & 585.00 & 588.00 & 741.00 \\
\hline $\mathrm{Ca}$ & 581.32 & 900.50 & 1200.67 & 1580.88 & 1140.64 & 1951.09 & 470.26 & 472.26 & 719.40 & 1891.05 & 1130.63 & 1130.63 \\
\hline $\mathbf{Y}$ & 682.00 & 1114.00 & 1410.00 & 1920.00 & 1265.00 & 2520.00 & 498.00 & 413.50 & 871.00 & 1810.00 & 1130.00 & 1170.00 \\
\hline $\mathbf{P}$ & 190.00 & 99.00 & 260.00 & 163.00 & 182.50 & 514.00 & 125.00 & 100.00 & 179.00 & 969.99 & 380.00 & 331.00 \\
\hline $\mathrm{Yb}$ & 216.00 & 344.00 & 360.00 & 448.00 & 310.50 & 750.00 & 149.00 & 139.50 & 230.00 & 325.00 & 266.00 & 289.00 \\
\hline Al & 16.00 & 39.10 & 11099.49 & 33.00 & 203.99 & 20.80 & 100.00 & 175.54 & 1799.92 & 689.97 & 289.99 & 3199.85 \\
\hline $\mathrm{Fe}$ & 3.80 & 99.00 & 1320.01 & 4.80 & 42.50 & 11.80 & 42.00 & 12.40 & 2.80 & 376.00 & 195.00 & 630.00 \\
\hline $\mathrm{Na}$ & 4.50 & 13.70 & 76.99 & 4.70 & 21.65 & 5.30 & 23.00 & 34.45 & 31.00 & 104.99 & 49.00 & 46.00 \\
\hline Mg & 0.77 & 6.00 & 680.04 & 2.45 & 23.00 & 1.15 & 7.00 & 9.89 & 1.11 & 28.30 & 29.40 & 230.01 \\
\hline $\mathrm{Pb}$ & 13.52 & 43.20 & 41.50 & 68.70 & 50.25 & 39.40 & 6.60 & 9.13 & 14.80 & 23.00 & 30.60 & 36.30 \\
\hline $\mathrm{Sr}$ & 0.76 & 1.31 & 4.34 & 1.93 & 1.75 & 1.64 & 1.30 & 1.00 & 1.14 & 6.60 & 3.50 & 3.55 \\
\hline La & 0.01 & 0.36 & 2.42 & 0.09 & 2.57 & 0.02 & 0.34 & 0.05 & 0.07 & 14.30 & 2.40 & 1.95 \\
\hline $\mathrm{Ce}$ & 12.38 & 36.50 & 44.10 & 30.00 & 23.70 & 18.10 & 6.20 & 4.68 & 11.95 & 320.00 & 37.00 & 25.50 \\
\hline $\mathrm{Pr}$ & 0.05 & 0.35 & 3.70 & 0.73 & 1.13 & 0.25 & 0.38 & 0.05 & 0.24 & 13.50 & 2.40 & 2.32 \\
\hline Nd & 1.03 & 5.40 & 26.30 & 12.20 & 10.75 & 5.30 & 2.50 & 1.10 & 3.87 & 81.00 & 12.10 & 16.80 \\
\hline Sm & 2.00 & 7.00 & 20.10 & 16.70 & 12.00 & 10.10 & 2.10 & 1.46 & 6.06 & 35.00 & 8.80 & 11.60 \\
\hline Eu & 0.43 & 2.05 & 5.64 & 1.15 & 1.90 & 1.15 & 1.60 & 0.67 & 0.36 & 14.40 & 3.20 & 3.51 \\
\hline Gd & 12.61 & 27.10 & 53.00 & 73.00 & 51.85 & 57.00 & 10.40 & 8.00 & 27.50 & 81.00 & 34.20 & 31.90 \\
\hline Th & 57.90 & 209.00 & 288.00 & 345.00 & 230.50 & 132.00 & 32.00 & 26.95 & 74.90 & 168.00 & 151.00 & 254.00 \\
\hline Dy & 57.30 & 93.00 & 147.00 & 207.00 & 141.50 & 237.00 & 41.00 & 29.55 & 87.90 & 167.00 & 100.00 & 102.00 \\
\hline Ho & 21.90 & 34.20 & 47.20 & 67.60 & 45.05 & 88.00 & 13.40 & 11.63 & 29.70 & 46.20 & 32.20 & 33.60 \\
\hline $\mathrm{Er}$ & 97.40 & 152.00 & 179.00 & 262.00 & 171.00 & 373.00 & 56.00 & 53.40 & 121.00 & 176.00 & 135.00 & 145.00 \\
\hline $\mathbf{U}$ & 114.30 & 322.00 & 385.00 & 320.00 & 303.00 & 320.00 & 72.00 & 61.25 & 83.70 & 350.00 & 335.00 & 324.00 \\
\hline Lu & 39.00 & 66.00 & 67.00 & 77.90 & 56.45 & 120.00 & 34.00 & 29.20 & 39.10 & 53.20 & 49.00 & 51.40 \\
\hline $\mathrm{Ta}$ & 0.88 & 0.87 & 0.78 & 1.73 & 1.76 & 5.66 & 0.14 & 0.25 & 0.91 & 0.99 & 1.07 & 1.01 \\
\hline $\mathrm{Nb}$ & 19.80 & 24.70 & 24.30 & 25.80 & 24.55 & 27.20 & 23.00 & 20.60 & 24.60 & 19.90 & 21.10 & 23.20 \\
\hline Ga & 0.40 & 1.47 & 5.60 & 1.31 & 1.85 & 0.72 & 0.14 & 0.17 & 0.57 & 12.70 & 1.64 & 2.48 \\
\hline Tb & 4.55 & 8.00 & 14.20 & 20.90 & 14.05 & 20.20 & 3.00 & 2.63 & 7.77 & 17.70 & 9.40 & 9.60 \\
\hline $\mathrm{Tm}$ & 21.90 & 38.40 & 39.10 & 52.80 & 34.25 & 79.60 & 14.80 & 13.46 & 24.80 & 35.60 & 28.00 & 32.50 \\
\hline
\end{tabular}

Tabela 5: Dados de química de zircão de metassedimentos do Domínio São Roque, obtidos via LA-Q-ICPMS. Campos em cinza representam cristais com assínaturas de zircões de gabros tipo MORB. 


\begin{tabular}{|c|c|c|c|c|c|c|c|c|c|c|c|c|}
\hline & VT-04 & \multicolumn{11}{|c|}{ Meta-wake feldspáticos da região de Pirapora de Bom Jesus } \\
\hline LA-ICPMS no & $17 \mathrm{a}$ & $1 \mathrm{a}$ & $2 a$ & $3 a$ & $4 a$ & $5 a$ & $5 b$ & $6 a$ & $6 b$ & $7 a$ & $7 \mathrm{~b}$ & $9 a$ \\
\hline U-Pb no & - & - & - & - & - & - & - & - & - & - & - & - \\
\hline Idades 207Pb/206 & - & - & - & - & - & - & - & - & - & - & - & - \\
\hline Feições & núcleo & núcleo & núcleo & núcleo & núcleo & núcleo & borda & núcleo & borda & núcleo & borda & núcleo \\
\hline$\overline{\mathrm{Si}}$ & 207028.55 & 179224.72 & 200727.68 & 173323.90 & 198027.31 & 191026.35 & 173023.86 & 164722.72 & 181625.05 & 149420.61 & 179024.69 & 210028.97 \\
\hline $\mathrm{Zr}$ & 500000.00 & 519000.00 & 481000.00 & 520000.00 & 579000.00 & 567000.00 & 478000.00 & 526000.00 & 544000.00 & 442000.00 & 542000.00 & 553000.00 \\
\hline $\mathrm{Hf}$ & 10010.00 & 10020.00 & 10120.00 & 10210.00 & 9940.00 & 10070.00 & 10050.00 & 9910.00 & 9880.00 & 9950.00 & 10320.00 & 10100.00 \\
\hline Sc & 734.00 & 689.00 & 642.00 & 681.00 & 799.00 & 759.00 & 686.00 & 720.00 & 742.00 & 606.00 & 706.00 & 718.00 \\
\hline $\mathrm{Ca}$ & 821.46 & 625.35 & 513.29 & 692.39 & 631.35 & 528.29 & 680.38 & 845.47 & 761.42 & 510.28 & 375.21 & 464.26 \\
\hline $\mathbf{Y}$ & 833.00 & 921.00 & 726.00 & 1050.00 & 852.00 & 746.00 & 830.00 & 1264.00 & 1068.00 & 711.00 & 550.00 & 568.00 \\
\hline $\mathbf{P}$ & 227.00 & 184.00 & 151.00 & 158.00 & 225.00 & 181.00 & 262.00 & 156.00 & 199.00 & 137.00 & 157.00 & 123.00 \\
\hline $\mathrm{Yb}$ & 243.00 & 271.00 & 249.00 & 288.00 & 294.00 & 227.00 & 258.00 & 363.00 & 331.00 & 210.00 & 193.00 & 170.00 \\
\hline Al & 1539.93 & 29.00 & 19.10 & 18.06 & 26.00 & 21.20 & 5899.73 & 17.00 & 21.90 & 849.96 & 39.10 & 21.10 \\
\hline $\mathrm{Fe}$ & 370.00 & 1.50 & 5.50 & 2.60 & 4.60 & 4.80 & 550.00 & -1.10 & 2.50 & 170.00 & 24.00 & 6.50 \\
\hline $\mathrm{Na}$ & 42.00 & 11.60 & 13.30 & 4.63 & 12.80 & 7.50 & 54.00 & 2.20 & 8.20 & 30.00 & 9.50 & 7.40 \\
\hline Mg & 124.01 & 1.80 & 0.51 & 1.60 & 2.80 & 0.49 & 75.00 & 0.34 & 0.48 & 31.00 & 1.04 & 0.53 \\
\hline $\mathrm{Pb}$ & 28.50 & 8.47 & 38.90 & 13.40 & 34.90 & 17.70 & 17.00 & 43.20 & 36.50 & 20.20 & 18.90 & 10.80 \\
\hline $\mathrm{Sr}$ & 1.35 & 0.91 & 0.93 & 0.87 & 0.72 & 0.75 & 2.60 & 1.01 & 0.99 & 1.33 & 0.67 & 0.67 \\
\hline La & 0.51 & 0.01 & 0.07 & 0.06 & 0.08 & 0.02 & 9.00 & 0.04 & 0.03 & 3.20 & 0.83 & 0.08 \\
\hline $\mathrm{Ce}$ & 13.70 & 8.90 & 12.20 & 8.63 & 14.80 & 15.92 & 53.00 & 14.19 & 12.39 & 33.00 & 10.40 & 11.49 \\
\hline $\mathrm{Pr}$ & 0.74 & 0.11 & 0.11 & 0.32 & 0.22 & 0.16 & 4.10 & 0.40 & 0.24 & 3.01 & 0.56 & 0.16 \\
\hline Nd & 4.30 & 2.26 & 1.46 & 5.78 & 3.03 & 3.30 & 22.00 & 6.60 & 4.23 & 19.80 & 5.30 & 2.97 \\
\hline Sm & 4.70 & 4.88 & 3.08 & 9.30 & 3.99 & 6.06 & 14.00 & 10.80 & 6.20 & 12.00 & 4.50 & 4.84 \\
\hline Eu & 1.28 & 0.96 & 0.50 & 0.84 & 1.16 & 1.60 & 3.70 & 2.29 & 1.69 & 3.67 & 1.32 & 1.49 \\
\hline Gd & 20.40 & 26.40 & 15.80 & 35.00 & 20.30 & 23.10 & 29.00 & 41.40 & 28.40 & 25.50 & 14.70 & 18.60 \\
\hline Th & 142.00 & 33.70 & 180.00 & 80.20 & 172.40 & 79.60 & 163.00 & 223.00 & 181.00 & 148.00 & 100.20 & 39.70 \\
\hline Dy & 71.10 & 93.40 & 62.10 & 110.00 & 71.90 & 68.30 & 87.00 & 126.40 & 102.60 & 76.00 & 46.80 & 54.80 \\
\hline Ho & 26.60 & 31.30 & 23.30 & 36.80 & 26.80 & 23.70 & 27.20 & 43.40 & 35.50 & 22.30 & 16.90 & 18.20 \\
\hline $\mathrm{Er}$ & 117.50 & 130.40 & 105.70 & 147.00 & 124.00 & 102.80 & 118.00 & 185.20 & 151.00 & 94.30 & 74.80 & 75.40 \\
\hline $\mathbf{U}$ & 213.00 & 56.30 & 465.00 & 101.60 & 360.00 & 120.00 & 187.00 & 266.00 & 242.00 & 324.00 & 323.00 & 78.40 \\
\hline Lu & 43.30 & 41.00 & 39.50 & 43.60 & 49.60 & 37.20 & 38.90 & 59.70 & 52.80 & 36.10 & 32.30 & 24.90 \\
\hline $\mathrm{Ta}$ & 0.70 & 0.50 & 1.45 & 1.12 & 1.19 & 0.54 & 1.06 & 0.57 & 0.71 & 0.76 & 0.53 & 0.41 \\
\hline $\mathrm{Nb}$ & 22.00 & 22.30 & 22.00 & 24.77 & 26.00 & 25.70 & 24.20 & 23.60 & 24.34 & 20.79 & 22.80 & 23.80 \\
\hline Ga & 1.13 & 0.30 & 0.31 & 0.44 & 0.59 & 0.67 & 2.90 & 0.56 & 0.64 & 1.84 & 0.46 & 0.49 \\
\hline $\mathrm{Tb}$ & 6.06 & 8.06 & 5.21 & 10.30 & 6.27 & 6.65 & 8.30 & 11.95 & 9.10 & 7.40 & 4.01 & 5.23 \\
\hline $\mathrm{Tm}$ & 25.40 & 27.60 & 24.30 & 30.40 & 28.20 & 22.60 & 26.40 & 39.60 & 33.10 & 20.80 & 17.80 & 16.40 \\
\hline
\end{tabular}

Tabela 5: Dados de química de zircão de metassedimentos do Domínio São Roque, obtidos via LA-Q-ICPMS. Campos em cinza representam cristais com assínaturas de zircões de gabros tipo MORB. 


\begin{tabular}{|c|c|c|c|c|c|c|c|c|c|c|c|c|}
\hline & & & & & a-wake feld & áticos da re & ião de Pirapol & a de Bom Je & & & & \\
\hline LA-ICPMS no & $9 b$ & $10 \mathrm{a}$ & $10 \mathrm{~b}$ & $11 \mathrm{a}$ & $11 \mathrm{~b}$ & $12 \mathrm{a}$ & $12 b$ & $13 a$ & $13 b$ & $14 a$ & $15 a$ & $16 a$ \\
\hline U-Pb no & - & - & - & - & - & - & - & - & - & - & - & - \\
\hline Idades 207Pb/206 & - & - & - & - & - & - & - & - & - & - & - & - \\
\hline Feições & borda & núcleo & borda & núcleo & borda & núcleo & borda & núcleo & borda & núcleo & núcleo & núcleo \\
\hline$\overline{\mathrm{Si}}$ & 163022.48 & 160022.07 & 186025.66 & 187025.79 & 305542.14 & 197027.17 & 1700234.50 & 222030.62 & 252034.76 & 243033.52 & 210028.97 & 181024.97 \\
\hline $\mathrm{Zr}$ & 438500.00 & 431000.00 & 425500.00 & 530000.00 & 660000.00 & 573000.00 & 1800000.00 & 592000.00 & 530000.00 & 629000.00 & 560000.00 & 442000.00 \\
\hline $\mathrm{Hf}$ & 10345.00 & 10050.00 & 11125.00 & 9840.00 & 9850.00 & 10230.00 & 12500.00 & 10090.00 & 9900.00 & 10110.00 & 10020.00 & 10700.00 \\
\hline Sc & 560.00 & 564.00 & 650.50 & 668.00 & 1060.00 & 732.00 & 3800.00 & 798.00 & 790.00 & 831.00 & 724.00 & 636.00 \\
\hline $\mathrm{Ca}$ & 433.74 & 651.36 & 1460.81 & 414.23 & 5252.93 & 826.46 & 6303.51 & 783.44 & 2101.17 & 820.46 & 522.29 & 400.22 \\
\hline $\mathbf{Y}$ & 488.50 & 960.00 & 1475.00 & 595.00 & 3700.00 & 1225.00 & 6800.00 & 1133.00 & 2200.00 & 1070.00 & 660.00 & 420.00 \\
\hline $\mathbf{P}$ & 159.00 & 169.00 & 545.00 & 178.00 & 1624.99 & 213.00 & 400.00 & 204.00 & 919.99 & 269.00 & 204.00 & 122.00 \\
\hline $\mathrm{Yb}$ & 132.50 & 324.00 & 411.00 & 194.00 & 766.00 & 367.00 & 2400.00 & 363.00 & 640.00 & 336.00 & 225.00 & 148.00 \\
\hline Al & 163.84 & 18.60 & 1154.95 & 21.60 & 2899.87 & 21.80 & 3599.83 & 23.60 & 2499.88 & 32.70 & 19.20 & 23.30 \\
\hline $\mathrm{Fe}$ & 144.50 & 10.50 & 1280.01 & 6.60 & 3120.02 & 1.00 & 2100.01 & 7.90 & 1270.01 & 2.10 & 1.70 & 4.00 \\
\hline $\mathrm{Na}$ & 34.80 & 12.10 & 135.49 & 12.90 & 415.96 & 5.20 & 669.94 & 17.70 & 259.98 & 16.00 & 9.50 & 4.80 \\
\hline Mg & 8.15 & 1.12 & 72.00 & 0.68 & 300.02 & 0.29 & 380.02 & 0.74 & 150.01 & 3.10 & 0.66 & 4.00 \\
\hline $\mathrm{Pb}$ & 14.45 & 20.60 & 23.50 & 5.27 & 16.40 & 12.20 & 38.00 & 47.10 & 33.00 & 49.00 & 32.60 & 14.90 \\
\hline $\mathrm{Sr}$ & 1.28 & 0.93 & 3.45 & 0.65 & 54.50 & 0.94 & 5.40 & 1.02 & 10.10 & 0.97 & 0.74 & 0.42 \\
\hline La & 2.47 & 0.06 & 8.35 & 0.02 & 23.00 & 0.04 & 28.00 & 0.15 & 9.90 & 0.18 & 0.01 & \\
\hline $\mathrm{Ce}$ & 39.90 & 7.50 & 119.50 & 9.01 & 128.00 & 17.50 & 220.00 & 13.70 & 140.00 & 14.50 & 13.78 & 3.23 \\
\hline $\mathrm{Pr}$ & 2.79 & 0.16 & 10.35 & 0.09 & 10.66 & 0.24 & 20.00 & 0.36 & 11.20 & 0.39 & 0.09 & 0.06 \\
\hline Nd & 16.50 & 2.15 & 51.40 & 1.43 & 84.50 & 4.90 & 87.00 & 5.71 & 72.00 & 5.80 & 1.29 & 0.53 \\
\hline Sm & 10.94 & 3.72 & 28.35 & 2.97 & 35.00 & 8.80 & 64.00 & 9.20 & 82.00 & 7.50 & 2.88 & 1.50 \\
\hline Eu & 3.96 & 0.14 & 10.05 & 0.27 & 18.30 & 1.64 & 31.00 & 2.16 & 19.90 & 1.82 & 1.00 & 0.19 \\
\hline Gd & 21.80 & 21.60 & 56.80 & 13.00 & 93.05 & 38.90 & 250.00 & 35.00 & 86.00 & 30.30 & 15.20 & 6.10 \\
\hline Th & 114.00 & 100.90 & 200.50 & 29.80 & 310.00 & 54.40 & 170.00 & 217.00 & 290.00 & 203.00 & 137.60 & 52.10 \\
\hline Dy & 59.75 & 90.70 & 186.00 & 54.00 & 340.50 & 125.00 & 360.00 & 113.20 & 203.00 & 101.00 & 53.90 & 28.10 \\
\hline Ho & 15.10 & 33.90 & 56.10 & 18.90 & 110.00 & 39.00 & 150.00 & 39.30 & 58.00 & 34.40 & 19.50 & 11.00 \\
\hline $\mathrm{Er}$ & 56.80 & 145.00 & 204.50 & 82.60 & 425.00 & 163.00 & 440.00 & 162.00 & 230.00 & 148.00 & 82.50 & 48.30 \\
\hline $\mathbf{U}$ & 186.00 & 327.00 & 470.00 & 57.70 & 570.00 & 81.40 & 190.00 & 363.00 & 700.00 & 364.00 & 233.00 & 310.00 \\
\hline Lu & 20.75 & 44.80 & 52.00 & 30.00 & 94.50 & 49.40 & 79.00 & 54.20 & 60.00 & 51.30 & 35.10 & 30.00 \\
\hline Ta & 0.89 & 0.80 & 2.30 & 1.13 & 6.85 & 0.47 & 1.50 & 0.84 & 4.00 & 1.03 & 1.00 & 0.61 \\
\hline $\mathrm{Nb}$ & 18.70 & 19.72 & 25.40 & 24.00 & 40.00 & 26.00 & 91.00 & 26.60 & 31.00 & 26.80 & 25.20 & 20.30 \\
\hline $\mathrm{Ga}$ & 1.71 & 0.30 & 6.65 & 0.35 & 8.05 & 0.79 & 10.00 & 0.65 & 11.10 & 0.65 & 0.44 & 0.11 \\
\hline $\mathrm{Tb}$ & 6.21 & 7.26 & 18.40 & 4.40 & 31.35 & 11.20 & 48.00 & 10.43 & 24.30 & 8.90 & 4.64 & 3.12 \\
\hline $\mathrm{Tm}$ & 12.85 & 31.40 & 45.80 & 19.00 & 99.50 & 34.40 & 68.00 & 35.30 & 58.00 & 33.80 & 20.20 & 13.50 \\
\hline
\end{tabular}

Tabela 5: Dados de química de zircão de metassedimentos do Domínio São Roque, obtidos via LA-Q-ICPMS. Campos em cinza representam cristais com assínaturas de zircões de gabros tipo MORB. 


\begin{tabular}{|c|c|c|c|c|c|c|c|c|c|c|c|c|}
\hline & \multicolumn{4}{|c|}{ JP-01 } & \multicolumn{8}{|c|}{$\mathrm{PJ}-1 \mathrm{M}$} \\
\hline LA-ICPMS no & $20 b$ & $25 b$ & $27 b$ & $?$ & $8 b$ & $15 b$ & $22 b$ & $26 b$ & $28 b$ & $29 b$ & $30 \mathrm{~b}$ & 33b' \\
\hline U-Pb no & - & 38.10 & - & - & - & - & - & - & - & - & - & - \\
\hline Feições & overgrowth & overgrowth & overgrowth & overgrowth & overgrowth & overgrowth & overgrowth & overgrowth & overgrowth & overgrowth & overgrowth & overgrowth \\
\hline $\mathrm{SiO}_{2}$ & 28.03 & 31.86 & 38.72 & 35.43 & 26.42 & 21.42 & 24.75 & 22.89 & 79.16 & 72.74 & 22.25 & 25.70 \\
\hline $\mathrm{ZrO}_{2}$ & 48.90 & 57.68 & 63.49 & 62.00 & 62.00 & 50.05 & 57.81 & 54.83 & 93.21 & 101.31 & 48.09 & 61.46 \\
\hline $\mathrm{HfO}_{2}$ & 1.20 & 1.18 & 1.21 & 1.18 & 1.15 & 1.15 & 1.32 & 1.19 & 1.08 & 1.21 & 1.19 & 1.19 \\
\hline $\mathrm{Fe}_{2} \mathrm{O}_{3}$ & 1.20 & 0.00 & 0.51 & 0.02 & 0.66 & 0.24 & 0.01 & 0.05 & 0.67 & 0.07 & 1.50 & 0.12 \\
\hline $\mathrm{FeO}$ & 1.08 & 0.00 & 0.46 & 0.01 & 0.59 & 0.21 & 0.01 & 0.04 & 0.60 & 0.07 & 1.35 & 0.11 \\
\hline $\mathrm{Na}_{2} \mathrm{O}$ & 0.03 & 0.00 & 0.00 & 0.00 & 0.01 & 0.02 & 0.00 & 0.01 & 0.22 & 0.03 & 0.06 & 0.01 \\
\hline $\mathrm{Al}_{2} \mathrm{O}_{3}$ & 0.60 & 0.00 & 0.39 & 0.04 & 0.13 & 0.29 & 0.03 & 0.52 & 18.89 & 0.17 & 2.55 & 0.09 \\
\hline $\mathrm{P}_{2} \mathrm{O}_{4}$ & 0.40 & 0.03 & 0.17 & 0.16 & 0.19 & 0.29 & 0.09 & 0.14 & 18.33 & 0.39 & 1.24 & 1.90 \\
\hline $\mathrm{CaO}$ & 0.51 & 0.06 & 0.22 & 0.43 & 0.25 & 0.32 & 0.16 & 0.31 & 2.80 & 0.53 & 0.90 & 4.48 \\
\hline $\mathbf{Y}$ & 2610.00 & 463.00 & 1230.00 & 2470.00 & 1500.00 & 1895.00 & 1210.00 & 2220.00 & 10000.00 & 2600.00 & 3890.00 & 1347.00 \\
\hline $\mathbf{U}$ & 2710.00 & 247.00 & 162.00 & 382.00 & 320.00 & 1089.50 & 233.00 & 393.00 & 1080.00 & 346.00 & 1807.00 & 140.00 \\
\hline $\mathrm{Ba}$ & 31.50 & 0.03 & 440.00 & 0.62 & 6.00 & 25.00 & 1.60 & 13.90 & 23.00 & 2.70 & 540.00 & 3.70 \\
\hline $\mathrm{Pb}$ & 33.60 & 25.30 & 58.00 & 92.60 & 94.00 & 51.75 & 24.50 & 95.30 & 76.00 & 16.90 & 950.00 & 25.60 \\
\hline Sr & 7.80 & 0.60 & 34.80 & 1.78 & 4.30 & 10.25 & 1.49 & 2.48 & 35.00 & 3.30 & 87.00 & 34.00 \\
\hline La & 168.00 & 0.00 & 74.00 & 12.00 & 15.00 & 26.40 & 5.40 & 5.00 & 68.00 & 8.00 & 153.50 & 270.00 \\
\hline $\mathrm{Ce}$ & 2380.00 & 16.90 & 255.00 & 39.00 & 120.00 & 210.50 & 35.00 & 88.70 & 630.00 & 53.00 & 864.00 & 640.00 \\
\hline Pr & 193.00 & 0.03 & 12.80 & 2.80 & 18.00 & 22.30 & 3.30 & 6.10 & 72.00 & 7.50 & 117.90 & 80.00 \\
\hline Nd & 980.00 & 0.69 & 46.00 & 22.30 & 110.00 & 128.50 & 58.00 & 34.90 & 430.00 & 39.00 & 565.00 & 350.00 \\
\hline Sm & 272.00 & 1.28 & 15.70 & 23.00 & 44.00 & 50.50 & 14.00 & 19.30 & 180.00 & 15.20 & 141.00 & 74.00 \\
\hline Eu & 104.00 & 0.14 & 3.76 & 1.64 & 19.00 & 23.30 & 4.30 & 6.50 & 63.00 & 5.80 & 61.10 & 18.10 \\
\hline Gd & 346.00 & 7.93 & 39.00 & 90.50 & 109.00 & 119.50 & 48.00 & 65.30 & 420.00 & 52.00 & 290.00 & 89.00 \\
\hline Th & 176.70 & 109.00 & 123.00 & 516.00 & 370.00 & 594.00 & 235.00 & 706.00 & 1060.00 & 234.00 & 1690.00 & 664.00 \\
\hline Dy & 304.00 & 38.20 & 118.40 & 252.00 & 250.00 & 255.00 & 124.00 & 229.00 & 900.00 & 170.00 & 565.00 & 172.00 \\
\hline Ho & 73.80 & 14.70 & 43.20 & 85.60 & 68.00 & 64.50 & 44.80 & 75.70 & 203.00 & 50.00 & 134.20 & 49.50 \\
\hline Er & 249.00 & 66.50 & 181.00 & 338.00 & 220.00 & 235.00 & 182.00 & 316.00 & 600.00 & 182.00 & 428.00 & 177.20 \\
\hline Yb & 532.00 & 134.00 & 366.00 & 542.00 & 420.00 & 480.00 & 301.00 & 606.00 & 1080.00 & 331.00 & 735.00 & 279.00 \\
\hline Lu & 78.80 & 24.60 & 71.00 & 96.50 & 73.00 & 78.50 & 48.00 & 104.50 & 187.00 & 52.00 & 119.00 & 49.70 \\
\hline $\mathrm{Ta}$ & 13.42 & 1.36 & 0.80 & 3.27 & 1.26 & 1.95 & 0.43 & 2.97 & 2.47 & 1.32 & 5.32 & 0.52 \\
\hline $\mathrm{Nb}$ & 28.40 & 19.80 & 23.10 & 29.80 & 25.00 & 20.45 & 20.00 & 26.11 & 55.00 & 37.00 & 36.10 & 22.80 \\
\hline Ga & 167.00 & 0.49 & 9.80 & 1.82 & 7.30 & 10.35 & 1.41 & 4.35 & 56.00 & 7.00 & 46.60 & 39.00 \\
\hline Sc & 558.00 & 635.00 & 780.00 & 634.00 & 721.00 & 656.00 & 640.00 & 585.00 & 1600.00 & 1800.00 & 554.00 & 705.00 \\
\hline
\end{tabular}

Tabela 6: Dados de química de sobrecrescimentos metamórficos em zircão de metassedimentos do Domínio São Roque, obtidos via LA-ICPMS. 


\begin{tabular}{|c|c|c|c|c|c|c|c|c|c|c|c|c|}
\hline & \multicolumn{7}{|c|}{ PJ-1M } & JP-19 & \multicolumn{4}{|c|}{ VT-04 } \\
\hline LA-ICPMS no & $34 b$ & $35 b$ & $36 b^{\prime}$ & $38 b$ & $39 b$ & $41 b$ & $42 b$ & $4 b$ & $5 b^{\prime}$ & $6 b$ & $14 b^{\prime}$ & $17 \mathrm{~b}$ \\
\hline U-Pb no & - & - & - & - & - & - & - & 8.10 & - & - & - & - \\
\hline Feições & overgrowth & overgrowth & overgrowth & overgrowth & overgrowth & overgrowth & overgrowth & overgrowth & overgrowth & overgrowth & overgrowth & overgrowth \\
\hline $\mathrm{SiO}_{2}$ & 29.53 & 37.87 & 30.38 & 29.12 & 37.42 & 26.96 & 32.31 & 28.75 & 32.95 & 38.10 & 42.15 & 26.96 \\
\hline $\mathrm{ZrO}_{2}$ & 71.46 & 64.30 & 57.00 & 55.92 & 68.35 & 45.79 & 54.03 & 48.76 & 58.62 & 68.76 & 64.70 & 43.36 \\
\hline $\mathrm{HfO}_{2}$ & 1.17 & 1.15 & 1.21 & 1.20 & 1.16 & 1.16 & 1.19 & 1.19 & 1.17 & 1.13 & 1.18 & 1.17 \\
\hline $\mathrm{Fe}_{2} \mathrm{O}_{3}$ & 0.13 & 1.02 & 1.12 & 0.12 & 1.07 & 1.77 & 2.43 & 0.00 & 1.36 & 0.02 & 0.11 & 0.17 \\
\hline $\mathrm{FeO}$ & 0.12 & 0.91 & 1.00 & 0.11 & 0.96 & 1.60 & 2.19 & 0.00 & 1.22 & 0.02 & 0.10 & 0.15 \\
\hline $\mathrm{Na}_{2} \mathrm{O}$ & 0.01 & 0.04 & 0.02 & 0.03 & 0.07 & 0.07 & 0.07 & 0.00 & 0.01 & 0.00 & 0.01 & 0.04 \\
\hline $\mathrm{Al}_{2} \mathrm{O}_{3}$ & 0.06 & 0.18 & 0.24 & 0.17 & 0.40 & 0.86 & 0.51 & 0.00 & 0.25 & 0.02 & 1.04 & 1.32 \\
\hline $\mathrm{P}_{2} \mathrm{O}_{4}$ & 0.10 & 0.38 & 0.35 & 0.26 & 0.66 & 1.49 & 0.50 & 0.10 & 1.74 & 0.07 & 0.10 & 0.38 \\
\hline $\mathrm{CaO}$ & 0.18 & 0.22 & 0.22 & 0.31 & 0.53 & 0.98 & 0.49 & 0.12 & 3.09 & 0.14 & 0.16 & 0.69 \\
\hline $\mathbf{Y}$ & 1050.00 & 1550.00 & 1580.00 & 2201.00 & 3610.00 & 6200.00 & 2490.00 & 1006.00 & 27000.00 & 1025.00 & 1190.00 & 4600.00 \\
\hline $\mathbf{U}$ & 416.00 & 216.00 & 468.00 & 498.00 & 832.00 & 1610.00 & 1200.00 & 173.00 & 741.00 & 161.00 & 229.00 & 1210.00 \\
\hline $\mathrm{Ba}$ & 1.73 & 1.70 & 4.30 & 4.00 & 6.90 & 15.90 & 8.20 & -0.01 & 19.00 & 2.30 & 28.20 & 26.00 \\
\hline $\mathrm{Pb}$ & 36.50 & 51.10 & 21.90 & 23.70 & 61.00 & 81.00 & 34.00 & 15.31 & 65.00 & 14.30 & 13.30 & 37.10 \\
\hline Sr & 2.25 & 3.22 & 3.70 & 2.93 & 8.18 & 16.70 & 10.50 & 0.85 & 14.90 & 2.44 & 3.17 & 15.50 \\
\hline La & 6.30 & 18.00 & 36.00 & 32.10 & 45.10 & 126.00 & 32.00 & 0.01 & 7.00 & 2.80 & 2.86 & 23.50 \\
\hline $\mathrm{Ce}$ & 50.00 & 106.00 & 142.00 & 175.00 & 298.00 & 750.00 & 216.00 & 18.89 & 131.00 & 53.00 & 58.70 & 360.00 \\
\hline Pr & 5.90 & 15.30 & 24.20 & 22.90 & 50.00 & 111.00 & 36.50 & 0.05 & 14.50 & 3.65 & 5.56 & 55.00 \\
\hline Nd & 35.00 & 95.00 & 120.00 & 105.00 & 265.00 & 551.00 & 190.00 & 0.94 & 140.00 & 22.50 & 44.20 & 350.00 \\
\hline Sm & 16.40 & 35.10 & 39.00 & 35.50 & 115.00 & 169.00 & 73.00 & 2.78 & 310.00 & 15.60 & 28.80 & 190.00 \\
\hline Eu & 7.30 & 15.50 & 18.10 & 11.90 & 44.10 & 74.00 & 31.80 & 0.17 & 320.00 & 6.60 & 12.60 & 80.00 \\
\hline Gd & 44.00 & 92.00 & 105.00 & 93.00 & 257.00 & 410.00 & 178.00 & 19.40 & 2900.00 & 38.60 & 67.00 & 380.00 \\
\hline Th & 164.00 & 770.00 & 960.00 & 206.00 & 1440.00 & 624.00 & 660.00 & 72.50 & 480.00 & 135.00 & 155.00 & 780.00 \\
\hline Dy & 113.00 & 186.00 & 211.00 & 239.00 & 496.00 & 790.00 & 360.00 & 92.50 & 4400.00 & 99.00 & 142.00 & 640.00 \\
\hline Ho & 33.00 & 50.10 & 54.00 & 73.50 & 121.10 & 190.00 & 84.00 & 34.11 & 900.00 & 31.80 & 40.60 & 152.00 \\
\hline Er & 132.00 & 171.00 & 180.00 & 285.00 & 390.00 & 600.00 & 289.00 & 150.40 & 2320.00 & 140.00 & 141.00 & 470.00 \\
\hline Yb & 269.00 & 250.00 & 320.00 & 504.00 & 659.00 & 1000.00 & 576.00 & 312.00 & 2220.00 & 330.00 & 245.00 & 630.00 \\
\hline Lu & 44.90 & 45.40 & 60.00 & 87.70 & 114.00 & 173.00 & 105.00 & 56.30 & 310.00 & 60.30 & 42.50 & 104.00 \\
\hline $\mathrm{Ta}$ & 0.66 & 2.07 & 5.80 & 1.86 & 3.15 & 4.45 & 4.19 & 1.51 & 1.95 & 0.52 & 0.33 & 0.83 \\
\hline $\mathrm{Nb}$ & 30.40 & 27.80 & 23.80 & 21.20 & 31.80 & 27.10 & 24.20 & 20.40 & 27.90 & 25.80 & 24.00 & 17.60 \\
\hline Ga & 2.80 & 9.10 & 8.80 & 8.60 & 19.40 & 42.40 & 13.80 & 0.56 & 8.10 & 1.77 & 3.87 & 30.00 \\
\hline Sc & 780.00 & 770.00 & 576.00 & 593.00 & 774.00 & 607.00 & 637.00 & 553.00 & 740.00 & 750.00 & 788.00 & 575.00 \\
\hline
\end{tabular}

Tabela 6: Dados de química de sobrecrescimentos metamórficos em zircão de metassedimentos do Domínio São Roque, obtidos via LA-ICPMS. 


\begin{tabular}{|c|c|c|c|c|c|c|c|c|c|}
\hline & VT-04 & VT-03 & \multicolumn{7}{|c|}{ VT-02 } \\
\hline LA-ICPMS no & $32 b$ & $2 b$ & $10 b$ & $16 b^{\prime}$ & $3 b$ & $7 b^{\prime}$ & $8 b$ & $15 b$ & $16 b$ \\
\hline U-Pb no & - & - & - & - & - & - & - & - & - \\
\hline Feições & overgrowth & borda & overgrowth & overgrowth & overgrowth & overgrowth & metamítico & overgrowth & overgrowth \\
\hline$\overline{\mathrm{SiO}_{2}}$ & 28.24 & 30.31 & 25.89 & 37.01 & 31.66 & 32.52 & 38.25 & 32.95 & 32.09 \\
\hline $\mathrm{ZrO}_{2}$ & 55.38 & 51.47 & 45.12 & 58.22 & 60.65 & 63.62 & 65.78 & 51.33 & 48.16 \\
\hline $\mathrm{HfO}_{2}$ & 1.22 & 1.18 & 1.19 & 1.17 & 1.20 & 1.17 & 1.16 & 1.15 & 1.21 \\
\hline $\mathrm{Fe}_{2} \mathrm{O}_{3}$ & 0.05 & 0.02 & 0.01 & 0.18 & 0.54 & 0.18 & 0.74 & 1.74 & 0.47 \\
\hline $\mathrm{FeO}$ & 0.05 & 0.02 & 0.01 & 0.16 & 0.49 & 0.16 & 0.67 & 1.57 & 0.42 \\
\hline $\mathrm{Na}_{2} \mathrm{O}$ & 0.01 & 0.00 & 0.00 & 0.02 & 0.04 & 0.02 & 0.12 & 0.09 & 0.04 \\
\hline $\mathrm{Al}_{2} \mathrm{O}_{3}$ & 0.09 & 0.02 & 0.01 & 0.91 & 1.59 & 0.28 & 0.42 & 1.79 & 0.61 \\
\hline $\mathbf{P}_{2} \mathbf{O}_{4}$ & 0.14 & 0.04 & 0.07 & 0.19 & 0.24 & 0.11 & 0.26 & 0.43 & 0.36 \\
\hline $\mathrm{CaO}$ & 0.30 & 0.05 & 0.14 & 0.41 & 0.42 & 0.20 & 1.46 & 2.30 & 1.10 \\
\hline $\mathbf{Y}$ & 2210.00 & 332.10 & 1200.00 & 3100.00 & 3500.00 & 1510.00 & 11300.00 & 12800.00 & 7470.00 \\
\hline $\mathbf{U}$ & 340.00 & 412.00 & 397.00 & 640.00 & 1370.00 & 450.00 & 2360.00 & 3360.00 & 2065.00 \\
\hline $\mathrm{Ba}$ & 4.60 & 1.11 & 1.40 & 22.50 & 23.00 & 8.60 & 110.00 & 102.00 & 26.90 \\
\hline $\mathrm{Pb}$ & 18.30 & 2.69 & 16.10 & 44.00 & 64.00 & 14.80 & 147.50 & 59.50 & 32.95 \\
\hline $\mathrm{Sr}$ & 6.60 & 2.39 & 2.00 & 12.60 & 21.00 & 7.60 & 85.00 & 150.00 & 64.95 \\
\hline La & 8.10 & 0.65 & 0.55 & 10.90 & 24.00 & 14.00 & 54.00 & 270.00 & 94.20 \\
\hline $\mathrm{Ce}$ & 144.00 & 4.78 & 9.00 & 86.00 & 257.00 & 131.00 & 457.00 & 1580.00 & 498.00 \\
\hline $\operatorname{Pr}$ & 21.00 & 0.72 & 0.47 & 12.90 & 27.00 & 14.00 & 49.00 & 179.00 & 57.25 \\
\hline Nd & 143.00 & 5.69 & 3.70 & 93.00 & 155.00 & 73.00 & 306.00 & 910.00 & 326.50 \\
\hline Sm & 80.00 & 4.30 & 4.60 & 61.00 & 93.00 & 34.00 & 191.00 & 340.00 & 147.50 \\
\hline Eu & 33.00 & 1.68 & 1.20 & 25.20 & 35.00 & 15.20 & 91.00 & 190.00 & 87.65 \\
\hline Gd & 151.00 & 13.85 & 26.10 & 152.00 & 170.00 & 72.00 & 440.00 & 770.00 & 350.00 \\
\hline Th & 370.00 & 19.85 & 120.00 & 550.00 & 910.00 & 220.00 & 1860.00 & 1430.00 & 1230.00 \\
\hline Dy & 270.00 & 38.50 & 119.00 & 354.00 & 460.00 & 167.00 & 1350.00 & 1810.00 & 850.00 \\
\hline Ho & 83.00 & 9.80 & 44.20 & 99.00 & 126.00 & 49.00 & 399.00 & 456.00 & 210.50 \\
\hline Er & 285.00 & 29.05 & 185.00 & 342.00 & 480.00 & 173.00 & 1470.00 & 1450.00 & 776.50 \\
\hline $\mathbf{Y b}$ & 480.00 & 43.75 & 385.00 & 580.00 & 840.00 & 300.00 & 2530.00 & 2130.00 & 1215.00 \\
\hline Lu & 88.00 & 7.18 & 62.00 & 89.00 & 124.00 & 47.00 & 328.00 & 266.00 & 156.00 \\
\hline $\mathrm{Ta}$ & 0.90 & 0.39 & 2.85 & 2.48 & 4.00 & 1.70 & 15.50 & 10.40 & 5.71 \\
\hline $\mathrm{Nb}$ & 25.00 & 17.80 & 19.60 & 30.90 & 26.20 & 21.60 & 105.80 & 69.00 & 38.45 \\
\hline Ga & 9.20 & 0.26 & 0.53 & 7.80 & 14.00 & 8.60 & 24.30 & 79.00 & 32.90 \\
\hline Sc & 653.00 & 619.00 & 473.00 & 625.00 & 740.00 & 756.00 & 870.00 & 699.00 & 567.50 \\
\hline
\end{tabular}

Tabela 6: Dados de química de sobrecrescimentos metamórficos em zircão de metassedimentos do Domínio São Roque, obtidos via LA-ICPMS. 


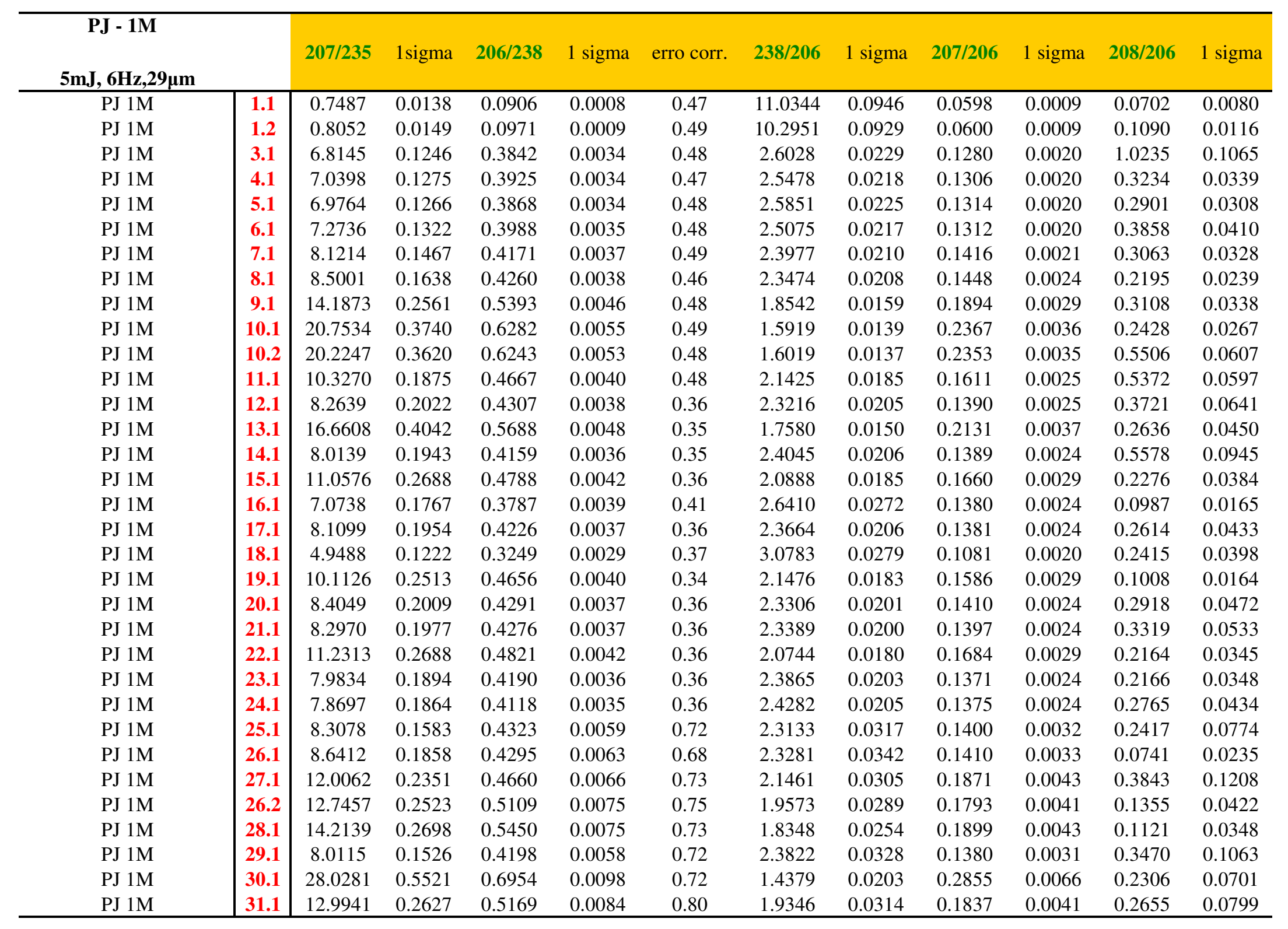

Datação U-Pb em zircões detríticos por LA-MC-ICPMS. Campos em cinza representam resultados com concordância abaixo de $95 \%$. 


\begin{tabular}{|c|c|c|c|c|c|c|c|c|c|c|c|c|}
\hline \multicolumn{2}{|l|}{ PJ - 1M } & \multirow[b]{2}{*}{$207 / 235$} & \multirow[b]{2}{*}{ 1sigma } & \multirow[b]{2}{*}{$206 / 238$} & \multirow[b]{2}{*}{1 sigma } & \multirow[b]{2}{*}{ erro corr. } & \multirow[b]{2}{*}{$238 / 206$} & \multirow[b]{2}{*}{1 sigma } & \multirow[b]{2}{*}{$207 / 206$} & \multirow[b]{2}{*}{1 sigma } & \multirow[b]{2}{*}{$208 / 206$} & \multirow[b]{2}{*}{1 sigma } \\
\hline $5 \mathrm{~mJ}, 6 \mathrm{~Hz}, 29$ & & & & & & & & & & & & \\
\hline PJ 1M & 32.1 & 10.9214 & 0.2070 & 0.4856 & 0.0067 & 0.73 & 2.0593 & 0.0286 & 0.1625 & 0.0036 & 0.4087 & 0.1220 \\
\hline PJ 1M & 34.1 & 9.3743 & 0.1771 & 0.4525 & 0.0063 & 0.74 & 2.2099 & 0.0307 & 0.1512 & 0.0034 & 0.3602 & 0.1057 \\
\hline PJ 1M & 35.1 & 11.2921 & 0.2152 & 0.4991 & 0.0070 & 0.73 & 2.0037 & 0.0279 & 0.1650 & 0.0037 & 0.3489 & 0.1016 \\
\hline PJ $1 \mathrm{M}$ & 36.1 & 7.9733 & 0.1615 & 0.4122 & 0.0064 & 0.76 & 2.4260 & 0.0374 & 0.1393 & 0.0031 & 0.5155 & 0.1488 \\
\hline PJ 1M & 37.1 & 9.6238 & 0.2558 & 0.4394 & 0.0022 & 0.19 & 2.2759 & 0.0114 & 0.1604 & 0.0040 & 0.0502 & 0.0138 \\
\hline PJ 1M & 38.1 & 6.8248 & 0.2311 & 0.3840 & 0.0078 & 0.60 & 2.6042 & 0.0528 & 0.1319 & 0.0033 & 0.1353 & 0.0368 \\
\hline PJ $1 \mathrm{M}$ & 39.1 & 7.8650 & 0.2530 & 0.4097 & 0.0074 & 0.56 & 2.4407 & 0.0443 & 0.1396 & 0.0035 & 0.7721 & 0.2062 \\
\hline PJ 1M & 40.1 & 7.9517 & 0.2075 & 0.4131 & 0.0020 & 0.18 & 2.4206 & 0.0115 & 0.1400 & 0.0034 & 0.2953 & 0.0781 \\
\hline PJ 1M & 41.1 & 13.2943 & 0.3471 & 0.5220 & 0.0027 & 0.20 & 1.9157 & 0.0099 & 0.1846 & 0.0045 & 0.3414 & 0.0896 \\
\hline PJ 1M & 42.1 & 8.4852 & 0.2555 & 0.3988 & 0.0026 & 0.22 & 2.5077 & 0.0165 & 0.1520 & 0.0038 & 0.0400 & 0.0115 \\
\hline PJ 1M & 43.1 & 13.9843 & 0.3622 & 0.5438 & 0.0026 & 0.18 & 1.8390 & 0.0088 & 0.1855 & 0.0045 & 0.2448 & 0.0632 \\
\hline PJ 1M & 44.1 & 25.7394 & 0.6724 & 0.6693 & 0.0033 & 0.19 & 1.4941 & 0.0074 & 0.2786 & 0.0067 & 0.3339 & 0.0853 \\
\hline PJ 1M & 46.1 & 16.1136 & 0.5194 & 0.5636 & 0.0108 & 0.60 & 1.7742 & 0.0341 & 0.2109 & 0.0051 & 0.1203 & 0.0303 \\
\hline PJ 1M & 47.1 & 13.5831 & 0.4491 & 0.5282 & 0.0102 & 0.58 & 1.8933 & 0.0365 & 0.1880 & 0.0049 & 0.3898 & 0.0974 \\
\hline PJ 1M & 48.1 & 14.2981 & 0.3682 & 0.5361 & 0.0028 & 0.20 & 1.8653 & 0.0098 & 0.1936 & 0.0046 & 0.3308 & 0.0818 \\
\hline PJ 1M & 49.1 & 10.7795 & 0.2771 & 0.4725 & 0.0022 & 0.18 & 2.1163 & 0.0100 & 0.1647 & 0.0039 & 0.4591 & 0.1125 \\
\hline PJ 1M & 49.2 & 11.1858 & 0.3911 & 0.4754 & 0.0202 & 0.99 & 2.1036 & 0.0892 & 0.1660 & 0.0045 & 0.2950 & 0.0345 \\
\hline PJ $1 \mathrm{M}$ & 62.1 & 14.0707 & 0.3892 & 0.5334 & 0.0040 & 0.27 & 1.8746 & 0.0139 & 0.1922 & 0.0051 & 0.3527 & 0.0409 \\
\hline PJ 1M & 63.1 & 7.7413 & 0.2089 & 0.4142 & 0.0029 & 0.26 & 2.4140 & 0.0166 & 0.1350 & 0.0035 & 0.5765 & 0.0667 \\
\hline PJ 1M & 52.1 & 25.4872 & 0.7124 & 0.6839 & 0.0056 & 0.30 & 1.4623 & 0.0121 & 0.2717 & 0.0073 & 0.0940 & 0.0109 \\
\hline PJ 1M & 53.1 & 6.8116 & 0.1877 & 0.3673 & 0.0031 & 0.31 & 2.7226 & 0.0233 & 0.1345 & 0.0035 & 0.3952 & 0.0457 \\
\hline PJ 1M & 8.2 & 7.8160 & 0.2099 & 0.4202 & 0.0032 & 0.28 & 2.3796 & 0.0179 & 0.1358 & 0.0035 & 0.3354 & 0.0387 \\
\hline PJ 1M & 55.1 & 12.1403 & 0.3423 & 0.5008 & 0.0051 & 0.36 & 1.9968 & 0.0202 & 0.1751 & 0.0046 & 0.2361 & 0.0274 \\
\hline PJ 1M & 56.1 & 5.5587 & 0.1778 & 0.3442 & 0.0050 & 0.46 & 2.9050 & 0.0426 & 0.1211 & 0.0034 & 0.0548 & 0.0067 \\
\hline PJ 1M & 57.1 & 6.3286 & 0.1684 & 0.3672 & 0.0025 & 0.25 & 2.7234 & 0.0184 & 0.1248 & 0.0032 & 1.2670 & 0.1458 \\
\hline PJ 1M & 58.1 & 5.8751 & 0.1565 & 0.3557 & 0.0025 & 0.26 & 2.8116 & 0.0195 & 0.1198 & 0.0031 & 0.5871 & 0.0675 \\
\hline PJ 1M & 59.1 & 6.9361 & 0.1892 & 0.3800 & 0.0030 & 0.29 & 2.6314 & 0.0210 & 0.1337 & 0.0035 & 0.0684 & 0.0087 \\
\hline PJ 1M & 60.1 & 7.8149 & 0.2051 & 0.4112 & 0.0027 & 0.25 & 2.4320 & 0.0162 & 0.1383 & 0.0035 & 0.4700 & 0.0539 \\
\hline PJ 1M & 61.1 & 23.5629 & 0.6507 & 0.6578 & 0.0072 & 0.40 & 1.5201 & 0.0166 & 0.2598 & 0.0067 & 0.4128 & 0.0483 \\
\hline PJ 1M & 2.1 & 11.7607 & 0.2442 & 0.4398 & 0.0048 & 0.52 & 2.2738 & 0.0247 & 0.1950 & 0.0031 & 0.2357 & 0.0246 \\
\hline PJ 1M & 33.1 & 5.4080 & 0.1052 & 0.3190 & 0.0045 & 0.72 & 3.1352 & 0.0437 & 0.1247 & 0.0028 & 0.0698 & 0.0207 \\
\hline PJ 1M & 45.1 & 4.7406 & 0.1264 & 0.2852 & 0.0019 & 0.25 & 3.5063 & 0.0236 & 0.1211 & 0.0029 & 0.0345 & 0.0089 \\
\hline
\end{tabular}

Datação U-Pb em zircões detríticos por LA-MC-ICPMS. Campos em cinza representam resultados com concordância abaixo de 95\%. 


\begin{tabular}{|c|c|c|c|c|c|c|c|c|}
\hline PJ - 1M & & & & & IDADES & & & Concord. \\
\hline $5 \mathrm{~mJ}, 6 \mathrm{~Hz}, 29 \mu \mathrm{m}$ & & $\mathbf{T}_{206 / 238}$ & 1 sigma & $\mathbf{T}_{207 / 235}$ & 1 sigma & $\mathbf{T}_{207 / 206}$ & 1 sigma & $\begin{array}{l}206 / 238 \\
207 / 206\end{array}$ \\
\hline PJ 1M & 1.1 & 0.559 & 0.005 & 0.567 & 0.008 & 0.591 & 0.033 & 95 \\
\hline PJ $1 \mathrm{M}$ & 1.2 & 0.598 & 0.005 & 0.600 & 0.008 & 0.597 & 0.033 & 100 \\
\hline PJ $1 \mathrm{M}$ & 3.1 & 2.096 & 0.016 & 2.088 & 0.016 & 2.068 & 0.026 & 101 \\
\hline PJ 1M & 4.1 & 2.134 & 0.016 & 2.116 & 0.016 & 2.104 & 0.026 & 101 \\
\hline PJ $1 \mathrm{M}$ & 5.1 & 2.108 & 0.016 & 2.108 & 0.016 & 2.114 & 0.026 & 100 \\
\hline PJ 1M & 6.1 & 2.163 & 0.016 & 2.146 & 0.016 & 2.111 & 0.026 & 102 \\
\hline PJ 1M & 7.1 & 2.247 & 0.017 & 2.245 & 0.016 & 2.243 & 0.026 & 100 \\
\hline PJ 1M & 8.1 & 2.288 & 0.017 & 2.286 & 0.017 & 2.281 & 0.029 & 100 \\
\hline PJ 1M & 9.1 & 2.781 & 0.019 & 2.762 & 0.017 & 2.740 & 0.025 & 101 \\
\hline PJ $1 \mathrm{M}$ & 10.1 & 3.142 & 0.022 & 3.127 & 0.017 & 3.101 & 0.023 & 101 \\
\hline PJ 1M & 10.2 & 3.127 & 0.021 & 3.102 & 0.017 & 3.092 & 0.023 & 101 \\
\hline PJ $1 \mathrm{M}$ & 11.1 & 2.469 & 0.018 & 2.465 & 0.017 & 2.465 & 0.026 & 100 \\
\hline PJ 1M & 12.1 & 2.309 & 0.017 & 2.260 & 0.022 & 2.211 & 0.030 & 104 \\
\hline PJ $1 \mathrm{M}$ & 13.1 & 2.903 & 0.020 & 2.916 & 0.023 & 2.936 & 0.028 & 99 \\
\hline PJ 1M & 14.1 & 2.242 & 0.016 & 2.233 & 0.022 & 2.209 & 0.030 & 101 \\
\hline PJ 1M & 15.1 & 2.522 & 0.018 & 2.528 & 0.022 & 2.516 & 0.030 & 100 \\
\hline PJ $1 \mathrm{M}$ & 16.1 & 2.070 & 0.018 & 2.121 & 0.022 & 2.198 & 0.030 & 94 \\
\hline PJ 1M & 17.1 & 2.272 & 0.017 & 2.243 & 0.022 & 2.200 & 0.030 & 103 \\
\hline PJ $1 \mathrm{M}$ & 18.1 & 1.813 & 0.014 & 1.811 & 0.021 & 1.771 & 0.032 & 102 \\
\hline PJ 1M & 19.1 & 2.464 & 0.017 & 2.445 & 0.023 & 2.438 & 0.031 & 101 \\
\hline PJ $1 \mathrm{M}$ & 20.1 & 2.302 & 0.017 & 2.276 & 0.021 & 2.235 & 0.029 & 103 \\
\hline PJ $1 \mathrm{M}$ & 21.1 & 2.295 & 0.017 & 2.264 & 0.021 & 2.219 & 0.029 & 103 \\
\hline PJ $1 \mathrm{M}$ & 22.1 & 2.536 & 0.018 & 2.543 & 0.022 & 2.541 & 0.029 & 100 \\
\hline PJ $1 \mathrm{M}$ & 23.1 & 2.256 & 0.016 & 2.229 & 0.021 & 2.186 & 0.029 & 103 \\
\hline PJ $1 \mathrm{M}$ & 24.1 & 2.223 & 0.016 & 2.216 & 0.021 & 2.192 & 0.029 & 101 \\
\hline PJ 1M & 25.1 & 2.316 & 0.027 & 2.265 & 0.017 & 2.223 & 0.039 & 104 \\
\hline PJ 1M & 26.1 & 2.304 & 0.028 & 2.301 & 0.019 & 2.235 & 0.040 & 103 \\
\hline PJ $1 \mathrm{M}$ & 27.1 & 2.466 & 0.029 & 2.605 & 0.018 & 2.720 & 0.038 & 91 \\
\hline PJ $1 \mathrm{M}$ & 26.2 & 2.661 & 0.032 & 2.661 & 0.018 & 2.648 & 0.038 & 100 \\
\hline PJ $1 \mathrm{M}$ & 28.1 & 2.804 & 0.031 & 2.764 & 0.018 & 2.745 & 0.038 & 102 \\
\hline PJ 1M & 29.1 & 2.260 & 0.026 & 2.232 & 0.017 & 2.198 & 0.038 & 103 \\
\hline PJ $1 \mathrm{M}$ & 30.1 & 3.403 & 0.037 & 3.420 & 0.019 & 3.389 & 0.037 & 100 \\
\hline PJ $1 \mathrm{M}$ & 31.1 & 2.686 & 0.036 & 2.679 & 0.019 & 2.689 & 0.038 & 100 \\
\hline
\end{tabular}

Datação U-Pb em zircões detríticos por LA-MC-ICPMS. Campos em cinza representam resultados com concordância abaixo de 95\%. 


\begin{tabular}{|c|c|c|c|c|c|c|c|c|}
\hline \multirow{3}{*}{$\begin{array}{c}\text { PJ - 1M } \\
5 \mathrm{~mJ}, 6 \mathrm{~Hz}, 29 \mu \mathrm{m}\end{array}$} & & \multirow{3}{*}{$\mathbf{T}_{206 / 238}$} & \multicolumn{5}{|c|}{ IDADES } & \multirow{3}{*}{$\begin{array}{c}\text { Concord. } \\
206 / 238 \\
207 / 206 \\
\end{array}$} \\
\hline & & & 1 sigma & $\mathbf{T}_{207 / 235}$ & 1 sigma & $\mathbf{T}_{207 / 206}$ & 1 sigma & \\
\hline & & & & & & & & \\
\hline PJ 1M & 32.1 & 2.552 & 0.029 & 2.516 & 0.017 & 2.479 & 0.038 & 103 \\
\hline PJ 1M & 34.1 & 2.406 & 0.028 & 2.375 & 0.017 & 2.355 & 0.038 & 102 \\
\hline PJ $1 \mathrm{M}$ & 35.1 & 2.610 & 0.030 & 2.548 & 0.018 & 2.505 & 0.038 & 104 \\
\hline PJ $1 \mathrm{M}$ & 36.1 & 2.225 & 0.029 & 2.228 & 0.018 & 2.214 & 0.038 & 100 \\
\hline PJ 1M & 37.1 & 2.348 & 0.010 & 2.399 & 0.024 & 2.457 & 0.042 & 96 \\
\hline PJ 1M & 38.1 & 2.095 & 0.036 & 2.089 & 0.030 & 2.120 & 0.043 & 99 \\
\hline PJ 1M & 39.1 & 2.214 & 0.034 & 2.216 & 0.029 & 2.218 & 0.042 & 100 \\
\hline PJ 1M & 40.1 & 2.229 & 0.009 & 2.226 & 0.023 & 2.223 & 0.041 & 100 \\
\hline PJ 1M & 41.1 & 2.708 & 0.011 & 2.701 & 0.024 & 2.697 & 0.040 & 100 \\
\hline PJ $1 \mathrm{M}$ & 42.1 & 2.163 & 0.012 & 2.284 & 0.027 & 2.364 & 0.042 & 92 \\
\hline PJ 1M & 43.1 & 2.799 & 0.011 & 2.749 & 0.024 & 2.706 & 0.040 & 103 \\
\hline PJ 1M & 44.1 & 3.303 & 0.013 & 3.337 & 0.025 & 3.350 & 0.037 & 99 \\
\hline PJ 1M & 46.1 & 2.882 & 0.045 & 2.884 & 0.030 & 2.919 & 0.039 & 99 \\
\hline PJ 1M & 47.1 & 2.734 & 0.043 & 2.721 & 0.031 & 2.728 & 0.043 & 100 \\
\hline PJ 1M & 48.1 & 2.767 & 0.012 & 2.770 & 0.024 & 2.777 & 0.039 & 100 \\
\hline PJ 1M & 49.1 & 2.495 & 0.010 & 2.504 & 0.024 & 2.503 & 0.040 & 100 \\
\hline PJ 1M & 49.2 & 2.507 & 0.088 & 2.539 & 0.032 & 2.516 & 0.046 & 100 \\
\hline PJ 1M & 62.1 & 2.756 & 0.017 & 2.754 & 0.026 & 2.765 & 0.044 & 100 \\
\hline PJ 1M & 63.1 & 2.234 & 0.013 & 2.201 & 0.024 & 2.160 & 0.045 & 103 \\
\hline PJ 1M & 52.1 & 3.359 & 0.022 & 3.327 & 0.027 & 3.311 & 0.041 & 101 \\
\hline PJ 1M & 53.1 & 2.017 & 0.015 & 2.087 & 0.024 & 2.154 & 0.045 & 94 \\
\hline PJ 1M & 8.2 & 2.262 & 0.014 & 2.210 & 0.024 & 2.171 & 0.044 & 104 \\
\hline PJ 1M & 55.1 & 2.617 & 0.022 & 2.615 & 0.026 & 2.607 & 0.044 & 100 \\
\hline PJ 1M & 56.1 & 1.907 & 0.024 & 1.910 & 0.027 & 1.972 & 0.048 & 97 \\
\hline PJ 1M & 57.1 & 2.016 & 0.012 & 2.022 & 0.023 & 2.025 & 0.045 & 100 \\
\hline PJ 1M & 58.1 & 1.962 & 0.012 & 1.958 & 0.023 & 1.952 & 0.045 & 100 \\
\hline PJ 1M & 59.1 & 2.076 & 0.014 & 2.103 & 0.024 & 2.143 & 0.044 & 97 \\
\hline PJ 1M & 60.1 & 2.220 & 0.013 & 2.210 & 0.023 & 2.202 & 0.043 & 101 \\
\hline PJ 1M & 61.1 & 3.259 & 0.028 & 3.250 & 0.027 & 3.243 & 0.038 & 100 \\
\hline PJ 1M & 2.1 & 2.350 & 0.021 & 2.586 & 0.019 & 2.790 & 0.026 & 84 \\
\hline PJ 1M & 33.1 & 1.785 & 0.022 & 1.886 & 0.017 & 2.023 & 0.038 & 88 \\
\hline PJ 1M & 45.1 & 1.618 & 0.010 & 1.774 & 0.022 & 1.972 & 0.042 & 82 \\
\hline
\end{tabular}

Datação U-Pb em zircões detríticos por LA-MC-ICPMS. Campos em cinza representam resultados com concordância abaixo de 95\%. 


\begin{tabular}{|c|c|c|c|c|c|c|c|c|c|c|c|c|}
\hline \multicolumn{2}{|c|}{$5 \mathrm{~mJ}, 6 \mathrm{~Hz}, 29 \mu \mathrm{m}$} & \multirow{2}{*}{$\begin{array}{r}207 / 235 \\
15.6942\end{array}$} & \multirow{2}{*}{$\begin{array}{c}\text { 1sigma } \\
0.1099\end{array}$} & \multirow{2}{*}{$\begin{array}{r}206 / 238 \\
0.5580\end{array}$} & \multicolumn{2}{|c|}{1 sigma erro corr. } & $238 / 206$ & 1 sigma & $207 / 206$ & 1 sigma & $208 / 206$ & 1 sigma \\
\hline JP 01 & 1.1 & & & & 0.0034 & 0.87 & 1.7921 & 0.0109 & 0.2051 & 0.0012 & 0.2379 & 0.0540 \\
\hline JP 01 & 2.1 & 19.2624 & 0.1418 & 0.6025 & 0.0038 & 0.86 & 1.6596 & 0.0105 & 0.2318 & 0.0015 & 0.3904 & 0.0898 \\
\hline JP 01 & 3.1 & 13.3942 & 0.0939 & 0.5219 & 0.0027 & 0.74 & 1.9159 & 0.0099 & 0.1871 & 0.0011 & 0.1752 & 0.0409 \\
\hline JP 01 & 4.1 & 9.8715 & 0.0856 & 0.4727 & 0.0029 & 0.70 & 2.1154 & 0.0129 & 0.1573 & 0.0011 & 0.2682 & 0.0637 \\
\hline JP 01 & 6.1 & 6.4323 & 0.0518 & 0.3609 & 0.0020 & 0.68 & 2.7705 & 0.0151 & 0.1299 & 0.0009 & 0.2335 & 0.0571 \\
\hline JP 01 & 7.1 & 6.3367 & 0.0407 & 0.3724 & 0.0018 & 0.77 & 2.6852 & 0.0132 & 0.1249 & 0.0007 & 0.3273 & 0.0809 \\
\hline JP 01 & 8.1 & 10.6237 & 0.0691 & 0.4707 & 0.0024 & 0.78 & 2.1243 & 0.0107 & 0.1651 & 0.0009 & 0.2707 & 0.0682 \\
\hline JP 01 & $9.2 \mathrm{~N}$ & 6.2528 & 0.0413 & 0.3742 & 0.0019 & 0.78 & 2.6722 & 0.0137 & 0.1221 & 0.0007 & 0.5603 & 0.1457 \\
\hline JP 01 & 10.1 & 6.4795 & 0.0417 & 0.3782 & 0.0018 & 0.74 & 2.6444 & 0.0127 & 0.1246 & 0.0007 & 0.5008 & 0.1324 \\
\hline JP 01 & $11.2 \mathrm{~N}$ & 4.7386 & 0.0302 & 0.3228 & 0.0016 & 0.76 & 3.0980 & 0.0150 & 0.1076 & 0.0006 & 0.4093 & 0.1120 \\
\hline JP 01 & $13.1 \mathrm{~N}$ & 11.8528 & 0.0761 & 0.4910 & 0.0037 & 0.99 & 2.0368 & 0.0152 & 0.1763 & 0.0012 & 0.3154 & 0.1409 \\
\hline JP 01 & $15.2 \mathrm{~N}$ & 6.3991 & 0.0750 & 0.3493 & 0.0038 & 0.93 & 2.8629 & 0.0312 & 0.1343 & 0.0009 & 0.2792 & 0.1412 \\
\hline JP 01 & $16.1 \mathrm{~N}$ & 15.9416 & 0.1021 & 0.5470 & 0.0040 & 0.99 & 1.8280 & 0.0134 & 0.2101 & 0.0013 & 0.3436 & 0.1778 \\
\hline JP 01 & 17.1 & 5.9490 & 0.0389 & 0.3534 & 0.0026 & 0.99 & 2.8297 & 0.0212 & 0.1214 & 0.0008 & 0.1181 & 0.0668 \\
\hline JP 01 & 18.1 & 19.0418 & 0.1208 & 0.5994 & 0.0043 & 0.99 & 1.6684 & 0.0119 & 0.2298 & 0.0015 & 0.2058 & 0.1199 \\
\hline JP 01 & 19.1 & 7.2287 & 0.0461 & 0.3842 & 0.0029 & 0.99 & 2.6027 & 0.0199 & 0.1364 & 0.0010 & 0.2167 & 0.1303 \\
\hline JP 01 & 20.1 & 6.4738 & 0.0415 & 0.3640 & 0.0027 & 0.99 & 2.7469 & 0.0202 & 0.1284 & 0.0008 & 0.2181 & 0.1353 \\
\hline JP 01 & 21.1 & 10.5357 & 0.3302 & 0.4269 & 0.0112 & 0.84 & 2.3425 & 0.0617 & 0.1827 & 0.0013 & 0.8793 & 0.6176 \\
\hline JP 01 & 23.1 & 6.6539 & 0.2138 & 0.3750 & 0.0101 & 0.84 & 2.6668 & 0.0720 & 0.1297 & 0.0009 & 1.0957 & 0.8410 \\
\hline JP 01 & 24.1 & 7.2996 & 0.2263 & 0.3895 & 0.0102 & 0.85 & 2.5675 & 0.0674 & 0.1372 & 0.0010 & 0.7313 & 0.5886 \\
\hline JP 01 & 25.1 & 11.0853 & 0.3374 & 0.4556 & 0.0117 & 0.85 & 2.1949 & 0.0565 & 0.1787 & 0.0012 & 0.7337 & 0.6207 \\
\hline JP 01 & 26.1 & 8.3469 & 0.3066 & 0.4278 & 0.0139 & 0.89 & 2.3376 & 0.0760 & 0.1437 & 0.0014 & 0.5147 & 0.4589 \\
\hline JP 01 & 27.1 & 6.6960 & 0.2051 & 0.3743 & 0.0097 & 0.84 & 2.6719 & 0.0691 & 0.1320 & 0.0010 & 0.6650 & 0.6217 \\
\hline JP 01 & 29.1 & 7.8116 & 0.2380 & 0.3956 & 0.0102 & 0.85 & 2.5277 & 0.0655 & 0.1440 & 0.0010 & 0.5878 & 0.6248 \\
\hline JP 01 & 30.1 & 8.0870 & 0.2590 & 0.4155 & 0.0116 & 0.87 & 2.4069 & 0.0670 & 0.1430 & 0.0012 & 0.8975 & 1.0197 \\
\hline JP 01 & 32.1 & 12.7248 & 0.4100 & 0.4830 & 0.0126 & 0.81 & 2.0704 & 0.0540 & 0.1972 & 0.0018 & 0.1614 & 0.2125 \\
\hline JP 01 & 23.1 & 6.6539 & 0.2138 & 0.3750 & 0.0101 & 0.84 & 2.6668 & 0.0720 & 0.1297 & 0.0009 & 1.0957 & 0.8410 \\
\hline JP 01 & 24.1 & 7.2996 & 0.2263 & 0.3895 & 0.0102 & 0.85 & 2.5675 & 0.0674 & 0.1372 & 0.0010 & 0.7313 & 0.5886 \\
\hline
\end{tabular}

Datação U-Pb em zircões detríticos por LA-MC-ICPMS. Campos em cinza representam resultados com concordância abaixo de $95 \%$. 


\begin{tabular}{|c|c|c|c|c|c|c|c|c|c|c|c|c|}
\hline $5 \mathrm{~mJ}, 6 \mathrm{~Hz}, 2$ & & 207/235 & 1sigma & $206 / 238$ & 1 sigma & rro corr. & . 238/206 & 1 sigma & $207 / 206$ & 1 sigma & $208 / 206$ & 1 sigma \\
\hline JP 01 & 25.1 & 11.0853 & 0.3374 & 0.4556 & 0.0117 & 0.85 & 2.1949 & 0.0565 & 0.1787 & 0.0012 & 0.7337 & 0.6207 \\
\hline JP 01 & 26.1 & 8.3469 & 0.3066 & 0.4278 & 0.0139 & 0.89 & 2.3376 & 0.0760 & 0.1437 & 0.0014 & 0.5147 & 0.4589 \\
\hline JP 01 & 27.1 & 6.6960 & 0.2051 & 0.3743 & 0.0097 & 0.84 & 2.6719 & 0.0691 & 0.1320 & 0.0010 & 0.6650 & 0.6217 \\
\hline JP 01 & 29.1 & 7.8116 & 0.2380 & 0.3956 & 0.0102 & 0.85 & 2.5277 & 0.0655 & 0.1440 & 0.0010 & 0.5878 & 0.6248 \\
\hline JP 01 & 30.1 & 8.0870 & 0.2590 & 0.4155 & 0.0116 & 0.87 & 2.4069 & 0.0670 & 0.1430 & 0.0012 & 0.8975 & 1.0197 \\
\hline JP 01 & 32.1 & 12.7248 & 0.4100 & 0.4830 & 0.0126 & 0.81 & 2.0704 & 0.0540 & 0.1972 & 0.0018 & 0.1614 & 0.2125 \\
\hline JP 01 & 45.1 & 6.1079 & 0.2118 & 0.3524 & 0.0063 & 0.51 & 2.8379 & 0.0507 & 0.1270 & 0.0025 & 0.3040 & 0.0427 \\
\hline JP 01 & 46.1 & 5.9941 & 0.2091 & 0.3605 & 0.0064 & 0.51 & 2.7738 & 0.0495 & 0.1226 & 0.0024 & 0.3493 & 0.0494 \\
\hline JP 01 & 47.1 & 6.4161 & 0.2260 & 0.3508 & 0.0066 & 0.54 & 2.8508 & 0.0538 & 0.1317 & 0.0026 & 0.3064 & 0.0437 \\
\hline JP 01 & 48.1 & 6.3687 & 0.2187 & 0.3653 & 0.0065 & 0.52 & 2.7371 & 0.0487 & 0.1271 & 0.0025 & 0.2549 & 0.0367 \\
\hline JP 01 & 49.1 & 6.8042 & 0.2328 & 0.3804 & 0.0068 & 0.52 & 2.6288 & 0.0467 & 0.1307 & 0.0025 & 0.4797 & 0.0695 \\
\hline JP 01 & 50.1 & 12.4982 & 0.4270 & 0.5059 & 0.0090 & 0.52 & 1.9765 & 0.0352 & 0.1792 & 0.0034 & 0.4569 & 0.0668 \\
\hline JP 01 & 51.1 & 27.7492 & 0.9445 & 0.6852 & 0.0122 & 0.52 & 1.4594 & 0.0260 & 0.2942 & 0.0057 & 0.2904 & 0.0428 \\
\hline JP 01 & 52.1 & 12.1232 & 0.4104 & 0.4971 & 0.0088 & 0.52 & 2.0118 & 0.0356 & 0.1778 & 0.0034 & 0.2520 & 0.0374 \\
\hline JP 01 & 53.1 & 13.0730 & 0.4417 & 0.5100 & 0.0090 & 0.52 & 1.9608 & 0.0348 & 0.1861 & 0.0036 & 0.4962 & 0.0744 \\
\hline JP 01 & 54.1 & 17.5849 & 0.6431 & 0.6005 & 0.0108 & 0.49 & 1.6652 & 0.0299 & 0.2128 & 0.0051 & 0.1314 & 0.0199 \\
\hline JP 01 & 55.1 & 11.2768 & 0.3779 & 0.4761 & 0.0084 & 0.53 & 2.1006 & 0.0370 & 0.1717 & 0.0033 & 0.5056 & 0.0770 \\
\hline JP 01 & 56.1 & 8.7291 & 0.2920 & 0.4290 & 0.0076 & 0.53 & 2.3311 & 0.0411 & 0.1482 & 0.0028 & 0.1233 & 0.0190 \\
\hline JP 01 & 57.1 & 7.3849 & 0.2461 & 0.3969 & 0.0070 & 0.53 & 2.5197 & 0.0443 & 0.1351 & 0.0026 & 0.6343 & 0.0983 \\
\hline JP 01 & 58.1 & 12.6635 & 0.4024 & 0.5100 & 0.0035 & 0.21 & 1.9609 & 0.0134 & 0.1808 & 0.0057 & 0.3403 & 0.0852 \\
\hline JP 01 & 60.1 & 6.4463 & 0.2027 & 0.3596 & 0.0024 & 0.21 & 2.7808 & 0.0184 & 0.1297 & 0.0040 & 0.3343 & 0.0837 \\
\hline JP 01 & 62.1 & 7.5283 & 0.2370 & 0.3950 & 0.0031 & 0.25 & 2.5320 & 0.0197 & 0.1381 & 0.0043 & 0.4284 & 0.1075 \\
\hline JP 01 & 63.1 & 7.9264 & 0.2469 & 0.4103 & 0.0027 & 0.21 & 2.4373 & 0.0162 & 0.1403 & 0.0043 & 0.2212 & 0.0554 \\
\hline JP 01 & 64.1 & 7.4315 & 0.2321 & 0.3735 & 0.0028 & 0.24 & 2.6774 & 0.0199 & 0.1405 & 0.0044 & 0.2132 & 0.0536 \\
\hline JP 01 & 65.1 & 13.6523 & 0.4226 & 0.5250 & 0.0036 & 0.22 & 1.9047 & 0.0130 & 0.1869 & 0.0057 & 0.4061 & 0.1017 \\
\hline JP 01 & $65.2 \mathrm{~B}$ & 11.5215 & 0.3603 & 0.4697 & 0.0033 & 0.22 & 2.1291 & 0.0148 & 0.1798 & 0.0055 & 0.2239 & 0.0561 \\
\hline JP 01 & 68.1 & 20.5725 & 0.6724 & 0.5977 & 0.0050 & 0.26 & 1.6732 & 0.0139 & 0.2497 & 0.0078 & 0.2716 & 0.0680 \\
\hline JP 01 & 22.2 & 16.4798 & 0.6742 & 0.5567 & 0.0107 & 0.47 & 1.7962 & 0.0345 & 0.2157 & 0.0071 & 0.0373 & 0.0096 \\
\hline
\end{tabular}

Datação U-Pb em zircões detríticos por LA-MC-ICPMS. Campos em cinza representam resultados com concordância abaixo de $95 \%$. 


\begin{tabular}{|c|c|c|c|c|c|c|c|c|c|c|c|c|}
\hline \multicolumn{2}{|c|}{$5 \mathrm{~mJ}, 6 \mathrm{~Hz}, 29 \mu \mathrm{m}$} & \multirow{2}{*}{$\begin{array}{r}207 / 235 \\
10.8373\end{array}$} & \multirow{2}{*}{$\begin{array}{l}\text { 1sigma } \\
0.3445\end{array}$} & \multirow{2}{*}{\begin{tabular}{|l}
$206 / 238$ \\
0.4395
\end{tabular}} & \multicolumn{2}{|c|}{1 sigma erro corr. } & $238 / 206$ & 1 sigma & $207 / 206$ & 1 sigma & $208 / 206$ & 1 sigma \\
\hline JP 01 & 59.1 & & & & 0.0033 & 0.23 & 2.2755 & 0.0169 & 0.1793 & 0.0056 & 0.0620 & 0.0156 \\
\hline JP 01 & 61.1 & 5.9112 & 0.1865 & 0.3308 & 0.0024 & 0.23 & 3.0231 & 0.0218 & 0.1305 & 0.0040 & 0.5715 & 0.1431 \\
\hline JP 01 & 66.1 & 6.3411 & 0.1978 & 0.3424 & 0.0027 & 0.26 & 2.9208 & 0.0234 & 0.1337 & 0.0041 & 0.1807 & 0.0452 \\
\hline JP 01 & 67.1 & 15.6884 & 0.4882 & 0.5100 & 0.0037 & 0.24 & 1.9606 & 0.0144 & 0.2213 & 0.0068 & 0.1184 & 0.0297 \\
\hline JP 01 & 33.1 & 13.3185 & 0.4479 & 0.4730 & 0.0130 & 0.82 & 2.1143 & 0.0582 & 0.2022 & 0.0017 & 0.2993 & 0.4283 \\
\hline JP 01 & 31.1 & 11.4277 & 0.3606 & 0.4505 & 0.0122 & 0.86 & 2.2196 & 0.0602 & 0.1858 & 0.0013 & 0.3775 & 0.4604 \\
\hline JP 01 & 28.1 & 5.8608 & 0.1884 & 0.3201 & 0.0085 & 0.83 & 3.1236 & 0.0833 & 0.1364 & 0.0010 & 0.5446 & 0.5441 \\
\hline JP 01 & 33.1 & 13.3185 & 0.4479 & 0.4730 & 0.0130 & 0.82 & 2.1143 & 0.0582 & 0.2022 & 0.0017 & 0.2993 & 0.4283 \\
\hline JP 01 & 21.1 & 10.5357 & 0.3302 & 0.4269 & 0.0112 & 0.84 & 2.3425 & 0.0617 & 0.1827 & 0.0013 & 0.8793 & 0.6176 \\
\hline JP 01 & 31.1 & 11.4277 & 0.3606 & 0.4505 & 0.0122 & 0.86 & 2.2196 & 0.0602 & 0.1858 & 0.0013 & 0.3775 & 0.4604 \\
\hline JP 01 & 28.1 & 5.8608 & 0.1884 & 0.3201 & 0.0085 & 0.83 & 3.1236 & 0.0833 & 0.1364 & 0.0010 & 0.5446 & 0.5441 \\
\hline JP 01 & 22.1 & 8.4260 & 0.3127 & 0.3372 & 0.0104 & 0.83 & 2.9657 & 0.0912 & 0.1834 & 0.0018 & 0.1457 & 0.1076 \\
\hline JP 01 & $16.2 \mathrm{~B}$ & 9.5814 & 0.0652 & 0.3977 & 0.0029 & 0.99 & 2.5142 & 0.0183 & 0.1747 & 0.0012 & 0.1219 & 0.0651 \\
\hline JP 01 & $14.3 \mathrm{~B}$ & 1.6857 & 0.0182 & 0.1348 & 0.0012 & 0.79 & 7.4201 & 0.0637 & 0.0950 & 0.0007 & 0.0377 & 0.0207 \\
\hline JP 01 & $13.2 \mathrm{~B}$ & 4.2454 & 0.0536 & 0.2677 & 0.0030 & 0.89 & 3.7358 & 0.0419 & 0.1175 & 0.0013 & 0.2869 & 0.1316 \\
\hline JP 01 & $14.1 \mathrm{~B}$ & 1.3140 & 0.0085 & 0.1051 & 0.0007 & 0.99 & 9.5119 & 0.0678 & 0.0919 & 0.0006 & 0.0524 & 0.0246 \\
\hline JP 01 & $14.2 \mathrm{~N}$ & 16.5281 & 0.1008 & 0.4884 & 0.0035 & 0.99 & 2.0476 & 0.0146 & 0.2477 & 0.0016 & 0.1416 & 0.0681 \\
\hline JP 01 & $15.1 \mathrm{~B}$ & 5.1014 & 0.0377 & 0.2878 & 0.0022 & 0.99 & 3.4744 & 0.0267 & 0.1295 & 0.0009 & 0.2943 & 0.1450 \\
\hline JP 01 & $11.1 B$ & 3.4955 & 0.0237 & 0.2433 & 0.0013 & 0.78 & 4.1096 & 0.0217 & 0.1052 & 0.0006 & 0.2646 & 0.0712 \\
\hline JP 01 & 5.1 & 10.3274 & 0.0648 & 0.4259 & 0.0021 & 0.78 & 2.3479 & 0.0115 & 0.1782 & 0.0010 & 0.2367 & 0.0569 \\
\hline JP 01 & $9.1 \mathrm{~B}$ & 2.2435 & 0.0227 & 0.1691 & 0.0015 & 0.87 & 5.9136 & 0.0517 & 0.0973 & 0.0006 & 0.1478 & 0.0379 \\
\hline
\end{tabular}

Datação U-Pb em zircões detríticos por LA-MC-ICPMS. Campos em cinza representam resultados com concordância abaixo de $95 \%$. 


\begin{tabular}{|c|c|c|c|c|c|c|c|c|}
\hline JP 01 & & & & & IDADES & & & Concordância \\
\hline & & $T_{206 / 238}$ & 1 sigma & $T_{207 / 235}$ & 1 sigma & $T_{207 / 206}$ & 1 sigma & $206 / 238$ \\
\hline $5 \mathrm{~mJ}, 6 \mathrm{~Hz}, 2$ & & & & & & & & $207 / 206$ \\
\hline JP 01 & 1.1 & 2.8584 & 0.0141 & 2.858 & 0.007 & 2.874 & 0.009 & 99 \\
\hline JP 01 & 2.1 & 3.0401 & 0.0153 & 3.055 & 0.007 & 3.069 & 0.010 & 99 \\
\hline JP 01 & 3.1 & 2.7074 & 0.0114 & 2.708 & 0.007 & 2.720 & 0.010 & 100 \\
\hline JP 01 & 4.1 & 2.4955 & 0.0126 & 2.423 & 0.008 & 2.423 & 0.012 & 103 \\
\hline JP 01 & 6.1 & 1.9867 & 0.0093 & 2.037 & 0.007 & 2.093 & 0.012 & 95 \\
\hline JP 01 & 7.1 & 2.0408 & 0.0086 & 2.024 & 0.006 & 2.026 & 0.009 & 101 \\
\hline JP 01 & 8.1 & 2.4868 & 0.0104 & 2.491 & 0.006 & 2.506 & 0.009 & 99 \\
\hline JP 01 & $9.2 \mathrm{~N}$ & 2.0492 & 0.0090 & 2.012 & 0.006 & 1.987 & 0.010 & 103 \\
\hline JP 01 & 10.1 & 2.0677 & 0.0085 & 2.043 & 0.006 & 2.022 & 0.009 & 102 \\
\hline JP 01 & $11.2 \mathrm{~N}$ & 1.8033 & 0.0076 & 1.774 & 0.005 & 1.762 & 0.010 & 102 \\
\hline JP 01 & $13.1 \mathrm{~N}$ & 2.5748 & 0.0158 & 2.593 & 0.006 & 2.618 & 0.011 & 98 \\
\hline JP 01 & $15.2 \mathrm{~N}$ & 1.9313 & 0.0182 & 2.032 & 0.010 & 2.151 & 0.012 & 90 \\
\hline JP 01 & $16.1 \mathrm{~N}$ & 2.8129 & 0.0167 & 2.873 & 0.006 & 2.913 & 0.010 & 97 \\
\hline JP 01 & 17.1 & 1.9508 & 0.0126 & 1.968 & 0.006 & 1.976 & 0.011 & 99 \\
\hline JP 01 & 18.1 & 3.0274 & 0.0172 & 3.044 & 0.006 & 3.056 & 0.010 & 99 \\
\hline JP 01 & 19.1 & 2.0960 & 0.0137 & 2.140 & 0.006 & 2.178 & 0.012 & 96 \\
\hline JP 01 & 20.1 & 2.0013 & 0.0126 & 2.042 & 0.006 & 2.074 & 0.011 & 97 \\
\hline JP 01 & 21.1 & 2.2917 & 0.0506 & 2.483 & 0.029 & 2.680 & 0.012 & 86 \\
\hline JP 01 & 23.1 & 2.0528 & 0.0473 & 2.067 & 0.028 & 2.091 & 0.012 & 98 \\
\hline JP 01 & 24.1 & 2.1204 & 0.0472 & 2.149 & 0.027 & 2.188 & 0.012 & 97 \\
\hline JP 01 & 25.1 & 2.4201 & 0.0517 & 2.530 & 0.028 & 2.642 & 0.011 & 92 \\
\hline JP 01 & 26.1 & 2.2957 & 0.0625 & 2.269 & 0.033 & 2.267 & 0.017 & 101 \\
\hline JP 01 & 27.1 & 2.0495 & 0.0453 & 2.072 & 0.027 & 2.122 & 0.013 & 97 \\
\hline JP 01 & 29.1 & 2.1488 & 0.0472 & 2.210 & 0.027 & 2.272 & 0.012 & 95 \\
\hline JP 01 & 30.1 & 2.2399 & 0.0524 & 2.241 & 0.029 & 2.260 & 0.015 & 99 \\
\hline JP 01 & 32.1 & 2.5403 & 0.0545 & 2.659 & 0.030 & 2.808 & 0.015 & 90 \\
\hline JP 01 & 23.1 & 2.0528 & 0.0473 & 2.067 & 0.028 & 2.091 & 0.012 & 98 \\
\hline JP 01 & 24.1 & 2.1204 & 0.0472 & 2.149 & 0.027 & 2.188 & 0.012 & 97 \\
\hline
\end{tabular}

Datação U-Pb em zircões detríticos por LA-MC-ICPMS. Campos em cinza representam resultados com concordância abaixo de $95 \%$. 


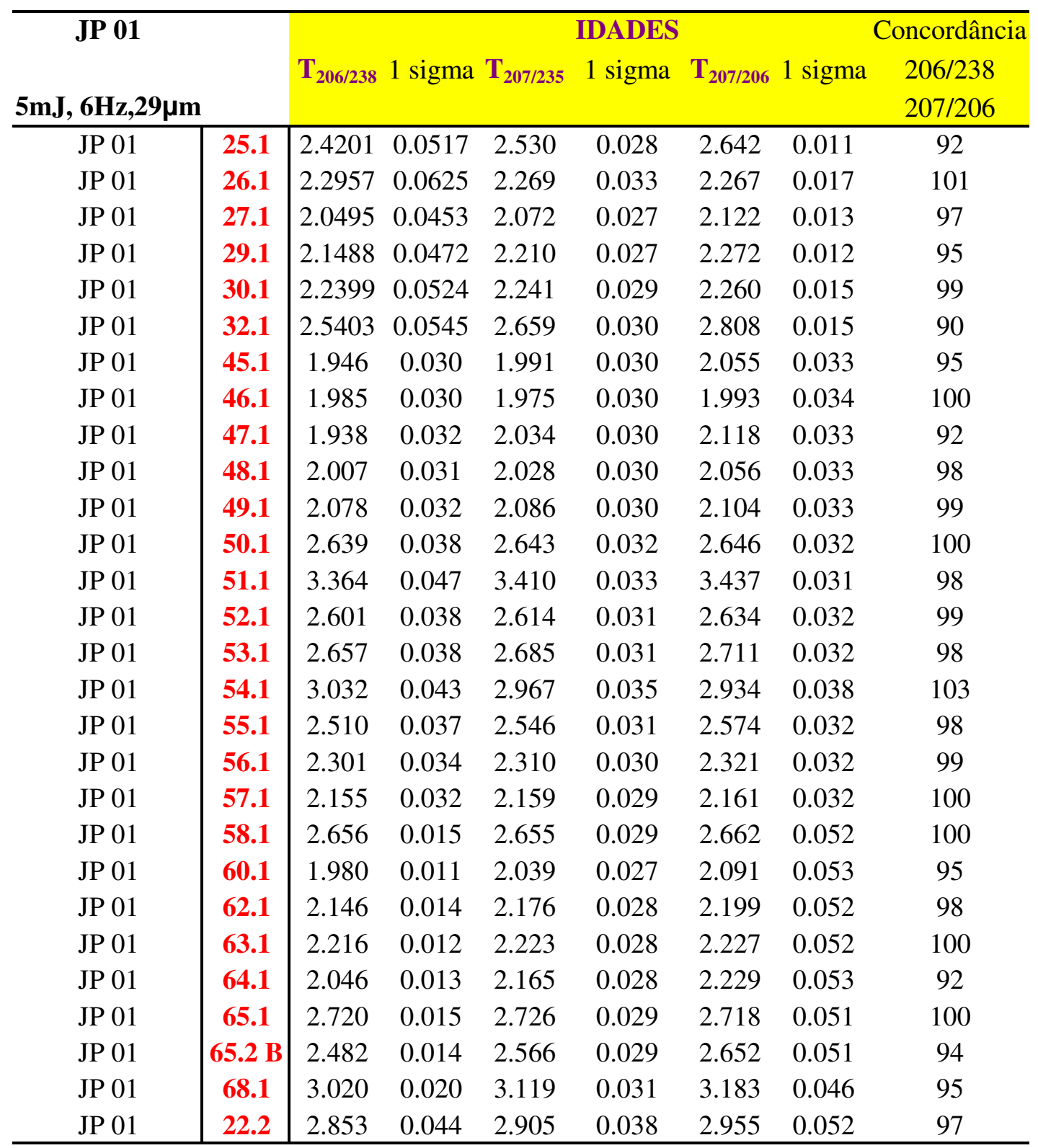

Datação U-Pb em zircões detríticos por LA-MC-ICPMS. Campos em cinza representam resultados com concordância abaixo de $95 \%$. 


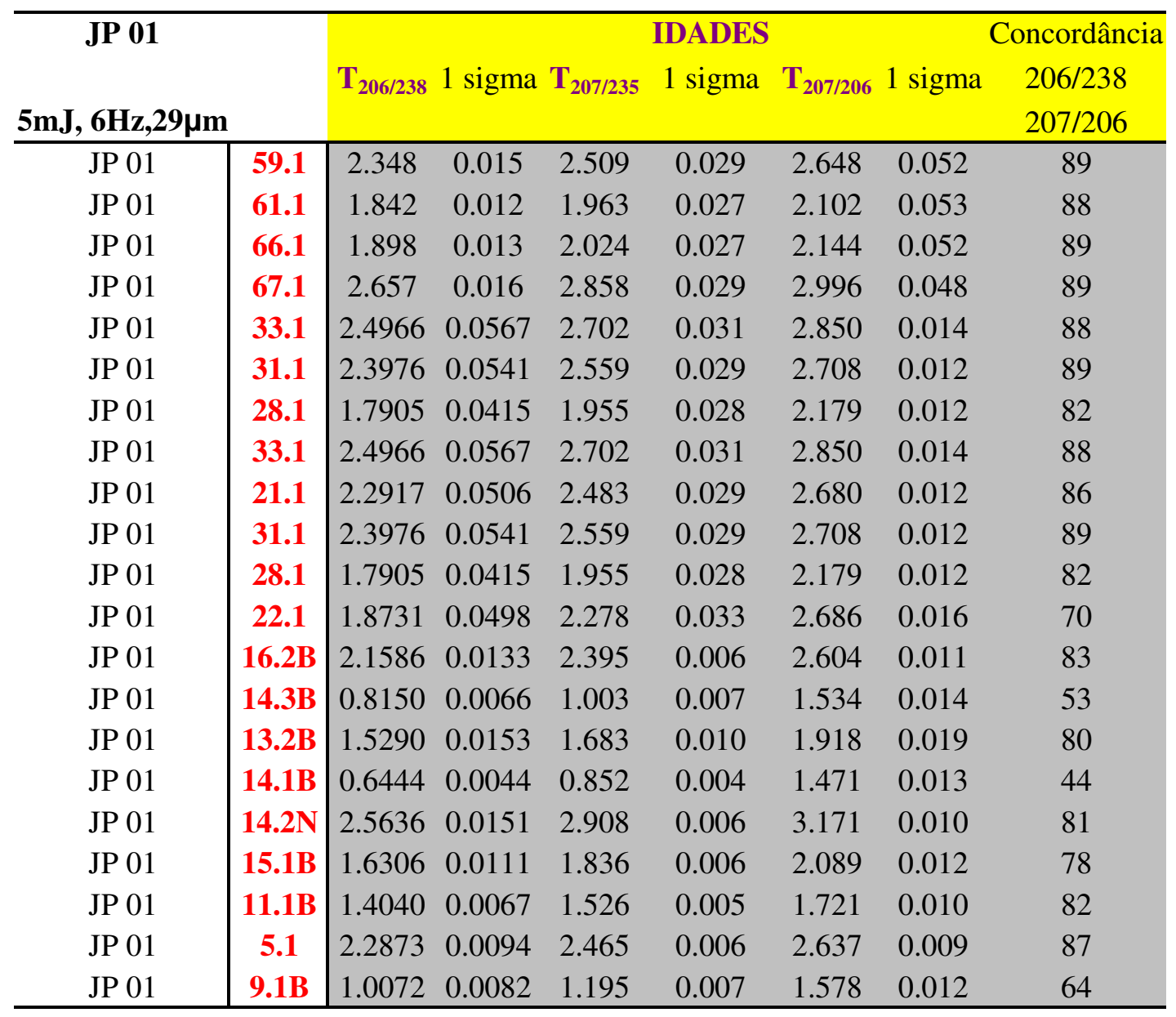

Datação U-Pb em zircões detríticos por LA-MC-ICPMS. Campos em cinza representam resultados com concordância abaixo de $95 \%$. 


\begin{tabular}{|c|c|c|c|c|c|c|c|c|c|c|c|c|}
\hline $5 \mathrm{~mJ}, 6 \mathrm{~Hz}, 29$ & & $207 / 235$ & 1sigma & $206 / 238$ & 1 sigma & erro corr. & $238 / 206$ & 1 sigma & $207 / 206$ & 1 sigma & $208 / 206$ & 1 sigma \\
\hline VT 04 & 1.1 & 7.8193 & 0.0406 & 0.4098 & 0.0040 & 0.99 & 2.4400 & 0.0236 & 0.1390 & 0.0011 & 0.7090 & 0.2001 \\
\hline VT 04 & 3.1 & 7.8524 & 0.0377 & 0.4103 & 0.0039 & 0.99 & 2.4372 & 0.0231 & 0.1392 & 0.0011 & 0.3125 & 0.0921 \\
\hline VT 04 & 4.1 & 8.0747 & 0.0411 & 0.4164 & 0.0041 & 0.99 & 2.4015 & 0.0239 & 0.1416 & 0.0011 & 0.4433 & 0.1366 \\
\hline VT 04 & 5.1 & 7.8071 & 0.0404 & 0.4078 & 0.0040 & 0.99 & 2.4521 & 0.0240 & 0.1388 & 0.0011 & 0.3706 & 0.1168 \\
\hline VT 04 & 6.1 & 4.1863 & 0.0326 & 0.2816 & 0.0031 & 0.99 & 3.5506 & 0.0396 & 0.1077 & 0.0010 & 0.3517 & 0.1133 \\
\hline VT 04 & 7.1 & 10.5183 & 0.0528 & 0.4707 & 0.0045 & 0.99 & 2.1245 & 0.0205 & 0.1633 & 0.0013 & 0.4626 & 0.1529 \\
\hline VT 04 & 7.2 & 11.1729 & 0.0744 & 0.4834 & 0.0049 & 0.99 & 2.0687 & 0.0211 & 0.1678 & 0.0013 & 0.4424 & 0.1500 \\
\hline VT 04 & 8.1 & 7.8878 & 0.0430 & 0.4101 & 0.0040 & 0.99 & 2.4381 & 0.0237 & 0.1387 & 0.0011 & 0.2584 & 0.0899 \\
\hline VT 04 & \begin{tabular}{|l|}
9.1 \\
\end{tabular} & 10.0508 & 0.0528 & 0.4613 & 0.0044 & 0.99 & 2.1679 & 0.0208 & 0.1571 & 0.0012 & 0.7729 & 0.2758 \\
\hline VT 04 & 10.1 & 15.6296 & 0.0801 & 0.5483 & 0.0053 & 0.99 & 1.8240 & 0.0176 & 0.2069 & 0.0016 & 0.3017 & 0.1106 \\
\hline VT 04 & 11.1 & 10.5942 & 0.0515 & 0.4664 & 0.0045 & 0.99 & 2.1443 & 0.0206 & 0.1649 & 0.0013 & 0.5013 & 0.1889 \\
\hline VT 04 & 12.1 & 7.9862 & 0.1834 & 0.4143 & 0.0047 & 0.50 & 2.4139 & 0.0275 & 0.1390 & 0.0016 & 0.1952 & 0.0181 \\
\hline VT 04 & 13.1 & 4.6477 & 0.1065 & 0.3119 & 0.0035 & 0.49 & 3.2062 & 0.0362 & 0.1080 & 0.0012 & 0.3794 & 0.0349 \\
\hline VT 04 & 13.2 & 4.3631 & 0.1018 & 0.2924 & 0.0035 & 0.52 & 3.4201 & 0.0411 & 0.1084 & 0.0013 & 0.3669 & 0.0335 \\
\hline VT 04 & 14.1 & 8.1606 & 0.1868 & 0.4184 & 0.0048 & 0.50 & 2.3902 & 0.0275 & 0.1420 & 0.0016 & 0.3318 & 0.0306 \\
\hline VT 04 & 15.1 & 7.3835 & 0.1687 & 0.3853 & 0.0044 & 0.51 & 2.5956 & 0.0300 & 0.1399 & 0.0016 & 0.2465 & 0.0223 \\
\hline VT 04 & 16.1 & 7.7605 & 0.1757 & 0.4056 & 0.0046 & 0.50 & 2.4654 & 0.0277 & 0.1386 & 0.0016 & 0.2512 & 0.0226 \\
\hline VT 04 & 17.1 & 7.7704 & 0.1756 & 0.4067 & 0.0046 & 0.50 & 2.4587 & 0.0277 & 0.1388 & 0.0016 & 0.2568 & 0.0230 \\
\hline VT 04 & 18.1 & 7.8792 & 0.1781 & 0.4117 & 0.0046 & 0.50 & 2.4289 & 0.0272 & 0.1376 & 0.0016 & 0.2336 & 0.0207 \\
\hline VT 04 & 18.2 & 7.8891 & 0.1773 & 0.4160 & 0.0047 & 0.50 & 2.4036 & 0.0270 & 0.1374 & 0.0016 & 0.2546 & 0.0225 \\
\hline VT 04 & 19.1 & 7.9808 & 0.1798 & 0.4201 & 0.0047 & 0.50 & 2.3804 & 0.0269 & 0.1374 & 0.0016 & 0.2790 & 0.0246 \\
\hline VT 04 & 20.1 & 10.8034 & 0.2423 & 0.4837 & 0.0055 & 0.51 & 2.0673 & 0.0234 & 0.1617 & 0.0018 & 0.4736 & 0.0412 \\
\hline VT 04 & 22.1 & 7.5631 & 0.1255 & 0.3959 & 0.0053 & 0.81 & 2.5256 & 0.0341 & 0.1384 & 0.0024 & 0.3063 & 0.0363 \\
\hline VT 04 & \begin{tabular}{|l|}
23.1 \\
\end{tabular} & 7.7975 & 0.1260 & 0.4084 & 0.0054 & 0.82 & 2.4483 & 0.0323 & 0.1387 & 0.0024 & 0.4030 & 0.0477 \\
\hline VT 04 & 24.1 & 13.3540 & 0.2668 & 0.5336 & 0.0079 & 0.74 & 1.8739 & 0.0277 & 0.1901 & 0.0035 & 0.1529 & 0.0181 \\
\hline VT 04 & 25.1 & 4.7147 & 0.0767 & 0.3112 & 0.0042 & 0.82 & 3.2130 & 0.0430 & 0.1102 & 0.0019 & 0.3519 & 0.0416 \\
\hline VT 04 & 26.1 & 8.4252 & 0.1391 & 0.4292 & 0.0058 & 0.83 & 2.3301 & 0.0317 & 0.1427 & 0.0024 & 0.1688 & 0.0200 \\
\hline
\end{tabular}

Datação U-Pb em zircões detríticos por LA-MC-ICPMS. Campos em cinza representam resultados com concordância abaixo de $95 \%$. 


\begin{tabular}{|c|c|c|c|c|c|c|c|c|c|c|c|c|}
\hline $5 \mathrm{~mJ}, 6 \mathrm{~Hz}, 29$ & & $207 / 235$ & 1sigma & $206 / 238$ & 1 sigma & erro corr. & $238 / 206$ & 1 sigma & $207 / 206$ & 1 sigma & $208 / 206$ & 1 sigma \\
\hline VT 04 & \begin{tabular}{|l|}
27.1 \\
\end{tabular} & 13.7229 & 0.2207 & 0.5270 & 0.0070 & 0.82 & 1.8976 & 0.0251 & 0.1894 & 0.0032 & 0.2494 & 0.0294 \\
\hline VT 04 & 30.1 & 29.7228 & 0.6148 & 0.7289 & 0.0100 & 0.66 & 1.3719 & 0.0188 & 0.2843 & 0.0058 & 0.4269 & 0.0505 \\
\hline VT 04 & 30.2 & 25.6670 & 0.5371 & 0.6683 & 0.0104 & 0.74 & 1.4963 & 0.0233 & 0.2734 & 0.0051 & 0.2504 & 0.0296 \\
\hline VT 04 & 31.1 & 4.7048 & 0.0775 & 0.3174 & 0.0043 & 0.82 & 3.1509 & 0.0427 & 0.1080 & 0.0019 & 0.3822 & 0.0450 \\
\hline VT 04 & 32.1 & 7.7724 & 0.1251 & 0.4133 & 0.0055 & 0.83 & 2.4195 & 0.0324 & 0.1373 & 0.0023 & 0.2037 & 0.0240 \\
\hline VT 04 & 33.1 & 11.3345 & 0.2508 & 0.4878 & 0.0056 & 0.52 & 2.0502 & 0.0237 & 0.1691 & 0.0020 & 0.2919 & 0.0453 \\
\hline VT 04 & 35.1 & 8.9453 & 0.1966 & 0.4389 & 0.0050 & 0.52 & 2.2787 & 0.0262 & 0.1475 & 0.0017 & 0.3072 & 0.0482 \\
\hline VT 04 & 36.1 & 4.8192 & 0.1031 & 0.3194 & 0.0037 & 0.55 & 3.1312 & 0.0366 & 0.1095 & 0.0013 & 0.4151 & 0.0655 \\
\hline VT 04 & 37.1 & 7.6127 & 0.1639 & 0.4014 & 0.0048 & 0.55 & 2.4912 & 0.0296 & 0.1387 & 0.0016 & 0.2581 & 0.0410 \\
\hline VT 04 & 38.1 & 7.6562 & 0.1672 & 0.3890 & 0.0050 & 0.58 & 2.5708 & 0.0328 & 0.1465 & 0.0017 & 0.4161 & 0.0669 \\
\hline VT 04 & 39.1 & 7.7060 & 0.1626 & 0.4044 & 0.0047 & 0.55 & 2.4729 & 0.0284 & 0.1381 & 0.0016 & 0.2433 & 0.0394 \\
\hline VT 04 & 40.1 & 7.3894 & 0.1574 & 0.3886 & 0.0046 & 0.56 & 2.5736 & 0.0307 & 0.1375 & 0.0016 & 0.4487 & 0.0738 \\
\hline VT 04 & 41.1 & 7.8403 & 0.1669 & 0.4032 & 0.0049 & 0.57 & 2.4803 & 0.0302 & 0.1413 & 0.0017 & 0.2257 & 0.0494 \\
\hline VT 04 & 42.1 & 7.7268 & 0.1610 & 0.4072 & 0.0046 & 0.54 & 2.4555 & 0.0276 & 0.1375 & 0.0016 & 0.2902 & 0.0478 \\
\hline VT 04 & 43.1 & 6.5030 & 0.1605 & 0.3557 & 0.0054 & 0.62 & 2.8117 & 0.0430 & 0.1309 & 0.0017 & 0.3174 & 0.0530 \\
\hline VT 04 & 44.1 & 6.1922 & 0.1004 & 0.3656 & 0.0051 & 0.87 & 2.7353 & 0.0385 & 0.1218 & 0.0015 & 0.3328 & 0.0220 \\
\hline VT 04 & 45.1 & 8.7805 & 0.2165 & 0.4359 & 0.0103 & 0.96 & 2.2942 & 0.0542 & 0.1495 & 0.0037 & 0.0790 & 0.0095 \\
\hline VT 04 & 46.1 & 9.5647 & 0.1383 & 0.4368 & 0.0054 & 0.86 & 2.2893 & 0.0285 & 0.1582 & 0.0020 & 0.1569 & 0.0103 \\
\hline VT 04 & 47.1 & 7.7068 & 0.1146 & 0.3980 & 0.0052 & 0.88 & 2.5128 & 0.0330 & 0.1412 & 0.0018 & 0.4044 & 0.0265 \\
\hline VT 04 & 48.1 & 8.0075 & 0.1282 & 0.4229 & 0.0060 & 0.89 & 2.3648 & 0.0336 & 0.1385 & 0.0017 & 0.2628 & 0.0172 \\
\hline VT 04 & 49.1 & 7.6722 & 0.1111 & 0.3989 & 0.0050 & 0.86 & 2.5067 & 0.0313 & 0.1396 & 0.0018 & 0.0860 & 0.0057 \\
\hline VT 04 & 50.1 & 7.4603 & 0.1093 & 0.4001 & 0.0051 & 0.88 & 2.4995 & 0.0321 & 0.1351 & 0.0017 & 0.0202 & 0.0018 \\
\hline VT 04 & 51.1 & 9.6358 & 0.1445 & 0.4383 & 0.0057 & 0.87 & 2.2815 & 0.0299 & 0.1600 & 0.0020 & 0.2936 & 0.0192 \\
\hline VT 04 & 52.1 & 9.7089 & 0.1443 & 0.4401 & 0.0058 & 0.88 & 2.2720 & 0.0298 & 0.1606 & 0.0020 & 0.2938 & 0.0192 \\
\hline VT 04 & 53.1 & 9.0745 & 0.1393 & 0.4274 & 0.0056 & 0.86 & 2.3399 & 0.0307 & 0.1549 & 0.0020 & 0.3711 & 0.0266 \\
\hline VT 04 & 54.1 & 7.6993 & 0.2942 & 0.4062 & 0.0118 & 0.76 & 2.4618 & 0.0715 & 0.1476 & 0.0055 & 0.1629 & 0.0151 \\
\hline VT 04 & 55.1 & 9.2137 & 0.1397 & 0.4319 & 0.0057 & 0.87 & 2.3154 & 0.0306 & 0.1524 & 0.0019 & 0.1883 & 0.0124 \\
\hline
\end{tabular}

Datação U-Pb em zircões detríticos por LA-MC-ICPMS. Campos em cinza representam resultados com concordância abaixo de $95 \%$. 


\begin{tabular}{|c|c|c|c|c|c|c|c|c|c|c|c|c|}
\hline $5 \mathrm{~mJ}, 6 \mathrm{~Hz}, 2 \mathrm{~s}$ & & $207 / 235$ & 1sigma & $206 / 238$ & 1 sigma & erro corr. & $238 / 206$ & 1 sigma & $207 / 206$ & 1 sigma & $208 / 206$ & 1 sigma \\
\hline VT 04 & \begin{tabular}{|l|}
56.1 \\
\end{tabular} & 6.7770 & 0.1047 & 0.3678 & 0.0051 & 0.89 & 2.7192 & 0.0375 & 0.1348 & 0.0017 & 0.3412 & 0.0225 \\
\hline VT 04 & 57.1 & 8.1107 & 0.1347 & 0.4180 & 0.0025 & 0.36 & 2.3921 & 0.0142 & 0.1397 & 0.0023 & 0.2744 & 0.0414 \\
\hline VT 04 & 58.1 & 8.6243 & 0.1382 & 0.4260 & 0.0021 & 0.30 & 2.3474 & 0.0114 & 0.1468 & 0.0024 & 0.1812 & 0.0270 \\
\hline VT 04 & 59.1 & 6.8729 & 0.1169 & 0.3724 & 0.0027 & 0.42 & 2.6855 & 0.0191 & 0.1347 & 0.0022 & 0.2647 & 0.0391 \\
\hline VT 04 & 60.1 & 9.1167 & 0.1462 & 0.4382 & 0.0022 & 0.31 & 2.2821 & 0.0113 & 0.1521 & 0.0024 & 0.1919 & 0.0280 \\
\hline VT 04 & 61.1 & 19.6597 & 0.3214 & 0.6049 & 0.0030 & 0.30 & 1.6532 & 0.0082 & 0.2310 & 0.0037 & 0.3059 & 0.0441 \\
\hline VT 04 & 62.1 & 8.1739 & 0.1606 & 0.4197 & 0.0050 & 0.61 & 2.3827 & 0.0284 & 0.1425 & 0.0023 & 0.4811 & 0.0687 \\
\hline VT 04 & 63.1 & 7.6220 & 0.1466 & 0.4008 & 0.0047 & 0.60 & 2.4953 & 0.0290 & 0.1435 & 0.0023 & 0.2465 & 0.0352 \\
\hline VT 04 & 64.1 & 8.4260 & 0.1922 & 0.4264 & 0.0049 & 0.51 & 2.3454 & 0.0270 & 0.1428 & 0.0024 & 0.4916 & 0.0690 \\
\hline VT 04 & 65.1 & 7.5781 & 0.1306 & 0.3973 & 0.0034 & 0.49 & 2.5171 & 0.0214 & 0.1390 & 0.0022 & 0.3602 & 0.0498 \\
\hline VT 04 & 66.1 & 7.1109 & 0.1156 & 0.3775 & 0.0022 & 0.36 & 2.6487 & 0.0157 & 0.1383 & 0.0022 & 0.1955 & 0.0268 \\
\hline VT 04 & 67.1 & 7.5824 & 0.1228 & 0.4036 & 0.0023 & 0.35 & 2.4778 & 0.0141 & 0.1362 & 0.0022 & 0.3526 & 0.0478 \\
\hline VT 04 & 68.1 & 19.8501 & 0.4756 & 0.6157 & 0.0111 & 0.75 & 1.6243 & 0.0293 & 0.2400 & 0.0041 & 0.2700 & 0.0363 \\
\hline VT 04 & 69.1 & 18.1260 & 0.2892 & 0.5855 & 0.0030 & 0.32 & 1.7080 & 0.0088 & 0.2236 & 0.0035 & 0.2636 & 0.0351 \\
\hline VT 04 & 2.1 & 1.3044 & 0.0110 & 0.0886 & 0.0010 & 0.99 & 11.2926 & 0.1280 & 0.1060 & 0.0009 & 0.2307 & 0.0665 \\
\hline VT 04 & \begin{tabular}{|l|}
3.2 \\
(n)
\end{tabular} & 6.2538 & 0.0514 & 0.3310 & 0.0038 & 0.99 & 3.0208 & 0.0344 & 0.1376 & 0.0011 & 0.3281 & 0.0988 \\
\hline VT 04 & 19.2 & 1.8417 & 0.0436 & 0.1319 & 0.0016 & 0.52 & 7.5792 & 0.0928 & 0.1042 & 0.0014 & 0.2736 & 0.0241 \\
\hline VT 04 & 21.1 & 3.4611 & 0.0790 & 0.2380 & 0.0029 & 0.53 & 4.2012 & 0.0512 & 0.1082 & 0.0013 & 0.3218 & 0.0278 \\
\hline VT 04 & 28.1 & 3.2467 & 0.0731 & 0.1830 & 0.0033 & 0.81 & 5.4635 & 0.0994 & 0.1276 & 0.0022 & 0.4886 & 0.0576 \\
\hline VT 04 & 28.2 & 4.9793 & 0.0869 & 0.2613 & 0.0038 & 0.84 & 3.8270 & 0.0562 & 0.1391 & 0.0024 & 0.1624 & 0.0191 \\
\hline VT 04 & 29.1 & 13.3533 & 0.3133 & 0.4651 & 0.0086 & 0.79 & 2.1501 & 0.0399 & 0.2014 & 0.0035 & 0.1407 & 0.0172 \\
\hline VT 04 & 34.1 & 7.0498 & 0.1616 & 0.3244 & 0.0045 & 0.61 & 3.0822 & 0.0432 & 0.1579 & 0.0019 & 0.1439 & 0.0226 \\
\hline VT 04 & 37.2 & 5.3439 & 0.1173 & 0.2855 & 0.0035 & 0.55 & 3.5032 & 0.0426 & 0.1376 & 0.0017 & 0.3819 & 0.0610 \\
\hline VT 04 & 43.2 & 1.2754 & 0.0555 & 0.0930 & 0.0032 & 0.80 & 10.7497 & 0.3731 & 0.0992 & 0.0013 & 0.1042 & 0.0175 \\
\hline
\end{tabular}

Datação U-Pb em zircões detríticos por LA-MC-ICPMS. Campos em cinza representam resultados com concordância abaixo de $95 \%$. 


\begin{tabular}{|c|c|c|c|c|c|c|c|c|}
\hline \multirow{3}{*}{$\begin{array}{c}\mathrm{VT}-04 \\
5 \mathrm{~mJ}, 6 \mathrm{~Hz}, 29 \mu \mathrm{m}\end{array}$} & & \multirow{3}{*}{$T_{206 / 238}$} & \multicolumn{5}{|c|}{ IDADES } & \multirow{3}{*}{$\begin{array}{c}\text { Concord. } \\
206 / 238 \\
207 / 206\end{array}$} \\
\hline & & & 1 sigma & $\mathbf{T}_{207 / 235}$ & 1 sigma & $T_{207 / 206}$ & 1 sigma & \\
\hline & & & & & & & & \\
\hline VT 04 & 1.1 & 2.214 & 0.018 & 2.210 & 0.005 & 2.211 & 0.014 & 100 \\
\hline VT 04 & 3.1 & 2.216 & 0.018 & 2.214 & 0.004 & 2.214 & 0.013 & 100 \\
\hline VT 04 & 4.1 & 2.244 & 0.019 & 2.239 & 0.005 & 2.243 & 0.014 & 100 \\
\hline VT 04 & 5.1 & 2.205 & 0.018 & 2.209 & 0.005 & 2.208 & 0.013 & 100 \\
\hline VT 04 & 6.1 & 1.600 & 0.016 & 1.671 & 0.006 & 1.765 & 0.017 & 91 \\
\hline VT 04 & 7.1 & 2.487 & 0.020 & 2.482 & 0.005 & 2.488 & 0.013 & 100 \\
\hline VT 04 & 7.2 & 2.542 & 0.021 & 2.538 & 0.006 & 2.534 & 0.013 & 100 \\
\hline VT 04 & 8.1 & 2.216 & 0.018 & 2.218 & 0.005 & 2.207 & 0.014 & 100 \\
\hline VT 04 & 9.1 & 2.445 & 0.019 & 2.439 & 0.005 & 2.421 & 0.013 & 101 \\
\hline VT 04 & 10.1 & 2.818 & 0.022 & 2.854 & 0.005 & 2.888 & 0.013 & 98 \\
\hline VT 04 & 11.1 & 2.468 & 0.020 & 2.488 & 0.004 & 2.504 & 0.013 & 99 \\
\hline VT 04 & 12.1 & 2.234 & 0.021 & 2.229 & 0.021 & 2.211 & 0.020 & 101 \\
\hline VT 04 & 13.1 & 1.750 & 0.017 & 1.758 & 0.019 & 1.769 & 0.021 & 99 \\
\hline VT 04 & 13.2 & 1.653 & 0.018 & 1.705 & 0.019 & 1.776 & 0.021 & 93 \\
\hline VT 04 & 14.1 & 2.253 & 0.022 & 2.249 & 0.020 & 2.247 & 0.020 & 100 \\
\hline VT 04 & 15.1 & 2.101 & 0.021 & 2.159 & 0.020 & 2.222 & 0.020 & 95 \\
\hline VT 04 & 16.1 & 2.195 & 0.021 & 2.204 & 0.020 & 2.205 & 0.020 & 100 \\
\hline VT 04 & 17.1 & 2.200 & 0.021 & 2.205 & 0.020 & 2.208 & 0.020 & 100 \\
\hline VT 04 & 18.1 & 2.223 & 0.021 & 2.217 & 0.020 & 2.194 & 0.019 & 101 \\
\hline VT 04 & 18.2 & 2.243 & 0.021 & 2.218 & 0.020 & 2.190 & 0.019 & 102 \\
\hline VT 04 & 19.1 & 2.261 & 0.022 & 2.229 & 0.020 & 2.191 & 0.020 & 103 \\
\hline VT 04 & 20.1 & 2.543 & 0.024 & 2.506 & 0.021 & 2.471 & 0.019 & 103 \\
\hline VT 04 & 22.1 & 2.150 & 0.025 & 2.180 & 0.015 & 2.204 & 0.030 & 98 \\
\hline VT 04 & 23.1 & 2.208 & 0.025 & 2.208 & 0.014 & 2.206 & 0.029 & 100 \\
\hline VT 04 & 24.1 & 2.757 & 0.033 & 2.705 & 0.019 & 2.747 & 0.030 & 100 \\
\hline VT 04 & 25.1 & 1.747 & 0.020 & 1.770 & 0.014 & 1.805 & 0.030 & 97 \\
\hline VT 04 & 26.1 & 2.302 & 0.026 & 2.278 & 0.015 & 2.256 & 0.029 & 102 \\
\hline
\end{tabular}

Datação U-Pb em zircões detríticos por LA-MC-ICPMS. Campos em cinza representam resultados com concordância abaixo de $95 \%$. 


\begin{tabular}{|c|c|c|c|c|c|c|c|c|}
\hline \multirow{3}{*}{$\begin{array}{c}\mathrm{VT}-04 \\
5 \mathrm{~mJ}, 6 \mathrm{~Hz}, 29 \mu \mathrm{r}\end{array}$} & & \multirow{3}{*}{$\mathbf{T}_{206 / 238}$} & \multicolumn{5}{|c|}{ IDADES } & \multirow{3}{*}{$\begin{array}{c}\text { Concord. } \\
206 / 238 \\
207 / 206\end{array}$} \\
\hline & & & 1 sigma & $\mathbf{T}_{207 / 235}$ & 1 sigma & $T_{207 / 206}$ & 1 sigma & \\
\hline & & & & & & & & \\
\hline VT 04 & 27.1 & 2.729 & 0.029 & 2.731 & 0.015 & 2.740 & 0.029 & 100 \\
\hline VT 04 & 30.1 & 3.529 & 0.037 & 3.478 & 0.020 & 3.382 & 0.032 & 104 \\
\hline VT 04 & 30.2 & 3.299 & 0.040 & 3.334 & 0.020 & 3.321 & 0.029 & 99 \\
\hline VT 04 & 31.1 & 1.777 & 0.021 & 1.768 & 0.014 & 1.769 & 0.031 & 100 \\
\hline VT 04 & 32.1 & 2.230 & 0.025 & 2.205 & 0.014 & 2.190 & 0.029 & 102 \\
\hline VT 04 & 33.1 & 2.561 & 0.024 & 2.551 & 0.020 & 2.548 & 0.020 & 101 \\
\hline VT 04 & 35.1 & 2.345 & 0.023 & 2.332 & 0.020 & 2.313 & 0.020 & 101 \\
\hline VT 04 & 36.1 & 1.787 & 0.018 & 1.788 & 0.018 & 1.793 & 0.021 & 100 \\
\hline VT 04 & 37.1 & 2.176 & 0.022 & 2.186 & 0.019 & 2.207 & 0.020 & 99 \\
\hline VT 04 & 38.1 & 2.118 & 0.023 & 2.191 & 0.019 & 2.301 & 0.020 & 92 \\
\hline VT 04 & 39.1 & 2.189 & 0.021 & 2.197 & 0.019 & 2.200 & 0.020 & 100 \\
\hline VT 04 & 40.1 & 2.116 & 0.021 & 2.160 & 0.019 & 2.193 & 0.020 & 97 \\
\hline VT 04 & 41.1 & 2.184 & 0.023 & 2.213 & 0.019 & 2.239 & 0.020 & 98 \\
\hline VT 04 & 42.1 & 2.202 & 0.021 & 2.200 & 0.019 & 2.192 & 0.020 & 100 \\
\hline VT 04 & 43.1 & 1.962 & 0.026 & 2.046 & 0.021 & 2.107 & 0.023 & 93 \\
\hline VT 04 & 44.1 & 2.009 & 0.024 & 2.003 & 0.014 & 1.982 & 0.022 & 101 \\
\hline VT 04 & 45.1 & 2.332 & 0.046 & 2.315 & 0.022 & 2.336 & 0.042 & 100 \\
\hline VT 04 & 46.1 & 2.336 & 0.024 & 2.394 & 0.013 & 2.433 & 0.022 & 96 \\
\hline VT 04 & 47.1 & 2.160 & 0.024 & 2.197 & 0.013 & 2.238 & 0.021 & 97 \\
\hline VT 04 & 48.1 & 2.273 & 0.027 & 2.232 & 0.014 & 2.205 & 0.022 & 103 \\
\hline VT 04 & 49.1 & 2.164 & 0.023 & 2.193 & 0.013 & 2.219 & 0.021 & 98 \\
\hline VT 04 & 50.1 & 2.169 & 0.024 & 2.168 & 0.013 & 2.162 & 0.021 & 100 \\
\hline VT 04 & 51.1 & 2.343 & 0.026 & 2.401 & 0.014 & 2.453 & 0.021 & 96 \\
\hline VT 04 & 52.1 & 2.351 & 0.026 & 2.408 & 0.014 & 2.458 & 0.021 & 96 \\
\hline VT 04 & 53.1 & 2.294 & 0.025 & 2.346 & 0.014 & 2.396 & 0.022 & 96 \\
\hline VT 04 & 54.1 & 2.198 & 0.054 & 2.197 & 0.034 & 2.314 & 0.062 & 95 \\
\hline VT 04 & 55.1 & 2.314 & 0.026 & 2.359 & 0.014 & 2.369 & 0.021 & 98 \\
\hline
\end{tabular}

Datação U-Pb em zircões detríticos por LA-MC-ICPMS. Campos em cinza representam resultados com concordância abaixo de $95 \%$. 


\begin{tabular}{|c|c|c|c|c|c|c|c|c|}
\hline \multirow{3}{*}{$\begin{array}{c}\mathrm{VT}-04 \\
5 \mathrm{~mJ}, 6 \mathrm{~Hz}, 29 \mu \mathrm{m}\end{array}$} & & \multirow{3}{*}{$T_{206 / 238}$} & \multirow{3}{*}{1 sigma } & \multicolumn{3}{|c|}{ IDADES } & & \multirow{3}{*}{$\begin{array}{c}\text { Concord. } \\
206 / 238 \\
207 / 206\end{array}$} \\
\hline & & & & $T_{207 / 235}$ & 1 sigma & $T_{207 / 206}$ & 1 sigma & \\
\hline & & & & & & & & \\
\hline VT 04 & \begin{tabular}{|l|}
56.1 \\
\end{tabular} & 2.019 & 0.024 & 2.083 & 0.014 & 2.158 & 0.021 & 94 \\
\hline VT 04 & 57.1 & 2.252 & 0.011 & 2.243 & 0.015 & 2.219 & 0.028 & 101 \\
\hline VT 04 & 58.1 & 2.288 & 0.009 & 2.299 & 0.014 & 2.305 & 0.027 & 99 \\
\hline VT 04 & 59.1 & 2.041 & 0.012 & 2.095 & 0.015 & 2.156 & 0.028 & 95 \\
\hline VT 04 & 60.1 & 2.343 & 0.010 & 2.350 & 0.015 & 2.365 & 0.027 & 99 \\
\hline VT 04 & 61.1 & 3.049 & 0.012 & 3.075 & 0.016 & 3.063 & 0.025 & 100 \\
\hline VT 04 & 62.1 & 2.259 & 0.023 & 2.250 & 0.018 & 2.253 & 0.028 & 100 \\
\hline VT 04 & 63.1 & 2.173 & 0.021 & 2.187 & 0.017 & 2.265 & 0.028 & 96 \\
\hline VT 04 & 64.1 & 2.289 & 0.022 & 2.278 & 0.020 & 2.257 & 0.029 & 101 \\
\hline VT 04 & 65.1 & 2.157 & 0.016 & 2.182 & 0.015 & 2.211 & 0.027 & 98 \\
\hline VT 04 & 66.1 & 2.065 & 0.010 & 2.125 & 0.014 & 2.202 & 0.027 & 94 \\
\hline VT 04 & 67.1 & 2.186 & 0.011 & 2.183 & 0.014 & 2.176 & 0.027 & 100 \\
\hline VT 04 & 68.1 & 3.093 & 0.044 & 3.084 & 0.023 & 3.123 & 0.026 & 99 \\
\hline VT 04 & 69.1 & 2.971 & 0.012 & 2.996 & 0.015 & 3.012 & 0.025 & 99 \\
\hline VT 04 & 2.1 & 0.547 & 0.006 & 0.848 & 0.005 & 1.735 & 0.015 & 32 \\
\hline VT 04 & 3.2 & 1.843 & 0.018 & 2.012 & 0.007 & 2.193 & 0.013 & 84 \\
\hline VT 04 & 19.2 & 0.799 & 0.009 & 1.060 & 0.015 & 1.704 & 0.024 & 47 \\
\hline VT 04 & 21.1 & 1.376 & 0.015 & 1.518 & 0.018 & 1.773 & 0.021 & 78 \\
\hline VT 04 & 28.1 & 1.084 & 0.018 & 1.468 & 0.017 & 2.063 & 0.030 & 53 \\
\hline VT 04 & 28.2 & 1.496 & 0.020 & 1.816 & 0.015 & 2.212 & 0.029 & 68 \\
\hline VT 04 & 29.1 & 2.462 & 0.038 & 2.705 & 0.022 & 2.843 & 0.028 & 87 \\
\hline VT 04 & 34.1 & 1.811 & 0.022 & 2.118 & 0.020 & 2.430 & 0.020 & 75 \\
\hline VT 04 & 37.2 & 1.619 & 0.017 & 1.876 & 0.019 & 2.194 & 0.021 & 74 \\
\hline VT 04 & 43.2 & 0.573 & 0.019 & 0.835 & 0.024 & 1.615 & 0.023 & 36 \\
\hline
\end{tabular}

Datação U-Pb em zircões detríticos por LA-MC-ICPMS. Campos em cinza representam resultados com concordância abaixo de $95 \%$. 


\begin{tabular}{|c|c|c|c|c|c|c|c|c|c|c|c|c|}
\hline \multicolumn{2}{|l|}{ JP-19 } & $207 / 235$ & 1sigma & $206 / 238$ & 1 sigma & erro corr. & $238 / 206$ & 1 sigma & $207 / 206$ & 1 sigma & $208 / 206$ & 1 sigma \\
\hline JP 19 & 1.1 & 13.7962 & 0.1290 & 0.5086 & 0.0050 & 0.99 & 1.9660 & 0.0195 & 0.2019 & 0.0012 & 0.0557 & 0.0263 \\
\hline JP 19 & 2.1 & 7.7307 & 0.0708 & 0.4043 & 0.0039 & 0.99 & 2.4736 & 0.0239 & 0.1404 & 0.0008 & 0.2576 & 0.1164 \\
\hline JP 19 & 3.1 & 7.9266 & 0.0716 & 0.4172 & 0.0040 & 0.99 & 2.3971 & 0.0228 & 0.1390 & 0.0008 & 0.3656 & 0.1586 \\
\hline JP 19 & 4.1 & 18.6593 & 0.1691 & 0.6195 & 0.0060 & 0.99 & 1.6143 & 0.0156 & 0.2228 & 0.0013 & 0.9226 & 0.3847 \\
\hline JP 19 & $5.1 \mathrm{~B}$ & 0.8117 & 0.0097 & 0.0979 & 0.0011 & 0.95 & 10.2161 & 0.1164 & 0.0604 & 0.0004 & 0.0163 & 0.0067 \\
\hline JP 19 & $5.2 \mathrm{~N}$ & 13.9956 & 0.1257 & 0.5222 & 0.0050 & 0.99 & 1.9149 & 0.0182 & 0.1959 & 0.0011 & 0.2539 & 0.0983 \\
\hline JP 19 & $6.1 \mathrm{~B}$ & 0.7366 & 0.0109 & 0.0910 & 0.0010 & 0.72 & 10.9934 & 0.1172 & 0.0602 & 0.0005 & 0.0033 & 0.0018 \\
\hline JP 19 & $6.2 \mathrm{~N}$ & 7.2060 & 0.0640 & 0.3819 & 0.0036 & 0.99 & 2.6182 & 0.0247 & 0.1380 & 0.0008 & 0.5024 & 0.1813 \\
\hline JP 19 & $7.1 \mathrm{~B}$ & 6.0687 & 0.0576 & 0.3350 & 0.0033 & 0.99 & 2.9852 & 0.0292 & 0.1338 & 0.0008 & 0.3352 & 0.1171 \\
\hline JP 19 & $7.2 \mathrm{~N}$ & 8.1828 & 0.0740 & 0.4304 & 0.0041 & 0.99 & 2.3232 & 0.0220 & 0.1392 & 0.0008 & 0.4556 & 0.1541 \\
\hline JP 19 & $8.1 \mathrm{~B}$ & 0.7436 & 0.0103 & 0.0915 & 0.0011 & 0.84 & 10.9253 & 0.1265 & 0.0592 & 0.0005 & 0.0575 & 0.0192 \\
\hline JP 19 & $8.2 \mathrm{~N}$ & 7.2074 & 0.0667 & 0.3995 & 0.0038 & 0.99 & 2.5031 & 0.0240 & 0.1330 & 0.0009 & 0.5698 & 0.1814 \\
\hline JP 19 & 9.1 & 7.4346 & 0.0655 & 0.3980 & 0.0037 & 0.99 & 2.5126 & 0.0234 & 0.1372 & 0.0008 & 0.1428 & 0.0441 \\
\hline JP 19 & $10.1 \mathrm{~N}$ & 7.8892 & 0.1017 & 0.4119 & 0.0050 & 0.93 & 2.4278 & 0.0292 & 0.1381 & 0.0015 & -0.3072 & 1.2934 \\
\hline JP 19 & $10.2 \mathrm{~B}$ & 7.4436 & 0.0934 & 0.3980 & 0.0045 & 0.91 & 2.5127 & 0.0286 & 0.1368 & 0.0014 & -0.1018 & 0.5187 \\
\hline JP 19 & 11.1 & 10.8552 & 0.1337 & 0.4834 & 0.0055 & 0.92 & 2.0685 & 0.0236 & 0.1631 & 0.0017 & -0.2626 & 1.6951 \\
\hline JP 19 & 11.2 & 8.6226 & 0.1084 & 0.3866 & 0.0045 & 0.93 & 2.5864 & 0.0302 & 0.1638 & 0.0017 & -0.0357 & 0.3138 \\
\hline JP 19 & $12.1 \mathrm{~N}$ & 8.0945 & 0.1008 & 0.4261 & 0.0049 & 0.93 & 2.3466 & 0.0270 & 0.1390 & 0.0015 & -0.0793 & 1.0975 \\
\hline JP 19 & $12.2 \mathrm{~B}$ & 0.7677 & 0.0110 & 0.0951 & 0.0011 & 0.79 & 10.5132 & 0.1196 & 0.0597 & 0.0007 & -0.0016 & 0.0519 \\
\hline JP 19 & 14.1 & 8.0557 & 0.1068 & 0.4098 & 0.0046 & 0.85 & 2.4403 & 0.0277 & 0.1454 & 0.0017 & 0.0130 & 0.2527 \\
\hline JP 19 & $15.2 \mathrm{~N}$ & 7.4635 & 0.0906 & 0.3986 & 0.0045 & 0.93 & 2.5085 & 0.0283 & 0.1366 & 0.0014 & 0.2259 & 1.6830 \\
\hline JP 19 & $16.1 \mathrm{~N}$ & 18.2927 & 0.3027 & 0.6033 & 0.0069 & 0.69 & 1.6576 & 0.0190 & 0.2217 & 0.0036 & 0.0343 & 0.1954 \\
\hline JP 19 & $16.2 B$ & 17.3158 & 0.3983 & 0.5802 & 0.0067 & 0.50 & 1.7236 & 0.0200 & 0.2180 & 0.0049 & 0.0305 & 0.1407 \\
\hline JP 19 & 17.1 & 9.2699 & 0.1198 & 0.4434 & 0.0050 & 0.88 & 2.2555 & 0.0257 & 0.1559 & 0.0017 & 0.2515 & 0.9742 \\
\hline JP 19 & 18.1 & 5.7606 & 0.0726 & 0.3460 & 0.0028 & 0.64 & 2.8899 & 0.0231 & 0.1232 & 0.0013 & 0.2815 & 0.0600 \\
\hline JP 19 & 20.1 & 6.2253 & 0.0807 & 0.3651 & 0.0031 & 0.67 & 2.7391 & 0.0236 & 0.1253 & 0.0012 & 0.2992 & 0.0654 \\
\hline JP 19 & 21.1 & 6.2189 & 0.0807 & 0.3649 & 0.0031 & 0.66 & 2.7402 & 0.0236 & 0.1252 & 0.0012 & 0.2956 & 0.0654 \\
\hline JP 19 & 22.1 & 10.0716 & 0.1775 & 0.4364 & 0.0055 & 0.72 & 2.2916 & 0.0290 & 0.1745 & 0.0022 & 0.0511 & 0.0115 \\
\hline
\end{tabular}

Datação U-Pb em zircões detríticos por LA-MC-ICPMS. Campos em cinza representam resultados com concordância abaixo de $95 \%$. 


\begin{tabular}{|c|c|c|c|c|c|c|c|c|c|c|c|c|}
\hline \multicolumn{2}{|l|}{ JP-19 } & $207 / 235$ & 1sigma & $206 / 238$ & 1 sigma & erro corr. & $238 / 206$ & 1 sigma & $207 / 206$ & 1 sigma & $208 / 206$ & 1 sigma \\
\hline JP 19 & 24.1 & 13.6121 & 0.1720 & 0.5332 & 0.0041 & 0.61 & 1.8756 & 0.0144 & 0.1873 & 0.0019 & 0.2122 & 0.0489 \\
\hline JP 19 & 27.1 & 5.4219 & 0.1695 & 0.3414 & 0.0072 & 0.68 & 2.9293 & 0.0619 & 0.1189 & 0.0029 & 0.0688 & 0.0223 \\
\hline JP 19 & 28.1 & 7.6099 & 0.1428 & 0.3934 & 0.0048 & 0.64 & 2.5420 & 0.0308 & 0.1396 & 0.0016 & 0.2894 & 0.0705 \\
\hline JP 19 & 30.1 & 9.0136 & 0.1082 & 0.4107 & 0.0030 & 0.61 & 2.4348 & 0.0179 & 0.1616 & 0.0016 & 0.3302 & 0.0826 \\
\hline JP 19 & 31.1 & 6.3355 & 0.1713 & 0.3699 & 0.0091 & 0.91 & 2.7037 & 0.0668 & 0.1242 & 0.0009 & 0.8188 & 0.3428 \\
\hline JP 19 & 32.1 & 16.9789 & 0.5113 & 0.5739 & 0.0155 & 0.90 & 1.7426 & 0.0472 & 0.2252 & 0.0028 & 0.7898 & 0.3233 \\
\hline JP 19 & 33.1 & 14.7816 & 0.4584 & 0.5377 & 0.0146 & 0.88 & 1.8598 & 0.0505 & 0.2083 & 0.0021 & 0.7315 & 0.2919 \\
\hline JP 19 & 36.1 & 7.9979 & 0.2200 & 0.4023 & 0.0101 & 0.91 & 2.4860 & 0.0625 & 0.1466 & 0.0010 & 0.4076 & 0.1519 \\
\hline JP 19 & 40.1 & 7.2310 & 0.2018 & 0.4026 & 0.0102 & 0.91 & 2.4838 & 0.0632 & 0.1313 & 0.0010 & 0.3329 & 0.1118 \\
\hline JP 19 & 41.1 & 7.4162 & 0.2069 & 0.4031 & 0.0103 & 0.92 & 2.4808 & 0.0633 & 0.1349 & 0.0010 & 0.3572 & 0.1176 \\
\hline JP 19 & 42.1 & 6.8119 & 0.1926 & 0.3777 & 0.0097 & 0.91 & 2.6476 & 0.0683 & 0.1323 & 0.0010 & 0.4931 & 0.1595 \\
\hline JP 19 & 43.1 & 7.9685 & 0.1372 & 0.4249 & 0.0072 & 0.99 & 2.3534 & 0.0401 & 0.1374 & 0.0029 & 0.2009 & 0.0684 \\
\hline JP 19 & 44.1 & 11.1228 & 0.1927 & 0.4815 & 0.0082 & 0.99 & 2.0770 & 0.0355 & 0.1691 & 0.0035 & 0.7265 & 0.2477 \\
\hline JP 19 & 45.1 & 7.5680 & 0.1306 & 0.4087 & 0.0070 & 0.99 & 2.4469 & 0.0417 & 0.1347 & 0.0028 & 0.2217 & 0.0756 \\
\hline JP 19 & $46.1 \mathrm{~B}$ & 6.9733 & 0.1238 & 0.3758 & 0.0064 & 0.97 & 2.6609 & 0.0456 & 0.1350 & 0.0028 & 0.3283 & 0.1121 \\
\hline JP 19 & $46.2 \mathrm{~N}$ & 8.9347 & 0.1581 & 0.4360 & 0.0079 & 0.99 & 2.2934 & 0.0414 & 0.1493 & 0.0032 & 0.4551 & 0.1559 \\
\hline JP 19 & $47.1 \mathrm{~N}$ & 7.8676 & 0.1385 & 0.4099 & 0.0073 & 0.99 & 2.4394 & 0.0437 & 0.1368 & 0.0030 & 0.3804 & 0.1303 \\
\hline JP 19 & $47.2 \mathrm{~B}$ & 6.6279 & 0.1150 & 0.3662 & 0.0062 & 0.98 & 2.7305 & 0.0462 & 0.1332 & 0.0028 & 0.1331 & 0.0456 \\
\hline JP 19 & 48.1 & 6.7939 & 0.1186 & 0.3893 & 0.0066 & 0.97 & 2.5688 & 0.0436 & 0.1267 & 0.0027 & 0.1574 & 0.0539 \\
\hline JP 19 & 49.1 & 6.9514 & 0.1225 & 0.3923 & 0.0069 & 1.00 & 2.5490 & 0.0448 & 0.1306 & 0.0028 & 0.2892 & 0.0994 \\
\hline JP 19 & 50.1 & 11.3835 & 0.1999 & 0.4809 & 0.0082 & 0.97 & 2.0796 & 0.0354 & 0.1739 & 0.0037 & 0.5330 & 0.1830 \\
\hline JP 19 & 51.1 & 7.3744 & 0.1315 & 0.4139 & 0.0070 & 0.95 & 2.4162 & 0.0411 & 0.1321 & 0.0028 & 0.2475 & 0.0850 \\
\hline JP 19 & 52.1 & 7.8686 & 0.1384 & 0.4295 & 0.0073 & 0.97 & 2.3283 & 0.0395 & 0.1357 & 0.0029 & 0.5609 & 0.1928 \\
\hline JP 19 & 53.1 & 15.7845 & 0.2751 & 0.5428 & 0.0091 & 0.96 & 1.8423 & 0.0309 & 0.2138 & 0.0045 & 0.4070 & 0.1401 \\
\hline JP 19 & 54.1 & 7.1899 & 0.3032 & 0.3909 & 0.0025 & 0.15 & 2.5580 & 0.0165 & 0.1340 & 0.0060 & 0.2130 & 0.0296 \\
\hline JP 19 & 55.1 & 7.5586 & 0.3171 & 0.4000 & 0.0026 & 0.15 & 2.4997 & 0.0160 & 0.1365 & 0.0061 & 0.2696 & 0.0376 \\
\hline JP 19 & 56.1 & 10.1661 & 0.4257 & 0.4553 & 0.0029 & 0.15 & 2.1965 & 0.0138 & 0.1596 & 0.0071 & 0.6314 & 0.0884 \\
\hline JP 19 & 57.1 & 9.3279 & 0.3878 & 0.4323 & 0.0027 & 0.15 & 2.3130 & 0.0147 & 0.1572 & 0.0070 & 0.5017 & 0.0706 \\
\hline
\end{tabular}

Datação U-Pb em zircões detríticos por LA-MC-ICPMS. Campos em cinza representam resultados com concordância abaixo de $95 \%$. 


\begin{tabular}{|c|c|c|c|c|c|c|c|c|c|c|c|c|}
\hline \multicolumn{2}{|l|}{ JP-19 } & 207 & 1sigma & 8 & na & erro & $238 / 206$ & 1 sigma & $207 / 206$ & $1 \mathrm{sig}$ & $208 / 206$ & $1 \mathrm{sig}$ \\
\hline JP 19 & 58.1 & 6.4452 & 0.2685 & 0.3776 & 0.0024 & 0.15 & 2.6485 & 0.0168 & 0.1242 & 0.0055 & 0.1089 & 0.0154 \\
\hline JP 19 & 59.1 & 6.2772 & 0.2585 & 0.3679 & 0.0023 & 0.15 & 2.7180 & 0.0171 & 0.1238 & 0.0055 & 1.5122 & 0.2144 \\
\hline JP 19 & 60.1 & 7.4401 & 0.3055 & 0.3990 & 0.0026 & 0.16 & 2.5065 & 0.0161 & 0.1355 & 0.0059 & 0.2621 & 0.0373 \\
\hline JP 19 & 61.1 & 6.2081 & 0.2552 & 0.3671 & 0.0024 & 0.16 & 2.7243 & 0.0176 & 0.1242 & 0.0054 & 0.3673 & 0.0525 \\
\hline JP 19 & 62.1 & 6.5095 & 0.2648 & 0.3728 & 0.0024 & 0.16 & 2.6823 & 0.0172 & 0.1266 & 0.0055 & 0.2298 & 0.0330 \\
\hline JP 19 & 63.1 & 11.1724 & 0.4656 & 0.4852 & 0.0031 & 0.15 & 2.0609 & 0.0133 & 0.1681 & 0.0074 & 0.2337 & 0.0337 \\
\hline JP 19 & 64.1 & 7.4258 & 0.2994 & 0.3968 & 0.0025 & 0.16 & 2.5199 & 0.0160 & 0.1353 & 0.0058 & 1.1441 & 0.1656 \\
\hline JP 19 & 65.1 & 7.3188 & 0.2940 & 0.3905 & 0.0025 & 0.16 & 2.5609 & 0.0166 & 0.1361 & 0.0058 & 0.2848 & 0.0415 \\
\hline JP 19 & 66.1 & 7.4693 & 0.2987 & 0.3997 & 0.0025 & 0.16 & 2.5017 & 0.0160 & 0.1363 & 0.0058 & 0.6560 & 0.0957 \\
\hline JP 19 & 13.1 & 8.9605 & 0.1162 & 0.3680 & 0.0042 & 0.87 & 2.7177 & 0.0308 & 0.1783 & 0.0018 & 0.0008 & 0.1790 \\
\hline JP 19 & 37.1 & 8.3371 & 0.2494 & 0.3897 & 0.0099 & 0.85 & 2.5658 & 0.0653 & 0.1607 & 0.0016 & 0.2494 & 0.0915 \\
\hline JP 19 & $38.1 \mathrm{~B}$ & 0.8195 & 0.0228 & 0.0965 & 0.0025 & 0.91 & 10.3648 & 0.2634 & 0.0637 & 0.0005 & 0.0246 & 0.0090 \\
\hline JP 19 & $38.2 \mathrm{~N}$ & 3.7243 & 0.1233 & 0.2423 & 0.0069 & 0.86 & 4.1267 & 0.1182 & 0.1165 & 0.0010 & 0.3764 & 0.1317 \\
\hline JP 19 & 39.1 & 5.6489 & 0.1585 & 0.3242 & 0.0083 & 0.91 & 3.0847 & 0.0790 & 0.1262 & 0.0009 & 0.3287 & 0.1126 \\
\hline JP 19 & 34.1 & 4.4615 & 0.1341 & 0.2538 & 0.0068 & 0.89 & 3.9399 & 0.1049 & 0.1289 & 0.0011 & 0.3278 & 0.1279 \\
\hline JP 19 & 35.1 & 4.8114 & 0.1421 & 0.2931 & 0.0077 & 0.89 & 3.4121 & 0.0899 & 0.1208 & 0.0010 & 0.3650 & 0.1391 \\
\hline JP 19 & 29.1 & 2.4702 & 0.0378 & 0.1740 & 0.0018 & 0.69 & 5.7486 & 0.0606 & 0.1043 & 0.0011 & 0.2957 & 0.0730 \\
\hline JP 19 & 25.1 & 9.7441 & 0.1252 & 0.3669 & 0.0031 & 0.66 & 2.7259 & 0.0230 & 0.1982 & 0.0020 & 0.4158 & 0.0969 \\
\hline JP 19 & 26.1 & 7.7803 & 0.1505 & 0.2705 & 0.0035 & 0.66 & 3.6974 & 0.0474 & 0.2134 & 0.0026 & 0.0306 & 0.0073 \\
\hline JP 19 & 23.1 & 15.9453 & 0.2736 & 0.4715 & 0.0055 & 0.68 & 2.1211 & 0.0246 & 0.2651 & 0.0035 & 0.0611 & 0.0140 \\
\hline JP 19 & 19.1 & 5.1844 & 0.0623 & 0.2913 & 0.0021 & 0.61 & 3.4335 & 0.0251 & 0.1307 & 0.0013 & 0.2102 & 0.0453 \\
\hline JP 19 & $15.1 \mathrm{~B}$ & 5.5332 & 0.0700 & 0.3129 & 0.0036 & 0.92 & 3.1963 & 0.0372 & 0.1302 & 0.0013 & 0.1430 & 1.5395 \\
\hline
\end{tabular}

Datação U-Pb em zircões detríticos por LA-MC-ICPMS. Campos em cinza representam resultados com concordância abaixo de $95 \%$. 


\begin{tabular}{|c|c|c|c|c|c|c|c|c|}
\hline JP-19 & & & & & IDADES & & & Concordância \\
\hline & & $T_{206 / 238}$ & 1 sigma & $T_{207 / 235}$ & 1 sigma & $T_{207 / 206}$ & 1 sigma & $206 / 238$ \\
\hline $5 \mathrm{~mJ}, 6 \mathrm{~Hz}, 2$ & & & & & & & & $207 / 206$ \\
\hline JP 19 & 1.1 & 2.651 & 0.021 & 2.736 & 0.009 & 2.847 & 0.009 & 93 \\
\hline JP 19 & 2.1 & 2.189 & 0.018 & 2.200 & 0.008 & 2.228 & 0.010 & 98 \\
\hline JP 19 & 3.1 & 2.248 & 0.018 & 2.223 & 0.008 & 2.211 & 0.010 & 102 \\
\hline JP 19 & 4.1 & 3.108 & 0.024 & 3.024 & 0.009 & 3.007 & 0.009 & 103 \\
\hline JP 19 & $5.1 \mathrm{~B}$ & 0.602 & 0.007 & 0.603 & 0.005 & 0.610 & 0.014 & 99 \\
\hline JP 19 & $5.2 \mathrm{~N}$ & 2.709 & 0.021 & 2.749 & 0.008 & 2.797 & 0.010 & 97 \\
\hline JP 19 & $6.1 \mathrm{~B}$ & 0.561 & 0.006 & 0.560 & 0.006 & 0.603 & 0.017 & 93 \\
\hline JP 19 & $6.2 \mathrm{~N}$ & 2.085 & 0.017 & 2.137 & 0.008 & 2.198 & 0.010 & 95 \\
\hline JP 19 & 7.1B & 1.863 & 0.016 & 1.986 & 0.008 & 2.145 & 0.010 & 87 \\
\hline JP 19 & $7.2 \mathrm{~N}$ & 2.308 & 0.018 & 2.251 & 0.008 & 2.213 & 0.010 & 104 \\
\hline JP 19 & 8.1B & 0.565 & 0.006 & 0.565 & 0.006 & 0.567 & 0.017 & 100 \\
\hline JP 19 & $8.2 \mathrm{~N}$ & 2.167 & 0.018 & 2.137 & 0.008 & 2.135 & 0.011 & 101 \\
\hline JP 19 & 9.1 & 2.160 & 0.017 & 2.165 & 0.008 & 2.188 & 0.010 & 99 \\
\hline JP 19 & $10.1 \mathrm{~N}$ & 2.224 & 0.023 & 2.218 & 0.012 & 2.199 & 0.019 & 101 \\
\hline JP 19 & $10.2 B$ & 2.160 & 0.021 & 2.166 & 0.011 & 2.184 & 0.018 & 99 \\
\hline JP 19 & 11.1 & 2.542 & 0.024 & 2.511 & 0.011 & 2.486 & 0.018 & 102 \\
\hline JP 19 & 11.2 & 2.107 & 0.021 & 2.299 & 0.011 & 2.493 & 0.018 & 85 \\
\hline JP 19 & $12.1 \mathrm{~N}$ & 2.288 & 0.022 & 2.242 & 0.011 & 2.211 & 0.019 & 103 \\
\hline JP 19 & 12.2B & 0.586 & 0.006 & 0.578 & 0.006 & 0.585 & 0.026 & 100 \\
\hline JP 19 & 14.1 & 2.214 & 0.021 & 2.237 & 0.012 & 2.288 & 0.020 & 97 \\
\hline JP 19 & $15.2 \mathrm{~N}$ & 2.163 & 0.021 & 2.169 & 0.011 & 2.181 & 0.018 & 99 \\
\hline JP 19 & $16.1 \mathrm{~N}$ & 3.043 & 0.028 & 3.005 & 0.016 & 2.999 & 0.025 & 101 \\
\hline JP 19 & $16.2 \mathrm{~B}$ & 2.949 & 0.027 & 2.952 & 0.022 & 2.972 & 0.036 & 99 \\
\hline JP 19 & 17.1 & 2.366 & 0.023 & 2.365 & 0.012 & 2.408 & 0.019 & 98 \\
\hline JP 19 & 18.1 & 1.916 & 0.013 & 1.941 & 0.011 & 2.002 & 0.018 & 96 \\
\hline JP 19 & 20.1 & 2.006 & 0.015 & 2.008 & 0.011 & 2.031 & 0.017 & 99 \\
\hline JP 19 & 21.1 & 2.006 & 0.015 & 2.007 & 0.011 & 2.030 & 0.017 & 99 \\
\hline JP 19 & 22.1 & 2.334 & 0.025 & 2.441 & 0.016 & 2.601 & 0.021 & 90 \\
\hline
\end{tabular}

Datação U-Pb em zircões detríticos por LA-MC-ICPMS. Campos em cinza representam resultados com concordância abaixo de $95 \%$. 


\begin{tabular}{|c|c|c|c|c|c|c|c|c|}
\hline JP-19 & & & & & IDADES & & & Concordância \\
\hline & & $T_{206 / 238}$ & 1 sigma & $T_{207 / 235}$ & 1 sigma & $T_{207 / 206}$ & 1 sigma & $206 / 238$ \\
\hline $5 \mathrm{~mJ}, 6 \mathrm{~Hz}, 2$ & & & & & & & & $207 / 206$ \\
\hline JP 19 & 24.1 & 2.755 & 0.017 & 2.723 & 0.012 & 2.722 & 0.017 & 101 \\
\hline JP 19 & 27.1 & 1.893 & 0.035 & 1.888 & 0.026 & 1.939 & 0.042 & 98 \\
\hline JP 19 & 28.1 & 2.139 & 0.022 & 2.186 & 0.017 & 2.219 & 0.020 & 96 \\
\hline JP 19 & 30.1 & 2.218 & 0.014 & 2.339 & 0.011 & 2.470 & 0.017 & 90 \\
\hline JP 19 & 31.1 & 2.029 & 0.043 & 2.023 & 0.023 & 2.016 & 0.013 & 101 \\
\hline JP 19 & 32.1 & 2.924 & 0.063 & 2.934 & 0.028 & 3.024 & 0.020 & 97 \\
\hline JP 19 & 33.1 & 2.774 & 0.061 & 2.801 & 0.029 & 2.899 & 0.016 & 96 \\
\hline JP 19 & 36.1 & 2.179 & 0.046 & 2.231 & 0.025 & 2.302 & 0.012 & 95 \\
\hline JP 19 & 40.1 & 2.181 & 0.047 & 2.140 & 0.025 & 2.112 & 0.013 & 103 \\
\hline JP 19 & 41.1 & 2.183 & 0.047 & 2.163 & 0.025 & 2.159 & 0.012 & 101 \\
\hline JP 19 & 42.1 & 2.066 & 0.045 & 2.087 & 0.025 & 2.126 & 0.013 & 97 \\
\hline JP 19 & 43.1 & 2.283 & 0.033 & 2.227 & 0.015 & 2.190 & 0.036 & 104 \\
\hline JP 19 & 44.1 & 2.534 & 0.036 & 2.533 & 0.016 & 2.548 & 0.035 & 99 \\
\hline JP 19 & 45.1 & 2.209 & 0.032 & 2.181 & 0.015 & 2.156 & 0.036 & 102 \\
\hline JP 19 & $46.1 \mathrm{~B}$ & 2.057 & 0.030 & 2.108 & 0.016 & 2.161 & 0.036 & 95 \\
\hline JP 19 & $46.2 \mathrm{~N}$ & 2.333 & 0.035 & 2.331 & 0.016 & 2.333 & 0.037 & 100 \\
\hline JP 19 & $47.1 \mathrm{~N}$ & 2.215 & 0.034 & 2.216 & 0.016 & 2.183 & 0.037 & 101 \\
\hline JP 19 & $47.2 B$ & 2.012 & 0.029 & 2.063 & 0.015 & 2.137 & 0.036 & 94 \\
\hline JP 19 & 48.1 & 2.119 & 0.031 & 2.085 & 0.015 & 2.050 & 0.036 & 103 \\
\hline JP 19 & 49.1 & 2.134 & 0.032 & 2.105 & 0.016 & 2.103 & 0.037 & 101 \\
\hline JP 19 & 50.1 & 2.531 & 0.036 & 2.555 & 0.016 & 2.596 & 0.036 & 98 \\
\hline JP 19 & 51.1 & 2.233 & 0.032 & 2.158 & 0.016 & 2.123 & 0.036 & 105 \\
\hline JP 19 & 52.1 & 2.303 & 0.033 & 2.216 & 0.016 & 2.170 & 0.036 & 106 \\
\hline JP 19 & 53.1 & 2.795 & 0.038 & 2.864 & 0.017 & 2.941 & 0.034 & 95 \\
\hline JP 19 & 54.1 & 2.127 & 0.012 & 2.135 & 0.037 & 2.148 & 0.076 & 99 \\
\hline JP 19 & 55.1 & 2.169 & 0.012 & 2.180 & 0.037 & 2.179 & 0.076 & 100 \\
\hline JP 19 & 56.1 & 2.419 & 0.013 & 2.450 & 0.038 & 2.448 & 0.075 & 99 \\
\hline JP 19 & 57.1 & 2.316 & 0.012 & 2.371 & 0.037 & 2.422 & 0.075 & 96 \\
\hline
\end{tabular}

Datação U-Pb em zircões detríticos por LA-MC-ICPMS. Campos em cinza representam resultados com concordância abaixo de $95 \%$. 


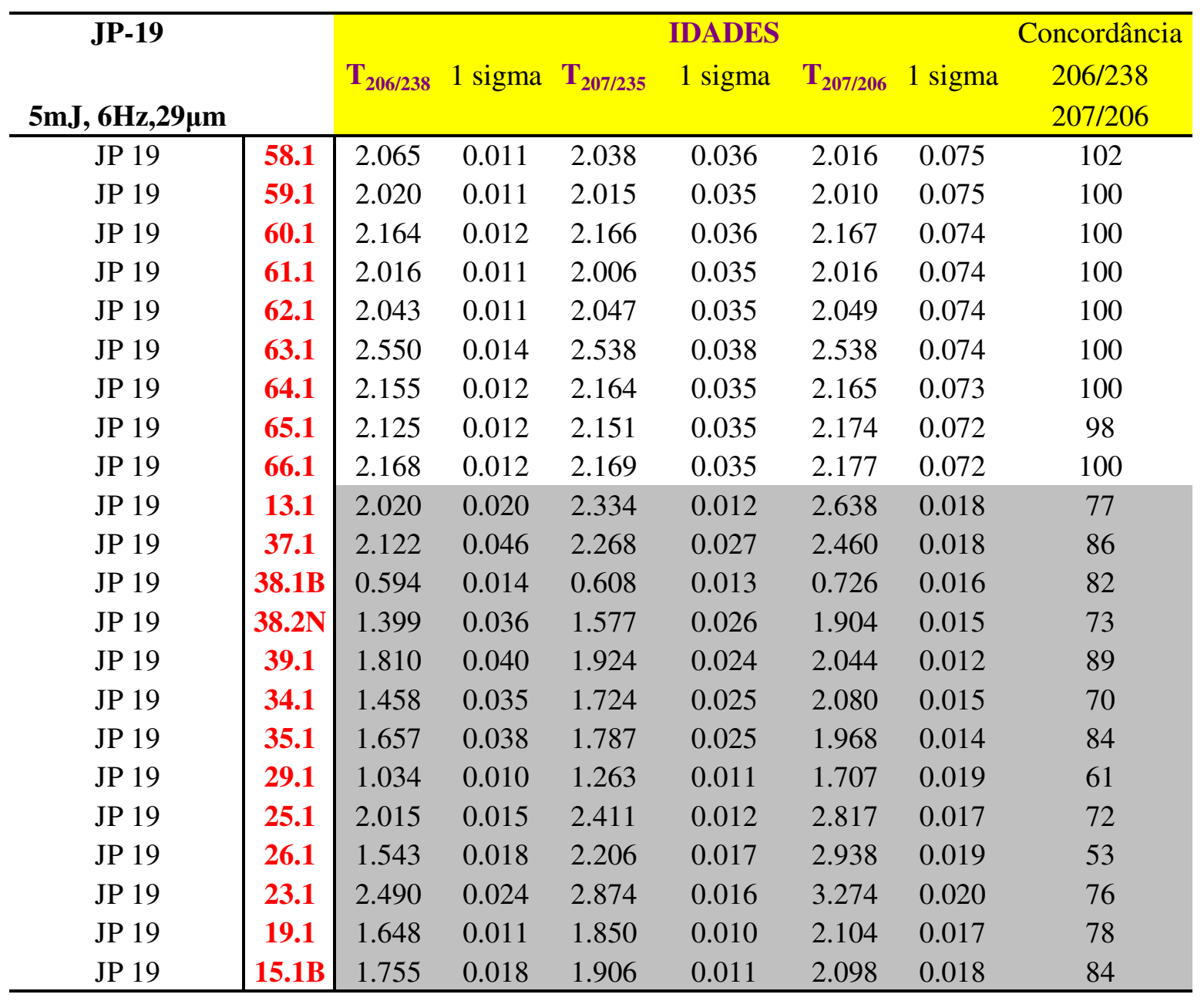

Datação U-Pb em zircões detríticos por LA-MC-ICPMS. Campos em cinza representam resultados com concordância abaixo de $95 \%$. 


\begin{tabular}{|c|c|c|c|c|c|c|c|c|c|c|c|c|}
\hline \multicolumn{2}{|l|}{ VT-03 } & $207 / 235$ & 1sigma & $206 / 238$ & 1 sigma & erro corr. & $238 / 206$ & 1 sigma & $207 / 206$ & 1 sigma & $208 / 206$ & 1 sigma \\
\hline VT 03 & 1.1 & 7.6570 & 0.1760 & 0.3980 & 0.0030 & 0.33 & 2.5128 & 0.0191 & 0.1393 & 0.0036 & 0.2296 & 0.0517 \\
\hline VT 03 & 2.1 & 10.0819 & 0.2336 & 0.4498 & 0.0035 & 0.34 & 2.2234 & 0.0175 & 0.1626 & 0.0042 & 0.2334 & 0.0532 \\
\hline VT 03 & 3.1 & 7.6696 & 0.1763 & 0.4055 & 0.0031 & 0.33 & 2.4664 & 0.0188 & 0.1369 & 0.0035 & 0.2912 & 0.0669 \\
\hline VT 03 & 4.1 & 6.9784 & 0.1641 & 0.3630 & 0.0032 & 0.38 & 2.7552 & 0.0244 & 0.1381 & 0.0035 & 0.0861 & 0.0201 \\
\hline VT 03 & 5.1 & 18.4971 & 0.4467 & 0.5983 & 0.0046 & 0.32 & 1.6714 & 0.0129 & 0.2250 & 0.0060 & 0.1845 & 0.0436 \\
\hline VT 03 & 6.1 & 7.3483 & 0.1672 & 0.3905 & 0.0030 & 0.34 & 2.5606 & 0.0197 & 0.1365 & 0.0035 & 0.1885 & 0.0448 \\
\hline VT 03 & 7.1 & 10.6374 & 0.2411 & 0.4704 & 0.0036 & 0.34 & 2.1259 & 0.0163 & 0.1640 & 0.0042 & 0.1452 & 0.0349 \\
\hline VT 03 & 9.1 & 7.5358 & 0.1699 & 0.4003 & 0.0031 & 0.34 & 2.4983 & 0.0191 & 0.1364 & 0.0034 & 0.4807 & 0.1182 \\
\hline VT 03 & 9.2 & 7.9092 & 0.1791 & 0.4213 & 0.0034 & 0.35 & 2.3733 & 0.0190 & 0.1358 & 0.0034 & 0.2923 & 0.0727 \\
\hline VT 03 & 11.1 & 4.5833 & 0.1031 & 0.3114 & 0.0024 & 0.35 & 3.2108 & 0.0252 & 0.1070 & 0.0027 & 0.2285 & 0.0582 \\
\hline VT 03 & 12.1 & 7.2600 & 0.1657 & 0.3953 & 0.0035 & 0.38 & 2.5294 & 0.0222 & 0.1324 & 0.0033 & 0.1737 & 0.0448 \\
\hline VT 03 & 13.1 & 6.8278 & 0.1884 & 0.3779 & 0.0024 & 0.23 & 2.6463 & 0.0167 & 0.1347 & 0.0040 & 0.2661 & 0.0277 \\
\hline VT 03 & 14.1 & 6.8252 & 0.1825 & 0.3720 & 0.0023 & 0.23 & 2.6879 & 0.0164 & 0.1347 & 0.0040 & 0.3848 & 0.0396 \\
\hline VT 03 & 15.1 & 7.5227 & 0.2001 & 0.3935 & 0.0023 & 0.22 & 2.5411 & 0.0148 & 0.1387 & 0.0041 & 0.3473 & 0.0355 \\
\hline VT 03 & 17.2 & 9.3625 & 0.2755 & 0.4509 & 0.0044 & 0.33 & 2.2176 & 0.0215 & 0.1559 & 0.0046 & 0.2818 & 0.0284 \\
\hline VT 03 & 18.1 & 6.9814 & 0.1889 & 0.3831 & 0.0033 & 0.32 & 2.6102 & 0.0224 & 0.1336 & 0.0039 & 0.1074 & 0.0107 \\
\hline VT 03 & 19.1 & 7.4275 & 0.1952 & 0.3996 & 0.0024 & 0.23 & 2.5025 & 0.0152 & 0.1344 & 0.0039 & 0.2202 & 0.0216 \\
\hline VT 03 & 20.1 & 10.7211 & 0.2846 & 0.4756 & 0.0033 & 0.26 & 2.1025 & 0.0144 & 0.1630 & 0.0047 & 0.3577 & 0.0349 \\
\hline VT 03 & 21.1 & 10.2271 & 0.2671 & 0.4683 & 0.0028 & 0.23 & 2.1356 & 0.0126 & 0.1588 & 0.0046 & 0.2119 & 0.0204 \\
\hline VT 03 & 22.1 & 8.0565 & 0.2124 & 0.3894 & 0.0027 & 0.27 & 2.5680 & 0.0180 & 0.1500 & 0.0043 & 0.2433 & 0.0234 \\
\hline VT 03 & 23.1 & 9.5348 & 0.2478 & 0.4366 & 0.0026 & 0.23 & 2.2902 & 0.0135 & 0.1587 & 0.0045 & 0.3068 & 0.0292 \\
\hline VT 03 & 24.1 & 4.4075 & 0.1154 & 0.3033 & 0.0020 & 0.25 & 3.2970 & 0.0213 & 0.1058 & 0.0030 & 0.3231 & 0.0305 \\
\hline VT 03 & 25.1 & 10.6953 & 0.3293 & 0.4721 & 0.0060 & 0.41 & 2.1182 & 0.0269 & 0.1648 & 0.0059 & 0.3945 & 0.0780 \\
\hline VT 03 & 26.1 & 7.5163 & 0.2179 & 0.3890 & 0.0041 & 0.36 & 2.5708 & 0.0269 & 0.1391 & 0.0049 & 0.1942 & 0.0381 \\
\hline VT 03 & 26.2 & 6.6279 & 0.1930 & 0.3553 & 0.0039 & 0.38 & 2.8145 & 0.0311 & 0.1354 & 0.0047 & 0.1764 & 0.0344 \\
\hline VT 03 & 27.1 & 15.8841 & 0.4806 & 0.5481 & 0.0065 & 0.39 & 1.8245 & 0.0216 & 0.2103 & 0.0074 & 0.2248 & 0.0434 \\
\hline VT 03 & 28.1 & 10.8383 & 0.3182 & 0.4722 & 0.0055 & 0.40 & 2.1176 & 0.0249 & 0.1644 & 0.0057 & 0.2414 & 0.0462 \\
\hline VT 03 & 29.1 & 11.0646 & 0.3239 & 0.4746 & 0.0056 & 0.40 & 2.1068 & 0.0249 & 0.1651 & 0.0057 & 0.2419 & 0.0460 \\
\hline
\end{tabular}

Datação U-Pb em zircões detríticos por LA-MC-ICPMS. Campos em cinza representam resultados com concordância abaixo de $95 \%$. 


\begin{tabular}{|c|c|c|c|c|c|c|c|c|c|c|c|c|}
\hline \multicolumn{2}{|l|}{ VT-03 } & $207 / 235$ & 1sigma & $206 / 238$ & 1 sigma & erro corr. & $238 / 206$ & 1 sigma & $207 / 206$ & 1 sigma & $208 / 206$ & 1 sigma \\
\hline VT 03 & 30.1 & 6.5568 & 0.1938 & 0.3643 & 0.0041 & 0.38 & 2.7451 & 0.0307 & 0.1239 & 0.0044 & 0.3671 & 0.0694 \\
\hline VT 03 & 33.1 & 10.4781 & 0.2967 & 0.4689 & 0.0050 & 0.38 & 2.1328 & 0.0227 & 0.1628 & 0.0056 & 0.2315 & 0.0427 \\
\hline VT 03 & 34.1 & 9.8912 & 0.3057 & 0.4497 & 0.0056 & 0.40 & 2.2236 & 0.0277 & 0.1623 & 0.0056 & 0.0700 & 0.0136 \\
\hline VT 03 & 36.1 & 10.2487 & 0.2988 & 0.4555 & 0.0058 & 0.44 & 2.1952 & 0.0281 & 0.1673 & 0.0058 & 0.2957 & 0.0547 \\
\hline VT 03 & 37.1 & 10.1380 & 0.2796 & 0.4549 & 0.0047 & 0.37 & 2.1984 & 0.0227 & 0.1640 & 0.0039 & 0.2537 & 0.0502 \\
\hline VT 03 & 38.1 & 7.2548 & 0.1990 & 0.3877 & 0.0035 & 0.33 & 2.5792 & 0.0234 & 0.1357 & 0.0033 & 0.0383 & 0.0077 \\
\hline VT 03 & 39.1 & 7.4773 & 0.2100 & 0.3989 & 0.0046 & 0.41 & 2.5067 & 0.0292 & 0.1347 & 0.0032 & 0.0812 & 0.0163 \\
\hline VT 03 & 40.1 & 10.4301 & 0.2767 & 0.4705 & 0.0041 & 0.33 & 2.1255 & 0.0187 & 0.1603 & 0.0038 & 0.1572 & 0.0317 \\
\hline VT 03 & 41.1 & 7.4870 & 0.2321 & 0.3842 & 0.0042 & 0.35 & 2.6027 & 0.0285 & 0.1435 & 0.0037 & 0.0991 & 0.0212 \\
\hline VT 03 & 42.1 & 6.9207 & 0.2374 & 0.3652 & 0.0061 & 0.49 & 2.7384 & 0.0456 & 0.1357 & 0.0034 & 0.1499 & 0.0312 \\
\hline VT 03 & 43.1 & 10.5919 & 0.2856 & 0.4712 & 0.0046 & 0.36 & 2.1222 & 0.0205 & 0.1643 & 0.0039 & 0.2155 & 0.0440 \\
\hline VT 03 & 45.1 & 4.7908 & 0.1246 & 0.3183 & 0.0026 & 0.31 & 3.1421 & 0.0253 & 0.1091 & 0.0025 & 0.2484 & 0.0511 \\
\hline VT 03 & 47.1 & 7.0260 & 0.1826 & 0.3800 & 0.0031 & 0.32 & 2.6315 & 0.0216 & 0.1341 & 0.0031 & 0.2714 & 0.0565 \\
\hline VT 03 & 48.1 & 6.8476 & 0.1781 & 0.3897 & 0.0034 & 0.33 & 2.5663 & 0.0222 & 0.1255 & 0.0029 & 0.2718 & 0.0572 \\
\hline VT 03 & 49.1 & 6.0577 & 0.1692 & 0.3483 & 0.0038 & 0.39 & 2.8707 & 0.0314 & 0.1242 & 0.0029 & 0.2105 & 0.0443 \\
\hline VT 03 & 50.1 & 7.0888 & 0.2075 & 0.3751 & 0.0042 & 0.38 & 2.6662 & 0.0297 & 0.1378 & 0.0035 & 0.0349 & 0.0053 \\
\hline VT 03 & 51.1 & 6.0664 & 0.2571 & 0.3554 & 0.0089 & 0.59 & 2.8134 & 0.0702 & 0.1239 & 0.0036 & 0.4046 & 0.0595 \\
\hline VT 03 & 52.1 & 9.7462 & 0.2796 & 0.4405 & 0.0046 & 0.36 & 2.2699 & 0.0235 & 0.1608 & 0.0040 & 0.0287 & 0.0043 \\
\hline VT 03 & 53.1 & 6.3908 & 0.2047 & 0.3672 & 0.0051 & 0.44 & 2.7233 & 0.0380 & 0.1242 & 0.0033 & 0.1681 & 0.0243 \\
\hline VT 03 & 54.1 & 7.0281 & 0.2057 & 0.3907 & 0.0047 & 0.41 & 2.5595 & 0.0308 & 0.1319 & 0.0033 & 0.1930 & 0.0278 \\
\hline VT 03 & 56.1 & 6.9088 & 0.1991 & 0.3704 & 0.0040 & 0.37 & 2.6995 & 0.0288 & 0.1359 & 0.0034 & 0.2230 & 0.0320 \\
\hline VT 03 & 57.1 & 8.7721 & 0.2489 & 0.4115 & 0.0043 & 0.36 & 2.4298 & 0.0252 & 0.1552 & 0.0038 & 0.2337 & 0.0334 \\
\hline VT 03 & 58.1 & 2.8837 & 0.1071 & 0.2439 & 0.0038 & 0.42 & 4.0997 & 0.0646 & 0.0890 & 0.0028 & 0.3123 & 0.0446 \\
\hline VT 03 & 59.1 & 9.7129 & 0.2867 & 0.4526 & 0.0055 & 0.41 & 2.2093 & 0.0269 & 0.1566 & 0.0039 & 0.1346 & 0.0192 \\
\hline VT 03 & 60.1 & 23.9914 & 0.6969 & 0.6727 & 0.0079 & 0.41 & 1.4866 & 0.0175 & 0.2723 & 0.0069 & 0.2051 & 0.0292 \\
\hline VT 03 & 61.1 & 6.9131 & 0.2025 & 0.3704 & 0.0045 & 0.41 & 2.6999 & 0.0327 & 0.1348 & 0.0033 & 0.0398 & 0.0057 \\
\hline VT 03 & 62.1 & 10.9240 & 0.3192 & 0.4720 & 0.0054 & 0.39 & 2.1185 & 0.0242 & 0.1695 & 0.0042 & 0.2651 & 0.0377 \\
\hline VT 03 & 63.1 & 7.2424 & 0.1855 & 0.3933 & 0.0030 & 0.30 & 2.5429 & 0.0195 & 0.1338 & 0.0028 & 0.0105 & 0.0016 \\
\hline
\end{tabular}

Datação U-Pb em zircões detríticos por LA-MC-ICPMS. Campos em cinza representam resultados com concordância abaixo de $95 \%$. 


\begin{tabular}{|c|c|c|c|c|c|c|c|c|c|c|c|c|}
\hline \multicolumn{2}{|l|}{ VT-03 } & $207 / 235$ & 1sigma & $206 / 2$ & $1 \mathrm{sig}$ & erro & $238 / 2$ & 1 sigma & $207 / 206$ & 1 sigma & $208 / 206$ & 1 sigma \\
\hline VT 03 & 64.1 & 16.6974 & 1.1888 & 0.5486 & 0.0297 & 0.76 & 1.8227 & 0.0986 & 0.2215 & 0.0090 & 0.2438 & 0.0383 \\
\hline VT 03 & 65.1 & 20.1490 & 0.5284 & 0.5872 & 0.0053 & 0.34 & 1.7031 & 0.0153 & 0.2498 & 0.0052 & 0.5900 & 0.0907 \\
\hline VT 03 & 66.1 & 12.2843 & 0.3111 & 0.4867 & 0.0032 & 0.26 & 2.0548 & 0.0134 & 0.1841 & 0.0039 & 0.2115 & 0.0321 \\
\hline VT 03 & 67.1 & 7.2471 & 0.1846 & 0.3722 & 0.0025 & 0.26 & 2.6870 & 0.0178 & 0.1405 & 0.0030 & 0.2503 & 0.0396 \\
\hline VT 03 & 68.1 & 12.2762 & 0.3364 & 0.4920 & 0.0048 & 0.36 & 2.0327 & 0.0198 & 0.1819 & 0.0039 & 0.2762 & 0.0425 \\
\hline VT 03 & 69.1 & 10.0802 & 0.2543 & 0.4492 & 0.0037 & 0.33 & 2.2260 & 0.0184 & 0.1614 & 0.0034 & 0.2390 & 0.0369 \\
\hline VT 03 & 71.1 & 6.5659 & 0.1797 & 0.3559 & 0.0036 & 0.37 & 2.8095 & 0.0288 & 0.1338 & 0.0028 & 0.0977 & 0.0161 \\
\hline VT 03 & 8.1 & 5.0256 & 0.1210 & 0.2967 & 0.0024 & 0.34 & 3.3707 & 0.0278 & 0.1234 & 0.0033 & 0.1726 & 0.0420 \\
\hline VT 03 & 10.1 & 1.2908 & 0.0441 & 0.0993 & 0.0018 & 0.52 & 10.0710 & 0.1800 & 0.0983 & 0.0026 & 0.0458 & 0.0116 \\
\hline VT 03 & 16.1 & 14.7832 & 0.4054 & 0.4983 & 0.0036 & 0.26 & 2.0069 & 0.0144 & 0.2214 & 0.0065 & 0.2376 & 0.0241 \\
\hline VT 03 & 17.1 & 3.8281 & 0.1178 & 0.2641 & 0.0020 & 0.24 & 3.7860 & 0.0285 & 0.1077 & 0.0033 & 0.1284 & 0.0136 \\
\hline VT 03 & 31.1 & 4.6884 & 0.1367 & 0.2880 & 0.0033 & 0.40 & 3.4721 & 0.0400 & 0.1181 & 0.0041 & 0.2306 & 0.0432 \\
\hline VT 03 & 32.1 & 18.1225 & 0.5507 & 0.5342 & 0.0069 & 0.42 & 1.8719 & 0.0241 & 0.2436 & 0.0084 & 0.2489 & 0.0463 \\
\hline VT 03 & 35.1 & 13.6316 & 0.4098 & 0.4856 & 0.0060 & 0.41 & 2.0594 & 0.0254 & 0.2058 & 0.0071 & 0.1853 & 0.0342 \\
\hline VT 03 & 44.1 & 8.0998 & 0.2240 & 0.3658 & 0.0043 & 0.42 & 2.7337 & 0.0319 & 0.1607 & 0.0038 & 0.2295 & 0.0471 \\
\hline VT 03 & 46.1 & 4.6767 & 0.1213 & 0.2814 & 0.0022 & 0.30 & 3.5542 & 0.0280 & 0.1199 & 0.0028 & 0.3573 & 0.0739 \\
\hline VT 03 & 55.1 & 7.4447 & 0.2138 & 0.3658 & 0.0039 & 0.37 & 2.7336 & 0.0290 & 0.1477 & 0.0037 & 0.2263 & 0.0326 \\
\hline VT 03 & 70.1 & 8.0424 & 0.2061 & 0.3814 & 0.0034 & 0.35 & 2.6218 & 0.0236 & 0.1530 & 0.0032 & 0.3649 & 0.0567 \\
\hline VT 03 & 72.1 & 5.3974 & 0.1385 & 0.3128 & 0.0027 & 0.34 & 3.1968 & 0.0279 & 0.1260 & 0.0026 & 0.2077 & 0.0327 \\
\hline
\end{tabular}

Datação U-Pb em zircões detríticos por LA-MC-ICPMS. Campos em cinza representam resultados com concordância abaixo de $95 \%$. 


\begin{tabular}{|c|c|c|c|c|c|c|c|c|}
\hline \multicolumn{2}{|l|}{ VT-03 } & \multirow{3}{*}{$T_{206 / 238}$} & \multicolumn{5}{|c|}{ IDADES } & \multirow{3}{*}{$\begin{array}{c}\text { Concordância } \\
206 / 238 \\
207 / 206 \\
\end{array}$} \\
\hline & & & 1 sigma & $\mathbf{T}_{207 / 235}$ & 1 sigma & $T_{207 / 206}$ & 1 sigma & \\
\hline \multicolumn{2}{|c|}{$5 \mathrm{~mJ}, 6 \mathrm{~Hz}, 29 \mu \mathrm{m}$} & & & & & & & \\
\hline VT 03 & 1.1 & 2.160 & 0.014 & 2.192 & 0.020 & 2.214 & 0.044 & 98 \\
\hline VT 03 & 2.1 & 2.394 & 0.016 & 2.442 & 0.021 & 2.480 & 0.044 & 97 \\
\hline VT 03 & 3.1 & 2.194 & 0.014 & 2.193 & 0.020 & 2.184 & 0.044 & 100 \\
\hline VT 03 & 4.1 & 1.996 & 0.015 & 2.109 & 0.021 & 2.200 & 0.043 & 91 \\
\hline VT 03 & 5.1 & 3.023 & 0.019 & 3.016 & 0.023 & 3.022 & 0.041 & 100 \\
\hline VT 03 & 6.1 & 2.125 & 0.014 & 2.155 & 0.020 & 2.179 & 0.043 & 98 \\
\hline VT 03 & 7.1 & 2.485 & 0.016 & 2.492 & 0.021 & 2.495 & 0.043 & 100 \\
\hline VT 03 & 9.1 & 2.170 & 0.014 & 2.177 & 0.020 & 2.178 & 0.043 & 100 \\
\hline VT 03 & 9.2 & 2.267 & 0.015 & 2.221 & 0.020 & 2.171 & 0.043 & 104 \\
\hline VT 03 & 11.1 & 1.748 & 0.012 & 1.746 & 0.019 & 1.753 & 0.044 & 100 \\
\hline VT 03 & 12.1 & 2.148 & 0.016 & 2.144 & 0.020 & 2.126 & 0.042 & 101 \\
\hline VT 03 & 13.1 & 2.066 & 0.011 & 2.089 & 0.024 & 2.157 & 0.050 & 96 \\
\hline VT 03 & 14.1 & 2.039 & 0.011 & 2.089 & 0.023 & 2.156 & 0.050 & 95 \\
\hline VT 03 & 15.1 & 2.139 & 0.011 & 2.176 & 0.024 & 2.207 & 0.050 & 97 \\
\hline VT 03 & 17.2 & 2.399 & 0.019 & 2.374 & 0.027 & 2.408 & 0.050 & 100 \\
\hline VT 03 & 18.1 & 2.091 & 0.015 & 2.109 & 0.024 & 2.142 & 0.049 & 98 \\
\hline VT 03 & 19.1 & 2.167 & 0.011 & 2.164 & 0.023 & 2.153 & 0.049 & 101 \\
\hline VT 03 & 20.1 & 2.508 & 0.014 & 2.499 & 0.024 & 2.484 & 0.049 & 101 \\
\hline VT 03 & 21.1 & 2.476 & 0.012 & 2.456 & 0.024 & 2.440 & 0.049 & 101 \\
\hline VT 03 & 22.1 & 2.120 & 0.013 & 2.237 & 0.024 & 2.342 & 0.049 & 91 \\
\hline VT 03 & 23.1 & 2.336 & 0.012 & 2.391 & 0.024 & 2.439 & 0.048 & 96 \\
\hline VT 03 & 24.1 & 1.708 & 0.010 & 1.714 & 0.021 & 1.733 & 0.051 & 99 \\
\hline VT 03 & 25.1 & 2.493 & 0.026 & 2.497 & 0.028 & 2.504 & 0.060 & 100 \\
\hline VT 03 & 26.1 & 2.118 & 0.019 & 2.175 & 0.026 & 2.212 & 0.060 & 96 \\
\hline VT 03 & 26.2 & 1.960 & 0.019 & 2.063 & 0.025 & 2.165 & 0.059 & 91 \\
\hline VT 03 & 27.1 & 2.817 & 0.027 & 2.870 & 0.028 & 2.914 & 0.056 & 97 \\
\hline VT 03 & 28.1 & 2.493 & 0.024 & 2.509 & 0.027 & 2.499 & 0.059 & 100 \\
\hline VT 03 & 29.1 & 2.504 & 0.025 & 2.529 & 0.027 & 2.506 & 0.058 & 100 \\
\hline
\end{tabular}

Datação U-Pb em zircões detríticos por LA-MC-ICPMS. Campos em cinza representam resultados com concordância abaixo de $95 \%$. 


\begin{tabular}{|c|c|c|c|c|c|c|c|c|}
\hline \multicolumn{2}{|l|}{ VT-03 } & \multirow{3}{*}{$T_{206 / 238}$} & \multicolumn{5}{|c|}{ IDADES } & \multirow{3}{*}{$\begin{array}{c}\text { Concordância } \\
206 / 238 \\
207 / 206\end{array}$} \\
\hline & & & 1 sigma & $T_{207 / 235}$ & 1 sigma & $T_{207 / 206}$ & 1 sigma & \\
\hline \multicolumn{2}{|c|}{$5 \mathrm{~mJ}, 6 \mathrm{~Hz}, 29 \mu \mathrm{m}$} & & & & & & & \\
\hline VT 03 & 30.1 & 2.002 & 0.019 & 2.054 & 0.026 & 2.012 & 0.060 & 100 \\
\hline VT 03 & 33.1 & 2.479 & 0.022 & 2.478 & 0.026 & 2.482 & 0.058 & 100 \\
\hline VT 03 & 34.1 & 2.394 & 0.025 & 2.425 & 0.028 & 2.477 & 0.058 & 97 \\
\hline VT 03 & 36.1 & 2.420 & 0.026 & 2.457 & 0.027 & 2.529 & 0.058 & 96 \\
\hline VT 03 & 37.1 & 2.417 & 0.021 & 2.447 & 0.025 & 2.494 & 0.041 & 97 \\
\hline VT 03 & 38.1 & 2.112 & 0.016 & 2.143 & 0.024 & 2.169 & 0.041 & 97 \\
\hline VT 03 & 39.1 & 2.164 & 0.021 & 2.170 & 0.025 & 2.157 & 0.040 & 100 \\
\hline VT 03 & 40.1 & 2.486 & 0.018 & 2.474 & 0.024 & 2.456 & 0.040 & 101 \\
\hline VT 03 & 41.1 & 2.096 & 0.020 & 2.171 & 0.027 & 2.265 & 0.044 & 93 \\
\hline VT 03 & 42.1 & 2.007 & 0.029 & 2.101 & 0.030 & 2.169 & 0.042 & 93 \\
\hline VT 03 & 43.1 & 2.489 & 0.020 & 2.488 & 0.025 & 2.498 & 0.040 & 100 \\
\hline VT 03 & 45.1 & 1.781 & 0.013 & 1.783 & 0.022 & 1.788 & 0.041 & 100 \\
\hline VT 03 & 47.1 & 2.076 & 0.015 & 2.115 & 0.023 & 2.149 & 0.039 & 97 \\
\hline VT 03 & 48.1 & 2.121 & 0.016 & 2.092 & 0.023 & 2.034 & 0.040 & 104 \\
\hline VT 03 & 49.1 & 1.927 & 0.018 & 1.984 & 0.024 & 2.016 & 0.040 & 96 \\
\hline VT 03 & 50.1 & 2.053 & 0.020 & 2.123 & 0.026 & 2.196 & 0.043 & 94 \\
\hline VT 03 & 51.1 & 1.961 & 0.042 & 1.985 & 0.036 & 2.011 & 0.049 & 97 \\
\hline VT 03 & 52.1 & 2.353 & 0.020 & 2.411 & 0.026 & 2.461 & 0.043 & 96 \\
\hline VT 03 & 53.1 & 2.016 & 0.024 & 2.031 & 0.028 & 2.016 & 0.046 & 100 \\
\hline VT 03 & 54.1 & 2.126 & 0.022 & 2.115 & 0.026 & 2.120 & 0.043 & 100 \\
\hline VT 03 & 56.1 & 2.031 & 0.019 & 2.100 & 0.025 & 2.172 & 0.043 & 94 \\
\hline VT 03 & 57.1 & 2.222 & 0.019 & 2.315 & 0.026 & 2.400 & 0.042 & 93 \\
\hline VT 03 & 58.1 & 1.407 & 0.020 & 1.378 & 0.028 & 1.410 & 0.058 & 100 \\
\hline VT 03 & 59.1 & 2.407 & 0.024 & 2.408 & 0.027 & 2.416 & 0.042 & 100 \\
\hline VT 03 & 60.1 & 3.316 & 0.031 & 3.268 & 0.028 & 3.314 & 0.039 & 100 \\
\hline VT 03 & 61.1 & 2.031 & 0.021 & 2.100 & 0.026 & 2.157 & 0.042 & 94 \\
\hline VT 03 & 62.1 & 2.492 & 0.024 & 2.517 & 0.027 & 2.551 & 0.042 & 98 \\
\hline VT 03 & 63.1 & 2.138 & 0.014 & 2.142 & 0.023 & 2.145 & 0.036 & 100 \\
\hline
\end{tabular}

Datação U-Pb em zircões detríticos por LA-MC-ICPMS. Campos em cinza representam resultados com concordância abaixo de $95 \%$. 


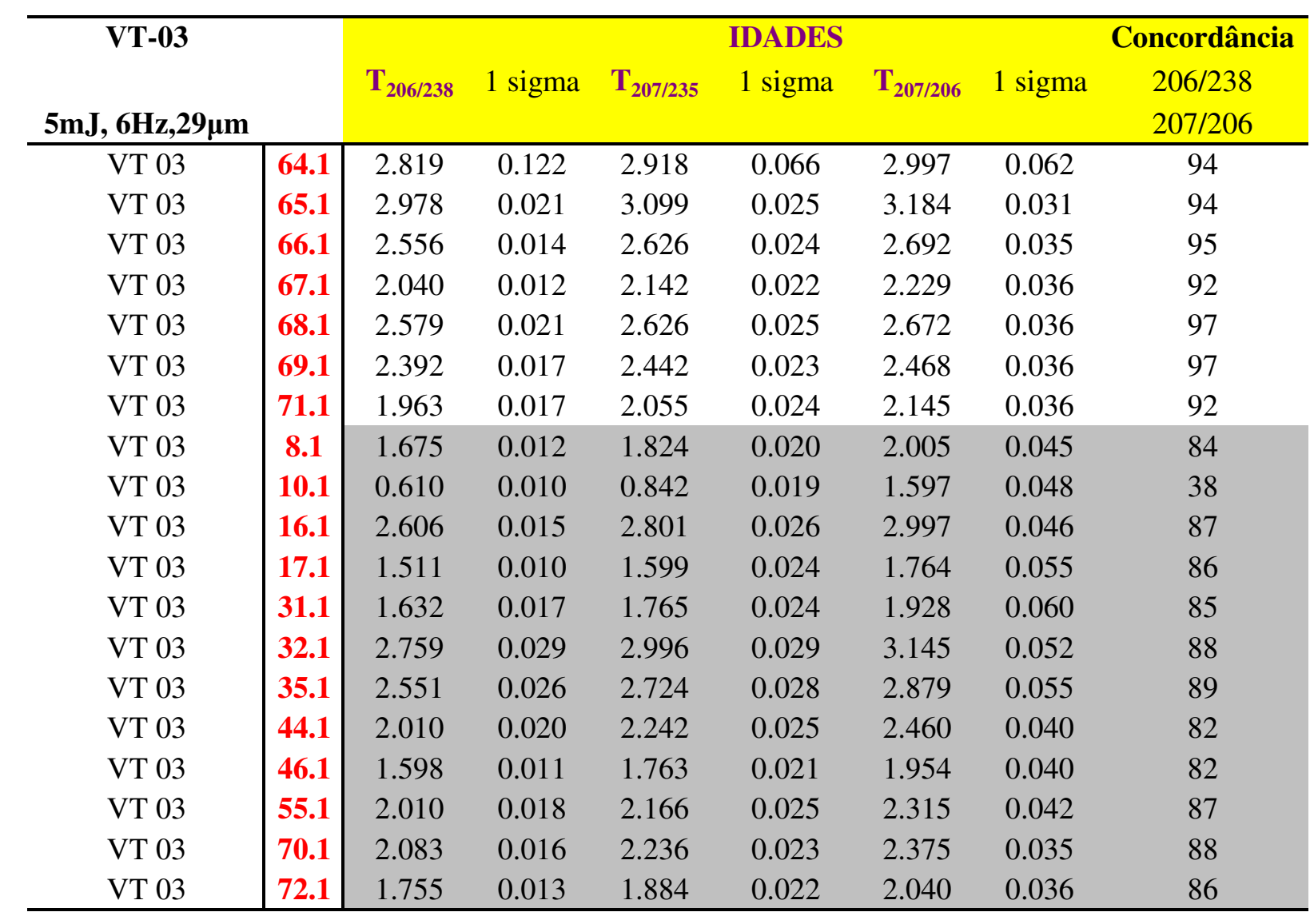

Datação U-Pb em zircões detríticos por LA-MC-ICPMS. Campos em cinza representam resultados com concordância abaixo de $95 \%$. 
ANEXO -VI

(Mapa Geológico Integrado) 
Mapa Geológico do Domínio São Roque: incluindo parte do Grupo São Roque, Grupo Serra do Itaberaba, Grupo Açungui, Complexo Embu, Domínio Socorro-Guaxupé, Bacia do Paraná e Bacia de São Paulo.

(A) Mapa regional modificado de Campos Neto (2000). 1- Rochas Fanerozóicas sedimentares e rochas intrusivas Mesozóicas (Bacia do Paraná); 2- Granitos do Neoproterozóico tardio e granitos pós-orogênicos; 3- (Granada)-(Muscovita)-Biotita granitos; 4- Biotita granitos porfiríticos; 5- (Hornblenda) Biotita granitos porfiríticos; 6Domínio Socorro-Guaxupé (com predomínio de granada migmatitos); 7 e 8- Domínio Embu: gnaisses do embasamento Paleoproterozóico (7); rochas meta-supracrustais (8); 9- Domínio Apiaí-São Roque: Grupos São Roque e Açungui; 10- Grupo Serra do Itaberaba; 11- Complexo Costeiro.

(B) Visão moderna do Gondwana ocidental durante o Paleozóico intermediário com fragmentos de escudos cratônicos representando massas continentais pré-existentes, além de assembléias de cinturões orogênicos formados durante no ciclo PanAfricano/Brasiliano (modificado de De Wit et al., 2008).

(C) 1- Coberturas aluvionares; 2- Bacia de São Paulo (Pleistoceno); 3- Zonas de falhas Neoproterozóicas com milonitos e ultramilonitos; 4- Granitos Neoproterozóicos indiferenciados; 5- Quartzo Sienitos (Neoproterozóico); 6 e 7- Domínio SocorroGuaxupé [predomínio de paragnaisses (6) e migmatitos (7)]; 8- Complexo Embu; 9Formação Pirapora do Bom Jesus (metacalcários e metadolomitos); [10, 11 e 12]anfibolitos (10), formações ferríferas bandadas (11) e metatufos (12) (Formação Pirapora do Bom Jesus/Grupo Serra do Itaberaba (?)); 13 e 14- Grupo Serra do Itaberaba $(13=$ cianita-estaurolita xistos; $14=$ rochas cálcio-silicáticas e tremolita mármores); 15- metawackes; 16= metasiltitos; 17- meta-quartzo arenitos, metasubarcóseos e metarcóseos; 18- metawackes feldspáticos e meta-quartzo wackes; 19metaconglomerados; 20- rochas metavulcânicas ácidas; 21- rochas metavulcânicas básicas; 22- Ortognaisses do embasamento (?); 23 Formação Votuverava (Grupo Açungui). Mapas compilados de IPT (1983), Dantas (1990), Bergmann (1988), Juliani (1993), Neves (2005) e Serviço Geológico do Brasil - CPRM (2006). 


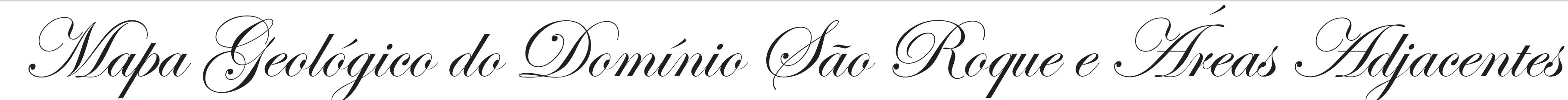
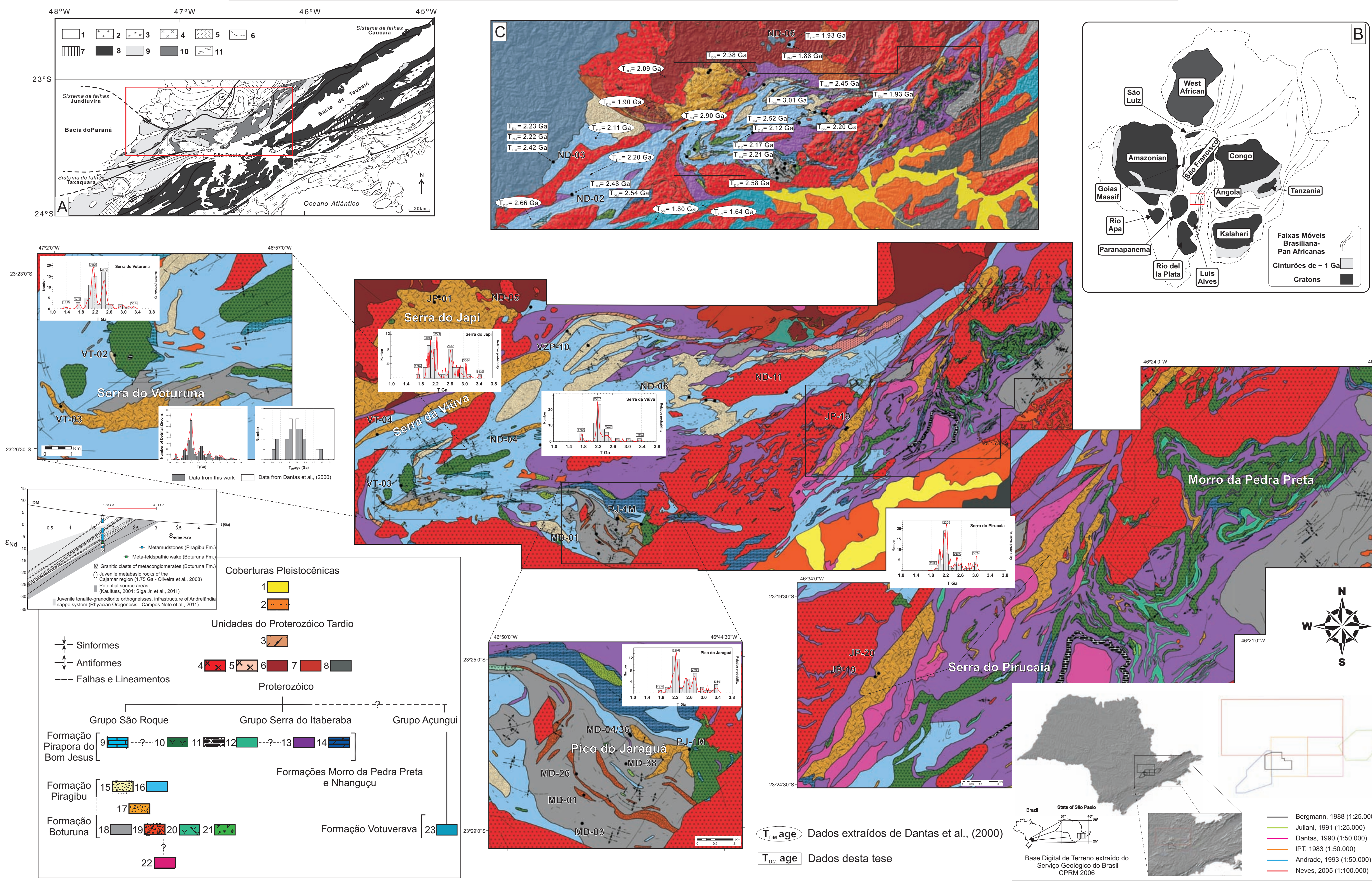